FACULDADE DE FILOSOFIA, LETRAS E CIÊNCIAS HUMANAS PROGRAMA DE PÓS-GRADUAÇÃO EM HISTÓRIA SOCIAL

Política e Retórica: estratégias de conversão nas missões jesuítas do Mogol, Tibete e Bengala (XVI-XVIII)

Bruna Dutra de Oliveira Soalheiro Cruz 


\title{
Política e Retórica: estratégias de conversão nas missões jesuítas do Mogol, Tibete e Bengala (XVI-XVIII)
}

\author{
Tese de doutorado apresentada ao Programa de Pós- \\ graduação em História Social do departamento de História da \\ Faculdade de Filosofia, Letras e Ciências Humanas da \\ Universidade de São Paulo, para a obtenção do título de doutor. \\ Orientador: Prof. Dr. Carlos Alberto de Moura Ribeiro Zeron \\ Co-orientadora: Prof. Dra ${ }^{\mathrm{a}}$. Ines Zupanov
}

São Paulo 


\section{FOLHA DE APROVAÇÃO}

\section{Banca Examinadora}

Prof(a). Dr(a)

Instituição

Assinatura

Prof(a). Dr(a)

Instituição

Assinatura

Prof(a). Dr(a)

Instituição

Assinatura

$\operatorname{Prof}(\mathrm{a}) \cdot \operatorname{Dr}(\mathrm{a})$

Instituição

Assinatura

Prof(a). Dr(a)

Instituição

Assinatura 


\section{AGRADECIMENTOS}

Ao longo de todos esses anos de pesquisa, incontáveis pessoas contribuíram para que meus esforços pessoais ganhassem hoje materialidade nas páginas que se seguem. A constatação óbvia de que eu não chegaria aqui sozinha leva-me a agradecer sinceramente a preciosa ajuda de professores, amigos e colegas de pós-graduação e, principalmente, de minha família.

Ao prof. Carlos Zeron eu gostaria de agradecer não só pela trabalhosa orientação, mas pela generosidade que sempre acompanhou o seu agir em relação a minha pesquisa. Primeiramente, por ter se disposto a dedicar tempo de trabalho a um tema que não integra o corpo principal de suas investigações acadêmicas. Em segundo lugar, por ter incentivado, desde o início de minhas pesquias, o diálogo com outros professores e pesquisadores, muitas vezes dispondo-se pessoalmente a enviar emails e conduzir apresentações. Foi seu empenho que tornou possível o estabelecimento da orientação em cotutela desenvolvida nesta tese.

A prof. Ines Zupanov agradeço o acolhimento e a delicadeza com que conduziu sua orientação, indicando-me caminhos e leituras que se revelaram determinantes para que essa tese ganhasse a forma que tem hoje.

Aos demais professores e pesquisadores que sempre se dispuseram a dialogar, ajudando-me com sugestões e indicações de leitura. Prof. Antonella Romano, Prof. Silvia Sebastiani, Prof. Vera Dorofeeva-lichtmann, Prof. Hilário Franco Junior, cujas disciplinas foram fundamentais para o avançar de minhas investigações. Prof. Fernando Londoño e prof. Janice Theodoro, que desde meu mestrado acompanham o desenvolvimento desta pesquisa, sempre me trazendo contribuições substanciais, frutos de atentas leituras. Prof. Carlos Ziller, responsável por me apresentar à obra de Francisco Suárez. Prof. Adone Agnolin, que compartilhou comigo resultados de sua pesquisa, os quais foram fundamentais para minhas investigações, em especial nos arquivos europeus. Prof. Celia Tavares, que desde meu projeto de mestrado sempre se disponibilizou a ajudar-me. Prof. Rodrigo Guerizoli e seus alunos que pacientemente se dispuseram a me explicar o básico.

Àqueles que me auxiliaram na finalização desta tese e com as dificuldades do idioma: Susanne, Carol Simmer e Patrick Xavier Wuillaume.

Aos funcionários do programa de pós-graduação em História Social e do Centre d'Études de l'Inde et de l'Asie du Sud (CEIAS). À CAPES, pelo financiamento da pesquisa no país e no exterior. 
Aos meus colegas que me auxiliaram nas pesquisas conduzidas fora do Brasil, Paolo Aranha, Ananya Chakravarti e Margherita Trento.

Aos meus queridíssimos "vizinhos” Caion Natal e Gustavo Costa de Souza, que me ajudaram a me sentir mais perto de casa, mesmo longe, e me apresentaram à culinária basca.

Aos meus amigos Leonardo Arruda, Mauro Amoroso, João Ricardo, Luigi Bonafé, Barba Ruiva e Cadu Marconi que desde a graduação acalmam minhas "angústias acadêmicas" e garantem a descontração necessária para dar continuidade ao trabalho. A Camila Correa e Victor Vigneron, pela companhia nos estudos da Companhia. A Ana Luiza Saramago, Clarissa Pepe Ferreira, Ana Emilia Lobato, que sempre ouvem.

Aos amigos que se foram, Danielzinho e Gabriel Buchmann, por me ensinarem a reconhecer os laços prioritários e seu papel essencial em nossa breve existência.

Agradeço também aos amigos de longa data, pela amizade que me é tão cara: Alexandre Brito, Andreia Saad, Daniel Medeiros, Eduardo Brasil, Marcio Christiani e Rodrigo Goulart.

À minha família, estrutura que me permitiu chegar até aqui. Ao meu avô Orestes, por me ensinar o valor dos estudos e do trabalho, garantindo materialmente que essa pesquisa fosse conduzida mesmo depois de sua partida. À minha avó Marcela, que sempre me perguntou o motivo de tanto estudo, mas que não chegou a ver a resposta (eu mesma não estou tão segura de tê-la encontrado...). À minha irmã, pela presença constante e suporte incondicional. À minha mãe por sempre me apoiar em minhas escolhas, ainda que desconfie de suas "utilidades" e "aplicações". Ao meu pai, agradeço pela compreensão, pelo afeto, pelo sustento, enfim, por ter tornado esse doutorado possível.

Finalmente, meu agradecimento a Ana Moura, que nos últimos cinco anos cismou de me acompanhar, incentivar, apoiar, ouvir, debater, ler, esperar, e ficar. 
Para Marcella Soalheiro Cruz, in memoriam. 
Eu não espero pelo dia em que todos os homens concordem Apenas sei de diversas harmonias bonitas possíveis sem juízo final.

Caetano Veloso 


\section{Resumo}

Esta tese tem como objetivo a análise de fontes escritas nos contextos das missões jesuítas estabelecidas na corte mogol e no Tibete. Abordamos também a presença da Ordem em Bengala, tecendo relações entre esse espaço e as missões supracitadas. Nosso recorte cronológico cobre o período de 1570 até 1721, isto é, iniciamos nossas investigações na década que antecede o estabelecimento dos religiosos na corte de Akbar, e encerramos nossas análises no ano em que Ippolito Desideri deixa Lhasa. Concentramo-nos principalmente na questão da necessária relação entre as estratégias de conversão adotadas nessas missões e a (re) elaboração de categorias que indicassem e respaldassem o diálogo, a persuasão e o convencimento como os mais prudentes métodos catequéticos.

Palavras-chave:

Diálogos inter-religiosos - Companhia de Jesus - Missionação - Índia - Tibete 


\begin{abstract}
In this thesis, we aim to analyze written sources produced by jesuits stablished at the Mughal court and in Tibet. We shall also approach the presence of the Order in Bengal, weaving relations between this space and the aforementioned missions. Our chronological limits concerns the period from 1570 to 1721, i.e., we began our investigations in the decade preceding the establishment of the jesuits in Akbar's court, and resume our survey in Ippolito Desideri's last year in Lhasa. We focus mainly on the necessary relationship between the conversion strategies adopted in these missions and the (re) elaboration of categories that indicate dialogue and persuasion as the most prudent catechetical method.
\end{abstract}

Keywords:

Interfaith dialogues - Society of Jesus - Missionary Work - India - Tibet 
Advertência metodológica

Todas as obras citadas no corpo do texto desta tese foram por nós livremente traduzidas para o português. Sempre que possível, procuramos manter o texto original em nota de rodapé, salvo quando a obra foi escrita ou consultada em espanhol. No caso específico deste idioma, levando em conta sua semelhança com o português e as formas “aportuguesadas" que ele ganha nas fontes, optamos por manter apenas a tradução.

Para os casos das obras que não puderam ser consultadas no idioma em que primeiramente foram publicadas, mantivemos em nota a língua da edição utilizada.

Para o caso de grafias que demandavam caracteres de outros alfabetos, optamos por manter a transliteração trazida pela publicação de referência.

Citações bibliográficas secundárias, que surgem apenas em notas de rodapé, aparecem no idioma original, sem tradução. 


\section{SUMÁRIO}

Agradecimentos

Abstract

SUMÁRIO

Prólogo

Parte I

1. retórica e política: a atuação dialógica dos missionários da Companhia de Jesus na corte mogol (1580-1583)

1.1 a negociação do Império: a historiografia e o contexto histórico da consolidação da dinastia mogol no norte da Índia 22

$1.2 \mathrm{O}$ estabelecimento da soberania mogol no industão: akbar e a questão religiosa 27

1.3 De Bengala a Fatehpur: primeiros encontros entre Akbar e cristãos portugueses 36

1.4 A missão sob encomenda: Akbar convida os padres da Companhia de Jesus para Fatehpur Sikri

1.5 Diálogos improváveis, consenso impossível: as disputas religiosas na corte de um imperador muçulmano na Índia (1570-1605).

1.6 Conclusão 66

2. Da necessidade de se fazer ouvir à possibilidade de persuadir: a elaboração do tratado apologético Fonte de Vida 74

2.1 Fonte de Vida: o tratado apologético dirigido a Akbar, seu contexto de produção e sua função catequética 75

2.2 À sombra da escolástica: uma proposta de leitura da apresentação da fé cristã em modo de oração e da dedicatória da Fonte de Vida. 85 
2.3 O primeiro livro de Fonte de Vida e o tomismo: da segunda escolástica à necessidade de se fazer ouvir

2.4 Jerônimo Xavier e Franciso Suárez: um possível diálogo entre cristãos em um contexto não cristão.

2.5 A natureza de Deus e o problema da unidade: a querela da individualização a favor da evangelização.

Parte II

3. A primeira missão da Companhia de Jesus no Tibete

3.1 Do Mogol para o Tibete: a interiorização da presença da Companhia de Jesus na Ásia .114 3.2 A formação do Tibete dos lamas: contextualização política, econômica e religiosa (séculos XIII - XVII)

3.3 A questão da autoridade religiosa no Tibete no século XVII

3.4 Uma breve História da missão do Tibete, no reino de Gugê, fundada por Antônio de Andrade (séc. XVII) 133

3.5 A descrição do Tibete e dos tibetanos: a gênese de um projeto missionário para a terra dos lamas 142

3.6 Da descrição às estratégias: as disputas travadas com os lamas no Tibete 152

3.7 A "nova" descrição do Tibete e dos tibetanos: a rudeza do povo e a ruína da missão..... 165

3.8 Antônio Mendes e a defesa da missão: observação local e modelo global 171

3.9 Diálogo com gente branca, temor para gente rude: implicações políticas da retórica missionária para o caso do Tibete

4. a segunda missão da Companhia de Jesus no Tibete 
4.2 Breve História do rei protetor: Lajang Khan e o contexto político tibetano após a morte do

V Dalai Lama

4.3 O veneno e o antídoto: Desideri estabelece seu projeto missionário na terra dos lamas .197

4.4 Virtude, piedade e cegueira: as descrições de Desideri da sociedade tibetana

4.5 O Grande Lama, seu governo e os erros de sua seita: a questão da transmigração de almas como um problema religioso e político

4.5.1 Ponto 1: O Dalai Lama e o governo eclesiástico

4.5.3 Ponto 3: Erros da seita tibetana: construindo e desmontando o ateísmo tibetano 242

4.6 A escrita de Desideri, a elaboração da categoria gente cega e seu projeto de missão 250

5. Considerações finais 254

Apêndices 270

Apêndice A: Descrição do documento Mongolicae Lagationis Commentarius 271

Apêndice B: Tabela de missionários jesuítas que atuaram em Bengal 275

Apêndice C: Lista de missionários que atuaram em Bengala 276

Apêndice D: Descrição do documento Relação de Akbar 277

Apêndice E: Tabela de assuntos da correspondência Jesuíta da primeira missão no Tibete.. 280 Apêndice F: Tabela de assuntos principais de Notícia Histórica do Tibete 281

Apêndice G: Tabela de fontes identificadas no Arquivo Romano Societatis Iesu 282

Apêndice H: Sumário parcial dos documentos encontrados no Armário Jesuítico, livro 28, Arquivo Nacional da Torre do Tombo (ANTT), Lisboa, Portugal. 293 
Anexos

Anexo A: Mapa da Ásia, século XVI.

Anexo B: Mapa do Império Mogol e suas conquistas....

Anexo C: Verso da carta de Antônio de Andrdade de 1627

(ARSI GOA, ff: 51v)

Anexo D: Itinerário do missionário Antônio de Andrade

Anexo E: Itinerário do missionário Francisco Azevedo

Anexo F: Itinerários dos missionários Estêvão Cacela e João Cabral

Anexo G: Mapa das missões e suas respectivas províncias no subcontinente indiano, séculos XVI-XVIII.

Anexo "H”: Roteiro de Ippolito Desideri

Anexo I: Tradução, publicada por Vincent Smith, do decreto de 1579.

REFERÊNCIAS

fontes

Bibliografia 


\section{PRÓLOGO}

Em 1510, a ilha de Goa foi ocupada por portugueses. Dezesseis anos depois, o norte da Índia foi invadido por um exército do Afeganistão e da Ásia Central comandado por um turco chamado Babur (1483-1530), que viria a fundar a dinastia Mogol. A consolidação do Império Mogol viria com seu neto Akbar (1556-1605), responsável por uma nova expansão territorial de seus domínios. Além disso, o herdeiro de Babur promoveu importantes reformas estruturais de ordem social, política e cultural.

Através de comerciantes portugueses que "mordiscavam" a costa do subcontinente indiano, o chefe mogol tomou conhecimento do cristianismo. Akbar teve seu primeiro contato com portugueses em 1573, enquanto cercava o então sultanato de Guzarate, ao tratar com uma deputação chefiada por um certo Antônio Cabral.

Em 1576, quando, em Bengala, dois jesuítas se recusaram a absolver mercadores cristãos que tinham deixado de pagar impostos ao governo Mogol, Akbar decidiu convidar um padre, Julião (grafado também como Julianes ou Gileanes) Pereira, para ir à corte, em Fatehpur Sikri, aonde este chegou em março de 1579.

O padre, que não era jesuíta, participou de vários debates na presença do soberano, com o qual conversava frequentemente. Parece, no entanto, que Pereira era um homem mais virtuoso que culto e não teria sido capaz de responder de forma eficaz às questões demandadas pelo imperador. Akbar mandou então um embaixador à Goa com cartas ao vicerei, ao arcebispo e aos jesuítas pedindo que fossem enviados dois padres a sua corte.

Em 10 de novembro de 1579, uma comissão de bispos decidiu em favor da partida da missão. Os padres escolhidos foram Rodolfo Acquaviva, Antônio Montserrat e Francisco Henriques, sendo o último de origem persa, natural de Ormuz, e convertido do islamismo. Ele seria o intérprete da missão.

A partir desse primeiro convite, os jesuítas instalados na corte de Akbar travaram debates com representantes de outras religiões ao longo de pelo menos três missões: a de 1579-83, a de 1591-93 e a de 1595-1605. Mesmo com algumas turbulências e frustrações nem Akbar nem seu filho Jahangir (1605-1627) tornaram-se cristãos - era inegável a liberdade queos padres tinham para atuarem na região. 
Acreditamos, portanto, que, desde os tempos de Rodolfo Acquaviva, a missão mogol é entendida como um local privilegiado, um "porto seguro" no que, para os jesuitas, seria o coração do subcontinente indiano. Essa missão não teria apenas um fim em si mesma, mas seria a porta de entrada ou a "escada" para conduzir a cristandade ao centro da Ásia. Em função do franco espaço de debate religioso, os jesuítas ganharam segurança para se estabelecerem na Ásia a partir do Hindustão e resolvem investigar os rumores sobre cristandades ao norte, seguindo as rotas de mercadores e peregrinos.

Assim, do Mogol foram enviados missionários para intentarem uma interiorização da presença da Ordem no continente. Dentre os padres que partiram dessa missão rumo ao c entro do continente, podemos citar Bento de Gois e Antônio de Andrade. Góis viajou pela Ásia entre 1602-1607. O segundo fundou a missão do Tibete em 1626, que será objeto de nossa análise nesta tese.

Ainda que tais missões não tenham rendido os frutos esperados pela Companhia de Jesus - seja pela morte dos missionários (Estevão Cacela em Utsang, em 1631, e Andrade em Goa, em 1634), seja pelas turbulências políticas do período - a Ordem não chega a desistir definitivamente do Tibete.

O século seguinte foi marcado por intensas disputas entre os jesuítas e os capuchinhos, que receberam permissão da Propaganda Fide e aprovação do Papa Clemente XI, em 1703, para atuarem na região tibetana, em detrimento da participação jesuíta. Nesse mesmo ano, a Companhia de Jesus foi condenada por permitir que os chineses e indianos convertidos em suas missões mantivessem alguns de seus ritos e costumes. O episódio ficou conhecido como "Querela dos Ritos" e é um dos fatos centrais desse período considerado de declínio para a Ordem fundada por Loyola.

Nesse contexto, em 1712, o Geral da Companhia de Jesus, Michelangelo Tamburini (1648-1730) envia o italiano Ippolito Desideri ao Tibete. Tamburini havia sido investido como Geral 12 anos antes e foi um personagem fundamental no cenário de disputas entre ordens religiosas ao longo de sua vida. Curiosamente, o próprio Papa Clemente XI - o mesmo que garantira o "monopólio" capuchinho sobre o Tibete - abençoa a viagem de Desideri em uma audiência pouco antes de sua partida.

Desideri, então, parte como uma espécie de herdeiro de Andrade, sem, contudo, demonstrar se tinha de fato domínio sobre algumas informações da viagem do português. $\mathrm{O}$ roteiro do italiano, por exemplo, passa por Srinagar, na Caxemira - onde ele permanece algum tempo estudando persa - quando, na verdade, a cidade chamada Srinagar, descrita por 
Andrade, localiza-se na região de Garhwal, no atual estado indiano de Uttarakhand, sendo uma cidade diferente.

Já no final do século XVIII, em um contexto político e religioso bastante distinto, o Império Britânico envia um representante de Calcutá (Bengala) ao Tibete para, em audiência com o Panchen Lama, ${ }^{1}$ negociar sua mediação junto à China, com o objetivo de abrir o Império do Meio ao comércio inglês. Ainda que essa empreitada não seja objeto desta nossa pesquisa, é preciso dizer que, para a sua viagem, o funcionário da Coroa Britânica recorreu não só a guias locais como também às informações deixadas por jesuítas que séculos antes já haviam visitado o "teto do mundo".

Nesta tese, pois, dedicamo-nos ao estudo das missões acima elencadas, concentrandonos na questão das disputas como estratégia de conversão. Por estratégia, queremos dizer um conjunto de ações que visam um determinado fim: a evangelização e a conversão. Por conversão entendemos um processo de transição, de uma religião para outra, ou de uma ausência de confissão religiosa para a adoção de uma religião. Nos casos aqui tratados, a conversão significaria, mais especificamente, o reconhecimento e a aceitação da doutrina católica e da autoridade papal. ${ }^{2}$ Quanto a isso, também julgamos pertinente considerarmos a idéia de Koselleck, exposta em seu livro Futuro passado:

Todos são potencialmente cristãos - como destinatários da missão - mas, uma vez alguém se tendo convertido, ele já não pode mais voltar ao paganismo: passaria a ser um herege. Por isso, segundo Tomás de Aquino, era preciso proceder contra os hereges com um rigor ainda maior do que contra os judeus e pagãos, que se encontravam na ante-sala do caminho para Deus. $^{3}$

Nossa análise, portanto, está focada em debates e diálogos - que chamamos de disputas ficcionais ou disputas não ficcionais narradas- travados entre os missionários e religiosos muçulmanos ou budistas tibetanos. Objetivamos identificar e analisar tais estratégias, defendidas e postas em prática nas missões jesuítas, a partir da correspondência de

\footnotetext{
${ }^{1}$ TELTSCHER, K. The High Road to China: George Bogle, the Panchen Lama and the first British expedition to Tibete. Londres: Bloomsbury Press, 2006.

${ }^{2}$ Partimos de um entendimento de conversão próximo àquele proposto por Maijastina Kahlos. A autora faz questão de ressaltar uma distinção identitária entre um primeiro momento e o segundo. Após a conversão, segundo Kahlos, eu deixo de ser o que antes eu fui. "Conversion may be delineated as a process of transition from one religious or non-religious allegiance to another. [...] Conversion is depicted either as a gradual personal growth or a radical personal change. In any case, it entails changes in structures and contents of belifs.[...]What I was before I am no more." KAHLOS, M. Debate and Dialogue: Christian and Pagan Cultures. Aldershot: Ashgate, 2007, p. 83.

3 KOSELlECK, R. Futuro passado: contribuição à semântica dos tempos históricos. Rio de Janeiro: Contraponto / PUC-RJ, 2006, p. 215.
} 
tais missões e de obras escritas por missionários que lá atuaram. ${ }^{4}$ Visando a conversão destes religiosos, mas, principalmente, a do soberano ou representante do poder temporal local, estes embates discursivos foram um expediente adotado recorrentemente na corte do Imperador Akbar, no Mogol (sec. XVI-XVII), e nas missões tibetanas estabelecidas em Tsaparang (sec. XVII) e Lhasa (sec. XVIII). Os missionários dedicaram-se também, com base nesses encontros dialógicos, a compor narrativas, catecismos e tratados apologéticos que descreviam ou faziam referência a esses momentos, levando-os a um público que não estava presente às missões. Os debates, capturados pela escrita jesuíta, alcançariam outros leitores-ouvintes, talvez ali "perto” em Goa, ou quiçá em Lisboa ou Roma.

De forma sintética, nossos objetivos podem ser resumidos em dois problemas, desdobrados nas seguintes questões: (a) por que e como os jesuítas acomodaram ${ }^{5}$ os debates que já vinham sendo exercitados na corte mogol e nos espaços de cultura tibetana como Gugê e Lhasa, transformando-os em um expediente para convencer muçulmanos e budistas? De que maneira as disputas adquiriram o papel de estratégias de conversão?; e (b) uma vez transformados em narrativa, teriam esses diálogos funcionado como uma forma de descrever, interpretar e classificar mogóis e tibetanos? Em outras palavras: podemos entender o relato desses debates como uma espécie de predicado, cuja função é categorizar, classificar e reiterar expressões como homens de razão, gente de cor branca, gente pia ou gente cega?

Quanto à primeira questão, nossa hipótese é de que os jesuítas se aproveitaram do contexto de reestruturação política-ideológica em curso na corte mogol, modificando a finalidade de dois processos religioso-culturais ícones dessa reestruturação. $\mathrm{O}$ primeiro processo que os missionários buscaram acomodar foi o ciclo de debates que ocorria na 'Ibādatkhānah ("Casa de adoração" ou "Casa de culto"). O segundo processo, no qual os jesuítas também tomaram parte, diz respeito à tradução de obras para o persa e à produção de comentários sobre essas obras. ${ }^{6}$ Do ponto de vista jesuíta, em ambos os casos, a ideia seria participar dos debates e dos trabalhos de produção de obras escritas sem, contudo, compartilhar do mesmo objetivo final. Se, para Akbar, estava em jogo a (re)elaboração de um

\footnotetext{
${ }^{4}$ Tais obras compunham o que genéricamente se denomina "ministério da palavra": "Jesuits histories and information concerning mission territories, often entitled as Sumário, Relação, Informatio, Apologia etc, were an integral part of what is called Jesuit "ministries of the word", defined broadly as preaching, teaching, sacred conversation, confession, and writing ans publishing edifying as pastoral literature". Cf: ZUPANOV, I. Jesuit Orientalism: Correspondence between Tomas Pereira and Fernão de Queiros. In: BARRETO, L. Tomás Pereira, S. J. (1646-1708), Life, Work and World. Lisboa: Centro Cultural e Cientifico de Macau, 2010, p. 4374.

${ }^{5}$ ZUPANOV, I. Accommodation. In: AZRIA, R.; HERVIEU-LEGER, D. Dictionnaire des fais religieux, Paris: PUF, 2010, p. 1-4.

${ }^{6}$ Cf: GANERI, J. The Lost Age of Reason: Philosophy in Early Modern India 1450-1700. Oxford: Oxford University Press, 2011.
} 
discurso que justificasse sua soberania política sobre um universo heterogêneo de "súditos", para os missionários esta finalidade fora modificada: o que estava em questão era a conversão das almas, em especial a do próprio Imperador.

Trabalhamos com uma hipótese análoga para o caso das missões tibetanas. Propomos que, no século XVII, os primeiros jesuítas que se estabeleceram em Tsaparang procuraram tirar algum proveito das tensões entre os monges e o régulo do Gugê. Com estratégias que visavam desacreditar os lamas e favorecer o soberano, os jesuítas empenharam-se em disputas verbais que seriam posteriormente narradas em cartas aos seus superiores da Ordem.

Quanto à segunda questão, nossa hipótese é que, uma vez transformados em narrativa, esses diálogos passaram a ter um valor predicativo. A apropriação escrita das falas dos "outros" passa a ter a função de descrever, interpretar e classificar mogóis e tibetanos. Procuramos demonstrar, ao longo desta tese, como essas (supostas) falas ganham valores análogos a expressões usadas para descrever sociedades e comunidades com as quais os missionários travaram contato. Tais categorias - elaboradas a partir das observações e descrições que os missionários realizaram sobre os povos encontrados, sua cultura, sua organização social e política, e, evidentemente, suas "seitas" - foram fundamentais para a escolha e o emprego da estratégia de conversão mais prudente e eficaz para cada caso. Assim, complementares às chamadas estratégias de conversão, estes conceitos-chave elaborados no contexto do chamado ministério da palavra, podem ser também denominados de estratégias epistemológicas ou representacionais. ${ }^{7}$

Nossa tese está dividida em duas partes. Na primeira delas, dedicamo-nos à análise das missões estabelecidas na Índia Mogol. Na segunda parte, tratamos das iniciativas da Ordem no Tibete, em Tsaparang e em Lhasa.

Em nosso primeiro capítulo, analisamos a obra produzida no final do século XVI por um jesuíta que fora enviado à corte mogol na primeira tentativa da Companhia de Jesus de lá estabelecer uma missão. O religioso chamava-se Antônio Montserrat, era Catalão, e, à época, tinha 43 anos. Chegou à cidade de Fathepur Sikri em fevereiro de 1580. A obra em questão chama-se Mongolicae Legationis Commentarius. ${ }^{8}$ Daremos enfoque principal aos diálogos

\footnotetext{
${ }^{7}$ Cf: ZUPANOV, I. Jesuit Orientalism; Correspondence between Tomas Pereira and Fernão de Queiros, In: BARReto, L. Tomás Pereira, S. J. (1646-1708), Life, Work and World, ed., Lisboa: Centro Cultural e Cientifico de Macau, 2010, p. 43-74.

${ }^{8}$ MONTSERRAT, A. Mongolicae Lagationis Commentarius. Texto integral, em latim: HOSTEN, H. (Ed.) Mongolicae Lagationis Commentarius. Memoirs of the Asiatic Society of Bengal, Calcutá, vol. III, n. 9, p. 518704, 1914; MONTSERRAT, A. Ambaixador a la cort del Gran Mogol: Viatges d'um Jesuïta Català Del segle XVI a l'India, Pakistan, Afganistan, Himalaia. Edição e tradução Josep Lluis Alay. Lleida: Pagès, 2002. Esta é uma edição contemporânea, em catalão, que se apresenta como uma tradução integral do "Commentarius".
} 
descritos pelo jesuíta nesse seu relato e teremos como objetivo localizar os religiosos cristãos nos debates promovidos por Akbar na 'Ibādatkhānah, contextualizar sua atuação e analisar suas estratégias.

No segundo capítulo, daremos continuidade à análise da atuação dos missionários da Companhia de Jesus no Mogol. Seguiremos nossas investigações acerca dos aspectos dialógicos das estratégias de conversão, abordando como foco principal a análise da obra Fonte de Vida, escrita pelo missionário Jerônimo Xavier, nascido em Navarra, no ano de 1549. ${ }^{9}$ Nossa hipótese é que essa obra pode ser entendida como uma adaptação jesuíta de um processo que se iniciava na corte de Akbar, o qual era caracterizado pela tradução para o persa de obras sagradas de outras religiões que não o islamismo.

Procuraremos defender a ideia de que Fonte de Vida, escrita em forma de diálogo, é uma espécie de refinamento das estratégias anteriores. Nessa obra, os debates não aparecem descritos em referência direta às audiências promovidas por Akbar e, portanto, se apresentam estritamente como um gênero literário a serviço dos objetivos principais dos missionários: a evangelização e a conversão.

$\mathrm{Na}$ segunda parte de nossa tese, abordaremos as missões jesuítas no Tibete. No terceiro capítulo, teremos como objeto a primeira missão, estabelecida em Tsaparang por Antônio de Andrade (1624-35). A principal questão é, mais uma vez, a relação entre as disputas como estratégias de conversão e o delicado contexto político em que se encontravam régulos tibetanos e monges budistas. Os primeiros viam o clero crescer em ritmo acelerado e acompanhavam os passos da escola Gelupa rumo à hegemonia político-religiosa. Os últimos, em represália, sofriam perseguições que muitas vezes culminavam em sua laicização forçada. Vale lembrar que o Tibete, nesse período, não era um Estado teocrático, e que, portanto, a figura centralizadora do Dalai Lama ainda não existia enquanto representante dos poderes temporais e espirituais.

Como fontes, utilizamos nesse capítulo as cartas jesuítas relativas a essa primeira iniciativa da Ordem no "teto do mundo". Esses relatos têm, no contexto do nosso presente trabalho, um duplo papel: o de nos apresentar descrições dos budistas tibetanos associadas a

Utilizaremos principalmente a sua tradução em espanhol, Embajador en la corte del Gran Mogol, feita por Ramon Sala e publicada em 2006 pela Editorial Milênio; A obra possui ainda uma tradução em inglês: HOYLAND, J.S.; BANERJEE, S.N. The commentary of father Montserrat on his journey to court of Akbar. Mahindra College, Patiala. Londres: Humphrey Milford, Oxford University Press, 1922. Todos os trechos dessa fonte presentes nesta tese foram traduzidos livremente do catelhano para o português. Para descrição detalhada desse documento, bem como a indicação das traduções e publicações utilizadas nesta tese, favor consultar o apêndice "A" ao final desta tese.

${ }^{9}$ XAVIER, J. Fuente de Vida: Tratado apologético dirigido al Rey Mogol de la Índia en 1600. San Sebastián: Universidad de Deusto, 2007. 
indicações de estratégias de conversão utilizadas e o de testemunhar os últimos anos de um Tibete laico, no período entre 1620 e o ano de investimento do V Dalai Lama (1642).

Por último, tomaremos como objeto, em nosso quarto capítulo, a missão conduzida pelo jesuíta italiano Ippolito Desideri já nas primeiras décadas do século XVIII. Evidentemente, estamos atentos às grandes diferenças que esse intervalo de tempo pode encerrar em si, em especial no que toca a perda de espaço da Companhia de Jesus nos planos missionários da Igreja, além das consequências das chamadas "Querelas dos ritos". Mas, por outro lado, acreditamos que nossa última análise pode ser construída justamente a partir da observação dessas conjunturas associadas ao percurso feito pela Companhia de Jesus nas "Índias".

Desideri estabeleceu-se em Lhasa, entre 1717 e 1721 . O missionário escreveu a obra intitulada Notícia Histórica do Tibete, composta por quatro livros, dos quais selecionamos prioritariamente para análise alguns capítulos que abordam mais especificamente os temas tratados em nossa tese. ${ }^{10}$ Focaremos nas descrições de Desideri da "seita dos lamas" e suas implicações políticas, em especial no que diz respeito ao protocolo de sucessão dos Dalai Lamas. Desenvolveremos nossa análise com a finalidade de apresentar como a elaboração da categoria "gente cega" e sua aplicação para o caso dos tibetanos foi construída mediante a observação da organização sócio-política daquela sociedade, constituindo-se como etapa fundamental para apontar o convencimento e o diálogo como as mais prudentes estratégias de conversão e catequese para o caso da missão no Tibete.

\footnotetext{
${ }^{10}$ Organizamos uma tabela com os principais temas tratados na Notícia Histórica do Tibete, redigida por Ippolito Desideri. Consultar apêndice "F" ao final desta tese.
} 


\section{PARTE I}

Just consider how terrible the day of your death will be Others will go on speaking and you will not be able to argue back.

Ram Mohan Roy

Que de donde nos nace la necessidad de hablar, de ahí nos viene la possibilidad. Dos cosas mueven a hablar y hablar alguna cosa: el bien que ella tiene en si y los bienes y provechos que della salen.

Jerônimo Xavier, S.J. 
1. RETÓRICA E POLÍTICA: A ATUAÇÃO DIALÓGICA DOS MISSIONÁRIOS DA COMPANHIA DE JESUS NA CORTE MOGOL (1580-1583) 


\subsection{A NEGOCIAÇÃO DO IMPÉRIO: A HISTORIOGRAFIA E O CONTEXTO HISTÓRICO DA} CONSOLIDAÇÃO DA DINASTIA MOGOL NO NORTE DA ÍNDIA

Movimento: palavra que bem descreve o contexto asiático no século XVI. ${ }^{11}$ Povos, produtos, culturas, formas de pensar e religiões disseminavam-se. Nesse período, os mogóis descendentes do conquistador mongol do século XII Gengis Khan e do turco-mongol Timur (séc. XIV-XV) - se estabeleceram na Índia. Apresentavam-se, a princípio, como mais um "elemento estrangeiro" no cenário político do norte do subcontinente indiano, seguindo as investidas de turcos e afegãos nos séculos anteriores. A vitória de Babur na batalha de Panipat, em 1526, deixava ainda mais complexa a dinâmica de disputas políticas na região e apontava para a ruína do sultanato de Delhi. Akbar, neto de Babur, estenderia os territórios do Indostão mogol às duas costas do subcontinente indiano e moldaria a Índia posteriormente conhecida pelos europeus. ${ }^{12}$

Akbar nasceu em 1542. No trono desde 1556, seus anos de governo são conhecidos como um período de profundas mudanças, que alicerçaram o poder da dinastia Mogol na Índia. Akbar deu continuidade à expansão territorial iniciada pelo avô e seus exércitos chegaram a Surat em 1572 e a Bengala em 1575-6. Depois de expandir seu domínio à Cachemira (1586), ao Sind (1591) e ao Decão (1601), morreu em 1605, sendo sucedido por seu filho Jahangir.

Por décadas, a historiografia debateu o Império Mogol e seu governo. A natureza do poder político, especialmente do período dinástico entre os governos de Akbar e de seu bisneto Aurangzeb, pode ser elencada como um dos principais temas tratados em História da Índia recentemente. "Com relação a essa problemática, encontramos hipóteses que vão de um elogio nostálgico às realizações [mogóis]" a "visões menos laudatórias, reivindicando o caráter opressivo e despótico desses governos." 13 Por algum tempo, "centralização" e

\footnotetext{
${ }^{11}$ Ver mapa em anexo "A".

${ }^{12}$ Ver mapa em anexo "B".

13 "Regarding this problem, we find hypotheses that range from nostalgically lauding their achievements in terms of both culture and material life, [while] others claiming that they always been an oppressive and despotic presence." ALAM, M.; SUBRAHMANYAM, S. Writing the Mughal World: Studies on Culture and Politics. Nova Iorque: Columbia University Press, 2012, p. 3. A introdução desse livro, sob o título de "The Old and New in Mughal Historiography", desenvolve importantes ideias sobre a historiografia indiana, em especial a chamada "Escola Aligarh" ("Aligarh School") e a guinada cultural ("cultural turn") de nossos dias.
} 
"burocracia" foram conceitos-chave em detrimento de, por exemplo, "religião" ou "ideologia". 14

Porém, especialmente após os anos 2000, identificamos um crescente interesse em relação à escolha do tema "religião" como objeto de estudo. "Ficou claro que o retrato da atitude religiosa da elite mogol precisaria de um exame mais detalhado." ${ }^{15}$ Essa guinada cultural, como enfatizada por Alam e Subrahmanyam, é justamente o ponto inicial de nosso trabalho.

Assim, neste primeiro capítulo, apresentaremos o processo no qual o imperador mogol Akbar patrocinou instituições culturais que se transformaram em instrumentos de seu projeto político. Propomos que tais instituições buscaram elaborar e reafirmar - ideologica e discursivamente - sua soberania política há pouco conquistada por seus exércitos.

Evidentemente, não temos como nosso objeto uma "História da Índia". Apenas focamos nas missões jesuítas, não tendo interesse em aprofundar um debate historiográfico. Para isso, tomaremos como referência central a concepção de Audrey Truschkey acerca da corte mogol: tratou-se de um espaço multilíngue no qual inúmeros intercâmbios culturais se deram. Tais trocas surgiram como consequência do encontro de duas tradições cosmopolitas que vieram a conviver em um mesmo espaço e que são sintetizadas em seus respectivos idiomas: o persa e o sânscrito. ${ }^{16}$ Dessa forma, a corte mogol foi cenário de negociações sociais, políticas e estéticas, que concorreram para a criação de um Império. ${ }^{17}$

A autora propõe ainda que eventos literários, envolvendo as tradições persa e sanscrítica, e a rede na qual tais eventos encontravam-se circunscritos são fundamentais para a compreensão não só da construção do poder da soberania mogol, mas também indispensáveis para o entendimento da História cultural da Índia moderna. Tais eventos, portanto, são decisivamente constituintes do processo de negociação no qual dois grupos culturais

\footnotetext{
${ }^{14}$ Cf: Ibidem, p. 22. Também podemos citar Ebba Koch por sua síntese perspicaz e eficiente em relação a essa temática: "The Aligarh scholars, moreover, have concentrated on economic and administrative issues and have viewed cultural and social studies (including art history) with reserve; thus some of the richest contributions of the Mughals are still insufficiently understood." KOCH, E. Jahangir as Francis Bacon's Ideal of the King as an Observer and Investigator of Nature. Journal of the Royal Asiatic Society, v. 19, n. 3, p. 297, 2009. Disponível em <http://journals.cambridge.org/abstract_S1356186309009699>.

15 "It became clear that the received portrayal of the Mughal elite's religious attitudes was in need of closer examination." ALAM, M.; SUBRAHMANYAM, S. Writing the Mughal World: Studies on Culture and Politics. Columbia University Press, 2012, p. 27.

16 Nesse momento, optamos por fazer uso dessas categorias linguísticas em detrimento da dicotomia muçulmanos versus hindus. Cf: TRUSCHKE, A. Cosmopolitan encounters: Sanskrit and Persian at the Mughal Court. Tese de doutorado inédita. Columbia University, 2012.

${ }^{17}$ “Mughal India provides a particular case study of how kings and poets alike dynamically mobilized the aesthetics and political resources of multiple traditions in order to further their intertwined literary, intellectual, and imperial interests." Ibidem, p. 3.
} 
dominantes elaboravam seus papeis estéticos, sociais e políticos. ${ }^{18}$ Assim sendo, nosso principal objetivo aqui é localizar a missão jesuíta nesse contexto, estabelecendo como tal cenário de negociação viabilizou a iniciativa catequética da Companhia de Jesus, tornando a missão possível. Além disso, objetivamos mostrar como os religiosos católicos buscaram adaptar esse processo político aos seus próprios objetivos, fazendo uso das instituições incentivadas e patrocinadas pela administração mogol.

A participação dos jesuítas nesse cenário nos remete à ideia de usus iuris, tal qual apresentada por Maijastina Kahlos em sua obra. Acreditamos que tal conceito aproxima-se da ideia de acomodação que nos guiará ao longo de nossa análise. A questão posta pela autora gira em torno do entendimento de conversão como renúncia de um passado em nome de um novo presente. Nesta oposição binária entre "antes" e "depois", ${ }^{19}$ o cristianismo nunca chegou a uma conclusão sobre quão radical deveria ser esta renúncia. Ainda que a Kahlos trate dos primeiros séculos de aparecimento da religião crista, é possível tecer relações entre o momento tratado por ela e aquele aqui analisado.

Em primeiro lugar, em ambos os casos o cristianismo é uma religião não hegemônica - até mesmo marginal - que busca se estabelecer em oposição às tradições anteriores, sejam politeístas (paganismo) ou monoteístas (judaísmo). Em segundo lugar, esta medida entre o que deve ser aceito e o que deve ser rejeitado ou interditado está em discussão durante os séculos XVII e XVIII. Em terceiro lugar, e é isso que principalmente importa em nossa análise, é que, segundo a autora, para este dilema "uma das soluções que os pais da Igreja ofereceram foi o "uso correto". (...) No uso correto, o que era crucial não seria quais textos seriam lidos (...), mas sim como a literatura seria lida." ${ }^{20}$ Propomos, portanto, que a participação dos jesuítas nos debates - e no processo de tradução promovido por Akbar parte do princípio de usus iustus, isto é, de aproveitar-se de uma tradição, de um traço cultural, ou mesmo de uma circunstância, e modificar sua finalidade, adaptando-a aos seus próprios interesses e adequando-a ao que previa a doutrina cristã.

\footnotetext{
18 "The network in which they [the literary events] were embedded are critical to understanding both the construction of power in Mughal rule and early modern Indian cultural history. These interactions are not mere curiosities in the literary landscape of South Asia. Rather, they are crucial moments when North India's two dominant cultures negotiated their aesthetic, social and political roles." TRUSCHKE, A. Cosmopolitan encounters: Sanskrit and Persian at the Mughal Court. Tese de doutorado inédita. Columbia University, 2012, p. 2.

${ }^{19}$ Nas palavras da autora: "formely" e "now". KAHLOS, M. Debate and Dialogue: Christian and Pagan Cultures. Aldershot: Ashgate, 2007, p. 85.

20 "One of the solutions that church fathers offered was the 'right use' (usus iustus). (...) In the right use, what was crucial was not which texts were read (...) but reather how literature (...) was read". KAHLOS, M. Debate and Dialogue: Christian and Pagan Cultures. Aldershot: Ashgate, 2007, p. 87. Grifos da autora.
} 
Além disso, em consonância, com aquilo proposto por Sanjay Subrahmanyam, acreditamos que dois elementos do contexto político mogol nomeados pelo autor possibilitaram a missão jesuíta: a interação entre (a) as mudanças na ideologia e na política interna; e (b) o contexto mais amplo de alianças internacionais, no qual portugueses e mogóis inseriam-se, ora em conflito, ora buscando alguma coligação. Esse cenário internacional concernia, ainda, otomanos e safávidas. ${ }^{21}$

Em nenhum momento de nossa tese reivindicamos qualquer protagonismo político ou religioso dos jesuítas. Nem nos posicionaremos em debate acerca de uma suposta primazia persa sobre as demais tradições, ou vice-versa. No entanto, nos opomos à ideia de que "o entusiasmo do imperador Akbar pelas traduções para o persa do Evangelho foi uma idiossincrasia que foi rapidamente esquecida. ${ }^{, 22} \mathrm{Na}$ verdade, nós supomos que tal “entusiasmo" relacionava-se com um profundo e articulado processo politico e cultural.

Passemos, pois, a identificação e nomeação das instituições mencionadas anteriormente. Em seu trabalho, Audrey Truschkey aponta duas delas que agiram como facilitadoras de diferentes intercâmbios culturais na corte mogol: a 'Ibādatkhānahe a Maktabkhana. ${ }^{23}$ A primeira, refere-se aos debates públicos que ocorriam em presença do imperador. A segunda, que pode ser entendida como uma espécie de "oficina de textos", relaciona-se com a produção escrita patrocinada por Akbar. Tais obras incluíam traduções do sânscrito, turco e árabe para o idioma persa. ${ }^{24} \mathrm{~A}$ proposta da autora é que devemos tomar tais traduções como instrumentos de legitimação do poder politico na Índia mogol. Segundo Truschke, eles foram fundamentais para a elaboração de mecanismos e estruturas de autoridade na gênese da Índia moderna. ${ }^{25}$

\footnotetext{
${ }^{21}$ Os termos, na obra de Subrahmanyam, são:"interaction between domestic political and ideological shifts" e "the wider system of international political alliances". SUBRAHMANYAM, S. Explorations in connected history: Mughals and Franks. Nova Deli: Oxford University Press, 2005, p. 67.

22 "Emperor Akbar's enthusiasm for Persian translations of the Gospels was an idiosyncrasy which was quickly forgotten." POWELL, A.A. Muslims and missionaries in pre-mutiny India. Londres: Rpoutledge Curzon, 2003, p. 24.

23 "Within the court, several institutions facilitated different types of cross-cultural contacts. For example, scholars have often concentrated on Akbar's house of religious debate (Ibadahtkhanah) that was established in the mid-1570s. We remain unclear how long dialogues continued in the Ibadahtkhanah proper, but religious discussions involving Muslims, Brahmans, Christians, and Jains persisted at least into Jahangir's reign." TRUSCHKE, A. Cosmopolitan encounters: Sanskrit and Persian at the Mughal Court. Tese de doutorado inédita. Columbia University, 2012, p. 10.

${ }^{24}$ Uma proposta um pouco diferente pode ser encontrada na análise de Muzafar Alam. Ele afirma que o persa se tornou a língua do poder na Índia mogol. Devido a essa declaração e suas consequências para pesquisas nessa área, recomendamos seu trabalho "The languages of political Islam in India", Permanent Black, 2004. Para outras interpretações um tanto opostas, consulte TRUSCHKE, A. Cosmopolitan encounters: Sanskrit and Persian at the Mughal Court. Tese de doutorado inédita. Columbia University, 2012.

25 Ibidem, p. 18.
} 
Nossa tese propõe, portanto, que os missionários jesuítas tiveram participação nas duas instituições. Nós podemos encontrá-los nos debates que ocorriam na 'Ibādatkhānahe também sabemos que eles protagonizaram a tradução de livros sagrados cristãos para o persa, bem como produziram catecismos e tratados apologéticos nesse idioma.

Arnuf Camps, por exemplo, lista uma série de textos persas produzidos no contexto das missões da Companhia de Jesus no Mogol. Dentre eles, destacamos Fonte de Vida, cujo título em persa é A'ina-yi haqq-numa. Em inglês, esse texto é conhecido como The truth showing mirror. ${ }^{26}$ Camps, referindo-se ao missionário Jerônimo Xavier, afirma que "ao escrever seus trabalhos religiosos e filosóficos, Jerônimo Xavier tentou fornecer [a Akbar e a seu filho Jahangir] informações confiáveis sobre a Cristandade e Filosofia Ocidental." ${ }^{27}$ Esse mesmo autor nos informa ainda que não está claro se Fonte de Vida foi escrito originalmente em portugês ou espanhol, antes de ser traduzida para o persa. ${ }^{28}$ No que diz respeito à participação dos missionários nos debates da Ibadakhanah, nossa análise baseia-se principalmente na narrativa escrita por outro missionário da mesma Ordem, chamado Antônio de Montserrat. Essa obra, intitulada Mongolicae Legationis Commentarius, será analisada no capítulo seguinte.

No que diz respeito à nossa hipótese de participação dos jesuítas em Maktabkhana, analisaremos a obra Fonte de Vida no capítulo subsequente de nossa tese.

\footnotetext{
${ }^{26}$ XAVIER, J. Fuente de Vida: Tratado apologético dirigido al Rey Mogol de la Índia en 1600. San Sebastián: Universidad de Deusto, 2007.

27 "By writing his religious and philosophical works, Jerome Xavier tried to supply [Akbar and his son Jahangir] with reliable information about Christianity and Western Philosophy". CAMPS, A. Studies in Asian Mission History. Leiden, Boston, Köln: Brill, 2000, p. 45. Alguns títulos listado por Camps: Maqulat-i Plutarku (Ditos de Plutarco); Sharh-i bina-yi ruma wa zikri padshaha-i u (A História da fundação de Roma e um relato de seus reis); Ba'zi muqaddamati-i Marku Tuliu (Algumas palavras de Marco Túlio); Bayan-i Iman-i 'Isawiyan (Explicação da fé dos cristãos); Zabur (Os salmos de David); Dastan-i ahwal-i hawariyan-i hazrat-i 'isa wa zikri manaqib-i Ishan (História das vicissitudes dos apóstolos e do Senhor Jesus, e suas virtudes). Todos os títulos entre parênteses foram traduzidos livremente a partir da tradução para o inglês feita pelo autor.

${ }^{28}$ CAMPS, A. Jerome Xavier S.J. and the Muslims of the Mogul Empire. Fribourg: Schonbeck-Beckenried (Nouvelle Revue de Science Missionnaire), 1957. Apud: DIDIER, H. Introducción al tratado Fuente de Vida. In: XAVIER, J. op.cit., p. 50
} 


\title{
1.2 O ESTABELECIMENTO DA SOBERANIA MOGOL NO INDUSTÃO: AKBAR E A QUESTÃO
}

\author{
RELIGIOSA
}

\begin{abstract}
Nesse momento, quando o centro do Califado [Fatehpur Sikri] foi glorificado com o advento de Sua Magestade, as antigas instituições eram renovadas e o templo do conhecimento Divino era iluminado às quintasfeiras pela luz da mente sagrada. Em 20 Mihr, mês Divino, 3 de outubro de 1578, e em tal casa de adoração ['Ibādatkhānah], a luz da sala particular do desapego estava acesa no hall de banquetes da vida social. A moeda dos tremores de sabedoria em faculdades e celas eram testados. $\mathrm{O}$ vinho puro era separado das borras, e as moedas verdadeiras das adulteradas. A capacidade imensa e a tolerância da Sombra de Deus foram descobertas. Sufistas, filósofos, oradores, juristas, sunitas, xiitas, brâmanes, jatis, siuras, carvacas, ${ }^{29}$ nazarenes, ${ }^{30}$ judeus, sabeus zoroastrianos, entre outros, gozaram do prazer maravilhoso de testemunhar a calma da reunião, a tomada de assento do senhor do mundo no púlpito nobre [mimbar] e os adornos da agradável morada da imparcialidade. Os tesouros de segredos foram revelados sem o medo de caçadores hostis após uma batalha. Aqueles que são justos e buscam a verdade em cada seita emergiram da arrogância e da prepotência, $e$ iniciaram uma nova busca. ${ }^{31}$
\end{abstract}

Em meio à ampliação de seus domínios, que se estendiam de uma costa à outra do subcontinente indiano, Akbar ordenou a edificação de um prédio que seria destinado a receber sábios para uma série de debates públicos. O prédio, erigido na cidade de Fatehpur Sikri,

${ }^{29}$ Carvaka é um ramo da filosofia indiana, também conhecida como Lokayata. É marcada por sua posição materialista e cética, refutando a existência da alma, do karma e da existência após a morte. Sobre esse assunto, sugerimos a leitura de: CHATTOPADHYAYA, D. Lokayata: A study in ancient Indian materialism. Deli: People's Publishing House, 1959; GANERI, J. The Hindu Syllogism: Nineteenth-Century Perceptions of Indian Logical Thought. Philosophy East and West, v. 46, n 1, 1996, p. 1-16.

${ }^{30}$ Termo utilizado para identificar os cristãos.

31، At this time, when the centre of the Caliphate [Fatehpur Sikri] was glorified by H. M.'s advent, the former institutions were renewed, and the temple of Divine knowledge was on Thursday nights illuminated by the light of the holy mind. On 20 Mihr, Divine month, 3 October 1578, and in that house of worship ['Ibādatkhānah], the lamp of the privy chamber of detachment was kindled in the banqueting-hall of social life. The coin of the hivers of wisdom in colleges and cells was brought to the test. The clear wine was separated from the lees, and good coin from the adulterated. The wide capacity and the toleration of the Shadow of God were unveiled. Sufi, philosopher, orator, jurist, Sunni, Shia, Brahman, Jati, Siura, Carbak, Nazarene, Jew, Sabi, Zoroastrian, and others enjoyed exquisite pleasure by beholding the calmness of the assembly, the sitting of the world-lord in the lofty pulpit [mimbar], and the adornment of the pleasant abode of impartiality. The treasures of secrets were opened out without fear of hostile seekers after battle. The just and truth-perceiving ones of each sect emerged from haughtiness and conceit, and began their search anew." FAZL, A. The Akbarnāma of Abu-l-Fazl, a history of the reign of Akbar including an account of his predecessors. Tradução H. Beveridge. Calcutá: Asiatic Society, 1910-1939. Tradução nossa. Grifos nossos. Disponível em: <http://persian.packhum.org/persian/main?url=pf\%3Ffile\%3D00701023\%26ct\%3D0>.

Esse trecho foi retirado da obra Akbarnama, a "História oficial" do governo de Akbar escrita por Abul Fazl. Em seus três volumes, Fazl descreveu as principais conquistas de Akbar, os eventos anuais mais importantes, cerimônias etc. 
ficou pronto em 1576. Os debates passaram a acontecer todas as quintas-feiras à noite e algumas vezes se estendiam até a manhã do dia seguinte. ${ }^{32}$ Dois anos mais tarde, as discussões, que até então eram conduzidas apenas por religiosos sunitas muçulmanos, passaram a ser abertas para sacerdotes de diversas religiões.

Em busca de uma interpretação histórica sobre a construção e a consolidação do Império Mogol, o historiador indiano M. Althar Ali, em um artigo publicado em 1978, buscou identificar quais teriam sido os novos elementos políticos a partir dos quais Akbar conseguiu consolidar tão larga, estável e duradoura estrutura política. ${ }^{33}$ A hipótese desenvolvida pelo autor ao longo do artigo é a de que Akbar conseguiu implementar uma nova base teórica para a sua soberania, aliada a uma equilibrada e estável composição das classes governantes.

Em relação a este último fator, o autor explica como funcionou o sistema chamado de Mansabdar, que, em linhas bem gerais, pode ser descrito como uma sistematização administrativa que classificava e categorizava a "aristocracia" ou a "nobreza" no Indostão. Essa espécie de classificação ou hierarquização, cuja complexidade não seríamos capazes de explicar sob pena de desviarmos por demais de nosso objeto principal, significou uma profunda reestruturação sociopolítica, administrativa e até mesmo tributária, na medida em que atribuía novos "lugares sociais" aos indivíduos que compunham a aristocracia do Império Mogol.

Podemos dizer, portanto, que a reestruturação administrativa conduzida por Akbar sistematizou e reorganizou os arranjos sociais no Indostão, mas, principalmente, redefiniu as relações entre os nobres e o imperador.

Ao lado dessas intervenções administrativas, Akbar tomou outras medidas que viriam a estabelecer novas bases teóricas para a sua à soberania. Se, por um lado, a nova organização social compunha uma nova nobreza, por outro, a religião - ou, melhor dizendo, a autoridade espiritual - passou a ser um componente fundamental para a consolidação da autoridade temporal no Mogol.

No entanto, o problema político causado pelo que Ali chamou de nova base teórica para a soberania de Akbar, curiosamente, não era uma questão de todo estranha aos europeus

\footnotetext{
32 REZAVI, S.A.N. Religious disputations and Imperial Ideology: The purpose and Location of Akbar's Ibadatkhana. Studies in History, Los Angeles, Londres, Nova Deli, Cingapura, v. 24, n. 2, p. 199, 2008.

33 "What, then, were the new elements of political chemistry out of which Akbar compounded such a large, stable, long lasting political structure? At the risk of over-simplification, I would say that these were an extreme systematization of administration, a new theoretical basis for sovereignty, and a balanced and stable composition of the ruling classes." ALI, M. A. Towards an Interpretation of the Mughal Empire, p. 40. The Journal of the Royal Asiatic Society of Great Britain and Ireland, Cambridge University Press, n. 1, p. 40, 1978. Disponível em: <http://www.jstor.org/stable/25210917>.
} 
no século XVI. Mais do que isso, na Europa impactada pelas 95 Teses de Lutero ${ }^{34}-$ e, consequentemente, agitada por movimentos político-religiosos como a Reforma e a Reforma Católica - o tema da natureza do poder político, a questão da governabilidade e o conflito existente na relação entre poder temporal e poder espiritual tornaram-se objetos de vasta produção intelectual. ${ }^{35}$

Como tratamos aqui de questões relativas à missionação jesuíta, é pertinente apontarmos algumas ideias deum filósofo da Ordem chamado Francisco Suárez. Suárez nasceu em Granada, na Andaluzia, em 1548, sendo um dos grandes nomes do movimento convencionalmente chamado de Segunda Escolástica. O filósofo produziu obras teológicas, de direito e de conteúdo metafísico, isto é, trabalhos a princípio estranhos a debates e querelas políticas. No entanto, em função de sua importância, tais escritos também serão pontualmente citados para referenciar questões filosóficas e doutrinárias em momentos nos quais tais questões passam a ganhar peso nas estratégias de conversão dialógicas utilizadas pelos jesuítas na corte mogol. ${ }^{36}$ Fazemos referência principalmente à chamada Querela da Individualização. Evidentemente, não é possível afirmar que os missionários na corte de Akbar leram os escritos de Suárez, principalmente por esses serem contemporâneos ou mesmo posteriores, em alguns casos. Assim, o que nos interessa aqui é a dupla contextualização do universo da missão e das polêmicas na Europa, e por isso escolhemos Suárez como uma espécie de índice para esses debates.

Das ideias políticas do autor que irão permear esta tese, elencamos algumas elementares: (1) o Estado tem sua origem necessariamente na natureza social e política do homem; (2) a Ratio Societatis é produzir uma estrutura estável, segura e justa (pax e justitia), de forma a viabilizar a realização das potências humanas, especialmente a mais alta de todas: glorificar a Deus; (3) a autoridade política é consequência necessária do caráter social e político do homem e está de acordo, portanto, com a lei natural; (4) a autoridade política tem origem em Deus, não por um ato especial, mas por consequência da natureza humana por Ele

\footnotetext{
${ }^{34}$ Publicadas em 1517.

35 Apenas para citar alguns autores: Maquiavel (O príncipe, 1532); o jesuíta Francisco Suárez (Tractatus de legibus ac Deo Legislatore,1612); Hobbes (Leviatã, 1651), Espinoza (Tratado Teológico-político, 1670).

${ }^{36}$ As principais obras de Suárez referenciadas ao longo desta tese são: Disputationes metaphysicae (1597) e Tractatus de legibus ac Deo Legislatore (1621). Para maiores informações sobre Francisco Suárez, sugerimos o site <http://www.sydneypenner.ca/>. Para as questões metafísicas pontualmente abordadas nesta tese, sugerimos a edição de Jorge Gracia das disputas metafísicas: SUÁREZ, F. Suárez on individuation: Metaphysical disputation V, individual unity and its principle. Tradução Jorge J. E. Gracia. Milwaukee: Marquette University Press, 1982. Para De legibus, sugerimos a seguinte edição em espanhol: TRACTATUS de legibus ac Deo legislatore. Madri: Consejo Superior de Investigaciones Cientificas, 1971-81. Para uma breve contextualização da Querela da Individualização, indicamos a leitura de: FAITANIN, Paulo. A Querela da Individuação na Ecolástica. Aquinate, n 1, p. 74-91, 2005.
} 
atribuída aos homens; (5) a comunidade política possui autoridade política no momento de sua formação por consentimento de seus membros, sem que seja necessário para isso um ato especial de Deus; e (6) a diferença entre uma mera multidão acidentalmente agregada e uma comunidade política, ou corpo místico político, é um laço jurídico-moral originário dessa união e, por isso, capaz de realizar um fim específico. ${ }^{37}$

Como já dissemos, pela importância de suas obras, Francisco Suárez tornou-se um dos grandes nomes da Segunda Escolástica. O impacto desse movimento na formação da Companhia de Jesus já foi indicado por Eisenberg em sua obra As missões jesuíticas e o pensamento político moderno. ${ }^{38}$ Aqui, ressaltamos resumidamente dois de seus principais conceitos: o de aggiornamento - isto é, atualização e reinterpretação da teologia de São Tomás de Aquino da parte dos religiosos da Ordem; e noster modus procedenti, identificado pelo autor como a especificidade do empreendimento do jesuíta, e que consistia numa dialética entre obediência e prudência, amparada institucionalmente pela atividade epistolar. ${ }^{39}$

Além de aggiornamento e noster modus procedenti, podemos também citar suas considerações sobre a prudência e sua associação, dentro da Ordem Jesuíta, com a obediência:

O destaque que as práticas de justificação gozavam no "modo de proceder" jesuítico fazia com que a obediência tivesse, portanto, que ser complementada pela prudência, tanto por parte daqueles que dão ordens como por parte daqueles que recebem. Isto, por seu turno, requeria que a estrutura organizacional da Companhia incluísse instituições que ensinassem os irmãos a ser prudentes. Assim, como o conceito de obediência, o conceito jesuítico de prudência também teve origem nos Exercícios Espirituais. Segundo Loyola, através do exame diário de sua consciência, o exercitante aprende a discernir entre os movimentos de sua alma, que provêm de Deus, daqueles que são produzidos pelo inimigo de Deus. ${ }^{40}$

\footnotetext{
${ }^{37}$ Cf: ROMMEN, H. Francis Suarez. The Review of Politics, v. 10, n. 4, out. 1948, p. 437-461.

${ }^{38}$ EISENBERG, J. As missões jesuíticas e o pensamento político moderno. Belo Horizonte: UFMG, 2000.

39 Ibidem, p. 14; 19-20. . Ao tema da Prudência, São Tomas de Aquino dedicou-se da questão 47 à questão 56 da II Seção da II parte da Suma Teológica. Sua definição inicial de Prudência, citando Santo Agostinho, é a seguinte: "Pois diz santo Agostinho: A prudência é um amor, que sagazmente seleciona o que nos ajuda, do que nos prejudica. (De Moribus Ecclesia (c. XV): Prudentia est amor, ea quibus adiuvatur, ad eis impeditur, sagaciter seligens.). E ainda: "à prudência pertence escolher sagazmente. (...) O mérito da prudência não consiste só em considerar; mas em aplicar-se à ação.” Cf:. SUMA Teológica. Edições Loyola: São Paulo, 2001, p. 7-11. Nesta tese também usamos a seguinte edição: AQUINO, Tomas de. Suma Teológica. Tradução Alexandre Correa.São Paulo: Faculdade de Filosofia Sede Sapiens, 1956.

${ }^{40}$ EISENBERG, J. As missões jesuíticas e o pensamento político moderno. Belo Horizonte: UFMG, 2000, p. 38. Outra referência interessante para salientar a importância da retórica, da prudência e da atividade epistolar para o modus procedenti jesuíta é o artigo de Grant Boswell, do qual retiramos a citação: "The ability to judge the propriety of words and arguments, together with the appropriate form of letter - taking into consideration the intended recipient and the author's purpose - is what Posevino calls wisdom (prudentia)." BOSWELL, G. Letter writing among the Jesuits: Antonio Possevino's advice in the Bibliotheca Selecta (1593) Huntington Library Quarterly, University of California Press, v. 66, n. 3/4, p. 252, 2003.
} 
Retornando à Índia: em 1579, Akbar promulgou um documento, conhecido na historiografia como "decreto da infalibilidade", cujo conteúdo não cessa de produzir novas interpretações. ${ }^{41}$ Segundo esse decreto, o imperador teria a palavra final em questões sobre as quais os intérpretes das leis corânicas - Mujtahid (sing.) - não estivessem de acordo entre si. Segundo Ali, o decreto seria "uma tentativa de assumir a posição de intérprete da lei islâmica" e, como consequência, a posição de legislador em circunstâncias permitidas pelo silêncio das leis. ${ }^{42}$ Para o indologista irlandês Vincent Smith, que escreveu sobre Akbar nas primeiras décadas do século XX, o decreto teria, de fato, o papel de dar a ultima palavra a Akbar nas questões religiosas que acabassem por interferir nos assuntos de Estado:

Em 1579, o momento foi considerado certo para a memorável inovação proposta, que estenderia a autocracia de Akbar do lado temporal para o espiritual, e torná-lo-ia tanto Papa quanto rei.

Finalmente, no início de setembro de 1579, Shaikh Mubarak apresentou um documento formal escrito em sua própria caligrafia, produzido de forma a estabelecer que o imperador deveria ser aceito como o árbitro supremo em todas as questões, sejam elas eclesiásticas ou civis. Provavelmente, isso foi sugerido pela informação revelada na época sobre a posição do Papa na Europa Ocidental. Não precisamos nos preocupar com as discussões técnicas que cercavam a interpretação dos termos legais, Mujtahid e Imam-i- Adil. É suficiente afirmar que Akbar era solenemente reconhecido como sendo superior a qualquer outro intérprete (mujtahid) da lei muçulmanaem sua capacidade de Imam-i-Adil e praticamente era atribuído com o dom da infalibilidade. Ambos os líderes de partidos rivais, Makhdumu-1 Mulk e Shaikh Abdu-n Nabi, assim como outros doutores eminentes conhecedores da lei, foram influenciados ou forçados a dispor seus selos no pronunciamento, fato que suas almas detestaram. ${ }^{43}$

\footnotetext{
${ }^{41}$ Cf: Apêndice "I".

42 "The Ottomans ultimately purchased from existing claimants the authority of the 'Abbasid caliphate; but they were anticipated by Akbar, who, through the mahzar of 1579, attempted to assume the position of an interpreter of Islamic law and, in spheres where the existing corpus was silent, of a legislator." ALI, M.A. Towards an Interpretation of the Mughal Empire. The Journal of the Royal Asiatic Society of Great Britain and Ireland. Cambridge University Press, n. 1, p. 40-41, 1978. Disponível em: <http://www.jstor.org/stable/25210917>.

43،'In 1579, the time was deemed to be ripe for the proposed momentous innovation which should extend the autocracy of Akbar from the temporal to the spiritual side, and make him Pope as well as King. Ultimately, at the beginning of September 1579, Shaikh Mubarak produced a formal document in his own handwriting, drafted in such a way as to settle that the emperor must be accepted as the supreme arbiter in all causes, whether ecclesiastical or civil. Probably it was suggested by the information then becoming available concerning the position of the Pope in Western Europe. We need not trouble about the technical discussions which raged round the interpretation of the legal terms, Mujtahid and Imam-i- Adil. It will suffice to say that Akbar was solemnly recognized as being superior in his capacity of Imam-i-Adil to any other interpreter (mujtahid) of Muslim law, and practically was invested with the attribute of infallibility. Both the rival party leaders, Makhdumu-1 Mulk and Shaikh Abdu-n Nabi, as well as other eminent doctors learned in the law, were induced or compelled to set their seals to a pronouncement, which their souls abhorred." SMITH, V.A. Akbar, the great Mogul, 1542-1605. Oxford: Clarendon Press, 1917, p. 179-80. Tradução nossa. Não estamos ainda seguros o suficiente para tecer relações entre tais iniciativas de Akbar e as notícias que teria recebido sobre o Papa (mesmo porque o decreto já havia sido promulgado antes da chegada dos jesuítas). No momento, indicamos apenas que a figura do Papa é mencionada em um dos principais documentos analisados nesta tese: "Em uma reunião em privado, (...) o rei se interessou pela dignidade e importância do Papa (...). Neste ponto, gostaria de expressar meu desassossego quando comprovo que a dignidade pontifícia, tão respeitada por este rei agareno, que só o conhece através das
} 
A opinião de Athar Ali é de que Akbar não teve sucesso em estabelecer tal posição de autoridade baseando-se exclusivamente na estrutura ideológica e religiosa do islamismo. Além disso, mesmo que conseguisse basear-se apenas nas ideias presentes na religião do Profeta Maomé, isso lhe causaria dificuldades para estender sua autoridade aos não muçulmanos. Sabe-se, evidentemente, que havia na Índia, nesse momento, uma série de comunidades religiosas não muçulmanas, como jainistas, zoroastrianos e aquelas futuramente denominadas "hindus", as quais aparecem nas fontes consultadas como "brâmanes" “juntamente com a política de tolerância religiosa da qual Akbar era autor, basear a autoridade política na santidade espiritual era uma manobra inteligente para reforçar a posição do soberano." 45

Soma-se a isso a capacidade de Akbar de remover a dependência de soberania exclusivamente da nobreza muçulmana. O imperador logrou compor uma classe dominante mista, aproximando-se política e publicamente da comunidade não muçulmana, especialmente através da sua política de tolerância religiosa denominada de Sulk $i$ kul.

Outro aspecto da política religiosa de Akbar foi a tentativa de criar uma nova religião, sob o nome de din-i ilahi, ou "fé divina". A análise de Vincent Smith acerca deste binômio decreto de 1579 e criação do din-i ilahi - é a seguinte:

A verdade é que a 'religião' fingida de Akbar consistia essencialmente na asserção de sua supremacia pessoal sobre fatos espirituais, assim como sobre fatos temporais. Seu 'criador solitário' era Shaikh Mubarak, que, quando Akbar voltou para casa em 1573, após a violenta campanha em Gujarat, recebeu seu soberano expressando seu desejo de que ele se tornasse o líder espiritual e temporal de seu povo. ${ }^{46}$

conversas que tem com extrangeiros (...) é (...) menosprezada por aqueles que se dizem cristãos e são reformadores dos Evangelhos”. MONTSERRAT, A. Mongolicae Lagationis Commentarius. Apud: ALAY, J.L. Embajador en la corte del Gran Mogol.Tradução Ramon Sala. Lleida: Milenio, 2006, p. 216.

${ }^{44}$ FAZL, A. The Akbarnāma of Abu-l-Faẓl, a history of the reign of Akbar including an account of his predecessors. Tradução H. Beveridge. Calcutá: Asiatic Society, 1910-1939. Disponível em: <http://persian.packhum.org/persian/main?url=pf\%3Ffile\%3D00701023\%26ct\%3D0>.

Para um debate sobre o uso da palavra "hindu" e suas implicações, sugerimos a leitura de Lorenzen, David N. "Who Invented Hinduism?" Comparative Studies in Society and History 41.04 (1999): 630-659.

45، [...] combined with the tolerant religious policy of which Akbar was the author, the basing of political authority on spiritual sancticity was an intelligent device to strength the sovereign's position." ALI, M.A. Towards an Interpretation of the Mughal Empire. The Journal of the Royal Asiatic Society of Great Britain and Ireland, Cambridge University Press, n. 1, p. 40-42, 1978. Tradução nossa. Disponível em: $<$ http://www.jstor.org/stable/25210917>.

46، .The truth is that Akbar's pretended ' religion ' consisted essentially in the assertion of his personal supremacy over spiritual things as well as things temporal. Its 'only begetter' was Shaikh Mubarak, who, when Akbar came home in 1573 after the victorious campaign in Gujarat, had greeted his sovereign with the expression of the wish that he should become the spiritual as well as the temporal guide of his people." SMITH, V.A. Akbar the Great Mogul, 1542-1605. Oxford: Clarendon Press, 1919, p: 213-4. Tradução nossa. 
Seja em relação ao decreto de 1579 ou em relação à criação dessa suposta religião de Estado, não gostaríamos de propor aqui uma análise ou interpretação sobre suas reais legitimidades, eficácias ou implementações. Nosso objetivo é ressaltar a importância da questão religiosa no processo de desenvolvimento de uma nova base teórica para a soberania política de Akbar. Além disso, nesta tese, propomos que essa nova base teórica construiu-se em meio aos debates promovidos por Akbar. ${ }^{47}$ Nossa hipótese é de que o imperador erigiu sua autoridade (do ponto de vista político, religioso e ideológico) baseando-se num traço cultural presente ao longo da história do subcontinente indiano que chamaremos aqui de tradição do diálogo.

Em 2005, Amartya Sen - vencedor do prêmio Nobel de economia de 1998 - publicou um livro com o sugestivo título de "The Argumentative Indian". Sen aponta o exercício da argumentação como um aspecto característico da sociedade indiana: "A Índia foi especialmente afortunada em ter uma longa tradição de discussões públicas com a tolerância a heterodoxidades intelectuais" ${ }^{\prime 4}$. Para sustentar essa ideia, ele traça uma espécie de genealogia da tradição do diálogo na Índia:

$\mathrm{Na}$ história do debate público na Índia, deve ser dado crédito considerável para os primeiros budistas indianos, que eram muito comprometidos em discutir sobre os meios de progresso social. (...) Os chamados "conselhos budistas", que tinham o objetivo de solucionar disputas entre pontos de vista diferentes, atraíam delegados de locais diferentes e de diferentes escolas de pensamento. (...) Tais conselhos estavam principalmente preocupados com a resolução de diferenças sobre princípios e práticas religiosas, porém, evidentemente, também lidavam com as demandas de deveres sociais e cívicos e, ademais, ajudavam, de forma geral, a consolidar e promover a tradição de discussões abertas em questões polêmicas. ${ }^{49}$

Apontado o que teria sido esse primeiro momento de debates públicos na história da Índia, Sen dá continuidade a sua análise, interpretando os debates que ocorreram na corte

\footnotetext{
47 "In a genuine dialogue the interlocutors agree on, first, that they discuss, and second, that they are attempting to create a world where they can understand each other”. Esta afirmação feita por Maijastina Kahlos em sua obra "Debate and Dialogue" possivelmente está em consonância com o que acreditamos ter sido o projeto político de Akbar e seu investimento nesses fórums de debates. KAHLOS, M. Debate and Dialogue: Christian and Pagan Cultures. Aldershot: Ashgate, 2007, p. 77.

48 "India has been specially fortunate in having a long tradition of public arguments, with toleration of intelectual heterodoxy." SEN, A. The argumentative Indian. Londres: Penguin, 2005, p. 12. Tradução nossa.

49" In the history of public reasoning in India, considerable credit must be given to the early Indian Buddhists, who had a great commitment to discuss as a means of social progress. (...) The so-called "Buddhist councils", which aimed at setting disputes between different point of views, drew delegates from different places and from different schools of thoughts. (...) These councils were primarily concerned with resolving differences in religious principles and practices, but they evidently also addressed the demands of social and civic duties, and, furthermore helped, in a general way, to consolidate and promote the tradition of open discussions on contentious issues." Ibidem, p. 15. Tradução nossa. Os concílios budistas tiveram as primeiras edições entre o sexto século antes de cristo e o segundo século AD.
} 
mogol como uma espécie de eco - o mais forte eco - da tradição iniciada pelos concílios mencionados acima:

A tese abrangente de Akbar de que 'a busca pela razão' em detrimento da 'dependência da tradição' era a forma de lidar com difíceis problemas de harmonia social incluía uma robusta celebração de diálogos racionais. $\mathrm{O}$ patrocínio real não é essencial para a prática de debate público, mas acrescenta uma nova dimensão ao alcance da história argumentativa da Índia. ${ }^{50}$

Ao indicar de que maneira uma defesa institucional - isso é, do Estado - interfere no alcance dos debates e no seu papel em busca da harmonia social, o autor continua suas considerações sobre o imperador mogol:

Akbar não apenas fez anúncios inequívocos sobre a prioridade da tolerância,
como também fundamentou as bases formais de uma estrutural legal secular
e da neutralidade do Estado, a qual incluía o dever de garantir que 'nenhum
homem deve ser incomodado devido a sua religião, e qualquer pessoa tem a
permissão de acreditar na religião que lhe agrade'. Apesar de seu profundo
interesse por outras religiões e sua breve tentativa de criar uma nova religião,
Din-ilahi (a religião de Deus), com base emuma combinação de pontos
positivos de diferentes crenças, Akbar continuou sendo um bom
mulçumano.

Ainda que a reflexão conduzida por Sen seja pertinente, durante o desenvolvimento de nossa pesquisa trabalhamos com hipóteses que não estão integralmente de acordo com a opinião do autor. Em primeiro lugar, é preciso deixar claro que, ao contrário de vasta literatura sobre o tema, nosso objetivo aqui não é nos posicionar quanto à ortodoxia de Akbar e se, ao final de sua vida, ele pôde ser considerado um "bom muçulmano".

Além disso, reconhecemos que um dos possíveis efeitos da política inclusiva de Akbar tenha sido a promoção de um ambiente mais tolerante, embora a ideia de tolerância, para nós, não pareça dar conta do cenário de disputas políticas em curso na corte mogol. Em geral, em nossa análise, evitamos trabalhar com esse conceito e preferimos priorizar a investigação acerca do projeto político do soberano "por trás" do seu incentivo à tolerância. No entanto, é preciso dizer que a criação desse ambiente "inclusivo" possibilitaria o convite dirigido aos

\footnotetext{
50، Akbar overarching thesis that 'the pursuit of reason' rather than the 'reliance on tradition' is the way to address difficult problems of social harmony included a robust celebration of reasoned dialogues. A royal sponsorship is not essential for the practice of public reasoning, but it adds another dimension to the reach of the argumentative history of Índia.” SEN, A. The argumentative Indian. Londres: Penguin, 2005, p. 16. Tradução nossa. Grifos nossos.

51، Akbar not only made unequivocal pronouncements on the priority of tolerance, but also laid the formal foundations of a secular legal structure and of religious neutrality of the state, which included the duty to ensure that 'no man should be interfered with on account of religion, and anyone is to be allowed to go over to a religion that pleases him.' Despites his deep interest in other religions and his brief attempt to launch a new religion, Din-ilahi (God's religion), based on a combination of good points chosen from different faiths, Akbar did remain a good Muslim himself." Ibidem, p. 18. Tradução nossa.
} 
religiosos da Companhia de Jesus, no fim da década de $1570 .^{52}$ Será a participação dos jesuítas nesse contexto de reformulação dialógica de uma nova soberania política nosso objeto a seguir.

\footnotetext{
52 Trataremos do convite, partida dos missionários e estabelecimento da missão no mogol em seguida.
} 


\title{
1.3 De Bengala A FATEHPUR: PRIMEIROS ENCONTROS ENTRE AKBAR E CRISTÃOS
}

\author{
PORTUGUESES
}

Os portugueses chegaram a Goa em 1510. "Viram-se instalados, nos séculos XVI e XVII, num mundo cujo equilíbrio de forças geopolíticas, sociais e econômicas estava em permanente mutação". ${ }^{53}$ Mas nem só de iniciativas formais da Coroa compunham-se as investidas portuguesas na Ásia. Do lado oposto do subcontinente indiano, alguns comerciantes lusitanos, por sua própria conta e risco, também buscavam tirar proveito das rotas comerciais da região. Assim, mercadores portugueses foram ocupando alguns "portos" ou "bandeis" ao longo da baía de Bengala. ${ }^{54}$

A cidade $^{55}$ de Ugulim, Golim ou Hugli,também chamada de "Porto Pequeno" (em oposição a "Porto Grande" ou Chatigão), surgiu possivelmente por volta de $1537 .{ }^{56}$ Ela não fazia parte do Império Português na Ásia, no sentido próprio do termo, pois não estava subordinada à jurisdição do vice-rei de Goa. Esse porto surgiu da iniciativa de particulares portugueses no mesmo período em que o Império Mogol expandia suas conquistas nessa direção. $\mathrm{O}$ aparecimento de Hugli está, portanto, relacionado às rotas comerciais do sul da Ásia, ao interesse econômico de portugueses "aventureiros" e às demandas da rica corte mogol.

As demandas da corte do Grão Mogol por produtos de luxo, especialmente seda e porcelana da China, era grande nesta época. O fornecimento desses produtos para o Indostão foi negociado com um português capitão do "Porto Pequeno", de nome Pero Tavares, em 1577. Em contrapartida, o imperador Akbar garantiu a Tavares o estabelecimento de portugueses em Hugli. ${ }^{57}$

\footnotetext{
${ }^{53}$ SUBRAHMANYAM, S. O Império político português 1500-1700 - Uma História Política e Econômica. Lisboa: Difel, 1993, p. 40.

${ }^{54}$ Bandel, do persa Bandar, ou porto. FLORES, J. Relic or Springboard? A note on the 'rebirth' of Portuguese Hughli, ca.1632-1820. Indian Economic Social History Review, 39, 2002, p. 382.

${ }_{55}$ Para a questão das "cidades" na Índia, ver: CHAUDURI, N. K. Some reflections on the town and the country in Mughal India. Modern Asian Studies, 12, I, p.77-96, 1978.

${ }^{56} \mathrm{Cf}$ : DEI, N. Notes on the History of the district of Hugli or the ancient Ráda. Journal and proceedings of the Asian Society of Bengal. New series. Calcutá, vol. VI, p. 599, 1910.

${ }^{57}$ Essas dificuldades são abordadas pelo padre jesuíta Francisco P. (sic) em sua carta escrita em agosto de 1614. ARSI, Goa, 17, fl: 130-1. Para mais informações sobre o assunto, indicamos o relato do religioso agostinho Sebastião Manrique, que narra, no quarto capítulo de sua obra,o encontro do enviado mogol com o comerciante Pero Tavares em Bengala. Cf: MANRIQUE, S. Itinerario de las missiones que hizo el Padre F. Sebastian Manrique. Roma: F. Caballo, 1649. Ver também: HOSTEN, H.; BESSE, P. A List of Portuguese Jesuit
} 
Os missionários da Companhia de Jesus, tais quais os comerciantes portugueses, também se estabeleceram na região, com residências em Hugli, Chandecan e na Ilha de Sundiva. No entanto, essas residências estavam inseridas num contexto bem distinto de outras paradigmáticas missões na Índia. Em função das instalações muitas vezes precárias das comunidades portuguesas nos portos da região, os religiosos ficavam vulneráveis às instabilidades políticas locais. Com a expansão territorial do Império Mogol em direção à Bengala, somada ao estabelecimento de irresolutos mercadores portugueses, que ora alinhavam-se ao Mogol, ora opunham-se à sua expansão, a situação missionária era delicada. Podemos traçar uma oposição, por exemplo, em relação ao caso de Goa. Lá, o Estado português era forte, e esse fator institucionalizava a atuação dos religiosos, que podiam agir com mais segurança e liberdade. O mesmo pode ser dito de missões nas quais o próprio soberano local oferecia apoio e proteção aos religiosos cristãos - de acordo com seus interesses políticos - ainda que a presença institucional do Império Português fosse nula ou apenas "diplomática”, como é o caso da missão do Mogol. As missões em Bengala ficavam, portanto, espremidas entre disputas "temporais" - políticas e econômicas - que nem sempre favoreciam os trabalhos espirituais. Dessa forma, eram missões entre dois impérios, cravadas em territórios de pequenos reis. Mesmo em condições adversas, os grupos de missionários chegaram a ter um contingente de nove religiosos (1620), mas foram reduzidos a apenas três ou quatro padres após o sítio de Hugli, em 1632. Ainda assim, Bengala teve um papel "logístico" nas estratégias das missões religiosas na Índia: de lá, os missionários passavam ao Arrakão, ao Pegu, e até mesmo ao Tibete, no século XVII.

O Império Português e o Mogol já haviam travado contato em Surat, mas foi de Bengala que saiu o primeiro religioso cristão convidado à corte mogol, em circunstâncias resumidas na seguinte passagem da Relação de Akbar: ${ }^{58}$

A ocasião de se afeiçoar à nossa lei foi ver o primor, a polícia, e o valor de alguns portugueses que acompanhavam Antônio Cabral quando o foi ver à Surat por mandado do Viso Rei Dom Antônio, e alguns anos depois o que ouvia dizer que faziam dois padres da Companhia em Bengala que lá foram no ano de 1576. E depois teve a Pero Tavares, Capitão do Porto Pequeno, na

missionaries in Bengal and Burma, 1576-1742. Journal of Asiatic Society of Bengal. Calcutá, vol. VII. p. 16, 1911. Ver também apêndices "B" e "C" ao final desta tese.

${ }^{58}$ MONTSERRAT, A. Relação de Akbar, rei dos mogóis. Texto original em português. Versão manuscrita encontrada no livro 28 do Armário Jesuítico (fl. 84v-85) no Arquivo Nacional da Torre do Tombo, em Lisboa, Portugal. Publicação de referência Documenta Indica, v. XII (1580-1583), doc. 114, p. 645-662. Esse documento, escrito por Montserrat em 26 de novembro de 1582, tem como tema principal a descrição do soberano do Mogol chamado de Equebar, ou Akbar. No entanto, o jesuíta extrapola a descrição do indivíduo e faz uma espécie de descrição do Estado Mogol, ou Indostão. Iniciando por sua "cabeça", o missionário descreve também a corte, a burocracia do Indostão, o funcionamento do Estado, a justiça etc. Para uma descrição detalhada desse documento, favor consultar o apêndice " $\mathrm{D}$ " desta tese. 
sua corte. E pelo que ouviu desejou de se informar das nossas coisas, e mandou trazer a si o Padre Jullianes Pareira, que governa agora o Bispado de Cochim, o qual com muito zelo lhe deu muita notícia da lei evangélica, e com seu bom exemplo, o afeiçoou a ela de maneira que deu tantos sinais de a querer aceitar que foi causa ${ }^{59}$ de em Bengala darem sobre os alevantados que se alevantaram porque El Rei queria deixar sua lei, e chamaram o príncipe de Chabul para se alevantar com ele, o qual entrou léguas pela terra dentro de Equebar, e não saiu delas até que eles abalou com o exército por cima desse. ${ }^{60}$

A partir desse relato, percebemos que, dos contatos entre Akbar e os portugueses em Bengala, surgiu o convite por parte do imperador para que um padre cristão viesse à corte ${ }^{61} \mathrm{O}$ primeiro padre a deixar Bengala em direção ao Mogol foi um religioso chamado Julianes Pereira ,que não pertencia à Companhia de Jesus. O padre esboçou as primeiras tentativas de levar o cristianismo ao conhecimento de Akbar. Ele ensinou algumas palavras em português para o imperador que, segundo Pereira, queria aprender a língua para ler os evangelhos. ${ }^{62}$ Porém, por carecer de formação intelectual necessária, o sacerdote não pôde cumprir um papel de esclarecedor da lei e doutrina católica. Não teria ele os conhecimentos adequados para responder às perguntas do soberano. Além disso, o sacerdote não sabia discorrer sobre as diferenças entre os livros sagrados do cristianismo e do islamismo, ${ }^{63}$ não sendo, portanto, capaz de acompanhar os debates em curso na corte.

Era Pereira de mais virtude, que letras, \& depois de responder o que sabia, disse a el-Rey que ele era um ignorante a respeito dos homens Letrados que havia em Goa, aonde S. Majestade os podia mandar buscar, para se informar pleníssimamente de todos os mistérios do Evangelho. ${ }^{64}$

\footnotetext{
${ }^{59}$ Riscado no texto "que em".

${ }^{60}$ MONTSERRAT, A. Relação de Akbar, rei dos mogóis. Texto original em português. Versão manuscrita encontrada no livro 28 do Armário Jesuítico (fl. 84v-85) no Arquivo Nacional da Torre do Tombo, em Lisboa, Portugal. Publicação de referência Documenta Indica, v. XII (1580-1583), doc. 114, p.660.

61 "Sabera VR que depois que Paulo [Menezes?] se partiu me chamou el Rei e me disse que escrevesse a VR que lhe mandasse aqui dois padres letrados que lhe saibam declarar as leis, porque diz que lhe parece a do Senhor Deus muito boa, e onde vê cruz ou imagem faz-lhe muita reverência, (...) não fala nem pratica com os seus grandes senão na lei dos cristãos. Eu, senhor, escrevo a Vossa R. o que vejo com os olhos, o que ele tem no coração não no sei, mas o que saberei dizer a VR é que vindo os padres serão del rei muito acatados com honras [sobejas?] e disto fico eu por fiador." CÓPIA de um capítulo de uma carta de Pero Tavares, Capitão-mor de Satagão nos reinos de Bengala, que escreveu da corte do Grão Mogor ao padre provincial da Companhia de Jesus da Índia” ANTT, Armário Jesuítico, n. 28, fl: 86v.

${ }^{62}$ CARTA de Gileanes Pereira (sic), de Fatepur, 5 de junho de 1579. ANTT, Armario Jesuitico, n. 28, ffl: 86-87. No entanto, Montserrat afirma que Akbar era analfabeto. Cf: Relação de Equebar

${ }^{63}$ ALAY, J.L. Ambaixador a la cort del Gran Mogol: Viatges d'um Jesuïta Català Del segle XVI a l'India, Paquistão, Afeganistão, Himalaia. Edição e tradução (do latim para o catalão): Josep Lluis Alay. Lleida: Pagès, 2002 , p. 59.

${ }^{64}$ SOUZA, F. O Oriente conquistado a Jesu Christo pelos padres da companhia de Jesus da provincia de Goa... Lisboa: na officina de V. Da Costa Deslandes, 1710. vol. 2, p. 938.
} 
Faltava a Pereira o que era, justamente, prerrogativa da formação jesuíta: vocação missionária, erudição e treinamento retórico ${ }^{65} \mathrm{O}$ próprio sacerdote recomendou, portanto, que Akbar escrevesse aos padres da Companhia de Jesus em Goa e os convidasse para ir ao Mogol. ${ }^{66} \mathrm{O}$ soberano mandou, então, um embaixador àquela cidade, com cartas ao vice-rei, ao arcebispo e aos jesuítas, pedindo que lhe fossem enviados padres. As notícias das intenções de Akbar, associadas à necessidade de se recorrer a religiosos com uma formação intelectual mais robusta, assim chegaram à Província de Portugal:

Parece que se moveu este rei de pedir os padres da Companhia por ocasião de uma missão que se fez à Bengala, a qual também é sua de dois padres da Companhia. Agora faz três anos os quais não queriam confessar aqueles que furtaram os direitos a El Rei, da qual sendo informado El Rei e espantandose muito da pureza e verdade da lei evangélica, que ordena e manda que se cumpra a justiça ainda com os estrangeiros e aqueles que vivem fora dela cobrou tanto desejo e vontade de saber a lei que procura quanto pode ser informado nela, e para isso mandou chamar de Bengala o vigário que é um clérigo secular de boa vida, mas sem letras, e por alcançar dele tem escrito ao arcebispo que alcance do Padre Provincial os padres quanto antes da ida do clérigo tenha mandado vir. ${ }^{67}$

Gostaríamos de pontuar alguns aspectos do extrato anterior. Em primeiro lugar, é preciso reiterar que a missão jesuíta do Mogol surgiu a partir de um convite do imperador Akbar. ${ }^{68}$ No entanto, isso não significa que a intenção de Akbar com esse convite era o estabelecimento de uma missão cristã em sua corte, o que seria uma dedução anacrônica. Nossa hipótese é que o soberano mogol estava desejoso "por saber a lei" que "manda que se

\footnotetext{
${ }^{65}$ Em especial, gostaríamos de ressaltar, como já feito por José Eisenberg, a casuística como aspecto sui generis da formação jesuítica. "A casuística incluía o estudo da retórica e da persuasão, o exercício da razão prática, e o desenvolvimento da capacidade de tomar 'decisões corretas'." EISENBERG, J. As missões jesuíticas e o pensamento político moderno. Belo Horizonte: UFMG, 2000, p. 40. O autor nos diz ainda que "O método de raciocínio prático empregado pelos jesuítas no treinamento de seus colegas era constituído, portanto, de dois conceitos básicos: adaptação das normas e tolerância das violações que não fossem extremamente ofensivas. (...) Sua influência porém ultrapassava o estudo dos casos de consciência e se refletia na organização institucional da Ordem como um todo." Ibidem, p. 45.

${ }^{66 " E q u e b a r ~ g r a n d e ~ E m p e r a d o r ~(S I C) ~ d o s ~ M o g o l e s ~ e s c r e v e o ~ e s t e ~ a n n o ~ a o ~ V i s o-R e y ~ d a ~ I ́ n d i a, ~ A r c e b i s p o ~ e ~ P r i m a ̀ s ~}$ (SIC) \& ao Padre Provincial Ruy Vicente, pedindolhes (SIC) dous Religiosos da Companhia [de Jesus], para lhe explicarem a Fé do Evangelho, \& a Lei de Christo. A carta para o provincial dizia assim: Para o Padre Provincial em nome de Deos. Formão de Zeladim Mahamed Equebar Xá, posto pela mão de Deus. Principais Padres da Ordem de São Paulo, saibão(SIC) que sou seu grande amigo. Eu mando lá a Ebadola (SIC) meu embaixador \& a Domingos Pires, a pedir dous Padres Letrados, \& tragão (SIC) os Padres comsigo (sic) livros principais da Ley, \& o Evangelho, para saber a Ley, \& perfeição della: porque desejo ter notícia da Ley. (...)." SOUZA, F. O Oriente conquistado a Jesu Christo pelos padres da companhia de Jesus da provincia de Goa... Lisboa: na officina de V. Da Costa Deslandes, 1710. vol 2, p. 936.

${ }^{67}$ CÓPIA de uma [carta] da Índia para a província de Porugal do ano de [15]79. ANTT, Armário Jesuítico, n. 28, ff. 91.

68 "In 1579, then, Akbar and his advisers were caught in a cleft stick. Their strategy of promoting heterodox religious debate - both within Islam and outside it - led them in the direction of encouraging the first Jesuit mission to Fatehpur Sikri from Goa." SUBRAHMANYAM, S. Explorations in connected history: Mughals and Franks. Nova Deli [ua]: Oxford University Press, 2005, p. 54.
} 
cumpra a justiça ainda com os estrangeiros e aqueles que vivem fora dela" ${ }^{69}$ Isso pode ser entendido como uma curiosidade em relação ao cristianismo. Akbar procurava informações sobre leis ou religiões com as quais travava contato, e essa parece ter sido a circunstância pela qual o cristianismo somou-se às demais crenças "pesquisadas".

Outro aspecto importante é que esse extrato reitera o que já foi dito anteriormente: o contato com portugueses se deu como consequência da expansão do Império Mogol. ${ }^{70}$ Isso pode reforçar a ideia de que a intenção de Akbar era trazer para sua corte o maior número possível de representantes das mais diversas leis, presentes nas mais diversas regiões submetidas ao seu domínio. Trazer esses sacerdotes para o centro do poder civil no Indostão o auxiliaria na implementação de sua política inclusiva (usualmente descrita como tolerante), identificada como a política de Sulk $i \mathrm{Kul}$, expressão que pode ser traduzida por "paz com todos" ou "paz absoluta".

Não obstante, como muito bem demonstrado por Jorge Flores em sua tese, era importante para o soberano mogol ter europeus em sua corte, através dos quais ele poderia ter notícia das intenções e movimentos dos representantes do Estado da Índia. ${ }^{71}$ É necessário manter em mente certa dimensão geopolítica dos encontros envolvendo portugueses (ou cristãos) e muçulmanos mogóis nesse período, ainda que, a princípio, tais eventos pareçam fortuitos. $^{72}$

A título de exemplo, citamos o caso do jesuíta André Pereira. Ele escreveu de Ugulim (Bengala) anos depois do período aqui estudado, em outubro de 1615. Além de fornecer informações gerais sobre sua viagem, a região e seus habitantes, Pereira identifica possíveis aliados - no temporal e no espiritual - para um projeto jesuíta de missão em Bengala, a saber: os capitães portugueses e os religiosos da Ordem de Santo Agostinho. ${ }^{73}$ É também

\footnotetext{
${ }^{69}$ CÓPIA de uma [carta] da Índia para a província de Porugal do ano de [15]79. ANTT, Armário Jesuítico, n. 28, ff. 91.

${ }^{70}$ Como dito anteriormente, Akbar conquista Bengala em 1576, ainda que a região permaneça sob certa instabilidade política pelos anos posteriores.

${ }^{71}$ FLORES, J. 'Firangistan' e 'Hindustan'. O Estado da Índia e os confins meridionais do Império Mogol (1572-1636). Tese de doutorado inédita. Lisboa: Universidade Nova de Lisboa.

${ }^{72}$ Para uma análise elaborada das questões geopolíticas referentes ao contexto luso-mogol desse período, que optamos por não aprofundar nesta tese sob pena de desvirtuarmos por demais de nosso tema central, sugerimos, além da tese supracitada, a publicação de Sanjay Subramanyam, principalmente seu terceiro capítulo: SUBRAHMANYAM, S. Explorations in connected history: Mughals and Franks. Nova Deli: Oxford University Press, 2005.

${ }^{73}$ Um grupo de cinco missionários da Ordem de S. Agostinho chegou a Ugulim na virada do século XVI para o século XVII. Em um ano, mais sete religiosos agostinhos se juntaram à primeira leva. Lá, construíram um mosteiro e, passado algum tempo, já tinham propriedades como Igreja, Colégio, Casa Professa e Biblioteca. Embora fosse a quarta ordem a chegar à Índia, a de S. Agostinho era a principal em Bengala em meados do século XVII. Passaram a possuir igrejas e mosteiros em vários locais ao longo do golfo - Dacca (1612); Chittagong (1621) - todos submetidos à diocese de Cochim até 1606, e à diocese de Meliapor nos anos
} 
mencionada a expectativa de se costurar um acordo político-diplomático a partir da missão jesuíta na corte do Grão-Mogol. Não obstante, o padre ainda esboça um planejamento geopolítico, defendendo a residência ou o colégio de Golim como cabeça da missão jesuíta em Bengala:

Com pouco cabedal se pode fazer muito, principalmente vindo-me do Grãomogol uma patente que por meio dos nossos santos padres que lá estão espero alcançar para poder fazer cristandade e igrejas por todos estes reinos de Bengala. ${ }^{74}$

É necessário, pois, mantermos em mente as implicações geopolíticas desses encontros, seja do ponto de vista dos portugueses, seja do ponto de vista mogol.

Do ponto de vista econômico, estavam em jogos as rotas de comércio de Chaul, Surat e Diu, mas Sanjay Subrahmanyam ressalta que, para além das disputas comerciais e fiscais, "uma tensão ideológica muito real existia entre as afirmações da cristandade da ContraReforma e o sunismo heterodoxo que os mogóis aceitaram no final do Século XVI". ${ }^{75}$

Gauvin Bailey, por sua vez, apresenta-nos uma afirmação muito sintética e eficaz relacionando a missão jesuíta e o contexto acima descrito:

A missão foi convidada para a corte de Akbar por dois motivos específicos: para fornecer argumentadores católicos para o fórum multi-religioso que ocorria com frequência no palácio de Akbar em Fatehpur Sikri e para fornecer trabalhos de arte renascentista europeia para seu entretenimento e edificação de artistas de sua corte. ${ }^{76}$

Ficam postas, lado a lado, na fala de Bailey, ambos os aspectos políticos e estéticos dos planos dos governos mogóis aqui destacados. Para o mesmo autor, o objetivo do soberano quando fez o convite aos religiosos da Companhia de Jesus não seria abandonar o Islão, mas criar uma irmandade sincrética, incorporando vários aspectos de diferentes religiões. ${ }^{77}$

seguintes. Segundo Joachim Campos, os agostinhos teriam convertido cinco mil arakaneses entre os anos 16211624. Cf: COLLIS, M. Na terra da grande imagem. Porto: Livraria Civilização, 1944, p. 83. Segundo Besse e Hosten, os missionários teriam chegado no ano de 1599, mas isso não parece ser consenso entre os historiadores. Cf: HOSTEN, H.; BESSE, P. A List of Portuguese Jesuit missionaries in Bengal and Burma, 1576-1742. Journal of Asiatic Society of Bengal. Calcutá, vol. VII. p. 16, 1911.

${ }^{74}$ CARTA de André Pereira, Golim, outubro de 1615. ARSI, Goa, 17, fl: 138v.

75، "...] a very real ideological tension existed between the claims of Counter-Reformation Christianity and the heterodox Sunnism that the Mughals espoused in the late sixteenth century." SUBRAHMANYAM, S. Explorations in connected history: Mughals and Franks. Nova Deli: Oxford University Press, 2005, p. 43. Tradução nossa.

76، The mission was invited to Akbar's court for two main purposes: to provide Catholic debaters for an interfaith forum held regularly in Akbar's palace at Fatehpur Sikri, and to provide works of European late Renassance art for his enjoyment and his court artist's edification." BAILEY, G.A.The Truth-Showing Mirror: Jesuit Catechism and the Arts in Mughal India. In: The Jesuits: cultures, sciences, and the arts, 1540-1773. Editor John W. O'Malley. University of Toronto Press, ed. 1, p. 480, 1999. Tradução nossa.

$77 \mathrm{O}$ autor, em seu artigo, se concentra na questão das imagens. Partindo de alguma de suas ideias iniciais, procuramos aqui ressaltar o lado político das escolhas estéticas de Jerônimo Xavier. Ibidem, p. 484-5. 
Para finalizar nossas considerações sobre os momentos que antecederam o convite de Akbar aos padres da Companhia de Jesus, propomos uma análise do extrato destacado abaixo: O documento prossegue, dizendo:

Por cartas de Pero Tavares, homem nobre e rico de nação portuguesa, que no porto pequeno de Bengala é seu capitão-mor da gente estrangeira e por cartas do clérigo que lá está e por outras informações se sabe ser este Rey muy bem inclinado, e amigo das cousas de Deus e que faz reverência e acatamento à Cruz e imagens, especialmente de Nosso Senhor e de Nossa Senhora, e que fazem o mesmo muitos senhores principais de seu reino ainda que escondidamente, e que no coração são cristãos. Del Rey se conta que conhecendo um que fora cristão e deixara a fé lhe perguntou que milagres vira fazer a Mahamede por que se fizesse mouro, e que tirasse a touca e vivesse como cristão. E o disse que os cristãos se fazem mouros não o fazem senão por viveram à larga, e tem-nos em conta de patifes, e maos homens e que por não poderem viver por grandes delitos entre nós, se fazem mouros. Têm ordinárias disputas à noite sobre a seita e por que hum casis disse uma blasfêmia contra Nossa Senhora, que ele crê que foi perpetua virgem como o é o desterrou de sua corte. Folga (...) com o trajo de Europa pera os homens e mulheres a sua mulher principal é gentia, e ele com os seus há pouco mais de trinta anos que se fizeram mouros pelo qual não estão (por serem homens de razão e gente de cor branca) muy afeiçoados a esta maldita seita. ${ }^{78}$

Já na primeira linha, o remetente da carta informa que foi principalmente através do capitão português do Porto Pequeno de Bengala que os jesuítas receberam as primeiras descrições do imperador Mogol.

Em seguida, Akbar é (promissoramente) descrito como bem inclinado, amigo das coisas de Deus e reverente a imagens sacras. Assim como o soberano mogol, os demais nobres demonstram a mesma consideração em relação às coisas sagradas, sendo alguns cristãos no coração, já que fazem-se mouros apenas falsamente, para viverem "à larga".

Em terceiro lugar, lê-se no extrato que Akbar realiza disputas sobre o islamismo, nas quais ele mesmo defende (de forma justa) a doutrina cristã. Casado com uma gentia, Akbar fez-se mouro não havia muito tempo, o que justifica sua pouca afeição à "maldita seita".

Por último, ressaltamos a descrição final do soberano mogol. Não só pelo pouco tempo de conversos, mas principalmente por sua natureza (homens de razão e brancos), não estavam os mogóis verdadeiramente ligados ao islamismo.

Iniciaremos nossa análise nos concentrando no primeiro e no último ponto identificados no relato acima, isso é, a descrição de Akbar. O que mais nos chama a atenção nesse trecho é a utilização de categorias como "homens de razão" e "gente de cor branca".

\footnotetext{
${ }^{78}$ CÓPIA de uma [carta] da Índia para a província de Portugal do ano de [15]79. ANTT, Armário Jesuítico, n. 28, ff. 91-2. Grifo nosso.
} 
Essa categorização necessariamente antecipa um modelo de atuação jesuíta, que deve priorizar justamente o uso da razão como meio de conversão. Passemos a algumas considerações teóricas que respaldam a nossa hipótese de que, ao se enfatizar a razão, antecipa-se o diálogo como forma de conversão. ${ }^{79}$

Em primeiro lugar, é preciso dizer que nas cartas e demais obras escritas por padres da Companhia de Jesus, não havia lugar para descrições ingênuas ou supérfluas. A prática missionária demandava que o religioso, já no seu escrever, propusesse uma maneira de agir e justificasse suas escolhas e ações. A escrita, para a Companhia, possui um valor estratégico. ${ }^{80}$ Inicialmente, o objetivo é dar notícia do que se passa nas missões ao superior. Mas não se trata apenas disso. A partir da ideia de narratio proposta por Alcir Pécora - um relato construído para uma pessoa ausente, que deve informar sobre o presente momento ("estado de coisas") - entendemos que a escrita missionária propõe, necessariamente, um diálogo entre a situação apresentada naquele momento e a perspectiva de um momento futuro. ${ }^{81}$

Dedicar-nos-emos agora a demonstrar porque essas expressões que procuram descrever a natureza de Akbar (e dos mogóis em geral) relacionam-se com uma estratégia de conversão específica e determinada e não com qualquer outra, a partir das ideias apresentadas por um jesuíta contemporâneo da missão mogol.

Do outro extremo da periferia do mundo cristão, isso é, no Novo Mundo, o jesuíta José de Acosta, escreveria, também pelos anos de 1580-90, sobre a organização sociopolítica das sociedades com as quais os jesuítas haviam travado algum contato. ${ }^{82}$ Em função dessa organização, Acosta propunha métodos de catequese e conversão adequados. Com essa proposta, o missionário no Peru apresenta uma definição muito precisa para o termo

\footnotetext{
79 'In the distant missions, Jesuit 'proselitism' and 'civilizing' were necessary coupled with the description, interpretation and classification of the phenomena, spaces and peoples whose mere existence presented disconcerting theological, sociological and political problems. Conversion methods ranged from total extirpation of all vestiges of non Christian religious practices, the so-called tabula rasa, which were applied to the 'stateless', illiterate barbarians', to various degrees of adaptation to the advanced civilizations of Mexico, Peru, China, China, Japan and India, and bear witness to the uneasy process of selecting appropriate strategies and missionary role models for the grafting of the Christian message, culture and government." ZUPANOV, I. Disputed Mission: Jesuit Experiments and Brahmanical Knowledge in 17th-century South India. Oxford University Press, 1999, p. 149.

80 "Letter writing, like the rest of their [i. e. jesuit's] rhetorical practice, was strategic. What the Jesuits taught about rhetorical form (...) is consistent with the function letters had for the society." BOSWELL, G. Letter writing among the Jesuits: Antônio Possevino's advice in the Bibliotheca Selecta (1593). Huntington Library Quarterly. University of California Press, 66/3-4, p. 247 - 262, 2003.

${ }^{81}$ PÉCORA, A. Máquina de gêneros. São Paulo: Editora Universidade de São Paulo, 2001.

${ }^{82}$ Cf: JOUSSELANDIÈRE, Victor Santos Vigneron de la. A dupla marginalidade de José de Acosta: religião e soberania no Vice-Reino do Peru (séc. XVI). Revista de História. n. 164, p. 101-125, 2011.
} 
"bárbaros": "são aqueles que se afastam da razão reta e das práticas comuns dos homens". 83 Eles podem ser divididos em três categorias, mas nosso foco será na primeira: aqueles que não se afastam demais da razão reta e das práticas comuns do ser humano. Estes são os que têm um sistema estável de governo, leis públicas, cidades fortificadas, magistrados, comércio próspero e bem organizado e, acima de tudo, bom uso das letras. ${ }^{84}$

Acosta inclui nesse primeiro grupo os chineses, seguidos dos japoneses e de grande parte da população do leste da Índia.

Estes povos, ainda que bárbaros e distantes em muitas questões da reta razão e da lei natural, hão de ser chamados à salvação do evangelho quase que da mesma maneira que foram em outros tempos os gregos e os romanos pelos apóstolos, assim como os demais povos da Ásia e Europa. Porque se destacam por sua capacidade e sua nada depreciável sabedoria humana, e é, sobretudo, por sua própria razão, com a atuação interior de Deus, que há de ter sucesso a vitória sobre eles e sua submissão ao Evangelho. Se nos empenharmos em submetê-los pela força e pelo poder não conseguiremos mais que afastá-los totalmente da lei cristã. ${ }^{85}$

Embora o conceito de "bárbaro" não esteja presente necessariamente nas obras que aqui analisamos, o termo é pertinente porque Acosta, além de categorizar os povos - seguindo critérios como hábitos, costumes, leis e uso da escrita - também associa tais categorias a estratégias de conversão. Atentar para este exercício dialético de observação (dos costumes) e adequação (das estratégias) exposto por Acosta e implícito muitas vezes nas fontes aqui abordadas é fundamental para a nossa análise. Acosta também nos conta sobre as vantagens das sociedades que apresentam um governo estável ou um líder. Ele diz que a existência de uma cabeza (líder) funciona como um ato providencial que permite a propagação do Evangelho. ${ }^{86}$

\footnotetext{
${ }^{83}$ ACOSTA, J. De procuranda Indorum salute. Madri: Consejo superior de investigaciones cientificas, 1984. p. 64. Todas as citações desta obra foram feitas livremente, a partir desta edição em espanhol.

${ }^{84}$ Ibidem, p. 63.

85 "Hae gentes, quamvis barbarae reverá sint et a recta et naturali lege plerisque in rebus discrepent, tamen ad salutem Evangelii non aliter fere vocandae sunt, quam olim ab apostolis graeci et romani caeterique Asiae atque Europae populi Nam et potentia praestant et nonulla humana sapientia atque a sua ipsi ratione potissimum, Deo intus agente, vicendi sunt et Evangelio subigendi. Quos si per vim et potentiam Cristo subicere pergas, nihil aliud quam ut a lege christiana alienissimos reddas". Ibidem, p.62-63. Grifo nosso.

${ }^{86}$ Acosta também nos conta sobre as vantagens das sociedades que apresentam um governo estável ou um líder. Ele diz que a existência de uma cabeza (líder) funciona como um ato providencial que permite a propagação do Evangelho. "Porque el haber en el orbe una cabeza, un señor temporal [...], hizo que el evangelio se pudiesse comunicar con facilidad a tantas gentes y naciones. Y lo mismo sucedió en las Índias, donde el haber llegado la notícia de Cristo a las cabezas de tantos reinos e gentes, hizo que con facilidade pesase por todas ellas". ACOSTA, J., S.J., História natural y moral de las Indias, en que se tratan las cosas notables del cielo, y elementos, plantas, y animales dellas ; y los ritos, cerimónias, leyes y govierno y guerras de los Indios (Sevilla, J. de León, 1590) Madrid: Historia 16, 1986. Livro VII; cap. XXVIII. Isso será mencionado em seguida, quando analisarmos o papel de Akbar nas disputas.
} 
Era, pois, necessário que o imperador fosse apresentado de forma adequada a uma audiência que só o conheceria mediatamente, isso é, apropriado pelas categorias missionárias. Assim sendo, na mesma passagem em que o jesuíta descreve Akbar dessa maneira, ele acrescenta que, no Mogol, ocorrem disputas à noite sobre a“seita".

Outro aspecto que gostaríamos de ressaltar, mediante a comparação das ideias de Acosta e a do trecho que havíamos destacado, é a menção a japoneses e chineses. Propomos, nesta tese, que o "modo de agir" missionário antecipado por essa carta é análogo ao que a Companhia de Jesus desenvolvia em outras partes da Índia, no Japão e na China. Tal forma de atuar levava o nome de acomodação.

No início da Era Moderna, o método de conversão chamado de acomodação era geralmente atribuído aos missionários jesuítas na Ásia, distinguindo-se de outros métodos, que, a princípio, seriam menos sensíveis à carga cultural trazida pelos catecúmenos. Para fins de explicação, podemos traçar uma oposição teórica entre o método de tábula rasa ou os aldeamentos e reduções praticados por jesuítas em determinados momentos nas missões na América. Ainda que seja discutível a ideia de que toda estratégia catequética previa, em menor ou maior grau, alguma adaptação, gostaríamos apenas de frisar a distinção entre os contextos asiáticos e os do Novo Mundo e seu correspondente missiológico. Na Ásia, os jesuítas não julgaram necessária uma reordenação estrutural da moral e do trabalho das sociedades nas quais estabeleceram missão, por exemplo. Além disso, em regiões nas quais a presença militar portuguesa era debilitada ou nula, privilegiar métodos de persuasão em detrimento à coerção foi uma prática comum adotada nas missões chinesas, japonesas e em territórios do subcontinente indiano não subordinados à Coroa Portuguesa.

Além disso, os missionários da Companhia de Jesus compreendiam a acomodação como uma fórmula antiga, empregada pela Igreja primitiva, que poderia ser transposta para realidades sociopolíticas análogas àquelas encontradas pelos primeiros cristãos em suas missões evangelizadoras dentre judeus, gregos e romanos, conforme podemos ler na citação de Acosta.

$\mathrm{Na}$ Ásia, em geral, os jesuítas privilegiaram, portanto, estratégias que giravam em torno do diálogo, do debate, da persuasão e do convencimento. Um aspecto elementar desse tipo de estratégia era a leitura de textos "teológicos", seu estudo, a identificação de seus 
"erros" ou "desvios", bem como a busca, a partir desses textos, pela compreensão da finalidade de ritos e cerimônias. ${ }^{87}$

A acomodação a que nos referimos no caso do Mogol, portanto, é justamente essa transposição de finalidades: utiliza-se do mesmo meio - sejam os debates ou a tradução e produção de determinadas obras escritas - com objetivo distinto. Um processo políticocultural engendrado dentro de uma lógica "mogol” é apropriado pelos missionários, passando a ter novo papel: de estratégia de conversão. No momento oportuno, analisaremos como foi a participação dos jesuítas nos debates e como se deu esta transposição de finalidades. A seguir, trataremos, finalmente, do convite de Akbar diretamente endereçado aos padres da Companhia de Jesus.

${ }^{87}$ ZUPANOV, I. Accommodation. In: Dictionnaire des fais religieux. Ed. Régine Azria e Danièle HervieuLeger. Paris: PUF. p. 1-4. 


\title{
1.4 A MISSÃO SOB ENCOMENDA: AKBAR CONVIDA OS PADRES DA COMPANHIA DE JESUS
}

\author{
PARA FATEHPUR SIKRI
}

Um convite improvável pegou de surpresa a comunidade religiosa cristã de Goa em 1579: o imperador muçulmano Akbar, soberano mogol, convidava a sua corte padres letrados "para lhe explicarem a Fé do Evangelho, \& a Lei de Christo". 88

Por ordem de Zeladin, o Grande, Rei por graça de Deus. Desejo fazer saber, autoridades dos Padres da Ordem de S. Paulo, que os tenho em grande apreço. Os mando Ebadulla, meu embaixador, e a Domingos Peres ${ }^{89}$ para solicitar que nos envieis a dois de vossos sacerdotes mais eruditos. Nos agradaria que nos trouxessem os livros supremos da Lei e o Evangelho, porque assim poderíamos aprender a Lei, seu significado completo, assim como as verdades perfeitas que nela se encontram contidas. Não permitirás que duvidem à hora de empreender a viagem junto a nossos embaixadores, quando esses abandonarem Goa em seu caminho de regresso; e permiti-lhes que tragam consigo os livros da Lei. Faça entender aos sacerdotes que os receberemos com amabilidade e com as honras correspondentes. Sua visita nos dará muito prazer e, assim que tivermos aprendido aquilo que tanto almejamos saber sobre a Lei, sua perfeição e salvação que nos oferece, serão autorizadosa empreender o caminho de retorno quando assim desejarem. Não os deixaremos partir sem render-lhes todas as honras e entregar-lhes muitos presentes. Não permitais que tenham temor de vir. Estarão sob nossa própria proteção e custodia. Que gozes de boa saúde. ${ }^{90}$

Nos documentos encontrados no Arquivo da Torre do Tombo, em Lisboa, o suposto formão de Akbar aparece da seguinte forma:

Em nome de Deus,

Formão do Zeladin Machamede Achebar, Rei posto por Deus.

Principais padres da Ordem de São Paulo,

Saibam que sou grande amigo. Em mando lá a Abadolá, meu embaixador, e Domingos Pires para vos pedir que me mandem por eles dois padres letrados, e tragam os livros da Lei mais principais, e Evangelhos, para saber

${ }^{88}$ SOUZA, F. O Oriente conquistado a Jesu Christo pelos padres da companhia de Jesus da provincia de Goa... Lisboa: na officina de V. Da Costa Deslandes, 1710. vol. 2, p. 936.

${ }^{89}$ Domingos Peres, Domingos Pires, Dominicus Peres ou Dominique Briz foi um cristão armênio, que se casou em 1582 com uma indiana. Ela auxiliava os jesuítas nas disputas, como intérprete. Cf: Nota 8, segundo capítulo de PAYNE, C. H. (Ed.) Akbar and the Jesuits. An account of the Jesuit Missions to the court of Akbar by Father Pierre du Jarric, S.J., Nova Deli: LPP, 1999. Em uma carta de Franciso Henriques para o Padre Lourenço Pires, publicada por Wicki, podemos ler: "Domingo Pirez, que é língua d'el Rei, que veio conosco da Índia e é armênio de nação." CARTA de Franciso Henriques para o Padre Lourenço Pires, Documenta Indica, vol XII, Doc 3, p. 14.

${ }^{90}$ MONTSERRAT, A. Mongolicae Lagationis Commentarius. Apud: ALAY, J.L. Embajador en la corte del Gran Mogol.Tradução Ramon Sala. Lleida: Milenio, 2006. p. 60. Outras versões do documento podem ser encontradas, variando muito pouco no conteúdo. Todos os trechos desta obra aqui citados foram livremente traduzidos desta edição, isto é, de sua publicação em língua espanhola. 
a lei, e perfeição dela, porque desejo muito sabê em meu coração. E peço que não faltem de vir com os mesmos embaixadores tanto que lá chegarem, e juntamente tragam os livros da lei. E saibam que os padres que vierem receberei com todas as honras possíveis, e receberei com muito gosto com a sua vinda. E tanto que eu for informado da lei, e da perfeição dela como desejo, eles se poderem ir cada vez que quiserem, e eu os mandarei com muitas honras e mercês, e não tenham receio de vir, porque eu os tomo à minha conta.

Feita em dezembro de $78 .^{91}$

Após a leitura dessas duas versões e de seu confronto com outras versões publicadas, percebemos que, como conteúdo comum, figura o pedido por dois padres da Companhia de Jesus - identificados como padres da Ordem de São Paulo em função do Colégio de São Paulo, em Goa. Além disso, repete-se nas duas versões o pedido para que se leve a Akbar "os livros da Lei mais principais, e Evangelhos”. Fica manifesto, em ambos os textos, o desejo do imperador mogol de conhecer o cristianismo, ainda que este nome não esteja presente em qualquer um dos dois documentos. Para isso, os missionários enviados deveriam ser instruídos o suficiente para que tivessem a capacidade de expor com clareza a lei cristã. Akbar insistia ainda que os padres não deveriam ter receio de aceitar o convite, já que iria recebê-los com todas as honras possíveis e colocá-los sob sua proteção. Uma vez satisfeito com as informações fornecidas, o mogol permitiria o retorno dos padres, quando e quantas vezes desejassem. O corpo principal da mensagem aos padres está em consonância com o contexto indiano de abertura a diversas religiões. No entanto, o salto entre a suposta "curiosidade" de Akbar e a possibilidade de missão é materializado de forma explícita na palavra salvação, presente apenas nas linhas de Montserrat. O soberano, na obra do jesuíta, desejava não só conhecer o cristianismo, mas saber da salvação que ele oferecia.

Reiteramos, portanto, que há uma distinção entre os projetos da Companhia de Jesus os quais ainda estavam por construir - e a literalidade do pedido. Os jesuítas eram convidados a fazer parte de um movimento ideológico-cultural em curso na corte do Indostão, sintetizado por Ganeri na expressão cosmopolitismo religioso. ${ }^{92} \mathrm{O}$ conteúdo do convite presente na versão do documento do Arquivo Nacional da Torre do Tombo (ANTT) pode ter sofrido inúmeros ruídos, mas é verossímil do ponto de vista mogol. A perspectiva de conversão, trazida de forma evidente pela palavra salvação, destoa (e em certo sentido, contradiz) da

${ }^{91}$ FORMÃO de Zeladin Machamede Achebar, rei posto por Deus, [aos] principais padres da Ordem de São Paulo. ANTT, Armário Jesuítico, n.28, fl: 88v.

92 "In the background, then, is what might be termed a religious cosmopolitanism, a belif that there is a common spiritual heritage to all humanity. This is a manifestation of the Sufi doctrine of whadat al-wujud ('Unity of Being'), which, as Muzaffar Alam has shown, contribuited to the shape of Hindu-muslim relations in northern India throughout the sixteenth and seventeenth centuries." GANERI, J. The Lost Age of Reason: Philosophy in Early Modern India 1450-1700. EUA: Oxford University Press, 2011, p. 25. Grifo nosso. 
intenção de se informar sobre as leis ou religiões daqueles que habitavam as terras do Império Mogol. Achamos pertinente insistir no papel que a escrita jesuíta tem de construir a missão num momento em que ela ainda não existe, materializá-la linguisticamente na inserção de uma palavra cujo conteúdo interfere na mensagem geral do texto.

Recebido o convite, a ideia foi debatida em Goa por um conselho composto pelos arcebispos e demais bispos das Índias. Eis a decisão do conselho:

Respondendo ao que por parte do senhor conde Visorei nos foi perguntado a mim, o Arcebispo de Goa, e aos reverendíssimos senhores Bispo de Cochim, Malaca, e China, e o licenciado André Fernandes nosso provisor, se deixava ir sua S. Ilustríssima ao Equebar, rei dos Mogores, os religiosos da Companhia de Jesus, que por seu embaixador e formões manda pedir sem ficarem com eles reféns para o que depois podia suceder. Considerada a qualidade e importância do negócio que sucedendo bem importa a conversão de tantas almas e a instância com que o dito Rei pede os ditos padres, e o Evangelho de Cristo Nosso Senhor nomeando por sua boca o que parece tocamento do Divino, porque como diz Paulo aos de Corinto ninguém pode dizer, ou nomear o Senhor Jesus senão em o Espírito Santo, e considerada soberdade (...) e o esforço com que os servos de Deus fizeram a pregação do Evangelho até por isso padeceram gloriosos martírios, mercê particular de Deus como o mesmo Paulo disse aos Filipenses, havendo por dom o benefício de Deus não somente crer em Cristo mas padecer por ele, e que fazia escândalo aos infiéis não irem os padres ao chamamento com tal e outra segurança e amparo mais que o da Divina Proteção (...). Nos parece bem assim e aos ditos senhores bispos (...) que S. S. Ilustríssima deveria despachar os ditos padres e deixa-los ir com o dito embaixador que os veio buscar sem outros reféns mais que os da Divina Providência, porém com os mais favores e crédito que pode ser confiando em Nosso Senhor e sua Divina Potência e bondade, por cuja glória e honra os ditos padres vão, os guardará de perigos e ajudará em tão santa empresa, como será vindo a efeito a conversão de hum rei tão poderoso que é se fizer cristão e receber a nossa lei. ${ }^{93}$

Fica claro, portanto, que o conselho respondeu de forma positiva. Isso não chega a ser uma surpresa, visto o caráter evangelizador da presença portuguesa no Oriente e a importância política de Akbar e de seu Império para os planos do Estado da Índia. Resta-nos, então, analisar minuciosamente os argumentos utilizados para sustentar o envio dos missionários.

Em primeiro lugar, identificamos que os religiosos deram bastante relevância ao convite, vista a "qualidade e importância do negócio que sucedendo bem importa a conversão de tantas almas". Ao contrário do que sustentamos acima, nesse caso fica explícita no texto a questão missionária. Estava em jogo a conversão de inúmeras almas.

\footnotetext{
${ }^{93}$ CONSELHO do Arcebispo de Goa e mais bispos da Índia sobre o que se faria acerca da embaixada do Grão Mogor. ANTT, Armário Jesuítico, fl: 89v-90.
} 
A argumentação desenvolve-se de maneira a demonstrar os aspectos positivos mesmo naqueles que poderiam ser entendidos como os piores cenários: para o caso da morte dos missionários, deveria se ter em mente que o martírio significava uma "mercê particular de Deus", já que era um valor não só crer em Deus "mas padecer por ele". Dito isso, o risco de morte dos jesuítas enviados não bastava como justificativa contra a sua partida.

Outro argumento utilizado é a hipótese de um escândalo no caso de "não irem os padres ao chamamento com tal e outra segurança...". A nosso ver, o escândalo envolve dois aspectos: o primeiro implica o que poderia ser entendido como "covardia" pelos muçulmanos. O segundo, e talvez mais grave, implica em abrir a possibilidade de se interpretar a não ida dos religiosos como falta de confiança na proteção de Deus, ou seja, falta de fé. Afinal, os missionários contavam com "amparo da Divina Proteção" e deviam confiar "em Nosso Senhor e sua Divina Potência e bondade, por cuja glória e honra os ditos padres vão, os guardará de perigos e ajudará em tão santa empresa”.

Por último, aparece o que seria o "melhor cenário": "a conversão de um rei tão poderoso que é se fizer cristão e receber a nossa lei." Ou seja, a morte não servia como argumento, já que o martírio era uma honra. Não ir era impossível, porque pareceriam covardes e incrédulos aos olhos dos muçulmanos. Era preciso confiar, já que, justamente pela Glória de Deus, partiam os religiosos. Ao final, existia ainda a possibilidade de conversão de um imperador oriental poderoso, que poderia vir a ser um novo Constantino para cristandade nas Índias, “como teve ao princípio em Europa para o desterro da idolatria e aumento da religião cristã". 94

Os argumentos a favor do envio dos padres não se concentram apenas no trecho destacado acima. A deliberação do conselho continua e a argumentação vai ganhando cores políticas. Para o caso de os missionários ficarem reféns no Indostão, isso é, caso seja "artifício e malícia" a garantia do "formão e salvo conduto" de que o imperador "os deixará retornar livremente para nós em paz", o Estado ficaria livre para "poder perseguir este rei, castigandoo como rebelde ao Evangelho, mal tratador de seus ministros e quebrantador (sic) de sua palavra e direito das gentes". ${ }^{95}$ Por conseguinte, poderia o Estado de Índia, nesse caso, "conquistar-lhe justamente seus portos, terras e embarcações.",96

\footnotetext{
${ }^{94}$ CONSELHO do Arcebispo de Goa e mais bispos da Índia sobre o que se faria acerca da embaixada do Grão Mogor. ANTT, Armário Jesuítico, fl: 89v.

${ }^{95}$ Ibidem, fl: 90.

${ }^{96}$ Ibidem, loc. cit.
} 
A recomendação do conselho não foi nem inocente, nem superficial. Ela levou em conta as ameaças e perigos envolvidos e indicou vantagens tendo em vista dois aspectos - o espiritual e o temporal. Apresentou o sofrimento - e até a eventual morte dos missionários como um valor positivo. Indicou a possibilidade do surgimento de um novo Constantino na Ásia. Abriu espaço para uma guerra justa, no caso de o imperador estar mentindo e não deixar os padres voltarem. ${ }^{97}$

Dada e justificada a decisão do conselho, partiram três jesuítas para o Indostão: Rodolfo Acquaviva, sobrinho do Geral Claudio Acquaviva, Francisco Henriques e Antônio de Montserrat. ${ }^{98} \mathrm{O}$ primeiro, foi designado como superior. $\mathrm{O}$ segundo teria a função de língua. Nascido em Ormuz, Henriques era um murtadd, um apóstata, ou um muçulmano convertido. ${ }^{99}$ O último, Montserrat, recebera do provincial da Índia, o padre Rui Vicente, a tarefa de tomar nota de tudo que se passasse, para além da já tradicional orientação de manter uma correspondência frequente com seus superiores. Assim, o padre dedicou-se a escrever uma obra na qual relataria, quase como um diário, o passo a passo dessa primeira experiência da Ordem na corte do imperador mogol Akbar. Essa obra viria a ser intitulada Mongolicae Legationis Commentarius e teria sido finalizada nos últimos anos do século XVI. Conforme podemos observar nesse relato, uma vez na corte de Akbar, os jesuítas passaram a tomar parte nos debates públicos promovidos pelo imperador. Ainda que seus escritos não discriminem religiosos que não muçulmanos, fontes mogóis indicam que várias religiões teriam

\footnotetext{
${ }^{97}$ Para Kahlos, "o valor propagandístico da conversão de um homem importante era provavelmente tão relevante quanto o poder de um patrono rico". ("The propagandistic value of the conversion of a proeminente man was probably as significant as the power of a wealthy patronus"). No caso de Akbar, ele representaria ambos: um líder político proeminente na Ásia e um patrono rico e poderoso. KAHLOS, M. Debate and Dialogue: Christian and Pagan Cultures. Aldershot: Ashgate, 2007, p. 92.

98،"Em vinte \& hum de Março de mil quinhentos e setenta \& quatro partio do rio de Lisboa para Índia hua armada de cinco naos, pelas quais vierão (SIC) repartidos quarenta e dous Missionários (SIC) da Companhia [de Jesus] bem providos do viático necessário pela liberal magneficencia (SIC) do serenissimo (SIC) Rey Dom Sebastião. O Padre Visitador Alexandre Valignano na nao Chagas, que era a Capitania (SIC): o Padre Nuno Rodrigues na nao Santa Fé: o Padre Francisco Riera em Santa Catharina: o Padre Antônio (SIC) de Monserrate (sic) na Annunciada: o Padre Ruy Vicente em Santa Barbara (SIC). Os nomeados eram superiores, aos que os outros vinhão (SIC) sugeitos (SIC) em cada hua das naos." SOUZA, F. O Oriente conquistado a Jesu Christo pelos padres da companhia de Jesus da provincia de Goa... Lisboa: na officina de V. Da Costa Deslandes, 1710. vol. 2 , p. 881.

${ }^{99}$ "Folgou el-rey de me ouvir o parcio (SIC), ainda que muito mais folgara se podera servir em coisas graves, por ver que o que entendo pronuncio bem em parcio, mas nao me ajuda a memória nem a idade pera cumprir em breve estes desejos a alguns. Domingos Pirez serve nas disputas, com me ajudar em algumas cousas ainda que poucas: por nao entender elle bem o portugues, deixo eu muito de ser ajudado delle." Documenta Indica, vol: XII, p. 7. O tradutor da missão, ou língua, seria Domingo Pirez. Cf: TRASLADO das cartas do Mogol, 29 de abril de 1580, Documenta Indica, p. 14. Longa passagem sobre Montserrat saber pérsio, no mesmo documento, p. 20. Cf: Documenta Indica, vol: XII, p: 7.
} 
representantes presentes nessas audiências. ${ }^{100}$ A seguir, trataremos da chegada dos jesuítas à Fatehpur Sikri e de sua participação nas disputas.

${ }^{100}$ FAZL, A. The Akbarnāma of Abu-l-Faẓl, a history of the reign of Akbar including an account of his predecessors. Tradução H. Beveridge. Calcutá: Asiatic Society, 1910-1939. Disponível em:<http://persian.packhum.org/persian/main?url=pf\%3Ffile\%3D00701023\%26ct\%3D0> 


\subsection{DIÁLOGOS IMPROVÁVEIS, CONSENSO IMPOSSÍVEL: AS DISPUTAS RELIGIOSAS NA} CORTE DE UM IMPERADOR MUÇULMANO NA ÍNDIA (1570-1605)

Ao chegarem à corte de Fatehpur Sikri, os missionários foram recebidos por Akbar e aproveitaram a ocasião para entregar-lhe um presente - um atlas - enviado pelo arcebispo de Goa. Segundo Montserrat, os padres foram bem recebidos e interpretaram a amabilidade de Akbar como indício de uma "rápida conversão do monarca à religião de Cristo" ${ }^{101}$

No dia seguinte, os recém-chegados missionários foram cear com o padre Pereira, que havia intermediado o convite aos jesuítas e estava na corte de Akbar há algum tempo. ${ }^{102}$ Os padres então the perguntaram sobre o "estado de ânimo" de Akbar em relação ao cristianismo. Pereira descreveu um soberano não só simpático ao cristianismo como também avesso ao islamismo. Disse que Akbar venerava a Cristo e à mãe de Deus e que não estava longe de considerar Cristo divino. Aprovava os preceitos do Evangelho, assim como admirava o fato de os cristãos prestarem tanta atenção à castidade a ponto de proibirem aos homens terem mais de uma mulher e requererem o cumprimento do celibato por parte dos padres. ${ }^{103} \mathrm{O}$ único problema, segundo Pereira, era a incapacidade de Akbar de entender que "havia três pessoas em um único Deus" e que "o filho de Deus foi concebido por uma virgem, que padeceu na cruz e que foi assassinado por judeus". ${ }^{104}$ Apesar disso, Pereira dizia que Akbar "aceitaria a verdade destas doutrinas" se os jesuítas fossem "capazes de convencê-lo de que os Evangelhos provinham de Deus". ${ }^{105}$

Deixando a imagem de Akbar ainda mais simpática ao cristianismo, Pereira acrescentou que ele não só ouvia de bom grado os relatos sobre os milagres de Cristo, como também acreditava que Maomé "era um impostor que havia enganado os homens." "106

Porém, se Akbar era assim tão suscetível às ideias da doutrina cristã, por que então Pereira não fora capaz de convertê-lo? A resposta que Montserrat nos dá para essa pergunta é a seguinte: antes da chegada dos sacerdotes, o padre Pereira havia tentado transmitir a Akbar

\footnotetext{
${ }^{101}$ MONTSERRAT, A. Mongolicae Lagationis Commentarius. Apud: ALAY, J.L. Embajador en la corte del Gran Mogol.Tradução Ramon Sala. Lleida: Milenio, 2006, p. 84.

102 Conforme dito nas páginas anteriores.

${ }^{103}$ MONTSERRAT, A., op. cit., p. 84.

104 Ibidem, loc. cit.

105 Ibidem, loc. cit. Grifo nosso.

106 Ibidem, p. 84.
} 
os ensinamentos que "resultaram decisivos para as próprias inclinações daquele [Akbar] em relação ao cristianismo. Porém, a missão não tivera êxito devido à ignorância do intérprete."107

Expostas as ideias de Pereira acerca do soberano, os jesuítas consideraram necessário "refletir com profundidade a fim de decidir sobre o curso dos acontecimentos". ${ }^{108}$ Era preciso ponderar para escolher com prudência as estratégias que seriam implementadas nessa missão.

Após a conversa com o padre e uma vez descansados de sua viagem, os jesuítas foram, então, convocados por Akbar. Montserrat evidencia em seu relato toda a prudência na escolha por uma determinada estratégia de conversão:

A partir de então [isto é, depois de terem refletido sobre os informes de Pereira e a convocação de Akbar, os missionários] se puseram a trabalhar para conseguir o objetivo que os havia levado àquelas terras através de tão largo e penoso caminho. A este fim, atuaram de modo seguinte. No dia três de março levaram à sala de audiências uma cópia da Sagrada Bíblia, escrita em quatro línguas e encadernada em sete volumes ${ }^{109}$, que deram de presente ao rei. Diante de seus nobres e doutores religiosos, Zelaldin [Akbar], de uma maneira muito devota, não só beijou a Bíblia como também a pôs sobre a cabeça. Em seguida, perguntou em que volume se encontrava o Evangelho e quando se indicou a ele, mostrou ainda mais veneração por este livro. Pediu aos sacerdotes que levassem a Bíblia a seus aposentos privados, onde mais uma vez abriu os volumes com grande devoção e gozo. Voltou a fechá-los com muito cuidado, e os colocou numa bela estante digna dos volumes sagrados que tinha no mesmo aposento privado no qual o rei passava boa parte do seu tempo de ócio. ${ }^{110}$

Esse trecho é bastante eloquente quanto à teatralização das atitudes dos jesuítas, bem como à tentativa de convencer o leitor da simpatia ou até mesmo veneração de Akbar pelo cristianismo. É importante pontuar que Montserrat faz questão de dizer que tudo isso se passou na "sala de audiências", ou seja, na frente dos doutores muçulmanos e nobres da corte.

Após essa entrada nada comedida, os jesuítas apresentaram-se para o primeiro debate:

Surgiu a oportunidade de estabelecer um debate, à noite, entre os sacerdotes e os mestres e doutores religiosos. Discutiram entusiasticamente sobre a exatidão e autoridade das Sagradas Escrituras, fundamento da religião cristã, e sobre o livro que os agarenos creem inspirado por Deus, ainda que Mahamed [sic] o enchera de inúmeras fábulas sem valor ou interesse. ${ }^{111}$

\footnotetext{
${ }^{107}$ MONTSERRAT, A. Mongolicae Lagationis Commentarius. Apud: ALAY, J.L. Embajador en la corte del Gran Mogol.Tradução Ramon Sala. Lleida: Milenio, 2006, p. 85

${ }^{108}$ Ibidem, loc. cit.

${ }^{109}$ Essa Bíblia, segundo nos informa Didier, fora preparada por Benito Arias Montano e publicada entre os anos de 1568 e 1572. Cf: DIDIER, H. Muslim heterodoxy, Persian murtaddun and jesuit missionaries at the court of king Akbar (1580-1605). The Heythrop Journal, p. 900, nov. 2008. Importante destacar que o próprio Akbar pedira por uma Bíblia em seu formão: “e tragam os livros da Lei mais principais, e Evangelhos".

${ }^{110}$ MONTSERRAT, A. Mongolicae Lagationis Commentarius. Apud: ALAY, J.L. Embajador en la corte del Gran Mogol.Tradução Ramon Sala. Lleida: Milenio, 2006. p. 90.

111 Ibidem, p. 91.
} 
Esse seria, portanto, o tema da primeira disputa: ${ }^{112}$ a exatidão e autoridade das Sagradas Escrituras, isso é, a Bíblia do ponto de vista cristão, e o Corão, que não é nomeado por Montserrat. É curioso notar que esse foi justamente o tema indicado por Pereira na conversa com os jesuítas (na qual ele disse que Akbar aceitaria as doutrinas cristãs uma vez convencido de que os Evangelhos provêm de Deus). ${ }^{113}$

Fica posta a dúvida quanto à temática escolhida para esses debates. Por um lado, temos a hipótese de que os assuntos eram escolhidos pelos sacerdotes muçulmanos ou por Akbar, ou ainda que fossem tópicos caros aos debates islâmicos "tradicionais". Isso é, supomos que, historicamente, alguns temas ou passagens do Corão fossem mais polêmicos e, portanto, privilegiados nesses debates. Nesse caso, os jesuítas não teriam nenhuma participação na escolha do tema, nem mesmo no encaminhamento da questão a ser discutida. $^{114}$

Por outro lado, temos a hipótese de que, nesse momento, os jesuítas possam ter tido algum espaço para a escolha do tema, uma vez que ele aparece antecipado pelo texto do Commentarius na conversa entre Pereira e os recém-chegados missionários.

Os desdobramentos dessas duas hipóteses são um tanto quanto antagônicos, uma vez que os jesuítas, já cientes do "ponto" a ser debatido, poderiam preparar melhor, isso é, com antecedência, a sua defesa, inclusive produzindo um texto escrito. Para o segundo caso, os jesuítas teriam que argumentar de forma mais espontânea, e, levando em conta a barreira linguística, talvez de forma mais improvisada.

\footnotetext{
112 Julgamos pertinentes apontarmos a definição de Maijastina Kahlos para debate e disputas, a qual serviu de base para a nossa formulação de "diálogos (não)ficcionais narrados": partiremos da definição fornecida por Maijastina Kahlos, que considera debate ou disputa "como a tentativa de persuadir outros debatedores através da argumentação" enfatizando "o objetivo da mudança de atitude em relação opiniões, atitudes ou crenças". Nas palavras da autora: "I use the term debate, dispute and polemic when describing the Christian rhetorical strategies against pagans. Debate refers to a discussion about a subjetc on which interlocutors have diferente views they defend. Debate and dispute are used here roughly as synonyms although dispute refers to a stronger disagreement between two or more persons. I regard debate as attempting to persuade other debaters through argumentation and I stress na aim ofchange of opinions, attitutes or beliefs." KAHLOS, M. Debate and Dialogue: Christian and Pagan Cultures. Aldershot: Ashgate, 2007. Grifos nossos.

${ }^{113}$ MONTSERRAT, A. Mongolicae Lagationis Commentarius. Apud: ALAY, J.L. Embajador en la corte del Gran Mogol.Tradução Ramon Sala. Lleida: Milenio, 2006, p. 84.

114 "The history of debate between Muslim and Christians begins with the Prophet himself. The Qur'an contains a substantial amount of teaching about Christianity, some of it portraying the faith favourably, but much of it warning against mistakenness. The greatest bulk of this teaching concerns the nature of Christ, who it repeatedly asserts was no more than a human warner. He was a prophet, and was granted many miraculous signs by God, but he was no greater than prophets before and after him, a human being and servant of the one transcendent divinity. Naturally, Muslims were influenced very deeply by this teaching and rarely demonstrated any independent estimation of Christianity, or indeed thought it necessary to do so." THOMAS, D. Early Muslim Relations with Christianity. Anvil, vol. 6, n. 1, 1989. Neste e em um outro artigo, Thomas afirma que desde o inicio do trabalho de síntese da Teologia Muçulmana, no século IX, a refutação da Santíssima Trindade e da Natureza divina de Cristo ou o mistério da encarnação são temas centrais do pensamento islâmico. Cf: THOMAS, D. Christian Doctrines in Islamic Theology. Lieden, Boston: Brill, 2008.
} 
Essas duas hipóteses que dizem respeito à escolha do tema e ao encaminhamento das questões ainda não estão claras para nós porque é possível que as fontes jesuítas procurem apresentar os missionários como sujeitos desses debates teológicos, o que pode sobrevalorizar a participação dos cristãos nas audiências na presença de Akbar.

De qualquer forma, o fato é que, segundo o texto de Montserrat, os jesuítas se saíram muito bem, argumentando que os Evangelhos já são mencionados nos livros de Moisés e também pelos profetas do Antigo Testamento. Até mesmo o Corão, que se opõe ao Evangelho, não pode evitar "testemunhar [sua] santidade e autenticidade. Também pode ler-se em seu livro [Corão] que Deus todo poderoso entregou o Evangelho a Jesus Cristo, por mais que o autor do Corão afirme sem rigor que Deus o ofereceu completo e acabado, de modo análogo a como ofereceu a Torá, isto é, a lei de Moisés, o Zabur, isto é, os salmos a David, e o Corão a ele mesmo." 115

Ainda que Montserrat peça desculpas pela presença de "tão peculiares termos"116, salta-nos aos olhos a sua atribuição de autoria dos Evangelhos a Cristo. Mesmo assim, os argumentos dos jesuítas parecem ter silenciado os religiosos muçulmanos, que não teriam sido capazes nem de atestar a autenticidade do Corão, nem refutar as objeções apresentadas contra seu próprio livro. "Envergonhados diante do rei, ficaram muito confusos, se retiraram do debate e, finalmente, sumiram em silêncio absoluto." 117

$\mathrm{Na}$ sequência do relato de Montserrat, fica dito que a argumentação teria agradado Akbar, que, ao final do debate, se retirou acompanhado dos missionários, elogiando a maneira pela qual os jesuítas provaram o seu ponto. Em seguida, Akbar abordou dois assuntos, ao que parece, reservadamente com os jesuítas. O primeiro, apresentado por Montserrat como um conselho, diz respeito à forma de atuação dos missionários: "falem e atuem com precaução, dado que seus inimigos não têm muitos escrúpulos". ${ }^{118}$ Isso pode indicar que os jesuítas procuraram impor uma dinâmica de disputa não muito adequada ao "protocolo" dos debates públicos conduzidos na corte mogol, talvez desconsiderando alguns aspectos da etiqueta ou normas desse tipo de evento.

O segundo assunto já havia sido antecipado por Pereira, tal como a questão da autenticidade e origem divina dos Evangelhos. "Agora queiram me explicar o seguinte" pede Akbar - "como é possível que Deus todo poderoso seja três e um ao mesmo tempo, e

\footnotetext{
${ }^{115}$ MONTSERRAT, A. Mongolicae Lagationis Commentarius. Apud: ALAY, J.L. Embajador en la corte del Gran Mogol.Tradução Ramon Sala. Lleida: Milenio, 2006, p. 91.

${ }^{116}$ Ibidem, loc. cit.

117 Ibidem, loc. cit.

118 Ibidem, loc. cit.
} 
como pode ter um filho, feito homem e nascido de uma virgem. Estas teses desafiam minha compreensão."119

Em uma carta de Rodolfo Acquaviva, essa passagem aparece com uma diferença bastante sutil, mas que, todavia, nos parece essencial. Akbar teria dito aos padres que

lhe parecia bem a nossa lei, mas como os seus eram maus, nos avisava que falássemos e tratássemos cautamente: somente desejava que lhe declarássemos os mistérios da Santíssima Trindade, e como Deus tinha filho e se fizera homem, porque tinha muita dificuldade de entender estas duas coisas. Respondemos que, quanto aos molas, que não por medo mas por fazer o que Sua Alteza nos mandava, trataria cautamente com eles. ${ }^{120}$

Sobre a resposta que os jesuítas teriam dado a Akbar, Acquaviva nada nos diz.

A nós parece que Akbar informa claramente aos jesuítas porque os chamara ali, pelo menos no que diz respeito aos assuntos estritamente religiosos, isso é, não considerando supostos interesses políticos relativos à presença portuguesa nas costas do subcontinente indiano. Mas os jesuítas optaram por engajá-lo em uma espécie de "catequese" progressiva e negaram-lhe uma resposta mais imediata.

Três dias após o debate sobre a autenticidade dos textos sagrados, os jesuítas participaram de um novo encontro, no qual o tema de discussão foi o Paraíso ${ }^{121}$ ou, nas palavras do jesuíta: a "glória celestial". ${ }^{122}$

Sobre esse debate, Montserrat nos informa muito pouco, dizendo apenas que "o gozo de prazeres e delitos impuros", isso é, o Paraíso definido falsamente pelo profeta Maomé, é um conceito de céu "rotundamente divergente dos que encontramos nos ensinamentos expostos nas Sagradas Escrituras". 123

Em uma carta datada de 13 de julho de 1580, assinada pelos três missionários da missão do Mogol, encontramos mais informações sobre tal disputa:

Passados três dias, tivemos outra disputa acerca do paraíso (sic), que Maphamede põe cheio de comer, mulheres e outras mentiras (...). El-Rey, que era o que disputava por saber mais que quantos molas tem, não sabendo responder conforme o Alcorão, buscou outras repostas de sua cabeça,

\footnotetext{
${ }^{119}$ MONTSERRAT, A. Mongolicae Lagationis Commentarius. Apud: ALAY, J.L. Embajador en la corte del Gran Mogol.Tradução Ramon Sala. Lleida: Milenio, 2006, p. 91-2.

${ }^{120}$ CARTA dos padres Rodolfo Aquaviva, Antônio de Montserrat e Francisco Henriques ao padre Provincial Roderico Vicente. Agra, 13 de julho de 1580. Documenta Indica, v. XII (1580-1583), doc. 05, p. 35-6. ANTT, Armário Jesuítica n. 28, ff.109r-12v.

121 "Eis uma imagem do Paraíso prometido aos piedosos. Nele correm rios de água sempre límpida, e rios de leite de um sabor inalterável, e rios de vinho - uma delícia para os que o bebem - e rios de mel destilado. E lá estão todas as frutas e o perdão do Senhor." Corão, Sura 47, \#14

${ }^{122}$ MONTSERRAT, A. Mongolicae Lagationis Commentarius. Apud: ALAY, J.L. Embajador en la corte del Gran Mogol.Tradução Ramon Sala. Lleida: Milenio, 2006. p. 92.

${ }^{123}$ Ibidem, loc. cit.
} 
porque, dizendo-lhe nós: 'VA não diz o que está no Alcorão' sorrindo-se ficou entendendo que sua lei era tal que não podia dar razão dela. ${ }^{124}$

Esse extrato é interessante, em primeiro lugar, porque indica que Akbar podia ter um papel ativo nos debates, tomando parte nas discussões e argumentando, não sendo apenas ouvinte, objeto ou destinatário dos discursos de outrem. ${ }^{125}$ Além disso, fica claro que, apesar da sua suposta "tolerância", Akbar defendia o islamismo, ou seja, se colocava na posição de defender os preceitos do Corão no que diz respeito ao Paraíso, ainda que a ideia geral dos relatos jesuítas seja justamente a oposta. Por fim, Akbar é descrito como um grande estudioso do Corão, pois “disputava por saber mais que quantos molas tem”. É possível que, mesmo não sendo um típico muçulmano ortodoxo, o imperador tivesse um conhecimento acima da média dos textos sagrados do Islã.

Por outro lado, os jesuítas também demonstraram conhecer o Corão, o que aponta para um investimento genuíno na catequização dos chamados "infiéis", o que por si só é um dado deveras interessante.

Por último, a frase que fecha nosso extrato é bastante emblemática, pois mais uma vez aponta para o privilégio da razão como estratégia de convencimento do soberano.Um extrato de conteúdo semelhante pode ser lido em uma carta do língua da missão, o jesuíta Francisco Henriques:

Algumas disputas diante dele [Akbar] com os seus mulás, e às coisas mais dificultosas que lhe perguntávamos, ele era o que respondia pelo seus mulás, o qual os não tirava de pequena confusão e trabalho, por naturalmente ser homem de muito bom juízo e entendimento, mas isto com escusas e sentidos que melhor achava, para não ficarem de todo convencidos. ${ }^{126}$

Nesse extrato, percebemos, como no anterior, a confirmação de que Akbar participava ativamente dos debates, inclusive defendendo o ponto de vista muçulmano. Porém, mais importante parece ser a associação estabelecida entre os debates e a descrição do soberano, "homem de bom juízo e entendimento".

Sobre o mesmo assunto, mas com uma visão um tanto diferente, Henriques escreve para o Padre Lourenço Peres:

${ }^{124}$ CARTA dos padres Rodolfo Aquaviva, Antônio de Montserrat e Francisco Henriques ao padre Provincial Roderico Vicente. Agra, 13 de julho de 1580. Documenta Indica, v. XII (1580-1583), doc. 05, p. 36.

${ }^{125}$ No Commentarius de Montserrat, não encontramos referência de que é Akbar que defende o ponto muçulmano nesse debate. Podemos supor que a forma sucinta em que o tema aparece tratado em sua obra possa estar relacionado com o fato de que é o imperador o interlocutor nesse momento, e talvez ele não tenha querido apontar as falhas do soberano ou mesmo justo o oposto, seu afinco em defender o islamismo.

${ }^{126}$ CARTA do Padre Francisco Henriques ao padre Laurentio Peres. Fatehpur, 6 de abril de 1580, p. 5. Documenta Indica, v. XII (1580-1583). ARSI, Goa, 38 I, ff: 121r-24v. Grifo nosso. 
Depois que chegamos, disputamos algumas vezes diante d'El-rey, com os seus mulás de algumas coisas do seu Mosafo [Mushaf, livro, no caso, Alcorão] e profeta, e de nossa santa fé acerca do juízo e da ressurreição dos mortos, e que quando um pecava, porque Deus não o ajudava pois era ofensa contra a sua bondade e outras coisas semelhantes. E aos três lanços se renderam ficando totalmente confusos e vários entre si, porque um diz uma coisa e outro outra, e não sabendo [o] que responder, começaram a pedir milagres, e ficaram com medo de disputar conosco. Está el-rey muito escandalizado deles, e assim ele é que responde a todas as perguntas com muita prudência, por lhes faltar respostas aos mulás. Sabendo falar bem a sua língua, poucas letras abastam para os convencer. ${ }^{127}$

Nesse relato, Henriques informa que Akbar passou a participar dos debates devido à incompetência dos mulás em responder às questões levantadas pelos jesuítas. Em seguida, reafirma, primeiro indiretamente, que as disputas eram um meio conveniente de buscar a conversão do rei, pois ressalta a prudência característica de Akbar. Em seguida, ele reitera, agora mais diretamente, que os debates eram a estratégia correta, insistindo na intenção de convencer o soberano. Faltava-lhes apenas, a essa altura, o conhecimento do idioma.

Não é incomum que, nos primeiros anos de missão, os jesuítas escrevessem relatos bastante promissores, afirmando que a tarefa à frente não será difícil uma vez dominada a língua do possível converso. No caso do Mogol, isso fica evidente, por exemplo, na leitura do extrato supracitado. ${ }^{128}$ Por outro lado, depois de participarem de alguns debates, o otimismo inicial abre espaço para certo ceticismo: "Com todas estas boas novas estamos com muita dúvida da conversão deste rei: primeiramente, porque de tudo duvida e por isso não basta provar-lhe os mistérios da fé com a Escritura, mas ele quer entender-los com a razão." ${ }^{129}$

$\mathrm{Na}$ medida em que os missionários passam a duvidar da eficácia desse método de conversão, é necessário que outras estratégias sejam propostas. Na mesma carta da qual retiramos o extrato acima, Acquaviva propõe:

Penso que ajudaria este rei se VP o escrevesse e o enviasse qualquer coisa santa. E porque sabe muito bem oo que é o Papa e por ele tem devoção, parece-me que se sua Santidade lhe escevesse eloginando-lhe ou ainda exaltando-lhe, mandando-lhe alguma coisa santa, o moveria muito ao amor da fé. Se VP mandasse alguma boa imagem, acenderia nesta gente a devoção à Mãe de Deus. Ainda, se se encontrasse algum Evangelho ou qualquer outro

127 CARTA do Padre Francisco Henriques ao padre Laurentio Peres. Fatehpur, 6 de abril de 1580, p. 5. Documenta Indica, v. XII (1580-1583). ARSI, Goa, 38 I, ff: 121r-24v.

${ }^{128}$ Nos capítulos seguintes de nossa tese, indicaremos que o mesmo olhar otimista pode ser identificado nas primeiras cartas enviadas pelos missionários no Tibete.

129 "Con tutte queste bone nove stiamo en molto dubio dela conversione de questo re: primo, porque di tutto dubita et por questo non basta provarli li misteri dela fede con la Scrittura, ma vole entenderli com la ragione" CARTA de Rodolfo Acquaviva, Fatepur Sikri, 18 de julho de 1580. Documenta Indica, v. XII (1580-1583), doc. 6, p. 49-50. ARSI, Jap-sin. 37, ff: 100r-02v. Tradução nossa. 
livro da Escritura em árabe, VP o pode mandar, poque aqui seria muito útil. $^{130}$

O Papa Gregório XIII, em 1582, talvez como um dos últimos recursos dessa fase da missão, envia a Akbar a carta intitulada Misericors Deus. ${ }^{131}$

Porém, os jesuítas não abrem mão dos debates e insistem nas disputas com os mulás.

Durante uma delas, sobre a qual a pena de Montserrat discorre com mais paciência, o tema da “arrogância de Mahamede” foi abordado. "No Corão", afirma o missionário,

[Maomé] deixou escrito que Cristo era justo e que havia sido concebido sem pecado por uma virgem, por obra do Espírito Santo, e que não tinha pai terreal. Por outro lado, Mahamed reconhecia que ele mesmo havia sido um pecador e um idólatra, ${ }^{132}$ além de nunca ter realizado um milagre. Ainda assim, afirmava com arrogância e sem nenhuma vergonha que era maior e mais poderoso que Cristo. ${ }^{133}$

Esse trecho é muito revelador, pois, ao comparar Cristo ao profeta do Islã e, consequentemente, as duas religiões, nos faz refletir sobre esse espaço de debate criado por Akbar na Índia, tão peculiar por colocar lado a lado os jesuítas e aqueles que são descritos pelos cristãos como infiéis. Aceitar debater com sacerdotes islâmicos sobre os temas que comparam e, de certa forma, hierarquizam as duas religiões, indica, por um lado, que as relações entre cristãos e muçulmanos não eram sempre belicosas e, por outro, um esforço da parte dos padres na elaboração de um discurso sobre temas supostamente refutados "a priori".

Em suma, o que queremos dizer é que o caso do Mogol indica que, pelo menos a essa altura da história da missão, os jesuítas de fato consideravam converter muçulmanos, mesmo um muçulmano pouco ortodoxo, como eles enxergavam Akbar.

Segue, então, a argumentação jesuíta:

Um homem que em sua defesa utiliza seu testemunho em benefício próprio necessariamente tem que carecer do sentido de ridículo, posto que para justificar um argumento [é necessário] buscar uma autoridade externa. Em

\footnotetext{
130 "Penso que agiutaria questo re screverli VP e mandarle alcuna cosa santa. Et porque sape molto bene que cosa è Papa e tienele devotione, pareme que se Sua Santità 1 escrevesse laudandolo o ancora esortandolo, mandandole alcuna cosa santa o moveria molto all'amor dela fe. (...) Se VP mandasse alcuna bona [imagine] acenderia a questa gente ala devotione della Matre de Dio. Ancora se si ritrovasse in Roma alcuno Evangelio et quasivoglia altro libro della Scrittura en arábico VP lo pò mandare porque cqui serveria muito (sic)." CARTA de Rodolfo Acquaviva, Fatepur Sikri, 18 de julho de 1580. Documenta Indica, v. XII (1580-1583), doc. 6, p. 51. ARSI, Japsin. 37, ff: 100r-02v.

${ }^{131}$ Cf: GREGORII XIII Litterae "Misericors Deus" imperatori Akbar Missae Roma, 18 de fevereiro de 1582. Documenta Indica, v. XII (1580-1583), doc. 102, p.372-374. Archivo secreto vaticano; Inst. 194, ff: 236 r-v.

${ }^{132} \mathrm{Na}$ mesma carta citada acima, lê-se que nessa disputa "tratou-se da soberba de Maphamede", que fora antes "gentio e pecador". Percebe-se, portanto, que gentio e idólatra são palavras aqui utilizadas para a caracterização do período anterior à conversão ao Islamismo. CARTA de Rodolfo Acquaviva, Agra, 13 de julho de 1580. Documenta Indica, vol. XII, doc. 5, p. 36.

${ }^{133}$ MONTSERRAT, A. Mongolicae Lagationis Commentarius. Apud: ALAY, J.L. Embajador en la corte del Gran Mogol.Tradução Ramon Sala. Lleida: Milenio, 2006. p. 92.
} 
segundo lugar, afirmaram que o testemunho de Cristo provém dos profetas [...] e do próprio Evangelho que descreve suas virtudes e milagres; por outro lado, o Evangelho não foi escrito por Jesus Cristo ele mesmo, à diferença do Corão, que foi escrito pelo próprio Mahamed. Em terceiro lugar, não tem testemunhos, ele é seu próprio testemunho. Tudo o que foi dito sobre ele e seus milagres foi escrito por ele mesmo. ${ }^{134}$

Após reduzir o livro sagrado dos muçulmanos a uma obra de autopromoção de um sujeito arrogante, pecador e ex-idólatra, a resposta dos debatedores é apresentada de uma forma proporcionalmente radical: "ponhamos à prova as verdadeiras escrituras sagradas. Preparemos uma pira e ateemos fogo. Depois, deixemos que um de vocês com os Evangelhos e um de nós com o sintagma subam na pira ardendo. O livro que emergir são e salvo, junto a seu portador, será considerado como verdadeiro."135 Para os jesuítas, essa seria uma saída típica dos muçulmanos, um "costume próprio de mouros, que, como não têm razão, pedem milagres."

Akbar pareceu ter gostado da ideia e insistiu que os missionários passassem pela prova. Os jesuítas retrucaram dizendo que não eram necessários milagres para demonstrar a verdade do cristianismo, afinal "desnecessários eram os milagres onde dávamos razão de nossa lei"137, ao que o imperador, aparentemente frustrado, respondeu que já havia presenciado suficientes discussões. Esse foi o fim da terceira disputa.

Estava posto o dilema: de um lado, o convencimento e o uso da razão como estratégia de conversão. De outro, a possibilidade do martírio, não menos nobre aos olhos do missionário Rodolfo Acquaviva. ${ }^{138}$

\footnotetext{
${ }^{134}$ MONTSERRAT, A. Mongolicae Lagationis Commentarius. Apud: ALAY, J.L. Embajador en la corte del Gran Mogol.Tradução Ramon Sala. Lleida: Milenio, 2006, p. 93.

${ }^{135}$ Ibidem, loc. cit.

${ }^{136}$ CARTA dos padres Rodolfo Aquaviva, Antônio de Montserrat e Francisco Henriques ao padre Provincial Roderico Vicente. Agra, 13 de julho de 1580, p. 37. Documenta Indica, v. XII (1580-1583), doc. 05, p.34-44. Lisboa. Arquivo Nacional da Torre do Tombo, Armário Jesuítica n.28, ff.109r-12v.

137 Ibidem, p. 37. Grifo nosso.

${ }^{138}$ Que nas fontes mogóis aparece como o proponente da tal "prova de fogo": "One night, the assembly in the 'Ibādatkhāna was increasing the light of truth. Padre Radīf, one of the Nazarene sages, who was singular for his understanding and ability, was making points in that feast of intelligence. Some of the untruthful bigots came forward in a blundering way to answer him. Owing to the calmness of the august assembly, and the increasing light of justice, it became clear that each of these was weaving a circle of old acquisitions, and was not following the highway of proof, and that the explanation of the riddle of truth was not present to their thoughts. The veil was nearly being stripped, once for all, from their procedure. They were ashamed, and abandoned such discurse, and applied themselves to perverting the words of the Gospels. But they could not silence their antagonist by such arguments. The Padre quietly and with an air of conviction said, "Alas, that such things should be thought to be true! In fact, if this faction have such an opinion of our Book, and regard the Furqān (the Qoran) as the pure word of God, it is proper that a heaped fire be lighted. We shall take the Gospels in our hands, and the 'Ulamā of that faith shall take their book, and then let us enter that testing-place of truth. The escape of any one will be a sign of his truthfulness." The liverless and black-hearted fellows wavered, and in reply to the challenge had recourse to bigotry and wrangling. This cowardice and effrontery displeased his (Akbar's) equitable soul(...)".FAZL, A. The Akbarnāma of Abu-l-Fazl, a history of the reign of Akbar including an account of his
} 
A proposta dessa prova, segundo o relato de Montserrat, permitiu a Rodolfo Acquaviva dirigir-se ao rei num discurso que, sem esquivar-se da possibilidade de ir ao fogo com a Bíblia, procurava demonstrar a fragilidade desse expediente. Para além de recorrer à orientação explícita no livro de Mateus, capítulo quatro ("Não tentará o Senhor teu Deus"), ${ }^{139}$ Acquaviva defendeu que "deve-se considerar a prova de fogo duvidosa e incerta". ${ }^{140}$ Para sustentar essa ideia, o missionário afirmou que ao longo da história existiam inúmeras ocasiões nas quais templos e livros considerados sagrados por ambas as religiões - isto é, igrejas e mesquitas, o Evangelho e o Corão - foram incendiados.

O religioso disse ainda que, caso saísse vivo com o Evangelho do fogo, nada impediria que os muçulmanos encontrassem um modo de esconder a verdade e refugiarem-se "na obscuridade da dúvida, em vez de crer na santidade do milagre."

A resposta de Akbar às questões levantadas por Acquaviva é interessante na medida em que faz transparecer, no relato de Montserrat, a existência de intenções outras por detrás dos embates públicos travados entre muçulmanos, cristãos e, eventualmente, outros religiosos. O imperador, segundo o jesuíta, admitiu que o objetivo da tal prova seria castigar um muçulmano que "se vangloria de ser um homem santo, apesar de ter as mãos manchadas de sangue, e que havia escrito um comentário novo e original sobre o Corão." ${ }^{142}$ Rodolfo, então, se recusou terminantemente a participar desse estratagema. Seu argumento final surgiu em forma de pergunta: "Se esse homem merece um castigo, por que armar toda essa confusão para levá-lo à pira"? ${ }^{143}$

É importante notar que o relato não problematiza o fato de que o suposto crime do acusado seria ter escrito um comentário "novo e original" do Corão. Vindo de um soberano que estimula os debates, as traduções e até mesmo a elaboração de novos comentários acerca de textos religiosos, ${ }^{144}$ por que mereceria esse homem ser castigado? A pergunta fica sem resposta no texto de Montserrat. Parece-nos que o mais importante seria demonstrar, para o leitor, a retidão dos missionários, que não compactuavam com esquemas secretos e intrigas

predecessors. Tradução H. Beveridge. Calcutá: Asiatic Society, 1910-1939. Vol. III, cap. 45. Disponível em: <http://persian.packhum.org/persian/main?url=pf\%3Ffile\%3D00701023\%26ct\%3D0>

${ }^{139} \mathrm{Mt} \mathrm{4:7.}$

${ }^{140}$ MONTSERRAT, A. Mongolicae Lagationis Commentarius. Apud: ALAY, J.L. Embajador en la corte del Gran Mogol.Tradução Ramon Sala. Lleida: Milenio, 2006, p. 95.

141 Ibidem, loc. cit.Tradução livre.

142 Ibidem, p. 96.

143 Ibidem, loc. cit.

${ }^{144}$ GANERI, J. The Lost Age of Reason: Philosophy in Early Modern India 1450-1700. EUA: Oxford University Press, 2011. 
palacianas. No entanto, podemos interpretar que a própria participação dos jesuítas nos debates em si contradiria esta ideia.

Além disso, o fato de o próprio relato de Montserrat indicar que havia uma intenção velada por detrás da prova de fogo corrobora com o nosso entendimento dos debates não só no seu aspecto retórico referente ao conteúdo, mas essencialmente ao aspecto performático dessas audiências. $^{145}$

Após a prova de fogo, identificamos, a partir da leitura do Commentarius, uma mudança na estratégia missionária. Montserrat afirma que "os sacerdotes não haviam esquecido a recomendação real de evitar mais discussões", ${ }^{146}$ então decidiram apresentar-lhe algumas considerações que já não se encontravam mais no terreno da teologia, mas sim no da moral.

Os jesuítas passaram a recomendar que Akbar mudasse suas ações para estar pronto para receber os ensinamentos cristãos. Montserrat faz referência a Paulo e sua ideia acerca do homem velho, dizendo que é necessário abandonar "nossa predisposição em relação às más ações". ${ }^{147}$

Akbar deveria, então, permanecer apenas com a primeira mulher com quem havia se casado, abandonando as demais - que seriam "concubinas e adúlteras". ${ }^{148}$ Deveria ainda arrepender-se de seus pecados. Por último, era necessário que o imperador jejuasse e realizasse outros atos de contrição, que rezasse para Deus, que oferecesse generosas esmolas e que praticasse atos piedosos. ${ }^{149}$

O rompimento com a estratégia de participar dos debates parece mais evidente na seguinte passagem:

Além disso, resultará vantajoso para ele [Akbar] e, sem dúvida necessário, que se abstenha de ocupações fúteis e decida um dia e uma hora para que, sozinho, o se desejar com alguns mistagogos de confiança - e sem vestígio de nenhum

\footnotetext{
145 Ao longo de nossa análise, não foi possível propor uma hierarquia entre a importância do conteúdo dos debates e a importância de seu efeito performático ou dramático. Percebemos que pelo menos uma questão é repetidas vezes por Akbar quando conversa com jesuítas: o mistério da Santíssima Trindade, mas especificamente sua dificuldade de entender que Deus é um só ainda que existam as três pessoas da Trindade. Evidente que o problema da unidade de Deus é um tema tipicamente islâmico e que foi debatido intensamente durante o período de formação da ortodoxia muçulmana, em especial de forma dialógica, isso é, considerando as outras tradições monoteístas - o judaísmo e o cristianismo. É interessante observar que, se por um lado, frente às sociedades idólatras, incutir a ideia do monoteísmo poderia ser um desafio para a atuação missionária, por outro, frente a uma religião monoteísta, os próprios cristãos têm que demonstrar que acreditam em um Deus único.

${ }^{146}$ Montserrat possivelmente se refere à fala de Akbar quando, ao propor a prova de fogo, afirma ter presenciado discussões suficientes. MONTSERRAT, A. Mongolicae Lagationis Commentarius. Apud: ALAY, J.L. Embajador en la corte del Gran Mogol.Tradução Ramon Sala. Lleida: Milenio, 2006, p. 96.

${ }^{147}$ Ibidem, p. 98.

${ }^{148}$ Ibidem, loc. cit.

${ }^{149}$ Ibidem, loc. cit.
} 
espírito de controvérsia - possa escutar-nos como se fora nosso discípulo. Se algum assunto não ficar bastante claro, será legitimo que nos interrompa. ${ }^{150}$

Para deixar ainda mais evidente que tipo de estratégia Rodolfo estava propondo, citase um exemplo:

Em nossos dias, os reis do Japão seguem este exemplo, posto que, frequentemente, visitam as humildes casas dos sacerdotes de nossa Companhia, e, deste modo, podem aprender os preceitos da fé cristã. ${ }^{151}$

A partir de então, os jesuítas na corte mogol passaram a se dedicar a outras estratégias, como a educação de um dos filhos de Akbar. Porém, o expediente dialógico em si não foi abandonado na missão do Mogol. Debates, como um sobre o tema do juízo final, ${ }^{152}$ continuaram contando com a presença dos jesuítas, além do que parecem ter sido conversas entre Akbar e os missionários. Além disso, os religiosos continuaram a recorrer ao diálogo, no seu formato escrito, quando dedicaram-se a elaborar obras a partir da experiência na corte de Akbar. Esse é o caso do Commentarius, mas também é o caso de Fonte de Vida, obra de Jerônimo Xavier escrita em persa. ${ }^{153}$

Além disso, a essa altura, o imperador mogol encontrava-se ocupado com a instabilidade política que assolava Bengala, o que "diminuiu seus interesses em assuntos sagrados, e não permitia que os sacerdotes o visitassem". ${ }^{154}$ Assim, os missionários "se dedicaram a traduzir parte do Evangelho para o persa". ${ }^{155}$

Observa-se uma mudança de postura, uma pluralização das estratégias, mas sem um completo abandono das formas dialógicas. Mesmo frustrados com as evidentes manifestações de Akbar que apontavam para a sua não conversão, os jesuítas decidiram permanecer no Mogol.

As justificativas para essa escolha aparecem explicitadas não só no Commentarius, mas na correspondência da Companhia de Jesus.

Não abandonaram [os missionários] o rei, porque quiçá existia ainda uma brisa de esperança em sua alma, graças aos esforços dos sacerdotes. Ainda que, depois de todos o que se há dito, as propostas do rei podiam parecer

\footnotetext{
${ }^{150}$ MONTSERRAT, A. Mongolicae Lagationis Commentarius. Apud: ALAY, J.L. Embajador en la corte del Gran Mogol.Tradução Ramon Sala. Lleida: Milenio, 2006, p. 98.

151 Ibidem, p. 99.

152 Ibidem, p. 172.

${ }^{153}$ XAVIER, J. Fuente de Vida: Tratado apologético dirigido al Rey Mogol de la Índia en 1600. San Sebastián: Universidad de Deusto, 2007.

${ }^{154}$ MONTSERRAT, op. cit., p. 107.

155 Ibidem, loc. cit.
} 
fraudulentas e cheias de hipocrisia, alguns outros feitos nos indicaram a possibilidade de albergar ainda algumas esperanças. ${ }^{156}$

Em primeiro lugar, Montserrat afirma que Akbar, ao regressar da guerra, "mostrou um renovado interesse em se instruir nos ensinamentos celestiais". ${ }^{157}$ Akbar teria dito:

Deus conhece muito bem meus sentimentos em relação à fé cristã. Ele pode comprovar todo interesse que tenho em ser instruído dentro de vossa religião, se bem que não posso entendê-los quando afirmam que existem três Deuses. ${ }^{158}$

E Montserrat prossegue dando motivos para a manutenção da missão:

Em uma conversa privada, [Akbar] acrescentou que queria estabelecer uma aliança com o rei de Portugal para fazer frente aos turcos e contribuir economicamente aos esforços do primeiro. ${ }^{159}$

Em nossa leitura, acreditamos que esse trecho aponta para o duplo papel da missão jesuíta no Mogol, seja do ponto de vista de Akbar, seja do ponto de vista europeu: os jesuítas e sua missão possuíam também um papel estratégico e político. A presença dos padres na corte, uma espécie de embaixada, auxiliaria nas negociações entre o Império Mogol e o Estado da Índia.

\footnotetext{
${ }^{156}$ MONTSERRAT, A. Mongolicae Lagationis Commentarius. Apud: ALAY, J.L. Embajador en la corte del Gran Mogol.Tradução Ramon Sala. Lleida: Milenio, 2006. p. 215.

157 Ibidem, loc. cit.

158 Ibidem, loc. cit.

159 Ibidem, loc. cit.
} 


\subsection{CONCLUSÃO}

O que os jesuítas enviados na primeira missão Rodolfo Acquaviva, Antônio de Monserrate e Francisco Henriques não sabiam era que a insatisfação de Akbar com os ulemás sunitas ortodoxos, juntamente com seus esforços políticos emfavor da centralização e seu tipo pessoal de milenarismo religioso, já haviam levado à sua corte representantes das maiores correntes religiosas do subcontinente: brâmanes, jainistas, xiitas mulçumanos, sufistas persas e zoroastrianos. Seus experimentos com "monoteísmo divino" (tauhid ilahi) ou "religião divina" (din-i ilahi), que funcionariam como um aparador para todas as experiências religiosas diversas e, geralmente, inconciliáveis existentes em seu império, fornecendo assim uma base ideológica para o Império Mogol, levaram-no a um sincretismo bastante complicado. O resultado foi uma nova reação sunita ortodoxa que serviu para ao mesmo tempo desestabilizar e deslegitimar as pretensões divinas e políticas de Akbar. ${ }^{160}$

Em 1582, o padre superior da missão, Rodolfo Acquaviva, escreve para o Geral da Companhia de Jesus, Claudio Acquaviva, uma carta na qual trata fundamentalmente das justificativas para a manutenção da missão. O padre provincial já havia escrito, naquele ano, informando que caso os missionários não tivessem esperança na missão, poderiam retornar à Goa. Em resposta, Rodolfo indica cinco justificativas para que a Companhia não desista do Mogol.

Em primeiro lugar, o jesuíta insiste que Akbar voltou a dar sinais de simpatia ao cristianismo e que, além disso, trata os padres com muito amor e familiaridade.

O segundo motivo apontado pelo superior no Mogol é a expectativa de que frutifiquem as lições que o segundo filho do soberano mogol (Pahari) estava recebendo de Montserrat. Em outras palavras, os jesuítas investem na possibilidade de terem um príncipe convertido ao cristianismo no Mogol. Outro possível converso seria o pai de Abul Fazl, um homem de idade avançada que "parece apto e disposto a receber o lume da fé, é muito nosso

\footnotetext{
${ }^{160}$ "What the Jesuits who were sent on the first mission Rodolfo Acquaviva, Antônio de Monserrate, and Francisco Henriques did not know was that Akbar's dissatisfaction with the orthodox Sunni ulema, combined with his political efforts at centralization and his personal type of religious millenarians, had already brought to his court representatives of the major religious currents of the subcontinent: Brahmans, Jains, Shia Muslims, Persian Sufis, and Zoroastrians. His experiments with a "divinemonotheism" (tauhid ilahi) or a "divine religion" (din-i ilahi) that would function as an umbrella for all the diverse, and often irreconcilable, religious experiences in his empire, and thus provide an ideological underpinning for the Mughal reign, led him to rather complicated syncretism. The result was a new Sunni orthodox reaction which worked at the same time to destabilize and delegitimize Akbar's divine and political pretensions." ZUPANOV, I. Compromise: India. In: HSIA, R. P.-C. In: A Companion to the Reformation World. Oxford: Blackwell Publishing Ltd., 2007. Tradução nossa.
} 
amigo e quer ouvir a nossa lei." ${ }^{\text {"161 }}$ Fazl tinha uma relação próxima com os missionários, que haviam até mesmo concordado com ouvir suas opniões sobre os temas a serem abordados ou evitados nos debates. ${ }^{162}$

Mais um motivo para a manutenção da missão seria a descoberta de uma "gentilidade chamada Bottan, a qual é gente muito bem inclinada e dadas a obras piedosas". ${ }^{163}$ Acquaviva, a essa altura, ainda não sabe, mas tais "gentios brancos" receberão uma missão da Companhia de Jesus dentro de aproximadamente 40 anos. Enquanto permaneceram no Mogol, os missionários buscaram se informar sobre os limites do Indostão. ${ }^{164}$ Porém, a mais importante razão para que se continuasse no Mogol, segundo Acquaviva, era que

Esta parte onde estamos é a própria india, e este reino é como escada para toda a Índia e como refúgio para onde concorrem de todas as partes da Índia e de muitas partes da Ásia. E já que a Companhia tem aqui posto um pé com tanta benevolência de um grande rei e de seu filho, não parece que PE conveniente deixar esta ocasião antes de tentar todos os meios que possamos para darmos início à conversão em terra firme na Índia, que a que agora é feita se dá apenas na costa do mar. ${ }^{165}$

Esse extrato talvez encerre em si toda a radicalidade e ousadia do projeto da Companhia de Jesus na Índia mogol. O que Rodolfo Acquaviva propõe nessas linhas não é a mera insistência na conversão de um soberano infiel, nem a simples perseverança em uma missão já aberta. Acquaviva propõe um novo projeto geopolítico para a Companhia de Jesus no Oriente. Ele apresenta um plano de interiorização da presença missionária na Ásia, em dissonância com a prática da Ordem naquele momento. Acompanhados pelo braço secular coercivo do Império Português, os jesuítas beliscavam as beiradas do subcontinente indiano. Na visão do missionário italiano, isso era o mesmo que não se dar conta de que o Indostão era “a própria Índia".

161 "Pare atto et disposto per ricevere il lume della fede: è molto nostro amico et vole udire la nostra lege" CARTA de Rodolfo Acquaviva para Claudio Acquaviva, Praep. Gen. S.I., Fatepur, 25 de abril de 1582. Documenta Indica, vol. XII (1580-1583), doc 106, p. 584. ARSI Jap-sin 37, ff: 109r-111v.

${ }^{162}$ MONTSERRAT, A. Mongolicae Lagationis Commentarius. Apud: ALAY, J.L. Embajador en la corte del Gran Mogol.Tradução Ramon Sala. Lleida: Milenio, 2006. p. 106.

163 "gentilità chiamata Bottant, (...) la quale è gente molto bem inclinata et dedita alle opere piè. Sono homini bianqui ...". Ibidem, loc. cit.

${ }^{164}$ Quando surgiu uma possibilidade, o jesuíta português Antônio de Andrade foi conferir a veracidade das informações colhidas na corte de Akbar. Andrade chegou ao Tibete em 1624 e lá estabeleceu uma missão em 1626, da qual trataremos a seguir.

165 “Queste parti onde stiamo è la própria India, et è questo regno como scala di tutta l'India et como asilo d'onde concorren de tutte le parti d'India et de moltas (sic) d'Asia. Et ja que la Compagnia tiene cqui (sic) posto il piè con tanta benevolentia d'hun re sì grande et de suoi figli, non pare que è conveniente lasciare questa ocasione prima di provare tutti li mezi que possiamo per commenzare conversione nella terra ferma dell'India, que quella que fin ora si è fatta è solamente nella costa del maré." CARTA de Rodolfo Acquaviva, Fatepur, 25 de abril de 1582. Documenta Indica, vol. XII, doc 106, p. 584. 
A partir da leitura desta última fonte, gostaríamos de concluir nosso capítulo com três considerações.

Os jesuítas sustentaram em seus escritos - cartas, relações e demais obras aqui apontadas - a viabilidade e a potencialidade da missão do Mogol. Mesmo em momentos de dúvida, a proposta dos padres não foi o abandono da missão, mas a troca de estratégia, ou melhor, a diversificação das estratégias. Para tanto, foi necessário observar de muito próximo o soberano mogol, descrevê-lo, estudá-lo, retratá-lo com as "cores" adequadas, categorizá-lo com as falas prudentes. Os diálogos, a nosso ver, apareceram simultaneamente como uma estratégia de conversão e como uma forma de ratificar, exemplificar e confirmar a descrição de Akbar como um soberano amigo da razão, prudente, amável com os padres e, portanto, aliado da cristandade na Índia.

Em segundo lugar, propomos que os missionários no Mogol testaram um modelo de missão na corte de Akbar. Diríamos que Fatehpur foi como um laboratório, caso pudéssemos cometer o anacronismo de imputarmos aos padres um perfil "científico". Esse modelo, essencialmente dialógico, pode ser entendido como uma tentativa simétrica ao que a Companhia estava aplicando no extremo-oriente, especialmente na China e no Japão. É interessante notar que, mesmo com a interrupção da primeira missão no Mogol, os jesuítas não abandonaram definitivamente nem o Indostão, nem o diálogo como estratégia. Tanto que, na missão seguinte, o jesuíta Jerônimo Xavier escreveria a obra Fonte de Vida, apresentada em forma de diálogo entre um padre, um filósofo e um mulá. ${ }^{166}$

Por último, gostaríamos de frisar que o modelo proposto por Rodolfo Acquaviva vingou, ainda que a Companhia de Jesus tenha tido que enfrentar inúmeros obstáculos no interior da Ásia no século XVII. Procuraremos demonstrar, nos capítulos a seguir, como as missões da Ordem no Tibete se constituíram enquanto uma experimentação da proposta geopolítica de Acquaviva e também como se revelaram enquanto um local de teorização e aplicação do método dialógico como estratégia de conversão.

Dessa forma, por todas as razões debatidas até aqui, defendemos que, na missão do Mogol, uniram-se a retórica jesuíta e a atuação política de ambas as partes: do soberano muçulmano e dos padres cristãos.

Insistimos na ideia de retórica porque sustentamos que houve uma grande importância dada à palavra, à fala, ao discurso e à escrita na missão no Mogol. Sabe-se que o estudo da

\footnotetext{
${ }^{166}$ XAVIER, J. Fuente de Vida: Tratado apologético dirigido al Rey Mogol de la Índia en 1600. San Sebastián: Universidad de Deusto, 2007.
} 
retórica ${ }^{167}$ era parte importante da formação missionária dos membros da Companhia de Jesus. É prudente frisarmos que entendemos retórica de uma forma bem ampla, tanto no que diz respeito à forma do que é dito quanto no que diz respeito ao conteúdo, isso é, à erudição.

Do ponto de vista dos jesuítas, o debate de pontos doutrinários era comum à suaformação: desde o trivium medieval (retórica, lógica e gramática), a prática de defender uma posição através de um "discurso" é por eles exercitada formalmente. No entanto, em função do período em que ocorreu a missão, não é possível utilizarmos a Ratio Studiorum como fonte para identificar, a partir dela, a formação retórica jesuíta. A Ratio encontrou seu formato final apenas em 1599, quando os jesuítas já haviam exercitado a "disputatio" na corte mogol há pelo menos 19 anos. ${ }^{168}$

Assim, enfatizamos que utilizamos tal palavra (retórica) com sentido de uso eficaz da linguagem falada e escrita, com o objetivo de influenciar e persuadir, ressaltando que essa eficiência é consequência de uma prática, de uma habilidade adquirida por meio de formação intelectual prévia, exercício e treinamento.

Estendemos, então, nosso entendimento de "retórica", e indicamos três níveis desse entendimento especificamente para o caso aqui analisado:

$\checkmark \quad$ O nível discursivo: os jesuítas pensaram e "atualizaram" um discurso que, antes de apresentar o cristianismo, ataca o islamismo.

$\checkmark \quad$ O nível erudito: os jesuítas forneceram informações, isto é, argumentos ou conteúdo para além da forma, aos ataques à fé islâmica.

$\checkmark \quad$ O nível ideológico: os jesuítas, ao lado dos demais religiosos, fizeram parte do projeto político de Akbar de reelaboração teórica e discursiva de sua soberania política.

Não se pode dizer, no entanto, que a utilização da palavra, do discurso - ou do próprio exercício de pensar a palavra e elaborar um discurso - seja uma estratégia exclusiva da missão aqui analisada. Dos sermões de Vieira na América colonial aos catecismos escritos nos idiomas nativos do subcontinente indiano, os jesuítas recorrem a uma forma discursiva - com aspectos formais específicos, objetivos e públicos determinados, como instrumentos de

\footnotetext{
167 "Classical rhetoric is superficially very easy to describe: it is that theory of discourse developed by Greeks and Romans of the classical period, applied both in oratory and in literary genres, and thaught in schools in antiquidy, in Greece and western Middle Ages, and throughout the Renaissance and early modern period." KENNEDY, G. A. Classical Rhetoric and Its Christian and Secular Tradition from Ancient to Modern Times. The University of North Carolina Press, 1999, p. 3.

168 Para o contexto da atuação jesuíta na Índia, podemos citar um trecho de uma carta do Padre Vicente, de Goa, no ano de 1580: "Em casa sempre tiveram disputas de teologia cada dia, e na classe uma vez por semana, fora as ordinárias conferências de casos [de consciência]" CARTA ânua, escrita pelo padre Rui Vicente ao Geral, Goa, 20 de outubro de 1580. Documenta Indica, vol. XII, doc. 13, p. 99.
} 
viabilização do projeto missionário. Isso significa que a própria formação jesuíta e sua maneira de proceder - adaptada, evidentemente, aos diversos contextos - viabilizou o engajamento dos padres nesses debates.

Por outro lado, isso não significa dizer que as disputas foram o único recurso utilizado pelos religiosos na missão do Mogol. A partir da mesma documentação, é possível perceber que os missionários também lançaram mão de outras iniciativas caras à Ordem. Podemos citar, por exemplo, a educação de jovens. O jesuíta Antônio de Montserrat foi instrutor do filho do meio de Akbar, que, ao lado de outros poucos nobres, recebia aulas de português e catecismo.

A utilização de relíquias e imagens sacras como forma de buscar a conversão dos infiéis e gentios também é citada nas fontes relativas às missões do Mogol e Tibete. Uma bibliografia expressiva sobre a pintura nos tempos de Akbar e sua relação com a presença dos jesuítas naquela corte pode ser encontrada sem dificuldade. ${ }^{169}$ Além disso, podemos mencionar, como exemplo pontual, a construção de presépios durante o período do Natal, que eram visitados por membros da corte em ocasiões solenes.

As reiteradas negativas às ofertas de dinheiro feitas por Akbar também parecem ter constituído uma espécie de estratégia para ganhar a simpatia e confiança do imperador. A negociação da sobrevivência material das missões junto ao poder temporal local, abrindo mão de determinadas esmolas sem prescindir totalmente do apoio financeiro desses régulos, pode ser considerada como um expediente que tinha como finalidade viabilizar a empresa missionária e cativar os soberanos. Podemos dizer, inclusive, que tal expediente pode ser analisado simultaneamente às disputas, já que compartilham muitas vezes do mesmo aspecto performático. $^{170}$

Dessa forma, nosso objetivo não foi demonstrar que a importância da retórica reside no fato de que os debates foram a única forma de estratégia adotada pelos padres. $\mathrm{O}$ que defendemos é que sua importância é justificada, por um lado, pelo fato de ela ter permitido aos padres tomarem parte num processo político em curso no Indostão no século XVII, através da formação jesuíta e do modelo de adaptação. Como vimos, o padre que os antecedeu não foi capaz de desempenhar esse papel. Por outro lado, a disciplina da escrita jesuíta antecipou o diálogo como principal estratégia ao descrever Akbar como "homem de razão".

169 BAILEY, G.A. The Indian Conquest of Catholic Art: The Mughals, the Jesuits, and Imperial Mural Painting. Art Journal. vol. 57, n. 1, The Reception of Christian Devotional Art, primavera 1998, p. 24-30 Publicado por College Art Association. Disponível em: <http://www.jstor.org/stable/777989>.

${ }^{170}$ Ideia a ser desenvolvida adiante. 
Acreditamos, portanto, que a adequação, o ajuste da realidade à narrativa, a elaboração da escrita e a operação narrativa dos jesuítas sobre as falas tinham como objetivos principais não só a descrição de Akbar e dos muçulmanos de sua corte, mas principalmente sua categorização. A categoria supera a simples descrição: ela enquadra um povo ou uma sociedade no lugar a partir do qual é possível se planejar a ação missionária. Assim, entendemos que as disputas não ficcionais narradas e expressões predicativas como homens de razão ou gente branca adquiriram a mesma função na escrita missionária.

Por fim, é importante ressaltar os aspectos propostos por Alcir Pécora em seu estudo sobre o diálogo enquanto gênero, a partir da obra de Nóbrega:

Talvez o que mais responda pela eficiência persuasiva particular do diálogo seja o de constituir-se discursivamente como uma dramatização da vitória argumentativa sobre o oponente, obtida no interior de uma dispositio que encerra ou prescreve etapas sucessivas de combate intelectual. ${ }^{171}$

Esse trecho contém duas ideias fundamentais para a análise que propomos, seja para o caso do Mogol, seja para as demais missões estudadas ao longo desta tese. Em primeiro lugar, a ideia de eficiência persuasiva, que reforça a hipótese de que tanto a atuação no momento do diálogo quanto no momento (posterior) de narraçãodesse diálogo, objetiva persuadir o interlocutor de algo. Ou seja, a estratégia de conversão que se utiliza da disputa - atuada e narrada - visa o convencimento e a conversão pelo uso da razão.

Outra ideia pertinente é a de dramatização (conforme aparece em Pécora), que nós entendemos também como atuação ou performance, ou mesmo como o conceito de modo teatral (Theatrical Mode) proposto por Ines Zupanov. ${ }^{172}$ Ainda que não entendamos os dois conceitos como semelhantes, notamos que eles podem exercer a mesma função, mesmo com aspectos distintos.

Pécora afirma ainda que:

a dinamicidade dramática do diálogo reside não apenas na dialética das falas particulares dos personagens, (...) mas também no grau de reordenação produzido por ele nas expectativas habituais face aos temas debatidos. ${ }^{173}$

Ou seja, para além de uma leitura que leve em conta a dicotomia de posições apresentadas no diálogo, é fundamental atentarmos para a hierarquia intelectual produzida no discurso $^{174}$ ou na narração desse diálogo. Essa hierarquia, em nossa análise, desdobra-se em

${ }^{171}$ PÉCORA, A. Máquina de gêneros São Paulo: Editora Universidade de São Paulo, 2001, p. 97.

172 Zupanov, I.G. Disputed Mission: Jesuit Experiments and Brahmanical Knowledge in Seventeenth-Century India. Oxford University Press, 2001.

${ }^{173}$ PÉCORA, A., op. cit. p. 98.

${ }^{174}$ PÉCORA, A. Máquina de gêneros São Paulo: Editora Universidade de São Paulo, 2001, p. 98. 
dois aspectos: o primeiro, mais evidente, em que o jesuíta - metonímia do cristianismo, nesse caso - localiza-se acima do interlocutor infiel ou idólatra. O segundo aspecto, um pouco menos óbvio, mas ainda assim facilmente inferido, é a localização desse interlocutor em um universo de interlocutores. Nesse sentido, o diálogo auxilia na construção de um lugar para esse interlocutor - neste momento, metonímia de sua "seita" - em um universo de possíveis alteridades ao cristianismo. ${ }^{175}$

Porém, se, por um lado, não podemos entender tais textos como inseridos exclusivamente no gênero diálogo- uma vez que não se tratam de textos argumentativos que se utilizam de um expediente ficcional, isto é, a criação de um diálogo para provar um determinado ponto - por outro, é certo afirmar que não se tratam de debates completamente inventados. ${ }^{176}$ No limiar entre a ficção e a nãoficção ${ }^{177}$, esses enxertos de debates em textos narrativos (cartas ou obras do tipo notícias, crônicas ou histórias) são uma espécie de fantasma de um momento que passou, ainda que não possamos estar seguros de que a disputa se deu como ela aparece descrita. Por isso, chamamos esses trechos dialógicos retirados das fontes e aqui analisados de disputas ou diálogos não ficcionais narrados. Não são transcrições fidedignas de conversas, mas são baseados em fatos que se passaram realmente, os quais podemos encontrar referenciados em outras fontes, jesuítas ou não. ${ }^{178}$

No entanto, se juntarmos todas as premissas até agora estabelecidas - a eficiência persuasiva, a dramatização ou teatralização, a hierarquização intelectual e a questão (não) ficcional - como podemos aceitar que as falas narradas são dos interlocutores apresentados? Acreditamos ser possível identificar uma (plausível) voz do outro no diálogo narrado, mas ela não é transparente. Ao contrário, o mais adequado talvez seja entender a fala de um interlocutor como a sobreposição ou condensação de várias falas atribuíveis à abstração desse outro.

Assim, consideramos que as disputas, enquanto estratégias, significaram uma adaptação dos jesuítas aos processos político-culturais em curso sob o reinado de Akbar. A participação nessas disputas, para além de ser um expediente familiar à formação jesuíta, também foi relatada, de forma dialógica, nos escritos jesuítas. Em tais diálogos não ficcionais

\footnotetext{
${ }^{175}$ Ao longo da tese, procuraremos desdobrar essa hipótese na ideia de predicação.

${ }^{176}$ Ao contrário do que observaremos no capítulo a seguir.

177 Zupanov, I.G. Disputed Mission: Jesuit Experiments and Brahmanical Knowledge in Seventeenth-Century India. Oxford University Press, 2001, p. 37.

178 A título de exemplo, podemos citar a fonte mogol Akbarnama, uma espécie de Crônica da História do governo de Akbar no Indostão. Cf: FAZL, A. The Akbarnāma of Abu-l-Faẓl, a history of the reign of Akbar including an account of his predecessors. Tradução H. Beveridge. Calcutá: Asiatic Society, 1910-1939. Disponível em: <http://persian.packhum.org/persian/main?url=pf\%3Ffile\%3D00701023\%26ct\%3D0>.
} 
narrados, Akbar surge como um prudente e heterodoxo muçulmano, soberano poderoso no coração da verdadeira Índia, amigo da razão e dos padres da Companhia. Para a audiência virtual $^{179}$ dessas disputas, tratar-se-ia de um novo Constantino, protetor da fé católica no Oriente, e o Indostão se converteria em um porto seguro para a cristandade na Ásia.

No capítulo a seguir, procuraremos apresentar outra obra jesuíta, elaborada no contexto da Maktabkhana,chamada Fonte de Vida. Analisaremos, portanto, as estratégias dos missionários, inserindo-os nas instituições político-culturais patrocinadas por Akbar.

${ }^{179}$ Como a imagem de uma lente ou de um espelho, a audiência pode ser real ou virtual: a primeira é a que estava presente no momento em que se deu o debate; a segunda, somente teve acesso ao debate mediatamente, a partir da leitura da obra que o relata. 
2. DA NECESSIDADE DE SE FAZER OUVIR À POSSIBILIDADE DE PERSUADIR: A ELABORAÇÃO DO TRATADO APOLOGÉTICO FONTE DE VIDA 


\subsection{FONTE DE VIDA: O TRATADO APOLOGÉTICO DIRIGIDO A AKBAR, SEU CONTEXTO DE} PRODUÇÃO E SUA FUNÇÃO CATEQUÉTICA

Dixo un philósopho la sabedoria deven estimar los hombres plebejos como plata, y los nobles como oro, y los príncipes y rejes como piedras preciosas. ${ }^{180}$

No capítulo anterior, procuramos contextualizar política e culturalmente o período em que os jesuítas primeiramente se estabeleceram na corte de Akbar. Também procuramos explicar como se deu o convite feitoaos missionários da Companhia de Jesus, que tornou possível o seu estabelecimento no norte da Índia. A Ordem, por três vezes, investiu na conversão de Akbar e seus descendentes, instalando missões no Mogol pelos períodos de 1579-83, 1591-93 e 1595-1605. Antônio de Montserrat e Rodolfo Acquaviva, desiludidos com os resultados de seus esforços catequéticos, partiram em 1583. O primeiro vai à Europa, mas não consegue deixar o Mogol antes de garantir que levará uma carta pedindo a manutenção da missão hindustana. O segundo pede licença a Akbar para reunirse com o provincial e discutir o futuro da missão. O governante, mesmo contrariado, e talvez contando com a volta do missionário, concede. No entanto, aos vinte e sete de julho de 1583, em Salsete, o jesuíta é martirizado. Diz-se que Akbar, profundamente aflito ao saber da notícia, teria dito: “Ah, padre! Não te dizia eu que não partisse?"181

Em 1591, mais uma vez a pedido do soberano mogol, são enviados dois padres e um irmão a sua corte. No entanto, depois de quase três anos sem conseguir que Akbar se converta, esses religiosos deixam o Mogol.

Jerônimo Xavier, nascido Jerónimo Expeleta y Goni em 1549, era sobrinho-neto de Franciso Xavier, adotando então seu nome quando admitido na Companhia de Jesus (1568). Antes de ingressar na Ordem, havia estudado na Universidade de Alcalá ${ }^{182}$ e chegou a Goa no ano de $1581 .^{183}$ Ele compunha o terceiro grupo de missionários da Companhia de Jesus a se estabelecer em missão na corte mogol, em 1594. Mais uma vez atendendo aos pedidos de

\footnotetext{
${ }^{180}$ XAVIER, J. Fuente de Vida: Tratado apologético dirigido al Rey Mogol de la India en 1600. San Sebastián: Universidad de Deusto, 2007. p. 69.

${ }^{181}$ MACLAGAN, S.E. Os Jesuítas e o Grão Mogol. Porto: Editora Livraria Civilização, 1946.

${ }^{182}$ UNZUÉ, J.L.O. La família y la pátria de Jerónimo Javier (1549-1617). In: XAVIER, J. op. cit., p.7-46.

${ }^{183}$ DIDIER, H. Introducción al tratado Fuente de Vida. In: XAVIER, J. op.cit., p. 47-60. Outras informações também podem ser colhidas de: MACLAGAN, E., op. cit., p. 62.
} 
Akbar, Bento de Góis, Jerônimo Xavier e Manuel Pinheiro foram enviados. Será nessa ocasião que Xavier escreverá Fonte de Vida.

Conforme apresentado na introdução desta primeira parte de nossa tese e desenvolvido no capítulo anterior, procuramos ressaltar a importância da questão religiosa no processo de elaboração de uma nova base teórica e ideológica e para a soberania política de Akbar. Além disso, propusemos que essa nova base foi construída discursivamente, sobre debates, traduções e escrita de novos textos, contando com oapoio e o patrocínio do imperador.

Assim sendo, sustentamos ser por isso que estes dois processos - o ciclo de debates e a produção de textos, tais como comentários e traduções de obras sagradas - devem ser compreendidos como instituições ('Ibādatkhānah e Maktabkhana) que atuaram como meios para fazer convergir os projetos políticos de Akbar. ${ }^{184}$ Uma vez estabelecido que seu governo fora cenário de negociações sociais, políticas e estéticas que apontavam para a elaboração de um novo discurso que respaldasse sua soberania sobre os territórios e populações em áreas por eles recém-conquistadas no subcontinente indiano, nós devemos aqui prosseguir, atribuindo um lugar aos jesuítas nesse ambiente.

Dessa forma, neste segundo capítulo, daremos continuidade à análise da atuação dos missionários da Companhia de Jesus no Mogol, no contexto do Maktabkhana. Nesse contexto, procuraremos identificar a bagagem teológica e doutrinária, política e filosófica que os missionários buscaram acrescentar ao debate. Seguiremos, portanto, nossas investigações acerca dos aspectos dialógicos das estratégias de conversão, abordando como foco principal a análise da obra Fonte de Vida, escrita pelo missionário Jerônimo Xavier. ${ }^{185}$

Apesar da convergência entre os pressupostos básicos em Tomás de Aquino e a grande ênfase dos primeiros jesuítas no ensino teológico, um ponto crucial que certamente discordavam era sobre como alguns contemporâneos interpretaram a afirmação de Aquino sobre a questão inicial da Suma de que teologia é uma disciplina principalmente "especulativa". A suposição teológica das "escolas" foi supostamente dirigida à eficácia pastoral, especialmente em sermões. ${ }^{186}$

\footnotetext{
${ }^{184}$ Utilizamos aqui um conceito de Ebba Koch, "means to convey", originalmente elaborado para a análise de outras mídias, como pinturas e imagens, mas que julgamos pertinente e aplicável ao caso aqui analisado. Cf: $\mathrm{KOCH}$, E. The Symbolic Possession of the World: European Cartography in Mughal Allegory and History Painting.Journal of the Economic and Social History of the Orient. 55.2-3, p. 547, 2012. Outro conceito muito eficaz nesse contexto é o formulado por Gauvin Bailey: "media[s] for proselytization ”. Cf: BAILEY, G.A. The Truth-Showing Mirror: Jesuit Catechism and the Arts in Mughal India. In: O'MALLEY, J.W. (Ed.) The Jesuits: cultures, sciences, and the arts, 1540-1773. University of Toronto Press, vol. 1, 1999, p. 484-5.

${ }^{185}$ XAVIER, J. Fuente de Vida: Tratado apologético dirigido al Rey Mogol de la Índia en 1600. San Sebastián: Universidad de Deusto, 2007.

186“'Despite the convergence between basic assumptions in Aquinas and major emphases in the theological teaching of the early Jesuits, on one crucial point they surely differed with how some contemporaries interpreted Aquinas's affirmation in the opening question of the Summa that theology was principally a "speculative" discipline. The theological speculation of the "schools" was supposedly directed ultimately to pastoral
} 
Antes de prosseguirmos, no entanto, faz-se necessário retomarmos algumas ideias. Como já dito anteriormente, a chegada dos jesuítas na corte mogol fora mediada por um padre a pedido de Akbar. Esse padre, chamado Pereira, recorreu aos padres da Ordem de Loyola, pois não possuía as virtudes específicas da formação jesuíta: vocação missionária, erudição e treinamento retórico. ${ }^{187}$ Assim sendo, a principal hipótese, desenvolvida a seguir, é que o jesuíta, formado no contexto da Reforma Católica e da segunda escolástica, foi capaz de transformar os conteúdos de teologia, política e filosofia em instrumentos para se fazer ouvir e buscar o convencimento de seus interlocutores, garantindo assim um espaço para o cristianismo nos fóruns multilinguísticos e de debate inter-religioso promovidos por Akbar.

Foi nesse contexto, mais precisamente no ano de 1596, que o missionário Jerônimo Xavier escreveu uma obra intitulada Fonte de Vida, dirigida ao imperador Akbar. Ao elaborar esse tratado, o jesuíta dedicou-se principalmente a dois objetivos: apresentar a Verdadeira Lei ao soberano mogol e demonstrar a superioridade da lei cristã sobre o Islamismo. Mais especificamente, o autor afirma que nessa obra se declaram as coisas do Evangelho, se dá razão dos principais mistérios e se impugnam as leis contrárias, especialmente a de Mahoma. ${ }^{188}$

No entanto, definir esses objetivos não confere nenhuma especificidade à fonte acima, apenas a insere em um amplo conjunto de obras chamadas de tratados apologéticos, isto é, textos cuja intenção é apresentar e defender uma religião, no caso o cristianismo, frente a outro sistema religioso. A Apologética é uma disciplina teológica cara ao cristianismo, que rendeu obras como De Civitate Dei contra Paganos, escrita no início do século V por Aurélio Agostinho, conhecido como Santo Agostinho, e Summa contra Gentiles, escrita por Tomás de Aquino na segunda metade do século XIII.

Em sua introdução para a tradução francesa de De Rationibus Fidei, Gilles Emery aponta dois importantes princípios da apologia tomasiana. O primeiro é pressupor que a verdade da fé ultrapassa a razão humana, mas não se opõe a ela. O segundo princípio sustenta que "a razão humana não pode provar a fé, mais pode dela alcançar alguma coisa e manifestar

effectiveness, especially in preaching." O'MALLEY, J.W. The first jesuits. Harvard University Press, 1993, p. 250-1. Tradução nossa.

${ }^{187}$ Cf: EISENBERG, J. As missões jesuíticas e o pensamento político moderno. Belo Horizonte: UFMG, 2000.

188 Ibidem, p. 61. Como afirma Maijastina Kahlos, os diálogos travados entre cristãos e não cristãos "did not mean a mutual search for a truth that might exist somewhere for both to find but rather it implied that Christians had already grasped the truth and had to deliver it to non-belivers". KAHLOS, M. Debate and Dialogue: Christian and Pagan Cultures. Aldershot: Ashgate, 2007, p. 79. 
a verdade da fé por razões prováveis ou similitudes." 189 Assim, esse aspecto "negativo" da apologética tomasiana - isto é, de reconhecer que a capacidade racional do homem não pode dar provas da fé, apenas pode apontar o que não há de falso (na fé do outro) por ir contra a razão - está presente na argumentação desenvolvida em Fonte de Vida, como veremos a seguir. Por sua vez, a obra de Ippolito Desideri, a ser analisada no último capítulo desta tese, também apresentará argumentações que recorrem a esses princípios advindos do tomismo.

Vale lembrar ainda que o cristianismo, em sua origem, surgiu como uma dissidência do judaísmo e em um ambiente pagão. A eles viria a se opor, retórica e ritualmente. Assim, já no século II da Era Cristã, Justino o Mártir escreveu Diálogos com Trifão,${ }^{190}$ obra que procura demonstrar a superioridade do cristianismo em relação ao judaísmo, escrita em forma de debate. Maijastina Kahlos lembra-nos que:

A apologética e a polêmica cristã eram filhas da antiga retórica greco-
romana em sua adaptação de artifícios argumentativos e figuras retóricas.
Elas também se utilizavam da tradição apologética judaica. Observamos
artifícios argumentativos [...] usados, como por exemplo, analogias e
metáforas, o uso dialético de perguntas e respostas, perguntas retóricas,
repetições, antecipação de possíveis contra-argumentos e introdução de
classificações. ${ }^{191}$

No caso da fonte aqui destacada, reiteramos que o formato de diálogo exacerba o caráter argumentativo e dialético da literatura apologética, projetando na voz do outro as questões a serem refutadas pelo cristão.

Não obstante, o que conferiu especificidade a Fonte de Vida enquanto tratado apologético foi, justamente, o contexto em que foi produzido e seu objetivo mais imediato: apresentar a Akbar argumentos de forma a convencê-lo da superioridade do cristianismo frente ao islamismo. O tratado, portanto, além de ter finalidade apologética, serviu como meio para os jesuítas se fazerem presentes nas instituições de debate inter-religioso patrocinadas pelo soberano.

\footnotetext{
${ }^{189}$ Nas palavras do autor: "La vérité de la foi dépasse la raison humaine mais elle ne lui est pas contraire, la raison étant - comme la foi - un don de Dieu. (...). La raison humaine ne peut pas prouver la foi, mais ele peut en saisir quelques chose et manifester la vérité de la foi par des raison probables et des similitudes." D'AAQUIN, S.T. Les raison de la foi. Introdução, tradução e comentários Gilles Emery. Paris: Les éditions du cerf, 1999, p. 25. Grifos nossos.

${ }^{190}$ Cf: ENSLIN, M.S. Justin Martyr: An Appreciation. The Jewish Quarterly Review 34, n. 2, p. 179, out. 1943. doi:10.2307/1452083. Disponível em: <http://www.jstor.org/stable/1452083>. Acesso em: 22 de janeiro de 2013.

${ }^{191}$ “'Christian apologetic and polemic was a daughter of ancient Greco-Roman rhetoric in its adaptation of argumentative devices and rhetorical figures. It drew from Jewish apologetic tradition as well. We observe rhetorical devices [...] utilized, for example, analogies and metaphors, the dialectical use of question and answer, rhetorical question, reiterations, anticipation of possible counter arguments and introduction of classifications." KAHLOS, M. Debate and Dialogue: Christian and Pagan Cultures. Aldershot: Ashgate, 2007, p. 66. Tradução nossa.
} 
No contexto multilinguístico mogol de negociação de tradições ético-religiosas distintas, observamos serem significativas a produção e circulação de textos de conteúdo político, isto é, que tratavam do tema da governança. Estamos fazendo referência aqui ao que Muzaffar Alam chama de "literatura Akhlaq". ${ }^{192}$ Nesse gênero, a "correta conduta" de um régulo era um dos objetos principais, de maneira que o tratado escrito por Xavier e destinado a Akbar possuiria um propósito religioso potencialmente associado a tal literatura política indo-persa. Dessa forma, para além de seu caráter apologético, Fonte de Vida assumiria, em alguma medida, papel análogo ao de obras da tradição turco-mogol, as quais articulavam religião, ética e política. Assim sendo, é possível que a obra de Jerônimo Xavier tenha sofrido alguma influência da produção textual especialmente destinada aos governantes.

Ainda segundo Alam, o tema da governança encontrava-se atrelado a um determinado entendimento da Sharia, especialmente no que diz respeito à relação entre governantes muçulmanos e governados não muçulmanos.

[A] Sharīa passou a ter mais de um significado durante este encontro entre árabes e não árabes; a língua do Leste Islâmico começou a se tornar uma mistura sincrética; um legado de cooperação e assimilação desenvolvido desde a época do Sultanato até o final do reino mogol; e situações de conflito tinham a tendência a serem resolvidas de acordo com um padrão formado por uma forte tradição política de acomodação do islamismo medieval. ${ }^{193}$

Um entendimento mais flexível e menos jurídico da Sharia propiciaria uma convivência mais tranquila entre islâmicos e não islâmicos, na mesma medida em que quão mais estrita fosse essa concepção, mais tensas seriam as relações sociais e políticas entre os seguidores de Maomé e os demais povos:

Ainda assim, fica claro que a Shari'a, que guiava o padrão de governo mogol, tinha impacto na tradição de Nasirean Akhlaq, o que era reforçado pelo mundo que poetas e sufis haviam, em seus domínios, delineado em persa, um mundo em que era possível usar o termo shari'a não necessariamente, ou apenas, em um sentido legal limitado. ${ }^{194}$

\footnotetext{
192،"TThe] Sharī'a came to acquire more than one meaning in the course of this encounter between Arab and nonArab; the language of the Islamic East moved towards a syncretic mix; a legacy of cooperation and assimilation developed from the days of the Sultanate to the end of Mughal rule; and conflictual situations tended to be resolved along a pattern informed by this strong political tradition of accommodation within medieval Islam." ALAM, M. Languages of Political Islam in India. Orient Blackswan, 2004, p. 12. Tradução nossa. O autor também nos diz na mesma página que "this akhlaqi tradition revealed nourishment from the Greek legacy, the rationalism of which had earlier been incorporated into Islam trought the writings if say, Ibn Sina and Farabi”.

Ibidem, p. 141. Tradução nossa.

194"'Yet, it is clear that the Shari'a, which guided the Mughal pattern of governance bore impact of the tradition of Nasirean Akhlaq, this being reinforced by the world that poets and Sufis had in their own domains delineated in Persian, a world in which it became possible to use the term shari'a not necessarily or merely in its narrow legalistic sense." Ibidem, p. 77. Tradução nossa.
} 
No trecho acima, percebemos que o mesmo autor introduz ainda um outro elemento ao contexto político de que tratamos aqui. Ao lado da tradição persa de uma literatura éticopolítica que se debruçava sobre o tema da governança, Alam ressalta ainda a presença do sufismo nesse cenário. Ele acrescenta:

Foi a crença sufista de unidade em multiplicidade, conhecida como wạ̣dat al- wujūd (Unidade do Ser), que forneceu a base da doutrina para todos esses desenvolvimentos no processo de síntese religiosa e amálgama cultural. ${ }^{195}$

Assim sendo, o conceito por nós grifado no extrato acima - waḥdat al- wujūd - é fundamental para que possamos prosseguir com nossa análise da obra de Xavier. Ele condensa nossas hipóteses acerca da religião ter emprestado a Akbar subsídios retóricos e ideológicos que viabilizassem e justificassem sua soberania e seu governo.

Jonardon Ganeri, autor anteriormente citado em função do nosso uso de seu conceito “cosmopolitismo religioso", também faz referência à questão da Unidade no contexto mogol nos tempos de Akbar. Mesmo tendo seu foco em um momento posterior, é válida a menção do seguinte trecho:

Na Índia, [o ano de 1656] foi o ano em que um longo processo de isomorfismo religioso, iniciado pelo cronista de Akbar, Abu al-Fadl, e orquestrado de acordo com a ideia de Ibn al-Arabis sobre a "Unidade do ser" (wahdat al-wujud), encontrou sucesso no grande projeto de Dara Shukoh de traduzir 52 Upanisads para o persa. (...) Dara acreditava que ele poderia definir que as diferenças entre hinduísmo e islamismo erammeramente terminológicas, e que até os Upanisads poderiam ser lidos como comentários sobre o Qur'an. ${ }^{196}$

O mesmo autor reitera as relações entre sufismo e política:

A ideia que diferentes pontos de vista coabitam uma única matriz e que, nessa medida, são susceptíveis ao sincretismo, é o que difere a visão cosmopolita de pluralismo, cujo princípio cardinal é que a falta irreconciliável de consenso é, por si só, algo com valor político, social ou filosófico. Na Índia da Idade Moderna, esses pensamentos assumiram uma importância tanto política quanto filosófica. Por boa parte dos séculos dezesseis e dezessete (...) a doutrina sufista de wahdat al-wujud guiou uma busca por uma única visão spiritual queseria a base de todas as religiões. ${ }^{197}$

\footnotetext{
195“'It was the Sufic belief in unity in multiplicity, known as waḥdat al- wujūd (Unity of Being), which provided the doctrinal basis for all these developments in the process of religious synthesis and cultural amalgam." ALAM, M. Languages of Political Islam in India. Orient Blackswan, 2004, p. 91.Tradução nossa.

196،'In India [the year 1656] was the year in which a long running process of religious isomorphism, pioneered by Akbar's chronicler Abu al-Fadl and orchestrated around Ibn al-Arabis idea of "Unity of being" (wahdat alwujud), reached fulfillment in Dara Shukoh's grand project to translate fifty two Upanisads into Persian. (...) Dara believed that he could establish that the differences between Hinduism and Islam were largely terminological, and even that Upanisads can be read as a sort of commentary upon Qur'an.” GANERI, J. The Lost Age of Reason: Philosophy in Early Modern India 1450-1700. EUA: Oxford University Press, 2011 , p. 13. Tradução nossa.

197، The idea that different viewpoints are co-inhabitants in a single matrix, and to that extent susceptible to
} 
Propomos, desta forma, que Fonte de Vida deve ser necessariamente entendido em diálogo com a tradição jurídica, ética e político-religiosa que séculos antes da chegada dos missionários já tratava do tema da governança, com ênfase no desenrolar do conceito de Shari'a tal qual exposto por Alam. Além disso, é preciso considerar a presença importante de uma corrente específica do pensamento islâmico, chamada de sufismo, cujo papel de mediação nas relações entre muçulmanos e não muçulmanos na Índia mogol foi determinante. Temos, portanto, dois elementos indispensáveis a serem considerados quando analisamos o contexto de produção de Fonte de Vida: a literatura Akhlaq e o sufismo:

A Sharīa, sendo jurista ou conforme definido pelas éticas de Nasirean, não era a única a moldar a cultura política medieval e mogol. (...) Também havia a forte influência de ideias sufistas e das crenças dos mogóis. Enquanto as ordens sufistas bā shar' geralmente enfatizavam que uma experiência mística verdadeira não legitimava uma violação da lei religiosa, a própria sharỉa não deveria ocuparuma posição muito crítica no caminho do progresso espiritual. ${ }^{198}$

Assim, é preciso ter em mente que Xavier escreve para uma Índia perso-islamizada. ${ }^{199}$ Desse modo, enfatizamos que Fonte de Vida é escrita em idioma persa, num contexto em que “o persa, então, emergiu como a língua do rei, da casa real e da alta elite mogol."200

Para Alam, o papel do idioma persa na estruturação do poder político mogol na Índia, bem como para a criação de uma espécie de amálgama social que pudesse dar conta das diferenças socioculturais e religiosas, foi decisivo. "O persa, então, forneceu as condições para que os mogóis pudessem construir uma classe de aliados a partir de grupos sociais e religiosos heterogêneos." ${ }^{201}$ Sendo assim, é sintomático, do ponto de vista político, que Fonte

syncretism, is what distinguishes the cosmopolitan vision from pluralism, whose cardinal tenet is that the irreconcilable absence of consensus is itself something of political, social or philosophical value. In early modern Índia, these thoughts assumed a political as well as philosophical importance. For much of the sixteenth and seventeenth centuries (...) the Sufi doctrine of wahdat al-wudul guided a quest for a single spiritual vision underpinning all religions." GANERI, J. The Lost Age of Reason: Philosophy in Early Modern India 14501700. EUA: Oxford University Press, 2011, p. 32. Tradução nossa.

198، The sharī'a, whether juristic or as defined within Nasirean ethics, was not alone in shaping medieval and Mughal political culture. (...) There was also the powerful influence of Sufi ideas and beliefs on the Mughals. While the bā shar' Sufi orders generally emphasized that true mystical experience did not legitimize a violation of religious law, the sharī'a itself was supposed not to occupy a very crucial place in the path of spiritual progress." ALAM, M. Languages of Political Islam in India. Orient Blackswan, 2004, p. 81. Tradução nossa.

199 "The mughals, who succeeded the Afghan sultans of the North Índia in the XVI century, showed unprecedented interest in patronizing Persian literature culture during their rule." Ibidem, p. 122.

${ }^{200}$ “[...] persian thus emerged as the language of the king, the Royal, household and the high mughal elite." Ibidem, p. 127. Tradução nossa.

${ }^{201}$ "Persian thus promoted the conditions in which the mughals could build a class of allies out of heterogeneous social and religious groups." ALAM, M. The Pursuit of Persian: Language in Mughal Politics. Modern Asian Studies, vol. 32, n’ 2, p. 324, maio 1998. Tradução nossa. 
de Vida tenha sido escrita em persa, pois insere o jesuíta no contexto político estruturante de que falamos.

De forma a relacionar os elementos acima mencionados - a literatura Akhlaq, ${ }^{202} \mathrm{O}$ sufismo e a questão da Sharia no contexto indo-islâmico mogol - e enfatizar o uso do persa na corte de Akbar, achamos pertinente recorrermos a outro trecho da obra de Alam:

Juntos, todos os variados desenvolvimentos e inovações religiosas, culturais e literárias que foram consequência do contato do islamismo com o hinduísmo ecoaram a preocupação mogol em garantir 'justiça' e 'paz' para todos. Em termos de sua teoria sobre o equilíbrio social (i'tidāl) e uma abordagem não sectária sobre questões de fé, eles faziam sentido político, mesmo divergindo do islamismo ortodoxo. Nessas tentativas de estabilidade social, a língua tinha um papel importante. O persa se tornou o veículo principal para o modo e idioma da política que a lei mogol tentava propagar. $^{203}$

Um terceiro autor, ao lado de Alam e Ganeri, também considera a influência do sufismo no trabalho de Xavier. Gauvin Bailey afirma que:

Entre os meios de proselitismo mais influentes e intelectualmente desempenhados empregados pelos jesuítas mogóis estavam o catecismo e outros tratados teológicos escritos entre 1596-1607 por Jeronimo Xavier em persa. (...) Eles foram escritos em uma versão básica do estilo literário persa e eram repletos de metáforas e referências retiradas da ala mística do islamismo conhecida como sufismo. Eram especialmente proeminentes as referências sobre espelhos, que eram fundamentais para a linguagem alegórica sufista. Esses trabalhos também se utilizavam da herança cultural neoplatônica que era compartilhada igualmente pelo islamismo e pela cristandade, derivada das raízes clássicas comuns que, em muitos casos, sobreviveram graças a esforços islâmicos anteriores. (...) [Os trabalhos de Xavier] eram uma mistura rica e intelectual de referências textuais do Leste e Oeste - uma síntese possível devido ao acesso à uma impressionante biblioteca imperial abrangente. ${ }^{204}$

202 Isto é, a tradição literária composta por escritos ético-políticos influenciados pela obra Akhlaq-e Nasiri, escrita por Nasir al-Din al-Tusi. Tusi nasceu em Tus, no Irã, em 1201, e morreu em Bagdá, em 1274. Uma cópia sob a guarda do Museu Aga Khan em Genebra, na Suíça, pode ser consultada a partir do site <http://www.ecorpus.org/notices/140434/gallery/1747565/fulltext $>$. Em sua descrição do documento, o mesmo site nos informa ainda que: "The text, although complex and written in a rather florid prose style, was a favouriteof Akbar, the Mughal ruler of Índia from 1564 to 1605." Disponível em: <http://www.ecorpus.org/eng/notices/140434-Akhlaq-e-Nasiri-Ethics-of-Nasir-by-Nasir-al-Din-TusiIndia-LahoreMughal--Akbar-r-1556-1605-c-\%C2\%A0-1590-1595.html>.

${ }^{203 ،}$ 'Taken together, all the varied religious, cultural and literary developments and innovations that were a consequence of Islam's contact with Hinduism echoed the Mughal concern for ensuring 'justice' and 'peace' for all. In terms of their theory of social equipoise (i'tidāl) and non-sectarian approach to matters of faith, these made political sense, even as they diverged from orthodox Islam. In these attempts at social stability, language played no small role. Persian became a crucial vehicle for the mode and idiom of politics that Mughal rule attempted to propagate.” ALAM, M. Languages of Political Islam in India. Orient Blackswan, 2004, p. 140. Tradução nossa.

204،Among the most influential and intellectually accomplished media for proselization employed by the mughal Jesuits were the Persian language catechism and other theological treatises written between 1596-1607 by Jeronimo Xavier. (...) They were written in a basic version of the literary Persian style and were full of metaphors and references taken from the mystical branch of Islam known as Sufism. Especially prominent were 
Como podemos observar, Bailey ressalta o contexto de negociação de que falamos anteriormente, indicando inclusive o papel que a biblioteca de Akbar pode ter tido nesse processo. Além disso, ele aponta pertinentemente o compartilhamento da tradição neoplatônica, que também é um aspecto deveras importante. Ressaltamos que, ainda que houvesse divergências graves em termos jurídicos, metafísicos ou teológicos, essa tradição compartilhada entre muçulmanos e cristãos auxilia de forma determinante a condução dos diálogos entre os jesuítas e seu público na Índia mogol. Veremos nos próximos capítulos que o mesmo não será observado no Tibete, justamente pela falta de tal vocabulário teológicofilosófico minimamente compartilhado. ${ }^{205}$

Não obstante, esse conteúdo neoplatônico compartilhado, uma espécie de vocabulário metafísico, será muitas vezes o denominador comum que viabilizará o diálogo entre cristãos e muçulmanos, ao lado da herança judaico-cristã. Isso é extremamente importante, pois questões filosóficas eram um instrumento a favor das estratégias dialógicas de conversão. Pensamos que temas debatidos pela segunda escolástica que transcendiam questões doutrinárias tiveram um papel análogo na missão do mogol àquele ocupado pela astronomia nas missões da China. Um dos temas que podemos citar como exemplo é o princípio de individualização, do qual já falamos anteriormente. ${ }^{206}$

Assim, uma vez descrito o contexto em que Jerônimo Xavier escreveu Fonte de Vida, procuraremos defender a hipótese de que a obra, escrita em forma de diálogo, é uma espécie de refinamento das estratégias anteriores. No Commentarius, escrito por Montserrat, por exemplo, os debates ainda apareciam descritos em referência às audiências promovidas por Akbar e, portanto, não se apresentavam estritamente enquanto um gênero literário a serviço dos objetivos principais dos missionários: a evangelização e a conversão.

Além disso, sustentamos que esse tratado apologético, ainda que possua inúmeras semelhanças com os tradicionais tratados cristãos tomistas (em especial Summa Contra Gentiles e De Rationibus Fidei), foi produzido num contexto estético-estilístico misto e negociado. Portanto, se o conteúdo é tomista e representativo da segunda escolástica, a forma

references to mirrors, both of which were central to Sufi allegorical language. These works also took advantage of the Neoplatonic cultural heritage that was shared by Islam and Christianity alike, derived from common classical roots that in many cases survived thanks to early Islamic efforts. (...) [Xavier's works] were a rich and scholarly blend of textual references from East and West - a synthesis made possible by access to a remarkably comprehensive imperial library." BAILEY, G.A. The Truth-Showing Mirror: Jesuit Catechism and the Arts in Mughal India. In: O’MALLEY, J.W. (Ed.) The Jesuits: cultures, sciences, and the arts, 1540-1773. University of Toronto Press, vol. 1, 1999, p. 383-4. Tradução nossa. Grifos nossos.

${ }^{205}$ Tal aspecto ficará mais evidente nas análises desenvolvidas na segunda parte desta tese.

${ }^{206}$ Anteriormente identificado como Querela da Individualização. 
lírica, a opção pela forma dialógica e a ênfase em determinadas questões em detrimento de outras refletem necessariamente tal contexto de produção negociado e proselitista.

Isto posto, é necessário ainda saber que Fonte de Vida possui a seguinte estrutura geral: a obra divide-se em cinco livros, que tratam respectivamente dos seguintes temas: 1 . o conhecimento de Deus e de sua verdadeira lei; 2. as coisas que de Deus ensina, a lei dos cristãos e quão conforme são à razão; 3. a divindade de Cristo; 4. os mandamentos da lei cristã e da lei dos mouros; 5. as ajudas que se dão na lei dos cristãos para viver a serviço do Criador e a vantagem em que nisso leva da lei dos mouros e das outras. Estes cinco livros são antecedidos pela apresentação da fé cristã "em modo de oração" e pela dedicatória da obra, feita a Akbar. ${ }^{207}$

Nas próximas páginas, abordaremos esta estrutura geral da obra, identificando semelhanças com importantes tratados apologéticos, como a Summa Contra Gentiles e De Rationibus Fidei, citados acima, além, obviamente, da própria Suma Teológica. Apontaremos elementos que são indícios da inserção de Fonte de Vida no contexto da segunda escolástica. Em seguida, levantarmos hipóteses sobre outros elementos encontrados no texto, os quais, não obstante sobóbvia influência do tomismo, ${ }^{208}$ podem ser entendidos como índices da situação político-religiosa na qual estavam inseridos os missionários. Estes elementos, supomos, são os que dão, justamente, especificidade à obra de Xavier.

\footnotetext{
${ }^{207}$ Xavier incluiu ainda, na parte introdutória de sua obra, uma seção chamada "Al curioso lector y deseoso de la verdad”. Nela, o missionário faz uma brevíssima introdução, anunciando os propósitos de seu livro. XAVIER, J. Fuente de Vida: Tratado apologético dirigido al Rey Mogol de la Índia en 1600. San Sebastián: Universidad de Deusto, 2007, p. 74-5.

208 "Nonetheless, the basic assumption of the compatibility between "nature and grace," between "reason and revelation" that underlay the Thomistic synthesis coincided with the Jesuits' conviction that in their pastoral activities they should not only rely upon God's grace but also use all the "human means" at their disposal, as the Constitutions prescribed. Thomistic reasoning would also help rationalize this conviction.”O’MALLEY, J.W. The first jesuits. Harvard University Press, 1993, p. 245.
} 


\section{2 À SOMBRA DA ESCOLÁSTICA: UMA PROPOSTA DE LEITURA DA APRESENTAÇÃO DA FÉ} CRISTÃ EM MODO DE ORAÇÃO E DA DEDICATÓRIA DA FONTE DE VIDA.

Al princípio, sin princípio, de quien depende el princípio, progresso e fin de todas las cosas, que al Dios alto soberano y todo poderoso, sean dadas gracias infinitas. ${ }^{209}$

Conforme dito acima, os cinco livros que compõem Fonte de Vida são antecedidos por duas seções a serem aqui analisadas: (1) a apresentação da fé cristã "em modo de oração"210; e (2) a dedicatória da obra, feita a Akbar.

Ambas as partes são importantes para nossa análise. A primeira porque apresenta, de forma um tanto poética, os mistérios do cristianismo. A segunda porque apresenta o livro e seu propósito a Akbar, defendendo a importância de se manter uma relação próxima entre reis e sábios. Em conjunto, sua importância reside no fato de destoarem - principalmente no que diz respeito aos aspectos formais e estilísticos do texto - do corpo da obra propriamente dito, isto é, do tratado em formato dialógico contido nos cinco livros seguintes.

Passemos a uma sucinta descrição destes elementos pré-textuais. Na primeira parte de sua obra, Jerônimo Xavier apresenta o princípio, o progresso e o fim de todas as coisas - isto é, Deus. Suas perfeições são enumeradas: Ele tudo sabe, tudo pode, tudo tem; é eterno, infinito e incompreensível; sua natureza é distinta da natureza das criaturas. É perfeito sem qualidade e por isso é sumo. Está em todo lugar, sem ser compreendido, e por isso é universal. Tudo obra sem mudança e por isso é imutável. ${ }^{211}$ Em seguida, Xavier aborda o mistério da Santíssima Trindade. O autor acrescenta ainda que Deus deu os profetas para que nos ensinassem, os anjos para que nos guardassem e seu único filho natural para que, feito homem, pudéssemos ver, ouvir, seguir e imitar. ${ }^{212}$

Ao longo dessa espécie de preâmbulo, percebemos que o autor ainda se utiliza de algumas imagens um tanto paradoxais para alguém que se dedica - com tanto esforço, como ele mesmo irá apontar adiante - a debater e escrever em nome da verdadeira lei. Xavier nos diz que Deus ensina sem ruído de palavras, sem tinta e sem livros. Ensina e dá entendimento

\footnotetext{
${ }^{209}$ XAVIER, J. Fuente de Vida: Tratado apologético dirigido al Rey Mogol de la Índia en 1600. San Sebastián: Universidad de Deusto, 2007, p. 61.

${ }^{210}$ Ibidem, loc. cit.

${ }^{211}$ Ibidem, p. 62.

${ }^{212}$ Ibidem, p. 64.
} 
para ser entendido. Dá doutrina e a capacidade para entendê-la. No entanto, ele também diz que não se conhece Deus pelo entendimento, já que quem mais alcança Deus é aquele que, quanto mais se chega Dele, mais distante fica de Seu entendimento. ${ }^{213}$

Gostaríamos de ressaltar a semelhança desta proposição de Xavier com o que São Tomás de Aquino recomenda no capítulo segundo de De rationibus fidei, intitulado Qualiter sit disputandum contra infideles(Capítulo II - Como se deve disputar com os infiéis):

Quero advertir-te primeiramente sobre isto: nas disputas sobre os artigos de fé contra os infiéis, não te deves esforçar para provar a fé por meio de razões necessárias. Isso derrogaria a sublimidade da fé, cuja verdade não só excede as mentes humanas como também as dos anjos; a verdade da fé é crida por nós como revelada por Deus. Ademais, uma vez que aquilo que procede da Suma Verdade não pode ser falso, a verdade da fé não pode ser impugnada por alguma razão necessária; assim como a nossa fé não pode ser provada por razões necessárias, já que excede a mente humana, de igual modo, por causa de sua verdade, não pode ser refutada por razão necessária. A isto, portanto, deve tender a intenção do disputador cristão: não prove ele a fé, mas a defenda. ${ }^{214}$

No entanto, percebemos também que a semelhança no conteúdo se choca com a distinção na forma. Afinal, é de maneira um tanto lírica, com imagens, metáforas e paradoxos, que Jerônimo Xavier abre a sua obra, como podemos perceber já no extrato destacado no alto desta página: “Al princípio, sin princípio, de quien depende el princípio, progresso e fin de todas las cosas, que al Dios alto, soberano y todo poderoso, sean dadas gracias infinitas". ${ }^{215} \mathrm{O}$ lirismo de Xavier aparece, pois, como uma alternativa, ou adaptação, à opção estilística escolástica de Tomás de Aquino. Façamos aqui uma comparação com a abertura do Corão:

Em nome de Deus, O Clemente, o Misericordioso

Louvado seja Deus, o Senhor dos mundos,

O Clemente, o Misericordioso,

O soberano do dia do Julgamento

A Ti somente adoramos. Somente de Ti imploramos socorro.

Guia-nos na senda da retidão,

\footnotetext{
${ }^{213}$ XAVIER, J. Fuente de Vida: Tratado apologético dirigido al Rey Mogol de la Índia en 1600. San Sebastián: Universidad de Deusto, 2007, p. 62-65.

${ }^{214}$ Infelizmente não encontramos publicação desta obra em português. Utilizamos tradução para o português feita pelo Pe. Elílio Júnior, que está disponível em: <http://padreelilio.blogspot.com.br/2009/01/de-rationibusfidei-santo-toms-de.html>. No original, em Latim: "De hoc tamen primo admonere te volo, quod in disputationibus contra infideles de articulis fidei, non ad hoc conari debes, ut fidem rationibus necessariis probes. Hoc enim sublimitati fidei derogaret, cuiús veritas non solum humanas mentes, sed etiam Angelorum excedit; a nobis autem creduntur quasi ab ipso Deo revelata. Quia tamen quod a summa veritate procedit, falsum esse non potest, nec aliquid necessaria ratione impugnari valet quod falsum non est; sicut fides nostra necessariis rationibus probari non potest, quia humanam mentem excedit, ita improbari necessariaratione non potest propter sui veritatem. Ad hoc igitur debet tendere Christiani disputatoris intentio in articulis fidei, non ut fidem probet, sed ut fidem defendat." AQUINO, T. De Rationibus Fidei.TraduçãoJoseph Kenny, O.P. Edição bilíngue latim-inglês. Disponível em: <www.dhspriory.org/thomas/Rationes.htm>.

${ }^{215}$ XAVIER, J., op. cit., p. 61.
} 
A senda dos que favoreceste, não dos que incorrem na Tua ira, nem dos que estão desencaminhados. ${ }^{216}$

Citemos ainda a abertura da primeira Sura, cujo título em português é "a vaca": "Em nome de Deus, o Clemente, o Misericordioso. Alef. Lam. Mim.”217

À semelhança das suras do Corão, Xavier opta por abrir seu texto com um louvor a Deus. Esse tom poético e lírico distingue-se da linguagem dos tratados apologéticos tomistas ou escritos metafísicos em geral, distinguindo-se também do estilo de escrita dos cinco livros principais de Fonte de Vida. Reparamos, evidentemente, que a natureza de Deus já está aí exposta - o criador não criado, de quem tudo depende, onipotente e soberano. Mas Xavier não lança mão de metáforas e figuras de imagem apenas na abertura de seu texto. Selecionamos alguns poucos trechos dessa "apresentação dos mistérios da Santa fé em forma de oração" para sustentar esta hipótese. Por exemplo:

Sua perfeição e bondade são infinitas, sem nenhum gênero de limite. É mar e abismo donde estão reolhidas todas as bondades que pelas criaturas estão repartidas e outras infinitas mais. (...) Tudo sabe, tudo pode, tudo tem. (...) Sua natureza não é como as de suas criaturas, lagoa de onde convergem as lagoas das perfeições acidentais. ${ }^{218}$

Podemos reiterar, a partir desta citação, o caráter lírico do texto. É importante frisar que os atributos teologicamente associados a Deus (eterno, infinito, onisciente, onipotente) são, nessa parte da obra, associados a imagens (metáforas) que garantem o aspecto poético do texto. Conceitos como natureza e acidentes - um vocabulário teológico-metafísico - não são definidos ou descritos, mas aparecem como que diluídos em figuras de linguagem. Não há definição dialética e racional de Deus. Ao contrário, trata-se de apresentar a Doutrina, isto é, essencialmente as mesmas ideias presentes na Suma Teológica de Tomás de Aquino, em uma forma não dialética, não racional, mas sensível, metafórica, poética, sinestésica.

Partindo da identificação desses elementos metafóricos e da ausência de um rigor escolástico, nosso único e exclusivo objetivo aqui é indicar que, nessa parte do texto, ao

\footnotetext{
${ }^{216}$ CORÃO. Tradução Mansur Chalita. p. 29. Transliteração do árabe: "Faatihah. Bismillaahir-RahmaanirRahiim. 1. 'Al-Hamdu Iillaahi Rabbil-'Aalamiin; 2. 'Ar-Rahmaanir-Rahiim;3.Maaliki Yawmid-Diin! 4. 'Iyyaaka na'-budu wa 'iyyaaka nasta-iin. 5. 'Ihdinas-Siraatal-Mustaqiim. 6. Siraatal-Iaziina 'na-amta'alay-him. 7. Gayril-magzuubi 'alay-him wa laz-zaaalliin.” Mantivemos a transliteração e a numeração tal qual ela aparece na seguinte publicação do Corão: ROMAN Traslitaration of The Holy Qur-'ann, with full arabic text. Tradução Allama Abdullah Yusuf Ali. Lahore: Qudrat Ullah co., s/d., p. 2.

217 "Bismillaahir-Rahmaanir-Rahiim". CORÃO. Tradução Mansur Chalita. p. 29. Alef, nam e mim são letras do alfabeto árabe.

${ }^{218}$ XAVIER, J. Fuente de Vida: Tratado apologético dirigido al Rey Mogol de la Índia en 1600. San Sebastián: Universidad de Deusto, 2007, p. 62.
} 
contrário de recorrer a uma retórica dialética, o autor faz uso de figuras de linguagem, as quais conferem a sua "oração" outros resultados retóricos e estéticos. Tal análise, contudo, encontra dois limites. Por um lado, não procuramos defender que não existe lirismo em escritos cristãos, por outro, não temos a intenção de afirmar que o caráter poético desta parte de Fonte de Vida é resultado exclusivo da influência muçulmana sufi.

Nossa hipótese, localizada entre esses dois polos, é a de que Xavier abre dessa forma sua obra para atingir um determinado tipo de leitor. Seria uma espécie benevolentiae captatio $^{219}$ para alcançar o círculo de leitores composto por cortesãos sufis ou seguidores do din-i ilahi.Isto é, pessoas politicamente influentes, além, evidentemente, do próprio Akbar.

Evidentemente, um dos limites desta tese é justamente a falta de leitura de tais textos sufis, ou mesmo dos textos elaborados e traduzidos na corte de Akbar. Para desenvolvermos nossa hipótese, portanto, baseamo-nos na bibliografia (especialmente Gauvin Bailey, neste caso) associada à distinção que fazemos dessa parte da obra da forma dialética encontrada em outros textos apologéticos, como De Rationibus Fidei. Retomemos o texto:

Todas estas e inúmeras outras perfeições tem [Deus] em si, sem que haja algum tipo de composição. É simplíssimo, é uníssimo, é puríssimo, porque todas as coisas são sua mesma essência infinita. Em outra coisa que tem mostra ainda mais a sua grandeza infinita e vence a capacidade de nosso entendimento: querer ser único e simplíssimo Deus de única e simplíssima essência. É três Pessoas distintas, Pai, Filho, Espírito Santo. ${ }^{20}$

Gostaríamos de ressaltar que já no segundo fólio de sua obra, Xavier aborda a questão central da divergência teológica cristo-islâmica: a natureza única de Deus e, ao mesmo tempo, o mistério da Santíssima Trindade. O missionário faz questão de afirmar a unicidade de Deus e, no mesmo parágrafo, inserir as três pessoas divinas: Pai, Filho e Espírito Santo. Além disso, ele já antecipa nesse mesmo extrato que a grandeza infinita de Deus vence a capacidade de entendimento do homem. Ou seja, nesse momento, Xavier não inicia um debate racional e dialético sobre a natureza de Deus. Ele apenas afirma, simultaneamente, a ideia central do wahdat al-wujud e o mistério da Santíssima Trindade. O tom poético do texto prossegue:

Oh, Deus, vencedor de entendimentos, vieste morar na casa do sol e da claridade, pois és suma verdade. E quando chego a ti me acho em trevas e escuridão, pois tanta é tua grandeza, que para suas criaturas és claríssimamente escuro e escuríssimamente claro. Não sei se te chamo obscuridade plena de resplendor ou resplendor cercado de obscuridade, (...) [pois] tua infinita claridad excede todo o nosso saber. ${ }^{221}$

${ }^{219}$ Ou seja, uma "ordenação das palavras para influir com eficácia na mente do receptor”. Cf: PÉCORA, A. Máquina de gêneros. São Paulo: Editora Universidade de São Paulo, 2001. p. 20.

${ }^{220}$ XAVIER, J. Fuente de Vida: Tratado apologético dirigido al Rey Mogol de la Índia en 1600. San Sebastián: Universidad de Deusto, 2007. p. 62.

${ }^{221}$ Ressaltamos que todos os pronomes que fazem referência a Deus se encontram iniciados por letra minúscula 
Terminamos a análise da oração inicial com a passagem acima destacada, pois acreditamos que ela sintetiza nosso objetivo imediato: indicar que a linguagem poética talvez barroca, para usarmos uma categoria literária ocidental - foi um recurso usado pelo missionário para se aproximar e se fazer ler por Akbar e pelos sufis e mulás mais próximos do soberano. Assim, nessas primeiras páginas, o jesuíta apresenta algumas das ideias principais da Doutrina católica, sem opô-las à crença sufi fundamental da unidade de Deus. Além disso, esse extrato deixa claro que o objetivo da parte inicial de Fonte de Vida não é defender apologeticamente, recorrendo ao entendimento e à razão, à superioridade da lei cristã. Ao contrário, nos parece evidente, pelo uso de paradoxos e metáforas, que Xavier, nesse momento, não tem interesse em argumentar, debater, convencer ou dissuadir. Seu principal objetivo, acreditamos, é convidar seu "público alvo" a ler o seu tratado. Para isso, a aproximação com as ideias e com o que supomos, baseando-nos na bibliografia, ser um certo lirismo sufi, foi fundamental.

À “oração" escrita por Xavier segue a dedicatória a Akbar, que se inicia com uma analogia estabelecida com a história de Amoxímenes e Sócrates. O primeiro, vendo que os demais discípulos do mestre filósofo lhe chegavam com presentes, se ofereceu como presente. Da mesma forma, ofereciam-se os jesuítas eles mesmos como presentes ao soberano. Ou seja, ofereciam ao imperador aquilo de que ele mais precisava - o conhecimento do Deus verdadeiro, criador e senhor de todos, e caminho que todos devem tomar para alcançar o outro mundo. ${ }^{222}$

Fizemos nossa conta de como essas coisas desse mundo nós não temos possibilidade, nem muito menos Vossa Alteza [tem] necessidade, pois Nosso Senhor Deus encheu-lhe tanto delas, não teríamos outra que oferecer à Vossa Grandeza, senão a nós mesmos. Assim, nos damos e oferecemos a todo o que for de seu serviço. (...) Por sermos tão pequenos, juntamente conosco the oferecemos a coisa de que mais precisamos e que Vossa Alteza mais que tudo deseja, que é o conhecimento do Deus verdadeiro, Criador e Senhor de todos, e do caminho que todos devem levar para o alcançar. ${ }^{223}$

O extrato acima indica não só como os jesuítas se oferecem como presente ao imperador, como também deixa claro a relação de identidade estabelecida pelo missionário entre o desejo de Akbar e o conhecimento dos jesuítas. Esta significação do suposto objeto de desejo do soberano mogol parece-nos uma estratégia acertada de Xavier, pois indica que o

na versão consultada da fonte. XAVIER, J. Fuente de Vida: Tratado apologético dirigido al Rey Mogol de la Índia en 1600. San Sebastián: Universidad de Deusto, 2007, p. 63.

222 Ibidem, p. 66.

${ }^{223}$ Ibidem, p. 67. 
missionário atentou para o interesse religioso crescente de Akbar. O missionário identifica essa suposta busca do soberano mogol e fornece-lhe uma lei, a única verdadeira lei, aquele que seria o único caminho verdadeiro, isto é, o cristianismo.

Após estabelecer essa relação de identidade entre a busca ou o desejo de Akbar e o cristianismo, Xavier passa a justificar a necessidade da relação entre o governo e o saber. $\mathrm{O}$ primeiro passo para isso é a elaboração de um importante elogio à figura do imperador mogol:

Vemos que os reinos deste Oriente, lançando de si seus reies que lhes governavam, se renderam de grado à Vossa Alteza, como digno senhor de tão ricas e grandes terras, com que fica tão grande e poderoso que o eco de seu nombre atordoa e espanta a todos os reies vizinhos e ainda chega aos mais distantes. Outra singular mercê tem feito à Vossa Alteza o todo poderoso Dios, ainda maior: que é lhe ter dado grandes reinos e o ter feito Rei grande e generoso, e lhe deu coração para saber governar com tanta paz, quietude, e justiça a seus vasalos. E lhe deu [ainda] tanto amor e estima aos sábios e letrados, donde nasce que de todas as partes os busca, convida e traz até si, e, trazidos, os sustenta tão liberalmente de seu tesouro. E nisso mostra sua singular prudência e saber, porque na verdade as letras e a espada devem ser companheiras, e o poder há de andar acompanhado do saber para que o que a espada e o braço ganhem, sustente e conserve a cabeça e a sabedoria. E assim, se algum rei conquistar reinos sem saberr meter tesouro, [o deixaria] em casa aberta e sem chave. ${ }^{224}$

Destaquemos os principais pontos deste trecho: tecer um elogio a Akbar, reconhecendo sua grandeza e poder; submeter as conquistas do imperador a Deus, pois são suas mercês; e apontar que Akbar cercava-se de sábios e letrados, o que, para o jesuíta, é indício de prudência e sapiência. Para Xavier, portanto, Akbar é um governante poderoso, prudente e sábio. Não obstante, o missionário, ainda neste extrato, estabelece uma relação necessária entre as letras (a sabedoria, o conhecimento ou a prudência) e a espada (o governo). Ao elogiar Akbar, o jesuíta realiza dois feitos: o primeiro sendo conquistar, supostamente, a simpatia e a boa vontade do soberano, e o segundo sendo apresentar uma descrição positiva do imperador Mogol para seu leitor. Ainda que a obra tivesse como público a corte indiana, não podemos ignorar os predicados que Xavier atribuiu a Akbar.

Além disso, o trecho deixa evidente o entendimento que Xavier - e os jesuítas em geral - tinha de seu papel em relação aos chefes de Estado, "cabeças" dos reinos, entendimento este que estava, obviamente, em consonância com o que dizia Tomás de Aquino:

Deve-se observar que é sobretudo o elemento principal de qualquer coisa que seja que determina o que ela parece ser. Todos os outros elementos parecem aderir àquele que é o principal e, de certo modo, ser assumidos por

224 XAVIER, J. Fuente de Vida: Tratado apologético dirigido al Rey Mogol de la Índia en 1600. San Sebastián: Universidad de Deusto, 2007, p. 67-8. 
ele, na medida em que o principal se vale dos outros segundo sua disposição, o que é manifesto em uma comunidade civil, em que os maiorais [príncipes civitatis] parecem constituir toda a cidade e dispõem dos outros segundo sua disposição na qualidade de membros seus. Tal se dá também na união natural. $^{225}$

Assim, Xavier defende a parceria entre a verdade das letras e a espada, para que um rei não conquiste reinos sem saber onde guardar e como manter seus tesouros. ${ }^{226}$ É curioso notar que nessa parte inicial da obra há uma distinção entre o papel do sábio exposto por Tomas de Aquino em Summa contra Gentiles e o que é aqui defendido por Xavier. Não se trata apenas de conhecer a verdade, mas de guiar o bom governo. O missionário continua:

Por esta causa disse que Vossa Alteza deve muito a Deus Nosso Senhor, pois lhe fez dobrada mercê em lhe dar tantos reinos e senhorios, juntamente com tanta discrição e prudência para governa-los, e tanto amor e estima aos sábois e letrados para deles obter ajuda. ${ }^{227}$

A conservação dos reinos, na opinião do jesuíta, reside no bom governo. Tal conservação, por sua vez, sustenta-se no bom conselho, que é filho da sabedoria. ${ }^{228}$ Por esta causa, segundo o missionário, Akbar devia muito a Deus, que lhe teria feito mercê dobrada: deu-lhe reinos e senhorios, juntamente com discrição e prudência para governá-los, bem como com amor e estima aos sábios para. ${ }^{229}$ Parece-nos ainda digno de nota que o adjetivo “discreto" também foi usado por Francisco Xavier para qualificar os japoneses.

O religioso argumenta ainda que, se a sabedoria humana é muito importante para o bom governo, a Divina é muito mais, já que ensina o caminho da salvação eterna, sem o qual “toda riqueza é pobreza, e toda felicidade é miséria". ${ }^{230}$

De todos os homens, prossegue Xavier, são os reis que mais padecem por seguirem falsas leis, pois a grandeza de seus negócios ocupa-lhes de tal forma que não se dedicam à verdade da Salvação. Além disso, avisa o jesuíta, a verdade - que é companheira inseparável

${ }^{225}$ Tradução do latim feita pelo padre Elílio Matos. No entanto, gostaríamos de fazer a ressalva de que não ficou claro para nós a escolha de traduzir "príncipes civitatis" por "os maiorais". Disponível em: <http://padreelilio.blogspot.com.br/2009/01/de-rationibis-fidei-santo-toms-de.html>. Em latim: "Est autem attendendum, quod um umquodque maxime videtur esse illud quod in eo invenitur esse praecipuum: omnia autem alia videntur ei quod est praecipuum adhaerere, et ab eo quodammodo assumi, inquantum id quod est praecipuum aliis utitur secundum suam dispositionem: quod quidem manifestum est non solum in adunatione civili, in qua príncipes civitatis quasi tota civitas esse videntur, et aliis utuntur secundum suam dispositionem, tamquam sibi adhaerentibus membris, sed etiam in adunatione naturali." AQUINO, T. De Rationibus Fidei. Tradução Joseph Kenny, O.P. Edição bilíngue latim-inglês. Disponível em: <www.dhspriory.org/thomas/Rationes.htm>.

${ }^{226}$ XAVIER, J. Fuente de Vida: Tratado apologético dirigido al Rey Mogol de la Índia en 1600. San Sebastián: Universidad de Deusto, 2007, p. 68. Este tema será mais desenvolvido dentro de algumas páginas.

${ }^{227}$ Ibidem, p. 69.

${ }^{228}$ Ibidem, loc. cit.

${ }^{229}$ Ibidem, loc. cit.

${ }^{230}$ Ibidem, p. 69-70. 
da verdadeira lei - anda desterrada dos palácios e das cortes. Os reis, diz o religioso, são amigos do doce e do deleitoso, mas a verdade, ao contrário, é áspera e amarga. ${ }^{231}$

Assim, Jerônimo Xavier recorre à metáfora do mercador, dizendo ao rei que viera a sua corte com tal boa mercadoria: "com este livro presenteamos a Vossa Alteza a suma da verdadera lei que Dues Nosso Senhor revelou ao mundo, para se salvarem os homens, fora da qual para ninguém há salvação.”232

Sobre seu formato, o jesuíta explica que o modo de se tratar tais aspectos é:

como un diálogo, (...) (que geralmente é mais desenfadado para os leitores, e mais claro) dando um razão e resposta ao que o outro pergunta, supondo ser a disputa entre um Padre, mestre na verdadera lei do Evangelio, e um filósofo, douto em filosofia humana, mas muito alheio a todo gênero de lei divina, porque tem para si que não há tanta veriedade de leis, e cada um deles traz as razões que têm da sua lei para defender o que ensina. ${ }^{233}$

Por último, o jesuíta explica o título do livro: chama-se Fonte de Vida porque quem o ler com atenção e seguir sua doutrina sem dúvida alcançará a vida eterna. ${ }^{234}$ Reiteramos, portanto, o duplo caráter da obra de Xavier. Por um lado, trata-se de um tratado apologético, destinado, por definição, à argumentação a favor da superioridade da lei cristã em detrimento da lei islâmica, o que ficará bem claro nos cinco livros que se seguem. Mas, além disso, tratase de um tratado com um destinatário específico: Akbar, o imperador mogol, cujos projetos políticos passavam por patrocinar a produção de obras escritas e pictóricas, as quais criariam um substrato discursivo para sua soberania política entre vassalos e súditos pertencentes a diferentes grupos linguístico-culturais e religiosos. Através dessa dedicatória foi possível perceber como um jesuíta missionário na Ásia na época moderna defende discursivamente seu duplo papel político e religioso: como letrado, orienta o bom governo; como missionário, apresenta ao governante a Verdadeira Lei. No caso da obra aqui analisada, a relação entre missão e política é materializada na identificação estabelecida por Xavier entre o desejo de Akbar e o cristianismo como o único caminho para a salvação.

Assim, ainda que de maneira frágil (dada as limitações de nosso corpo documental), procuramos demonstrar que, pelo uso reiterado de figuras de linguagem e pela associação entre o papel do missionário e o bom governo, as etapas introdutórias de Fonte de Vida dizem bastante do contexto político-religioso e estético em que a obra foi produzida. Não seria possível convencer o leitor "alvo" de Xavier a ler seus livros se sua forma e seu conteúdo

231 XAVIER, J. Fuente de Vida: Tratado apologético dirigido al Rey Mogol de la Índia en 1600. San Sebastián: Universidad de Deusto, 2007, p.71.

232 Ibidem, p. 71-2.

${ }^{233}$ Ibidem, p.73

${ }^{234}$ Ibidem, loc. cit. 
fossem por demais distantes do que devia estar sendo produzido no âmbito da Maktabkhana. Era necessário dialogar com o sufismo e também posicionar-se quanto à questão da governabilidade. Afinal, como expusemos anteriormente, era isso que estava em jogo para Akbar no final do século XVI e início do século XVII.

A seguir, abordaremos os livros iniciais de Fonte de Vida. Procuraremos indicar como são distintos o estilo e a forma do preâmbulo para o desenvolvimento da obra. A negociação ou adaptação - formal concentrou-se principalmente na parte inicial. Em seguida, veremos que teologia e doutrina, política e filosofia são os instrumentos de que Xavier se utiliza para se fazer ouvir - isto é, se fazer ler - na corte de Akbar. O questionamento da unidade de Deus em função de uma suposta influência sufi não parece se fazer sentir, de fato, nos cinco livros de Xavier. 


\title{
2.3 O PRIMEIRO LIVRO DE FONTE DE VIDA E O TOMISMO: DA SEGUNDA ESCOLÁSTICA À
}

\author{
NECESSIDADE DE SE FAZER OUVIR
}

\begin{abstract}
"Estando um dia no darvar ${ }^{235}$ e palácio do Rei Acbar assistindo ao seu serviço, acertou a chegar-se a mim um homem honrado [e] velho quehavia vindo de longínquas ierras a esta corte (...). Estranhando meu traje, me pergunou quem [eu] era e de onde havia vindo."236
\end{abstract}

Assim tem início o tratado propriamente dito, escrito de forma dialógica pelo jesuíta no Mogol Jerônimo Xavier. O personagem que supostamente representa o missionário, identificado como "padre" no diálogo, responde ao filósofo que o abordou que é "português ${ }^{237}$ de nação, cristão por lei e padre e mestre de cristãos por profissão. ${ }^{238}$ Seu interlocutor é um homem filósofo, que afirma: "livros são minhas armas, livros [são] minhas mercadorias, ensinar e disputar sempre foi minha principal ocupação." ${ }^{239}$ A esta altura do texto, o diálogo dá-se apenas entre os dois, pois o terceiro personagem "mulá" ainda não foi apresentado.

Podemos perceber desde já que o ofício de um filósofo, segundo a fonte, compreende a leitura de livros "de quase todas as ciências" 240 , o ensino e as disputas. O aspecto dialógico é, portanto, um importante componente do ofício de um homem de letras, pois quanto mais nobre e mais próxima de Deus é a criatura, mais ela se comunica. ${ }^{241}$

Já nesse momento inicial é impossível não perceber imediatamente a semelhança com a parte inicial de Summa Contra Gentiles. Tomás de Aquino também ressaltou logo no início de sua obra qual seria o papel do homem sábio. Sob o subtítulo de Quod sit officium sapientes, podemos ler:

Portanto, como pertence ao sábio considerar principalmente o primeiro princípio e discorrer sobre os outros, pertence-lhe impugner também o erro

\footnotetext{
${ }^{235} \mathrm{O}$ tradutor de Fonte de Vida indica-nos que darvar é o nome da sala na qual os imperadores muçulmanos da Índia davam audiências públicas. XAVIER, J. Fuente de Vida: Tratado apologético dirigido al Rey Mogol de la Índia en 1600. San Sebastián: Universidad de Deusto, 2007, p. 81. Nota 10.

${ }^{236}$ Ibidem, loc. cit.

${ }^{237}$ É interessante notar que Xavier nasceu em Navarra, mais precisamente em Beire (Olite), em 1549. Ele mesmo, portanto, não é português, mas o personagem que dá voz às suas argumentações sim. Supomos que este é mais um indício do aspecto político da obra, uma vez que a presença portuguesa no subcontinente indiano era peça importante para o equilíbrio geopolítico da região. Além disso, a identidade "portuguesa" devia ser mais facilmente entendida por um interlocutor asiático do que qualquer outra nação europeia no período. De qualquer forma, é importante ressaltar a aproximação entre a Coroa Portuguesa e a Companhia de Jesus refletida nesse extrato.

${ }^{238} \mathrm{O}$ padre apresenta três possiblidades de "profissão": armas, mercadoria ou letras. XAVIER, J., op. cit., p. 82.

239 Ibidem, loc. cit.

240 Ibidem, loc. cit.

241 Ibidem, p. 83.
} 
contrário. É, pois, mui convenientemente declarado, pela boca da Sabedoria, o duplo ofício do sábio, no texto supracolocado. Refere-se à verdade divina meditada, que por antonomásia é a verdade, quando diz: Minha boca publicará a verdade. Refere-se a impugnação do erro contrário à verdade, quando diz: Os meus lábios odeiam a impiedade. Está aqui designada a falsidade contrária à Religião, pois também se chama piedade. Daí a falsidade, que lhe é contrária, assumir para si o nome de impiedade. ${ }^{242}$

Ressaltamos, portanto, que desde o início propriamente dito da obra de Xavier, ela já se remete estruturalmente à Summa contra Gentiles.

Apresentados os personagens, inicia-se uma conversa acerca dos animais levados à presença de Akbar. ${ }^{243}$ A partir desse tema, surge uma argumentação acerca da superioridade do homem em relação aos animais:

E como pelo entendimento faz-se o homem senhor das criaturas, assim um homem faz-se superior aos outros monens se os excede em entendimento. Por isso, qyeda superior a los otros hombres si los excede, en el entedimento. Por esto, do sábio é [próprio] governar, ensinar e mandar nos demais hombens, que não têm tanto saber. ${ }^{244}$

Assim, conclui-se que, para o padre, é próprio dos sábios governar (ou auxiliar no governo) os demais, e que o homem é senhor de outros homens na medida em que os excede em entendimento. Esse conceito de entendimento, portanto, é fundamental tanto para a argumentação política quanto para a argumentação teológico-filosófica do padre. Podemos destacar algumas concepções de entendimento presentes no texto, todas em tom poético, isto é, recorrendo a figuras de linguagem: [Entendimento é] centelha daquele fogo que abrasa em seu amor e alumbra os espíritos celestiais; um arrojo daquela fonte e mar de todo saber; um raio daquele sol de todo resplendor; os pés com que se chega a Deus, as mãos com que se

\footnotetext{
242 "Unde sicut sapientis est veritatem raecipue de primo principio meditari et aliis disserere, ita eius est falsitatem contrariam impugnare. Convenienter ergo ex ore sapientiae duplex sapientis officium in verbis propositis demonstratur: scilicet veritatem divinam, quae antonomastice est veritas, meditatam eloqui, quod tangit cum dicit, veritatem meditabitur guttur meum; et errorem contra veritatem impugnare, quod tangit cum dicit, et labia mea detestabuntur impium, per quod falsitas contra divinam veritatem designatur, quae religioni contraria est, quae etiam pietas nominatur, unde et falsitas contraria ei impietatis sibi nomen assumit." AQUINO, T. Suma contra os gentios. Tradução D. Odilão Moura e D. Ludgero Jaspers. Porto Alegre: Escola Superior de Teologia São Lourenço de Brindes, 1990.

${ }^{243} \mathrm{O}$ interesse de Akbar por animais já havia sido mencionado por Montserrat em sua Relação de Akbar. MONTSERRAT, A. Relação de Akbar, rei dos mogóis. Texto original em português. Versão manuscrita encontrada no livro 28 do Armário Jesuítico (fl. 84v-85) no Arquivo Nacional da Torre do Tombo, em Lisboa, Portugal. Publicação de referência Documenta Indica, v. XII (1580-1583), doc. 114, p.645-662. Porém, acreditamos que seu filho, Jahangir, será principalmente reconhecido pela sua curiosidade em relação a animais. Cf: KOCH, E. Jahangir as Francis Bacon's Ideal of the King as an Observer and Investigator of Nature. Journal of the Royal Asiatic Society, 19, p. 293-338, 2009.

${ }^{244}$ XAVIER, J. Fuente de Vida: Tratado apologético dirigido al Rey Mogol de la Índia en 1600. San Sebastián: Universidad de Deusto, 2007, p. 85.
} 
alcança, o olho com que se deixa ver; é um retrato vivo que sobretudo representa Deus, nosso Criador. ${ }^{245}$

Estamos supondo que o termo "entendimento" de Xavier pode ser por nós compreendido de duas formas complementares: como tradução para intellectus, isto é, a faculdade que permite que um ser espiritual conheça o universal, o imaterial ou a própria essência das coisas. Em outro momento, debatendo sobre o livre arbítrio, o padre afirmará que "próprio é do entendimento entender as coisas universaisles e comuns, e não estar limitado a entender somente as coisas presentes e particulares". ${ }^{246}$

Não obstante, supomos que a expressão "retrato de Deus" remeta mais à conotação de razão natural e não exatamente a essa capacidade de abstrair da matéria o que dela é inteligível. De qualquer forma, ambas as ideias de entendimento - seja sinônimo de intelectus, seja significando algo próximo à razão natural - são fundamentais. Portanto, tal momento inicial do diálogo é bastante significativo, uma vez que pontua uma premissa fundamental da atividade missionária: o universalismo decorrente da razão natural, ressaltando o importante papel que o intelectus e a razão têm especificamente neste tipo dialógico de estratégia de conversão.

Feitas estas considerações iniciais, a primeira questão da conversa entre os dois que gostaríamos de analisar diz respeito à salvação. O filósofo propõe que a salvação poderia ser alcançada por várias vias. Já o padre defende que a lei que há de salvar deve ser em tudo verdadeira. Não pode haver mais de uma lei ou mais de um caminho que leve à cidade de Deus, porque a verdade em todo gênero de negócio da salvação é uma e as mentiras são muitas. ${ }^{247}$ Leis contrárias não podem ser de Deus. ${ }^{248}$ Para seu argumento, o padre recorre à metáfora de um governante e à distinção entre costume e lei: os primeiros podem variar, mas a última é sempre a mesma:

\footnotetext{
${ }^{245}$ XAVIER, J. Fuente de Vida: Tratado apologético dirigido al Rey Mogol de la Índia en 1600. San Sebastián: Universidad de Deusto, 2007, p. 85.

${ }^{246}$ Ibidem, p. 99.

247 "E para caminhar mais confiadamente nessa fé para a verdade - a própria verdade, Deus filho de Deus, assumindo o homem sem anular a Deus, fundou e estabeleceu essa mesma fé para que o homem tivesse um caminho para o Deus do homem por intermédio do homem-Deus. Este é que é, realmente, Mediador entre Deus e os homens - o homem Jesus Cristo: é mediador por ser homem e como tal é caminho. Porque, se entre o que caminha e o lugar para onde se caminha há no meio um caminho, há esperança de lá chegar; se, porém, falta ou se desconhece por onde se deve seguir, que interessa que se saiba para onde se deve seguir? Só há, portanto, um caminho que exclui todo o erro: que o próprio Deus e o homem sejam o mesmo - Deus para onde se vai, homem por onde se vai." SANTO Agostinho. Cidade de Deus. Volume 2. Tradução J. Dias Pereira. $2^{a}$ Edição. Lisboa: Edição Calouste Gulbenkian, Livro XI, cap. II, 2000. "Ao conhecimento de Deus nenhum homem chega senão pelo Mediador entre Deus e os homens - o homem Jesus Cristo", p. 991.

${ }^{248}$ XAVIER, J., op. cit., p. 89-90.
} 
Se o Rei, ainda que tenha reinos de várias seitas e costumes, mas todos o reconhecem a ele apenas como rei e senhor que, se a outro rei seguissem e a ele desconhececem, não seria servido deles senão muito ofendido. (...) Assim também [é] na lei verdadeira de Dios sobre o verdadeiro conhecimento. Admitem-se vários costumes e ânimos, como de penitência [,] de oraçión, de abstinência. Uns são casados [,] outros continentes. Uns ricos [,] outros pobres. Mas todos connhecem ao mesmo Deus e Senhor. ${ }^{249}$

A isso, o filósofo argumenta que bastaria viver conforme a doutrina dos filósofos, tendo por guia o juízo natural e a razão que Deus dá para seguir a virtude e evitar o vício. Bastaria, portanto, que o homem se governasse pela razão para que fosse salvo. ${ }^{250} \mathrm{O}$ padre refuta-o, dizendo que para que os homens se salvem é forçosamente necessária a lei revelada.

Gostaríamos de pontuar aqui a correspondência entre esse momento do debate entre o padre e o filósofo e a Suma Teológica, em que o autor trata da natureza e extensão da sagrada doutrina. No primeiro artigo - "É necessária outra doutrina além das disciplinas filosóficas" da primeira questão do primeiro livro, podemos ler:

Era necessário existir para salvação do homem, além das disciplinas filosóficas, que são pesquisadas pela razão humana, uma doutrina fundada na revelação divina. Primeiro porque o homem está ordenado para Deus, como para um fim que ultrapassa a compreensão da razão [...]. Era, pois, necessário que estas coisas que ultrapassam sua razão lhe fossem comunicadas por revelação divina. ${ }^{251}$

O Filósofo (personagem do diálogo) retoma sua fala dizendo que trabalha para viver bem e conforme à razão, ${ }^{252}$ e não para salvar-se, pois acredita que inferno e paraíso são invenções do homem para persuadir os ignorantes de viver bem e conforme a razão. A partir disso, o padre inicia uma longa argumentação partindo da questão da existência de Deus. Semelhante ao que podemos ler no artigo 3 da questão 2 do tratado do Deus Único da Suma teológica, ${ }^{253} \mathrm{o}$ padre inicia a defesa desse ponto a partir da ideia de movimento. ${ }^{254}$ Além disso,

\footnotetext{
${ }^{249}$ XAVIER, J. Fuente de Vida: Tratado apologético dirigido al Rey Mogol de la Índia en 1600. San Sebastián: Universidad de Deusto, 2007, p. 91.

${ }^{250}$ Ibidem, loc. cit.

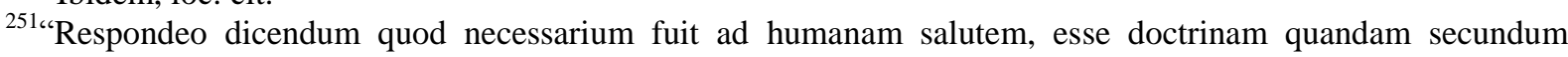
revelationem divinam, praeter philosophicas disciplinas, quae ratione humana investigantur. Primo quidem, quia homo ordinatur ad Deum sicut ad quendam finem qui comprehensionem rationis excedit, secundum illud Isaiae LXIV, oculus non vidit Deus absque te, quae praeparasti diligentibus te. Finem autem oportet esse praecognitum hominibus, qui suas intentiones et actiones debent ordinare in finem. Unde necessarium fuit homini ad salutem, quod ei nota fierent quaedam per revelationem divinam, quae rationem humanam excedunt." AQUINO, T. Suma Teológica. São Paulo: Ed. Loyola, 2001. Primeira parte, questão 1, artigo 1, vol. 1, p. 138.

252 Capítulo 2: Que aj Dios y que el hombre tiene livre alvedrio para obrar bien y mal em el sevicio de su Criador. XAVIER, J.,op. cit., p. 92.

253 Questão 2: “A existência de Deus, em três artigos" (De Deo, an Deus sit), artigo 3 "Deus existe" (Utrum Deus sit). AQUINO, T., op. cit., p. 165-6.

254 "É necessário chegar a um primeiro motor, não movido por nenhum outro, e um tal ser, todo estendem: é Deus". (Ergo necesse est devenire ad aliquod primum movens, quod ad nullo movetur: ET hoc omnes intelligunt
} 
o padre aborda a ordem de perfeição, a necessidade de existir, ${ }^{255} \mathrm{o}$ fato de todas as nações confessarem um Deus ${ }^{256}$ e a perfeição do mundo: ${ }^{257}$

Antes declara todo homem discreto de haver alma no corpo humano que Deus no mundo, que o governa com sumo saber e providência. [Assim,] nenhuma dúvida deveis ter senão que há Deus no mundo, que é primeiro e causa de todas as coisas. Criou-as todas com seu poder. Especialmente criou entre elas o homem, e deu-lhe entendimento e vontade, com o que pode conhecer e amar. ${ }^{258}$

Percebemos que, até agora, o padre expôs ao filósofo sua posição frente às seguintes questões: o entendimento é prerrogativa do ser humano e é o que permite que ele conheça as coisas materiais e a Deus, e que também permite que ele tenha governo sobre os animais e sobre os outros homens. Além disso, o padre afirma que só uma lei permite que se chegue à Cidade de Deus, e que a razão humana não é suficiente para isso se não for associada à verdade revelada. Por último, percebemos que o personagem cristão dá razões sobre a existência de Deus. Não obstante, enfatizamos a repetição do termo "discrição", realçando a importância que o discernimento tem na argumentação do padre. Ainda nesse livro, o padre e o filósofo debatem outros temas, como o livre arbítrio e a imortalidade da alma. ${ }^{259}$ Mas julgamos serem suficientes os trechos destacados acima para demonstrarmos as semelhanças entre a obra elaborada por Xavier e as partes iniciais de duas grandes obras de Tomás de Aquino: a Suma Teológica e a Summa contra gentiles. Passemos, pois, da abordagem de aspectos doutrinários aos aspectos políticos.

Deum.”) AQUINO, T. Suma Teológica. Ed. Loyola: São Paulo, 2001. Primeira razão exposta no artigo 3 da questão 2, p. 166-7.

${ }^{255}$ É a terceira razão exposta no terceiro artigo da Suma supracitado: "A terceira via é a tomada do possível e do necessário". (Tercia via est sumpta ex possibili et necessário.) Ibidem, p. 167.

${ }^{256}$ No último capítulo de nossa tese, veremos que a suposta inexistência de uma sociedade completamente ateia é questão debatida por Desideri, missionário jesuíta que atuou no Tibete no século XVIII.

${ }^{257}$ Este argumento do padre está de acordo com a "quarta via" exposta por Tomás de Aquino no artigo supracitado.

${ }^{258}$ XAVIER, J. Fuente de Vida: Tratado apologético dirigido al Rey Mogol de la Índia en 1600. San Sebastián: Universidad de Deusto, 2007, p. 99.

${ }^{259}$ Sobre o livre arbítrio, podemos ler na obra de Xavier: "Quiso Dios escoger de todas las criaturas corpóreas al hombre pera ser servido dél. Y assí le Dio entendimento para ló poder conosçer, pera conosçer el bien y el mal. Y le Dio voluntad para amarlo a él y a outra cosa buena. (...) Y teniendo el hombre livre alvidrío, razón es que sepa la voluntad de su Sennor pera servilo mejor. Y essa voluntad de Dios llamamos lej pera que obedesçiendo a sus mandamientos alcance Mercedes dél o sea castigado si desobedeçiere. (...) Avemos de confessar que que aj outra vida donde los buenos hallen premio de sus serviçios y los malos castigo de sus pecados. Ibidem, p 102. Sobre a imortalidade da alma: "El alma del hombre es substancia subsistente qye tiene ser, pues no es cuerpo. Luego no puede perder el ser. Luego no se puede corromper. Luego es imortal.” Ibidem, p. 107. 


\title{
2.4 JERÔNIMO XAVIER E FRANCISO SUÁREZ: UM POSSÍVEL DIÁLOGO ENTRE CRISTÃOS EM
}

\author{
UM CONTEXTO NÃO CRISTÃO
}

Debrucemo-nos sobre uma outra questão debatida ainda no primeiro livro de Fonte de Vida: a necessidade de haver lei dada por Deus por meio de seus profetas. Para o filósofo, se todos possuímos entendimento e razão, não é necessário que haja lei revelada de Deus aos homens. ${ }^{260}$ "Todos tem lei bastante para se governar e salvar sem mais haver revelação de Deus nem de profetas que a denunciem aos homens." ${ }^{261}$ Esse debates, como bem vemos, complementa um anterior sobre os vários cominhos que levariam à cidade de Deus.

O padre, então, responde que é necessário que haja lei dada aos homens.

A cidade sem leis e [sem] ordem não merece nome de cidade, nem a casa e a família se lhe falta guia por donde se tenha de governar. Soldados sem ordem nem lei não merecem nome de exército. Enfim, toda congregação e multidão de gente tem necessidade de ordem de vida e lei que a todos conserve em uniformidade e paz. Se os homens do mundo não tiviessem lei, que sería o mundo senão um monte de pedras ou de areias soltas, secas e desunidas. (...) E havendo de ter toda multidão ordem de vida para ser bem governada, claro está que àquella multidão devia dar essa ordem que [quem?] é cabeça dela. Às crianças da escola dá as leis seu mestre; ao exército seu capitão; à família da casa o pai e senhor dela; à cidade, seu governador; e finalmente ao reino seu rei, para que conforme sua cabeça procedam todos uniformemente. E ao mundo todo deve dar lei Deus que é Senhor dele. (...) Por donde claramente se vê que é necessário haver lei dada por Deus aos homens do mundo, para que unidos todos entre si, vão em sua odediêcia bem encaminhados." ${ }^{.262}$

Julgamos bastante interessante este trecho, pois ele transfere o eixo do debate da questão estritamente teológico-filosófica para o campo do político, remetendo a ideias como “cidade", "lei”, "governo". Tais temas são abordados por São Tomás de Aquino principalmente no "Tratado de conservação e governo das criaturas" e no "Tratado da Lei",

\footnotetext{
${ }^{260}$ XAVIER, J. Fuente de Vida: Tratado apologético dirigido al Rey Mogol de la Índia en 1600. San Sebastián: Universidad de Deusto, 2007, p. 115.

261 Ibidem, loc. cit.

${ }^{262}$ No caso específico deste trecho, acreditamos ser necessário citar tal qual aparece na versão da fonte utilizada, pois não conseguimos em nossa tradução distinguir de maneira eficaz "multitude" e "muchedumbre", cujo significado é fundamental para diferenciar uma multidão organizada politicamente de um grupo de pessoas desordenado: "Y avendo de tener toda multitud, orden de vida pera ser bien governada, claro está que a aquella muchedumbre devia dar essa orden que es cabeça della”. Ibidem, loc. cit.
} 
questões 103-119 da Primeira Parte e questões 90-108 da Primeira Seção da Segunda Parte da Suma Teológica, respectivamente. ${ }^{263}$

Das teorias políticas surgidas da "atualização" ("aggiornamento") ${ }^{264}$ do tomismo na segunda escolástica - de que foram autores muitos jesuítas - gostaríamos de destacar algumas ideias gerais. A primeira delas é a de que de todos os governos, o mais perfeito é a Igreja. A origem do seu poder não é o povo, a multidão, os homens, mas o próprio Cristo, de quem o Papa é vigário. Assim, para o caso da Igreja, o poder foi dado imediatamente por Deus. Seu fim é sobrenatural: a salvação dos homens. O Sagrado Estado da Igreja é, portanto, o modelo e o ideal de todos os governos.

A partir deste princípio, necessariamente o Estado Secular ocupa uma posição inferior ao Estado Eclesiástico. Seu fim é (apenas) a paz e o bem-estar terreno dos homens, enquanto que o governo espiritual tem como fim a vida eterna. $\mathrm{O}$ governo civil, ainda que venha de Deus, o faz apenas porque Deus é o criador dos homens, que os criou como animal político. O governo civil regula apenas os atos externos ao homem, não os internos, e baseia-se na natureza humana, com utilidade apenas terrena. Ainda que a supremacia do governo espiritual sobre o governo civil seja evidente, o Papa, em teoria, fora de seus domínios, só poderia interferir em negócios temporais caso estes estivessem relacionados ao bem estar espiritual do homem.

Além disso, o poder dos reis não é ilimitado nem foi outorgado imediatamente por Deus. Os reis não são mestres de seus súditos, mas governantes de cidadãos livres. O poder político, portanto, é derivado da natureza política do homem. Uma vez que os homens entrem em acordo e aceitem viver em comunidade, o governo surge sem significar qualquer tipo de violação. O poder político, portanto, é advindo da comunidade, a qual delega tal poder a um rei ou governante. ${ }^{265}$

É necessário, contudo, observar que o debate entre o padre e o filósofo não é sobre governo. É sobre lei. Mais especificamente, sobre a Lei Divina. Assim sendo, a teoria política por trás dessa argumentação não tem um fim político imediato, mas serve como um instrumento, uma espécie de linguagem, que auxiliará o jesuíta em seu esforço de convencer seu interlocutor.

\footnotetext{
${ }^{263}$ Cf: AQUINO, T. Suma Teológica. Ed. Loyola: São Paulo, 2001, vol. II e IV.

${ }^{264}$ Cf: EISENBERG, J. As missões jesuíticas e o pensamento político moderno. Belo Horizonte: UFMG, 2000.

${ }^{265}$ FIGGIS, N.J. On some political theories of the early jesuits. Transactions of the Royal Historical Society, New Series, vol. 11, p. 89-112, 1897.
} 
Não obstante, podemos também reparar que a ideia de cabeça surge claramente nesse extrato. Os homens devem agir segundo a cabeça da comunidade à qual pertencem. Isso significa que devem se submeter a Deus, que é senhor de tudo. Mas, para além disso, esse extrato também fala sobre a estratégia de conversão priorizada no Mogol. Não se pode esquecer que a obra é dedicada a Akbar, ele mesmo cabeça de seu Império. Pois se os membros de uma comunidade devem agir conforme a sua cabeça, quão proveitoso para o cristianismo não seria fazer cristão um poderoso imperador muçulmano no coração da Índia?

\section{Continua o filósofo:}

Porque a cada um deu conhecimento bastante do bem e do mal, e duma inclunação ao bem e uma aversão ao mal com que se pode governar. E assim como Deus deu ao homem juízo e razão, assim lhe deus dois princípios universair de bem viver em toda comunidade: o que queres que te façam a ti, tu deves fazer aos outros; e o que não queres que te façam, não faças a pessoa alguma. (...) E estas [coisas] todas as têm marcadas em sua natureza e todos as sabem. Logo, todos os homens não têm necessidade de mais engenho nem profeta enviado por Deus",266

Neste momento, a fala do filósofo resume uma consequência possível a partir da concepção de razão natural, a qual os jesuítas de fato prezam. Se Deus deu ao homem a razão natural, a inclinação para o bem obrar e a capacidade de viver em comunidade, por que dar uma lei anunciada por um profeta? A lei natural, ela mesma, seria suficiente. Ao que o padre responde: "Não bastam homens para dar lei que os leve ao paraíso, senão que é necessário que Deus ele mesmo a revele ao mundo."267

A lei natural corresponde a um fim natural. Para um fim sobrenatural - a salvação, a vida eterna - é necessária uma lei divina. Ao que o filósofo argumenta que para isso não precisa ser revelada, bastam homens sábios, discretos e experimentados. ${ }^{268} \mathrm{O}$ padre diz, ao contrário, que é necessário que o próprio Deus revele a lei aos homens, pois se a lei natural tem fim natural e deve guiar para o bem viver, a lei revelada, cujo fim é sobrenatural, deve versar sobre a salvação. A lei para salvar-se, diz o padre, há de ser conforme vontade e gosto de Deus. Para sabê-la em detalhes é necessário que Ele mesmo a revele. Assim, além da lei natural, é necessária a lei dada por Deus por meio de seus profetas. Além disso, a lei da salvação deve ser regra certíssima, sem nenhum gênero de dúvida, sem falsidade ou engano. Essa certeza só se pode ter se Deus a revelar ele mesmo, logo, é necessária a lei revelada por Deus, pois

\footnotetext{
${ }^{266}$ XAVIER, J. Fuente de Vida: Tratado apologético dirigido al Rey Mogol de la Índia en 1600. San Sebastián: Universidad de Deusto, 2007, p. 116.

${ }^{267}$ Ibidem, p. 118.

${ }^{268}$ Ibidem, p. 118.
} 
É necessário cimento mais firqme que o homano, e olhos de mais vista que os dos homens, e assim é necessária a autoridade do mesmo Deus que nos aquiete, porque ele é infinitamente sábio e sumamente bom, que nem se pode enganar nem nos há de querer enganar. ${ }^{269}$

O padre continua: a lei de salvação, pois, deve ser única para todos os homens, portanto universal. Logo, apenas Deus a pode fazer e nenhum outro homem. Para que a lei seja universal, isto é, dada a todos os homens, é necessário que quem as dê seja senhor sobre todos os homens, ou seja, tenha poder e senhorio sobre todos os homens. Não obstante, como a lei da salvação obriga o homem em seu interior e exterior - em vontade e ato - é necessário que quem a dê tenha jurisdição sobre o coração dos homens. Por fim, não há homem que possa castigar todos os homens, logo, não há homem que possa fazer lei universal para $\operatorname{todos}^{270}$

Percebemos, a essa altura, uma espécie de diálogo entre o que Xavier expõe em Fonte de Vida e a obra de Francisco Suárez. Ainda que o primeiro não tenha lido o segundo, ambos ecoam os debates jesuíticos da segunda escolástica e as teorias políticas desenvolvidas no contexto da Reforma Católica. ${ }^{271}$

Para Suárez, as propriedades da lei são: 1. mover e aplicar ao súdito a execução da ação; 2. ter força para obrigar; 3. dar lei é um ato de jurisdição e poder; e 4. a lei é um ato de justiça legal, já que o príncipe, ao dar uma lei, antes de tudo deve atender ao bem comum. “Toda comunidade perfeita é um corpo político propriamente dito, e se governa por verdadeira jurisdição dotada de força coercitiva, que é a que dá as leis.”272

Suárez afirma ainda que "a lei é um preceito imposto por quem tem poder para obrigar, e que, portanto, a lei requer que a dê quem tem autoridade pública." ${ }^{273}$ Assim, nem todo homem pode mandar em outro, "nem um igual - por assim dizer - pode obrigar a um igual, como é evidente, porque não existe nenhuma razão para que um esteja obrigando a

\footnotetext{
${ }^{269}$ XAVIER, J. Fuente de Vida: Tratado apologético dirigido al Rey Mogol de la Índia en 1600. San Sebastián: Universidad de Deusto, 2007, p. 121.

${ }^{270}$ Ibidem, p. 122-3.

${ }^{271}$ Fonte de Vida foi escrito em 1600. Francisco Suárez escreveu o Tractatus De Legibus Ac Deo Legislatore em 1582-1603.

272، Toda comunidade perfecta es um cuerpo político propriamente dicho y se gobierna por verdadeira jurisdicción dotada de fuerza coativa, que es la que da las leyes." SUÁREZ, F. Tractatus de legibus ac Deo legislatore. Madri: Consejo Superior de Investigaciones Cientificas, vol. I, livro I, 1971-81, p. 37. Esta obra foi lida apenas em sua versão em espanhol, de onde retiramos as citações aqui presentes. Infelizmente, não foi possível recuperar, para a redação desta tese, todas essas passagens no idioma original, isto é, em latim.

273 "La ley es um precepto impuesto por quien tiene poder para obligar, y que, por tanto, la ley requiere que la dé quien tiene autoridade pública." Ibidem, p. 44.
} 
obedecer a outro mais que este a ele, e a guerra que por ele se entabularia seria justa por ambas as partes. Logo, se necessita um especial poder superior para manda-la eficazmente". ${ }^{274}$

Como diz o padre do diálogo, apenas o senhor de todos os homens pode promulgar leis universais. Suárez também aborda esse problema: "Por isso, cada um pode dar leis segundo a medida do poder que lhe foi confiado e não mais, pois (...) as leis dos reis são válidas dentro de seus territórios." ${ }^{275}$

Para finalizar, destacamos uma passagem de Suárez que nos parece emblemática da raiz da argumentação do padre em seu diálogo com o filósofo:

Em toda comunidade existe um poder soberano em sua esfera: na Igreja o Pontífice, nos reinos temporais o rei, nos estados que se governam aristocraticamente - quer dizer, por si mesmos - todo o estado. Porque não pode haver um corpo sem cabeça, a não ser um corpo monstruoso e truncado. Desta cabeça disse São Tomas que ela é ou a mesma multidão quer dizer, a república - ou um representante seu. E esse representante pode ser indicado ou por ela mesma ou por Deus imediatamente, como se dirá depois. $\mathrm{E}$ - prescindindo de ambos - muito bem concluiu que a lei deve ser dada por pessoa pública que tem o cuidado de toda multidão. ${ }^{276}$

Como o fim do governo civil é (apenas) a paz terrena e a boa convivência, e a cabeça da multidão limita-se a legislar somente sobre o que possui jurisdição, deduz-se que "nada fora de Deus pode mover o homem ao fim sobrenatural."277

Porém, ainda segundo Suárez, toda lei deve ser promulgada publicamente. Fica dada a necessidade, portanto, de uma mediação entre Deus e a comunidade de homens para que a lei divina seja conhecida pela humanidade. Dessa forma, o padre da obra de Xavier afirma que:

Todavia, à verdade e à misericórida de Deus convinha que enviasse a todos os pecadores algum serviço seu que lês dicesse o que deviam, de sua parte, fazer para se salvar. A este homem, chamamos profeta, e o bom governo assim pede qiue por meio de algum escolhido seus revele Deus a todos sua vontade. ${ }^{278}$.

\footnotetext{
274 SUÁREZ, F. Tractatus de legibus ac Deo legislatore. Madri: Consejo Superior de Investigaciones Cientificas, vol. I, livro I, 1971-81, p. 44.

${ }^{275}$ Ibidem, p. 46.

${ }^{276}$ Ibidem, loc. cit.

${ }^{277}$ Ibidem, livro IV, p. 362.

${ }^{278}$ Ainda: "É necessário que haja lei de Deus, que é regra e artifício de salvação, a qual ensina, manda e obriga a todos, no interior e no exterior. E essa [lei] é comunicada por Deus. [...] É necessário [portanto] que haja pessoa que a descubra para anuncia-la aos outros. A essa [pessoa] chamamos de profeta." XAVIER, J. Fuente de Vida: Tratado apologético dirigido al Rey Mogol de la Índia en 1600. San Sebastián: Universidad de Deusto, 2007, p. $124 ; 125-6$.
} 
Dada, portanto, a necessidade de mediação para tornar pública a lei de Deus, pode ficar a dúvida quanto à veracidade das leis comunicadas por homens. Como saber qual a verdadeira lei e qual profeta a trouxe e ensinou? ?79 $^{279}$

Conforme recomendado por Tomás de Aquino, ${ }^{280}$ Xavier refuta o uso dos Evangelhos para argumentar a favor do cristianismo neste ponto:

Colocam-os sob suspeita, dizendo que esses livros que agora temos não são os verdadeiros revelados por Deus, [sendo aqueles que] nós Cristãos corrompemos, pondo e tirando [desses livros] o que queríamos. E assim antes de usarmos o Evangelho (...) contra os mouros, temos de averiguar por outra via que [esses] são os legítimos e verdadeiros [livros] de Deus, não havendo neles mudança. ${ }^{281}$

Então, o padre aponta dois caminhos para averiguar qual seria a verdadeira lei: o sobrenatural e divino, e o natural e humano. $\mathrm{O}$ primeiro relaciona-se com os milagres. $\mathrm{O}$ segundo relaciona-se com a razão. Assim, quanto mais de acordo com a razão, mais certo é ser de Deus: "se queremos dizer que esperamos por revelação de Deus" diz o padre, "também a razão há de ser o juíz de que essa é a verdadeira de Deus ou aparente do demônio.”282

Segundo o padre, a lei verdadeira deve ter três propriedades: permitir-nos conhecer a Deus; declarar o gosto e a vontade de Deus; e ajudar à fraqueza humana. Além disso, a lei de Deus há de ser mais conforme o espírito, o que significa que, quanto mais a lei for dada aos apetites do corpo, mais mostras dá de não ser de Deus. ${ }^{283}$ Percebemos aqui uma crítica direta ao islamismo, em especial à descrição do paraíso.

\footnotetext{
${ }^{279}$ XAVIER, J. Fuente de Vida: Tratado apologético dirigido al Rey Mogol de la Índia en 1600. San Sebastián: Universidad de Deusto, 2007, p. 128. Capítulo $5^{\circ}$ : De las señales por onde se conoscerá quoal de las lejs que aj em el mundo es verdadera lej de Dios.

280 "Porque entre os que erram, alguns, como os maometanos e pagãos, não aceitam, como nós, a autoridade de algum texto das Escrituras, pelo qual possam ser convencidos. Por meio delas, no entanto, podemos disputar contra os judeus, usando o Velho Testamento, e contra os heréticos, usando o Novo. Mas não o podemos contra quem não aceita nenhum dos dois. Por ese motivo, deve-se recorrer à razão natural, com a qual todos são obrigados a concordar. Além disso, ao investigarmos uma verdade, juntamente mostraremos os erros por ela excluídos e como a verdade racional concorda com a fé da religião cristã." Em latim: "Quia quidam eorum,ut Mahumetistae et Pagani, non conveniunt nobiscum in auctoritate alicuius Scripturae, per quam possint convinci, sicut contra Iudaeos disputare possumus per vetus testamentum, contra haereticos per novum. Hi vero neutrum recipiunt. Unde necesse est ad naturalem rationem recurrere, cui omnes assentire coguntur. Quae tamen in rebus divinis deficiens est. Simul autem veritatem aliquam investigantes os endemus qui errores per eam excludantur. Et quomodo demosntrativa veritas, fidei cristiana religionis concordet." AQUINO, T. Suma contra os gentios. Tradução D. Odilão Moura e D. Ludgero Jaspers. Porto Alegre: Escola Superior de Teologia São Lourenço de Brindes, 1990, p. 21.

${ }^{281}$ XAVIER, J., op. cit. 129

${ }^{282}$ Ibidem, p. 130.

${ }^{283}$ Ibidem, p. 132.
} 
Não obstante, a verdadeira lei não pode admitir em nenhum caso "coisas más", de forma que não basta que a lei tenha "coisas boas", é necessário que todas as coisas sejam boas e que não admita nenhuma coisa má, por menor que seja. ${ }^{284}$

Ainda que a verdadeira lei deva moderar o corpo, a lei de Deus não é a que mais mostra preceitos e cerimônias corporais (como lavatórios, ingestão de certas comidas) porque são questões menores em comparação à reformação da vida, às virtudes e ao pecado.

Dois outros indícios apontam para a verdadeira lei: "Da nobreza do mensageiro se conhece a nobreza do recado" 285 ; e "Para se conhecer a verdadeira lei, é necessária a ajuda de Deus." 286

Observamos nesse livro aqui analisado que a argumentação sustentada em elementos políticos e fornida por um vocabulário legal não tem como fim o debate sobre o governo em si, mas serve de instrumento para o convencimento do interlocutor - no caso, o filósofo. $\mathrm{O}$ padre recorre a essa linguagem para justificar, em última análise, porque a sua lei é superior ao islamismo. É fundamental, portanto, atentarmos para a proficuidade da produção intelectual jesuítica do período. A erudição e, neste caso, a teoria política, não tem apenas um fim em si mesmo, mas transcende a sua finalidade na medida em que se presta ao fim missionário: o convencimento e a conversão.

Pudemos perceber, dessa forma, que a teologia e a política serviram de linguagem ou instrumento retórico para a implementação da estratégia de conversão jesuíta no Mogol: as disputas. Veremos a seguir como um outro campo do conhecimento - a filosofia - terá papel semelhante.

${ }^{284}$ XAVIER, J. Fuente de Vida: Tratado apologético dirigido al Rey Mogol de la Índia en 1600. San Sebastián: Universidad de Deusto, 2007, p. 133-4.

${ }^{285}$ Ibidem, p. 135.

${ }^{286}$ Ibidem, p. 136-7. 


\subsection{A NATUREZA DE DEUS E O PROBLEMA DA UNIDADE: A QUERELA DA}

INDIVIDUALIZAÇÃO A FAVOR DA EVANGELIZAÇÃO

Quien meterá el sol em una estrela, el çielo en la palma, y a Deus infinito em razones humanas? ${ }^{287}$

A ideia geral do primeiro livro de Xavier é que Deus deu entendimento aos homens, o que lhes permite o senhorio sobre os animais e mesmo sobre outros homens de menor entendimento. Daí resulta a necessidade dos governantes de serem guiados por homens de letras. Mais que isso, o fato de Akbar estimar tais homens de letra é um indício de sua prudência e discrição. Lembrando que discrição foi o termo usado por Francisco Xavier para descrever os japoneses. Esta é a primeira abordagem política que gostaríamos de identificar.

No entanto, apenas entendimento não é suficiente para que se conheça Deus e sua verdadeira lei, ainda que seja fundamental e indispensável. É necessário que Deus revele sua lei, pois, em se tratando de coisas sobrenaturais, é necessário que o homem e seu (limitado) entendimento sejam auxiliados em matérias delicadíssimas. Neste momento, gostaríamos de identificar a segunda abordagem política de Xavier: ele parte da ideia de lei e de quem pode promulgá-la para defender a necessidade da Lei Revelada.

Ele propõe que a Lei Revelada (e, portanto, verdadeira) não deve possuir nada mal nem que vá contra a razão. Partindo dessa premissa, Xavier aponta que a lei dos mouros não pode ser revelada, porque detem-se em coisas frívolas e superficiais, e, mais que isso, vai contra a razão.

Findado o primeiro livro de Fonte de Vida, passemos ao segundo. Este parece-nos central para o desenvolvimento das hipóteses levantadas nesta tese, pois é nesta etapa que será abordado o tema da Unicidade de Deus. Nossa expectativa inicial era de encontrarmos com mais facilidade, nessa etapa, aquilo que poderíamos identificar como a voz do outro. Isto é, supúnhamos que ficaria transparente na escrita de Xavier seu antagonismo às ideias sufis sobre a unidade de Deus (wahdat al-wujud).

\footnotetext{
${ }^{287}$ XAVIER, J. Fuente de Vida: Tratado apologético dirigido al Rey Mogol de la Índia en 1600. San Sebastián: Universidad de Deusto, 2007, p. 139.
} 
Na parte inicial do segundo livro, o padre abordou os seguintes temas: Deus é único, simplíssimo, sem corpo, sem acidentes; Sua essência corresponde à Sua natureza; Deus existe; e Não pode haver mais de um Deus, pois Deus é o movedor de todas as coisas e a causa primeira de todas as coisas e o fim de todas elas. Ou seja, Deus não é apenas único: Ele também é simplíssimo e uníssimo.

Além disso, é apresentada a ideia de que se conhece Deus a partir da criação. Para tanto, estabelece-se a distinção entre as coisas naturais e sobrenaturais. As primeiras são alcançadas pela razão, as últimas não são alcançadas pela razão. As coisas que se sabe acerca de Deus são de dois tipos: naturais e sobrenaturais. As coisas sobrenaturais, isto é, aquelas que não podemos alcançar apenas pelo entendimento, devem ser reveladas por Deus. Já as coisas naturais, que são mais acomodadas ao nosso entendimento, não carecem de revelação divina.

Ao natural de Deus que reluz em suas criaturas, pudesse chegar [o homem] com a força natural do entendimento. Mas ao alto e supremo de sua essência, por nenhum caso [chegaríamos] sem grande cansaço e trabalho nosso, e ajudoa de Deus ele próprio. ${ }^{288}$

Assim sendo, o padre prossegue explicando que observar a criação permite que saibamos algumas coisas sobre o criador, mas nem tudo:

Assim, à consideração das criaturas (...) se pode adicionar que há Deus, que as fez, e que é sábio [e] poderoso, e que tem muitos outros atributos. Mas não se pode se saber por elas se Deus é trino e uno, e que modo tem de salvar os homens e outras coisas. E a essas [coisas] chamamos sobrenaturais. ${ }^{289}$

Por três razões, explica o padre, é necessário que Deus declare por meio dos profetas o verdadeiro conhecimento sobre Si. Primeiramente, porque Deus é altíssimo e suas coisas são altíssimas. Para entendê-las, é necessário delicado entendimento que poucos podem alcançar por si. Além do delicado entendimento, é necessário desocupar-se para contemplação. Não obstante, é necessário que o mesmo Deus dê de Si notícia e conhecimento para que estejam os homens seguros. ${ }^{290}$

Pois o que de Nosso Senhor Deus ensina nossa lei é que há Deus, e que é um só, puro e simplíssimo. Que atualmente tem todo gênero de perfeição infinita. [É] todopoderoso, eterno, sem princípio nem fim. Que ele sozinho

\footnotetext{
${ }^{288}$ XAVIER, J. Fuente de Vida: Tratado apologético dirigido al Rey Mogol de la Índia en 1600. San Sebastián: Universidad de Deusto, 2007, p. 138.

289 Ibidem, loc. cit.

${ }^{290}$ Ibidem, p. 138-9.
} 
criou todas as cosas visíveis e invisíveis. E que este mundo criou do nada, e como criou um mundo, pode criar quantos for servido. ${ }^{291}$

Tem início a argumentação sobre a existência de apenas um Deus: não pode haver mais que uma só divindade, pois Deus é o primeiro movedor de todas as coisas. Se houvessem dois deuses ou ambos de igual saber, bondade e iguais em tudo, não há necessidade de serem dois. ${ }^{292}$ Se um tivesse menor saber, bondade etc., não seria Deus, uma vez que há outro maior que ele. E se nenhum deles é necessário, nenhum deles é Deus, pois não há no mundo necessidade dele. ${ }^{293}$

O padre passa, em seguida, à definição de composição: algo composto possui parte das coisas das quais resulta, não sendo nenhuma delas (individualmente) senão o que resulta delas. O padre prossegue expondo que a composição matéria e forma é a menor composição que há nas coisas naturais. Mas tais coisas são compostas em comparação às substâncias separadas ou intelectuais. Elas ainda têm sua composição, que é substância e acidente. ${ }^{294}$

Assim, tais inteligências que chamamos de simplíssimas substâncias têm composição, ainda que delicada. Mas Deus não tem qualquer dessas composições. Ele é simplíssimo, sem gênero de composição. O padre apresenta cinco razões para isso. A primeira é que todo composto depende das partes que o compõe. Deus não depende de ninguém, mas é Dele que tudo depende. Logo, Deus não pode ser composto. A segunda razão é a seguinte: quando uma coisa é composta por duas, não se pode fazer algo de ambas se não houver algo que as una. Como Deus não tem causa de seu ser, não pode ser composto. Como terceira razão, o padre afirma que toda coisa composta existe de maneira que uma das partes componentes é como forma e a outra como matéria. Ambas as partes estão como em potência do todo. Deus não pode estar em potência, pois assim Ele seria imperfeito, uma vez que toda coisa que está em potência é menos perfeita do que a que está em ato. Logo, Deus, que é perfeitíssimo e primeira causa de tudo, não pode ser composto. O quarto motivo é que toda coisa composta é coisa que não encaixa em alguma de suas partes. "O sábio não é somente sabedoria, nem somente homem, senão ambas as coisas juntas." ${ }^{295}$ Assim, se Deus fosse composto, ele seria Deus, e suas partes não seriam Deus, seriam criaturas. Se primeiro entendêssemos as partes e

291 Ibidem, p. 139.

292 "To be an individual was to be one and consequently that individuality was a kind of unity." GRACIA, J. In: Suárez, F. Suárez on individuation: Metaphysical disputation V, individual unity and its principle. Milwaukee: Marquette University Press, 1982, p. 2.

${ }^{293}$ XAVIER, J. Fuente de Vida: Tratado apologético dirigido al Rey Mogol de la Índia en 1600. San Sebastián: Universidad de Deusto, 2007, p. 140.

${ }^{294}$ Ibidem, p. 142-3.

${ }^{295}$ XAVIER, J. Fuente de Vida: Tratado apologético dirigido al Rey Mogol de la Índia en 1600. San Sebastián: Universidad de Deusto, 2007, p. 142. 
não o todo, pergunta o padre, quem as teria juntado para que se fizesse Deus? ${ }^{296}$ Nem de si mesmo poderia juntar, pois nada pode fazer a si mesmo, nem se pode agir antes de existir. Logo, não pode ser Deus coisa composta. A quinta e última razão é que antes da multidão é necessário unidade, logo, antes de todas as coisas não existe composição.

Além disso, o padre sustenta ainda que toda coisa é mais perfeita quanto menos mistura tem. Logo, Deus é perfeito e não pode ter mistura. Por isso, os filósofos o chamam de Ato Puro, que carece de toda imperfeição e mistura. Também não é possível haver em Deus coisa que não seja Deus. ${ }^{297}$

Segue-se uma argumentação que Deus nem tem, nem é corpo, e que Ele também não tem nenhum acidente: nem corporal, nem espiritual. É possível concluir que Deus é sua mesma essência e que é simplíssimo. Essa propriedade não se encontra em qualquer outra criatura, porque por menor que sejam compostas, são ainda compostas de ser e essência.

Neste momento do diálogo, surge uma dificuldade do filósofo. Ele questiona que, se Deus é simplíssimo, Ele não poderia ter qualquer perfeição.

O padre responde à questão do filósofo argumentando que Deus tem todo ser e é o mesmo ser sem limite, tendo em si todo gênero de perfeição. Além disso, ninguém pode dar o que não tem. Sendo assim, como tudo depende de Deus, necessariamente há de estar Nele todo bem "com altíssimo e perfeitíssimo modo." 298

O filósofo contra-argumenta, dizendo que se Deus é simplíssimo, como pode ter tantas coisas boas, como ser imutável e ser infinito?

Tal momento do diálogo é interessante porque o padre chama à conversa o mulá, pedindo-lhe a sua opinião neste ponto. O mulá reconhece a controvérsia, que teria dado muito o que falar aos "doutores antigos e modernos". Para ele, oito são os atributos de Deus: vida, poder, saber, vontade, ouvido, olhos, falar e perpetuidade. E continua: "A estos se reduçen todos los demás que tiene. Y destos y de todos dizen que ni son el mesmo Dios, ne están fuera de serlo." 299

O padre não gostou da resposta, porque, em sua opinião, seria o mesmo que dizer que nem existe Deus, nem deixa de existir, ou seja, a resposta do mulá não diz coisa alguma. Então, ele prossegue ponderando se, caso os tais atributos enumerados pelo mulá não estão

\footnotetext{
${ }^{296}$ Ibidem, p. 143.

${ }^{297}$ XAVIER, J. Fuente de Vida: Tratado apologético dirigido al Rey Mogol de la Índia en 1600. San Sebastián: Universidad de Deusto, 2007, p. 143.

${ }^{298}$ Ibidem, p. 145.

${ }^{299}$ Ibidem, p. 146.
} 
em Deus, isso significaria que Deus é composto, o que seria o mesmo que dizer que não é Deus.

Para o padre, Deus e seus atributos são sua mesma essência, sem gênero de distinção. Mas, como o nosso entendimento não compreende tantas coisas juntas, as distinguimos e repartimos, dando a cada parte um nome diferente, não por entender que em Deus sejam diferentes, mas porque nosso entendimento é limitado e está acostumado a entender as coisas segundo o modelo das criaturas. Todas as perfeições, em Deus, estão unidíssimas, sendo todos os atributos que nomeamos de formas diferentes, em Deus, uma mesma coisa. E para finalizar a questão, o padre encerra expondo que "Deus nosso senhor de tal maneira é único e simplíssimo, é tão infinito que é três pessoas distintas, que chamamos de Pai, Filho e Espírito Santo: um só Deus verdadeiro." 300 Inicia-se, nesse momento, o debate sobre a Santíssima Trindade.

Desta enorme parte do segundo livro que julgamos pertinente mencionar aqui, podemos deduzir algumas hipóteses. Mas antes, gostaríamos de expor os limites de nossa análise. Em primeiro lugar, não pretendemos, nem seríamos capazes de debater as questões metafísicas trazidas pelo personagem do padre na obra de Xavier. Dito isso, alertamos que o nosso objetivo é questionar o porquê deste tipo de argumentação em detrimento de qualquer outro. Para essa questão, temos duas respostas possíveis. A metafísica, como a política e a teologia, serviu de instrumento retórico para que o padre se qualificasse para o debate. Além disso, a refutação dos chamados "erros" do islamismo já possuía uma espécie de protocolo desde São Tomás de Aquino. Julgamos, portanto, que Xavier achou eficaz adaptar o conteúdo da Summa Contra Gentiles e De Rationibus Fidei a um formato dialógico, mas sem que o outro ganhasse muita voz na disputa. Parece-nos que Xavier manteve-se bastante próximo destes tratados que o antecederam, usando os demais personagens (filósofo e mulá) como recursos dialéticos. Mas, ao contrário do Commentarius, o outro só tem voz na medida em que isso permite e facilita a exposição da Doutrina.

Por último, gostaríamos de acrescentar que, tais quais as teorias políticas abordadas pelo padre e expostas na sessão acima, a questão do princípio de individuação também era um tema discutido pelos contemporâneos de Xavier na Europa. Novamente, podemos citar o próprio Francisco Suárez como exemplo, que publicou em 1597 as Disputationes metaphysicae.

\footnotetext{
${ }^{300}$ XAVIER, J. Fuente de Vida: Tratado apologético dirigido al Rey Mogol de la Índia en 1600. San Sebastián: Universidad de Deusto, 2007, p. 149.
} 
Outro limite de nossa análise é, evidentemente, o desconhecimento do Kalam, isto é, da teologia islâmica especulativa. Então, o que pudemos fazer neste capítulo foi procurar identificar as questões levantadas no debate fictício entre as três personagens, além de pontuar as semelhanças entre a obra e outros tratados apologéticos cristãos.

Assim, de nossa parte, satisfaz-nos a percepção de que, na missão do Mogol, tudo aquilo que era prerrogativa da formação missionária - no sentido mais estrito de formação intelectual - serviu de instrumento (ou mesmo arma) em nome da defesa do cristianismo e de ataque ao islamismo. Como dissemos no início de nossa tese, os jesuítas foram chamados ao Mogol por um padre a quem faltava justamente aquilo que é marca da identidade jesuíta: vocação missionária, erudição, treinamento retórico. A Ordem, formada no contexto da Reforma Protestante e inserida nos principais debates filosóficos e políticos da Europa Moderna, foi eficaz em formar sujeitos capazes de se fazerem ouvir e de atuarem politicamente nos mais diversos locais do globo.

Heyberger propôs em seu artigo que os missionários franceses do século XVII:

foram convencidos de que era possível debater com mulçumanos, contanto que um tipo certo de locutor fosse encolhido entre homens respeitados e educados, com quem eles [os missionários] dividissem um código de conduta e certas preocupações religiosas e intelectuais. ${ }^{301}$

Assim sendo, na mesma medida em que Heyberger apresenta as proposições acima, nós, de nossa parte, propomos que, no caso da missão do mogol, a recíproca foi tão importante quanto a premissa dos evangelizadores acima citados. O que viabilizou a missão no norte da Índia foi a capacidade dos jesuítas de acompanhar, ainda que apenas em certa medida, o que se passava na corte mogol. Nesse sentido, Fonte de Vida pode ser considerado um refinamento do ponto de vista da estratégia de conversão dialógica adotada na corte de Akbar desde o início da primeira missão, pois a obra supõe não apenas o aprendizado da língua política - o persa - como a capacidade de identificação e posicionamento do jesuíta no que concerne às questões políticas e religiosas que marcavam o ambiente intelectual do norte da Índia no período aqui estudado.

\footnotetext{
301 “were convinced that it was possible do debate with muslims, provided that the right type of locutor was chosen from among distinguished and educated men, with whom they [the missionaries] share a code of conduct and certain religious and intellectual concerns." HEYBERGER, B. Polemic Dialogues between Christians and Muslims in the Seventeenth Century. Journal of the Economic and Social History of the Orient 55.2-3, p. 1, 2012. Tradução nossa.
} 


\section{PARTE II}

The modern perception of discrepancy and dissimulation (...) is likely an anachronism consequent on our failure to understand the Jesuist's knowledge and use of rhetoric, both to convey information and to respond to circumstances in a rapidly changing Europe.

Grant Boswell 
3. A PRIMEIRA MISSÃO DA COMPANHIA DE JESUS NO TIBETE 


\title{
3.1 Do MOGOL PARA O TIBETE: A INTERIORIZAÇÃO DA PRESENÇA DA COMPANHIA DE
}

\author{
JESUS NA ÁSIA
}

...cuidamos que os Padres de Agra teriam nos olhos e coração esta empresa, pois é filha daquela, e em grande grau de maiores esperanças que a do Mogol. ${ }^{302}$

Nesta introdução da segunda parte de nossa tese, nos dedicaremos a realizar um breve balanço da primeira parte da tese, de modo a estabelecer uma relação entre a missão mogol e a missão do Tibete, guiando o leitor pelas questões que justificariam a ida de um missionário jesuíta à região por vezes chamada de "teto do mundo". Em seguida, contextualizaremos a partida do jesuíta Antônio de Andrade da corte mogol, levantando hipóteses sobre as razões que o fizeram deixar o Indostão.

Como dito na parte anterior desta tese, ainda que a missão jesuíta estabelecida no Mogol tenha sido uma experiência riquíssima do ponto de vista do estabelecimento de diálogo entre cristãos e muçulmanos na Idade Moderna, fato é que os sacerdotes não tiveram sucesso em converter nem o imperador Akbar (1556-1605), nem seu filho Jahangir (1605-1627). O projeto de erigir uma cristandade no coração da Ásia, mediante a conversão de um soberano mogol, jamais se concretizou.

Contudo, a frustração desse plano se deu a despeito de grande investimento e insistência da Ordem. As fontes indicam que os jesuítas foram perseverantes, e, ao todo, são identificadas três missões da Companhia de Jesus no Mogol. A primeira, conforme já apresentamos nos capítulos anteriores, estabeleceu-se em 1580 e durou até 1583. A segunda tentativa iniciou-se no ano de 1591 e teve duração aproximada de três anos.

A terceira tentativa ocorreu em 1594. Mais uma vez atendendo aos pedidos de Akbar, os jesuítas Bento de Góis, Jerônimo Xavier e Manuel Pinheiro foram enviados à corte mogol. Pouco mais de 10 anos depois, morre o soberano, em outubro de $1605 .{ }^{303}$

Este último e duradouro seguimento das investidas da Companhia de Jesus entre os muçulmanos no Indostão interessa-nos aqui, principalmente, por dois motivos. Primeiro,

${ }^{302}$ CARTA de Alano dos Anjos e Antônio de Andrade, Tibete, 29 de agosto de 1627. ARSI, Goa 73, fl: 50r-50v. ${ }^{303}$ Segundo consta na carta do missionário Jerônimo Xavier, do Laore, datada de 1606. CARTA de Jerônimo Xavier, Laore, 25 de setembro de 1606. Documentação Ultramarina Portuguesa, Lisboa: Centro de estudos históricos ultramarinos, 1963. 
porque foi nesse período que o missionário Jerônimo Xavier escreveu suas obras em persa, em especial Fonte de Vida. Segundo, porque da missão saiu o fundador da primeira missão no reino de Gugê, no Tibete.

O português Antônio de Andrade nasceu em Oleiros no ano de 1580, mesmo ano de estabelecimento dos primeiros jesuítas na corte de Akbar. Entrou na Companhia de Jesus em 15 de dezembro de 1596 e, no ano seguinte, iniciou o noviciado em Lisboa. Enviado para a Índia em 1600, ele terminou seus estudos no Colégio de São Paulo, em Goa. No ano de 1612, Andrade completou seus votos. Durante a sua permanência na capital do Estado Português na Índia, ele foi reitor do Colégio de São Paulo, bem como secretário da Santa Inquisição, em Goa.

Em 1621, o missionário português torna-se superior da missão jesuíta no Mogol. ${ }^{304}$ Três anos mais tarde, Andrade resolveu certificar-se pessoalmente se eram verdadeiros os rumores sobre a existência de uma cristandade escondida ${ }^{305}$ para além do Himalaia. Lançou-se em direção à região central do continente asiático, acompanhado do irmão Manuel Marques. Os religiosos partiram seguindo peregrinos em romaria ao templo de Badrinath, no norte do atual estado de Uttarakhand, na Índia. Em agosto do mesmo ano, Andrade e Marques chegaram à Tsaparang, capital do reino tibetano de Gugê. ${ }^{306}$

Andrade foi o primeiro europeu a descrever a viagem ao Tibete pelas altas montanhas cobertas de neve, e também são suas as primeiras descrições ocidentais da religião praticada pelos tibetanos, que o jesuíta chamou de "seita dos lamas." É importante frisar que, para os europeus do inicio da Época Moderna, as nações do mundo se dividiam entre cristãos, judeus, muçulmanos e gentios. ${ }^{307}$ Para um jesuíta, no entanto, só havia uma religião verdadeira.

\footnotetext{
${ }^{304}$ Sobre a atividade de Andrade no Mogol, pelo menos um relato seu foi publicado, datado de 1623 - às vésperas, portanto, de sua jornada ao Tibete. Nesta, o jesuíta faz um apanhado geral da história recente da região, comentando guerras, disputas entre herdeiros e ressaltando a liberdade que havia para a pregação do Evangelho, ao mesmo tempo em que pondera os frutos da missão, comparando-a com as da China, Etiópia e Japão. A essa altura, Andrade parece parcialmente satisfeito com os resultados da missão e esperançoso e certo da estratégia de conversão do soberano mogol. Ao longo de nosso trabalho, desenvolveremos a hipótese de que o missionário levou a experiência no Mogol em conta quando procurou adaptar este estratagema no Tibete, sempre que possível. CARTA do Padre Antônio de Andrade para o Provincial da Companhia de Jesus na Índia (Agra, 14 de agosto de 1623) Documentação Ultramarina Portuguesa. Lisboa: Centro de estudos históricos ultramarinos, 1963.

${ }^{305}$ Quanto ao suposto passado cristão dos tibetanos, devemos entender primeiramente, conforme expõe Didier, que há dois significados complementares das expressões cristandades exteriores, antigas ou escondidas. Estas seriam: reinos cristãos análogos aos existentes na Europa; ou “virtualidades de recristianização 'do interior' de povos outrora cristãos, mas que já não o eram quando da chegada dos missionários”. DIDIER, H. Os portugueses no Tibete. Os primeiros relatos dos jesuítas (1624-1635). Lisboa: Comissão Nacional pra Comemoração dos Descobrimentos Portugueses, 2000, p. 27.

${ }^{306}$ Para trajetória de Antônio de Andrade, consultar anexo "D" ao final dessa tese.

${ }^{307}$ Cf: ZUPANOV, I. Jesuit Orientalism; Correspondence between Tomas Pereira and Fernão de Queiro. In: BARRETO, L. Tomás Pereira, S. J. (1646-1708), Life, Work and World, ed., Lisboa: Centro Cultural e
} 
Assim, ao descrever um sistema religioso de que ele ainda não havia tido notícia, o missionário poderia associar ao termo "seita" uma característica que ele julguesse sintética dessa "nova" religião, sempre em comparação - ou em gradação - à Verdade cristã. O budismo, isso é, a seita dos lamas, foi, antes de tudo, uma questão epistemológica para os primeiros missionários, frente a qual os missionários se puseram tendo sempre em vista seu objetivo proncipal: a conversão.

Ricardo Ventura, em seu artigo entitulado "O Budismo nas fontes do Padroado Português do Oriente" ${ }^{308}$ apresenta-nos uma síntese das representações do budismo em fontes portuguesas dos séculos XVI e XVII, produzidas nas áreas sob influência do Padroado onde a encontravam-se os seguidores de Buda (Ceilão, Sudeste Asiático, China, Tibete e Japão). Nesse texto, o autor sustenta que as descrições sobre o que viria a ser chamado de budismo foram esparsas e confusas até pelo menos o final do século XVI, de maneira que os religiosos não foram realmente capazes de reconhecer uma identidade essas manifestações religiosas encontradas pelo continente.

Sendo, contudo, a missão tibetana iniciada já no século XVII - portanto posterior as experiências da Ordem no Ceilão (1520), Japão (1550) e China (1550) - causa surpresa no autor supracitado que os missionários não tenham sido capazes de reconhecer as semelhanças entre a seita dos lamas e as demais seitas já descritas por Francisco Xavier, Luis Fróes, Matteo Ricci e outros companheiros. Nas palavras do autor:

De fato, tendo em conta o período em que foram redigidas as cartas e o contexto em que elas se inserem, é difícil explicar como puderam as lendas da evangelização de toda a Ásia nos primórdios do Cristianismo sobrepor-se (sic) totalmente às notícias vindas do Japão e da China. ${ }^{309}$

Percebemos, pois, que, em suas cartas de 1624, 1626 e 1627, o missionário se esforça para não apenas descrever essa nova seita, mas também se dedica a dar-lhes um lugar na história universal, segundo a tradição cristã. Suas cartas foram publicadas em português, entre 1626 e 1629, na Europa, e rapidamente traduzidas para o alemão, italiano e espanhol. ${ }^{310}$

Apesar de seus esforços para estabelecer uma missão no reino de Gugê - onde ele conseguiu construir uma igreja (Nossa Senhora da Esperança) com a ajuda do rei e lamas

Cientifico de Macau, 2010, pp. 43-74.

${ }^{308}$ VENTURA, R. O Budismo nas fontes do Padroado Português do Oriente (séculos XVI e XVII) - um roteiro documental. In: BORGES, P.; BRAGA, D. (Comp.) O Buda e o Budismo no Ocidente e na Cultura Portuguesa. Lisboa: Ésquilo Edições e Multimédia, 2007, p. 127-172.

309 Ibidem, p. 168.

310 "Porque estando o Padre Antônio de Andrade por superior da Missão do Mogor e assim pelo que cá em Goa tinha ouvido como pela notícia que ali achou mais clara com o espírito de fervor que Nosso Senhor lhe tinha comunicado e foi com tão bom sucesso como mostrou a primeira carta que dela escreveu, a qual correo toda a Índia e Europa de muita satisfação e edificação de todos”. CARTA de Antônio Mendes, ARSI, Goa 73101 r. 
(sacerdotes budistas) - a primeira missão no Tibete desapareceu sem deixar vestígios logo após a morte de seu principal incentivador. Antônio de Andrade morreu no Colégio de São Paulo, em Goa, no ano de 1634. O jesuíta foi misteriosamente envenenado enquanto preparava sua nova jornada de volta a Tsaparang. ${ }^{311}$

As hipóteses que justificariam a partida de Andrade para o Tibete são inúmeras, mas nenhuma explicação parece conclusiva. A própria partida, faz-se necessário frisar, foi uma decisão que não contou, a princípio, com consulta a seu superior. Para nós, esse tipo de atitude missionária só é possível justamente por causa do que Eisenberg chamou de noster modus procedenti, isto é, uma relação que dialética entre obediência e prudência, amparada institucionalmente pela atividade epistolar. ${ }^{312}$

A primeira hipótese retoma as questões postas por Rodolfo Acquaviva, décadas antes, e já analisadas nos capítulos anteriores: era preciso interiorizar a presença da Companhia de Jesus na Ásia a partir do Mogol, usando-o como um porto seguro ou uma espécie de escala para todo o continente. Andrade, portanto, teria levado à prática as ideias de Acquaviva. ${ }^{313}$

Segue-se a justificativa dada pelo próprio Andrade: a necessidade de se comprovar as histórias ouvidas na corte mogol de que cristãos viveriam para além dos limites do Indostão. A partir dos relatos do próprio jesuíta, sua partida é justificada pela necessidade de assegurar se haveria ou não uma "cristandade escondida" em algum lugar da Ásia Central. Além dos supostos rumores que Andrade diz ter ouvido - bem como a expectativa explicitada pelo próprio Acquaviva em uma de suas cartas - é preciso lembrar que a suspeita de existirem cristãos entre as populações asiáticas era de fato uma possibilidade, tendo em vista a propagação do nestorianismo pela região.

\footnotetext{
311 O processo de investigação decorrente do envenenamento e morte do religioso indica que, pelo menos a princípio, seu assassinato não estaria diretamente relacionado com a missão do Tibete. Intrigas dentro da própria Ordem e a atuação de Andrade no Tribunal do Santo Ofício de Goa, do qual era deputado, são hipóteses mais aceitas para explicar seu envenenamento. O "Traslado da devassa sobre a morte de Antônio de Andrade", documento que esmiúça o caso (1634-1636), está sob a guarda do Arquivo Nacional da Torre do Tombo, em Lisboa, Portugal. Essa fonte traz informações importantes sobre as tensões dentro da própria Companhia de Jesus, além de fornecer detalhes sobre o envenenamento em si. TRASLADO da devassa sobre a morte do dito [Antônio de Andrade]. Tribunal do Santo Ofício (TSO), Inquisição de Lisboa, 028 processos 1536-1820, Caixa 1581, documento 13942, Correspondência de Antônio de Andrade. Disponível em: <http://digitarq.dgarq.gov.pt/details?id=2314138>.

${ }^{312}$ EISENBERG, J. As missões jesuíticas e o pensamento político moderno. Belo Horizonte: UFMG, 2000, p. $14 ; 19-20$.

${ }^{313}$ Sobre este assunto, consultar a introdução da obra Jesuit in the roof of the world, tópico "Rumors of Cathay". Cf: POMPLUN, T. Jesuit on the Roof of the World: Ippolito Desideri's Mission to Eighteenth-Century Tibet, Nova Iorque: Oxford University Press, 2002, p. 46-55.
} 
Soma-se a isso a frustração que os missionários deviam carregar por estarem já há cerca de quarenta anos - dentre interrupções e retomadas - investindo na missão do Mogol, sem conseguirem a conversão de seus "cabeças".

São relatados, ainda, grandes conflitos entre os anos 1619 e 1622, cujas razões giravam em torno da oposição a Jahangir, sucessor de Akbar. Havia uma disputa entre ele e seu filho Khrusau pelo trono.

Não obstante, uma última hipótese, ainda mais frágil e, por hora, carente da devida comprovação documental, diz respeito à chegada de franciscanos à corte de Jahangir, na década de 1620. É possível que os jesuítas já pensassem em alternativas para a missão do Indostão, em especial se estivessem considerando um conflito entre ordens pelo espaço missionário no norte da Índia. ${ }^{314}$

Qualquer que tenha sido a principal razão que motivou Andrade a deixar a corte mogol, nosso objetivo aqui não é apontá-la de forma definitiva, mas apenas deixar devidamente explicitado o contexto no qual a decisão foi tomada. Além disso, gostaríamos de enfatizar as relações entre a primeira missão tibetana e a missão mogol. A historiadora Ines Zupanov, por exemplo, defende uma estreita relação entre ambas. Para ela,

As fracas perspectivas da conversão do império Mogol, apesar da importante, variada, e demorada campanha de evangelização, foram temporariamente compensadas pela esperança numa nova região para lá das montanhas do Himalaia, ao norte do país. Assim se fundou uma Missão Tibetana a partir da missão 'Mogor'. ${ }^{315}$

Essa relação de "filiação" entre as duas missões também foi traçada por Hugues Didier e Sir Edward MacLagan. Este último, em sua obra intitulada Os Jesuítas e o Grão Mogol, abre um capítulo exclusivamente para tratar da missão tibetana. Já Hugues Didier defende que:

Deve considerar-se a empresa do Tibete como simples anexo da missionação começada em 1579, quando o rei Akbar permitiria a vinda de Padres jesuítas à corte do Mogol. Uma futura 'História' da missão portuguesa nos reinos de Guguê (sic) e Uçangue pressupõe ou requer uma completa exploração da missão jesuítica no norte da Índia, ainda inacabada. ${ }^{316}$

\footnotetext{
${ }^{314}$ No caso da missão seguinte, conduzida por Ippolito Desideri no século XVIII, haverá de fato um conflito entre Jesuítas e Capuchinhos sobre o direito de atuação no Tibete.

315 ZUPANOV, I. O Império Oriental, 1458-1665, p. 48. Disponível em: <http://www.ineszupanov.com/publications/HIST\%D3RIA\%20DA\%20EXPANS\%C3O\%20PORTUGUESA\%2 02001.pdf >. Acesso em: 21 de janeiro de 2008.

${ }^{316}$ Cf: MACLAGAN, S.E. Os Jesuítas e o Grão Mogol. Porto: Editora Livraria Civilização, 1946; e DIDIER, H. As fontes e o Tibete. In: A Companhia de Jesus e a missionação no Oriente: actas do colóquio internacional. Lisboa: 2000, p. 458.
} 
Posto que seja amplamente aceita a ideia de que a missão tibetana é originária da missão mogol, a afirmação de que a missão tibetana deve ser entendida como um "simples anexo" não nos parece completamente adequada. Uma análise um pouco mais cuidadosa indicará que suas especificidades a distinguem da experiência jesuíta no norte da Índia. Estas distinções mais óbvias e imediatamente reconhecíveis são, por exemplo, a inexistência de muçulmanos no reino de Gugê,; ${ }^{317}$ o diálogo estabelecido, pela primeira vez, com o budismo; e a organização econômica e social tibetana, que estava muito mais próxima de um feudalismo com unidades político-econômicas relativamente autônomas do que da estrutura de centralização política e o caráter imperial do Mogol.

De qualquer modo, fica evidente que os principais incentivadores da missão tibetana e organizadores das informações que viabilizariam a viagem ao Tibete são os próprios missionários no Mogol, em especial Rodolfo Acquaviva e Antônio de Andrade. Em função do franco espaço para o debate religioso na corte de Jahangir - herança de seu pai, Akbar - os jesuítas ganham segurança para se estabelecerem na Ásia a partir do Indostão. Dessa forma, resolvem investigar rumores sobre possíveis cristandades ao norte, seguindo as rotas de mercadores e peregrinos.

Tudo indica, portanto, que a missão mogol, para além de seus próprios objetivos catequéticos, serviu como uma espécie de "centro de pesquisas" ou ainda como um "quartel general" voltado para as regiões vizinhas. Acreditamos que essas "pesquisas" eram organizadas a partir, basicamente, de duas fontes. O primeiro tipo seria as próprias cartas jesuítas, trocadas entre os membros da Ordem, que traziam novas de viagens e de missões pela região. O segundo tipo, talvez primordial, seria as notícias ouvidas pelos padres da parte de viajantes - comerciantes ou peregrinos - mediante inquirição ou conversa. ${ }^{318}$ Poderiam ser rumores ou até certa apropriação do conhecimento geográfico local, uma leitura já influenciada pelas próprias expectativas da Companhia de Jesus. Esses comerciantes ou peregrinos poderiam ser hindus, muçulmanos ou cristãos armênios, o que poderia influenciar tanto no relato quanto na disposição do ouvinte jesuíta, mais ou menos suscetível a notícias de cristãos pela Ásia. A própria natureza religiosa do indivíduo poderia determinar a sua visão sobre o cristianismo e o budismo, favorecendo a confusão dos jesuítas. Seja qual for o caso, é

\footnotetext{
317 A divergência entre tibetanos do Tibete Ocidental e muçulmanos é tão radical que Gugê sofrerá com a invasão do Ladakh, reino muçulmano, na década de 1630.

318 Sobre este tema, sugerimos a leitura de RICHARDSON, H. Armenians in India and Tibet. Journal of the Tibet Society, vol. I, p. 63-67, 1981; Desideri, cuja obra analisaremos no último capítulo desta tese, também menciona o fluxo de mercadores armênios, hindus, caxemires e nepaleses nas rotas que envolviam o Tibete. DESIDERI, I. Mission to Tibet: the extraordinary eighteenth-century account of father Ippolito Desideri, S.J. Tradução Michael J. Sweet. Edição Leonard Zwilling. Boston: Wisdom Publications, 2010, p, 226.
} 
necessário levar em consideração em nossa análise a influência de certo "olhar local” sobre a "geografia" a qual os religiosos tiveram acesso em Agra, significando também reconhecer uma essência indostana desse conhecimento jesuíta em formação, ao lado da tradição europeia. Infelizmente, não poderemos nos aprofundar acerca das relações - comerciais e culturais - estabelecidas entre o Tibete e a Índia. Mas cabe a observação de que as duas regiões estavam em contato, seja do ponto de vista da difusão do budismo, seja do ponto de vista das rotas comerciais que atravessavam a Ásia desde a península arábica até a China.

Feita essa espécie de investigação conduzida pelos missionários desde os tempos de Acquaviva e Montserrat, Andrade parte para a ação. Disfarçado de muçulmano e sem aviso, “com todo segredo possível [...] sem disso terem notícia os próprios cristãos e moços nossos, que até ali nos tinham acompanhado a caminho do Laore"319, o jesuíta português deixa a corte mogol em 1624. A seguir, nos deteremos em algumas considerações preliminares sobre o Tibete encontrado pelos religiosos.

${ }^{319}$ CARTA de Antônio de Andrade, Agra, 8 de novembro de 1624. In: DIDIER, H. Os portugueses no Tibete. Os primeiros relatos dos jesuítas (1624-1635). Lisboa: Comissão Nacional pra Comemoração dos Descobrimentos Portugueses, 2000, p. 76. 
3.2 A FORMAÇÃO DO TIBETE DOS LAMAS: CONTEXTUALIZAÇÃO POLÍTICA, ECONÔMICA E RELIGIOSA (SÉCULOS XIII - XVII)

Antes de iniciarmos nossas análises das fontes deixadas pelos jesuítas que atuaram no Tibete nos séculos XVII e XVIII, julgamos ser necessário apresentar ao leitor algumas características gerais do contexto histórico do Tibete no período em questão. A seguir, procuraremos expor, de forma sucinta, como as escolas budistas e seus mosteiros passaram a ter um papel político acentuado na História do Tibete. Por último, trataremos do surgimento da Escola Gelupa, a escola reformada dos lamas "amarelos", cujo líder, o Dalai Lama, seria investido de poderes temporais e espirituais em 1642, passando a reinar sobre um Tibete supostamente unificado. ${ }^{320}$

No período em que os primeiros jesuítas chegaram ao reino de Gugê, no Tibete Ocidental, a sociedade era dividida basicamente entre senhores e camponeses. A historiografia procura aproximar esse período da história do Tibete com o passado feudal europeu. A organização político-social dava-se a partir de propriedades rurais com grande autonomia, tais como os senhorios medievais do Ocidente. Estes senhorios, tal como na Europa, poderiam ser laicos - pertencentes a famílias nobres - ou religiosos, isto é, monastérios.

Com a difusão do budismo na região de cultura tibetana, tiveram origem, ao longo do tempo, as escolas ou linhagens budistas. Distintas entre si - do ponto de vista de doutrina, prática e organização da vida comunitária - essas escolas expandiram-se numa espécie de sistema de teia ou rede de monastérios.

Os senhorios leigos, por sua vez, pertenciam a famílias nobres de grande influência política, e, como os monastérios, também eram unidades político-econômicas autônomas.

\footnotetext{
320 "The picture that I am trying to draw is of a constant process of negotiation between local authorities, none of whom were in a position to dominate Tibetan politics or to create and maintain a state apparatus in their own right. Increasingly, as time went on, the Mongolian tribes in North-East Tibet and the Chinese emperors were drawn into the process, usually when one side or another within Tibet appealed for their assistance. However, the Mongol tribes were unstable, and it was only at times of unusual strength that the Chinese empire could send an effective military force to Tibet, so neither of these additional elements changed the pattern decisively until the Chinese takeover in 1951." Sobre as dificuldades de se considerar que, de fato, a figura do Dalai Lama era soberana em toda a região do Tibete, recomendamos a leitura de SAMUEL, G. Tibet as a Stateless Society and Some Islamic Parallels. The Journal of Asian Studies, 41, n. 2, p. 215-229, 1 fev. 1982.
} 
Evidentemente que esta é uma descrição deveras simplificada, mas que, por hora, satisfaz as demandas de nossa investigação, uma vez que não nos propomos a escrever uma História do Tibete.

Os monastérios budistas da região cultural do Tibete, portanto, foram configurando, desde os seus primeiros estabelecimentos junto ao "mosaico de principados"321 no século X, como elos na malha "feudal" tibetana. Pouco a pouco, eles deixaram de ser exclusivamente um lugar de oração e vida contemplativa e passaram a ser uma unidade político-econômica análoga aos senhorios leigos, isto é, os monastérios passaram a possuir direitos senhoriais sobre homens (servos) e bens (fiscalidade). Finalmente, os monastérios transformaram-se em centros de poder temporal, na medida em que seus líderes religiosos passaram a aconselhar e dar assistência espiritual a famílias nobres politicamente influentes e poderosas.

A relação entre as linhagens leigas (famílias nobres) e as linhagens budistas (monastérios de escolas específicas) seguia uma lógica que chamaremos aqui de relação de patronagem, a qual, além de ser fundamental para o entendimento do Tibete neste período, é elementar para a nossa análise futura. O termo tibetano para essa relação é yon-mchod e pode ser assim definido:

A definição comum do termo é "dono de casa que emprega sacerdotes para executar sacrifícios" ou um "distribuidor de presentes". Em descrições posteriores surge o significado de patrono leigo que dá apoio a um lama em alguma atividade, sendo o lama conhecido como mchod-gnas e o patrono como yon-bdag. ${ }^{322}$

Especificamente, esse conceito é aplicado em relações estabelecidas entre um príncipe ou imperador e seu lama. Porém, para o caso da pesquisa aqui desenvolvida, também entendemos o sistema da seguinte forma: um determinado nobre passava ser a "protetor" de uma escola, ou monge individual e, dependendo do caso, um membro desta família passava a ser o líder de um mosteiro da escola determinada. Em geral, esse processo sucessório dentro dos mosteiros seguia a linhagem da família leiga que o "protegia", com o sobrinho sucedendo o tio à frente do mosteiro. É preciso indicar, portanto, que o segundo filho dessas famílias

\footnotetext{
${ }^{321}$ DESHAYES, L. Histoire du Tibet. Paris: Fayard, 1997, p. 97.

322 "The usual definition of this term is 'a householder who employs priests to perform sacrifices' or a 'disppenser of gifts'. It occurs in later accounts meaning a lay patron who supports a lama in some undertaking, the lama being known as a mchod-gnas and the patron as yon-bdag." WYLIE, T. Mar-Pā's Tower: Notes on Local Hegemons in Tibet. History of Religions, vol. 3, n. 2, p. 278-291, inverno 1964. Tradução nossa. As citações indicadas dentro do trecho acima são, respectivamente: DAS, S.C. Tibetan-english dictionary. Calcutá, 1902; JASCHKE, H.A. Tibetan-english dictionary. Londres, 1949. Para uma compreensão mais aprofundada do conceito e de sua relação com a ideia de chos rgyal (dharmaraja), sugerimos a leitura de RUEGG, S. Mchod yon, yon mchod and mchod gnas/yon gnas: on the historiography and semantics of a tibetan religio-social and religiopolitical concept". In: Tibetan history and language: studies dedicated to Uray Géza on his seventieth birthday, n. 26,1991 , p. 441-453.
} 
normalmente ingressava na vida religiosa. Além disso, para o caso de ordens que observavam o celibato, o vácuo de poder quando da morte do lama superior tornou-se um problema de difícil solução para as linhagens. No momento oportuno, aprofundaremos essa questão, relacionando-a com o aparecimento da regra da reencarnação. ${ }^{323}$

Em determinados contextos históricos em que o Tibete estava, por algum motivo, mais suscetível à influência estrangeira, ou mesmo a invasões, a lógica da "patronagem" pode ser claramente observada. Assim, quando, no século XIII, Kublai Khan invadiu o Tibete e a dinastia Yuan estabeleceu-se na Ásia Central, a Escola Budista Sakyapa ${ }^{324}$ reconheceu o líder mongol como seu protetor. ${ }^{325}$ A Escola Sa-skya-pa foi a primeira grande escola ou "ordem" budista do Tibete. Seu nome deriva do monastério Sa-skya fundado em 1073. A família Khon garantiu os primeiros anos de patronagem da nova escola. Com o apoio temporal de Kublai Khan, a Escola se estabeleceu hegemonicamente no Tibete. Séculos mais tarde, observaremos um processo parecido com outro líder mongol e a Escola Gelupa. ${ }^{326} \mathrm{O}$ líder do mosteiro de Sakyapa garantiu a Kublai Khan a iniciação religiosa e, em troca, o líder mongol lhe garantiu a soberania sobre o Tibete. ${ }^{327}$

A aliança estabelecida entre Kublai Khan e a Escola Sakyapa foi seguida, de forma análoga, por outras Escolas e linhagens budistas, as quais buscaram estabelecer alianças semelhantes com outros lideres mongóis, irmãos de Kublai Khan. ${ }^{328}$

Os Sakyapa, então, obtiveram o poder de regência sobre todo o Tibete das mãos de Kublai Khan, através do surgimento da figura administrativa e militar do Panchen, com assento em mosteiro da escola Sakyapa. O Panchen estava sob a autoridade do tutor imperial com assento em Pequim. Em 1288, formou-se um conselho político para administrar os

\footnotetext{
${ }^{323}$ A expressão "regra da reencarnação" é uma tentativa de tradução da expressão em inglês "rule of reincarnation". No entanto, a tradução encontra alguma dificuldade em virtude da utilização da palavra 'rule' tanto para regra quanto para autoridade, soberania ou dominium.

${ }^{324}$ SNELLGROVE, D.; RICHARDSON, H. A Cultural History of Tibet. Bangkok: Orchid Press, 2003, p. 132.

${ }^{325}$ Sobre as relações estabelecidas entre Kublai Khan e os líderes da Escola Sakya, Snellgrove afirma que: "From this time dates that particularly relationship between Tibet and China, known as Yon-m Chod, or 'Patron and Priest', by which the ruler of Tibet in the person of the predominant grand lama was regarded as the religious adviser and priest of the Emperor, who in return acted as patron and protector." Ibidem, p. 148.

${ }^{326}$ Este processo, no século XVII, culminou no investimento do líder da Escola Gelupa (Dalai Lama) dos poderes temporais e seculares sobre um Tibete politicamente unificado.

${ }^{327}$ TUCCI, G. The religions of Tibet. Berkley: University of California, 1988, p. 27.

328 "The Karma-pa, the mTshal-pa and the 'Bri-khung-pa all found patrons among the great Mongol chiefs, and the support of monasteries by different members of Genghiz' relatives and descendents infected Tibetan affairs with a new bitterness derived from involvement in the endless and internecine factions of the Mongols." SNELLGROVE, D.; RICHARDSON, H, op.cit., p. 149.
} 
assuntos religiosos e seculares do Tibete, que contava com um membro do clã tibetano Kuen, o qual dirigia a Escola budista Sakyapa. ${ }^{329}$

Nosso interesse em retomarmos esse momento anterior ao nosso recorte principal não é nem aprofundarmos o estudo de uma História do Tibete, nem problematizarmos a questão política acerca do pertencimento do Tibete à China contemporânea. Nosso principal objetivo com a exposição desse contexto é indicar como se deram as relações entre escolas religiosas e famílias nobres, inclusive para o caso de invasores estrangeiros. Outro ponto importante é encaminharmos o debate para a caracterização desses senhorios religiosos e suas respectivas escolas budistas enquanto centros de poder -temporal e espiritual -que permaneceram em disputa pelo menos até o século XVII. Nas palavras do tibetólogo Giuseppe Tucci:

O poder das abadias veio, perceptivelmente, para substituir aquele que foi perdido pela nobreza feudal como um fator orientador na História do Tibete. Os monastérios de várias seitas tornaram-se organizações com natureza tanto econômica quanto política, algumas vezes entrando em oposição entre si, algumas vezes unidas temporariamente para motivos específicos, mas sempre guardando a sua independência. Esse desenvolvimento necessariamente fez com que a aristocracia se tornasse (...) o braço secular desses poderes, a quem era ligada por interesses comuns. ${ }^{330}$

Dito isso, é preciso acrescentar também que, ao longo da história do Tibete, ou, ainda, ao longo da história da disseminação e estabelecimento do lamaísmo ${ }^{331}$ na região de cultura tibetana, a existência de várias escolas não deve ser entendida como uma ruptura radical em sua unidade. Mais uma vez, segundo Tucci:

A multiplicidade de opiniões deve ser entendida como a coexistência de caminhos igualmente válidos, um mais fácil de negociar e o outro mais difícil; um direto e o outro indireto. Todos, no entanto, levam a um objetivo digno de alcançar: a 'liberação do sofrimento'. ${ }^{332}$

\footnotetext{
${ }^{329}$ DESHAYES, L. Histoire du Tibet. Paris: Fayard, 1997, p. 107.

330 "The power of the abbots perceptibly came to replace that of the hereditary feudal nobility as driving factor in the history of Tibet. The monasteries of the various sects became organizations both economics and political in nature, sometimes opposed to each other, sometimes united in temporary unions for specific ends, although always in reality guarding their independence. This development led necessarily to the aristocracy becoming (...) the secular arm of these powers, to whom they were bound by common interests." TUCCI, G. The religions of Tibet. Berkley: University of California, 1988, p. 40. Tradução nossa.

${ }^{331}$ Nome por vezes dado a vertente do budismo desenvolvido no Tibete.

332 "The multiplicity of opinions was to be understood as the co-existence of equally valid paths, one easier to negotiate while another is harder, one straight while another is indirect. All, however, lead to the one goal worthy of pursuing: 'liberation from suffering.'” TUCCI, G. op. cit., p. 43. Tradução nossa. Snellgrove também afirma que "There were no essential differences in doctrine between all these various orders. Their main differences consisted in their traditional attachments to different lines of teachers and particular tutelary divinities." SNELlGrove, D.; RICHARDSON, H. A Cultural History of Tibet. Bangkok: Orchid Press, 2003, p. 139. Sobre a importância da multiplicidade de escolas budistas para a disseminação do Budismo na China, recomendamos ainda: ZÜRCHER, Erik. Bouddhisme, Christianisme et société chinoise. Paris: Julliard, 1990 .
} 
Assim, o aparecimento de "novas" escolas ou de interpretações distintas sobre a maneira de "se livrar do sofrimento" não são, a princípio, um problema. Essa ideia, proposta pelo autor, nos é válida uma vez que corrobora com a leitura política dos conflitos entre as escolas, mais propriamente do que uma interpretação doutrinária dessas desavenças. Além disso, a relativa "flexibilidade" em relação à "ortodoxia" budista possivelmente facilitou o estabelecimento das missões jesuítas na região. Isso pode significar que tanto Antônio de Andrade quanto Ippolito Desideri se utilizaram dessa característica mais "liberal" do budismo tibetano de poder se filiar a um mestre ou a uma linhagem de mestres específica, que não necessariamente é uma unanimidade para as demais escolas. Nossa hipótese é que os jesuítas se utilizaram dessa ênfase do budismo tibetano na relação lama-discípulo em oposição ao zelo por uma ortodoxia rígida.

Existiam, portanto, diversos monastérios budistas no Tibete que estavam ligados a uma determinada linhagem ou escola. Tais escolas buscavam, ao mesmo tempo, mais adeptos e mais "protetores" entre as famílias abastadas e politicamente influentes.

Na segunda metade do século XIV, um lama chamado Tson Kha Pa (1357-1419) escreveu o Lam rim Chen mo, uma espécie de síntese do lamaísmo, segundo a visão do próprio lama. Esse trabalho marca sua cisão com a Escola Sakyapa e o aparecimento da linhagem reformada ou "seita amarela", ${ }^{333}$ chamada de Escola Gelupa. ${ }^{334}$ Tson Kha Pa conseguiu estabelecer-se como um mestre carismático, atraindo novos discípulos, bem como o apoio de famílias importantes. A Escola Gelupa construiu seus monastérios na região central do Tibete, nos arredores de Lhasa, estabelecendo-se assim estrategicamente, com o objetivo de atrair mais aderentes e mais protetores dentre as famílias aristocráticas. ${ }^{335} \mathrm{Na}$ mesma medida em que as novas ideias de Tson Kha $\mathrm{Pa}$ avançavam pelo Tibete Central, o apoio mongol à Escola "rival" Sakyapa ia à ruína: com o surgimento da dinastia Ming (13681424), os sakyapa perderam seu principal aliado temporal.

Neste contexto, identificamos, portanto dois fatores (um externo e outro interno) que possibilitaram o surgimento de uma nova escola budista no Tibete: o enfraquecimento do apoio Yuan à Escola Sakyapa e o aparecimento da Escola reformada Gelupa, cujo líder revelava-se um mestre espiritual carismático.

\footnotetext{
${ }^{333}$ Os lamas da Escola Gelupa eram geralmente identificados como "mitras amarelas" em oposição aos mitras vermelhas e pretas (Karmapa ou Sakyapa).

${ }^{334}$ TUCCI, G. The religions of Tibet. Berkley: University of California, 1988, p. 39.

${ }^{335}$ McCLEARY, R.; KUJIP, L.W.J.V.D. The formation of the Tibetan state religion the geluk school 14191642. 
Porém, segundo McCleary e van der Kujip, não foram apenas estes fatores que garantiram a hegemonia Gelupa no centro do Tibete. Para os autores, algumas características da "reforma" gelupa também contribuíram para o seu sucesso. A escola reformada passou a dar uma maior ênfase ao aspecto doutrinário e à disciplina monástica. A influência de questões seculares na gestão de seus monastérios foi diminuída. ${ }^{336}$

Contudo, mais uma vez o fator estrangeiro pesa no equilíbrio de forças entre as escolas budistas tibetanas e, apesar dos primeiros anos de alienação a questões "mundanas", os Gelupas dão um passo semelhante àquele dado pelos Sakyapa séculos antes. Sonan Gyatso, lama da escola reformada, aceitou um convite para visitar Altan Khan, líder do ramo Tumed dos mongóis. Os dois se encontraram em 1578. No século XVI, Altan Khan e seus seguidores mongóis já haviam se convertido ao budismo. A expressão de "conversão ao budismo" não nos parece muito precisa, mas indica que os mongóis passaram a reconhecer o lama da Escola Gelupa como seu mestre espiritual.

À semelhança do que já acontecera com a linhagem Sakyapa, isso auxiliaria a Escola Gelupa em sua busca por hegemonia temporal e espiritual no Tibete Central. Deste encontro, o lama gelupa sairia com o título de Ta-le (Dalai) ou "Oceano [de sabedoria]". ${ }^{337}$ O título foi transmitido retrospectivamente aos grandes lamas anteriores a ele, fazendo de Sonan Gyatso o terceiro Dalai Lama. ${ }^{338}$ Althan Khan tornava-se, assim, o protetor mongol da Escola Gelupa, apoiando os monastérios da linhagem, bem como os nobres leigos que também garantiam suporte temporal aos mosteiros dos "lamas de chapéu amarelo".

O terceiro Dalai Lama morreu em 1588 e sua reencarnação foi descoberta no bisneto de Atan Khan. Assim, "através desse ato de diplomacia, a Ordem dGe-lugs-pa ganhou de forma conclusiva o apoio interessado da família regente mongol.". ${ }^{339}$

$\mathrm{O}$ retorno da influência estrangeira ${ }^{340}$ nos assuntos tibetanos e o surgimento de um protetor dessa magnitude não foram recebidos com bons olhos pelas demais escolas. A

\footnotetext{
336 "The example of a religious school which was as yet taking no part in the political rivalries of the day and insisted on the observance of strict monastic discipline, may well have appealed to many who were critical of the apparent worldliness of the older established orders". SNELLGROVE, D.; RICHARDSON, H. A Cultural History of Tibet. Bangkok: Orchid Press, 2003, p. 181.

337 Ibidem, p. 184.

${ }^{338}$ Esse processo só foi possível graças a regra da reencarnação, a ser explicada mais adiante

339 "By this piece of diplomacy the dGe-lugs-pa Order gained conclusively the interested support of the Mongol ruling family." SNELLGROVE, D.; RICHARDSON, H., op. cit., p. 193. Tradução nossa. O IV Dalai Lama, porém, apenas foi trazido à Lhasa aos 12 anos, isto é, em 1601.

${ }^{340}$ Uma vez que não existe reino tibetano unificado até o investimento do V Dalai Lama, a utilização do termo "estrangeiro" nos causa complicações. O próprio XIV Dalai Lama (atual) não diz que os mongóis eram estrangeiros quando comenta esta parte da História do Tibete: "[Gushri Khan] se considérait comme um Tibétain, pas comme un étranger. Il était devenu citoyen du Tibet. (...) Le roi du Tsang et le Kagyupa menaçaient constamment le Cinquième Dalai Lama. Le but de Gushri Khan, très simple, consistait à détruire l'opposition au
} 
linhagem dos Dalai Lamas, apesar de um início avesso às disputas mundanas, embrenhava-se cada vez mais nas teias de disputas políticas entre escolas que por tantos séculos definiram os caminhos da História do Tibete. Os conflitos entre a escola reformada e os reis de Tsang (apoiados por outras escolas mais antigas, como a Karmapa) começaram em 1610, na região de Tsang. Tendo seus monastérios invadidos, os monges "amarelos" decidiram pedir ajuda ao seu protetor mongol. Em 1621, um grande exército mongol invadiu o Tibete em defesa dos Gelupas. Porém, em função da mediação feita por diversos lamas, chegou-se a uma trégua entre o rei do Tsang e a Escola dos Dalai Lamas.

Não havia passado muito tempo desde o incidente - o Tibete ainda vivia sob o fantasma da influência estrangeira sobre seus assuntos temporais - quando outro líder mongol, Gushri Khan, resolveu visitar o Tibete em peregrinação. Era o ano de 1638, e, mais uma vez, um ramo mongol pôs seus exércitos à disposição da Escola Gelupa. Dois anos mais tarde, essa aliança derrotou o rei do Tsang e as demais escolas a ele aliadas. ${ }^{341}$

É preciso lembrar ainda que, nesse mesmo período, o rei do Ladakh também invadiu o Tibete, mais especificamente o reino de Gugê, enquanto outro vizinho, a China, pouco interesse demonstrava pela terra dos lamas. No Império do meio, a essa altura, os Manchus eram preocupação suficiente.

Dessa forma, podemos dizer que a primeira metade do século XVII foi marcada pela ascensão política dos Gelupa em ambas as regiões ocidentais e centrais do Tibete, e que esse processo culminou em 1642, no investimento do V Dalai Lama como líder espiritual e político, realizado com o apoio do rei mongol.

Assim, o então Grande Lama da Escola Gelupa, o V Dalai Lama, tornou-se o primeiro soberano que efetivamente uniu em uma única pessoa ambos os poderes espirituais e temporais.

Após sair vitorioso contra seus rivais em 1642 , o Dalai Lama uniu o Tibete
Central e iniciou reformas históricas na literatura, medicina, governo e
política agrária tibetana. Ele também reescreveu a história tibetana com ele
próprio, enquanto reencarnação de Avalokitesvara, em seu centro. (...) O
Dalai Lama coroou sua própria apoteose ao construir o palácio Polata. ${ }^{342}$

Cinquième Dalai Lama, ou l'instituition du Dalai Lama" LAIRD, T. Une Histoire du Tibet. Conversations avec le Dalai Lama. Tradução do inglês Christophe Mercier. Paris: Plon, 2007, p. 169. Para deixar o contexto ainda mais complexo, ao lado do rei de Tsang e da Escola Karmapa, mongóis do leste lutaram contra os exércitos de Gushri Khan.

${ }^{341}$ Para informações mais detalhadas sobre este episódio, Cf: SNELLGROVE, D.; RICHARDSON, H. A Cultural History of Tibet. Bangkok: Orchid Press, 2003, p. 194-9.

342 "After emerging victorious over his rivals in 1642, the Dalai Lama united central Tibet and initiated epochal reforms in Tibetan literature, medicine, government, and land polity. He also rewrote Tibetan history with himself, as reincarnation of Avalokitesvara, at its centre. (...) The Dalai Lama crowned his own apotheosis by 
A partir deste parágrafo escrito por Trent Pumplun, podemos perceber de forma sintética a importância que o V Dalai Lama teve na histórica política tibetana. O grande líder político-espiritual tibetano morreu aos 68 anos, em Potala, no ano de $1682 .{ }^{343} \mathrm{O}$ seu sucessor o VI Dalai Lama - não conseguiria figurar na memória e na História do Tibete de forma semelhante. Ao contrário, descrito como boêmio e de vida incompatível com a função de Dalai Lama, sua recusa em fazer seus votos como Gelong contribuiu para mais uma nova crise política no Tibete Central. Aos vinte anos, ele deveria tornar-se um monge totalmente ordenado, mas a poesia e a vida "mundana" lhe pareciam mais atraentes.

Nas próximas páginas, trataremos das missões jesuítas estabelecidas na terra dos lamas. No entanto, nenhum dos padres europeus aqui estudados chegou a presenciar o apogeu da época do V Dalai Lama. Os primeiros religiosos chegaram antes de sua ascensão ao primeiro plano do Estado Tibetano. Quando Ippolito Desideri chegou ao Tibete em 1716, à época portanto do VI Dalai Lama, o Tibete era governado, de fato, por Lhazang Khan. O líder de origem mongol Qosod, neto de Gushri Khan, governou entre 1705 e 1717. Foi deposto e morto enquanto o missionário italiano ainda estava em terras tibetanas. Trataremos, em seguida, desses contextos de forma mais aprofundada, na medida em que abordamos as missões jesuítas no Tibete nos séculos XVII e XVIII.

building the Potala palace." POMPLUN, T. Jesuit on the Roof of the World: Ippolito Desideri's Mission to Eighteenth-Century Tibete. Nova Iorque: Oxford University Press, 2002, p. 106. Tradução nossa.

${ }^{343}$ SHAKABPA, W. D. Tibet: A Political History. Nova Iorque: Potala Publications, 1984, p. 123. 


\subsection{A QUESTÃo DA AUTORIDADE RELIGIOSA NO TIBETE NO SÉCULO XVII}

Sob a patronagem de reis poderosos, (...) o budismo começou a assegurar um relacionamento duradouro com o Estado, consolidando noções de governo justo e o rei virtuoso [S. Dharmaraja], o que culminaria no governo dos Dalai Lamas mais tarde no Tibet. ${ }^{344}$

Nas páginas anteriores, procuramos expor uma contextualização histórica e política do Tibete, com o objetivo de situarmos o leitor quanto à realidade sociopolítica encontrada pelos primeiros jesuítas quando estes chegaram ao reino de Gugê, na parte ocidental do Tibete.

Porém, além disso, julgamos ser necessário apresentar, antes de iniciarmos nossas análises, algumas ideias fundamentais para o entendimento de como foi possível - e desejável, seja do ponto de vista dos jesuítas, seja do ponto de vista do rei de Gugê - o estabelecimento de uma missão em Tsaparang.

Em primeiro lugar, reiteramos a importância do sistema de patronagem, isto é, o apoio que era esperado de um rei, ou nobre, em relação a um mosteiro, ordem religiosa budista ou lama.

Em segundo lugar, é preciso expor que se esperava que tal rei, ou nobre, tivesse uma determinada postura ética e política que pode ser resumida na expressão "rei virtuoso", uma espécie de tradução livre da expressão em sânscrito Dharmaraja. ${ }^{345}$

Além disso, é necessário enfatizarmos que as mudanças políticas em curso no Tibete no século XVII, em especial aquelas relacionadas à ascensão da Escola Gelupa, além de serem um indício da atmosfera política do Tibete no período, apontam para outro problema estreitamente relacionado com o estabelecimento dos jesuítas. A este problema daremos o nome, nesta tese, de autoridade religiosa. ${ }^{346}$

Já foi dito anteriormente que, no budismo, de uma forma geral, a autoridade religiosa de uma pessoa - ou de uma Ordem - não está atrelada exclusivamente a uma "ortodoxia". As escolas deviam apresentar "caminhos" para uma vida livre de sofrimento. Quanto a

\footnotetext{
344 "Under the patronage of powerful kings, (...) Buddhism began to secure an enduring ideological relationship with the state, consolidating notions of righteous rule and the virtuous king [S. Dharmaraja], which would culminate in the rule of the Dalai Lamas in later Tibet." MILLS, M. Identity, ritual and State in Tibetan Buddhism.Nova Iorque: Routledge, 2003, p. 10. Tradução nossa.

345 "In general, the word Dharmaraja means the king who protects his subjects and rules according to Buddhist tenets/Chos". SINHA, N.C. Making of Dharmaraja. Bulletin of Tibetology, 28, n. 1, p. 5-10, 1992.

${ }^{346}$ Dividiremos em três aspectos: o aspecto da relação mestre-discípulo; o aspecto da regra da reencarnação e o aspecto da mediação entre este mundo e um outro mundo.
} 
interpretações dos ensinamentos de Buda, divergências eram esperadas. O que queremos dizer é que é previsto, no caso do budismo, uma maior flexibilidade quanto ao entendimento da “doutrina”, o que não pode ser dito do cristianismo ou do islamismo. Nos capítulos anteriores, procuramos demonstrar como questões teológicas e metafísicas ocuparam jesuítas e mulás nos debates que ocorriam na corte de Akbar. Questionar um dogma católico ou pôr em dúvida a Unidade de Deus - ou mesmo discutir o Corão - não é um comportamento adequado para alguém que quer ter sua autoridade religiosa reconhecida entre seus pares.

Ao contrário, muitas vezes o que parece é que, no caso do budismo tibetano, trata-se de um "método", uma prática, algo próximo da ideia de tantra. Não estamos querendo dizer que a "verdade" por trás dessa prática é irrelevante ou inexistente. O que propomos é que, em função de um determinado entendimento de autoridade religiosa, foi possível o estabelecimento dos jesuítas no Tibete. Esse entendimento passa por indícios práticos, especialmente aqueles reforçados quando do surgimento da Escola Gelupa, isto é, o monasticismo, o celibato e, em certo sentido, a distância de questões temporais. ${ }^{347}$ Com exceção do primeiro, todas as outras características são, idealmente, atribuídas a um jesuíta. Mesmo para o caso do monasticismo, ainda que a Companhia de Jesus não seja uma Ordem conventual, o fato do jesuíta apresentar-se como pertencente a uma comunidade religiosa determinada - justamente uma ordem - possivelmente foi visto, pelos tibetanos, como algo esperado de um preceptor religioso.

Em outras palavras, é necessário ter em mente um entendimento social da autoridade religiosa, expressa em palavras como lama. Nossa hipótese inicial é a de que, retirada a ênfase da doutrina e focando na apresentação de um novo "método", um jesuíta que mimetizasse ou que fosse reconhecido como lama estaria apto a tornar-se o preceptor espiritual de um nobre ou rei, estando portanto elegível para ter, na figura deste nobre, seu "protetor".

O papel de preceptor espiritual (lama, S. Guru), (...) se refere a qualquer pessoa que seja considerada por alguém como fonte de ensinamentos religiosos. (...) ["Lama" se refere a] um relacionamento de tutelagem espiritual, (...) um iniciador tântrico, ou (...) um lama encarnado, cujo status como uma manifestação reencarnada do budismo o qualifica como professor. $^{348}$

\footnotetext{
347 "The Gelupa order (...) saw celibate monasticism as the founding basis of all recognized religious authority within its ranks". MILLS, M. Identity, ritual and State in Tibetan Buddhism. Nova Iorque: Routledge, 2003. 348 "The role of the spiritual preceptor (lama, S. Guru), (...) refers to anyone that a person regards as source of religious teaching. (...) ["Lama" refers to] either a relationship of spiritual tutelage, (...) a tantric initiator, or (...) an incarnate lama, whose status as a reincarnating manifestation of Buddahood automatically qualifies them as teachers." Ibidem, p. 28. Tradução nossa.
} 
Em resumo, o que queremos dizer é que, ao contrário do que percebemos nos debates ocorridos no Indostão, para o caso do Tibete é fundamental compreendermos desde já que a autoridade religiosa não está fundamentalmente atrelada apenas a um livro ou a um corpo de verdades ou doutrinas. Essa autoridade também é dada socialmente, mediante o estabelecimento de uma relação do tipo mestre-discípulo, da qual pode fazer parte, em tese, qualquer um que possa ser entendido como preceptor espiritual. ${ }^{349}$

Porém, como dito no trecho destacado acima, essa autoridade está atrelada a uma outra "natureza" de lama. Trata-se dos lamas reencarnados, ou tulkus. Entender esse aspecto da questão da autoridade religiosa é importante não só para a compreensão da ascensão da Escola Gelupa, mas fundamentalmente porque a base da sucessão do Estado Tibetano à época da segunda missão jesuíta era, justamente, o conceito de transmigração da alma. No nosso caso, isso também é importante por ser foco de análise - e consequentemente, de crítica - por Ippolito Desideri em sua Notícia Histórica do Tibete. ${ }^{350}$

A utilização do conceito de transmigração da alma não tinha, em sua origem, nenhuma relação com as questões de estado tibetanas. Segundo Karubaki Datta, a primeira referência histórica de utilização da ideia de transmigração de almas data do século XIII. O monge líder da Escola Karmapa teria profetizado sua reencarnação, na véspera de sua morte, indicando exatamente o local e a família nos quais ele apareceria como um recém-nascido. ${ }^{351}$

Ainda segundo o mesmo autor, a ideia de reencarnação foi adotada por outra Escola, a Ordem "reformada" Gelupa, como forma de resolver o problema da sucessão decorrente do celibato entre os lamas. Assim, o sucessor do fundador da Escola Gelupa adotou a regra da reencarnação como maneira de solucionar a sucessão entre os altos cargos da Escola:

Tal conceito religioso [reencarnação] acabou por ser escolhido pela sua utilidade prática conveniente a uma ordem religiosa que insistia no celibato e, assim, excluía a possibilidade de herdeiros biológicos. ${ }^{352}$

\footnotetext{
349 "The lama as spiritual teacher and the lama as magical practitioner are natural concomitants of the political role of the lamas. These two aspects of the lama's role (spiritual teacher and magical practitioner) provide both the ideological and the real basis for the creation of a strong personal tie between lama and follower". SAMUEL, G. Tibet as a Stateless Society and Some Islamic Parallels. The Journal of Asian Studies 41, n. 2, p. 215-229, 1 fev. 1982.

${ }^{350}$ É preciso lembrar que, durante o estabelecimento da primeira missão jesuíta no Tibete, a regra da reencarnação já valia para a linha sucessória Gelupa, mas não estava atrelada ao governo temporal do Tibete. Isso só ocorreu em 1642, com o investimento do V Dalai Lama de ambos os poderes, temporal e secular.

${ }^{351}$ A Escola Karmapa, durante a guerra entre os reis do Tsang e os mongóis (aliados da Escola Gelupa), apoiou os primeiros em detrimento dos segundos.

352 "This religious concept [reincarnation] was ultimately picked up for a practical purpose it served in a religious order that insisted on celibacy and thus ruled out the possibility of biological inheritors." DATTA, K. Reincarnation and Politics in Tibet. Bulletin of Tibetology. vol. 36, números 1-3, p. 3, 2000.
} 
Outra distinção que precisa ser feita é entre o aparecimento da figura do Dalai Lama como autoridade política e a passagem de autoridade religiosa dentro de uma Ordem a partir da utilização do conceito de transmigração de almas.

O primeiro lama da Escola Gelupa a receber o título de Dalai Lama foi Sonan Gyatso. Ele recebeu o título, como já dissemos, de Altan Khan, no século XVI. No entanto, como ele era a terceira reencarnação da "linhagem" Gelupa iniciada por Gedun Truppa, ele é conhecido como o terceiro Dalai Lama. Seguindo a lógica da reencarnação, o título de "Dalai" foi passado retrospectivamente. Assim, temos que Tsong Khapa, fundador da Escola Gelupa, foi sucedido por Gedun Truppa ( $1^{\circ}$ Dalai Lama), cuja primeira reencarnação foi Gedun Gyatso ( $2^{\circ}$ Dalai Lama), seguido por Sonan Gyatso ( $3^{\circ}$ Dalai Lama).

Trent Pomplun também nos auxilia na compreensão desta passagem de um fenômeno a princípio religioso para um fator decisivo na organização política do Tibete:

Antes do final do século XIV, títulos monásticos e propriedades geralmente
eram passados de tio para sobrinho, sem que nenhum deles precisasse
quebrar seu voto de celibato. Disputas por propriedades entre a Ordem
Kagyu levaram a uma nova interpretação da doutrina da reencarnação no
final do século XIV ou início do século XV. De acordo com essa
interpretação, era possível descobrir entre os vivos a reencarnação de um
possível proprietário de títulos através da interpretação de vários sinais e
testes cuidadosos de várias crianças. Essa interpretação engenhosa, que
rapidamente se tornou proeminente entre a maioria das ordens monásticas do
Tibete, teve um forte efeito na política tibetana. ${ }^{353}$

Desta forma, a instituição da reencarnação como regra de sucessão, essencialmente religiosa em sua origem, passou a ter significado político. Independentemente de convicções particulares sobre a ideia (transmigração de almas), o que gostaríamos de pontuar aqui é, apenas, a passagem de um rito originariamente do campo religioso para uma forma de "escolha" de um chefe de Estado. Essa complexa relação entre os poderes temporal e secular será objeto de investigação, descrição e atuação dos padres da Companhia de Jesus. Será justamente dessa questão que trataremos a seguir.

\footnotetext{
353 "Before the late fourteen century, monastic titles ande states were usually passed from uncle to nephew, with neither needing to break his vow of celibacy. Estate disputes among the Kagyu order led to a novel interpretation of the doctrine of reincarnation in the late fourtennth or early fifteeenth century. According to this interpretation, one could discover among the living reincarnation of a recently deceased titleholder by interpreting various omens and carefully testing several children. This ingenious interpretation, which quickly became proeminent among most of the monastic orders in Tibet, had a powerfull efect on Tibetan politics." POMPLUN, T. Jesuit on the Roof of the World: Ippolito Desideri's Mission to Eighteenth-Century Tibet. Nova Iorque: Oxford University Press, 2002, p. 104-5. Tradução nossa.
} 


\subsection{UMA BREVE HISTÓRIA DA MISSÃO DO TIBETE, NO REINO DE GUGÊ, FUNDADA POR}

ANTÔNIO DE ANDRADE (SÉC. XVII)

Após vencer as "serras", isto é, as montanhas da cordilheira do Himalaia que separam o norte da Índia da região de cultura tibetana, o padre Antônio de Andrade e o irmão Manuel Marques chegam a Tsaparang, no reino de Gugê. O rei já os esperava, pois o padre havia mandado mensagem sobre sua chegada. Ao entrarem na cidade, as pessoas vinham às janelas e saíam às ruas para ver os recém-chegados - "gente muito estranha e nunca vista por aquelas terras. ${ }^{354} \mathrm{O}$ rei, contudo, não apareceu de imediato, mas a rainha se interessou em receber os visitantes. Em uma "varanda no paço" 355 foram feitas as primeiras reverências, e, então, os religiosos recolheram-se em residências que já haviam sido preparadas para acolhê-los.

A expectativa do rei de Gugê, Thi Tashi Dagpa, chamado de Chodapô nas cartas dos jesuítas, era de que a visita teria propósitos comerciais, pois assim ele tinha sido avisado. ${ }^{356}$ Nossa hipótese é de que Andrade mandara um comunicado acerca de sua chegada identificando-se como "frangue", que quer dizer europeu ou português. No entanto, o termo também era usualmente associado a comerciante, em função das atividades exercidas pelos portugueses na Ásia. Frustrado ao perceber que os estrangeiros não eram mercadores, ${ }^{357}$ Thi Tashi Dagpa os manteve presos, sem audiência, por alguns dias ${ }^{358}$, durante os quais os religiosos foram inquiridos sobre o motivo da viagem. Andrade, em seus relatos, afirma ter confirmado que não era mercador e pedido uma audiência de uma hora com o rei a fim de tudo explicar.

\footnotetext{
${ }^{354}$ CARTA de Antônio de Andrade, Agra, 8 de novembro de 1624. In: DIDIER, H. Os portugueses no Tibete. Os primeiros relatos dos jesuítas (1624-1635). Lisboa: Comissão Nacional pra Comemoração dos Descobrimentos Portugueses, 2000, p. 89.

355 Ibidem, loc. cit.

356 "Imaginava El rei, e assi lho tinham escrito, que nós devíamos trazer algumas pérolas e joias de grande preço...". Ibidem, loc. cit. E ainda: "Festejou ele [o rei] muito [a chegada dos jesuítas] e nos mandou receber quatro dias antes ao caminho com mostras de amor, imaginando que éramos mercadores e que traríamos muitas pérolas e coisas ricas, como lhe tinham dito os caxemires que estavam na sua primeira cidade." CARTA de Antônio de Andrade, 15 de agosto de 1626. In: DIDIER, H. Os portugueses no Tibete. Os primeiros relatos dos jesuítas (1624-1635). Lisboa: Comissão Nacional pra Comemoração dos Descobrimentos Portugueses, 2000, p. 105.

${ }^{357}$ Francisco Azevedo, um jesuíta enviado ao Tibete em 1631, explica que "o mesmo é dizer por cá frangue, que o homem cheio de pedraria e de riquezas". CARTA de Francisco Azevedo, Agra, 1631. In: DIDIER, H. Os portugueses no Tibete. Os primeiros relatos dos jesuítas (1624-1635). Lisboa: Comissão Nacional pra Comemoração dos Descobrimentos Portugueses, 2000, p. 172.

${ }^{358}$ Em uma carta, Andrade diz terem sido dois ou três dias. Em outra carta, Andrade diz terem sido seis ou sete dias. CARTA de Antônio de Andrade, Agra, 8 de novembro de 1624. op. cit., p. 89; CARTA de Antônio de Andrade, 15 de agosto de 1626. op. cit., p. 105, respectivamente.
} 
Finalmente, o rei concedeu a audiência, na qual um mouro caxemir, possivelmente comerciante, fez o papel de tradutor. Inicia-se aqui um problema que será uma constante na missão do Tibete: as dificuldades com o idioma. Nossa suposição é de que Andrade falaria em persa com o comerciante, que passaria para o tibetano para o rei, e vice-versa. Supomos que a conversa se dava em persa porque esta era uma língua comumente falada por mercadores naquela parte da Ásia. Além disso, Andrade vinha da corte mogol, onde se falava o idioma. O jesuíta, segundo seu relato, esclarece ao rei que o motivo da viagem era se

certificar das novas que me tinham chegado de [ele] ser cristão, e seguir com seus povos a verdadeira lei, e que, se era servido, ali me tinha para declarar e mostrar os erros da sua, e que desejos de sua salvação somente me faziam desterrar de minha pátria, deixar irmãos e amigos, e passar tantos trabalhos; que se aproveitasse da ocasião que Deus lhe metia nas mãos, lembrando-lhe, que por tantos anos atrás a não tinha dado a seus antepassados, que se não fizesse indigno das mercês que o Céu lhe oferecia. ${ }^{359}$

Deste trecho, inferimos que a expectativa, ao menos retórica, de Andrade era encontrar cristãos nestorianos, e seu objetivo seria trazê-los para a Igreja Católica Apostólica Romana mediante a correção de seus erros. Não há nas cartas de Andrade, a esta altura, descrições acerca da religião dos tibetanos.

O primeiro encontro, segundo o jesuíta, não foi muito positivo "por causa do mouro intérprete". ${ }^{360} \mathrm{O}$ religioso diz ter percebido que o língua "muito pouco referia ao Rei do que lhe dizíamos", pois o intérprete imaginaria "que faríamos mercancias como eles" ou, então, "por zelo de sua seita" recusava-se a traduzir adequadamente. ${ }^{361}$

As dificuldades de tradução - quaisquer que tenham sido as intenções do língua - e a frustração do rei ao descobrir que não negociaria pérolas e joias devem, de fato, ter influenciado na recepção dos missionários. No entanto, com o passar dos dias, o rei foi "se mostrando mais favorável e lhe pareciam muito bem as coisas de nossa Santa fé". ${ }^{362}$ Andrade, em uma de suas cartas, afirma que foi chamado logo no dia seguinte "porque já aquele pequeno grão de mostarda evangélica ia lançando raízes e causando grandes efeitos nos

\footnotetext{
${ }^{359}$ CARTA de Antônio de Andrade, Agra, 8 de novembro de 1624. In: DIDIER, H. Os portugueses no Tibete. Os primeiros relatos dos jesuítas (1624-1635). Lisboa: Comissão Nacional pra Comemoração dos Descobrimentos Portugueses, 2000, p. 89-92.

${ }^{360}$ CARTA de Antônio de Andrade, 15 de agosto de 1626. In: DIDIER, H. Os portugueses no Tibete. Os primeiros relatos dos jesuítas (1624-1635). Lisboa: Comissão Nacional pra Comemoração dos Descobrimentos Portugueses, 2000, p. 105.

361 Ibidem, loc. cit.

362 CARTA de Antônio de Andrade, Agra, 8 de novembro de 1624, op. cit., p. 92.
} 
corações Del-Rei e da Rainha". ${ }^{363}$ O jesuíta teria explicado alguns dos mistérios principais do cristianismo e, segundo o relato, o rei e a rainha ouviram com gosto. Thi Tashi Dagpa teria, então, garantido a Andrade livre acesso ao paço. Nesse novo encontro, o missionário optou por ter um gentio como língua, mas isso parece não ter resolvido o problema de forma definitiva, "pois era necessário falar por três línguas diferentes". ${ }^{664}$

Os planos do jesuíta pareciam estar bem encaminhados e seus relatos estão repletos de indicações da boa vontade do rei para com ele. No entanto, Andrade saíra de Agra sem ordens superiores, o que o impedia de fundar imediatamente uma missão. Além disso, o jesuíta diz ter tido seus bens confiscados na viagem, ficando sem o necessário para rezar missa. Assim, era preciso retornar à missão mogol, onde era superior. Passados vinte e cinco dias em Tsaparang, Andrade parte, mas não sem antes negociar seu retorno ao Gugê.

A saída de Andrade do Tibete revela-se um momento muito emblemático quanto à maneira de agir dos jesuítas, não só no que diz respeito especificamente à experiência no Tibete, mas a toda uma forma de atuação dos missionários da Companhia de Jesus. Trata-se da exposição para o rei das condições do padre para retornar e estabelecer-se em Tsaparang num futuro próximo. As reivindicações foram: 1) pleno direito à pregação; 2) sítio para a construção de uma igreja; 3 ) distanciamento de assuntos relativos ao comércio, inclusive para o caso de aparecerem comerciantes portugueses; e 4) descrédito aos mouros: "Que [o rei ] não daria crédito a cousa alguma que lhe dissessem os mouros caxemires contra nós". ${ }^{365}$

O resultado dessa negociação, segundo Andrade declara em sua carta, é um documento selado que diria o seguinte:

Nós, El-rei do reino de Potente, ${ }^{366}$ recebendo grande alegria com a vinda do padre Antônio "Frangim" às nossas terras para nos ensinar a Santa Lei, ao qual tomamos por nosso mestre lama-maior, e lhe damos autoridade para livremente poder pregar e ensinar aos nossos povos a Lei Santa, nem consentiremos que alguém lhe dê por isso moléstia, e lhe mandaremos dar sítio e toda a ajuda que quiser, para fazer casa de oração, e somos contentes que sendo o caso que venham a nossas terras mercadores "frangues", o dito padre e seus companheiros não intervenham em coisa alguma na matéria de compras e vendas, pois são contra o que professam. Assim, mais não daremos crédito a coisas que contra os ditos padres quiserem intentar os

\footnotetext{
${ }^{363}$ CARTA de Antônio de Andrade, Agra, 8 de novembro de 1624. In: DIDIER, H. Os portugueses no Tibete. Os primeiros relatos dos jesuítas (1624-1635). Lisboa: Comissão Nacional pra Comemoração dos Descobrimentos Portugueses, 2000, p. 92.

364 Ibidem, loc. cit.

365 Ibidem, p. 93.

366 “A palavra Tibet é de origem turco-árabe. Em árabe: Tubbat e em turco Tübat. Em hindi, Bhotanta é o mesmo que Tibete, o que muitas vezes foi traduzido como "Botente" ou "Potente" e daí para as demais línguas ocidentais: 'le puissant, the powerfull, das mächige'.” DIDIER, H. Os portugueses no Tibete. Os primeiros relatos dos jesuítas (1624-1635). Lisboa: Comissão Nacional pra Comemoração dos Descobrimentos Portugueses, 2000, p. 23. Em tibetano, dir-se-ia algo parecido com "be" e "pot" (Bot = Tibet).
} 
mouros, porque bem entendemos que, como não têm lei, assim encontram aos que seguem a verdadeira e pedimos que em tudo encarecidamente ao padre grande nos envie logo o dito padre Antônio para remédio de nossos povos. Dada em Chaparangue, firmada com nossas armas etc. ${ }^{367}$

Gostaríamos de ressaltar um aspecto que julgamos muito importante no momento do estabelecimento inicial das relações entre Andrade e o rei de Gugê. Conforme procuramos propor na introdução desta segunda parte de nossa tese, julgamos que a questão da autoridade religiosa é central para a compreensão do que se passa entre o régulo tibetano e o missionário jesuíta. Propomos que as seguintes expressões "tomamos por nosso mestre lama-maior"; "Ihe damos autoridade" e "padre grande" indicam que, nesse momento, Andrade adapta ou acomoda um costume tradicional nas sociedades de cultura tibetana: a relação de "patronagem" e de "mestre-discípulo". Andrade possivelmente se fez passar por um lama no sentido de preceptor espiritual, ou "guru" - ou pelo menos assim foi recebido por Thi Taghsi Dagpa. O religioso foi "tomado por mestre lama-maior", e, uma vez estabelecida esta relação, ele passa a ter autoridade para pregar. Por último, Andrade não ousou, não teria achado prudente ou simplesmente não quis desdobrar esta relação estabelecida entre o rei e ele para o nível de seu superior na Companhia, ainda que a figura do "padre grande" apareça no documento. Fica assim mimetizada a imagem de lama: um preceptor espiritual que veio ensinar a Santa Lei, fazendo parte de uma comunidade religiosa que possui um superior (padre grande) e que, para tanto, recebe as devidas licenças e apoio do rei - seu protetor.

Outro ponto que julgamos relevante pontuar é certa semelhança entre a origem da missão do Mogol e esses primeiros momentos do que viria a ser a missão tibetana. Em ambos os casos, o representante do poder temporal convida ou demanda a presença dos missionários. Se, para o caso do Tibete, o convite não foi tão espontâneo como no caso do Mogol, é fato que a existência de um pedido escrito manifestando o interesse de um régulo pela presença dos jesuítas auxilia no processo de justificativa para a criação de uma missão. Mesmo que duvidemos da existência do convite tal qual apresentado por Andrade, se tomarmos apenas a sua narrativa como objeto - e não os fatos aos quais ela se refere - ainda assim observamos a construção de um projeto missionário, cuja gênese, ainda que retórica, terá efeitos práticos, geopolíticos e, evidentemente, religiosos.

Acertadas as condições de retorno do religioso para o Tibete, Andrade deixa o reino de Gugê e retorna à Índia, de onde irá organizar a fundação da missão em Tsaparang. Neste

\footnotetext{
${ }^{367}$ CARTA de Antônio de Andrade, Agra, 8 de novembro de 1624. In: DIDIER, H. Os portugueses no Tibete. Os primeiros relatos dos jesuítas (1624-1635). Lisboa: Comissão Nacional pra Comemoração dos Descobrimentos Portugueses, 2000, p. 93.
} 
período, o jesuíta teria levantado dinheiro suficiente para o estabelecimento dos padres no Tibete Ocidental. Havia um cristão armênio na corte de Jahangir (imperador mogol filho de Akbar) que supostamente teria financiado, por meio de suas esmolas, o projeto de Andrade. $\mathrm{Na}$ correspondência da missão do Mogol, encontramos cartas que afirmam que Mirza Zulcarnian teria dado ao padre Antônio de Andrade, em 1622 - portanto, antes de sua primeira viagem ao Tibete - uma grande esmola, a ser aplicada "no que VR julgar que será de mais gloria de Deus, e proveito seu espiritual. ${ }^{368}$ Supõe-se que Andrade, como superior da missão do Mogol à época, teria contado com tal esmola para financiar seu projeto alguns anos após a doação. ${ }^{369}$ No entanto, a documentação não deixa claro se o padre realmente conseguiu aplicar esse dinheiro na missão do Tibete. ${ }^{370}$

Feitos os preparativos necessários, Andrade deixa Agra na companhia de Gonçalo de Souza em junho de 1625 e se reestabelece em Tsaparang em agosto do mesmo ano. ${ }^{371}$ No domingo de Páscoa de 1626, segundo nos informa Ippolito Desideri, é iniciada a construção da igreja da missão. ${ }^{372}$ No mesmo ano, Andrade envia uma carta ânua ao seu superior. Nela, são dadas notícias da missão, iniciando pela descrição do Tibete e dos lamas, e passando pelas disputas com eles travadas. ${ }^{373}$

No intervalo de tempo entre o estabelecimento da missão (1626) e a prisão do rei de Gugê (1630), a correspondência mostra que os padres no Tibete preocupavam-se em apresentar o potencial da missão e defender-se das críticas que sofriam dos companheiros na Índia. Percebe-se nas cartas que os religiosos estabelecidos em Tsaparang - e, em especial, Andrade - estavam sendo acusados de fazer comércio. Essa suspeita, com o passar do tempo, pesou contra a imagem da missão.

Curiosamente, em meio à polêmica que envolvia os padres no Tibete Ocidental, a Companhia de Jesus enviou, ainda no ano de 1626, dois padres e um irmão ao Tibete Central.

\footnotetext{
368 Cf: "Traslado de carta que em pérsio escreveu Mirza Sulcarnem (sic) por sua mão ao padre Antônio de Andrade da Companhia de Jesus superior da missão do Mogol em dezembro de 1622”. ARSI, Goa 73 fl: 49v. E ainda: RICHARDSON, H. Armenians in India and Tibet. Journal of the Tibet Society, vol. I, p. 65, 1981.

${ }^{369}$ Não fica claro se a oferta de Mirza Zulkarnian foi feita em espécie ou pela doação de uma pérola, que deveria ser vendida, e o dinheiro aplicado na missão do Tibete.

${ }^{370}$ No verso de uma carta de Andrade de 1627, lê-se: "Queixam-se [os padres] de não exprimentarem o favor que merece a missão do Tibet. (...) Em Agra lhe represaram 6 mil [sinal que parece fazer referência a um tipo de moeda] que mandaram para em Europa se empregarem em (censo?), para ajuda do temporal da missão. Para este (censo?) aplicou o Padre Andrade mil e quinhentas patacas que Mirza Zulearnem lhe tinha dado, e mais lhe deu o Rei." ARSI, Goa 73, ff: 51v. Ver anexo C. Além disso, cf: DESIDERI, I. Mission to Tibet: the extraordinary eighteenth-century account of father Ippolito Desideri, S.J. Tradução Michael J. Sweet. Edição Leonard Zwilling. Boston: Wisdom Publications, 2010, p. 153.

371 Ibidem, p. 198.

372 Ibidem, loc. cit.

${ }^{373}$ As cartas serão objeto de análise a seguir.
} 
Estevão de Cacela, João Cabral e o irmão Bartolomeu Fonteboa são enviados de Cochim, centro da província do Malabar, para uma missão em Utsang. ${ }^{374}$ Segundo relato do próprio Cacela, ele teria saído de Bengala acompanhado pelo padre Simão de Figueiredo, mas não fica claro se Figueiredo de fato seguiu viagem até o Tibete. ${ }^{375}$ Nas cartas escritas por ambos (Cacela e Cabral), observamos os mesmos objetivos de localizar o Cataio e descrever os budistas tibetanos, bem como sua "seita". 376

No ano seguinte, 1627, mais padres se juntaram aos companheiros na terra dos lamas: João de Oliveira, Alano dos Anjos e Antônio Pereira chegam à missão de Tsaparang. Nesse ano, 12 pessoas teriam sido batizadas, segundo o posterior relato de Desideri. ${ }^{377}$

Entre os anos de 1627 e 1630, a Companhia de Jesus possuía, portanto, duas missões no Tibete. A primeira, fundada por Antônio de Andrade, localizava-se em Tsaparang, capital do reino de Gugê. A segunda localizava-se no Tibete Central, na região de Utsang, e recebeu os padres João Cabral e Estevão Cacela, que vieram da província do Malabar. ${ }^{378}$ Apesar de supostamente terem recebido apoio dos régulos locais, liberdade de pregação e talvez até mesmo sustento material, nada disso garantiu de forma definitiva o sucesso da missão. Entre os motivos para o suposto "fracasso" das investidas da Companhia na Ásia Central estão a dificuldade de adaptação e a morte de missionários (Cacela morreu em Shigasté, em 6 de março de 1630), ${ }^{379}$ a falta de apoio que a missão parece ter recebido da província após a morte de Antônio de Andrade e as instabilidades políticas da região.

Como já dissemos anteriormente, o rei do Ladakh invade o reino de Gugê no ano de 1630. Michael Sweet afirma que a invasão de Tsaparang estaria relacionada ao estreitamento das relações entre o rei e os missionários. ${ }^{380}$ Os monges budistas teriam negociado a guerra com o rei do Ladakh, supostamente ameaçados pela iminente conversão de Thi Tashi Dagpa.

\footnotetext{
374 Identificada por Desideri como "o terceiro e Grande Tibete". DESIDERI, I. Mission to Tibet: the extraordinary eighteenth-century account of father Ippolito Desideri, S.J. Tradução Michael J. Sweet. Edição Leonard Zwilling. Boston: Wisdom Publications, 2010, p. 198.

${ }^{375}$ Relação que mandou o Padre Estevão de Cacela da Companhia de Jesus ao Padre Alberto Laércio, provincial da Província do Malabar da Índia Oriental, de sua viagem para o Cataio, até chegar ao reino de Potente. In: DIDIER, H. Os portugueses no Tibete. Os primeiros relatos dos jesuítas (1624-1635). Lisboa: Comissão Nacional pra Comemoração dos Descobrimentos Portugueses, 2000, p. 216.

${ }^{376}$ Para os roteiros de Cacela e Cabral, cf: anexo "F".

${ }^{377}$ DESIDERI, I. op. cit., p. 199.

${ }_{378}^{378}$ Para mapa das províncias no subcontinente indiano, consultar anexo "G".

${ }^{379}$ Informação retirada da carta de Franciso Azevedo, em parte que ele supostamente copia uma carta de João Cabral. Carta de Francisco de Azevedo, Agra, 1631. In: DIDIER, H. Os portugueses no Tibete. Os primeiros relatos dos jesuítas (1624-1635). Lisboa: Comissão Nacional pra Comemoração dos Descobrimentos Portugueses, 2000, p. 193.

${ }^{380}$ DESIDERI, I. Mission to Tibet: the extraordinary eighteenth-century account of father Ippolito Desideri, S.J. Tradução Michael J. Sweet. Edição Leonard Zwilling. Boston: Wisdom Publications, 2010, nota do editor. p. 690 , n. 558.
} 
Não temos elementos suficientes, a essa altura, para corroborar com a hipótese de Sweet; ao contrário, estamos mais inclinados a interpretar essa guerra a partir das tensões políticas locais. Dois fatos podem ser apontados como estopim para o conflito com base em uma de cartas escritas por Andrade. ${ }^{381} \mathrm{O}$ padre aponta como razão para a guerra um acordo de casamento entre o rei de Gugê e a irmã do rei do Ladakh, acordo este que foi abruptamente quebrado pelo primeiro. O jesuíta também sugere que a perseguição e laicização forçada dos lamas deixaram os monges de Tsaparang - dentre eles o irmão do rei - mais inclinados a apoiarem os invasores. ${ }^{382}$ Ainda assim, é possível que o envolvimento do régulo com os padres tenha, em alguma medida, colaborado para a sua queda. O fato é que, como consequência da invasão da cidade, o rei que tanto apoiava os jesuítas foi levado preso para Leh, capital do Ladakh. Também foram presos a rainha, o príncipe e o lama que supostamente teria apoiado os invasores. Cristãos também foram feitos cativos, dentre eles dois padres, mas estes foram postos em liberdade logo em seguida.

O cenário do início da década de 1630, ao contrário dos anos anteriores, não parece favorável ao projeto de evangelização do Tibete. Na mesma carta em que Andrade narra as dificuldades que a missão enfrenta em função da queda de Thi Tashi Dagpa, ele também menciona que a região de fronteira entre o Mogol e o Tibete era assolada por fome e peste. $\mathrm{O}$ jesuíta, a essa altura provincial da Companhia de Jesus em Goa, envia então um padre ao Tibete para ter notícias do que se passava. ${ }^{383}$

O jesuíta Francisco Azevedo, acompanhado do padre João de Oliveira, chegou a Tsaparang em 25 de agosto de 1631, "tão moído e magoado dos pés que me não pude servir deles por mais de 20 dias." ${ }^{384}$ Uma vez lá, ele decide negociar com o novo régulo a manutenção da missão em Gugê. ${ }^{385}$ Em sua carta, o missionário afirma terem já 400 cristãos

${ }^{381}$ CARTA de Antônio de Andrade de 4 de fevereiro de 1633. ARSI, Goa 73, fl: 93-95.

$382 \mathrm{O}$ debate acerca desta guerra foge ao objetivo do presente trabalho. Para maiores informações sobre o episódio, sugerimos as leituras de PETECH, L. A Study on the Chronicles of Ladakh. The Calcutta Oriental Press, 1937; YA-TS'E, Gu-ge, Pu-ran: a new study. In: PETECH, L. Selected papers on Asian history. Roma: Ismeo, 1988; THE KINGDOM of Ladakh C. 950-1842 A.D. Roma: Istituto italiano per il medio ed estremo oriente, 1977.

383 "Partio-se o padre e teve na viagem grandes trabalhos assim por ser tempo que os reinos do mogor ardiam em peste e guerras e sendo a fome tal que havia públicos açougues de carne humana e houve várias mães e pais que comeram os seus próprios filhos." Carta de Antônio de Andrade, fevereiro de 1633. ASRI Goa 73, fl: 73v.

${ }^{384}$ Carta de Francisco de Azevedo, Agra, 1631. In: DIDIER, H. Os portugueses no Tibete. Os primeiros relatos dos jesuítas (1624-1635). Lisboa: Comissão Nacional pra Comemoração dos Descobrimentos Portugueses, 2000 , p. 187. Para sua rota até o Tibet, cf: anexo "E" ao final desta tese.

385 "Vendo eu o estado da missão, tratei com os padres do remédio dela e assentamos que o seria em parte verme com o novo rei com algum presente, suposto que era tão cobiçoso para o benevolear (sic) na forma possível, o que ainda não tinha ordem, e o caminho era comprido e difícil, houve contudo que aquela seria a vontade de Nosso Senhor e da obediência e que poderia com minha ida melhorar-se de alguma maneira aquela missão tratando e pedindo ao Rei que nos fizesse respeitar no Chaparangue como dantes, e de novo [desse] licença 
no Tibete neste período, ${ }^{386}$ dos quais grande parte foi levada cativa para Leh, capital do reino de Ladakh, após a guerra. Depois de uma espera de oito dias entre a audiência e a tomada de decisão do rei, Azevedo foi informado

\begin{abstract}
por um privado seu [do rei], pelo qual mandou dar formão passado para podermos viver e estar como no tempo do Rei passado, não só no reino de Cogé [Gugê], mas também em Ridocho e na sua cidade real. Esta resposta não quis dar pessoalmente por se não obrigar a favores, nem a muitas despesas. (...) Nos mandou dar um cavalo que se parecia muito com o de Dom Quixote (...) e licenças para partir e pregaremos (sic) nossa Santa lei como dantes. ${ }^{387}$
\end{abstract}

No ano seguinte (1632), Andrade, ainda como provincial, envia para o Tibete um novo grupo de missionários, composto por Antônio Pereira, Domenico Capece, Francisco Morando e, mais uma vez, Francisco Azevedo. Essa informação consta da história que Desideri escreve sobre a missão, e não podemos, por hora, confirmá-la por outras fontes. ${ }^{388}$ No mesmo texto, o italiano afirma que, em 1635, um novo contingente de missionários partiu para o Tibete. O grupo, liderado por Nuno Coresma, contava com seis jesuítas, entre eles: Balthazar Caldeira, Pedro de Freitas e o irmão Faustino Barreiros. ${ }^{389} \mathrm{O}$ autor informa ainda que, em 1640, o padre Tomé de Barros foi enviado ao Tibete acompanhado por mais dois padres e um irmão. No entanto, ele afirma que não teve maiores informações sobre o que sucedeu a tal grupo de missionários.

Um dado curioso que Desideri nos traz diz respeito ao financiamento da missão. No mesmo ano (1640), o Geral da Companhia de Jesus (Muzio Vitelleschi) recebeu por carta um pedido para que Mirza Sulkarnain e seus filhos recebessem o título de fundadores da missão do Tibete devido às doações que fizeram à Ordem na Índia ao longo dos anos. ${ }^{390}$

Outro ponto importante abordado pelo italiano é que Andrade, antes de morrer envenenado no colégio de São Paulo, em Goa, se preparava para voltar ao Tibete acompanhado de mais seis missionários.

Contudo, além das informações dadas por Desideri - as quais ele deve ter coletado a partir da leitura de cartas que circularam dentro da própria Companhia de Jesus - pouco podemos dizer do que se sucedeu à missão após 1635. O jesuíta italiano afirma que o irmão

[para] nossa Santa Lei porque, como o bom modo dos padres, ali poderia ser que o ganhássemos e dali podíamos favorecer com isso e acudir aos padres que estiverem por outras partes do reino." Carta de Francisco de Azevedo, Agra, 1631. In: DIDIER, H. Os portugueses no Tibete. Os primeiros relatos dos jesuítas (1624-1635). Lisboa: Comissão Nacional pra Comemoração dos Descobrimentos Portugueses, 2000, p. 194.

386 Ibidem, p. 192.

387 Ibidem, p. 199.

${ }^{388}$ DESIDERI, I. Mission to Tibet: the extraordinary eighteenth-century account of father Ippolito Desideri, S.J. Tradução Michael J. Sweet, Edição Leonard Zwilling. Boston: Wisdom Publications, 2010, p. 200.

389 Ibidem, loc. cit.

390 Ibidem, p. 200-1. 
Manuel Marques, que havia acompanhado Antônio de Andrade em sua primeira e segunda jornadas ao Tibete, ainda estava na terra dos lamas no ano de 1642. Ocorre, contudo, que, por razões a serem analisadas em momento oportuno, Desideri tinha interesse em demonstrar que a Companhia de Jesus jamais desistiu do Tibete. Ficam ainda por responder várias questões em relação à história da missão, em especial dos fatos posteriores a 1635. Não sabemos se de fato permaneceram jesuítas em Tsaparang ou em outra região do Tibete após esta data, ou se a missão foi encerrada em função das críticas feitas por Nuno Coresma, a serem abordadas a seguir.

Nas próximas páginas, proporemos uma análise das fontes provenientes da correspondência da missão Tibetana, dividida em três partes. Na primeira, analisaremos as cartas iniciais de Antônio de Andrade, nas quais o Tibete é apresentado de forma positiva. Na segunda parte, analisaremos a carta de Nuno Coresma, na qual a missão é condenada e vemos surgir uma "nova" descrição dos tibetanos. Por último, nos debruçaremos sobre a carta de Antônio Mendes, que intenta defender a missão e criticar a decisão de retorno dos padres do Tibete.

Ao longo de nossa análise, manteremos o foco em nossa questão principal: a relação que se estabelece entre a descrição e categorização dos tibetanos e as estratégias de conversão julgadas como prudentes para cada caso. 


\begin{abstract}
Aos trinta de Março de 1624 partimos de Agra, o padre Manuel Marques e eu, para acompanhar a El-Rei (...). Chegamos à cidade de Deli, da qual atualmente partiam muitos gentios a um famoso pagode, em romaria, que dista de Agra mês e meio de caminho; e como tínhamos muitas informações tiradas por várias vias com grande diligência, com as quais nos certificamos serem aqueles reinos cristãos, além da fama, que de vinte anos a esta parte tinha chegada aos padres na mesma conformidade. Vendo-me em companhia de gente, que me podia servir de guia em grande parte do caminho (...) resolvi a ir tomar notícia daquelas nações. ${ }^{391}$
\end{abstract}

Nesta etapa de nossa tese, propomos aprofundar um debate iniciado já em nossa dissertação de mestrado ${ }^{392}$ acerca da descrição dos tibetanos e as respectivas estratégias de conversão associadas a tais descrições. ${ }^{393}$ Nas linhas a seguir, desenvolveremos principalmente três ideias.

Em primeiro lugar, propomos que, considerando as leis e o governo, os jesuítas que primeiro descreveram o Tibete para o público europeu (membros ou não da Companhia de Jesus), apresentam-no como um Estado governado por reis no qual a participação política dos sacerdotes (lamas) ganha mais ou menos ênfase, de relato para relato. Além disso, os missionários procuram demonstrar que, em função do apoio recebido da parte dos soberanos locais (principalmente em Tsaparang), gozam de grande liberdade de pregação. Tal liberdade não só favorece a evangelização, como viabiliza o estabelecimento da missão, especialmente do ponto de vista político e material.

Quanto aos interesses geopolíticos da Ordem, o Tibete estaria, ainda segundo os relatos, privilegiadamente localizado entre dois grandes centros de comércio e missionação no Oriente no século XVII: a China e o Mogol. Além disso, os reinos vizinhos, segundo os religiosos, tinham essencialmente a mesma linguagem e compartilhavam da mesma fé, o que faria desse "reino" uma "porta” ou "escada" para a pregação do Evangelho por toda a Ásia. ${ }^{394}$

${ }^{391}$ CARTA de Antônio de Andrade, 1624. In: DIDIER, H. Os portugueses no Tibete. Os primeiros relatos dos jesuítas (1624-1635). Lisboa: Comissão Nacional pra Comemoração dos Descobrimentos Portugueses, 2000 , p. 75.

${ }^{392}$ Disponível em: <http://www.teses.usp.br/teses/disponiveis/8/8138/tde-21102009-164743/pt-br.php>.

393 Organizamos os principais temas tratados na correspondência da missão de Guge em uma tabela, consultar Apêndice E.

394 "Mas descendo ao particular deste reino em que já estamos é que é a porta única para todos os demais, há nele muitos eclesiásticos a que chamam lamas, os quais se dividem em dez ou doze sortes, mas todos professam 
No que diz respeito aos costumes e à religião, os Tibetanos são identificados como cristãos antigos ou gentios. O Tibete foi também descrito como estando livre da presença muçulmana; os budistas, ${ }^{395}$ segundo os missionários, teriam aversão à seita do Profeta. Neste aspecto, os jesuítas lançam mão de categorias como "gente branca", "gente pia" e outras expressões semelhantes, cujo uso remete-se necessariamente a uma estratégia de conversão baseada no convencimento em detrimento da força física ou da coerção.

Passemos às fontes: a primeira carta de Andrade sobre o Tibete é datada de 8 de novembro de 1624, e nela encontramos os argumentos iniciais a favor do investimento da Companhia de Jesus no Tibete. A missiva inicia-se anunciando o propósito da jornada: confirmar os relatos sobre o Grão-Cataio, dos quais a Ordem tinha tomado conhecimento a partir de notícias colhidas nas missões na Índia - em especial, no Mogol - e disseminadas através da correspondência de missionários.

Já em sua parte introdutória, pode-se destacar da carta do missionário: (a) o objetivo da viagem - procurar os cristãos mencionados em rumores; (b) que Andrade já havia coletado informações sobre a região; (c) que as fontes dessas informações eram diversas; (d) que havia, portanto, uma forte expectativa de encontrar cristãos naquela parte da Ásia; e (e) que Andrade parte aproveitando as circunstâncias e, portanto, sem ordens diretas para a viagem.

Para uma análise dessa fonte, propomos sua divisão em duas partes. Na primeira, são descritos os lugares por onde passaram o jesuíta e seus companheiros em sua jornada, até a chegada ao Tibete. Nesta etapa do percurso, o missionário concentra-se na descrição dos hindus: sua aparência, hábitos, costumes e religiosidade, os quais muitas vezes não passam incólumes às severas críticas do jesuíta. O missionário também se dedicou a descrever a vegetação, o clima e os rios encontrados. São mencionadas as dificuldades da viagem, que se deveram tanto em função da árdua subida - e da ainda mais complicada descida - como também em razão do frio. Andrade chega a perder parte de um dos dedos da mão, além de ficar parcialmente cego. As montanhas e a neve são minuciosamente descritas, tanto como obstáculos quanto como maravilhas da Criação.

A segunda parte dessa carta diz respeito à chegada ao Tibete - mais especificamente ao reino de Gugê, ou Tibete Ocidental. Trata-se da recepção do rei e das relações travadas entre o missionário, o rei e a rainha. Andrade esforça-se em apresentar o rei do Tibete, para o

a mesma crença, posto que em vários ritos têm diferença entre si." CARTA ânua de Antônio de Andrade, 1626. In: DIDIER, H. Os portugueses no Tibete. Os primeiros relatos dos jesuítas (1624-1635). Lisboa: Comissão Nacional pra Comemoração dos Descobrimentos Portugueses, 2000, p. 107.

${ }^{395}$ Que ainda não levam este nome. 
leitor, como um homem muito generoso para com os missionários, a ponto de discriminar os “presentes" recebidos: carneiro, arroz, farinha, entre outros. ${ }^{396} \mathrm{O}$ jesuíta apresenta-nos também informações sobre os gêneros alimentícios que são produzidos no reino de Gugê e os que são obtidos por trocas comerciais com vizinhos, indicando assim relações de comércio entre Tsaparang e outros reinos.

Podemos ler ainda neste relato a descrição do povo tibetano, em especial dos lamas, com clara associação ao clero cristão - confessam pobreza, vivem de esmola, cantam do mesmo modo suave. O missionário é capaz de identificar no budismo tibetano - que ele não reconhece como tal nem nomeia desta forma - o mistério da santíssima trindade "mui distinto". O português aponta também o uso da "água benta" e dos sacramentos do batismo e da confissão. ${ }^{397}$

De uma forma geral, podemos dizer que todo o trabalho da carta $^{398}$ é mostrar o Tibete como um espaço fértil para a atividade missionária, através da descrição de um rei de Gugê muito interessado no cristianismo e muito disposto a dar aos jesuítas a liberdade de pregação almejada; apresentando a rainha como "prudentíssima", aliada dos cristãos no repúdio aos muçulmanos; qualificando o Tibete como um terreno livre de "infiéis" e "hereges": os tibetanos, segundo Andrade, são, "muito pia, inclinada às cousa de Nosso Senhor, [...] tem a lei dos mouros por abominável e zombam muito da do gentio". 399

Essa primeira carta sobre o Tibete foi traduzida em diversos idiomas e teve grande repercussão em toda a Europa católica. ${ }^{400}$ Isso significa dizer que, provavelmente, as primeiras notícias (escritas) acerca do Tibete que chegaram à Europa vindas de um europeu que, de fato, esteve em terras tibetanas, foram dadas por Andrade e publicadas por Mateus Pinheiro. ${ }^{401}$ No que diz respeito as nossas hipóteses, sugerimos em nosso trabalho que as primeiras impressões ocidentais do budismo - ainda não identificado por esse nome - foram marcadas

\footnotetext{
${ }^{396}$ CARTA de Antônio de Andrade, Agra, 1624. In: DIDIER, H. Os portugueses no Tibete. Os primeiros relatos dos jesuítas (1624-1635). Lisboa: Comissão Nacional pra Comemoração dos Descobrimentos Portugueses, 2000, p. 93.

397 Ibidem, p. 99.

398 Por "trabalho da carta" entendemos a atividade de escrita das missivas, segundo os pressupostos da disciplina e da retórica jesuítas. "Trabalho", neste caso, significa uma adequação, um ajuste da realidade à narrativa e, portanto, aos objetivos primeiros da Companhia de Jesus: a evangelização e a catequese.

${ }^{399}$ CARTA de Antônio de Andrade, Agra, 8 de novembro de 1624. In: DIDIER, H. Os portugueses no Tibete. Os primeiros relatos dos jesuítas (1624-1635). Lisboa: Comissão Nacional pra Comemoração dos Descobrimentos Portugueses, 2000, p. 98-9. Grifo nosso.

${ }^{400}$ DIDIER, H. Os portugueses no Tibete. Os primeiros relatos dos jesuítas (1624-1635). Lisboa: Comissão Nacional pra Comemoração dos Descobrimentos Portugueses, 2000, p.16

401 Esta carta foi publicada em 1626 pelo livreiro Mateus Pinheiro, sob o título de: "Novo descobrimento do gram Cataio ou reinos do Tibete, pelo padre Antônio de Andrade, da Companhia de Jesus, português, no ano de 1624 ". Ibidem, p.75.
} 
pela visão de Andrade e, consequentemente, pela tradição jesuíta. É sobre a primeira iniciativa descritiva que irão se sobrepor as demais, as quais, ao longo dos séculos, comporão o conhecimento ocidental sobre o Tibete. Isso implica dizer que o primeiro modo de conhecer o Tibete pelos ocidentais seguiu "das penas" da Companhia de Jesus e assim continuará até, pelo menos, a viagem de Desideri, mudando talvez com o início das expedições do século XIX.

Quanto à apresentação positiva do Tibete, ela não se restringe à primeira missiva. A ânua da recém-instalada missão de 1626 reitera uma visão promissora acerca da região e de seus habitantes, remetendo-se mais uma vez às notícias ouvidas na missão do Mogol:

Mais de vinte e cinco anos correram depois que tivemos as primeiras novas destas vastíssimas nações por via dos mouros caxemires, que às mais vizinhas vinham vindo com suas mercancias e afirmavam que o "Grão Thibet" era todo de cristãos pela semelhança que havia entre os nossos e seus templos. Por este nome de "Thibet Grande" nomeiam os persas estas terras (a que os hindustões chamam Potente) pera distinção de outro "Thibet Pequeno", que corre além do reino de Caxemir, que é todo já de mouros, os quais sendo há poucos anos gentios receberam a infame seita. Ouvidas estas novas, que foram de grande alegria, pretenderam os padres que residiam na corte del-Rei mogol tomar inteira notícia do que na verdade passava e para isso partiu um padre do mesmo Caximir em descobrimento destas nações. Foram, porém, tantas as dificuldades que se ofereceram na passagem que não foi possível ir muito adiante, particularmente por razão das grandes neves (...). Depois de alguns anos residindo eu na corte Del-Rei mogol, tive varias informações desta jornada, assim por via dos mouros caxemires, como de pessoas graves que dela tinham notícia, e achei que todas conformavam entre si, pelas quais parecia ser a gente toda cristã, e ter recebido a verdadeira fé nos tempos antigos. ${ }^{402}$

A importância desta citação não está apenas no modo como Andrade conta a sua história - ele chegou a um lugar chamado Tibete caminhando de Agra (norte da Índia) - mas muito mais no fato de que sua narrativa pretende defender a conversão "iminente" dos budistas tibetanos. A citação é válida também pelo que pode representar em termos de uma proposta ou um "plano" das estratégias de conversão. No caso de nossa pesquisa, especificamente, este trecho pode nos contar sobre o conhecimento que o povo europeu tinha acerca da Ásia Central no início do século XVII e suas implicações no que dizia respeito à geopolítica e às estratégias de conversão defendidas e aplicadas pelos missionários jesuítas nessa área durante o período. Gostaríamos de reiterar a hipótese, já mencionada, de que o budismo (nesse caso, o budismo tibetano), representou um problema epistemológico para os

402 CARTA de Antônio de Andrade, 15 de Agosto de 1626. In: DIDIER, H. Os portugueses no Tibete. Os primeiros relatos dos jesuítas (1624-1635). Lisboa: Comissão Nacional pra Comemoração dos Descobrimentos Portugueses, 2000, p. 103-4. ARSI, Goa 73, ff: 2-3. 
jesuítas - como certamente aconteceu muitas vezes na Índia e no continente americano - e teve que ser resolvido levando em conta o principal objetivo dos jesuítas: a conversão. ${ }^{403} \mathrm{Em}$ outras palavras: para que fosse convertido, o povo tibetano e o budismo tibetano tiveram que ganhar um "espaço" e uma "História" dentro da tradição cristã ocidental. Assim, reconhecemos que, ao longo de nossa tese, utilizamos um conceito que falta aos missionários. A ideia de budismo - isto é, a noção contemporânea de uma religião de seguidores de Buda com crenças e ritos próprios, ainda que variáveis da Índia à Tailândia, China ou Japão - não está presente no simbólico dos missionários cujas trajetórias estudamos. É justamente essa "falta" que está sendo elaborada pela escrita jesuíta dos séculos XVII e XVIII. O "budismo", para os religiosos, é um objeto que ainda não possui significante correspondente, e por isso é necessário recorrer a um arcabouço "etnográfico" para que a experiência ganhe sentido. ${ }^{404}$ Essencialmente é esse exercício de ordenação epstemológica e linguística que está em jogo no relato de Andrade, Para analisar justamente esse processo de elaboração de um significante - uma expressão ou uma palavra que o defina e que, a partir de então, sirva para invocar universalmente tal objeto - pedimos licença para usar o conceito inteligível para nós, inexistente pare eles, ainda que se trate, stricto senso, de um anacronismo.

Seguindo tal lógica, percebemos que essas suspeitas sobre formas de cristianismo aparecem com frequência como um objeto de "pesquisa" ou "estudo". Andrade faz uma referência específica a um determinado período no tempo: "há mais de 25 anos", ele diz. Hugues Didier, ${ }^{405}$ que publicou algumas das cartas sobre a missão no Tibete, garante que esta é uma referência clara a um jesuíta chamado Jerônimo Xavier, que algumas décadas antes também havia se estabelecido em Mogol e que coletara informações sobre cristandades para além do Indostão. Para o caso da missão de encontrar esses cristãos além das fronteiras do Império Mogol, é possível que Andrade se refira a outro jesuíta, Bento de Gois. Outros jesuítas, como Rodolfo Acquaviva e Antônio de Montserrat, também coletaram informações sobre a possibilidade de existirem sociedades cristãs na Ásia enquanto estavam na corte

\footnotetext{
403 "A descoberta do Novo Mundo, o fracionamento da cristandade, as clivagens sociais que acompanham o nascimento de uma política e de uma razão novas engendram um outro funcionamento da escrita e da palavra. Presa na órbita da sociedade moderna, sua diferenciação adquire uma pertinência epistemológica e social que não tinha antes; em particular torna-se o instrumento de um duplo trabalho que se refere, por um lado à relação com o homem "selvagem", por outro à relação com a tradição religiosa. Serve para classificar problemas que o sol nascente do "Novo Mundo" e o crepúsculo da cristandade "medieval" abrem à intelligentsia." CERTAU, M. A escrita da História. Rio de Janeiro: Forense Universitária, 2002. p. 213. Grifos do autor.

404 ZUPANOV, I. Jesuit Orientalism; Correspondence between Tomas Pereira and Fernão de Queiros ”, In: BARRETO, L. Tomás Pereira, S. J. (1646-1708), Life, Work and World. Lisboa: Centro Cultural e Cientifico de Macau, 2010, p. 43-74.

${ }^{405}$ DIDIER, H. Os portugueses no Tibete. Os primeiros relatos dos jesuítas (1624-1635). Lisboa: Comissão Nacional pra Comemoração dos Descobrimentos Portugueses, 2000.
} 
mogol. Conforme dissemos na primeira parte desta tese, Acquaviva escrevera que havia ouvido falar em uma "gentilidade dadicada a obras pias". ${ }^{406}$

Nós podemos encontrar vestígios desses "estudos" desde a época de Marco Polo e Guilherme de Rubruck, mas, neste caso, devemos reconhecer a referência feita por Andrade. O missionário se apresenta como um tipo de "herdeiro" dessa geração passada de jesuítas, os quais, assim como ele, permaneceram por algum tempo na corte mogol.

Outro aspecto importante deste trecho diz respeito às questões geográficas. $\mathrm{Na}$ tentativa de trazer à Europa notícias de primeira mão sobre essa parte da Ásia Central, Andrade indica onde ele está e, posteriormente, apresenta outras regiões tibetanas. Enfatizamos a intenção de se atribuir um "lugar" - geográfico e religioso - ao Tibete, sendo esta, de acordo com Giuseppe Toscano, a primeira descrição geográfica correta, ainda que curta. Acima de tudo, o autor destaca o fato de que Andrade difere o Pequeno Tibete do Grande Tibete. ${ }^{407}$ Ou seja, há cautela em relatar que esse reino não é muçulmano, apesar da existência do "pequeno Tibete", uma região que antes de ser muçulmana, foi gentia.

Para obter-se um estudo detalhado da geografia do Tibete apresentada por Andrade, podemos consultar os trabalhos de Giuseppe Toscano e Sven Hedin. ${ }^{408}$ Aqui, porém, o objetivo é compreender as implicações dessa forma de apresentar o Tibete, considerando o proselitismo jesuíta. No entanto, gostaríamos de ressaltar que essa descrição foi feita e publicada cerca de 90 anos antes que Desideri - possivelmente o jesuíta cujo trabalho sobre o Tibete seja o mais conhecido atualmente - tivesse a chance de chegar a Lhasa.

Toscano também aponta que, se para Andrade Cataio era uma cidade e não um país, ele provavelmente não tivera contato com as cartas de Ricci e Goes, em que Cataio - algo

${ }^{406}$ CARTA de Rodolfo Acquaviva para Claudio Acquaviva, Praep. Gen. S.I., Fatepur, 25 de abril de 1582. Documenta Indica, vol. XII (1580-1583), doc 106, p. 584. ARSI Jap-sin 37, ff: 109r-111v.

${ }^{407}$ Em outra passagem, Andrade continua: "O Tibete ou o Potente, que de ambos estes modos se nomeia como já disse, compreende o reino de Coque [Gugê] que é em que presente estamos, o de Ladaca [Ladakh, La dvags], o de Mariul [Mar yul], o de Rudoc, o de Utsang [dBus gtsan], e outros dois, que ficam para Oriente, e todos esses com o grande reino de Sopô [Sop po, Mongólia] que confina por uma parte com a China e por outra com a Moscóvia, fazem a Grão Tartária. É este império do Sopô grandíssimo e, segundo dizem, tem mais de cem régulos tributários." CARTA ânua de Antônio de Andrade, 1626. In: DIDIER, H. Os portugueses no Tibete. Os primeiros relatos dos jesuítas (1624-1635). Lisboa: Comissão Nacional pra Comemoração dos Descobrimentos Portugueses, 2000, p. 107.

${ }^{408}$ TOSCANO, G. Contributto dei missionari gesuiti del '600 alla conescenza della geografia del Tibete, dell'antica regione Tibeteana detta bon e del buddhismo Tibeteano. Estrato da Annali dell'Instituto niversitario Orientali. Volume 44. 1984. HEDIN, S.A. Central Asia and Tibet. Londres: Hurst and Blackett, vol. 1, 1903. HEDIN, S.A. Southern Tibet: discoveries in former times compared with my own researches in 1906-1908. B.R. Deli: Publishing Corporation, 1991. 
como um Preste João da Ásia - é claramente associada com a China. Isso nos leva a fazer uma pergunta muito importante: por que, depois de Matteo Ricci e Benedito de Goes, a Companhia enviaria Andrade (supondo que ele tenha sido enviado na sua segunda viagem ao Tibete, pois havia decidido ir sozinho na primeira) e outros dois jesuítas passando por Bengala - Cacela e Cabral - a esse lugar? E mais: por que era importante, na narrativa da carta e, posteriormente, durante a publicação, associar o Tibete ao cristianismo místico, mesmo que fosse para anunciar que não o haviam encontrado?

Em sua "geografia" - ou, em outras palavras, em sua tentativa de criar um espaço para o Tibete na concepção europeia do Oriente ou da Ásia - Andrade defendeu a importância estratégica da terra dos lamas e, consequentemente, a importância da própria missão no Tibete. Nesse lugar, ao norte do Império Mogol e perto da China, Andrade encontrara grandes reinos com a mesmo seita e que falavam quase o mesmo idioma. Embora ele ainda não tivesse conseguido encontrar cristãos, parecia estar perto do "cristianismo perdido" sobre o qual já se ouvia falar havia algum tempo.

Feitas estas considerações iniciais, gostaríamos de prosseguir e apresentar outro trecho da mesma carta:

Em todos estes reinos corre esta mesma seita Tibetense, sem diferença alguma de momento e com pouca na linguagem nos mais deles. É gente pela maior parte de boa natureza, pia e inclinada às cousas da salvação. Têm grande aversão e ódio à seita maometana; não se têm por gentios e, na verdade, são muito diferentes de todos aos de que (sic) tivemos notícia até agora. ${ }^{409}$

Observamos, portanto, que, para justificar a missão e, em seguida, propor um método ou aplicar a estratégia mais prudente e adequada de conversão, era necessário, antes de tudo, categorizar os budistas tibetanos. O primeiro passo seria inscrevê-los e alocá-los no mundo cristão e na História cristã.

Isso também quer dizer que encontramos nos relatos de Andrade uma descrição geopolítica intrinsecamente associada a uma geografia religiosa. As notícias que Andrade pretende fornecer estão acomodadas em um conhecimento ou tradição anterior. Ao mesmo

409 CARTA escrita por Antônio de Andrade, em 15 de agosto de 1626. In: DIDIER, H. Os portugueses no Tibete. Os primeiros relatos dos jesuítas (1624-1635). Lisboa: Comissão Nacional pra Comemoração dos Descobrimentos Portugueses, 2000, p. 107. Alguns anos depois, um outro jesuíta em visita ao Tibete escreverá uma descrição semelhante: "É a gente destas regiões do Pot, que quer dizer "terra de neve", nas feições e olhos achinada, nos rostos tão ajavada [...]. A índole é muito boa e branda. Nem são mouros, antes lhe[s] têm aversão, nem gentios, nem cristãos. A lei que têm errada da nossa divina teve seu princípio, mas como lhe foi dada escrita de mão e a foram por tantos séculos tresladando, foram dela tirando o que lhe[s] não pareceu a seu gosto e metendo infinitas patranhas." CARTA de Francisco de Azevedo, Agra, 1631. In: DIDIER, H. Os portugueses no Tibete. Os primeiros relatos dos jesuítas (1624-1635). Lisboa: Comissão Nacional pra Comemoração dos Descobrimentos Portugueses, 2000, p. 189. 
tempo, ele está preocupado com o seu leitor imediato (provavelmente seu superior), pois sua intenção é descrever uma missão em potencial, focando primeiramente em apresentar (ou representar) o Tibete como um reino não muçulmano. Em seguida, o missionário admite que o Tibete não era um reino cristão, mas que é possível que tivesse sido em algum momento.

O que vemos aqui pode ser entendido como uma reformulação dos cristãos de São Tomé, conforme exposto por Ines Zupanov:

A "descoberta" dos cristãos de São Tomé, permitiiu aos recém-chegados
tecerem uma legitimação genealógica, graças a um mito fundador, a fim de
se inscreverem no espaço indiano, mascarando as descontinuidades
geográficas e culturais, [transformando-as em] uma continuidade
espiritual. ${ }^{410}$

Afirmamos isso não porque os tibetanos tivessem sido de fato uma sociedade cristã, mas por causa do instrumento retórico que esta descrição pode representar. Uma vez que Andrade destaca que o Tibete não é um reino muçulmano e que, além disso, ele pode ter sido cristão no passado, o jesuíta estava, de certa forma, construindo uma ponte - retórica e política - que torna a missão possível e desejável. Essa descrição permite conceber no horizonte de possibilidades a conversão dos budistas tibetanos. Não obstante, a narrativa pode ser entendida como uma ponte que liga dois pontos no tempo: o cristão do passado e o futuro cristão, do mesmo modo que Koselleck nos apresenta o dualismo paulino em Futuro passado. ${ }^{411}$ Esse estado de coisas apresentado por Andrade é uma forma de antecipar a estratégia de conversão defendida por ele no futuro como a mais coerente e prudente para o povo tibetano.

\footnotetext{
410 "La "découverte" des chrétiens de Saint Thomas, (...) devait permettre aux nouveaux arrivés de se tisser une légitimation généalogique grâce à un mythe fondateur, afin de s'inscrire dans l'espace indien en masquant les discontinuités géographiques et culturelles par une continuité spirituelle". A autora diz ainda: «L'objectif des Portugais était donc défini comme un retour, une reconquête des lieux saints, une re-christianisation des espaces orientaux et une étape dans la re-fondation de la monarchie chrétienne universelle, le cinquième empire, quinto império." ZUPANOV, I. Une ville reliquaire: São Tomé de Meliapor. La politique et le sacré en Inde portugaise au XVI e siècle. <http://www.ineszupanov.com/publications/zupanov\%20Mylapore\%20Une\%20ville\%20reliquaire\%202002. pdf $>$.

411 "O dualismo paulino - de um lado todos os homens, do outro os libertados por Cristo - só permitia uma solução, para que esse paradoxo não continuasse a existir. A antítese tinha que ser estendida no tempo, tinha que ser temporalizada. O cristão, ou mais precisamente aquele que vive em Cristo, é o homem novo, que depôs o velho. Então, a totalidade - anterior - de todos os homens pode, por negação, ser confrontada com a potencial universalidade dos cristãos. (...) A negação paulina não é mais para ser entendida espacialmente, e sim, antes de tudo, temporalmente. (...) Esta implicação temporal distingue o dualismo paulino [dos demais anteriores a ele.]." KOSELLECK, R. Futuro passado: contribuição à semântica dos tempos históricos. Rio de Janeiro, Contraponto / PUC-RJ, 2006, p. 208.
} 
Em suas próprias palavras, Andrade conta-nos que "para essas pessoas, assuntos palpáveis e comuns são as melhores para serem persuadidas e convencidas do que as que detêm uma postura teológica e questionadora, pois desconhecem tais conceitos." ${ }^{412}$

Para os tibetanos devotados e de boa natureza, a atitude pacífica e a argumentação racional são as formas mais adequadas de conversão, o que transforma as disputas em um método prudente. Tal método satisfaria ao mesmo tempo a necessidade de convencer o rei e a de enfraquecer os lamas não apenas no aspecto teológico, mas também no político. ${ }^{413}$

Outro exercício retórico dos primeiros relatos sobre o Tibete e o lamaísmo tibetano relaciona-se à descrição dos lamas. Antônio de Andrade buscou descrever os sacerdotes budistas de forma a aproximá-los do clero cristão, acentuando as semelhanças e esmaecendo as diferenças:

Os lamas são os seus sacerdotes, muitos e em grande número. Uns vivem em comunidade como os nossos religiosos, outros em suas casas particulares, como clérigos entre nós. Todos, porém, professam pobreza e vivem de esmolas. É gente de muito bom viver, não se casam, ocupam-se a maior parte do dia em rezar, e pelo menos o fazem pelas manhãs, por espaço de duas horas, e à tarde, outro tanto. Cantam a nosso modo suavemente, como cantochão entre nós. O pai que tem dois filhos faz um desta profissão dos lamas. O próprio rei tem um irmão também lama (...). Parece gente muito mansa e, até nos seculares se ouvirá raramente uma palavra mal soante. Têm casas de oração como as nossas igrejas, mas muito limpas, pintadas pelos tetos e paredes; e com serem em suas pessoas e vestidos pouco limpos, geralmente no que toca às igrejas, as têm de sobremaneira limpas; as imagens são de ouro, e uma que vimos em Chaparang estava assentada com as mãos levantadas; representava uma mulher, que eles dizem ser a mãe de Deus. E assim reconhecem o mistério da Encarnação, dizendo que o Filho de Deus se fez homem; e tem mais o mistério da Santíssima Trindade, mui distinto, e dizem que Deus é Trino e Uno. Usam de confissão, mas em certos casos somente com o seu lama-maior. Têm vasos de água benta muito limpos, da qual levam os particulares para a sua casa. Usam certos lavatórios que parecem representam o santo

412 CARTA ânua de Antônio de Andrade, Tibete, 1626. In: DIDIER, H. Os portugueses no Tibete. Os primeiros relatos dos jesuítas (1624-1635). Lisboa: Comissão Nacional pra Comemoração dos Descobrimentos Portugueses, 2000, p.126.

${ }^{413}$ Em comparação com a experiência jesuíta na América, é possível notar, por exemplo, que o problema da Lei da Natureza ou a questão da racionalidade não está em debate. Nem a sobrevivência material da missão, que possibilita que os missionários mantenham alguma distância das questões comerciais, administrativas e financeiras. Do mesmo modo, outras estratégias - a organização do trabalho, por exemplo - seriam inadequadas para a sociedade tibetana "civilizada": Andrade não faz referência a qualquer tentativa de reunir alguns tibetanos em uma comunidade. Assim, de forma semelhante ao que pode ser observado na experiência de Francisco Xavier na China e no Japão, bem como nos escritos de Rodolfo Acquaviva sobre os possíveis cristãos, Andrade usa a categoria "povo devotado", análogo à "gente discreta" do primeiro e "bom caráter" ou "boa índole" e "dado a obras piedosas" do segundo. Essas expressões se encontram, respectivamente, na carta de Xavier de 29 de janeiro de 1552 e na carta de Rodolfo Acquaviva de 1582. Sobre a expressão "gente discreta", sugerimos a leitura de PREVATTO, A. Conversão à comunicação: a trajetória do missionário que foi São Francisco Xavier. 1542-1552. 2010. 192 f. Dissertação de Mestrado apresentada ao programa de pós-graduação em História Social. Universidade de São Paulo, 2010. 
batismo. Tem a lei dos mouros por abominável e zombam muito da do gentio. ${ }^{414}$

Propomos que esse exercício retórico de aproximação se deu, no texto, de duas formas. A primeira de forma mais direta, através da comparação simples, marcada pela preposição "como". Assim, o jesuíta é capaz de traçar ele mesmo uma analogia entre algo a ser descrito e algo familiar ao leitor, como, por exemplo, no caso da passagem "Têm casas de oração como as nossas igrejas". Defronte a um mosteiro, ou a um lugar de oração, o jesuíta abriu mão de usar palavras como "templo" ou "pagode" e optou por aproximá-las das "casas de oração" das igrejas cristãs. O mesmo processo é repetido em referência ao entoar de mantras dos lamas, possivelmente identificado pelo jesuíta como "cantar": "Cantam a nosso modo suavemente, como cantochão entre nós".

Outra forma menos direta e um pouco mais sutil de aproximação entre o clero budista e o cristão é a identificação de práticas cristãs dentre os lamas. Andrade ressalta que os sacerdotes tibetanos "professam pobreza e vivem de esmolas" e "não se casam, ocupam-se a maior parte do dia em rezar", identificando assim algo como os "votos" de pobreza e celibato feitos pelos padres e monges cristãos.

O mesmo recurso aplicado às práticas acima é desdobrado para os sacramentos e a "doutrina" budista. Andrade é capaz de identificar a confissão e o batismo entre os tibetanos. Além disso, ele reconhece os mistérios da encarnação e da santíssima trindade na "seita dos lamas".

Nossa hipótese é que esse exercício retórico tem como finalidade apresentar o Tibete como um terreno favorável à missionação, justificando o investimento da Ordem na missão no reino de Gugê. A negação da presença muçulmana, a boa natureza e devoção dos tibetanos e a semelhança entre seus sacerdotes e o clero cristão são indícios inseridos na narrativa de forma a viabilizar epistemologicamente a criação de um lugar e de uma história para o Tibete, bem como assegurar retoricamente que estes sejam assistidos por uma missão da Companhia de Jesus.

\footnotetext{
${ }^{414}$ CARTA de Antônio de Andrade, Agra, 8 de novembro de 1624 In: DIDIER, H. Os portugueses no Tibete. Os primeiros relatos dos jesuítas (1624-1635). Lisboa: Comissão Nacional pra Comemoração dos Descobrimentos Portugueses, 2000, p. 98-9.
} 
3.6 DA DESCRIÇÃO ÀS ESTRATÉGIAS: AS DISPUTAS TRAVADAS COM OS LAMAS NO TIBETE

Uma vez de volta a Tsaparang, em agosto de 1625, Andrade envia uma carta ao seu superior. Nesta ânua de 1626, Andrade dá notícias da missão, iniciando pela descrição do Tibete e dos lamas, às quais fizemos referência nas páginas anteriores. Agora, passaremos a abordar as disputas descritas na mesma missiva, em associação a uma outra carta, escrita em $1628 .^{415}$

Andrade afirma que o rei ficou muito feliz com a notícia de seu retorno ${ }^{416}$ e mandou lhe buscarem no caminho, enviando três cavalos, "um em particular de singular andadura para me trazer". ${ }^{417}$ Segue, então, uma lista dos presentes dados pelo rei para demonstrar ao leitor sua generosidade para com Andrade. Entre eles, podemos citar uma capa de lã, vinho, carneiros, manteiga, entre outros. O rei também dispensou Andrade de passar na alfândega na entrada da cidade. O discurso do missionário enfatiza o apoio do soberano, chegando a comportar a narrativa de um episódio no qual o jesuíta reclama da casa onde deveria ficar: manda dizer ao rei que é muito pequena, ao que o soberano responde que as maiores foram danificadas no inverno, mas que já seriam consertadas. Andrade lamenta então a localização, dizendo ter ficado "longe do paço", isto é, distante do centro do poder local. ${ }^{418}$

Sobre o encontro com o rei, o missionário diz que chegara na segunda-feira e foi recebido no sábado

com grande benevolência e amor, dizendo [o rei] que já estava triste por lhe dizerem que este ano não havíamos de vir, e como estava de caminho para uma guerra de grande risco, nos pediu que o encomendássemos a Nosso Senhor. [...] A outro dia, em que partiu, nos mandou chamar [...] e se pôs de joelho e eu lhe rezei os Santos Evangelhos, tendo ele o missal sobre a cabeça [...] e ao pescoço levou uma cruz. ${ }^{419}$

Andrade prossegue, indicando a predileção do rei por ele em detrimento de outros estrangeiros:

fomos o acompanhando até sair da cidade, em companhia da rainha, e estando já para cavalgarem se despediu de nós com grande cortesia, o que

\footnotetext{
${ }^{415}$ CARTA de Antônio de Andrade, Tsaparang (Tibete Ocidental), 1628. ARSI, Goa 73, ff: 47-48v.

416 Parece-nos que Andrade retoma na carta os acontecimentos desde seu estabelecimento no Tibete, no ano de 1626.

417 ARSI, Goa 73, fl.47r.

${ }^{418}$ CARTA de Antônio de Andrade, Tsaparang (Tibete Ocidental), 1628. ARSI, Goa 73, fl.47v.

419 Ibidem, loc. cit.
} 
não fez de outra pessoa alguma, estando presentes muito caxemires, e outra gente estrangeira. ${ }^{420}$

O português diz ainda ter se oferecido para acompanhar o rei em sua viagem, mas o soberano recusa, dizendo que não há lugar e que, por estarem cansados da recente viagem, "não nos queria [os missionários] dar outro trabalho de novo". ${ }^{421}$

Indicada a relação próxima entre o ele e o rei, o jesuíta relata ainda que um lama “que são seus eclesiásticos" ${ }^{422}$ - os visitou. Foi então que se deu este diálogo:O jesuíta perguntou-lhe quantos deuses adoravam, ao que o lama lhe respondeu "um somente, que era trino". ${ }^{423}$ Perguntou-lhe também se Deus tinha filho. "Sim, e que este filho se fizera homem, e que depois morrera e se fora para o céu, e lá estava com seu pai”, teria respondido o lama. ${ }^{424}$

Perguntou-lhe ainda se esse filho era Deus como o Pai, ao que o lama responde que sim, "mas que juntamente era homem". ${ }^{425}$ Indagou se sua mãe era mulher ou não, e o lama responde que sim, e "que também fora para o céu e que lá estava". ${ }^{426}$

Então Andrade questiona o lama sobre quantos anos havia que o filho de Deus morrera e qual era a causa de sua morte. O religioso budista responde que havia 1600 anos de sua morte, "pouco mais ou menos [...] e que ele já havia dito tudo o que sabia". ${ }^{427}$

De forma análoga ao que propusemos para o caso da missão do Mogol, nossa hipótese aqui é a de que as supostas respostas dos lamas têm a mesma função que os predicados atribuídos aos tibetanos, analisados na sessão anterior. As declarações atribuídas ao religioso budista reiteram a potencialidade da missão, aproximando a seita dos lamas do cristianismo.

Andrade aborda ainda outras disputas travadas com os lamas.

Neste tempo tratei de visitar o mesmo Rei e mui de propósito armei questões com os seus lamas diante dele, para que, vendo sua ignorância, lhe ficassem servido de laço a eles mesmos, e de meio para o rei se livrar melhor do que eu armava.

Em todas estas disputas ficaram sempre corridos e envergonhados e, quando não mais sabiam, davam em zombar, mas tudo isto lhe arguia diante do mesmo Rei. Por muitas vezes tendo entrado em disputas, fingiram e trataram varias coisas para o divertir, outras usavam na prática de palavras que eu não pudesse entender, e como se feito as não entendia, ajuntavam que era necessário primeiro saber a língua tibetense e então ficariam eles e eu satisfeitos. (...)

${ }^{420}$ CARTA de Antônio de Andrade, Tsaparang (Tibete Ocidental), 1628. ARSI, Goa 73, fl.47v.

421 Ibidem, loc. cit.

422 Ibidem, fl.48r.

423 Ibidem, loc. cit.

424 Ibidem, loc. cit.

425 Ibidem, loc. cit.

426 Ibidem, loc. cit.

427 Ibidem, loc. cit. 
Foi a primeira [disputa] sobre esse ponto: que coisa era Deus. Dizem eles que Deus é trino e uno. Porém, no modo de explicar ajuntam coisas ridículas. Chamam a deus "Lama conjoe [bLa ma dKon mc'og], que é a primeira pessoa; a segunda, "Chô conjoe" [C'os dKon mc'og], quer dizer livro grande; a $3^{\text {a }}$ (sic), "Sanguyâ conjoe" [Sans rgyas dKon mc'og], que quer dizer "ver e amar na glória". Perguntei se esta $2^{a}$ pessoa, que chamam Chô conjoe, Livro grande de Deus, era o livro por onde liam e que traziam entre as mãos; responderam que sim. Pois, digo, "este livro que aqui tendes e está embrulhado neste pano é Deus? Como pode ser se ele não tem vida e é como uma pedra ou pau, e se botardes na água ou no fogo se desfará brevemente, sendo Deus vivo, eterno e imutável. Mais, a este fez o escrivão que o escreveu e não consta de outra coisa que de papel e tinta, sendo Deus o que tem de si o ser e o dá a todas as coisas, nem este que me pode fazer de mal ou de bem, pois não tem sentido nem poder. Botado no caixão, aí está e estará em bulir consigo e quanto vós não bulirdes, sendo Deus vivo, eterno, que a tudo está presente, tudo entende e governa, e tudo sucede por ordem e governo seu.

Ficaram olhando uns pera os outros sem saberem que responder (...). Porque para esta gente as [ideias] palpáveis e ordinárias são as melhores para os persuadir e convencer, que outras teológicas e especulativas, nem as entendem, nem lhe armam seus termos, porque sabem muito pouco. ${ }^{428}$

Sobre este extrato, gostaríamos de fazer algumas considerações. Em primeiro lugar, indicamos que, em concordância com que foi dito acima, logo no início de sua narrativa, Andrade indica que as disputas deveriam ocorrer na frente do rei. Isso era proposital e não poderia ser deixado ao acaso. Fica evidente, portanto, o caráter político da estratégia de conversão, que visava convencer a cabeça da comunidade a partir do descrédito de seus sacerdotes ou preceptores espirituais.

Outro ponto interessante é certo aspecto dialético da estratégia que Andrade busca indicar: utilizar-se dos erros dos lamas para demonstrar que a sua crença está equivocada e a dele (Andrade) certa. Isso pressuporia a capacidade de Andrade de identificar quais seriam os principais "erros" da seita dos lamas. A seguir, quando abordarmos os temas das disputas, perceberemos que o missionário parece ter encontrado de fato tais "desvios". Ainda que em seus relatos a descrição do budismo não seja tão complexa quanto a feita por Desideri, a crença em transmigração de almas é identificada pelo português, por exemplo.

Percebemos também que Andrade se dá ao trabalho de reconhecer a crítica que lhe é feita - que ele deveria aprender a língua - mas parece não fazer muito caso disso. Ao contrário, atribuía aos lamas o uso capcioso de construções e palavras como artifício para

428 CARTA ânua de Antônio de Andrade, Tibete, 1626. In: DIDIER, H. Os portugueses no Tibete. Os primeiros relatos dos jesuítas (1624-1635). Lisboa: Comissão Nacional pra Comemoração dos Descobrimentos Portugueses, 2000, p.125-6. Grifo nosso. 
dificultar o seu entendimento. ${ }^{429}$ Mais uma vez, de forma semelhante ao que questionamos sobre a missão do Mogol, isso pode nos deixar uma dúvida: teria o jesuíta ganho a oportunidade de participar de um debate com os lamas ou teria ele mesmo proposto o debate, tal qual é afirmado no texto? Pela sugestão dos lamas, parece-nos que os lamas se dispuseram a permitir que Andrade participasse de sessões de debates e formulasse perguntas por terem o reconhecido, a princípio, como um preceptor espiritual.

Por último, fica explícita a dificuldade do missionário em entender o que ele assemelha ao mistério da Santíssima Trindade. Assim, parece-nos que a consideração final (de que as ideias "palpáveis e ordinárias são as melhores para os persuadir e convencer, que outras teológicas e especulativas, nem as entendem, nem lhe armam seus termos, porque sabem muito pouco") diz mais respeito às evidentes limitações de compreensão do missionário do que às supostas fragilidades da "teologia" tibetana. Ao contrário do que pôde ser observado no Mogol, a missão do Tibete não foi antecedida por séculos e séculos de disputas, apologias e intercâmbios filosóficos entre cristãos e os "outros" (muçulmanos para o caso da Índia e "budistas" para o caso do Tibete). ${ }^{430}$

Em outro momento, Andrade volta a disputar com os lamas. O tema da transmigração das almas foi debatido. A questão da reencarnação parece ser uma constante nos diálogos entre cristãos e budistas tibetanos, e surgem nos escritos dos missionários da primeira e da segunda missão no Tibete.

O debate se inicia com considerações sobre o que se sucede após a morte de um homem. Os lamas, segundo Andrade, defendem que existem três grupos de homens. Os do primeiro grupo "são muito bons e sem pecados, estes morrendo vão diretos ao Céu." 431 Já os homens "muito maus, cheios de vícios e pecados, se vão ao inferno." ${ }^{432}$ Porém, entre um grupo e outro existe um intermediário, de homens "que fazem pecados, mas que também fazem boas obras. (...) Estes morrendo tornam suas almas a entrar em corpos de outros animais. $" 433$

Exposto o tema e as ideias principais dos lamas sobre transmigração de almas, Andrade começa a fazer perguntas aos lamas. Na primeira delas, questiona se as almas

\footnotetext{
${ }^{429}$ Veremos no próximo capítulo que Desideri foi mais feliz em reconhecer e aprender mais sobre a língua e a dialética - isto é, a forma de disputar - dos lamas tibetanos.

${ }^{430}$ No capítulo seguinte ficará mais evidente a complexidade da "dialética" e da "teologia budista", na medida em que o missionário Ippolito Desideri se aprofunda nos estudos dos livros dos lamas.

${ }^{431}$ CARTA ânua de Antônio de Andrade, Tibete, 1626. In: DIDIER, H. Os portugueses no Tibete. Os primeiros relatos dos jesuítas (1624-1635). Lisboa: Comissão Nacional pra Comemoração dos Descobrimentos Portugueses, 2000, p. 127.

432 Ibidem, loc. cit.

433 Ibidem, loc. cit.
} 
"entravam em todos os animais, elefantes, bois, leões, tigres, e se também em moscas, formigas e outros desta qualidade." ${ }^{434}$ Os lamas responderam que sim, que as almas entravam em "toda sorte de viventes, segundo a qualidade das culpas que tinham feito: os muito pecadores em animais piores, como tigres, cobras, ratos; os melhores em animais de mais estima, como em corpos de homens". ${ }^{435}$ Andrade não deixa de mencionar que alguns retornam "segundo os estados que antes tiveram, v.g., os reis tornavam a ser reis, os lamas lamas, os pobres pobres, os ricos ricos. ${ }^{\$ 36}$

O missionário pergunta então por que "tornavam a nascer nesta forma" e se "tornando a morrer, iam alguns ao Céu." ${ }^{437}$ A isto, segue-se uma resposta um tanto confusa, que servirá para o argumento de crítica de Andrade. Os lamas teriam respondido que os homens:

muito maus, ainda que do Inferno tornavam à vida, era depois de muitas centenas de anos lá penarem, porém que os outros tornavam muitas vezes, pera que fazendo mais pecados se fossem ao Inferno penar. Perguntei no terceiro lugar se todos nós tínhamos já nascido outras vezes e parecia que sim, pois Deus, segundo diziam, não criava de novo, mas aquela criação que no princípio se fez, se ia renovando ou revezando de uns em outros, como tinham dito. Deram por resposta que assim era.

Andrade cessa então as perguntas e inicia suas considerações:

"Ora vede agora", digo, "quão evidentemente estais enganados: primeiramente, se Deus tornasse a introduzir as almas em outros corpos a fim de fazerem mais pecado e se irem ao Inferno, ele se poderia chamar causa primeira e autor dos tais pecados e em Deus nem sombra deles pode haver; e que culpa têm nos pecados aqueles que, a fim só de os fazerem Deus fez tal qualidade? Mais, se os que tornam à vida são para fazerem mais pecados e se irem ao inferno outra vez e nenhuns (sic) ao Céu, logo dos que agora vivem nenhuns (sic) podem ir ao Céu, pois, conforme ao que tendes dito, todos temos nascidos já outras vezes e agora vivemos para fazermos mais pecados e na morte irmos ao inferno ou tornamos à vida a nascermos em outros corpos. ${ }^{438}$

Podemos perceber que o missionário inicia suas críticas no terreno do debate teológico. Ele infere que, se as almas retornam em novos corpos para voltarem a pecar, então seria plausível deduzir que Deus seria a causa primeira de tal pecado. Esse desenvolvimento lógico parece partir da premissa que "os que tornam à vida são para fazerem mais pecados e se irem ao inferno outra vez" e "nenhuns (sic) ao Céu", logo: "dos que agora vivem nenhuns

\footnotetext{
434 CARTA ânua de Antônio de Andrade, Tibete, 1626. In: DIDIER, H. Os portugueses no Tibete. Os primeiros relatos dos jesuítas (1624-1635). Lisboa: Comissão Nacional pra Comemoração dos Descobrimentos Portugueses, 2000, p. 127.

435 Ibidem, loc. cit.

436 Ibidem, loc. cit.

437 Ibidem, loc. cit.

438 Ibidem, p.127-8.
} 
(sic) podem ir ao Céu", isto é, que nenhuma alma que volta a viver é salva. Mesmo cientes dos nossos limites quanto ao debate de ideias teológicas, uma vez que não é esse o objeto da tese, nesse caso específico, supomos ser pertinente lançarmos algumas questões: qual teria sido o motivo de Andrade ter formulado dessa forma a questão da transmigração das almas? Por que ele conclui que nenhuma dessas almas pode ir ao Céu?

A primeira hipótese é que ele teria formulado assim justamente para enfraquecer o argumento dos lamas e indicar o cristianismo como o único meio de salvação. No entanto, essa hipótese nos parece frágil, pois sabemos que, qualquer que fosse o entendimento de Andrade sobre o budismo, essa seria a sua resposta. Isso posto, por que insistir que nenhuma alma se salva?

Nossa segunda hipótese, complementar à primeira, é que pode ter havido um problema formal no desenvolvimento do debate. Um problema lógico, de concatenação de argumentos. Supomos que Andrade teve dificuldade de entender o formato do discurso dos lamas e sua forma de demonstrar premissas e conclusões. O que buscamos propor é que, para além de divergências teológicas, houve um problema retórico, formal. Andrade deparou-se com uma espécie de silogismo com o qual não estava acostumado a raciocinar. Não se trata apenas de uma questão de tradução, mas sim de uma questão de dialética. Isso significa dizer que o missionário, naquele momento, é metonímia do cristianismo em dois níveis: em sua forma de pensar e em suas ideias. No caso do debate acima, a "confusão" deu-se, portanto, em ambos os níveis. ${ }^{439}$ Deus não poria as almas nos corpos com a finalidade (a fim de) de pecarem, não podendo ser, portanto, causa primeira desses pecados. Mas parece que o missionário português entendeu justamente o contrário.

O motivo que julgamos necessário enfatizar esse ponto e levantar as hipóteses acima é porque gostaríamos de indicar uma questão de método. Andrade julgou apropriado ou prudente disputar com os lamas. Mas não nos deu indícios de que ele teria se preparado para tal. Isso indica que seu objetivo pode não ter sido superar os lamas em sua dialética "budista", mas tão somente apontar incoerências em seu discurso, de forma a enfraquecê-los perante o rei. Ou seja, o alvo do convencimento não são os lamas, mas a audiência, isto é, o soberano.

Esta nossa hipótese é reforçada com o prosseguimento da argumentação de Andrade:

\footnotetext{
${ }^{439}$ Em sua Notícia Histórica - fonte a ser analisada a seguir - Desideri dedica assim entitula seu XV capítulo de se segundo livro: "Delle lettere e alfabeto de' Thibetani e abilità di quelle genti agli studj e alle arti". Quando Desideri expõe suas dificuldades sobre o idioma e a forma de debater dos lamas, ele nos diz que "Nelle materie poi scolastiche, dispute, e argomenti, antecipano la conseguenza e pospongono l'antecedente, essendo il loro entimema e argomento a maniera d'una proposizione causale". DESIDERI, I. La relazione di Ippolito Desideri, apud: PETECH, L. I missionari italiani nel Tibet e nel Nepal. Libr. dello Stato, vol. VI, DR. 2, 1952, p 95.
} 
Ouço-vos [os lamas] cada hora dizer que esperais de ir ao Céu, e que os lamas em morrendo quase todos vão ao Céu, e assim aconselhais aos seculares que morrem que façam grandes esmolas aos lamas, porque fazendo-as se salvem, e a esta conta lhe dizeis que as façam grande, ainda que fiquem seus filhos sem nada, à conta de segurarem a salvação. Logo, ou lhe[s] não falais a verdade e os enganais, ou podem eles ir ao Céu se fizerem o que convém. ${ }^{440}$

Nesse momento, o missionário está no limite do debate teológico. Seu interesse é insinuar a má fé dos lamas, ou, por outro lado, a possibilidade de salvação de todos por meio da Verdadeira Lei (que ele ainda não trouxe ao discurso). Novamente, supomos que o objetivo da fala é desacreditar os lamas antes de demonstrar a superioridade do cristianismo.

O terceiro argumento de Andrade retoma questões teológicas. Para ele, "se quando morremos entram nossas almas nos animais para fazerem mais pecados, logo há neles perfeito conhecimento para discernirem que fazem mal ou bem quando obram, pois não pode haver pecado aonde não há conhecimento do mal." ${ }^{441}$

O missionário lança mão de uma das potências da alma - o entendimento - para dar sequência ao debate. A esta questão, os lamas admitem haver entendimento nos animais, pois "mostrando a erva verde ao carneiro, vinha correndo e por outra parte fugia o pássaro por temor de lhe fazerem mal (...) por entenderem o mal que lhe podia vir." 442

A isto, responde o português: "como podem ter entendimento para o que dizeis e que não tenham memória para se lembrar do que fizeram outras vezes quando andaram cá na vida?" ${ }^{443}$ Mais uma vez, o debate teológico se mistura com a abordagem política de Andrade:

Se El-Rei, que aqui está presente, já veio outras vezes ao mundo, por que se não lembra em que animal apareceu, e de alguma das coisas que então fez (...)? E devia de se lembrar, pois memória é potência da alma, que sempre em toda parte a acompanha. ${ }^{444}$

Observamos neste extrato dois elementos estruturais da estratégia de disputa do missionário. O primeiro deles é, sem dúvida, o arcabouço tomista que sustenta e perpassa toda a sua argumentação. Esse é um dado referente ao conteúdo do debate. Associado a ele, percebemos um segundo elemento, que se remete à estrutura do debate: o endereçamento da fala ao rei e sua implicação no conteúdo do que está sendo dito. O soberano, nesse momento,

\footnotetext{
440 CARTA ânua de Antônio de Andrade, Tibete, 1626. In: DIDIER, H. Os portugueses no Tibete. Os primeiros relatos dos jesuítas (1624-1635). Lisboa: Comissão Nacional pra Comemoração dos Descobrimentos Portugueses, 2000, p. 128.

441 Ibidem, loc. cit.

442 Ibidem, loc. cit.

443 Ibidem, p. 129.

444 Ibidem, loc. cit.
} 
é ao mesmo tempo o alvo da disputa e o objeto da questão. Implicar o rei no debate significa que, para além de uma disputa teológica, toma lugar um embate político.

Finalmente, Andrade apresenta pela primeira vez o cristianismo de forma direta: "para remédio a nossos pecados" afirma o missionário, Deus "fez seu Filho homem, e que morresse por nós todos à força de tantos tormentos". ${ }^{445}$ A salvação residia ali, no mistério da encarnação, e não na crença na reencarnação.

O efeito desta fala, Andrade não nos diz. Ele informa apenas que

Neste ponto foi um largo discurso, mas o que por remate de tudo se colheu foi responderem ao rei, que os apertava com estas e outras razões, que eu tinha razão, mas que o seu livro dizia que as almas tornavam cá outra vez, e que o livro não podia estar errado. ${ }^{446}$

Evidentemente, essa seria a "deixa" para que o missionário concluísse que "se o vosso livro diz isso, sendo tanto contra o entendimento, logo deveis de crer que não é de Deus, porque o livro de Deus não contém nem ensina coisas contra a razão". ${ }^{447}$ Depois de buscar o descrédito dos próprios lamas, Andrade extrapola a desconfiança à fonte da doutrina budista. Porém, ele faz uma espécie de ressalva temporal: "se este vosso [livro] alguma hora foi livro de Deus, agora vai fora de caminho". ${ }^{448}$ Fica implícita a ideia de um primeiro momento possivelmente cristão, prejudicado pelo contato com as gentilidades vizinhas: "Sem dúvida, muitas coisas destas se vos pegaram dos gentios vizinhos, porque eles dizem que há esta transmigração de almas para vários corpos, com vós." ${ }^{449}$ Mas não seria apenas este um "erro de mistura". A interdição de matar e comer carne, presente no que viria a ser chamado de hinduísmo, também seria algo de que os tibetanos se apropriaram. Para os gentios vizinhos, matar animais é pecado, bem como comer carne, mas "vós discrepais, porque tendo o primeiro por pecado, comeis a carne sem escrúpulo, achando que o pecado fica só com o criado que matou tal animal." ${ }^{450} \mathrm{E}$ continua: "uma coisa sinto daqui muito e é que vós lamas sois ocasião de se fazerem imensos pecados porque não o sendo matar animais, fazeis crer

445 CARTA ânua de Antônio de Andrade, Tibete, 1626. In: DIDIER, H. Os portugueses no Tibete. Os primeiros relatos dos jesuítas (1624-1635). Lisboa: Comissão Nacional pra Comemoração dos Descobrimentos Portugueses, 2000, p. 129.

446 Ibidem, loc. cit.

447 Ibidem, loc. cit.

448 Ibidem, loc. cit.

449 Ibidem, p. 130.

${ }^{450}$ Ibidem, loc. cit. Desideri, no século seguinte, também vai observar esta questão da interdição de matar animais, cujas consequências ele percebe refletidas na organização social tibetana: "Non v'è tra loro diversità di casti, o sai di tribù, ma tutti hanno recíproco tratto com tutti (...). Solamente abborriscono e fuggono la conversazione de' macellari, i qualli insieme o son carnefici o son considerati como tali, quasi persone spietate, perchè ammazzano gli animali. A questo non permettono gli altri d'entrar nelle loro case, nè che bevano nelle tazze, o mangino de vase loro.” DESIDERI, I. La relazione di Ippolito Desideri, apud: PETECH, L. I missionari italiani nel Tibet e nel Nepal. Libr. dello Stato, vol. VI, DR. 2, 1952, p. 82. 
que o é, e, por conseguinte, [fazer crer] que pequem os que tal fazem." ${ }^{451}$ Feita essa pontuação de uma suposta incoerência entre as ideias e as práticas dos lamas, Andrade mais uma lança mão do recurso de trazer para o debate a figura do rei: "E como podeis crer que carreguem tantos pecados sobre El-Rei, que está presente, quantas são as vacas e carneiros que se matam em sua casa em que ele consente. ${ }^{\$ 452}$ Mas o salto de um argumento no campo doutrinário para considerações no campo da política, isto é, de como deve um soberano se comportar, não se encerra com essa consideração. O missionário vai ainda mais longe, dizendo que defender que matar animais é pecado, quando isto não é verdade,

é converter em peçonha mortal as mercês de Deus, mas não há que se espantar, pois também dizeis que ir o Rei à guerra ou mandando sua gente para se defender de quem lhe entrar as terras é pecado e quereis que se deixe estar com as mão amarradas ou que lhas venham amarrar sem ele as bolir. ${ }^{453}$

A consequência deste último discurso não seria diferente da esperada. Andrade encerra a narrativa das disputas demonstrando ao leitor como, pelo uso da retórica, ele teve sucesso em convencer o rei de que tinha razão. "Festejou [o rei] este modo de falar e disse aos que estavam presentes que bruto se devia chamar quem tal dissesse e que o padre em tudo o que

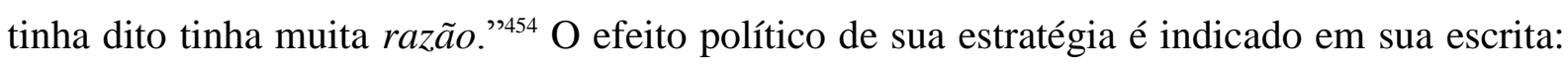
"Foram várias as práticas desta matéria e de outras semelhantes e el-Rei tornou a sua casa tão afeiçoado a nossas coisas como primeiro, zombando e menoscabando em público os costumes e ritos de seus lamas." ${ }^{455}$

Em consonância com o que procuramos propor na primeira parte de nossa tese, aqui também defendemos que os jesuítas mostraram para o leitor como forneceram elementos retóricos eficazes de forma a instrumentalizar o representante do poder temporal local em suas disputas políticas particulares com os representantes do poder secular local. Se, no caso de Akbar, o Mogol buscava esmaecer o peso político dos mulas - e, por consequência, equilibrar o jogo de forças entre muçulmanos e outros crentes, como hindus e jainistas - no caso do reino de Gugê, Andrade demonstra conseguir "armar" o rei de razões para desacreditar os lamas.

Mais uma vez, a veracidade do relato é algo passível de discussão. Evidentemente, é necessário desconfiar da euforia do jesuíta português. Porém, o que principalmente nos

451 CARTA ânua de Antônio de Andrade, Tibete, 1626. In: DIDIER, H. Os portugueses no Tibete. Os primeiros relatos dos jesuítas (1624-1635). Lisboa: Comissão Nacional pra Comemoração dos Descobrimentos Portugueses, 2000, p. 130.

${ }^{452}$ Ibidem, loc. cit.

453 Ibidem, loc. cit.

454 Ibidem, loc. cit.

455 Ibidem, loc. cit. 
interessa aqui é perceber de que maneira o relato é construído, em especial para o público constituído de companheiros da Ordem e europeus no geral. Foi possível perceber que a audiência virtual - isto é, o leitor, aquele que não estava presente de fato à disputa - é convencido da eficácia da estratégia dialógica e da retórica de Andrade. Essa eficácia, no entanto, não se deu no campo estritamente teológico. Não são os lamas que saem convencidos da superioridade do cristianismo ou da "Verdadeira Lei". Ao contrário, o sucesso da estratégia é mensurado pelo fato de que a afeição do rei ao padre e as suas coisas aumentou em detrimento da proximidade do régulo tibetano com os lamas. É também no terreno da política que se pretende a salvação das almas.

A continuação da análise da mesma fonte permite-nos reforçar a nossa hipótese de que a opção por uma estratégia que mesclasse política e retórica foi priorizada na primeira missão jesuíta no Tibete. Em outra oportunidade, Andrade teria perguntado ao rei "que faziam os seus lamas para alcançar o céu?". ${ }^{456}$ A pergunta por si só já surge carregada de indícios do entendimento que o missionário tinha da organização político-social tibetana e da maneira que ele julgaria apropriada para se aproximar do soberano de Gugê. Percebemos que, em primeiro lugar, Andrade dirige a pergunta ao rei, e não aos próprios lamas. Em segundo lugar, no relato escrito do jesuíta aparece o pronome possessivo seus. Supomos que esta expressão - "seus lamas" - sugere duas ideias: uma distinção do tipo nós $x$ eles (padres cristãos x lamas tibetanos), ou que a mesma expressão insinue uma hierarquia entre o rei e os lamas, como se os últimos fossem sacerdotes do rei, de alguma forma subordinados a ele.

A resposta do régulo surge da seguinte forma no relato de Andrade: "Vós não vedes? Rezam e dizem que jejuam, mas seu jejum é para engordarem." ${ }^{457}$ Supondo que a tensão entre os lamas e o rei estivesse próxima do seu mais alto grau, ainda assim a fala de Thi Tashi Dagpa parece-nos por demais adequada ao discurso do missionário.

A resposta surge como uma espécie de confirmação, na narrativa, deste conflito entre o poder temporal e o secular no reino de Gugê, na mesma medida em que indica uma confirmação da estratégia de Andrade. Seria o mesmo que dizer que o rei estaria descontente com os lamas. Mas o missionário escolhe inserir, em seu relato, uma fala supostamente do próprio rei para passar essa ideia ao leitor. É na voz de Thi Tashi Dagpa, em seu diálogo com o missionário, que a insatisfação com o clero budista aparece, não numa constatação do

456 CARTA ânua de Antônio de Andrade, Tibete, 1626. In: DIDIER, H. Os portugueses no Tibete. Os primeiros relatos dos jesuítas (1624-1635). Lisboa: Comissão Nacional pra Comemoração dos Descobrimentos Portugueses, 2000, p. 130. Grifo nosso.

457 Ibidem, loc. cit. 
jesuíta. Julgamos que, de forma semelhante ao que foi dito nos capítulos anteriores, o método dialógico objetiva, certamente, o convencimento do interlocutor não cristão. Porém, ele também surge para o leitor, via obra escrita, com o objetivo de ratificar a descrição da sociedade em questão e a escolha da estratégia de conversão.

Seguem-se, no relato, as considerações de Andrade após a resposta do rei:

é bem que pondereis a forma de sua [dos lamas] reza e das obras que fazem e por elas podereis entender qual seja o seu livro que tal ensina. Vós não vedes que, quando rezam, parecem cegos, contando grandes lendas, divertindo-se para várias coisas sem consideração alguma que falam com Deus e cometendo mil descortesias. Pois o seu jejum não é só de nome e zombaria, almoçando duas vezes muito bem pela manhã e comendo ao meio-dia carne e outras coisas até não poder mais, e à tarde fruta, nozes, passas, doce, e outras coisas, bebem leite, daim, etc e no cabo acham ser jejum, que quer isso dizer? Jejum para que coma? $?^{458}$

Neste extrato, Andrade aponta que o rei faz bem em "ponderar" os hábitos dos lamas e, por conseguinte, relativizar a verdade de seu livro. Porém, ele também fornece ao leitor uma descrição menos generosa dos lamas, um tanto distinta da sua postura até então, que enaltecia as semelhanças entre os sacerdotes tibetanos e os cristãos.

Parece-nos que, nos momentos em que é conveniente traçar uma espécie de genealogia entre cristandades antigas e a seita dos lamas, criando uma espécie de fundação retórica mítica da missão, o missionário julga oportuno enaltecer as semelhanças e silenciar as diferenças. Neste caso, o endereço primordial da mensagem de Andrade é o seu leitor, possivelmente seu superior na Ordem. No entanto, quando o seu objetivo é agir politicamente junto ao rei, desacreditando os lamas, é lícito que o clero tibetano receba uma descrição menos generosa. O missionário prossegue:

Fazem grande fundamento em trazerem a ombro um certo pano com várias listras por ser vestido do filho de Deus, como eles dizem, e de trazerem à ilharga um frasquinho d'água para enxaguarem a boca quando comem ou bebem chá, e descalçarem as botas para o mesmo e cuidam que com isto vão ao Céu muito direitos sem tratarem do arrependimento dos pecados e fazerem boas obras. Não vedes, senhor, o engano em que vivem! $!^{459}$

O missionário português deixa transparecer neste trecho toda a atenção que ele dedicou em observar os hábitos dos lamas. Na opinião que ele emite ao rei, não fica evidente uma reprovação direta aos costumes dos lamas. A crítica do jesuíta, parece-nos, se concentra

${ }^{458}$ O editor das cartas, Hugues Didier, informa que Dahim é um leite coalhado. CARTA ânua de Antônio de Andrade, Tibete, 1626. In: DIDIER, H. Os portugueses no Tibete. Os primeiros relatos dos jesuítas (16241635). Lisboa: Comissão Nacional pra Comemoração dos Descobrimentos Portugueses, 2000, p. 130-1.

${ }^{459}$ Ibidem, p.131. 
mais em considerar que estes hábitos - e não o arrependimento dos pecados e o bem obrar garantiriam a salvação. Esse seria o engano.

É interessante reparar que Andrade utiliza a palavra engano nesse momento, ao invés de erro, pecado, ou qualquer outra expressão que pudesse enfatizar ainda mais sua reprovação dos lamas. Supomos que se abster de uma crítica mais veemente indica a inclinação de Andrade ao método de acomodação. Retomaremos essa ideia a seguir.

Concentremo-nos agora na resposta do rei, mais uma vez uma espécie de corolário da atuação do jesuíta. Ele teria dito: "Sim, vejo [o engano em que vivem] (...) Antes vos digo que usam de mil traças para viverem à larga como vivem, sustentando-se do trabalho da outra gente. ${ }^{460}$

Julgamos, desta forma, que esse suposto diálogo entre o missionário e Thi Tashi Dagpa indica que o caminho para o sucesso da primeira missão jesuíta no Tibete passava pela conversão do soberano. Tal conversão, por sua vez, vincular-se-ia ao enfraquecimento do clero budista, o que, independentemente da presença missionária, já estava em curso no reino de Gugê. No que concerne esse conflito de poder temporal contra poder secular, Andrade poderia fornecer os instrumentos retóricos ao rei para colaborar com seu projeto. Simultaneamente, o missionário lançava mão da pretensa proximidade com o régulo tibetano para construir uma narrativa que justificaria a missão e corroboraria com as estratégias escolhidas.

Nossa hipótese, portanto, é que o missionário reconhece toda uma organização sóciopolítica propícia para a evangelização, isto é, os tibetanos estariam aparelhados para receber a Verdadeira Lei e o contexto político parecia favorável. A natureza pia e as semelhanças por ele apontadas entre o clero budista e o cristão seriam indícios de tal aparelhamento. Porém, aos olhos do missionário, algumas coisas iam fora de lugar. O papel evangelizador de Andrade residiria, por consequência, em dar conta de uma falta, de um quase, sem a necessidade de intervenções estruturais. Nesse sentido, seria necessário acomodar alguns aspectos dos hábitos e costumes dos tibetanos. E é justamente isso que Andrade fez em seguida:

Perguntei a um seu lama que remédio tinha um homem para se pôr bem com Deus. Respondeu que dizer estas palavras: "om mani patmenónri” [om mani pad me hum ri] e que, com as dizer, por mais pecados que um homem fizesse ia pro Céu. "Se assim é", digo, "tomai esta faca que tendes e atravessai com ela a fuão, furtai aqueles alforjes que tem el-Rei e outras

460 Carta ânua de Antônio de Andrade, Tibete, 1626. In: DIDIER, H. Os portugueses no Tibete. Os primeiros relatos dos jesuítas (1624-1635). Lisboa: Comissão Nacional pra Comemoração dos Descobrimentos Portugueses, 2000, p. 131. 
coisas semelhantes, e no cabo dizei: "om mani patmenori", e logo vos salvareis". Vós não vedes quão fora de caminho vai esse vosso dito e quão enganada está vossa confiança nessas palavras? Sem boas obras ninguém vai ao Céu, diga as palavras que disser". Ficou o lama corrido e o Rei com os circunstantes zombando dele e de suas rezas e dizendo mil louvores do que o padre ensinava. (...)

Perguntei mais a este lama que queria dizer este "Om mani patmenori". Nem ele soube, nem outros a quem fiz esta mesma pergunta, se só me dizem que são palavras de Deus e, sem dúvida, ou não têm sentido algum, ou totalmente o não sabem. Porém, não há pessoa que de contínuo as não repita e é a reza mais ordinária de suas contas. Pareceu-me então conveniente darlhe o sentido que elas não têm, porque é moralmente impossível deixarem de as dizer pelo muito hábito e costume. (...) "Já que não sabeis, eu vo-lo direi: "Om mani patmenori" quer dizer "Conjô sumbo ga dipâ ta e Rô" [dKon mc'og gsum pa na sDig pa dag dbyen ro] (Senhor perdoai-me meus pecados) e, quando as disserdes seja sempre neste sentido, e com esta consideração". (...) Daí por diante a todos fui dizendo o significado e assim lhe ficara a peçonha delas em medicina do Céu. ${ }^{461}$

Até este momento, a narrativa da missão é coerente: Andrade encontrou uma comunidade politicamente organizada que guarda certas semelhanças, em sua crença e em seus costumes, com a "Verdadeira Lei". Portanto, o missionário julgou prudente participar de disputas e armar questões aos lamas, de forma a utilizar-se de seus erros para que o rei, na audiência dos debates, tomasse uma posição mais crítica em relação aos seus sacerdotes. Assim, o missionário estaria mais próximo de converter o cabeça daquela sociedade, e, aproveitando-se de uma possível relação de patronagem, Andrade garantiria o apoio do rei para a disseminação do cristianismo por toda a região de mesma seita e língua.

Mas, infelizmente, o futuro da missão não foi de acordo com os planos do jesuíta português. A década da seguinte marcaria o início da decadência da missão na terra dos lamas, e é disso que trataremos a seguir.

461 CARTA ânua de António de Andrade, Tibete, 1626. In: DIDIER, H. Os portugueses no Tibete. Os primeiros relatos dos jesuítas (1624-1635). Lisboa: Comissão Nacional pra Comemoração dos Descobrimentos Portugueses, 2000, p.132-3. Om mani pad me hum ri (sânscrito) é um mantra budista que, literalmente, significa "salve a joia da flor de lótus". Sobre isso, c.f. POWERS, J. Introduction to Tibetean Budhism. Ithaca: Snow Lion Publications, 1995, p.22-25. 
3.7 A “NOVA” DESCRIÇÃO DO TIBETE E DOS TIBETANOS: A RUDEZA DO POVO E A RUÍNA DA MISSÃO

No início da década de 1630, dois episódios não relacionados entre si ameaçaram a manutenção da missão: a invasão de Gugê e a prisão do rei; e a morte de Andrade, por envenenamento, em Goa.

A esses eventos, somam-se notícias sobre o Tibete radicalmente distintas do que se havia recebido até então. A esperança de cristandade e a potencialidade da missão, reiteradamente expressas na correspondência, vão dando lugar a um pessimismo incontornável. Em 1635, o então superior da missão do Tibete, Nuno Coresma, escreve ao provincial expondo uma situação limite e pedindo que se promova uma consulta para se decidir se vale ou não a pena manter a missão. ${ }^{462}$ Os argumentos de Coresma giram em torno de dois aspectos principais: a falta de esperança de se fazer cristãos em Gugê e o fim do apoio temporal garantido pelo rei Thi Tashi Dagpa, que, agora preso, nada podia fazer pelos missionários. Coresma é taxativo em sua carta:

Duas cousas entre outras julguei serem sempre necessárias a depois de intentada uma missão a fundar e conservar: esperança de cristandade [e] suficiente comodidade no temporal. Uma e outra faltam nesta do reino de coque [Gugê]. ${ }^{463}$

A formulação sintética e objetiva do missionário aponta para a condenação da missão. Sua defesa, nos moldes que Andrade e outros religiosos vinham fazendo, tornou-se insustentável. Coresma sustenta que os batismos são poucos e que os tibetanos que aceitam o sacramento o fazem por interesses materiais, já que os jesuítas por vezes os auxiliam em seu sustento.

A esperança de cristandade é tão pouca que em dez anos que os padres nela residem não chegam ainda os batizados a cem pessoas, e destas a maior parte são cativos nossos e do rei, que por razão de comprarmos aqueles e remediarmos a estes com o comer e vestir aceitaram nossa lei ou para melhor

\footnotetext{
${ }^{462}$ É preciso dizer que a missão no Tibete não parecia ser consenso dentro da Companhia de Jesus. Em um relato de 1631 é dito que "O padre provincial Gaspar Fernandes não mostra gosto de continuar esta missão [no Tibete] e desistirá sabendo da morte dos padres”. Este trecho faz referência aos missionários que atuavam na missão do Tibete Central (Utsang) e que haviam falecido naquele ano. CARTA de Francisco de Azevedo, Agra, 1631. In: DIDIER, H. Os portugueses no Tibete. Os primeiros relatos dos jesuítas (1624-1635). Lisboa: Comissão Nacional pra Comemoração dos Descobrimentos Portugueses, 2000, p. 194.

${ }^{463}$ CARTA do Padre Nuno Coresma ao Provincial de Goa, Tsaparang, 30 de Agosto de 1635. ARSI, Goa 73, fl.97r.
} 
dizer [a porção?] a outra parte que é menor consta de pobres, principalmente viúvas ou mulheres que não tem remédio outro fora o que de nos pretendem. E sobre tudo não poderei afirmar com verdade haja entre todos eles um só que além do nome seja cristão, e boa prova seja os que, por sermos forçados a lhes faltar no temporal, se fizeram mouros. ${ }^{464}$

Este extrato aponta para um contexto muito distinto daquele apresentado por Andrade. Em primeiro lugar, notamos que a estratégia de conversão "pelo alto" está ausente no relato. Ao contrário, o jesuíta esforça-se em desqualificar socialmente os conversos e catecúmenos. Além disso, a existência de mouros foi negada reiteradas vezes por Andrade, mas os muçulmanos aparecem no relato de Coresma. A invasão de Gugê pelo rei do Ladakh pode justificar a recente presença infiel, mas, de qualquer forma, isso faz da região de Gugê, aos olhos dos superiores da Companhia, um local menos propício para a missionação do que aquele pintado pelo seu fundador.

Ainda no mesmo relato, observamos uma crítica, mesmo que indireta, ao modelo dialógico perseguido no início dos trabalhos missionários em Gugê:

Dizem-nos os enganamos e que o nosso livro nem é melhor do que o seu, fazendo tal entendimento dele e nossas coisas, depois de no catecismo com vagar e clareza se lhe explicar. ${ }^{465}$

Coresma sugere que, mesmo se catequizando devagar e explicando com clareza, a médio e longo prazo, os tibetanos não reconheceram o cristianismo como superior ao budismo (que ele não nomeia). Mas as divergências com as notícias lidas anos antes nas cartas de Andrade não param por aí. Nuno Coresma descreve um Tibete tão distinto do de Andrade que nem com o nome ele concorda:

É gente muito pouca, em forma que em todo este reino, o que por falta do conhecimento e experiência deram nome de Cataio ou Tibete. ${ }^{466}$

O mito do Cataio e toda a ideia subsequente de refundação do cristianismo a partir de vestígios de cristandade no coração da Ásia caem por terra em decorrência das palavras do religioso. Ele possivelmente conhece a palavra tibetana para Tibete, isto é, Po, e, portanto, supõe o uso de "Tibete" como um equívoco.

Dando sequência ao seu trabalho de identificar cristãos em potencial, ou seja, um público alvo no qual a Ordem poderia investir, Coresma passa à identificação dos lamas. O jesuíta, nesse aspecto, é muito sensato ao identificar a força do lamaísmo: com a enorme

\footnotetext{
${ }^{464}$ CARTA do Padre Nuno Coresma ao Provincial de Goa, Tsaparang, 30 de Agosto de 1635. ARSI, Goa 73, fl.97r.

${ }^{465}$ Ibidem, loc. cit.

${ }^{466}$ Ibidem, loc. cit.
} 
quantidade de religiosos, como converter os tibetanos? Sobram poucas pessoas para catequizar. Grande parte da população, diz Coresma,

são lamases (sic), com que não há que tratar de mudança de lei, por viverem de cantar suas patranhas ao povo, inda que entre eles há bem poucos que em as contar sejam coerentes ainda que todos os mais não saibam nem podem dizer em que lei vivem. ${ }^{467}$

Ou seja, mesmo estando estabelecidos no centro de um reino comercialmente importante, para onde concorre todo o tipo de gente, Coresma não identifica possíveis catecúmenos:

Nesta cidade em que residimos sendo cabeça do reino assento dos reis, escala dos mercadores e donde todo o mais reino se provê, não se puderam contar tal sorte adjetos a seu serviço que o seu cativeiro não é inferior ao que por dinheiro se redime. Per leve impedimento se podia inda isto julgar quando não tivemos este rei tão pouco afeiçoado a nossas coisas como este de Ladakh. ${ }^{468}$

De um problema quantitativo, isto é, falta de pessoas para quem pregar, evangelizar e converter, Coresma passa para uma questão qualitativa:

É gente geralmente incapaz de perceber nossas coisas e de qualquer modo entender os mistérios de nossa fé, pois a rudeza e brutalidade é tal que até agora não vi nem li semelhante: a cultivação nenhuma a polícia, nem sabem o nome. ${ }^{469}$

Encontra-se aqui um rompimento radical com o processo de descrição e categorização dos tibetanos que vinha sendo feito desde os tempos de Andrade. Coresma põe em questão a capacidade do povo do Tibete de compreender o cristianismo. De "gente pia", os tibetanos passam a ser descritos como "cristãos de barriga":

[Só na feitiçaria] reconhecem santidade, e tudo o mais em que não entra trejeito ou feitiçaria, não é possível perceberem, pois sua capacidade e

E ainda: natural rudeza os não ajuda a mais, salvo se for proveito de barriga. ${ }^{470}$

É gente em nenhuma forma dada a piedade, pois o lugar em que para com Deus a deviam exortar seriam suas igrejas, mas é coisa certa que achas, não vão nem nelas se ajuntam, mais que para comer e beber. ${ }^{471}$

\footnotetext{
${ }^{467}$ CARTA do Padre Nuno Coresma ao Provincial de Goa, Tsaparang, 30 de Agosto de 1635. ARSI, Goa 73, fl.97r.

${ }^{468}$ Ibidem, fl.97r.-97v.

${ }^{469}$ Ibidem, fl. $97 \mathrm{v}$.

${ }^{470}$ Ibidem, loc. cit.

${ }^{471}$ Ibidem, loc. cit.
} 
Fica evidente neste trecho uma descrição oposta dos tibetanos, na qual a "rudeza natural" contrasta-se radicalmente com a formulação "gente pia" e "gente aparelhada" de Andrade.

Coresma passa, então, para a questão do apoio material do poder temporal local. Com o rei de Gugê feito cativo, os jesuítas encontram pouco ou nenhum apoio no régulo invasor. $\mathrm{O}$ rei do Ladakh não proíbe os padres de evangelizarem, mas concede relativa liberdade aos religiosos apenas por estar interessado nos presentes e nas vantagens financeiras que a Companhia de Jesus pode lhe render:

Quanto ao Rei, é tão pouco afeiçoado a nossas coisas e santa lei que pouco fora fazer-lhe mal rosto, quando tivera entendimento, para penetrar o que sobre ela se lhe tem praticado e se nos não proíbe fazermos cristãos, e permite estarmos em seu reino é pelo que interessa em nossos presentes, além dos roubos e laços que nos tem dado não perdoando a cálices e coisas sagradas. ${ }^{472}$

Por último, Coresma indica um problema típico das missões que se estabelecem fora do contexto colonial ou do Estado Português propriamente dito:

Donde sem favor de rei em terras tão remotas aonde não há braço português, temor, (...) aonde a gente é tão dependente do rei ou toda é cativa ou obrigada a seu serviço, contudo tão pouca, tão pobre, tão interesseira, tão rude, sem culto algum, sem piedade, mal se poderá esperar fruto de cristandade. ${ }^{473}$

Para o jesuíta, uma missão só é viável se conta com apoio do rei local ou braço português. Nesse momento, a missão tibetana não conta com qualquer um dos dois.

O Tibete descrito nessa carta em nada lembra o Gugê dos tempos de Antônio de Andrade. Pela quantidade de religiosos enviados (Coresma diz terem sido seis), supõe-se que inicialmente houve uma tentativa de refundação da missão após a negociação conduzida por Azevedo junto ao rei do Ladakh. No entanto, a penúria da terra, a pobreza extrema da população que restou depois dos conflitos e a ganância do novo rei são fatores elencados por Coresma como "incômodos" difíceis de serem contornados. Contudo, o religioso enfatiza que ficará nas terras tibetanas caso seja esse o parecer do provincial. É possível sentir certo desespero na carta, em especial quando o jesuíta pede que a resposta seja rápida. Sem apoio no temporal e sem esperança de cristandade, Coresma não defende a permanência da Ordem em Gugê.

${ }^{472}$ CARTA do Padre Nuno Coresma ao Provincial de Goa, Tsaparang, 30 de Agosto de 1635. ARSI, Goa 73, fl. $97 \mathrm{v}$.

${ }^{473}$ Ibidem, fl.98r. 
O Jesuíta escreve ainda uma carta em separado, na qual reitera seu pessimismo em relação à missão. Nela, ele insiste na distinção entre o Tibete e o Cataio:

Dizerem que isto se chama Cataio, ou Tibete é falsíssimo. Tal nome nunca achei em natural ou estrangeiro mercador, [mesmo] fazendo eu particulares diligências. Dizerem que a gente é muita e bem entendida, é cegueira porque muito pouca em número e a mais rude e bruta que eu nunca imaginei encontrar. ${ }^{474}$

Por último, Coresma evidencia outra estratégia de conversão, que nada tinha a ver com as disputas defendidas retoricamente nas cartas de Andrade. Ele insinua que Andrade "comprava" o apoio do rei, e que seria insustentável manter a missão nestes termos:

As peças que o Padre Antônio de Andrade deu ao Chodaipo, rei cativo, pois ainda lhas achou, quando o levou cativo, como aljofres, coral, alambre, (...). O certo é que mal poderíamos nem podemos sustentar o foro de semelhante dar. E homens acho por estas serras que choram a morte do Padre, mas bem cuido choram mais as cem rupias, e dinheiro e as peças que dele esperavam receber, como eles confessam receberam em outros tempos, o que eu não me atrevi a continuar. E ainda que tivesse a dispensa de Agra tão rica como em tempos de Janguir [Jahangir] e Mirza, como ele teve com seus poderes[,] não continuaria. ${ }^{475}$

Coresma interrompe essa prática de dar presentes. Aqui, fica bem clara a distinção entre dois tempos, um "antes" e um "agora”. No antes, os jesuítas tinham, em Agra e no Tibete, apoio no temporal. Ou seja, tinham bens, esmolas, eram "ricos", protegidos do rei, que era uma espécie de "protetor". Agora, sem apoio do soberano mogol (muito pelo contrário, Shah Jahan é inimigo dos portugueses a ponto de lhes declarar guerra em Bengala) e no Tibete, como manter o 'esquema' de presentes de Andrade? ${ }^{476}$

Nesse sentido, a argumentação de Coresma é bem interessante: se as coisas mudaram da época de Andrade para cá ou se as pintara com as cores que bem quis, isso ele não pode dizer. O que ele pode assegurar é que, com a falta de apoio do rei, manter a missão, pode não ser inviável, mas é muito difícil.

Tem fim a representação positiva - quase mítica - que Andrade construiu de Gugê. O olhar generoso do fundador da missão não sobrevive às críticas de seu irmão de Ordem. Porém, a importância do relato de Coresma não é apenas a de dar conta da história da missão após Andrade, nem apenas de indicar quão deslocada da realidade poderiam estar as notícias

\footnotetext{
${ }^{474}$ CÓPIA de uma carta de Nuno Coresma superior da missão do Tibete escreveu ao padre provincial Álvaro Tavares acerca da dita missa, de 30 de agosto de 1635. ARSI, Goa 73, fl: 99r.

475 Ibidem, loc. cit.

${ }^{476}$ Após os problemas enfrentados em Bengala, já em 1626, a cidade de Hugli é tomada em 1632 por ordem do soberano mogol Shah Jahan (1628-1658), filho de Jahangir. Cf: COLLIS, M. Na terra da grande imagem. Porto: Livraria Civilização, 1944.
} 
dadas por ele. O que nos salta aos olhos, principalmente, é a relação entre a descrição geopolítica e da natureza dos tibetanos associada à estratégia que deveria ser adotada. Se o régulo local não é favorável ao cristianismo, então é necessária a força do Estado Português. Se a população não é capaz, a força volta a ser indicada, e não o convencimento ou a persuasão. Sem o apoio local, sem o braço secular cristão no Tibete, não há esperança de converter os tibetanos, nem manter na fé os "cristãos de barriga". 
3.8 ANTÔNIO MENDES E A DEFESA DA MISSÃO: OBSERVAÇÃO LOCAL E MODELO GLOBAL

No ano de 1636, depois de uma junta ter decidido pelo retorno dos missionários da missão de Gugê, o jesuíta Antônio Mendes escreve uma carta com o objetivo de posicionar-se contra a volta dos religiosos. Mendes usa diversos argumentos para defender que a resolução tomada na consulta - isto é, a decisão de mandar voltarem os padres - foi equivocada.

A carta é muito bem estruturada, os argumentos são claros e bem desenvolvidos, e é possível dizer que o jesuíta chega ao limite do "decoro" ao manifestar de forma tão transparente sua reprovação em relação ao retorno dos companheiros.

Infelizmente, parece que não temos mais a página inicial da missiva. Sendo considerada a partir da segunda página, a carta inicia-se com a indicação de seu objetivo defender a missão do Tibete. Em seguida, Mendes faz um sucinto retrospecto da história da missão, o que pode indicar que ele acompanhava as iniciativas de Antônio de Andrade e possivelmente leu algumas das cartas escritas pelo missionário português.

Mendes prossegue, iniciando a sua argumentação a favor da missão, ou, por outro lado, contra a decisão de chamar de volta os missionários que atuavam no Tibete. Sua argumentação é organizada da seguinte forma: em primeiro lugar, Mendes expõe as razões gerais pra se interromper qualquer missão. Em segundo lugar, o jesuíta indica que o contexto da missão tibetana não apresentava nenhuma dessas razões ou motivos para a sua descontinuidade. Em seguida, o jesuíta apresenta as razões expostas por Nuno Coresma na correspondência que teria demandado por uma consulta sobre a manutenção ou abandono da missão, a qual, consequentemente, resultou na interrupção das atividades da Companhia de Jesus no reino de Gugê.

Feita a exposição de seus argumentos, Mendes conclui que a volta dos missionários foi um equívoco, que os religiosos vieram fugidos e sem ordens superiores e que, portanto, deveriam ser punidos. No entanto, o jesuíta indica que, ao invés de punição, os padres teriam sido beneficiados, e passa a elencar uma série de considerações sobre o que se passou após a volta dos missionários. Entre essas considerações, ele afirma que a junta responsável pela deliberação acerca da missão do Tibete era composta por padres que também já haviam abandonado outras missões. O jesuíta acrescenta ainda que um dos padres da tal junta - 
chamado Domingos Pereira - nunca havia sido muito simpático à figura de Andrade, tendo dito, quando da chegada das primeiras notícias do Tibete, que se tratavam de patranhas.

Os argumentos de Mendes, que iremos apresentar a seguir, e todo o seu relato são muito importantes para a compreensão da missão tibetana, pois sintetizam aspectos factuais e informações contidas em outros relatos de maneira a construir um complexo quadro da missão. Porém, propomos que a importância da carta não se encerra apenas em sua potencialidade informativa referente às questões particulares de Gugê. Na medida em que se dispõe a defender a missão fundada por Andrade, Mendes nos expõe ideias muito relevantes em termos do que seria uma missão, seus objetivos, como ela deve ser pensada, como devem ou não agir os missionários etc. Sendo assim, ao analisarmos a carta, nos aproximamos da construção de uma ideia de missão da Companhia de Jesus no século XVII, que, acreditamos, será melhor acabada na obra de Desideri, a ser analisada no próximo capítulo. Para tanto, é preciso ter em mente que manteremos estes dois níveis de interpretação da fonte em nossas análises: o primeiro relativo ao contexto da missão iniciada por Antônio de Andrade; e o segundo relativo a um contexto mais amplo de missionação na Ásia, que propomos ser um modelo de atuação da Companhia de Jesus quando em contato com "gente branca". Passemos, pois, para a análise da fonte.

A partir da apresentação dos motivos da sua carta, Mendes nos informa - ou melhor, confirma o que já havia sido antecipado por Nuno Coresma - que, em virtude de notícias pessimistas vindas do reino de Gugê, uma junta foi congregada para decidir se a Companhia de Jesus deveria continuar no Tibete Ocidental ou se os religiosos deveriam ser chamados de volta à Província.

A decisão da junta foi de descontinuar a missão, e como Mendes entende que ninguém na dita comissão se dispôs a defender a continuidade dos padres em Gugê, salientando também que até pouco tempo a mesma missão era bem falada e creditada na Ordem, ele se dispõe a demonstrar que a resolução tomada pelos padres foi equivocada.

Antes de apresentar seus argumentos, Mendes retoma as origens da missão, indicando que há muito tempo a Companhia de Jesus tinha notícias de "rastros de cristandade" na Ásia. Ou seja, o que Mendes faz no início da sua missiva é retomar o mito do Cataio, retomando um discurso de "refundação mítica" que justificaria a presença da Ordem no Oriente.

O jesuíta nos informa que, à época em que Jerônimo Xavier estava na missão do Mogol, o padre Bento de Goes havia sido incumbido de buscar essa tal cristandade perdida de à qual os rumores se referiam. Como se sabe, Goes de fato chegou à China, onde morreu 
pouco tempo depois. ${ }^{477}$ Não fica claro, no entanto, se Mendes entende que em função disso a Companhia decidiu diferenciar Cataio de China, e por isso se justificaria o novo envio de outro missionário com o mesmo objetivo para a Ásia Central. ${ }^{478} \mathrm{O}$ jesuíta afirma apenas que Antônio de Andrade, então superior da missão do Mogol, decidiu ir conferir a verdade de tais rumores, obtendo sucesso em sua iniciativa "como mostrou a primeira carta que dela escreveu, a qual correu toda a Índia e Europa de muita satisfação e edificação de todos". ${ }^{479}$

Dito isso, Mendes indica estar ciente de que o agora cativo rei de Gugê havia apoiado a missão estabelecida pelo missionário português até o momento de sua prisão. Não obstante, o jesuíta afirma ainda que "o padre Antônio de Andrade como autor dela a tratava como coisa sua e para ela voltaria com seus companheiros largando o Reitorado de São Paulo" ${ }^{480}$, estabelecendo assim que a missão teria continuidade em um futuro próximo.

Mendes prossegue, mencionando a morte de Andrade, a qual, segundo seu relato, não parece ter sido, a princípio, tão impactante para o futuro da missão tibetana. Os companheiros que seguiriam com Andrade para o Tibete "com muito fervor e instância pediram ao Padre Provincial esta missão, e sobre todos se mostrou neste particular mais fervoroso VP Nuno Coresma, que foi por superior dela." 481

A narrativa segue, informando que as primeiras notícias que Coresma deu da missão foram positivas "porque logo entrando fez um batismo e para pouco depois prometia outro mais copioso no número e quantidade dos batizados". Porém, algo aconteceu e, em menos de

\footnotetext{
${ }^{477}$ WESSELS, C. Early Jesuit travellers in Central Asia, 1603-1721 Deli: Low Price Publications, 2008.

${ }^{478}$ A confusão entre Tibete, Cataio e China aparece ainda em outra carta, a do missionário Francisco Azevedo que, em 1631, escreve do Ladakh: "Confina este reino de Ladakh pela parte do sul com o de Chaparangue ou Cogê [Guge], pelo nascente com o reino dos três mouros [por] profissão, gente branca tão bem afeiçoada como esforçada, chama-se por outro nome Archande [yarkand], cuja cidade real é Carcar [Kasgar], donde em cáfilas levam à China o barro de que se fazem as porcelanas. Por ali passou o irmão Bento de Gois da nossa Companhia de Jesus que Deus o tem, não dista deste reino de Ladac mais que seis jornadas.". CARTA de Francisco de Azevedo, Agra, 1631. In: DIDIER, H. Os portugueses no Tibete. Os primeiros relatos dos jesuítas (1624-1635). Lisboa: Comissão Nacional pra Comemoração dos Descobrimentos Portugueses, 2000, p. 198. Em outra missiva, do missionário Estêvão Cacela, a confusão também aparece: "Fizemos todas as diligências e perguntas acerca do reino de Cataio e não temos dele notícia alguma por este nome, que é aqui totalmente não sabido. É porém aqui muito célebre um reino que dizem ser muito grande, e se chama Xembala (...). Não se sabe este Rei que lei tenham (...). Deste reino cuidamos poder ser o Cataio." "Relação que mandou o Padre Estevão de Cacela Da Companhia de Jesus ao Padre Alberto Laércio, provincial da Província do Malabar da Índia Oriental, de sua viagem para o Cataio, até chegar ao reino de Potente". Ibidem, p. 236. E, nas palavras de João Cabral: "do Cataio, quanto mais imos sabendo da terra, menos sabemos dele." "Relação que mandou o Padre Estevão de Cacela da Companhia de Jesus ao Padre Alberto Laércio, provincial da Província do Malabar da Índia Oriental, de sua viagem para o Cataio, até chegar ao reino de Potente". Ibidem, p. 146.

${ }^{479}$ CARTA de Antônio Mendes, ARSI, Goa 73, fl: 101r.

480 Ibidem, loc. cit.

481 Ibidem, loc. cit.

481 Ibidem, loc. cit.
} 
dois anos, Coresma "desarmou com tudo". O superior do Tibete mandou notícias pessimistas da missão:

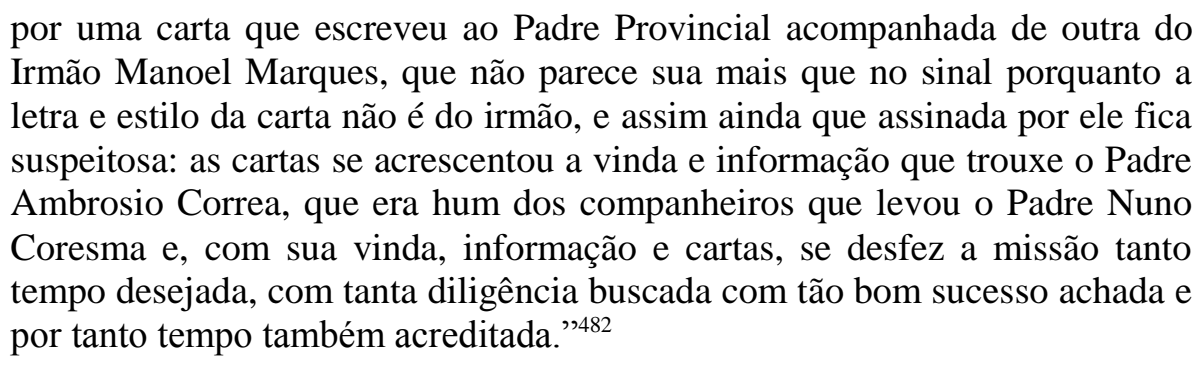

Informado o leitor do contexto em que se encontrava a missão tibetana, Mendes passa para a parte argumentativa de sua carta. "Antes de vir aos fundamentos que tiveram os Padres para largarem esta missão" "883, o jesuíta inicia sua ponderação apresentando motivos

que ordinariamente podem ser impedimentos para qualquer missão empreender ou que obrigam a larga-la depois de a intentar e provar por experiência e largo tempo. Primeiro: incapacidade da gente para receber e conservar nossa santa fé. $2^{\circ}$ evidentes e grandíssimos perigos de vida ou crédito dos missionários, sem fruto nem proveito nenhum da conversão. $3^{\circ}$ A sustentação temporal para os ministros dela." ${ }^{484}$

E antecipa: "conforme ao que entendo, nenhum destes impedimentos tinha a missão do Tibete". ${ }^{485}$

Gostaríamos de destacar alguns aspectos desse trecho antes de prosseguirmos com nossa análise. Em primeiro lugar, enfatizamos a capacidade de síntese de Antônio Mendes. Parece-nos que ele foi capaz de resumir princípios missionários expostos ao longo de toda correspondência e demais obras de religiosos da Companhia de Jesus em três tópicos objetivos e diretos. A essa altura de nossa pesquisa, não temos elementos para indicar se essa elaboração é de exclusiva autoria de Mendes ou se ele apenas reproduz tópicos de "missiologia" antecipados em outros textos da Ordem. De qualquer forma, nos parece digna de nota a condensação de princípios "missiológicos".

Em segundo lugar, gostaríamos de destacar que Mendes parte de um entendimento global de missão para, em seguida, tratar do caso da missão tibetana. Ao longo de sua carta, o jesuíta passará de análises globais para análises locais de forma muito pertinente, indicandonos que a Companhia de Jesus de fato conseguiu estabelecer uma rede de informação eficaz. A leitura desta fonte, na qual se encontram associadas notícias de diversas partes do globo

\footnotetext{
${ }^{482}$ CARTA de Antônio Mendes, ARSI, Goa 73, fl: 101v.

483 Ibidem, loc. cit.

484 Ibidem, loc. cit.

485 Ibidem, loc. cit.
} 
com princípios gerais de atuação missionária - uma espécie de binômio teoria e prática muito nos diz acerca do modo de atuação jesuíta.

Por último, tal binômio teoria e prática não serve apenas para uma análise do que se passou no Tibete, mas está a serviço de uma eficácia pragmática. O jesuíta objetiva posicionar-se em uma determinada situação de maneira a propor um modelo de comportamento ou de ação global para casos como esse.

Dando continuidade a nossa análise, passemos para a argumentação de Mendes, a qual se inicia pelo terceiro ponto, isto é, a sustentação temporal da missão:

Começando pelo último da sustentação temporal, esta missão era a que melhor e mais segura tinha sustentação de quantas tem esta Província, nem ainda as mais de toda a Índia, pois sem carga alguma da Província nem dependência de pessoas ou de esmolas Particulares (como vemos as mais deste Oriente) lhe tinha o Padre Antônio de Andrade, com sua grande indústria, negociada sustentação para todos os sujeitos que em muitos anos ao diante lhe podiam ser necessários, e para os que lá estavam, (...) e consigo levava sustentação para mais de dois anos (...), de maneira que bastantemente estava a missão cotada do que lhe era necessário. ${ }^{486}$

Esta afirmação de Mendes pode ser desdobrada em três consequências lógicas. A primeira decorrência das proposições do jesuíta é que a missão planejada e estabelecida por Andrade em Gugê era materialmente e financeiramente autônoma em relação à Província. Donde também se desdobra que, mesmo sofrendo com o aprisionamento do rei de Gugê, o sustento dos missionários estava desassociado do apoio financeiro de Thi Tashi Dagpa, ainda que possamos admitir que seu apoio político pudesse ser, todavia, necessário. O terceiro e último desdobramento que aqui propomos é a suspeita de que Andrade fazia comércio como forma buscar a manutenção material de "sua" missão. A natureza dessas trocas ou o grau de envolvimento do jesuíta português com essas práticas não pode ser esmiuçado no presente momento. Mas temos elementos suficientes para supor que, de fato, Andrade teria viabilizado a missão do Tibete fazendo mais do que apenas arrecadando esmolas.

Passemos para a análise do segundo tema abordado por Mendes: "a boa capacidade da gente para receber e conservar nossa santa fé" ${ }^{487}$ Este tópico é especialmente caro para nós, pois se relaciona diretamente com o que propomos ao longo desta tese: uma estreita relação entre a categorização - ou predicação - das sociedades nas quais os jesuítas buscaram implementar um projeto de conversão, mediante a escolha prudente de estratégias de catequese e convencimento.

\footnotetext{
${ }^{486}$ CARTA de Antônio Mendes, ARSI, Goa 73, fl: 101v.

${ }^{487}$ Ibidem, fl: 102r.
} 
Mendes lança mão de três argumentos para sustentar que os tibetanos eram capazes de receber a Santa Fé. Primeiramente, ele afirma que Antônio de Andrade já havia demonstrado isso em seus escritos. Em segundo lugar, ele afirma que os demais religiosos que atuaram no Tibete também defenderam a capacidade natural dos tibetanos. Em seguida, Mendes nos fornece uma informação um tanto curiosa: ele afirma que, ao voltar do Tibete, Andrade veio acompanhado de tibetanos, de forma que outros religiosos - em Goa ou em Agra - puderam pessoalmente se certificar da capacidade desse povo. Além disso, "basta saber-se que é gente branca $^{488}$ que, com facilidade e benevolência, recebeu os Padres e a notícia do Verdadeiro Deus com nossa Santa fé e (achando?) nela Vestígios de antiga cristandade" ${ }^{489}$

Mendes, então, parte para uma argumentação comparativa, hierarquizando os tibetanos, os habitantes do novo mundo e os africanos:

e quando os Brasis, gente tão agreste, bárbara e fera, teve capacidade para receber nossa dita fé e outras nações bárbaras (da linha pra lá?) receberam com tanto fruto nossa santa fé, e da linha para cá outras muitas e mui várias e ainda os cafres gente mais incapaz e bruta ao parecer e trato humano com que tão pouco se faz para sua muita rudeza e poner capacidade com tudo não quer VP que se largue, como é possível que se largue esta por incapaz e que faltemos a estes que tão diferente são, se mostram com tudo. E mais havendo já número de cristãos que parece grande desumanidade, e antes pouca piedade e menos caridade deixar os cristãos que convertemos. ${ }^{490}$

Como dissemos anteriormente, Mendes mostra-se capaz de estabelecer comparações globais para construir argumentos em favor da missão. Além disso, propomos que tais elaborações reiteraram uma interpretação geopolítica da Companhia de Jesus, que ordena os povos de acordo com sua capacidade de receber a santa fé, aferida a partir de princípios políticos, isto é, relativos à vida em comunidade. Por último, percebemos que abandonar a missão atenta contra os princípios de caridade e piedade, caros à Ordem.

Passemos ao terceiro tópico: "evidentes e gravíssimos perigos" ${ }^{491}$ condicionados à pouca esperança ou ausência de frutos da missão. "Do fruto", afirma Mendes,

não temos que duvidar, pois como consta nas cartas do Padre Antônio de Andrade, dos mais padres e ainda do Padre Nuno Coresma, não só se fizeram e havia Cristãos feitos com muita facilidade, mas (sic) muito grande

\footnotetext{
${ }^{488}$ Outro missionário que optou pela formulação "gente branca" foi Estêvão Cacela. Referindo-se aos tibetanos do Tibete Central, o missionário afirma que "é a gente destes reinos branca, ainda que a pouca limpeza com que se tratam faz que o não pareçam tanto." "Relação que mandou o Padre Estevão de Cacela Da Companhia de Jesus ao Padre Alberto Laércio, provincial da Província do Malabar da Índia Oriental, de sua viagem para o Cataio, até chegar ao reino de Potente". DIDIER, H. Os portugueses no Tibete. Os primeiros relatos dos jesuítas (1624-1635). Lisboa: Comissão Nacional pra Comemoração dos Descobrimentos Portugueses, 2000, p. 241.

${ }^{489}$ CARTA de Antônio Mendes, ARSI, Goa 73, fl: 102r. Grifos nossos.

${ }^{490}$ Ibidem, loc. cit.

491 Ibidem, loc. cit.
} 
esperanças de crescer e se fazer ali grande cristandade, pela natural inclinação e pia afeição que aquela gente mostrava às coisas da nossa santa fé o que em nenhuma missão de todo este Oriente se viu em seus princípios, antes nas mais delas grandes impedimentos e dificuldades. ${ }^{492}$

Mais uma vez, condiciona-se o futuro da missão às descrições dos tibetanos. Novamente, a expressão "pia" aparece adjetivando a afeição dos tibetanos, relacionada à sua natureza. Parece-nos que Mendes faz referência à categoria elaborada por Andrade em suas primeiras cartas, nas quais o jesuíta condiciona o investimento da Ordem no Tibete à natureza pia da gente tibetana.

Sobre os "perigos", Mendes argumenta a partir de fatos internos à missão tibetana, e, em seguida, comparando com a missão do Mogol. O jesuíta reconhece dois momentos distintos, o primeiro em que os missionários contavam com o apoio do rei de Gugê, e o segundo, no qual esse apoio se perdeu em função da prisão do rei. No entanto, Mendes lança mão da comparação com o Mogol para demonstrar que não havia iminência de perigo real:

deste rei intruso e tirano nem até agora aconteceu fazer-se agravo nem ainda alguma leve descortesia aos padres como se tem feito noutras partes, e em particular no Mogol, aonde se tem espancado e apedrejado e feito várias afrontas não só aos padres mas também nas Igrejas e coisas sagradas. ${ }^{493}$

Mais uma vez, o jesuíta foi capaz de transcender uma análise local para construir uma argumentação a favor da missão tibetana, na qual "se não acham mais perigos que os que queremos imaginar ou temer." ${ }^{494}$ Mendes sente-se em posição, inclusive, de sustentar que "quando alguns [perigos] na verdade houvesse, não se lhe deviam dar as costas e fugir deles, mas por-lhe o peito". ${ }^{495}$ Para respaldar sua posição, o jesuíta recorre à memória de Francisco Xavier e sua atuação "no cabo deste Oriente e quase no do mundo" ou seja, na "perseguida e arriscada missão e cristandade do Japão". ${ }^{496}$

Por último, a este respeito, o jesuíta fala da expectativa dos missionários, "como se o estar em missão remota e entre infiéis houvesse de ser como quem está nos colégios e casas do meio da cristandade, sem haver coisa arriscada nem que lhe dê moléstia ou pena". ${ }^{497}$ Arrematando com certa ironia "pois certo que nem nestes mesmos colégios e nos de maior observância faltam muitos e mui grandes perigos, se bem o ponderarmos" ${ }^{498}$, Mendes fecha

\footnotetext{
492 CARTA de Antônio Mendes, ARSI, Goa 73, fl: 102r.

493 Ibidem, loc. cit.

${ }^{494}$ Ibidem, loc. cit.

495 Ibidem, loc. cit.

496 Ibidem, loc. cit.

${ }^{497}$ Ibidem, loc. cit.

498 Ibidem, loc. cit.
} 
sua argumentação sobre este último ponto fazendo uma referência velada ao assassinato de Andrade.

Encerrada a parte da carta em que tece considerações gerais seguidas de argumentos a favor da missão, Mendes passa para os argumentos específicos que ele colheu na correspondência dos missionários no Tibete e da decisão da junta:

Três sãos os fundamentos que me disseram houve para se tomar esta resolução [de retorno dos missionários]. Primeiro: pela gente não ser capaz de nossa santa fé nem haver esperanças de cristandade; $2^{\circ}$ pelo nos terem por mercadores; $3^{\circ}$ por os padres estarem como presos e arriscados a serem roubados e cativos. ${ }^{499}$

Mais uma vez, o jesuíta inicia sua argumentação pelo último tópico, novamente recorrendo à memória do apóstolo das Índias:

bem diferente espírito era o de nosso santo padre Francisco Xavier quando nas portas da China sabendo de certo pela lei inviolada dos Chinas que se entrasse pela aquela terra dentro havia de ser morto ou perpetuamente havia de ficar cativo. Contudo, a tanto se arriscou. ${ }^{500}$

Mendes então retoma o primeiro fundamento para se abandonar a missão do Tibete: a capacidade dos tibetanos. Assim, ele retoma o que já havia defendido anteriormente:

fica provado pelas cartas e batismos do mesmo padre Coresma [a capacidade dos tibetanos]; e quando ele diga que foi apressado em escrever, e que se enganou naqueles primeiros princípios, também se lhe pode dizer que se pode enganar no que escreve agora, e que pode ser muito o medo, e pouca a consideração (...) e a confiança em Deus, e que se apressou em escrever agora, e [também se apressou] no fugir, fazendo-lhe o temor e o receio crer outra coisa diferente do que entendia e tem escrito. ${ }^{501}$

O jesuíta passa então para o segundo tópico, isto é, a crença de que os jesuítas eram encarados no Tibete como mercadores:

Quanto ao $2^{\circ}$ de nos terem por mercadores, é coisa a qual não acho razão nem força fundamental, porque piores coisas cuidam, (...) dizem e apregoam de nós os hereges, e nem por isso desamparamos e fugimos de sua redumpção (sic) à fé católica. Antes, por isso mesmo trabalhamos mais e nos arriscamos para lhes reduzir. ${ }^{502}$

E mais uma vez, surge o exemplo de Xavier:

por Mercadores tiveram os japoins e São Francisco Xavier e com este conceito dele entrou aquele bonxo[bonzo?] principal que com o santo quis entrar em disputa. Antes este era o conceito geral que os japoins tinham do

499 CARTA de Antônio Mendes, ARSI, Goa 73, fl: 102r.

500 Ibidem, loc. cit..

${ }^{501}$ Ibidem, fl: 103r.

${ }^{502}$ Ibidem, loc. cit. 
santo, quando viram que entrava Em suas terras em companhia de mercadores, (...) e nem por isso deixou o santo a empresa que com o tempos se foram desenganados os japoneses e entendendo que era mercadores de outras Mais altas e divinas mercadorias que as da terra. (...) Este é o modo de negociar que nos encomenda Cristo Senhor Nosso e devem exercitar os bons mercadores e evangélicos. Que cuidem alguns no Tibete que somos mercadores, vai pouco nisso, que nosso trato, procedimento e vida (se for a que devemos) nos dará a conhecer, e os desenganara e lhes dirá quem somos.(...) Enfim, nosso procedimento e vida no Tibete apagaria este conceito de mercadores que de nos tinham, e tapariam as bocas dos que nisso falassem. ${ }^{503}$

Por último, Mendes volta a argumentar contra a iminência de prisão como justificativa de se fazer voltar os padres do Tibete. Outra vez, o jesuíta recorre a exemplos externos. Poderíamos dizer, por outras palavras, que Mendes se remete à experiência da Companhia no Oriente - usando como exemplo o que se passou na Etiópia e na missão do Mogol, quando da ascensão de Shah Jahan ao trono. Recortemos aqui o caso do Mogol:

Menos há de dois anos, no tempo do governo do Padre Provincial, vieram cartas do Mogor quando o rei e seus ministros estavam mais assanhados contra os Padres, e os tinham presos em suas casas com gente de armas em vigia às portas. (...) Os padres em tanto aperto e receio que manifestadamente temiam a morte, o que temendo os padres escreveram ao Padre Provincial [para que] lhe desse (sic) licença para se virem às escondidas, ou thes ordenassem o que haviam de fazer. Tratada a coisa em consulta, (...) se assentou (...) que em nenhuma maneira se saíssem os padres e deixassem aqueles poucos cristãos; antes se ficassem confiados da divina proteção que os guardaria. E sendo o caso que o mogor mandasse sair de suas terras e os obrigasse a isso, então se podiam vir em paz. ${ }^{504}$

Terminada sua argumentação, Mendes conclui que

com estes exemplos diante, fica bem notada a resolução na consulta que se tomou do mandar vir o Padre Coresma e largar a missão nem pode deixar de ser matéria de grande confusão para todos os missionários dela virem fugindo só com imaginação e medo dos trabalhos. ${ }^{505}$

Até então, o jesuíta se utilizou principalmente de dois expedientes para sustentar sua argumentação. O primeiro, de contradizer as informações dadas por Coresma em sua carta, baseando-se provavelmente na correspondência da própria missão do Tibete, bem como nas notícias acerca de outras missões na região. No segundo, Mendes lança mão de exemplos de apóstolos e da memória do padre Francisco Xavier em sua atuação no Extremo Oriente. Mas

\footnotetext{
${ }^{503}$ CARTA de Antônio Mendes, ARSI, Goa 73, fl: 103r-103v.

${ }^{504}$ Ibidem, fl:103v.

${ }^{505}$ Ibidem, fl:104r.
} 
o jesuíta recorre ainda a um terceiro expediente para embasar sua posição: relatos de pessoas que tiveram contato direto com a missão no Tibete.

O primeiro a ser mencionado pelo jesuíta é o padre Alano dos Anjos, o qual teria escrito que não se deveria dar crédito nenhum aos que chegam de Gugê "porque são como soldados fracos que fogem com medo da guerra." 506

O segundo é um brâmane que Mendes diz que "esteve com o Padre Antônio de Andrade nesta missão e voltou outra vez com o padre Coresma". ${ }^{507}$ Segundo o relato, o brâmane, a princípio, teria confirmado as informações dadas pelos padres Coresma e o padre Ambrósio em público e perante a junta, porém,

ainda que diante do Padre Provincial e no público disse o que os padres nomeados the aconselharam, no particular e em segredo diz outra coisa mui diferente. (...) E posto que seja homem preto, e por ser tal de menos créditos que os padres, contudo o afeto com que na matéria fala, as circunstâncias que aponta, e o que afirma lhe mandaram dizer os padres, (...) tem muita força para se lhe dar (...) algum crédito, e não cuido que pouco.(...) Enfim é brâmane honrado, homem já casado, de bom procedimento, e bom cristão que se entende muito bem. ${ }^{508}$

Mendes encontrou até mesmo nas palavras de um "homem preto" uma forma de defender a missão entre a "gente branca" no Tibete. Pelo princípio que desenvolvemos até aqui, parece-nos incomum - para dizer o mínimo - que os adjetivos "preto" e "honrado" sejam predicados do mesmo sujeito. Talvez o que resolva essa aparente impossibilidade seja, justamente, o fato de ser cristão. Mais do que isso, a categoria final final, nas palavras do jesuita, é “bom cristão".

\footnotetext{
506 CARTA de Antônio Mendes, ARSI, Goa 73, fl: 104r.

507 Ibidem, loc. cit.

508 Ibidem, loc. cit.
} 
3.9 DIÁLOGO COM GENTE BRANCA, TEMOR PARA GENTE RUDE: IMPLICAÇÕES POLÍTICAS DA RETÓRICA MISSIONÁRIA PARA O CASO DO TIBETE

A partir da leitura da documentação referente à primeira missão jesuíta no Tibete disponível principalmente no códice "Tibete História" 509 sob guarda do arquivo da Companhia de Jesus em Roma (ARSI) - propomos aqui uma divisão da História da missão em três fases. $^{510}$

A primeira fase diz respeito à chegada de Andrade ao reino de Gugê, no ano de 1624. Nesse momento, é estabelecida uma relação de identidade entre o Tibete e o mito do Cataio. A “confusão" não parece ter sido obra do próprio Andrade, mas decorrência da publicação e divulgação de suas notícias dentro da Companhia e fora dela, na Índia e na Europa. Essa primeira fase se caracteriza, portanto, pela relação identitária estabelecida entre o Tibete e o reino mítico cristão do Cataio, e também por mais outros dois fatores principais: a descrição positiva dos tibetanos quanto à sua capacidade de reconhecer, receber e conservar a santa fé, e a justificativa de investimento na missão, sustentada especialmente por Antônio de Andrade.

A segunda fase da missão inicia-se em 1626, com a sua implementação. Andrade, acompanhado de outros religiosos, retorna a Gugê, é recebido pelo rei, funda a missão, garante sua sustentação temporal e passa a escrever aos seus superiores dando notícias. Essa fase é caracterizada, portanto, pelo estabelecimento propriamente dito de missões em Tsaparangue e na região de Utsang, pela negociação e garantia do seu sustento temporal, pela reiterada justificativa de investimento na missão mediante descrições positivas, e, finalmente, pelo início da implementação das estratégias de conversão. No entanto, neste momento, não se vê mais a identificação Tibete/Cataio.

A terceira e última fase aqui proposta caracteriza-se pela decadência da missão, acompanhada de uma consulta junto à Província sobre sua manutenção ou suspensão. A essa consulta, segue-se uma espécie de debate epistolar, no qual dois jesuítas - Nuno Coresma e Antônio Mendes - tomam posições opostas e passam a argumentar contra e a favor da missão, respectivamente. A fase é marcada por três fatos externos ao desenvolvimento da missão. O primeiro diz respeito ao contexto político do reino de Gugê: em virtude de um acordo de

${ }^{509}$ ARSI, Goa 73.

${ }^{510}$ Para a listagem de nosso levantamento de fontes no Arquivo da Companhia de Jesus em Roma (ARSI), consultar apêndice "G". Para as fontes levantadas no Arquivo Nacional da Torre do Tombo (ANTT), consultar o apêndice "H". 
casamento descumprido pelo rei de Gugê, o rei do Ladakh invade Tsaparang e leva a família real cativa para Leh. A missão perde seu maior "protetor local". Nesse mesmo período, a iniciativa da Ordem no Teto do Mundo perde também seu principal "protetor" junto à Companhia de Jesus: Andrade é envenenado dentro do refeitório do Colégio de São Paulo em Goa. Pela devassa conduzida em função de seu assassinato, supomos que sua morte não estava relacionada com a missão do Tibete, ainda que esta estivesse longe de ser uma unanimidade junto aos padres da Companhia no Mogol e em Goa.

O terceiro fator diz respeito à relação de "filiação" entre a missão do Tibete e a missão do Mogol. Em 1628, sobe ao trono mogol o imperador Sha Jahan. Ao contrário de seu pai e seu avô, ele não se interessa por manter uma boa relação com cristãos, sejam mercadores portugueses ou religiosos jesuítas. Os padres em Agra não podem mais contar com a boa vontade do "cabeça" do Império Mogol, e a promessa de um Constantino no coração da Ásia dá lugar à certeza de um soberano infiel, inimigo de Cristo e dos portugueses. Como se não fosse suficiente, após a suspensão do apoio temporal à missão jesuíta, no ano de 1632, Shah Jhan cerca os portugueses estabelecidos em Bengala, dando início a um confronto armado.

$\mathrm{Na}$ terceira fase, portanto, concentram-se os argumentos contra e a favor da missão, os quais estão relacionados a três pontos principais: a subsistência temporal da missão; a natureza do povo tibetano e sua capacidade para receber e manter a santa fé; e a identificação dos jesuítas como mercadores. Tanto Coresma quanto Mendes se posicionam em relação a essas três questões centrais. Mesmo após a defesa de Mendes, a missão em Tsaparang foi possivelmente interrompida no ano de 1635.

Apesar do suposto fracasso da missão, a documentação por ela deixada é bastante rica quanto a informações sobre o encontro entre o cristianismo e o budismo tibetano. Além disso, a correspondência jesuíta da missão de Gugê nos permite avaliar de forma criteriosa as hipóteses que levantamos em nossa pesquisa: isto é, que as estratégias de conversão estão estreitamente relacionadas com a categorização das comunidades nas quais os jesuítas se estabelecem.

Não obstante, observamos a adoção, e posteriormente a crítica, do método dialógico, de forma análoga ao que percebemos na missão mogol. Os jesuítas também recorreram a disputas, o que está associado às características de gente branca e gente pia. No caso da gente rude de Nuno Coresma, o jesuíta se ressente da falta de temor em decorrência da ausência do braço secular do Estado Português no Tibete. 
Assim sendo, percebemos que a retórica das cartas, isto é, seu trabalho de acomodação de uma realidade aos termos inteligíveis para os leitores europeus - em especial para os membros da própria ordem - obedece à lógica de atribuição de "lugar" e "história" aos povos encontrados. Essa atribuição, por sua vez, tem raízes e desdobramentos políticos, na medida em que, ao mesmo tempo, criam uma unidade política e se utilizam das tensões entre poderes - secular e temporal - para alcançar seu objetivo último: a conversão.

Passaremos a seguir à abordagem da segunda tentativa de estabelecimento da Ordem no Tibete com o jesuíta Ippolito Desideri. Poderemos perceber que tanto a descrição dos tibetanos quanto a elaboração das estratégias e o entendimento de missão tornam-se mais complexos. No entanto, perceberemos também que a forma dialógica, associada a observação e ação políticas, estará no centro das estratégias defendidas pelo italiano. 
4. A SEGUNDA MISSÃO DA COMPANHIA DE JESUS NO TIBETE 


\subsection{IPPOLITO DESIDERI E A “SEITA TIBETANA"}

Um missionário e um teólogo comprometidos com um diálogo interreligioso encontram desafios similares: cada um deve buscar as crenças compartilhadas que tornam o diálogo possível, ao mesmo tempo em que reconhecem e respeitam as diferenças entre as duas religiões no encontro inter-religioso. ${ }^{511}$

Neste capítulo, tomaremos como objeto a missão jesuíta estabelecida por Ippolito Desideri no Tibete. ${ }^{512}$ Desideri estabeleceu-se principalmente em Lhasa, entre 1717-21. O missionário escreveu a obra intitulada Notícia Histórica do Tibete, composta por quatro livros, dos quais selecionamos prioritariamente para análise alguns capítulos que abordam mais especificamente os temas tratados em nossa tese. Focaremos nas (preciosas) descrições de Desideri do budismo tibetano e suas implicações políticas, em especial no que diz respeito ao protocolo de sucessão dos Dalai Lamas.

A apresentação da obra de Ippolito Desideri é, sem duvida, a mais complexa dentre as fontes aqui analisadas. Não se trata de uma carta, ou mesmo de um relato nos moldes do Comentário. Como indica M. Sweet, a rubrica "Notícia Histórica" é utilizada, desde o século XVIII, para trabalhos que forneçam informações gerais sobre um lugar especifico. ${ }^{513} \mathrm{~A}$ Notícia, portanto, é extensa, e abrange diversos assuntos distintos, além de ser rica em detalhes. Não obstante, a obra de Desideri foi produzida num contexto diferente do Commentarius: ela foi pensada e escrita em um período em que a Companhia de Jesus enfrentava grandes dificuldades, e seus conflitos com a Propaganda Fide eram recorrentes. A missão do Tibete estava em disputa entre Jesuítas e Capuchinhos, enquanto a Querela dos Ritos era julgada. Foi nesse ambiente tenso que Desideri escreveu sua obra sobre o Tibete.

A nossa leitura da fonte foi feita a partir da publicação do ano de 2010, de Michael J. Sweet e edição de Leonard Zwilling. A opção pela leitura do texto em inglês e, em seguida, seu confronto com a publicação de Petech em italiano, deveu-se às seguintes razões: ao

\footnotetext{
511 "A missionary and a theologian commited to interreligious dialogue face similar challenges: each must search for the shared assumptions that make dialogue possible while recognizing and respecting the very differences between the two religions in the interreligious encounter." POMPLUN, T. Jesuit on the Roof of the World: Ippolito Desideri's Mission to Eighteenth-Century Tibet, Nova Iorque: Oxford University Press, 2002, p. 5.

${ }_{512}$ Desideri nasceu em Pistoia, na Toscana, em 1684, quase dois séculos antes da unificação italiana. No entanto, cometeremos, ao longo desta tese, o pequeno anacronismo de chamá-lo de italiano. Acreditamos que o uso desse gentílico não compromete o entendimento do texto.

${ }^{513}$ Cf: DESIDERI, I. Mission to Tibet: the extraordinary eighteenth-century account of father Ippolito Desideri, S.J. Tradução Michael J. Sweet, Edição Leonard Zwilling. Boston: Wisdom Publications, 2010, p. 4.
} 
contrário da edição do Commentarius de Montserrat, a publicação de Sweet e Zwilling é muito bem cuidada, com uma introdução muito bem feita e bastante elucidativa, que conta com umadetalhada descrição dos manuscritos que subsidiaram a publicação da obra. Houve grande respeito à apresentação do texto original, e todas as interferências são claramente indicadas. Os comentários dos editores foram alocados em notas ao final da publicação, e não incorporados ao corpo do texto, o que permite uma leitura mais direta da fonte original, sem a interferência da fala do editor.

A publicação mais recente conta ainda com a seguinte vantagem: como o manuscrito C só foi descoberto após a edição de Petech, ele só pode ser considerado naversão de Sweet e Zwilling. Além disso, a edição de Petech tem um formato que dificulta bastante a leitura, com inúmeras indicações nas margens, referências cruzadas a manuscritos e extensas notas de rodapé com trechos adicionados do chamado manuscrito $\mathrm{F}$.

Optar pela edição em inglês, no entanto, significava privilegiar um idioma outro que não o original. Por isso, realizamos o confronto da tradução de Sweet com a edição em italiano feita por Luciano Petech na década de 1950, com a finalidade de uniformizar as citações e mantermos nossa análise menos sescetível a problemas de tradução. ${ }^{514}$

Além das publicações feitas a partir da tradução de M. Sweet e curadoria de L. Petech, é importante ressaltar que um jesuíta holandês chamado Cornelius Wessels publicou, no início do século XX, uma boa apresentação desta obra de Desideri, além do sumário ou índice de um manuscrito identificado por ele como Notizie istoriche del Thibet e memória de' viaggi e missione ivi fatti del P. Ippolito Desideri, della companhia de Giesu. Dal medesimo aceites, e dedicate 1712-1733. ${ }^{515}$

Temos que destacar ainda o trabalho de Bargiacchi em "Ippolito Desideri, opere e bibliografia", no qual o autor apresenta os manuscritos que deram origem à Notícia tal qual ela se encontra publicada hoje, e identifica as várias publicações da obra do jesuíta italiano.

\footnotetext{
${ }^{514} \mathrm{O}$ italiano Luciano Petech dedicou-se à publicação da obra de Desideri de forma integral nos três últimos volumes de "I missionari italiani nel Tibet e nel Nepal", lançados entre os anos de 1952-1956. PETECH, L. I Missionari italiani nel Tibet e nel Nepal. Roma: Libreria dello Stato, 1952-1956. vol. 6.

${ }^{515}$ WESSELS, C. Early Jesuit travellers in Central Asia, 1603-1721 Delhi: Low Price Publications, 2008. O livro é dividido em capítulos independentes, cada um tratando de um viajante europeu e seu respectivo relato. Os dois primeiros capítulos dedicam-se a Bento de Gois e Antonio de Andrade, e já haviam sido publicados em holandês, (Cf: WESSELS, p. VIII.) mas foram reescritos para esta edição de 1924. Os capítulos seguintes tratam das viagens de Francisco Azevedo, Estevão de Cacela e João Cabral, John Grueber e Albert d'Orville; e, por fim, Ippolito Desideri. Além dos capítulos propriamente ditos, o autor publica ainda alguns relatos, numa sessão chamada de apêndice. As cartas de Francisco Azevedo, de 1631; Estevão de Cacela, de 1627; e de João Cabral já aparecem aqui publicadas, em português. Estas cartas fazem parte de nosso corpus documental principal e foram lidas a partir da publicação feita por Hugues Didier, em português, em 2000: DIDIER, Hugues. Os portugueses no Tibet. Os primeiros relatos dos jesuítas (1624-1635). Lisboa: Comissão Nacional pra Comemoração dos Descobrimentos Portugueses, 2000.
} 
Bargiacchi também realiza um levantamento bibliográfico das publicações que tratam de Desideri. $^{516}$

Sendo assim, não nos preocuparemos em apresentar os manuscritos um a um, identificando as mudanças promovidas pelo jesuíta versão a versão, ou apontando as diferenças entre eles, uma vez que isso já foi feito. ${ }^{517}$ Dedicar-nos-emos, portanto, a fazer uma apresentação da obra a partir publicação de M. Sweet, tendo como foco principal as questões desta pesquisa e ressaltando sua importância para a nossa tese. Isso significa dizer que não faremos um resumo ou resenha de toda a obra, mas procuraremos destacar apenas as ideias pertinentes à nossa pesquisa.

A Notícia Histórica é composta de quatro livros. No primeiro, Desideri narra sua viagem da Europa até Lhasa, capital do Tibete Central. O segundo traz uma espécie de descrição "antropológica" ou mesmo "sociológica" do Tibete, iniciando pela descrição dos aspectos naturais, passando pela abordagem de temas políticos numa espécie de "história política", finalizando com a apresentação dos costumes - como casamento e ritos funerários, por exemplo. ${ }^{518} \mathrm{O}$ terceiro livro aborda a "falsa seita" do Tibete, isto é, o budismo ou lamaísmo, que, no entanto, ainda não ganhou esse nome. O livro quatro narra a volta de Desideri à Europa, desde o Tibete até Roma. Ao final deste último livro, Desideri faz considerações sobre as missões nas Índias e o papel do missionário. ${ }^{519}$

Uma informação importante é que Desideri não só relata suas próprias experiências, mas faz uma espécie de balanço bibliográfico do que até então havia sido divulgado na Europa sobre o Tibete, o que inclui, dentre outras obras, a publicação da carta de Antônio de Andrade. Além disso, Desideri propõe uma leitura crítica dos demais autores que trataram do

${ }^{516}$ BARGIACCHI, E. Opere e Bibliografia [Subsidia ad Historiam Societatis Iesu 15]. Roma: Institutum Historicum Societatis Iesu, 2007.

${ }^{517}$ A relação de Ippolito Desideri possui quatro manuscritos. Todos eles são muito bem descritos por Bargiacchi na obra citada acima, p. 1-3. Manuscrito F: Descoberto em pistola em 1875, foi preservado na biblioteca nacional central de Florença. Pertencera ao sobrinho de Desideri. Ainda que não seja o mais antigo, representa muito das etapas inicias da obra do jesuíta. Não é autografado. Manuscrito A: Descoberto por Wessels no ARSI. Foi assim denominado por Wessels seguindo seu critério de importância, tal como o B. É autografado. Manuscrito B: Descoberto por Wessels no ARSI. É autografado. Manuscrito C: descoberto por Giuseppe Toscano em 1981, e, portanto, desconhecido por Luciano Petech quando este publicou sua edição da Relação de Desideri. (PETECH, L. I Missionari italiani nel Tibet e nel Nepal. Roma: Libreria dello Stato, 1952-1956. vol. 6) Para maiores informações sobre os quarto manuscritos, consultar a introdução de DESIDERI, I. Mission to Tibet: the extraordinary eighteenth-century account of father Ippolito Desideri, S.J. Tradução Michael J. Sweet; Editado por by Leonard Zwilling. Boston: Wisdom Publications, 2010, p. 63; e também PETECH, L. op. cit., p. XXVIII.

${ }_{518}$ Essa estrutura (descrição natural, historia política e costumes) deve ser objeto de nossa análise mediante ideias desenvolvidas por Antonella Romano. Cf. ROMANO, A. Entre Nature et écriture. Artigo apresentado no Colóquio Anciens, Modernes, Sauvages, na USP, São Paulo, 2009.

${ }^{519}$ Para uma apresentação da obra de Desideri, uma espécie de resenha, cf. BARGIACCHI, E. Opere e Bibliografia [Subsidia ad Historiam Societatis Iesu 15]. Roma: Institutum Historicum Societatis Iesu, 2007. 
Tibete, indicando que ele não só pesquisou e leu antes de finalizar sua obra, mas também foi capaz de "corrigir" os erros das descrições anteriores. ${ }^{520}$

Em sua "advertência ao leitor", Desideri afirma que originalmente não era sua ideia publicar essas notícias sobre o Tibete ou mesmo as memórias de suas viagens. Porém, tendo sido encorajado por "homens de letras", cavalheiros, e "eminentes personagens", Desideri resolve escrever de forma ordenada - respeitando tempo e lugar - as histórias que seus companheiros na Europa o ouviam contar. Para não desapontá-los, o jesuíta, decide, então, publicar suas anotações e memórias.

Além disso, Desideri afirma não haver ainda em seu tempo informações confiáveis sobre o Tibete, e para dar um fim a esse silêncio, o missionário se convence da importância de seu relato, uma vez que, em sua obra, o leitor "não lerá coisa alguma que eu mesmo não tenha visto ou examinado minuciosamente antes de dar o devido crédito". 521

De maneira bastante sintética, organizamos as principais ideias de Desideri expostas na Notícia em uma tabela em anexo, ${ }^{522}$ procurando justificar sua importância para a nossa pesquisa. Propomos dividir em quatro aspectos os temas que nos são pertinentes, abordados por Desideri: Definição e descrição do "Tibete" e sua "seita"; apresentação e defesa das estratégias e métodos de convencimento e conversão defendidos e aplicados por ele; identificação dos "erros" da "seita" tibetana; e relações entre política, poder ou Estado Tibetano e as estratégias de Desideri.

Como já dissemos, não temos como objetivo uma análise da obra em si, mesmo porque os escritos de Desideri já foram objeto de inúmeras publicações. ${ }^{523}$ Nosso propósito, portanto, é identificar, selecionar, fichar e analisar os capítulos da obra que tratam de estratégias de conversão, ao lado daqueles que abordam temas políticos, tais como governo espiritual e temporal no Tibete, a figura do Dalai Lama, por exemplo, procurando estabelecer relações entre esses aspectos políticos e as estratégias propostas pelo missionário.

\footnotetext{
${ }^{520}$ Por outro lado, o missionário italiano chega a desestimular a leitura dessas publicações, o que nos faz pensar se ele não estaria contrariando a própria ideia de divulgação dos trabalhos missionários e, portanto, indo contra a propaganda das missões jesuítas (e talvez de outras ordens) nas Índias.

521 "Queste mie notizie altro non hanno di buono, se non che sono notizie, e purchè siano tali, cioè schiette e di cosec he si meritino d'essere note, basta questo per tutto ill or bello." DESIDERI, I. La relazione di Ippolito Desideri, apud: PETECH, L. I missionari italiani nel Tibet e nel Nepal. Libr. dello Stato, vol. V, DR 1, p. 121. ${ }^{522}$ Cf: apêndice "F".

${ }^{523}$ Cf: BARGIACCHI, E. Opere e Bibliografia [Subsidia ad Historiam Societatis Iesu 15]. Roma: Institutum Historicum Societatis Iesu, 2007.
} 
No mais, nos guiaremos pelas análises realizadas principalmente por Trent Pomplun ${ }^{524}$ e pelas informações levantadas por Enzo Bargiacchi. Procuraremos estabelecer um diálogo desta fonte com as anteriores. Nossa ideia mais fundamental, no que diz respeito à política, é a de que os missionários que atuam no Oriente possuem uma expectativa - ou noção inicial do que seria um Estado, que por vezes é contestada, frustrada, subvertida ou mesmo imputada aos reis e reinos encontrados na Ásia. ${ }^{525}$ Essa expectativa, confrontada com o observado "na realidade", irá pautar as propostas de estratégias encontradas nos textos desses jesuítas.

Além disso, observamos que o debate feito por Desideri em sua apresentação da seita tibetana, em especial dos seus "erros", é interessante porque adiciona mais uma categoria que, até então, não havia sido identificada em outros relatos, quer sobre a Índia, quer sobre o Tibete: o ateísmo. ${ }^{526}$

Ainda que o próprio jesuíta, ao final de sua argumentação, negue o suposto ateísmo dos tibetanos, parece-nos evidente uma espécie de esgotamento das categorias anteriores no que diz respeito a uma descrição e antecipação de uma forma prudente de catequese. Idólatra, pagão, infiel etc., nenhuma dessas categorias parece ter sido suficiente para resolver os problemas epistemológicos e missiológicos apresentados pelo budismo tibetano.

De forma a concluir nossa investigação, abordamos uma espécie de apêndice da Notícia Histórica do Tibete, no qual Desideri escreveu suas sugestões para os missionários que iriam para as Índias. Serão justamente essas sugestões, quase em formato de um manual, que servirão de base para as nossas considerações finais. Teceremos uma linha desde as estratégias identificadas na primeira missão mogol até o modelo defendido por Desideri, sempre estabelecendo uma relação entre essas estratégias e os contextos de tensões políticas temporais e religiosas - nos três momentos analisados, a fim de desenharmos uma proposta interpretativa para a atuação da Companhia de Jesus nas missões ao norte do subcontinente indiano e no Tibete, nos séculos XVII e XVIII.

Assim sendo, podemos estabelecer como marco inicial para o estudo desta segunda fase dos investimentos da Companhia de Jesus em missões no Tibete o ano de 1712, quando o jesuíta italiano foi incumbido de dar continuidade à missão iniciada em 1624 por Antonio de

\footnotetext{
${ }^{524}$ POMPLUN, T. Jesuit on the Roof of the World: Ippolito Desideri's Mission to Eighteenth-Century Tibet. Nova Iorque: Oxford University Press, 2002.

${ }^{525}$ Se fossemos pensar em uma espécie de negativo do texto (tal como o negativo de uma fotografia) sobre a sucessão do Dalai Lama, enxergaríamos as expectativas de Desideri do que seria uma sucessão política.

${ }_{526}$ Sobre a questão do ateísmo em outros contextos de relações entre missionários e representantes da religião budista, cf.: VENTURA, R. O Budismo nas fontes do Padroado Português do Oriente (séculos XVI e XVII) um roteiro documental. In: BORGES, P.; BRAGA, D. (Comp.) In: O Buda e o Budismo no Ocidente e na Cultura Portuguesa. Lisboa: Ésquilo Edições e Multimédia, 2007, p. 167.
} 
Andrade. Em seu livro Jesuit in the roof of the world, Trent Pomplun assim descreve o padre italiano:

O primeiro ocidental a tentar tal crítica interna sobre a metafísica do budismo tibetano foi o missionário jesuíta Ippolito Desideri, que viveu em regiões de língua tibetana entre 1715 e 1721. (...) Ele escreveu tratados filosóficos e teológicos em tibetano, incluindo um catecismode tamanho médio e uma imensa refutação da reencarnação. (...) Ele foi espião, explorador, historiador, proponente de diálogos inter-religiosos e, finalmente, um codificador de nossas próprias ansiosas fantasias sobre a terra das neves. ${ }^{527}$

Não perderemos de vista todos os aspectos que Pomplun reconhece em Desideri. No entanto, focaremos mais especificamente na figura do missionário como alguém que parte para o Tibete com um propósito específico: converter os tibetanos. ${ }^{528}$ Reiteramos também o caráter dialógico da proposta de missão do jesuíta, devidamente apontado pelo autor.

Mas retomemos a trajetória do missionário: Desideri deixou Roma em setembro de 1712 para iniciar sua viagem às Índias. ${ }^{529}$ Em abril de 1713, o missionário partiu de Lisboa, chegando a Goa em 20 de setembro de 1713.

Em 12 de maio de 1714, o jesuíta chegou a Delhi, capital do Império Mogol naquele tempo, onde a Companhia de Jesus tinha duas igrejas e duas residências. No fim do mesmo mês, Desideri chegou a Agra, onde haviam se estabelecido os primeiros jesuítas que missionaram na corte mogol décadas antes. ${ }^{530}$ Lá, o italiano passou três meses aprendendo o idioma persa, ${ }^{531}$ cuja importância para a missão do Tibete havia sido indicada, mas que, no futuro, o próprio jesuíta perceberá ter sido inútil. O hindustani, segundo o missionário, terlhe-ia sido mais útil para em seguida conseguir alguém que lhe ensinasse tibetano.

Após reunir-se com o visitador José da Silva em Agra, Desideri retornou a Delhi, onde encontrou seu companheiro de viagem - o português Manuel Freire - com quem partiu, em

\footnotetext{
527 "The first Western to attempt such an internal critique of Tibetan Buddhist metaphysics was the Jesuit missionary Ippolito Desideri, who lived in Tibetan speaking regions from 1715 to 1721 . (...) He composed philosophical and theological treatises in Tibetan, including a middling-size catechism and an immense refutation of reincarnation. (...) He has been a spy, an explorer, a historian, a proponent of interreligious dialogue and, finally, a cipher for our own anxious fantasies about the land of snows." POMPLUN, T. Jesuit on the Roof of the World: Ippolito Desideri's Mission to Eighteenth-Century Tibet. Nova Iorque: Oxford University Press, 2002, p. 3. Tradução nossa.

${ }^{528} \mathrm{O}$ mesmo autor afirma: "I will also treat him [Desideri] for what he was: a missionary of the Society of Jeusus in the early eighteen century." Ibidem, p.10.

${ }_{529}$ DESIDERI, I. La relazione di Ippolito Desideri, apud: PETECH, L. I missionari italiani nel Tibet e nel Nepal. Libr. dello Stato, DR 1, p. 123.

530 Ibidem, p. 137-143.

${ }^{531}$ Sobre a importância do idioma persa na corte mogol, sugerimos as indicações bibliográficas referenciadas no segundo capítulo desta tese.
} 
setembro de 1714 , para o Tibete. ${ }^{532}$ No caminho, Desideri passa pela cidade de Srinagar, na Caxemira, possivelmente acreditando que esta teria sido a rota feita por Andrade. No entanto, o português passara por Srinagar no Garwal. É possível que Desideri tenha perdido alguns dias fazendo esse trajeto, um tanto mais longo. Em trinta de maio, Desideri chega no "Pequeno Tibete", isto é, no Baltistão, atual província do Paquistão. ${ }^{533}$

Em março de 1716, Desideri chega à cidade de Lhasa, capital do terceiro e grão Tibete: o destino de sua missão. ${ }^{534}$

O contexto político encontrado por Desideri é um tanto diferente daquele dos tempos de Antônio de Andrade. No inicio do século XVII, o Tibete - em especial sua região ocidental - ainda se encontrava dividido em pequenos reinos. Essa organização política, como já dissemos, se modificou durante o processo que culminou no investimento do V Dalai Lama. Por outro lado, no século XVIII, quando o missionário italiano chegou a Lhasa, a figura centralizadora do V Dalai Lama não mais existia, pois ele havia morrido em 1682. Assim, Desideri se instala num Tibete mais centralizado, do ponto de vista político, porém já "órfão" de seu líder político-espiritual mais importante.

O jesuíta será recebido por um governante leigo chamado Lajang Khan, que, supostamente, lhe garantirá o apoio necessário para a sua missão. A seguir, procuraremos identificar as principais forças e os principais atores políticos no cenário Tibetano do início do século XVIII. Para a compreensão do contexto em que o italiano Ippolito Desideri se instalou, é importante termos em mente as disputas políticas internas e externas que envolvem o Tibete nesse momento. Essas disputas relacionam-se, internamente, com a complexa estrutura do governo criada ao fim da guerra entre o líder mongol Qoshot Gushri Khan e o exército de Tsang. No contexto externo, fatores como a fragmentação do poder político mongol e as disputas entre a China e os mongóis também pesaram no desenrolar dos eventos anteriores e contemporâneos à chegada do missionário a Lhasa.

Assim, nas páginas a seguir, propomos uma análise da obra Notícia Histórica do Tibete de Desideri. Num primeiro momento, faremos uma brevíssima descrição do cenário

\footnotetext{
${ }^{532}$ Para maiores informações sobre o companheiro de Desideri, sugerimos a leitura de: SWEET, M. Desperately Seeking Capuchins: Manoel Freyre's Report on the Tibets and their Routes (Tibetorum ac Eorum Relatio Viarum)' and the Desideri Mission to Tibet. Journal of the International Association of Tibetan Studies 2, 2005. p. 1-33.

${ }^{533}$ Cf: Apêndice "H".

534 “Luogo da me stabilito e prefissomi per incomincar la mission di quel regno". DESIDERI, I. La relazione di Ippolito Desideri, apud: PETECH, L. I missionari italiani nel Tibet e nel Nepal. Libr. dello Stato, DR. 1, p. 183.
} 
político tibetano quando da chegada do missionário. Trataremos especificamente do período de Lajang Khan à frente do Estado Tibetano.

Em sequência, utilizamos a própria Notícia Histórica do Tibete para elaborarmos uma "história" da missão, isto é, uma narrativa que, ao mesmo tempo, apresente o desenrolar dos fatos e proponha uma análise da escrita de Desideri.

Por último, passamos à parte mais descritiva e menos narrativa da Notícia Histórica do Tibete, que sustenta nossas hipóteses sobre as relações entre categorias descritivas e estratégias de conversão. Nesta última parte, serão de fundamental importância as ideias de Eisenberg $^{535}$ já apresentadas nas páginas anteriores, em especial seu entendimento da atividade missionária jesuíta necessariamente atrelada à segunda escolástica. Evidentemente que estamos atentos ao fato de que Desideri atuou no Tibete e escreveu suas obras no século XVIII, já um tanto distante do apogeu dessa forma de pensar. No entanto, partimos da premissa que, mesmo nesse período, fazia parte do noster modus procedenti "atualizar"(aggiornare) a doutrina a partir da experiência e vice-versa, sem, contudo, pôr em cheque premissas essenciais do tomismo.

${ }^{535}$ EISENBERG, J. As missões jesuíticas e o pensamento político moderno. Belo Horizonte: UFMG, 2000. 


\title{
4.2 BREVE HiSTÓRIA DO REI PROTETOR: LAJANG KHAN E O CONTEXTO POLÍTICO
}

\author{
TIBETANO APÓS A MORTE DO V DALAI LAMA
}

No quinto dia do quarto mês do ano do Cavalo-água, correspondente a 2186 anos após a morte de Buda ou ao ano cristão de 1642, o Dalai Lama foi levado a Shigatse e entronado no salão de audiências do palácio. Em dois tronos um pouco abaixo do seu, sentavam Gushri Khan e Sonam Chospel. ${ }^{536}$

Este parágrafo, extraído do livro Tibete: uma história política, auxilia-nos na identificação dos principais atores políticos no cenário tibetano à época do investimento do $\mathrm{V}$ Dalai Lama dos poderes espirituais e temporais. Além do líder Gelupa, completam a cena o líder mongol que venceu o exército tibetano do Tsang e o regente Sonam Chospel. O primeiro teria oferecido sua conquista - o Tibete - para o V Dalai Lama. Sob responsabilidade de Gushri Khan estava a proteção militar do Tibete. Já Sonam Chospel seria uma espécie de primeiro-ministro, responsável pela burocracia e administração do Estado Tibetano. ${ }^{537}$ Para nomearmos essa função, utilizaremos a palavra Desi (Sde-srid) ou regente, e seguiremos a definição proposta por Luciano Petech:

Entre 1642-1706, o regente foi o chefe da administração civil e política (mas não da militar) e exercia os poderes temporais que pertenciam ao Dalai Lama, mas não podiam ser exercidos pessoalmente por ele. Primeiramente, ele foi nomeado por Qoshot Khan, mas logo a escolha praticamente caiu nas mãos do V Dalai Lama. ${ }^{538}$

No período tratado em nosso capítulo, o V Dalai Lama - que de fato se destacou no exercício do poder sobre um Tibete unificado - já havia morrido. ${ }^{539}$ Como já comentamos em nossa introdução da segunda parte desta tese, quando Desideri chegou ao Tibete, em 1716, o

\footnotetext{
536، On the fifth Day of the fourth month of the Water-Horse year, corresponding to 2186 years after the death of the Buddha or the Christian year 1642, the Dalai Lama was led in state to Shigatse and placed on the throne in the audience hall of the palace. On two thrones a little lower than his sat Gushri Khan and Sonam Chospel." SHAKABPA, W. D. Tibet: A Political History. Nova Iorque: Potala Publications, 3 ed., 1984, p. 111. Tradução nossa.

${ }^{537}$ Esta é uma interpretação possível para o período em questão. Para uma análise aprofundada, sugerimos a leitura de SHAKABPA, W. D. op. cit., loc. cit.; e MCKAY, A. The History of Tibet. Londres: Routledge, 2003.

538 "From 1642-1706, the regent was the head of the civil and political (but not of the military) administration, and exercised the temporal rights which belonged [to] the Dalai Lama, but could not be wielded personally by him. At first he was appointed by the Qosot Khan, but soon the choice fell practically in the hands of the 5th Dalai Lama." PETECH, L. The Dalai Lamas and the regents of Tibet: a cronological study. In: MCKAY, Alex. The History of Tibet. Routledge, 2003, vol 2, p: 571. Tradução nossa.

${ }^{539}$ O V Dalai Lama morreu no ano de 1682, em Potala, aos 68 anos. SHAKABPA, W. D. op. cit., p. 123.
} 
Estado era, de fato, governado por Lajang Khan, neto de Gushri Khan. Lajang Khan foi o último mongol a governar o Tibete.

A ascensão de Lajang Khan à "cabeça" do Estado Tibetano não foi simples. Como dissemos, ainda que o Dalai Lama, em 1642, tivesse sido investido dos poderes espirituais e temporais, o avô de Lajang e um regente também foram entronados. Conforme exposto anteriormente, a relação de patronagem fundamentou a presença do líder mongol na cerimônia. Ou seja, é preciso levar em conta que lideres mongóis como Altan Khan, Gushri Khan e Lajang Khan participaram ativamente da história política do Tibete.

No caso do último, podemos iniciar a narrativa de seu percurso até o governo do Tibete a partir do ano de 1682, quando morreu o V Dalai Lama e o regente (ou Desi) chamava-se Sangye Gyatso. Ele estava no cargo há apenas três anos, e, apesar disso, Gyatso revelou-se, segundo a historiografia levantada, um regente muito capaz e politicamente astuto.

Sangye Gyatso optou por manter a morte do líder Gelupa em segredo enquanto buscava sua reencarnação. Ainda em segredo, zelou pela formação espiritual do "novo" Dalai Lama, chamado Tsangyang Gyatso. Utilizando-se de um monge como substituto do Dalai Lama falecido em cerimônias solenes ou sempre que necessário, o regente pôde manter o sigilo por aproximadamente 15 anos, adiando assim o máximo que pode o entronamento do VI Dalai Lama.

No entanto, o regente não podia saber que, com o passar do tempo, Tsangyang Gyatso demonstraria tão pouca vocação para assuntos espirituais. O jovem negou-se a se tornar um monge totalmente ordenado, recusando-se a realizar os últimos votos. Dedicava-se à poesia e às saídas noturnas, levando uma vida escandalosa para parâmetros sacerdotais. ${ }^{540} \mathrm{Em}$ um desses passeios noturnos, disfarçado com as roupas de um amigo chamado Targyané, o VI Dalai Lama sofreu uma tentativa de assassinato, orquestrada pelo regente. Salvou-se às custas do amigo, com quem trocara de roupa.

Nesse contexto tumultuado, a figura do regente enfraquecia na medida em que o Khan aspirava progressivamente ao trono tibetano. Finalmente, a notícia de que o regente havia escondido a morte do Dalai Lama e a atual postura do líder religioso fortaleceram Lajang. ${ }^{541}$ Nas palavras de Luciano Petech:

\footnotetext{
540 "In short, the sixth Dalai Lama was a man-about-town who enjoyed the company of women. He composed excellent, romantic verses and songs, which became popular." SHAKABPA, W. D. Tibet: A Political History. Nova Iorque: Potala Publications, 3 ed., 1984, p. 129.

541 "In 1695 the Potala palace was completed. In the following year, the Desi, Sangye Gyatso, announced that the fifth Dalai Lama had died in 1682 and that his reincarnation was already thirteen years old. In 1697 Nyimathang Shabdrung was sent to the Imperial Court in China to make an official report of the death of the fifth Dalai
} 
Lajang Khan era um homem de caráter e energia, que não tinha a intenção de continuar a tolerar o estado impotente ao qual os chefes Qoshot estavam rebaixados. Imediatamente, ele começou a mostrar atividade e interesse em relação a questões tibetanas, o que causou uma renovação da importância quase obsolete de sua família. ${ }^{542}$

De sua parte, o Desi não via com bons olhos as aspirações de Lajang, e chegou a envenenar a ele e ao seu primeiro-ministro em uma ocasião entre os anos de 1702 e 1705 . A situação alcançou um ponto tal que o regente decidiu renunciar em 1703. No entanto, essa renúncia parece ter sido mais uma estratégia de Gyantso para continuar atuando politicamente nos "bastidores". 543

Em 1705, foi convocada uma conferência com o objetivo de resolver, de forma definitiva, as disputas entre o ex-Desi e o líder Qoshot. Ficou decidido que o último não deveria continuar em Lhasa e que deveria voltar à Kokonor ${ }^{544}$, de onde manteria uma relação amigável com o Tibete.

Em sua suposta viagem a Kokonor, Lajang Khan reuniu um exército mongol e ameaçou invadir Lhasa. Uma nova negociação foi iniciada, e então ficou decidido que o exDesi deveria deixar a cidade, indo para Gonkar. O antigo regente aceitou a decisão, mas, em sua viagem, foi preso e morto pelo líder mongol, que pode finalmente retornar a Lhasa e assumir totalmente o governo civil do Tibete.

Após tal evento, Lajang foi reconhecido como rei (rgyal-po k'ri-pa) (...). O título de cortesia de Jingis Khan era geralmente usado por estrangeiros; os missionários no Tibete e Unkovskij, o enviado russo para Dsungaria, não conheciam outro nome. ${ }^{545}$

Lama. The K'ang-hsi Emperor went in person to meet the Tibetan envoy at the second door of the Imperial palace. Nyimathang announced that the Dalai Lama had died years before and that his reincarnation now sat on the throne in the Potala. The Manchus used this announcement to convince the Chahar, Qoshot, and other Mongol tribes that the Desi had kept the Dalai Lama's death a secret in order to retain power in his own hands. They also accused the Desi of showing disfavor to those Mongols living in Tibet. (...)The Desi became unpopular with the Qoshot Mongols in the Kokonor region, when they heard the rumor that their fellow tribesmen in Tibet were being ill treated. At the same time, learning that the Dalai Lama was dead, the Qoshots lost interest in trying to recover Tibetan territory lost to the Manchus." SHAKABPA, W. D. Tibet: A Political History. Nova Iorque: Potala Publications, 1984, p. 128.

542 "Lajang Khan was a man of character and energy, who did not intend to tolerate any longer the powerless state to which the Qosot chiefs had sunk. At once he began to show an activity and interest in Tibetan affairs, which portended a revival of the almost obsolete paramountcy of his family.” PETECH, L. Lajang Khan, the last qosot ruler of Tibet (1705-1717). In: MCKAY, A. The History of Tibet. Nova Iorque: Routledge, 2003, vol 2, p. 585. Tradução nossa.

543 "A number of circumstances, including the discontent of the Mongols and the growing estrangement with the Dalai Lama, forced the Desi to resign in 1703 (...) Following the resignation of Sangye Gyatso, Ngawang Rinchen was appointed Desi; however, Sangye Gyatso remained behind the scene and continued to have control of the administration.” SHAKABPA, W. D., op. cit., p. 131.

${ }^{544}$ Região que atualmente corresponde à província chinesa de Qinghai, mas que, no período tratado, estava sob domínio dos mongóis Qoshots.

545 "After this, Lajang was recognized as king (rgyal-po k'ri-pa) (...). This courtesy title of Jingis Khan was normally used by foreigners; the Italian missionaries in Tibet and Unkovskij, the Russian envoy to Dsungaria, 
Será assim que Desideri se referirá ao rei do Tibete: o Rei Gengis Khan. E será esse rei que receberá e protegerá o missionário. A seguir, partiremos da narrativa do próprio missionário, na qual encontramos indícios para sustentar a nossa hipótese de que Lajang Khan e Desideri estabeleceram entre si uma relação análoga à de patronagem. 


\title{
4.3 O VENENO E O ANTÍDOTO: DESIDERI ESTABELECE SEU PROJETO MISSIONÁRIO NA
}

\author{
TERRA DOS LAMAS
}

Uma vez em Lhasa e em audiência no palácio ${ }^{546}$ com o comandante das forças armadas que ali estava em nome do rei, Desideri apresenta-se como

Cristão, religioso, e lama, isto é, sacerdote, com obrigação e ofício de guiar outros pelo correto caminho da salvação, e atualmente em exercício de procurar remover, com toda minha força, aqueles que estivessem em erro do seu desvio e de conduzi-lo à nossa Santa Lei, como o unicamente verdadeiro e legitimo caminho, fora do qual não há outro para alcançar o céus e conseguir a felicidade eterna. ${ }^{547}$

Após apresentar-se à corte, Desideri soube que o "primeiro-ministro do rei" ${ }^{548}$ gostaria de conhecê-lo e oferecer-lhe proteção.

Isso andava eu muito desejando e buscando; não tanto para ter em tão remoto país um apoio para minha defesa e proteção, quanto para ter obter pouco a pouco a licença para poder livremente e sem oposição ensinar naquele reino e naquela corte a nossa Santa fé..$^{549}$

Estas palavras do missionário são muito importantes, pois indicam que uma parte essencial da estratégia de viabilizar o estabelecimento da missão é assegurar o apoio político local, principalmente para o caso de missões que estão distantes do raio de atuação de Coroas Cristãs. Além disso, ao contrário da experiência da Ordem anteriormente estabelecida no Tibete, seu principal missionário não é português, mas italiano. Os tempos mudaram. Na missão anterior, o missionário Nuno Coresma ressaltava a necessidade da presença do braço secular português, sem o qual não haveria como garantir a liberdade de pregação e a

\footnotetext{
${ }^{546}$ No segundo livro de sua Notícia Histórica, Desideri indica que a residência do rei é o palácio chamado "Tondrupp-zze-ring" [Don-grub-ts'e-rin]. DESIDERI, I. La relazione di Ippolito Desideri, apud: PETECH, L. I missionari italiani nel Tibet e nel Nepal. Libr. dello Stato, DR. 1, p. 184. Na publicação, em inglês, "Tromsikhang". DESIDERI, I. Mission to Tibet: the extraordinary eighteenth-century account of father Ippolito Desideri, S.J. Tradução Michael J. Sweet, Edição Leonard Zwilling. Boston: Wisdom Publications, 2010, p. 230. 547 "Cristiano e religioso ed esser Lamà, cioè sacerdote, in obbligo e in uffizio di guidar altri per il diritto sentiero della salute; e attualmente in esercizio di procurar con tutte le mie forze di ritirar quelli che fossero in errore da'loro traviamenti e di condurli alla nostra S. Legge, come a unicamente vera e legittima strada, fuori di cui non v'è altra per arrivar al cielo e al conseguimento dell'eterna felicita" DESIDERI, I. La relazione di Ippolito Desideri, apud: PETECH, L. I missionari italiani nel Tibet e nel Nepal. Libr. dello Stato, DR. 1, p. 184.

${ }^{548}$ Ibidem, p. 185.

549 "Quest'appunto andava io molto desidetrando e cercando; non tanto per aver in sì remote paese un appoggio per mia difesa e protezione, quanto per aver adito a ottener a poc'a la licenza di poter liberamente e senz'opposizione insegnar in quel regno e in quella corte la nostra Santa Fede.” Ibidem, p. 185.
} 
observância das leis cristãs. O "temor" exercido pela Coroa dá lugar a outras estratégias: faz-se necessário, mais do que nunca, criar laços políticos locais.

Em 28 de abril de 1716, Desideri retorna ao palácio para encontrar-se com o primeiroministro. Nessa ocasião, é chamado à presença do rei, mas recusa-se a ir de imediato. Suas explicações para não atender ao chamado do soberano dizem muito sobre a teatralização ou atuação dos missionários da Ordem, à semelhança do que já vimos na corte mogol e na experiência anterior dos religiosos em Tsaparang:

Em parte para aumentar no coração do rei o desejo de falar comigo, e em parte por respeito, com boas maneiras declinei de receber naquele dia tão grande honra, alegando o costume de não ter por ora alguma coisa digna de oferecer a Sua Magestade. ${ }^{550}$

Em função disso, Desideri adquire vários objetos com mercadores estrangeiros, aos quais ele acrescenta duas pedras de bezoar ${ }^{551}$ que ele trouxe de Goa e o que ele chama de "cocco di balsamo del Brasile", o que supomos ser uma espécie de resina de copaíba. ${ }^{552}$

No dia primeiro de maio, o missionário italiano vai ao palácio com os presentes e mostra-os ao primeiro-ministro que, depois de examiná-los, encaminha Desideri à presença do rei. O régulo estava acompanhado de vários lamas, governadores e outras pessoas importantes, as quais também estavam lá para a audiência real. Após entregar os presentes, Desideri julgou oportuno pedir ao soberano que lhe garantisse liberdade de pregação, em público e no privado, para falar com qualquer pessoa sobre a verdade da "santa lei". Após conceder a permissão, o missionário relata que o rei: "elogiou-me como uma pessoa bem-

\footnotetext{
550 "Parte per far crescer maggiormente nel cuor del re il desiderio di parlarmi, e parte per rispecto, mi scusai con buone maniere del ricever in quel giorno un onore sì segnalato, allegando il costume di non comparir alla presenza de' grandi con le mani vuote, e del non aver io per allora alcuna cosa degna d'offerirsi a Sua Maestà." DESIDERI, I. La relazione di Ippolito Desideri, apud: PETECH, L. I missionari italiani nel Tibet e nel Nepal. Libr. dello Stato, DR. 1, p. 186.

${ }^{551}$ Bezoar é uma espécie de pedra retirada do interior, em geral do estômago, de determinados animais. O imperador mogol Jahangir, por exemplo, posou segurando um bezoar em um de seus retratos. "It was costumary [for foreign embassies] to bring presents which gave credit to offer as also pleasure to receive. One such object, prized in every court, was bezoar, the antidote against poisoning. Men with power, nobilities and rulers, were always in danger of assassination and the easiest manner of killing them was poisoning. Hence bezoar, supposed to be a cure against poisoning, was always treasure as one of the indispensable items of royal household." MAHIDASSAN, S. Bezoar presented to emperor Jehangir (sic). Annals of the Bhandarkar Oriental Research Institute. vol. 56. n. 1/4, p. 232-233, 1975.

${ }_{552}$ DESIDERI, I. La relazione di Ippolito Desideri, apud: PETECH, L. I missionari italiani nel Tibet e nel Nepal. Libr. dello Stato, v. V, DR. 1, p. 186. Sobre isso, sugerimos consultar a obra THE PHILOSOPHICAL Transactions of the Royal Society of London, disponível em: <https://play.google.com/books/reader?id=bQ_AAAAYAAJ\&printsec=frontcover\&output=reader\&authuser=0\&hl=en\&pg=GBS.PP7 $>$.

Na página 239 do artigo On the Use of Ipecacuanha, for Loosenesses, pode-se ler: "It seems to have been first noticed by an anonympus Portuguese, who lived in Brasil, (supposed to be one Manoel Tristaon) whose book falling into the hands of the English, is translated and published by Purchas, in the year 1625. [The book mentions] an herb called in Brasil, igpecaya, or pigaya, which I believe to be this." SLOANE, H. Of the Use of the Root IPecacuanha, for Loosenesses. Traduzido de um artigo em francês, com notas do autor. Philosophical Transactions, n. 20, p. 69-79.
} 
versada nas ciências, enfática e persuasive em seus discursos, franca, dedicada à verdade e resoluta e determinada em mantê-la." ${ }^{553} \mathrm{O}$ soberano teria declarado ainda que Desideri deveria permanecer em seu reino, seguro de que, caso alguém o molestasse, ele tomaria para si a tarefa de protegê-lo e punir quem de direito fosse. Desideri deveria, então, continuar o estudo do idioma tibetano para que, no futuro, o rei pudesse ter o prazer de conversar com o missionário mais livremente, sem a necessidade de intérprete.

Dos fatos iniciais relatados por Desideri, podemos enumerar algumas características que aproximam a maneira de agir do missionário do que os outros jesuítas abordados anteriormente também fizeram quando chegaram aos reinos em que deveriam se estabelecer.

O primeiro aspecto que gostaríamos de ressaltar é a teatralização da atuação de Desideri, manifestada de duas formas: ele explicita para o leitor os expedientes de que fez uso para despertar a curiosidade do rei a seu respeito. Em segundo lugar, ele descreve a cerimônia de audiência de maneira a deixar claro que estava na presença de um grande número de pessoas importantes, que foram "plateia" de sua apresentação, além de conferirem tom solene ao evento narrado pelo jesuíta.

Desde o relato de Montserrat, passando pela carta de Andrade, podemos perceber que o momento em que um missionário se apresenta para a corte é um acontecimento de destaque na narrativa, pois se trata de uma ocasião importante para o projeto missionário. Concluímos que, no caso das missões na Ásia, em que, a princípio, o principal alvo do trabalho evangelizador é o "rei" ou "cabeça", e em cujas sociedades os religiosos reconhecem algum tipo de organização política associada a protocolos e normas de etiqueta, as circunstâncias nas quais o religioso se apresenta ganham bastante destaque nos relatos.

Para nossa análise isso é importante, pois também fornece indícios do método de adaptação que pode estar sendo antecipado pelo missionário. Desideri apresenta-se como "lama", mas não só isso: ele é reconhecido como uma espécie de "sábio", culto, erudito. Esse traço pode aproximar o método do italiano dos métodos que outros missionários da Ordem adotaram, em especial na China e no Japão.

Seja para o caso aqui retratado ou para os que abordamos anteriormente, a este momento inicial de apresentação segue-se o pedido por liberdade de pregação, que é aceito,

\footnotetext{
553 “Con larghe e magnifiche espressioni m'accordò egli publicamente la dimandata licenza; e rivoltosi in giro a tutto il coonsenso, si degnò di farmi un elogio, come d'uomo che mostrava aver fatto studio nelle scienze, che nel parlar abbia enfasi e persuasive, schietto, impegnato pela verità, risoluto e intrépido per sostenerla." DESIDERI, I. La relazione di Ippolito Desideri, apud: PETECH, L. I missionari italiani nel Tibet e nel Nepal. Libr. dello Stato, DR. 1, v. V, p. 187. Tradução nossa.
} 
variando de caso a caso e com mais ou menos reservas, pelo agente identificado com o poder temporal local. ${ }^{554}$

A mise-en-scène desse momento, em geral, envolve a entrega de presentes, o que pode ser uma adequação aos costumes locais, mas, por outro lado, não chega a ser nada muito estranho ao costume europeu. De qualquer forma, é necessário distinguir, aos olhos da Companhia de Jesus, o momento de oferta de presentes e a manutenção dessas ofertas, que podem configurar uma "chatinagem", ou ainda uma espécie de troca de favores e compra da simpatia do soberano local. Isso parece ter sido fortemente condenado no caso da missão tibetana conduzida por Andrade, como vimos anteriormente.

Por último, gostaríamos de ressaltar o estabelecimneto de uma relação análoga a de patronagem, abordada no início desta segunda parte da tese. Seja de forma deliberada ou não, fato é que Desideri tirou proveito do costume local, segundo o qual, um lama, isto é, um preceptor espiritual, deve ser "apadrinhado" por um nobre. Neste caso específico, Desideri buscou - e conseguiu, pelo menos a princípio - ser protegido pelo próprio rei.

Segue-se no relato a antecipação do método, isto é, o jesuíta desde o início indica que seu primeiro objetivo é aprender a língua. O missionário inclusive menciona o desejo do próprio rei de poder conversar com ele mais livremente e sem intérprete.

Mas o sucesso ou fracasso das ações missionárias não dependem apenas das atuações dos padres e das estratégias por eles priorizadas. Como vimos na missão anterior, uma série de acontecimentos estranhos à atuação jesuíta (fome, pestes, guerras, mortes etc.) podem apresentar-se fortuitamente como obstáculos à empresa missionária. No caso de Desideri, o acaso parece ter lhe favorecido, ao contrário do que se passou com os missionários anteriores.

Em uma circunstância pouco esmiuçada no texto do italiano, o rei do Tibete e o primeiro-ministro haviam sido, no passado, vítimas de envenenamento. Tal fato já foi mencionado por nós há algumas páginas. Lajang Khan sofreu uma tentativa de assassinato de

\footnotetext{
${ }^{554}$ Infelizmente, não podemos nos aprofundar neste tema por hora, mas para futura referência, gostaríamos de indicar que uma outra apresentação menos feliz, do ponto de vista da atuação missionária, ocorreu quando o jesuíta Francisco Azevedo foi encontrar-se com o rei do Ladakh para negociar apoio à missão de Tsaparang. É curioso notar as distinções entre as narrativas deste momento e dos outros (Mogol, Tsaparang e Lhasa), nos quais a descrição positiva do rei e da corte é associada à garantia de liberdade de pregação. Na narrativa de Azevedo, nem o rei nem a rainha aparecem descritos de forma positiva, servindo esta passagem de contraponto para as demais analisadas nesta tese: "É homem alto de corpo, nas cores baço, nas feições jau, na postura severo, com cambaia de pano vermelho grosso, e pouco limpo, com uma capa do mesmo, barrete vermelho bem safado (...) e encruzado sobre uma colcha de veludo de carmesim do tempo de Matusalém. Junto a Sua Majestade estava a Rainha sua senhora, uma perra jaua que o governa, de má natureza, balofa, e tão abotoada nos olhos que escassamente se deixam ver, vestida como o marido." A descrição, por si só, já é um indício que as negociações com este régulo não saíram como o jesuíta esperava. CARTA de Francisco de Azevedo, Agra, 1631. In: DIDIER, H. Os portugueses no Tibete. Os primeiros relatos dos jesuítas (1624-1635). Lisboa: Comissão Nacional pra Comemoração dos Descobrimentos Portugueses, 2000, p. 198.
} 
autoria atribuída ao antigo Desi. Na ocasião do ressurgimento dos efeitos consequentes ao envenenamento ocorrido entre 1703 e 1705, um dos presentes dado por Desideri - dosado e administrado por ele - parece ter salvo o régulo da morte.

Essa contingência permitiu ao missionário não só se aproximar do rei e do primeiroministro, como também colocar em prática mais uma faceta da atuação já mencionada. Além disso, os dois passaram a ter uma dívida de gratidão com o jesuíta, que soube manipular a "dívida" de forma conveniente.

Em primeiro lugar, Desideri não fornece o antídoto ao rei sem antes "dourar a pílula":

Expliquei a ele sobre as propriedades e os benefícios do meu remédio, ao mesmo tempo em que exagerei na sua importância como proteção para minha vida, dizendo que, enquanto viajante do mundo e tendo vivido entre pessoas desconhecidas, sempre o guardei com muito apego. No entanto, disse a ele, 'Valorizo a saúde do rei e do primeiro-ministro mais que a minha própria vida.' (...) Como resultado, o amor e o compromisso que me mostraram anteriormente agora parecia nada em comparação com o novo vigor de suas afeições; agora, mais e mais me favoreciam, protegiam e ofereciam demonstrações do grande senso de gratidão que sentiam por $\operatorname{mim}{ }^{555}$

Por mais que os tibetanos perguntassem a Desideri o que ele queria por ter salvado a vida do rei e do primeiro ministro, o missionário sempre respondia que nada queria. Desejava apenas que "continuassem, com verdadeira preocupação com seu próprio bem-estar, o que já havia começado, isto é, a escutar e se beneficiar das maiores verdades de nossa sagrada fé." 556 Às reiteradas recusas aos presentes e recompensas a ele oferecidos, Desideri acrescenta, em suas justificativas, uma distinta apresentação do papel de um jesuíta em uma corte. De forma a deixar ainda mais claro seus "interesses", o missionário se descreve como um homem religioso, desinteressado das coisas mundanas, mas cuja presença imiscui-se com os assuntos de Estado:

O rei, sendo parente do imperador da China, e você, como membros beminformados da corte, sabem bem que por muitos anos, religiosos europeus

\footnotetext{
555 "Gli spiegai la qualità ed eccellenze di tal mio rimedio; gli esagerai ul gran conto che ne facevo, como di guardia della mia propria vita; e perciò, como uomo che correva il mondo e passava tra genti incognite, lo conservavo sempre con molta gelosia. Nondimeno stimar io assai più la sanità del re e del primo ministro, cha la mia vita medésima. Andasse, portasse loro tutt'il vasetto; dasse loro un tal rimedio nella quantità e modo che gli spiegai, e facesse lor animo, con assicurarli a mio nome che ne sperimenterebbero il giovamento. Riferì egli fedelmente il tutto, ed essi in quell'ora medesima si prevalsero dell'inviato rimedio. (...) Per questa cagione l'amor e impegno che già antecedentemente avevano verso di me, parve un niente rispetto al nuovo vigore che la lor affezione prese, per sempre più favorirmi, protegermi, e redermi manifesto co' fatti l'estremo sentiment di gratitudine che per tal causa mi protestarono.” DESIDERI, I. La relazione di Ippolito Desideri, apud: PETECH, L. I missionari italiani nel Tibet e nel Nepal. Libr. dello Stato, DR. 1, p. 190.

556 "Continuassero, come di già avevano cominciato, con vera premura del lor bene a udir e a conferir l'importantissime verità della nostra $\mathrm{S}$. Fede, e che continuassero altresì a permettermi di parlar in quel regno publicamente (..) senza verun ostacolo, e a voce e in iscritto, e di poterle a tutti universalmente annunzuare Ibidem, DR. 1, p. 191. Tradução nossa.
} 
foram aceitos em tal importante império no mesmo ministério que vim aqui exercitar. Da mesma forma, muitos desses religiosos estão em domínios mogóis e em outros reinos, ilhas e impérios. Tais homens, que são vindos, em sua maioria, de berços importantes e com aprendizado amplamente reconhecido, não possuem qualquer interesse mundano nem buscam proveito pessoal. ${ }^{557}$

Esta passagem é deveras interessante, pois não só traça o (suposto) perfil de um missionário, mas o insere num contexto geopolítico amplo e global. Se tomarmos como endereço esta fala o próprio rei, percebemos que Desideri nomeia unidades políticas de destaque no contexto asiático, insinuando que a presença de um missionário como ele "elevaria" ou "igualaria" a corte de Lajang Khan às dos Impérios Mogol ou Chinês. Por outro lado, se tomarmos o público europeu como alvo do discurso, percebemos que o missionário é capaz de identificar elementos geopolíticos importantes e disso lançar mão quando necessário, de forma a demonstrar um "método". Acreditamos que passagens como esta demonstram o olhar geopolítico global que a Companhia de Jesus elaborou ao longo de sua atuação nos diversos continentes durante a Época Moderna. Não obstante, também propomos que tal olhar tem uma finalidade prática: auxiliar a atuação missionária. A erudição e os instrumentos intelectuais prezados pelos jesuítas não possuem apenas fins pedagógicos, atrelados somente ao estabelecimento de instituições de ensino e locais de saber. Evidente que o aspecto pedagógico é de suma importância para a atuação da Ordem. Mas a identidade missionária dos membros da Companhia de Jesus reside no binômio intelecto-político: na erudição, no saber e na retórica a serviço do proselitismo na ponta da atuação da Ordem nas missões. Afinal, segundo Desideri, homens como ele têm por objetivo "ir a terras estrangeiras pelo único motivo de ensinar a verdade sobre a sagrada lei de Cristo. (...) Eu desejo nada mais que disseminar a verdade e a verdadeira lei da salvação." ${ }^{558}$

Neste trecho, portanto, o missionário consegue juntar em seu relato dois aspectos centrais de nossa análise: o caráter espiritual do trabalho da Companhia de Jesus e sua faceta geopolítica. Desideri não se apresenta apenas como preceptor espiritual. Ele se apresenta

\footnotetext{
557 'Saper molto bene Il re, como parente dell'imperator della Cina, ed assi ancora, come bem informati di quella corte, Che sin da molt'anni si trovano in quel grand'imperio altri molti religiosi europei impiegati in quell'intesso ministerio, per cui esercitar erro io cola venuto. Nel medesimo modo, ritrovarsene altri nel Mogol e altri in altri regni, isole e imperi. Sì fatti uomini, per ló più di nascita illustri e di dottrina molto acreditati, non solamente non pretendere ne cercar in si lunghi e penosi pelleggrinaggi e com si imensi travaglial cun lor interesse o vantaggio temporale, ma abbandonando quanto nelle loro patrie avevano o potevano separare, andar a stranieri paesi, no per altro fine che per insegnar le verità della S. Legge di Cristo.” DESIDERI, I. La relazione di Ippolito Desideri, apud: PETECH, L. I missionari italiani nel Tibet e nel Nepal. Libr. dello Stato, DR. 1, p. 191. Tradução nossa.

558 “che per insegnar le verità della S. Legge di Cristo. (...) Ad altro, anch'io non aspirate che alla propagazione della verità e della vera legge di salute." Ibidem, loc. cit. Tradução nossa.
} 
como alguém erudito e culto, de bom nascimento, que pertence a um grupo de homens semelhantes a ele, os quais atuam na grandes cortes do mundo. Dessas cortes, ele dá dois exemplos importantes: o Mogol e a China.

Não obstante, Desideri parece partir de uma premissa curiosa: a relação entre o rei do Tibete e o Imperador Chinês. Isso também diz muito sobre a concepção geopolítica global que os jesuítas possuem nesse momento, a qual possivelmente pressupõe a necessidade de se estabelecer uma ponte entre as missões na Índia e na China. ${ }^{559}$

Neste extrato, portanto, Desideri procura se credenciar como um homem sábio, pertencente a um grupo de homens distintos que, em nome da Santa Lei, exercem um importante ministério nos principais Estados daquela parte da Ásia. Fazendo isso, Desideri não só nos apresenta o seu próprio entendimento do seu papel - e de como ele deve atuar como também inverte a expectativa de relação entre ele e o rei. Não é mais o missionário estrangeiro que precisa da proteção do poderoso soberano; ao contrário, é o rei que deve se sentir honrado de estar na presença de um representante de um grupo de eruditos altruístas, cujo ministério é exercido em várias cortes importantes.

Em sequência, Desideri se nega a aceitar qualquer oferta em nome do rei, a não ser aquelas relativas ao seu pedido inicial: liberdade de pregação. Em sua narrativa, os enviados do rei parecem confusos, inconvenientemente demandando ao missionário que diga o que realmente quer. Ao perceberem que não iriam ouvir da boca do italiano "o que eles queriam", passaram a mensagem para o rei. Este, por sua vez, teria ficado espantado:

o rei possui convicção quase segura de que os ensinamentos de nossos pregadores do evangelho são, sem dúvida, verdadeiros, já que levam a tanta generosidade e desdém pelo mundo, e não devem, portanto, ignorar a pessoa que veio instruí-los nesta verdade, devendo ouvi-los com grande avidez e atenção. ${ }^{560}$

Uma vez conquistado seu objetivo inicial - a atenção do rei - Desideri parte para a execução, isto é, a prática de seu ministério. Umas das riquezas de seu texto é a exposição de um método que ele ao mesmo tempo põe em prática e defende retoricamente. Desideri explicita "como fazer" em seu relato, na mesma medida em que compõe a sua narrativa do

\footnotetext{
${ }^{559}$ É pertinente lembrar que Althanasius Kircher já havia publicado, em 1667, sua obra China Illustrata.

560 “Concepi uma quase ferma pesuasioane del dover senza dubbio esser veri gl'insegnamenti de' nostri predicatori evangelici, che a tanta generosità e disprezzo del mondo conducono; e perciò non esser de trascurarsi chi a là era venuto per instruir loro in tali verità, ma doversi com molta ansia e premura ascoltare". DESIDERI, I. La relazione di Ippolito Desideri, apud: PETECH, L. I missionari italiani nel Tibet e nel Nepal. Libr. dello Stato, DR. 1, p. 192. Tradução nossa.
} 
desenrolar dos fatos. Assim, ele anuncia seu novo objetivo: compor um livro em tibetano ${ }^{561}$ "que permitiria que eu tomasse os primeiros passos para explicar nossa sagrada fé e contestar sua falsa religião". ${ }^{562}$

Esta obra teria a seguinte estrutura. Em primeiro lugar, objetivaria demonstrar a falsidade da máxima corrente entre incrédulos, segundo a qual qualquer um pode salvar-se através da sua própria lei religiosa. A observação de Desideri corrobora com a nossa interpretação de que a presença dos jesuítas no Tibete, seja no século XVI ou XVII, foi facilitada pelo tradicional entendimento budista de que é possível salvar-se por mais de um caminho, isto é, há várias maneiras de livrar-se do sofrimento. Em segundo lugar, o livro trataria da "verdadeira lei da Salvação". ${ }^{563}$ Por último, Desideri indicaria e abordaria "os sinais e as características pelas quais uma pessoa pode facilmente distinguir a forma verdadeira da falsa, dentre todas as leis contraditórias e diversas que podem ser encontradas no mundo." ${ }^{564}$

Da mesma forma que agira anteriormente, o missionário relata no texto que o rei e o primeiro-ministro, ao saberem da obra, teriam ficado muito ansiosos. O livro foi terminado em dezembro de 1716 e foi dedicado ao rei. A entrega de sua obra ao régulo se deu em uma cerimônia pública, na qual se encontravam presentes lamas e pessoas politicamente influentes, que Desideri indica serem depas, isto é, funcionários públicos e governadores. A cerimônia é descrita em detalhes, e o missionário tem o cuidado de mencionar três fatos, os quais julgamos de grande importância para a nossa análise.

Em primeiro lugar, o livro foi envolto por Desideri em um pano de seda chinesa, o que reforça a ideia de que o jesuíta buscava seguir um protocolo, atender à cerimônia de forma decorosa e, ao mesmo tempo, indicar o valor que sua obra possuía.

\footnotetext{
${ }^{561}$ Trent Pomplun indica que se trataria de uma obra apologética em formato de diálogo, com o título "Tho rangs mun sel nyima shar ba'i brda" (em inglês: "Daybreak, the sign of the dawn that dispels darkness"). Além disso, o autor afirma que "Apologetic works setting forth the signs by which one could distinguish the true religion from its false copies were common among missionaries. Often these works of proclamations were written as dialogues, and Desideri's Daybreak is similar in form and content to two better known dialogues, Matteo Ricci's True meaning of the Lord of Heaven (Tianzhu shiyi) and Roberto de Nobili's Dialogue on eternal life (Nittiya Civana Callapam). Desideri explicitly modeled his first Tibetan work, however, on The Truth showing mirror (A'ine-yi haqq-numa) of Jerome Xavier (1549-1617)." O missionário escreveu ainda "Questions on rebirth and emptiness", "The origin of setinent beings and other phenomena" e um catecismo chamado "The heart of the Christian Doctrine". POMPLUN, T. Natural Reason and Buddhist Philosophy: The Tibetan Studies of Ippolito Desideri, SJ (1684-1733). History of Religions, vol. 50, n. 4, p. 390, maio 2011.

562 "Que mi potesse aprir la strada alla spiegazione della nostra fedde e alla confutazion di quella falsa religion." DESIDERI, I. La relazione di Ippolito Desideri, apud: PETECH, L. I missionari italiani nel Tibet e nel Nepal. Libr. dello Stato, DR. 1, p. 193. Tradução nossa.

${ }^{563}$ DESIDERI, I. La relazione di Ippolito Desideri, apud: PETECH, L. I missionari italiani nel Tibet e nel Nepal. Libr. dello Stato, DR. 1, p. 193.

564 "Vari segni e distintivi per i quail l'uomo può facilmente, frat ante, sì diverse, e sì opposte leggi che son al mondo, discerner la vera dale false." Ibidem, loc. Cit.
} 
Em seguida, o italiano diz que o rei "abriu o fecho e as amarras com as quais, nos costumes deste país, estava amarrado e abriu-0." 565 Parece-nos que a materialidade do livro serve-nos de metáfora para própria prática jesuítica, isto é, Desideri teve que se adaptar a elaborar um livro que não tinha formato de um códice à maneira europeia. As linhas de explicação da doutrina católica e os argumentos de refutação do budismo acomodaram-se ao formato que tinham os escritos tibetanos. Evidente que não pretendemos propor que esta foi a única iniciativa que pode simbolizar, materialmente, a acomodação da prática jesuíta. Sabemos que os catecismos escritos nas missões na Índia não se apresentavam como códices. Mas até mesmo por isso, ou seja, por uma certa universalidade da concretude da acomodação, é que nos parece tão emblemática a condição material dos primeiros escritos de Desideri em tibetano. ${ }^{566}$

Por último, o missionário ressalta que, antes de iniciar a leitura de seu livro, o rei ordenou que todos na audiência sentassem-se conforme sua condição ou lugar social e que o jesuíta se sentasse face ao trono. ${ }^{567}$ Mais uma vez, fica evidente a leitura social que Desideri faz desses acontecimentos, atentando para a organização e hierarquização da sociedade na qual ele se estabelece. Além disso, ele não guarda essas observações para si, mas, ao contrário, busca indicar em seu relato que ele mesmo foi colocado em lugar de destaque, em meio a um público distinto e hierarquicamente organizado.

Esse tipo de visão social está intrinsecamente associada à prática jesuíta. Reconhecer e atribuir um lugar - espacial, geográfico ou social - é fundamental, pois determina de que forma se deve abordar o outro. Da mesma forma que a Sociedade de Jesus organizou teoricamente e (re)ordenou o mundo no início da Idade Moderna, no cotidiano os jesuítas faziam um exercício semelhante, reconhecendo e dando lugar às pessoas com quem conviviam. O desdobramento da estratégia de conversão pelo alto não seria possível se não fosse esse olhar que reconhece e atribui lugares.

\footnotetext{
565 “con le sue mani lo sviluppò, indi sciolse la fibbia e legatura con cui, secondo il costume del paese, era legato, e apertolo" DESIDERI, I. La relazione di Ippolito Desideri, apud: PETECH, L. I missionari italiani nel Tibet e nel Nepal. Libr. dello Stato, p. 194.

${ }^{566}$ Sobre uma possível acomodação estilística, isto é, sobre a utilização de um modelo tibetano para a redação de suas obras, Trent Pomplun afirma que o livro tibetano Padma bka' thang foi utilizado por Desideri como modelo para o livro que o jesuíta apresentou a Lajang Khan sobre epifania. POMPLUN, T. Jesuit on the Roof of the World: Ippolito Desideri's Mission to Eighteenth-Century Tibet. Nova Iorque: Oxford University Press, 2002, p. 76.

567 "Diede ordine di far sedere per i suoi gradi tutta l'audienza, e me dirimpetto al suo trono." DESIDERI, I. La relazione di Ippolito Desideri, apud: PETECH, L. I missionari italiani nel Tibet e nel Nepal. Libr. dello Stato, p. 194.
} 
O rei passa então para a leitura do livro, e, em seguida, entrega-o ao rapjampa, apresentado por Desideri como doutor da religião, ${ }^{568}$ que lhe dá continuidade. Após ouvir atentamente por algum tempo, o rei pega de volta o livro e diz que nele havia vários princípios contrários à sua "seita". Nesse momento, ao invés de recusar-se a ouvir mais sobre o cristianismo, o rei conclui, segundo Desideri, que tais pontos mereceriam uma discussão mais séria e aprofundada. ${ }^{569}$ Não obstante, o rei teria indicado duas grandes dificuldades iniciais: aceitar um ser supremo de natureza única, não criada e incorpórea e a completa negação da metempsicose. O livro, que teria agradado muito o régulo, permitiu a Desideri aproximar-se ainda mais de seu objetivo: a conversão do soberano. Agora, o italiano havia logrado em iniciar um debate com o ele e seus lamas, estabelecendo um diálogo entre o budismo tibetano e o cristianismo.

Um dos aspectos interessantes desse desenrolar dos fatos é que o debate não aparece, na narrativa de Desideri, como proposto por ele, mas sim pelo rei. Em um momento posterior à apresentação e ao debate inicial acerca das ideias lidas em público, o rei comunica a Desideri que

ele leu meu livro e levou-o em grande consideração, e pediu para vários lamas e doutores de religião que o examinassem e o lessem. (...) Portanto, ele considerou muito apropriado e essencial que não tomasse uma decisão dado a divergência entre nossos preceitos opostos em questões tão importantes até que ambos os lados fossem pesados na balança do pensamento razoável. Com tal propósito, ele decidiu realizar uma disputa, comigo de um lado e com os lamas e doutores de religião daquele país e suas universidades de outro. ${ }^{570}$

Além de não apresentar a ideia do debate como sendo sua, Desideri ainda põe na fala do rei a decisão de dar-lhe tempo para se preparar para a disputa, acrescentando que até lá ele deveria educar-se

totalmente nos princípios e livros de tal seita, ler seus autores mais aclamados e me familiarizar com seus métodos de dialética e argumentação. Ademais, ele [o rei] pediu para que passasse certo tempo em algumas de suas universidades, participando das palestras e debates que lá ocorrem com frequência. Para isso, ele ordenou que eu tivesse livre acesso para entrar e

\footnotetext{
568 "Rangiambà", DESIDERI, I. La relazione di Ippolito Desideri, apud: PETECH, L. I missionari italiani nel Tibet e nel Nepal. Libr. dello Stato, p. 195.

${ }^{569}$ Ibidem, loc cit.

570 “Mi disse aver già letto e ben considerate il mio libro, e averlo fatto legger e ben esaminar a diversi Lamà e dottori. Il parer di tutti essero questo, che gli assiomi e principj in esso contenuti son ben propositi e non lasciano d'appagar la ragione; esser però molto opposti a' loro dogma e opinion. Giudicar, per tanto egli molt'opportuno e necessario, in mezzo alla contrarietà d'opposti insegnamenti in material sì rilevante, non prender alcuna risoluzione, se non dopo d'aver ben peseta l'un' e l'altra parte colla bilancia di sode ragioni. Per tal fine aver egli stabilito di voler far venir a dispute, me da una parte, e i Lamà e dottori di quell paese e di qualle università dall'atra"; DESIDERI, I. La relazione di Ippolito Desideri, apud: PETECH, L. I missionari italiani nel Tibet e nel Nepal. Libr. dello Stato, Vol. V, DR. 1, p. 196. Tradução nossa.
} 
ficar em qualquer mosteiro ou universidade no país de minha escolha, para receber ou ver qualquer livro que eu queira olhar, e para que um doutor de religiões ou professores me expliquem qualquer questão ou passagem difícil que eu não entenda. Finalmente, ele me pediu de forma muito progressiva para que tenha o trabalho de anotar os motivos e argumentos que eu possua contra as crenças de tal seita. ${ }^{571}$

Segue-se a consideração de Desideri sobre as orientações do rei:

Os termos que o prudente rei me apresentou foram tão justos e sábios, e, de fato, muito de acordo com as minhas próprias preferências e desejos que (...) eu declarei vigorosamente que cumpriria exatamente com tudo.$^{572}$

A esta altura, gostaríamos de ressaltar alguns aspectos da narrativa e das falas atribuídas a cada uma das "personagens". Percebemos que há uma suposta elaboração dialógica do método apresentado por Desideri. O rei, descrito pelo missionário, teria argumentos tão sábios e justos que estariam completamente de acordo com o que ele mesmo desejava. Há uma sobreposição de vontades e projetos, evidenciada pela distribuição das falas pelas "bocas" dos personagens. Ambos querem o que é sábio e justo. Ambos julgam que o mais indicado, talvez mais prudente, seja que o missionário eduque-se, familiarize-se com a forma de argumentar (que ele nomeia como "dialética"), e que ele prossiga na formação de lama, não nomeada dessa forma. Desideri deveria ir a uma universidade, frequentar os cursos e participar dos debates. ${ }^{573}$ Por último, o italiano deveria escrever os argumentos que ele tinha contra a seita dos tibetanos. Percebemos a exposição do método apresentada de forma dialógica, isto é, partindo do rei e indo ao encontro das aspirações do missionário.

Desideri escolhe, então, um monastério perto do palácio e parte para lá, entusiasmado em cumprir o que o rei tinha lhe incumbido. Assim, ambos os aspectos de sua estratégia são

\footnotetext{
571 "Ben conoscer egli ça gravezza di sì importante affare. Non volermi prender di sorpresa, senza saper io con qual'armi fossero per combattermi gli avversari. Voler dunque che non si venga subito all'attacco, ma che intanto io procure di rendermi pienamente erudite ne' principj e libri di quella seta; che ne legga gli autori più classici; che n'osservi la maniera della loro dialettica, e che ne penetri il tenor delle loro dispute; desiderar in oltre che per qualque tempo in alcuna delle loro università assista qualche volta alle conferenze e conclusion che quivi molto frequentemente si sostegno. A tal intent dar egli ordine che mi sia dia libertà e commodo di poter andar e restar a mio talent in qualche convent di religiosi del paese e in quelche università. E di più comandar che mi si diano e mi si facciano veder tutt'i libri che volessi; e che da dottoru e maestri mi si spieghino tutt'i luoghi e passi che io desiderassi. Finalmente pregarmi instantemente a volermi preder a pena di metter in iscritto la ragioni e argomenti che avessi a poter opporre all'opinione di quella seta." DESIDERI, I. La relazione di Ippolito Desideri, apud: PETECH, L. I missionari italiani nel Tibet e nel Nepal. Libr. dello Stato, Vol. V, DR. 1, p. 196. Tradução nossa.

572 "Essendo così giusto e savio, anzi così conforme al mio genio e desiderio il partito che il prudente re mi proponeva, non solamente non contradisse, nè mi scusai in alcuna di tali cose, ma protestandomi che l'eseguirei a puntino, senza perder un solo giorno di tempo, scelto a ciò un convent più vicino al suo pallazo reale e alla case dove dimoravo (...) cominciai con un sommo studio e assiduità a pore in esecuzione ciò che il re m'aveva ordinate ed io avevo promesso.” Ibidem, Vol. V, DR. 1, p. 196. Grifos nossos. Tradução nossa.

573 "The great sport with which Tibetans enjoyed such disputations also attracted the Jesuit". POMPLUN, T. Jesuit on the Roof of the World: Ippolito Desideri's Mission to Eighteenth-Century Tibet. Nova Iorque: Oxford University Press, 2002, p. 91.
} 
satisfeitos: sua atuação junto ao centro do poder político e sua atuação intelectual, junto aos lamas no mosteiro.

Assim, toda a estratégia posta em prática pelo missionário aparece, em sua narrativa, como proposta pelo próprio rei. ${ }^{574}$ Mais uma vez, como aconteceu no Mogol, os jesuítas partem para o debate com sacerdotes de outras religiões com o objetivo de, através da razão, persuadir sua audiência de que o cristianismo é a verdadeira e única lei, caminho único para a salvação. Ainda que os debates estejam em consonância com a própria formação e prática jesuíta, a proposta, na narrativa, aparece inserida no contexto de formação dos lamas, segundo suas normas e regras. $\mathrm{O}$ contexto de atuação demanda uma performance do missionário que a sua formação prévia torna possível, mas não foi essa formação que determinou de forma categórica a adoção das disputas como estratégia de conversão. Em outras palavras: Desideri não parte para as disputas apenas porque elas são um método familiar a ele. Ele tem que se adaptar ao que ele nomeia como disputa, uma parte da formação dos lamas, que possui normas e "dialética" próprias. Não se trata apenas de aplicação do que foi aprendido nos Colégios da Ordem: se trata também de adaptação.

Uma vez no monastério, ${ }^{575}$ Desideri dedica-se à leitura do Kangyur, os 115 volumes que contêm os ritos, máximas, preceitos e leis religiosas dos tibetanos. ${ }^{576}$ Desideri devotou-se a ler, anotar e assimilar os assuntos presentes nos cânones budistas. O missionário também estudou a dialética dos tibetanos, que têm

sua própria dialética, termos, definições, divisões de argumentos, todos na forma de entimemas simples, uma forma de proposições, de convencimento por deduções, de negativas ou admissão, de negação de hipóteses, reformulação de argumentos e assim por diante. ${ }^{577}$

Os métodos retóricos, avisa Desideri, não estão presentes nos livros que ele estuda, mas são vigorosamente e incansavelmente praticados no Tibete Central. No monastério, que é visto mais como uma universidade do que como um lugar de contemplação ou estritamente de vida religiosa, Desideri

\footnotetext{
${ }^{574}$ Em um momento futuro, abordaremos as instruções que Desideri deixa em seus escritos para os missionários que desejam evangelizar as Índias. Elas estão intrinsecamente ligadas à trajetória do próprio Desideri e que, curiosamente, aparece aqui como uma determinação alheia a ele, ainda que vá ao encontro de seus anseios.

${ }^{575}$ Desideri permaneceu em dois monastérios diferentes. Primeiro, ficou de março a julho no monastério de Ramoché. Em agosto, mudou-se para o monastério chamado Sera.

${ }^{576}$ DESIDERI, I. La relazione di Ippolito Desideri, apud: PETECH, L. I missionari italiani nel Tibet e nel Nepal. Libr. dello Stato, p. 197.

577 'Hanno (..) la dialettica, la spiegazion de' termini, le definizioni, divisioni e argomentazioni, che stutte son a forza di semplici entimemi; la maniera di promuovere gli argomenti, di convicere d'implicanza, di negare, di concedere, di negar il supposto, di ritorcer l'argomento, e così del resto.” DESIDERI, I. La relazione di Ippolito Desideri, apud: PETECH, L. I missionari italiani nel Tibet e nel Nepal. Libr. dello Stato, p. 197. Tradução nossa.
} 
busquei com muito esforço assimilar tudo que lia, comparando um livro com outro, (...) fazendo anotações e transcrevendo as passagens que me seriam úteis, tendo discussões frequentes, quase diárias, sobre tais assuntos, e criando um dicionário separado de terminologia selecionada relevante a questões científicas ou religiosas. ${ }^{578}$

Neste trecho, o italiano deixou bastante claro, quase de forma didática, os detalhes do que poderia ser nomeado como sua proposta de método de adaptação. Assim, o estudo da dialética budista tibetana - bem como o engajamento em discussões com monges, doutores e professores budistas - fez parte do cotidiano de Desideri no Tibete. O missionário frequentava debates e exames públicos dos religiosos budistas para se familiarizar com os conceitos mais complexos e abstratos e entendê-los profundamente. Em especial, Desideri destaca o conceito de tongpanyi ou vacuidade.

Por conseguinte, após aprofundar-se nos ditos estudos, o jesuíta decide iniciar, em novembro, uma nova obra escrita em tibetano, cujo objetivo seria "refutar os erros daquela seita e elucidar a verdade da nossa santa fé." ${ }^{579}$ No entanto, o trabalho do missionário foi surpreendido por fatores estranhos à sua vontade e que, dessa vez, revelavam-se obstáculos ao invés de facilitadores de sua missão. Em dezembro, o rei protetor de Desideri foi assassinado, o reino foi invadido por tártaros e Lhasa foi saqueada. O primeiro-ministro foi feito prisioneiro. Os trabalhos continuariam em outro monastério, chamado Dakpo Khyer, onde o jesuíta terminou seu livro.

A segunda obra de Desideri dividia-se em três volumes. No primeiro, os "erros" relativos à questão da metempsicose foram refutados. No segundo, foi a vez da ideia de vacuidade ser rejeitada. ${ }^{580}$ No terceiro e mais breve volume, o missionário apresenta a doutrina cristã e alguns catecismos. ${ }^{581}$ Ao descrever o segundo volume, isto é, aquele que refuta a ideia de vacuidade, Desideri utiliza, talvez pela primeira vez, o conceito de ateísmo.

\footnotetext{
578 Con intenso studio e applicazione a leggere I libri del Kâa-n-ghiur per imparar appieno tutto ciò che appartiene a quella falsa religion. Nel medesimo tempo procurai con ogni possibli diligenza e impegno di ben digeri ogni cosa, col confronter or un libro con l'altro (...) col far annotazioni e transcrivere que' luoghi che mi potevan giovare; col far frequenti e quasi quotidiane conferenze sopra tali cose e materie; e con far un dizionario a parte di termini scelti, proprj di punti di religion o scientific". DESIDERI, I. La relazione di Ippolito Desideri, apud: PETECH, L. I missionari italiani nel Tibet e nel Nepal. Libr. dello Stato, p. 198. Tradução nossa.

579 "Comporre in lingua thibetana l'opera della confutazion degli errori di quella setta, e della dichiarazione delle verità della nostra Santa Fede.” Ibidem, v. V, DR. 1, p. 200. Tradução nossa.

580 "Conduce i suoi seguaci all'ateismo, escludentdo la possibilita d'um Ente che da sè stesso esista, increato e creator del mondo". Ibidem, vol. V, DR. 1, p. 202.

581 “... com metodo e stile adattato no già a uma cristianità adulta e ben addottrinata, ma a uma cristianità novella e che sta sul formasi...” Ibidem, vol. V, DR. 1, p. 202. Tradução nossa.
} 
Os dois primeiros livros são inteiramente em estilo argumentativo e disputativo, seguindo, segundo o italiano, a forma e os métodos que os tibetanos utilizam. O terceiro livro é em forma de diálogo.

Porém, mais uma vez, o desenrolar dos fatos não auxiliou o missionário, apesar de seus esforços pessoais. Em 1721, ele recebe uma ordem para deixar a missão. Por decisão da Propaganda Fide, apresentada a Desideri em 16 de abril de 1721, ele é forçado a deixar os reinos do Tibete. A Companhia de Jesus havia perdido o direito de missionar na terra dos lamas, que se tornaria terreno de evangelização de outra ordem. Os capuchinhos, que conviveram com Desideri - e inclusive, segundo ele, pediram para que ele lhes deixasse suas obras - ficariam à frente da evangelização do Tibete.

O missionário permaneceu ainda algum tempo no Nepal, onde diz ter dado o acabamento final aos seus capítulos, além de ter dado prosseguimento às discussões com lamas e doutores em religião sempre que possível. Ainda no Nepal, Desideri teve a oportunidade de batizar um menininho, que morreria horas depois.

Termina assim, para a Companhia de Jesus, seu último investimento na conversão dos lamas tibetanos. Fica praticamente impossível não estabelecer uma comparação entre a missão conduzida apenas por Desideri582 e o menino batizado no Nepal, uma vez que ambos cessaram de existir em poucos anos, de forma precoce. Depois de permanecer sete anos no Tibete, Desideri parte contra sua vontade, deixando Lhasa em 28 de abril de 1721.

\footnotetext{
${ }^{582}$ Manuel Freire, seu companheiro, abandou a missão pouco depois de chegar ao Tibete. DESIDERI, I. Mission to Tibet: the extraordinary eighteenth-century account of father Ippolito Desideri, S.J. Tradução Michael J. Sweet, Edição Leonard Zwilling. Boston: Wisdom Publications, 2010, p. 203.
} 


\title{
4.4 VIRTUDE, PIEDADE E CEGUEIRA: AS DESCRIÇÕES DE DESIDERI DA SOCIEDADE
}

\author{
TIBETANA
}

Nesta terceira parte de nosso último capítulo, trataremos mais especificamente, das descrições que Desideri fez da sociedade e da religião tibetana. Como dissemos há algumas páginas, o missionário organizou sua obra (Notícia Histórica do Tibete) em quatro livros. Grosso modo, podemos dizer que o primeiro e o último livro têm uma estrutura mais narrativa, de sucessão de fatos, ainda que o jesuíta dedique-se a descrições de lugares, costumes, pessoas ou eventos quando ele julga relevante. Os dois livros centrais da Notícia Histórica do Tibete - isto é, o segundo e o terceiro livros - são mais descritivos. Em termos contemporâneos - e um tanto anacrônicos - podemos dizer que estes últimos concentram as observações "sociológicas" e "antropológicas" feitas pelo missionário.

Conforme desenvolvemos ao longo de nossa tese, procuramos associar as descrições feitas por Desideri às estratégias de conversão que ele adotou enquanto estava no Tibete, bem como, futuramente, ao modelo de atuação missionária que ele proporá ao final de sua obra. Nossa premissa é que essas descrições estão intrinsecamente relacionadas ao método de missionação proposto e são objeto de intenso escrutínio e cuidado retórico. Isso fica particularmente acentuado na obra de Desideri, que possivelmente foi submetida a inúmeras revisões. Além disso, o missionário tem uma espécie de agenda tripla: descrever o Tibete e os tibetanos seguindo a prática jesuíta de (re)organização do mundo e atribuição de lugar (histórico, político e religioso) aos povos encontrados; propor e justificar um método de atuação para missionários que vão para as Índias; e, por último, defender a Companhia de Jesus e sua forma de atuar. Para o caso específico da missão de Lhasa, Desideri buscou argumentar e sustentar a primazia da Ordem no território de cultura tibetana, de onde foi expulso em favor da presença de missionários capuchinhos.

Podemos dizer que Desideri acompanha Antônio de Andrade em sua descrição positiva do povo Tibetano, ainda que o fôlego e a profundidade de sua obra escrita dificilmente possam ser comparados com a dos missionários anteriores, incluindo as cartas do próprio Andrade. Como no capítulo anterior apresentamos a voz dissidente de Nuno Coresma, acreditamos que ficará evidente para o leitor, por comparação, que Desideri apresenta o Tibete como um lugar propício para a missionação. Em nossa análise, a demonstração dessa 
hipótese (isto é, que o Tibete é um bom lugar para se investir em termos missionários) se dá a partir de descrições políticas e "sócio-antropológicas" positivas. Políticas, porque o Tibete seja tendo sido organizado sob o regime monárquico seja sob a tutela ${ }^{583}$ manchu - apresenta uma organização política favorável à missionação. Nos termos que outros jesuítas ${ }^{54}$ cunharam $^{2}$ anteriormente, a presença de uma "cabeça" facilitaria o trabalho evangelizador.

Como acreditamos que a estrutura do livro diz muito sobre a organização mental do jesuíta, bem como sobre a ordenação intelectual e a visão de mundo dos membros da Companhia de Jesus, faremos uma breve descrição dos capítulos que compõe o terceiro livro da Notícia Histórica do Tibete.

A descrição de Desideri inicia-se pela geografia do Tibete, seus limites, fronteiras, clima, fauna e rios. O meio natural apresenta-se, portanto, como uma espécie de introdução na tarefa de apresentação do Tibete para o leitor europeu (missionário ou não). O meio natural antecipa as descrições sociais e políticas, seja nas cartas de Antônio de Andrade, ${ }^{585}$ seja na obra do jesuíta da Toscana.

Em seguida, são descritas as províncias tibetanas, do oeste para o leste. Esse movimento da esquerda para a direita, além de análogo à própria ação de leitura e escrita, encontra algum respaldo no objeto descrito em si. No século XVIII, isto é, no período de Desideri, a atuação missionária - jesuíta e capuchinha - concentrava-se no centro do Tibete, enquanto que, no período anterior, os religiosos iniciaram suas atividades pelo reino de Gugê, no Tibete Ocidental.

Os capítulos seguintes da obra de Desideri contam uma espécie de história política do Tibete, explicando as tensas relações entre tibetanos, tártaros e chineses. Após esta contextualização, o jesuíta passa para uma descrição mais “estrutural” da organização política, identificando dois momentos distintos: o anterior e o posterior à soberania Manchu. É interessante notar que o missionário identificou e nomeou o regime político do Tibete: monarquia. $^{586}$

A descrição feita pelo missionário culmina com a conclusão de que a organização política tibetana apresenta vantagens para a missionação.

\footnotetext{
${ }^{583}$ Termo nosso, não utilizado pelo missionário.

${ }^{584}$ Referimo-nos especialmente a Acosta, conforme mencionado em outro capítulo, e a Suárez.

585 Referimo-nos, principalmente, à carta ânua de Antônio de Andrade de 1626, apud: DIDIER, H. Os portugueses no Tibete. Os primeiros relatos dos jesuítas (1624-1635). Lisboa: Comissão Nacional pra Comemoração dos Descobrimentos Portugueses, 2000, p. 103-146.

586 Outros temas que não priorizamos em nossa análise também são tratados por Desideri: vestimenta, alimentação, descrição física, jogos e momentos de lazer, sistema de justiça, organização agrária e direito de propriedade, fiscalidade, matrimônio e costumes funerários.
} 
Até 1720, o Tibete possuía um governo civil monárquico sob o domínio de um único rei, independente e absoluto. Após outubro de 1720, quando o reino passou a ser regido pelo imperador da China, começou a ser governado por um conjunto de magistrados compostos por vários ministros de diferentes nacionalidades e indicados pelo próprio imperador, em cujo nome conduziam seus deveres oficiais. ${ }^{587}$

Percebemos que a descrição do "governo civil do Tibete" é composta tanto por uma visão acerca do sistema de governo como pela apresentação da organização social da comunidade tibetana, e culmina na conclusão de que o Tibete é local propício para missionação em função, principalmente, dos seguintes fatores: os tibetanos eram amigáveis com estrangeiros; mesmo não podendo possuir as próprias casas - deviam alugá-las - o jesuíta pôde, com licença do rei, comprar uma grande casa na principal rua de Lhasa; e foi permitido aos missionários possuírem altares em suas residências e celebrar missa. Mesmo quando Desideri estava estudando em um mosteiro, teve a permissão de celebrar o sacramento da eucaristia. Nessas circunstâncias, diz o religioso:

Tive o conforto de celebrar a missa todos os dias e de espalhar as primeiras sementes da religião cristã entre os estudiosos e os lamas quando, por curiosidade, pediram para participar dela. ${ }^{58}$

A mesma curiosidade parecia mover os leigos tibetanos, que pediam explicações sobre imagens, prostravam-se e adoravam o "Divino Salvador" 589 , pediam para participar da missa, e traziam incenso para queimar no altar. Por outro lado, essa "tolerância" 590 não se estendida aos muçulmanos, considerados inferiores e ridicularizados por suas "superstições vãs". ${ }^{591}$ Evidentemente, isso era visto com certa simpatia pelo missionário.

Outra característica da sociedade tibetana, segundo Desideri, seria a ausência de castas ou tribos:

Politicamente, os tibetanos não têm muitos graus ou distinções entre eles. no máximo podem ser divididos em três classes, primeiro sendo os ministros do rei, os governadores e oficiais similares que, juntamente com o resto da nobreza, formam um grupo; depois os comerciantes; e, em terceiro lugar, aqueles que vivem de sua renda pessoal. Assim, o Tibete não possui $\mathrm{o}$

\footnotetext{
587 “La maniera del governo civile del Thibet sin all'anno 1720 fu affato monarchica, comecché sotto d'un solo Re assoluto e indipendente. Dall'ottobre del 1720, essendo quel regno passato sotto Il domínio del l'imperatore della Cina, è ora governato da um magistrato composto di piú ministri di diversi nazioni deputati dall'istesso imperatore, di cui sostegono le veci." La relazione di Ippolito Desideri, apud: PETECH, L. I missionari italiani nel Tibet e nel Nepal. Libr. dello Stato, 1952, p. 75. MITN, p. 75. Tradução nossa.

588 "Né solamente mi permettevano l'uso della cappella dentro la mia casa di Lhasa ma ancora quando abitavo nel loro convento di Serà per studiare i loro libri, avevo commodità di celebrare ongi giorno e di spagere fra que' dottori e Lamà i primi semi della religione Cristiana, quando per curiosità mi chiedevano d'assistervi". MITN,DR 2, vol. VI, p. 81. Tradução nossa.

589 Ibidem, loc. cit.

${ }^{590}$ Desideri não usa esta palavra, mas achamos válido fazer menção a esta ideia no contexto dado.

${ }^{591}$ MITN, DR 2, vol. VI, p. 81.
} 
obstáculo de propagação da fé que pode ser encontrado em outras partes da Ásia, em que mesmo compatriotas não lidam uns com os outros, mas sentem desprezo entre eles. Esta é outra grande vantagem para os missionários designados para um ministério evangélico neste reino. ${ }^{592}$

Acreditamos ser necessário ter em mente, quando lemos este trecho, que Desideri possivelmente estava traçando uma analogia entre a sociedade tibetana e as vizinhas, em especial a indiana. Nesse sentido, é provável que ele também esteja se remetendo às missões e aos métodos catequéticos que seus companheiros de Ordem implementaram em diversas regiões da Ásia. Infelizmente, não temos subsídio historiográfico necessário para comparar as propostas de Desideri com a atuação de Nobili no sul da Índia, mas gostaríamos de deixar como hipótese a possibilidade de o jesuíta atuante no Tibete estar denotando no trecho acima sua preocupação com dois fatores distintos: o regime de castas ou, melhor dizendo, a ausência dele no Tibete, e a estratégia de se mimetizar características de um membro pertencente a uma casta superior (no caso de Nobili) que, na situação de Desideri, significava apresentar-se como preceptor espiritual ou lama.

No caso de Nobili, sua estratégia necessariamente passaria por diferenciar-se e distanciar-se de outras castas ou grupos sociais. Para o caso de Desideri, e é isso que ele parece estar querendo expressar, não havia essa necessidade. Ele poderia apresentar-se como preceptor espiritual, o que não o forçava obrigatoriamente a tomar distância de nenhum grupo social do Tibete. Uma vez sendo entendido como lama, ele poderia entrar em contato com todos os extratos sociais, que ele mesmo já havia identificado, sem que sua credibilidade fosse posta em questão.

Supondo que nossa hipótese tenha alguma substância, podemos pensar, portanto, que Desideri não precisou incorporar interdições religiosas ou sociais - como abster-se de comer carne ou evitar o contato com determinadas castas sob pena de tornar-se "impuro". Mantendo sua atuação essencialmente na corte, junto ao rei, e junto aos lamas, estudando e produzindo textos, Desideri não se viu necessariamente constrangido por interditos sociais do outro, os quais, para o caso de Nobili, causaram-lhe uma série de inconvenientes, que se arrastaram no que chamamos de querela dos ritos. A suposta distinção entre "social", "moral", "religioso", "aspectos interiores", “aspectos exteriores" etc., no caso do missionário que atuou no Tibete,

\footnotetext{
592 "Nel politico, non hanno i Thibetani molti gradi o distinzioni fra di loro; piochè a più si posson divider in tre ordini, cioè, primo in ministri del re, governatori e simi uffiziali, co' quail fa un corpo medesimo il restante della nobilità; second in mercanti. E terzo in persone che vivono delle loro entrate ordinarie. Qiuindi quell'intoppo alla propagazione della Fede che s'incorntra in altre parti dell'Asia, di non tratarsi gli uni con gli altri benchè del medesimo paese, anzi d'aversi a schifo, non c'è nel Thibet. Ciò che è anco d'un gran vantaggio a' missionari destinati in quell regno al ministerio evangelico." DESIDERI, I. La relazione di Ippolito Desideri, apud: PETECH, L. I missionari italiani nel Tibet e nel Nepal. Libr. dello Stato, vol. VI, DR. 2, p. 82. Tradução nossa.
} 
lhe serviu para livrar-se de outra dificuldade: a possibilidade de os tibetanos serem ateus. Mas isso será abordado em outro momento.

Infelizmente, a impossibilidade de estender essa hipótese para as missões da China e do Japão revela um limite de nossa pesquisa atual. De qualquer forma, fica a observação de que Desideri tem como objetivo situar-se a si e também a sua ação num contexto missionário mais amplo e regional, estabelecendo analogias e comparações de forma a ressaltar, sempre que possível, as especificidades e vantagens da terra dos lamas.

Retomemos, pois, a escrita do italiano:

Finalmente, sobre o seu comportamento, essas pessoas possuem um caráter muito bom e são inclinadas à virtude, e (eu diria) possuem uma grande propensão a piedade, dentro do possível de sua falsa seita. (...) Sua maior virtude, acima de todas as outras, é a propensão à misericórdia: dão esmolas aos pobres e necessitados, até aos animais em estradas que parecem ter fome. (...) Tudo praticado por essas pessoas cegas, para o seu falso deus, podem servir como reprovação aos cristãos que, em certos momentos, não conseguem agir da mesma forma pelo Deus verdadeiro a quem adoram. ${ }^{593}$

Após uma longa descrição da sociedade, Desideri expõe suas impressões sobre o comportamento geral dos tibetanos. De forma bastante elogiosa, o missionário afirma que eles são pessoas de bom caráter, muito inclinadas à piedade. A piedade, como sabemos, é uma virtude, e toda virtude indica uma inclinação essencial para bem obrar ou bem agir (habitus operativus bonus). Um homem virtuoso, portanto, é essencialmente inclinado a bons atos, isto é, a agir conforme a reta razão. No caso específico da misericórdia, tal inclinação refere-se a sensibilizar-se com o sofrimento do próximo, mobilizando-se naturalmente para agir em auxílio desse próximo. ${ }^{54}$ Mas o missionário não se satisfaz em apenas reconhecer essa

593 “Finalmente per quel che spetta al costume, sono genti 'dun indole assai buona e molto inclinada alla virtù, e nel modo che posson esserlo nella loro falsa setta molto propense (dirò cosi) alla divozione. Apparisce ciò da vari segni che ne' Thibetani comunemente si scorgono. Primieramente nelle massime della loro credenza son ben instruiti e ne parlano con sentiment e portano una grandissima venerazione e sommo rispetto a I loro Lamà e religiosi e a tutte le cose che apresso loro son sacre. (...) Quel che più ha de virtuoso, oltre modo inclinati alla misericordia, facendo limosina a tutti I poveri e bisognosi e sino agli animali della strata, quando li credono affamati. Cose tutte che praticate da quella cieca nazione, in grazia di false deità, possono servire di rimprovero a' Cristiani che talora non giungono a fare altrettanto per il vero Dio che adorano." DESIDERI, I. La relazione di Ippolito Desideri, apud: PETECH, L. I missionari italiani nel Tibet e nel Nepal. Libr. dello Stato, DR. 2, p. 1012. Tradução nossa.

${ }^{594}$ A definição de São Tomas de Aquino para misericórdia pode ser lida no primeiro artigo da $30^{\circ}$ Questão da segunda parte de Suma Teológica: "Como diz Agostinho, a misericórida é a compaixão do nosso coração pela miséria alheira, que nos leva a socorre-la, se o pudermos." ("Dicendum quod, sicut Augustinus dicit, IX DE civit. Dei (cap. V) misericordia est alienate miseriae in nostro corde compassion, qua utique, si possumus, subvenire compellimur".) Não obstante, frisamos a necessária relação entre misericórdia e razão, que garante a primeira ser reconhecida como uma virtude: "Donde o dizer de Agostinho: este movimento da alma, i. e., a misericórdia, serve à razão, quando nós a dispensamos para conservar a justiça, quer dando ao necessidado, quer perdoando o arrependido. Ora, a virtude humana consistindo essencialmente num movimento da alma regulado pela razão (...) é, por consequência, virtude." (Unde Augustino dicit, in IX De civit. Dei (cap. V), quod iste molus animi, scilicet misericordia, servit rationi, quando ita praebetur misericordia, ut iustitia conservatur, 
qualidade no povo do Tibete: ele os compara com os maus cristãos, dizendo que os primeiros serviriam de reprovação para os últimos.

Tal sentença, no entanto, guarda em si um paradoxo: como comparar cristãos com gentios? Pois é justamente nesse ponto que Desideri elabora a significação de que falamos anteriormente. Foi necessário elaborar um significante para dar conta desse povo virtuoso, mas que não segue a verdadeira lei, apesar de sua natural inclinação para obras misericordiosas. Eles não são chamados de gentios por Desideri porque a palavra não daria conta do que o missionário quer descrever e antecipar ao leitor e aos seus companheiros de Ordem. Para dar conta dessa "falta", da alteridade tibetana, o italiano lança mão da expressão “gente cega". Mas por que recorrer a essa categoria e não à outra?

Nossa hipótese é que Desideri fez uma referência à cegueira comentada por Tomás de Aquino na questão 79 da Primeira parte da segunda parte de sua Suma Teologica, entitulada Das causas exteriores do pecado e primeiro por parte de Deus:

A cegueira é preambulo do pecado. Ora, o pecado leva a duas coisas: por ele mesmo, à condenação; mas, pela misericordiosa providência de Deus, à cura. (...) Por conseguinte, a cegueira, por sua própria natureza, leva à condenação daquele que se cega e por isso se afirma como efeito da reprovação. Entretanto, pela misericórdia divina ele é temporariamente ordenada como uma medicina para a salvação daqueles que são obcecados. Entretanto, esta misericórdia não é concedida a todos os obcecados, mas unicamente aos predestinados, para os quais "tudo concorre para o bem", como diz a carta aos Romanos. Deste modo, para alguns a cegueira se ordena à salvação. ${ }^{595}$

Isso significa que não se trata de qualidade essencial ao povo tibetano, como a piedade ou misericórdia. Trata-se de uma cegueira temporária, uma dificuldade passageira, um obstáculo que, por ora, não permite que a luz da graça alcance os tibetanos. Em parte, ela também é uma punição devido à adoração de uma falsa lei. ${ }^{596}$

sive cum indigent tribuitur, sive cum ignoscitur poenitenti. Et Quia ratio virtutis humanae consistit in hoc quod mutus animi ratione reguletur, ut ex superioribus patet: consequens est misericordiam esse virtutem) Suma teológica, questão 30, artigo I e artigo III respectivamente. Grifo do autor. AQUINO, T. Suma Teológica. Tradução Alexandre Correa. São Paulo: Faculdade de Filosofia Sede Sapiens, vol. 17, 1956, p. 289; 300-1.

595 "Respondeo dicendum quod excecatio est quoddam preambulum ad peccatum. Peccatum autem ad duo ordinatur: ad unum quidem per scilicet ad dammantionem; ad aliud autem ex misericordi Dei providentia, silicet ad sanationem, inquantum Deus permittit aliquos cadere in peccatum, ut peccatum suum agnoscentes, humilientur et convertantur, sicut Augustinus dicit, in libro de Natura et Gratia. Unde et excaecatio ex sui natura ordinatur ad damnationem eius qui excaecatur, propter quod etiam ponitur reprobationis effectus: sed ex divina misericordia excaecatio ad tempus ordinatur medicinaliter ad salute eorum qui excaecantur. Sed haec misericordia non omnibus impeditur excaecatis, sed praedestinatis solum, quibus omnia cooperantur in bonum, sicut decitur Rm 8, 28. Unde quantum ad quosdam, excaecatio ad sanationem." AQUINO, T. Suma Teológica. São Paulo: Ed. Loyola, 2001. Primeira parte da Segunda parte, questão 79, artigo 3, Vol. IV, p. 410-11.

${ }_{596}$ Para outros exemplos de utilização do termo "cegueira" em referência ao budismo em outras partes da Ásia, 
Essa cegueira, portanto, é a potência cristã nomeada pelo missionário. Será justamente tal categoria que norteará as estratégias de conversão de Desideri, sendo a pedra basilar da edificação do jesuíta:

Francamente, devo confessar que após chegar ao Tibete e me dedicar atenciosamente a descobrir as qualidades deste povo, dois fatos me deram uma boa impressão desde o início e fizeram com que eu me dedicasse completamente, com a ajuda divina, a sua conversão. A primeira foi vivenciar visivel e tangivelmente a grande autoridade que Deus, em sua maior e adorada sabedoria, deu ao Diabo sobre essas pessoas, permitindo que todo o trabalho que realizam através de sua inclinação natural ao bem e sua propensão a virtude sejam vergonhosamente retirados de seu fim correto. ${ }^{597}$

É fundamental, para nossa análise, atentarmos para o fato de que o missionário insiste na ideia de inclinação natural, associada à ideia de desvio no momento em que tratar justamente da sua atuação catequética. A autoridade de Deus dada ao Diabo ganha um papel quase providencial, que antecipa e justifica o trabalho missionário:

O outro fato foi a minha descoberta no tibetano de uma inclinação natural totalmente direcionada ao bem e a ações virtuosas. Isso me deu esperanças de que se Deus decidiu abençoar meu trabalho, só será necessário para transformar os tibetanos em cristão exemplares e fervorosos, a mudança do objeto de sua tola devoção e observações vãs. ${ }^{598}$

Esta é a acomodação proposta por Desideri: trocar o objeto. Esse é o projeto, baseado na descrição política e moral (relativa ao comportamento e às virtudes) do povo tibetano. Não há necessidade de ensinar-lhes preceitos cristãos básicos, como o amor ao próximo, pois eles já são sensíveis ao sofrimento alheio. Não há necessidade de organizá-los politicamente, pois eles já conhecem governo e já se apresentam como uma comunidade perfeita. Assim sendo, a conversão, para o caso do povo da terra dos lamas, significava trocar o objeto de devoção, substituindo a "falsa seita" pela verdadeira lei. Para isso, é necessário, através do uso da

sugerimos a leitura de VENTURA, R. O Budismo nas fontes do Padroado Português do Oriente (séculos XVI e XVII) - um roteiro documental. In: BORGES, P.; BRAGA, D. (Comp.) O Buda e o Budismo no Ocidente e na Cultura Portuguesa. Lisboa: Ésquilo Edições e Multimédia, 2007, p. 127-172.

597 "Confesso ingenuamente che arrivato al Thibet e attentamente applicatomi a scoprir le qualità di quelle gente, due cose, sin dal principio, fecero sì grand'impressione nel mio animo, che m'impregnarono ad applicarmi tutto col divina ajuto nella loro conversione. Una fu il vedere sensibilmente e toccar com mano la gran licenza che, per i suoi altissime e adorabili giudizi , ha dato Dio al demonio sopra que' popoli, permettendo che restino sì sconciamente stravolte dal retto suo fine quelle tant'opere ch'essi esercitano er inclinazione naturale che hanno al bene e propensione alla virtù.” DESIDERI, I. La relazione di Ippolito Desideri, apud: PETECH, L. I missionari italiani nel Tibet e nel Nepal. Libr. dello Stato, vol. VI, DR. 2, p. 102. Tradução nossa. Grifos nossos.

598 'L'altra cosa fu lo scorpire ne' Thibetani e nel loro naturale un'indole tutta fatta al buono e propensa de sè a virtuosamente operare. Facendomi ciò sperare che, se Dio si degnasse di benedire le mie fatiche, altro non vi sarebbe bisognato per fare che diventassero nella Legge Cristiana molto esemplari e ferventi, se non che mutare l'oggeto a quelle loro tanto sciocche divozioni e vanissime osservanze.” Ibidem, vol. VI, DR. 2, p. 102-3. 
razão, convencer os tibetanos de seus erros e dos equívocos de sua lei. Será, portanto, esse o tema das próximas páginas de nossa análise. 


\subsection{O GRANDE LAMA, SEU GOVERNO E OS ERROS DE SUA SEITA: A QUESTÃO DA}

TRANSMIGRAÇÃO DE ALMAS COMO UM PROBLEMA RELIGIOSO E POLÍTICO

Após descrever a natureza, os costumes e o governo civil do Tibete, e elaborar uma categoria que desse conta dos tibetanos (tal qual abordado nas páginas anteriores), Desideri inicia seu terceiro livro. Neste, ele apresenta ao leitor a "falsa seita da religião única observada no Tibete". ${ }^{599}$

É nesta parte de sua obra que o missionário aprofunda, de fato, sua descrição da "seita" encontrada no local. A exposição da "seita dos lamas" inicia-se pela apresentação da figura do Grande Lama, chefe da religião, comparado ao Papa católico. Em seguida, o jesuíta italiano aborda o complexo processo sucessório dos grandes lamas. ${ }^{600}$ Para o missionário, esse intrigante processo baseado na possibilidade de transmigração das almas não pode ser artifício de homens, senão trabalho direto do Diabo. Seus argumentos são esmiuçados em sequência.

A partir daí, Desideri parte para a descrição do clero budista, isto é, dos demais lamas, sua organização e seus costumes. Seguem-se os "erros" da religião do Tibete, cujo primeiro a ser abordado é justamente a transmigração das almas ou metempsicose. O segundo erro seria a ausência de um deus Criador na crença tibetana, o que leva o jesuíta a ponderar sobre a possibilidade de considerar os tibetanos ateus.

$\mathrm{Na}$ sequência, Desideri apresenta os objetos de devoção da seita dos lamas e demonstra não ser neles reconhecida nenhuma divindade. Ou seja, debatida e descartada a categoria "ateu", o missionário passa a debater a categoria "idólatra". Seguem-se a isso ponderações sobre a moral e a normatização da conduta dos tibetanos.

Finalmente, o religioso apresenta ao leitor a figura de Buda e as "fábulas" existentes sobre ele. É feita, então, uma espécie de história da introdução do budismo no Tibete. Ao final

\footnotetext{
599 "Della falsa setta di religione particularíssima che s'osserva nel Thibet." Título do terceiro livro da Notícia Histórica do Tibete.

${ }^{600}$ Michael Sweet, tradutor da publicação em língua inglesa da Notícia Histórica, aborda este tema em seu artigo "The Devil's Stratagem or Human Fraud: Ippolito Desideri on the Reincarnate Succession of the Dalai Lama". Sugerimos a leitura desse artigo para temas que não abordaremos aqui, como, por exemplo, uma breve explicação sobre as visões ocidentais sobre o processo sucessório do Dalai Lama anteriores à obra de Desideri. SWEET, M.J. The Devil's Stratagem or Human Fraud: Ippolito Desideri on the Reincarnate Succession of the Dalai Lama. Buddhist-Christian Studies, n. 1, p.131-140, 2009.
} 
do livro, o missionário aborda temas secundários, como outros objetos rituais e autores que teriam escrito sobre o Tibete.

Nas páginas a seguir, dedicar-nos-emos à análise de três pontos principais expostos na parte do terceiro livro da Notícia Histórica do Tibete. O primeiro deles, como já foi dito, é a descrição do Grande Lama, associada à explicação sobre o processo sucessório do líder da "seita tibetana". A expressão "governo eclesiástico" possivelmente traduz de forma eficaz o conteúdo do primeiro tópico. O segundo ponto ainda diz respeito à figura do Grande Lama, mas agora o missionário concentra-se mais especificamente em temas como sua autoridade $\mathrm{e}$ seu domínio, isto é, complementa a descrição religiosa anterior com seu aspecto político correspondente. Podemos dizer que aqui o missionário trata do "governo civil". O terceiro ponto que analisaremos é justamente a identificação, feita por Desideri, do que seriam os erros da seita dos lamas, dentre os quais os mais graves parecem ser, como já dissemos, a metempsicose e o suposto ateísmo. 


\subsubsection{PONTO 1: O DALAi LAMA E O GOVERNO ECLESIÁSTICO}

O chefe da hierarquia que, segundo Desideri, corresponde ao governo eclesiástico do Tibete, é o Grande Lama. Para explicar a figura do Dalai Lama (ou Grande Lama), o missionário italiano opta por iniciar apresentando o mais importante ídolo da religião tibetana: [sPyan-ras-gzigs]. Cen-reê-sij (que também pode ser encontrado grafado como Chenrezik) é o mesmo que Avalokitesvara (sânscrito), a "incorporação da pura compaixão universal”, nas palavras de Frank Usarski. ${ }^{601}$

"Dizem que Cherensik, por um longo tempo, tem retornado e retornado em uma sucessão ininterrupta de manifestações humanas." ${ }^{\text {602 }} \mathrm{O}$ propósito disso, segundo o jesuíta, não seria tanto para o recebimento de homenagens dos pios tibetanos, mas principalmente para assustá-los e guiá-los com mais facilidade em seu caminho religioso, para que "o caminho" nunca decaísse no Tibete. ${ }^{603}$ "Também para afastá-los do mal, guiá-los para a virtude e leválos ao alcance da felicidade eterna e perfeita com mais eficiência." ${ }^{04}$

Os tibetanos diziam, segundo Desideri, que a forma mais adequada ou eficaz para que a divindade conseguisse alcançar todos esses objetivos seria aparecer na função de Grande Lama em cada um de seus renascimentos. ${ }^{605}$ Em resumo: "Acreditam que ele [o Grande Lama] é Chenresik, que voluntariamente se tornou humano várias vezes, sempre retornando a suas transmigrações humanas pelo bem do reino e pela salvação de suas almas." ${ }^{606}$ Quando um Grande Lama morre, ${ }^{607}$ afirma Desideri, os tibetanos identificam sua nova encarnação, restabelecem-no ao trono e o levam de volta a Potala, acompanhado de uma multidão de

${ }^{601}$ USARSKI, F. O Budismo e as outras. Encontros e desencontros entre as grandes religiões mundiais. Aparecida: Ideias \& Letras, 2009, p. 51.

602 "Dicon dunque che questo Cen-reê-sij da lunghissimo tempo in qua successivamente uma volta dopo l'atra senza mai interrompere torna e ritorna a prender corpo umano.” DESIDERI, I. La relazione di Ippolito Desideri, apud: PETECH, L. I missionari italiani nel Tibet e nel Nepal. Libr. dello Stato, vol. VI, DR. 3, p. 115. Tradução nossa.

${ }^{603}$ DESIDERI, I. La relazione di Ippolito Desideri, apud: PETECH, L. I missionari italiani nel Tibet e nel Nepal. Libr. dello Stato, vol. VI, DR. 3, p. 116. Tradução nossa.

604 “e per poterli più sensibilmente ritirare dal male, guidarle alla virtù condurre al conseguimento d'un'eterna e perfettissima felicita” Ibidem, vol. VI, DR. 3, p. 116. Tradução nossa.

605 "The Dalai Lama is an emanation (incarnation) of the bodhisattva Avaloketisvara. A bodhisattva is an enlightened being' who postpones his final entry into nirvana to work to liberate all sentient creatures from the misery of samsaric existence. Avaloketisvara, the bodhisattva of compassion, thus continually returns to human form through the line of the Dalai Lamas and the Dalai Lama is not, like the Pope, the representation of the deity, but rather a manifestation of it." GOLDESTEIN, M.C. The Circulation of Estates in Tibet: Reincarnation, Land and Politics. The Journal of Asian Studies, 32, p. 445-455, 1973.

606 "Credono ch' egli sia Cen-reê-sij volontariamente fattosi più volte uomo e tornando sempre nelle sue trasmigazioni a farsi uomo per ben di quell Regno e per salute delle lor anime.” Ibidem, vol. VI, DR. 3, p. 116. Tradução nossa.

${ }^{607}$ Sweet alerta para o rompimento promovido por Desideri em relação à ideia de Kircher de que o Dalai Lama seria imortal: "he takes particular pains to refute Kircher's error in stating that the Tibetans believe the Dalai Lama to be immortal, pointing out that the time of his death is made public and known to all, that he is mourned, and his relics are venerated". SWEET, M.J. The Devil's Stratagem or Human Fraud: Ippolito Desideri on the Reincarnate Succession of the Dalai Lama. Buddhist-Christian Studies 29, n. 1, p. 131-140, 2009. 
pessoas, uma ocasião de extrema solenidade. Isso seria possível porque, segundo narra o missionário, os tibetanos dizem que o Grande Lama prevê, antes de morrer, o lugar no qual renascerá dentro de alguns meses.

Após a passagem de certo tempo, isto é, alguns anos, um menino aparecerá no local previamente previsto; a idade do menino, incluindo os nove meses de seu desenvolvimento no útero da mãe e o tempo que passou desde o seu nascimento, serão compatíveis com o tempo passado desde a morte do Grande Lama. O menino fala e diz que é o Grande Lama que morreu em tal dia, mês e ano. Ele diz que retornou novamente para continuar a ajudar os pios tibetanos e, finalmente, pede para ser levado para sua residência em Potala. ${ }^{608}$

Neste extrato, além de reportar ao seu público leitor como se passa o processo de aparecimento e reconhecimento do novo Grande Lama, Desideri utiliza duas expressões que julgamos deveras interessantes. A primeira delas - o lugar "anteriormente previsto" -, indica que o missionário de certa forma dá alguma credibilidade à história da antecipação do local de nascimento do novo lama. A expressão, acreditamos, mais reitera o suposto relato que Desideri ouviu ou leu do que, como observamos anteriormente e continuaremos a observar, reforça uma crítica à história.

A outra expressão - "pios tibetanos" - também nos parece reveladora da posição acrítica (a essa altura) do missionário. Ou seja, Desideri não põe em questão os antecedentes, reconhecendo-os e nomeando-os como "previsão". Além disso, reitera a piedade dos tibetanos. É como se houvesse uma espécie de substrato ou essência positiva nos tibetanos que, infelizmente, estivesse sendo objeto de manipulação de outrem. Este ponto será mais desenvolvido adiante.

Quando a notícia do nascimento do menino, que supostamente teria nascido conforme as indicações do falecido lama, espalha-se e chega à corte, vários lamas, homens letrados e monges da mais alta autoridade,

que são os mais estimados em seu conhecimento desta doutrina única, assim como possuem bom senso comprovado, são enviado para o local onde o menino foi encontrado, com toda a autoridade do rei e do governo, para examinar o menino e julgar se ele é realmente o Grande Lama renascido. ${ }^{609}$

\footnotetext{
608 "Passato (...) alcuni pochi anni, e nel luogo pronisticato e già avanti indicato qualche fanciullo che, compresi li nove mesi della sua formazione nel ventre della madre e il tempo della morte del Gran Lama sin allora; qualche fanciullo, dico, parla e dice esser egli tornato di nuovo per continuar ad ajuntar i suoi divoti Thibettani; e in fine domanda d'esser ricondotto alla sua residenza del Potala." DESIDERI, I. La relazione di Ippolito Desideri, apud: PETECH, L. I missionari italiani nel Tibet e nel Nepal. Libr. dello Stato, vol. VI, DR. 3, p. 117. Tradução nossa. Grifos nossos.

609،Sparsasi da per tutto e arrivata alla Corte la nuova, con ordine e autorità del Re e del governo si mandono al luogo, in cui si trova il fanciullo, varij Lama, dottori e religiosi de' più cospicui nell'autorità e dignità e de più accreditati per oppinione di singular dottrina e sperimentata prudenza, affin d'esaminare e giudicare se veramente egli sia il Gran Lama rinato.” Ibidem, vol. VI, DR. 3, p. 117. Tradução nossa. Grifo nosso.
} 
Enquanto examinado por tais lamas - prossegue Desideri -, o menino declara o que aconteceu em sua vida passada. A criança fornece ainda detalhes sobre livros e roupas que teria usado em sua última encarnação, o que, segundo o missionário, por mais incrível que pareça, é verdade. Da mesma forma que na passagem anterior, observamos que valores positivos continuam a ser atribuídos aos tibetanos, mais especificamente neste caso, aos religiosos.

Quando os lamas chegam à conclusão que se trata de fato do falecido Grande Lama, os religiosos reverenciam o menino e retornam com ele para a corte. A criança, então, é escoltada até Potala e recolocada em seu trono, o qual, segundo o missionário, permanece vazio desde a morte do último Dalai Lama. ${ }^{610}$ Tudo isso ocorre com o consentimento do governo e com celebrações públicas, segundo a narrativa do italiano.

Após essa descrição deveras acurada do processo de identificação do novo Grande Lama, o jesuíta passa a apresentar suas próprias impressões. Sua principal questão gira em torno de duas hipóteses: seria esse processo de sucessão do líder religioso do Tibete obra do Diabo ou artimanha dos pais da criança em associação com os lamas? ${ }^{611}$ Estas duas únicas opções surgem, evidentemente, da impossibilidade do missionário aceitar como "verdadeiro" o processo de sucessão, pois isso seria o mesmo que concordar com a possibilidade de transmigração de almas, o que não era compatível com a doutrina da Igreja. Ainda assim, a identificação dessa crença nos sistemas religiosos das sociedades nas quais os jesuítas estabeleciam missões era deveras importante. Além de estar presente nas doutrinas religiosas ditas "orientais" (contemporaneamente chamadas, por exemplo, de hinduísmo e budismo), a possibilidade de a alma renascer em um novo corpo havia sido defendida por filósofos da antiguidade como Pitágoras e Platão. Desta forma, tal como afirma Trent Pomplun, a importância de se identificar esse tipo de crença em sociedades asiáticas relacionava-se com a possibilidade de se estabelecer analogias com o paganismo antigo europeu. ${ }^{612}$ Esse seria um

\footnotetext{
${ }^{610}$ Esta vacância do posto de Dalai Lama, associada ao período de menoridade do líder religioso, é uma das peculiaridades da organização política do Tibete e decorre diretamente da sucessão baseada no conceito de reencarnação. Os regentes, portanto, geralmente são figuras de grande peso político no contexto tibetano. Isso possivelmente influenciou Desideri na sua identificação de um "rei" do Tibete.

${ }^{611}$ DESIDERI, I. La relazione di Ippolito Desideri, apud: PETECH, L. I missionari italiani nel Tibet e nel Nepal. Libr. dello Stato, vol. VI, DR. 3, p. 119.

612 "Missionaries were particularly interested whether Asian cultures believed in reincarnation, largely because it allowed them to relate Asian cultures to their own European antiquity through the analogous notion of metempsychosis, or the "transmigration of souls," associated with Pythagoras." POMPLUNT, T. The Holy Trinity in Ippolito Desideri's Ke ri se ste an kyi chos lugs kyi snying po. Buddhist-Christian Studies. p. 117130, 2009.
} 
passo crucial para a adoção do diálogo como estratégia de conversão, possivelmente calcado na estratégia dialógica e epistolar paulina.

Retomando a Notícia Histórica do Tibete, a opinião de Desideri é a favor da primeira hipótese, isto é, ele atribui ao Diabo a responsabilidade pelo processo sucessório dos Grandes Lamas. O missionário busca defender sua convicção nas páginas do segundo e terceiro capítulos do penúltimo livro de sua obra.

Para demonstrar seus argumentos, Desideri parte de duas premissas. A primeira é que o menino, por ser muito novo, não poderia ser capaz de tamanha manobra. Além disso, sua motivação seria supostamente a ambição de tornar-se o grande Dalai Lama em um momento em que "ele ainda não é capaz de dizer a diferença entre o marido de sua ama de leite e seu pai." ${ }^{\prime 613}$

A segunda premissa de Desideri é a reafirmação de seu caráter real. Ela não é imaginária, nem invenção, nem fábula pagã. O jesuíta reitera que tudo se passa tal qual ele narra:

Não se pode duvidar que toda a fraude que descrevi ocorre no Tibete. Precisamos apenas descobrir como acontece ou, melhor dizendo, buscar o criador de tal truque, isto é, se são os homens que ensinam a criança ou se é o Diabo que usa a língua da criança como instrumento de fraude."

Ou seja, o missionário não põe em questão o processo em si, mas o que estaria por trás dele. ${ }^{615}$ Não se trata de questionar "o quê" se passa, mas “como" é possível que se passe. Seria uma armação pensada e executada por homens, que treinariam e manipulariam o menino lama, ou seria tudo obra do demônio?

A hipótese de Desideri é que o Diabo estaria por trás do método de identificação do lama reencarnado. Para o italiano: "O Diabo intervém nessa questão como o principal arquiteto de toda a mentira. Portanto, acredito que um evento como esse deve ser geralmente

613 "Quando non saprà ancora ben discernere tra il balio e il padre". DESIDERI, I. La relazione di Ippolito Desideri, apud: PETECH, L. I missionari italiani nel Tibet e nel Nepal. Libr. dello Stato, vol. VI, DR. 3, p. 120. "He is still not able to tell the difference between his wet nurse's husband and his father." DESIDERI, I. Mission to Tibet: the extraordinary eighteenth-century account of father Ippolito Desideri, S.J. Tradução Michael J. Sweet, Edição Leonard Zwilling. Boston: Wisdom Publications, 2010., p. 301. Tradução nossa. Como tivemos dificuldade para traduzir "balio", uma expressão supostamente correspondente ao masculino de "babá", adotamos a versão em lingua inglesa como guia.

614، Non si può in verun modo dubitare che nel Thibet succeda il detto inganno; mas solamente doversi cercare del modo con cui avvienne; o per meglio dire, chi ne sia l'artefice cioè se siano uomini che indettino il fanciullo, o se sia il demonio che si serva della di lui lingua por instromento dell'inganno. Ibidem, vol. VI, DR. 3, p. 120. Grifo nosso.

615 "His belief in the conventional discovery narrative as factual, rather than an edifying tale concealing a complex political process, along with his need to deny the validity of reincarnation, would lead Desideri into creating a labyrinth of bizarre reasoning." Este "labirinto de argumentação bizarra" é justamente o nosso objeto de análise. SWEET, M.J. The Devil's Stratagem or Human Fraud: Ippolito Desideri on the Reincarnate Succession of the Dalai Lama. Buddhist-Christian Studies, v. 29, n. 1, p.134, 2009. 
atribuído ao próprio Diabo como a causa, não aos homens. ${ }^{916}$ Para sustentar sua posição, o italiano lança mão de sete argumentos principais, os quais podem ser sintetizados nas seguintes ideias: consenso universal, frequência, perseverança e constância (do menino lama), sobrevivência, espírito sobre-humano, discernimento ou astúcia dos lamas, e cui bono, isto é, quem se beneficia.

O primeiro argumento é o que podemos chamar de consenso ou consentimento universal. Todos reconhecem o menino como o lama que voltou à vida. Para Desideri, a multidão de opiniões tenderia à discórdia e não à unanimidade.

(...) a multidão é geralmente a mãe da discórdia; quanto mais pessoas devem certificar uma decisão, mais difícil fica para que se unam e cheguem a um consenso. Isso é especialmente verdadeiro quando se trata de escolher um líder, que todos devem reconhecer como seu Príncipe e soberano. Assim, quando se vê muitas pessoas elegerem alguém para uma posição, mesmo uma de pouca importância, existem sempre muitas diferenças de opinião prévias, a oposição de facções e muitos esforços divergentes em nome de vários rivais que aspiram à posição, de forma que quando alguém for finalmente selecionado, ele não será aprovado por todos. ${ }^{617}$

É preciso entender que tal consenso é alcançado devido a alguns fatores: o período de morte do lama coincide com o de nascimento do menino, que fora previsto pelo falecido lama. O local em que surge a criança também coincide com o que fora previsto; o menino apresenta, segundo o relato do missionário, lembranças de sua vida passada. Todos esses fatores, que levam a multidão à certeza do reconhecimento da criança como o lama falecido, só podem ocorrer, na opinião de Desideri, por intervenção diabólica.

Faz-se necessário notar o aspecto político da argumentação do missionário, em especial no que se refere à eleição ou à escolha de uma liderança. Para ele, nessas circunstâncias, é natural que existam opiniões divergentes. Para o caso do Grande Lama, no entanto, o italiano não identifica tais correntes ou opiniões destoantes.

Um passo fundamental na construção do raciocínio feito pelo missionário é a identificação dos atores políticos. Dito de outra forma, o desmembramento dessa multidão é

616 "Il Demonio intervegna in quel fatto come principale architetto di tutta quella menzogna.Onde stimo cha al Demonio medesimo come cagione, e non agl'huomini, debassi un tal evento communemente attribuire. DESIDERI, I. La relazione di Ippolito Desideri, apud: PETECH, L. I missionari italiani nel Tibet e nel Nepal. Libr. dello Stato, vol. VI, DR. 3, p. 120-1. Tradução nossa.

617 "Si rende ciò manifesto dal considerare che la moltitudine suol esser madre della discordia, e quanti più sono quelli che col loro assenso devono concorrere in una risoluzione, tanto maggiore per ordinario è la difficoltà d'unirli insieme e d'accordarli, principalmente ove si tratti d'eleggere un capo, che debbano tutti riconoscere er loro principe e sovrano. Quindi non avverrà mai che si veda un'elezione, ancor che sia di poco rilievo, fatta da molti d'un soggetto a qualche posto, che non sia preceduta da dissension di pareri, da contrarietà di fazzioni, da moltitudine d'impegni a favore di diversi concorrenti, che v'aspiravano, di maniera che nè anche quello che è stato finalmente l'eletto riporta la piena approvazione di tutti, ma spesso restano di molti che li contradicono e sforzatamente l'accettano." Ibidem, vol. VI, DR. 3, p. 121. Tradução nossa. 
realizado na medida em que Desideri nomeia suas partes: o povo, o governo secular e o próprio rei. Seria da articulação ou da disputa entre as vontades destas três entidades políticas distintas que sairia um soberano. Pois é justamente essa articulação que é posta em questão pelo missionário. Para ele, o natural seria o dissenso: tal deliberação "nunca ocorreria sem discordâncias violentas, sem falar de inimizades abertas e guerras civis." ${ }^{18}$

Nossa hipótese é que, para Desideri, a comunidade política ${ }^{619}$ pressuporia, em sua natureza, o dissenso e a disputa. Essa seria a expectativa do missionário acerca da confirmação e legitimação do poder de um soberano. Dessa forma, como ele mesmo descreve o processo de sucessão do Grande Lama como sendo naturalmente consensual, quando deveria ser imanentemente conflituoso, sendo portanto necessário que uma força transcendente (ainda que não divina) atue como a causa desse consenso.

Outra hipótese concomitante seria a existência de uma gradação de perfeição das comunidades políticas humanas. ${ }^{620}$ Quão mais perfeita fosse a comunidade, mais natural (ou imanente) seria o consenso. Porém, isso geraria um problema para o jesuíta, pois ele próprio reconhece que até mesmo para a escolha do Papa surgem dissidências.

Sabemos que mesmo na eleição mais sacrossanta que ocorre na Terra, a do Vigário de Cristo, podem existir muitas divisões profundas, pedidos de apoio e rivalidades; sabemos como o impasse entre os eleitores já colocou a Igreja em grande perigo, já que são apenas seres humanos que indicam e elegem o pontífice com seus votos. ${ }^{621}$

Se até mesmo para o caso da comunidade política mais perfeita - a comunidade da Igreja Católica Apostólica Romana - não há consenso natural, mas rivalidades, como é

\footnotetext{
618 "non andrebbe mai esente da discordia fierissime, anzi da inimicizie aperte e da guerre civili." DESIDERI, I. La relazione di Ippolito Desideri, apud: PETECH, L. I missionari italiani nel Tibet e nel Nepal. Libr. dello Stato, vol. VI, DR. 3, p. 122. Tradução nossa.

${ }^{619}$ As hipóteses levantadas a partir deste momento baseiam-se principalmente na leitura do primeiro livro da obra Tractatus de legibus ac Deo legislatore, ponto 18 (Como deve ser a comunidade para que seja capaz de lei? Quantas classes de comunidade existem?), de Francisco Suárez. Neste ponto, podemos ler que "para que haja comunidade não basta uma multidão de homens se não se unem entre si com alguma aliança em ordem, para algum fim e abaixo de uma cabeça. Também Aristóteles disse que a cidade é uma multidão de cidadãos que entre si têm um vínculo moral. (...) Se chama perfeita, em geral, a que é capaz de governo político; esta, enquanto tal, se basta a si mesma." E ainda: "Toda comunidade perfeita é um corpo político propriamente dito e se governa por verdadeira jurisdição dotada de força coativa, que é a que dá as leis.” SUÁREZ, F. Tractatus de legibus ac Deo legislatore. Madri, 1967, p. 36-7. Primeira edição: Coimbra, 1612. Todos os trechos desta obra aqui citados foram traduzidos livremente a partir da tradução em espanhol.

${ }^{620}$ Uma divisão teológica largamente utilizada e, segundo Trent Pomplun, à qual Desideri parece ter se filiado, é a divisão em três estágios: de natureza, da lei, e da graça. Cf: POMPLUN, T. Natural Reason and Buddhist Philosophy: The Tibetan Studies of Ippolito Desideri, SJ (1684-1733). History of Religions, vol. 50, n. 4, p. 392, 2011.

621 "Sapiamo pure nell'elezione la più sacrossante cha si faccia sulla terra, cioè del Vicario di Cristo, quanto possano le disunion, l'impegni, le gare, e in quanto pericolo habbiamo posto talora la Chiesa degl'elettori, solamente perchè huomini propongono, huomini eleggono co' loro voti il Pontefice.” DESIDERI, I. La relazione di Ippolito Desideri, apud: PETECH, L. I missionari italiani nel Tibet e nel Nepal. Libr. dello Stato, vol. VI, DR. 3 , p. 122. Tradução nossa.
} 
possível que "esse povo bárbaro possa ser tão contido em suas paixões" ${ }^{622}$ ? Como seria possível para uma comunidade menos perfeita que a ecclesia ser mais capaz de subjugar suas paixões e agir de uma forma supostamente mais racional e virtuosa? A resposta do missionário para este problema é: o processo de sucessão do líder religioso do Tibete não é obra dos homens, mas sim artimanha do demônio.

No entanto, é preciso pontuar uma limitação de nossa análise. Não nos parece claro o motivo pelo qual Desideri lança mão dessa ideia de consenso, se foi justamente à época do VI Dalai Lama que observamos a instalação de uma crise política dentro do chamado governo eclesiástico. Como dissemos anteriormente, o sexto Dalai Lama não chega a completar a totalidade dos votos necessários para se tornar de fato um monge plenamente ordenado. Além disso, ele é assassinado e substituído pelo "verdadeiro" Dalai Lama, que não é reconhecido pelo povo. Isso tudo é dito pelo próprio missionário nas páginas anteriores. Por que ele resolveu esmaecer essas tensões e optou por enxergar um consenso quando ele mesmo já indicou tanta tensão e rivalidade, para nós não é possível dizer.

Passemos para o segundo argumento de Desideri para confirmar a responsabilidade do Diabo sobre o que ocorre no Tibete. Para ele, a frequência com que o processo sucessório se dá enfraquece a hipótese de que seria um esquema pensado e executado por homens. Esse privilégio do suposto renascimento não era apenas para o caso da morte do Grande Lama, mas também para o caso de outros lamas menores. A recorrência de aparecimentos de meninos nascidos nos locais e períodos coerentes com as previsões e mortes dos lamas, pelo raciocínio do italiano, suscitaria suspeitas caso se tratasse de uma fraude humana. Na opinião do missionário, é muito difícil que um grande grupo de pessoas concorde em manter um segredo por muito tempo.

Porém, para sustentar esse argumento, Desideri cai em uma pequena contradição. A fim de insistir que seria difícil enganar tanta gente por tanto tempo, o missionário decide enfatizar que não se trata de ludibriar "alguns ignorantes do povo comum". ${ }^{623}$ Ao contrário, neste momento de sua argumentação, o italiano opta por ressaltar o caráter civilizado dos tibetanos: "O local em que a supracitada fraude ocorre no Tibete, um país civilizado e habitado com pessoas atentas. ${ }^{9624}$

\footnotetext{
622 "E pensate se nel Tibet quella gente barbara haverebbe le passion tanto moderate" Ibidem, p. 122. Tradução nossa. Grifo nosso.

623 "Non si tratta già d'ingannare alcuni rozzi tra'l volgo". Ibidem, p. 122. Tradução nossa.

624 "Il luogho poi dove succeed la frode sopradetta è il Tibet, paese culto, popolato e di gente svegliata." Ibidem, vol. VI, DR. 3, p. 122. Tradução nossa.
} 
Percebemos que, para cada argumento, adjetivos de significados opostos surgem para qualificar o povo tibetano. Em comparação com a comunidade da Igreja e ao processo de eleição do papa, os tibetanos são bárbaros que não chegariam naturalmente ao consenso senão por intervenção de uma força transcendente e diabólica. Porém, quando é necessário demonstrar que seria difícil para um grupo de homens engambelar todo um povo por tanto tempo, Desideri opta por ressaltar a capacidade intelectual e organização sócio-política do povo. ${ }^{625}$ São civilizados, ele diz. Pensamos que a única maneira de resolver esta aparente incoerência é entendermos as proposições do missionário de forma relativa.

Pensemos, pois, hierarquicamente: a comunidade política humana mais perfeita seria aquela formada pelos membros religiosos da Igreja Apostólica Romana. ${ }^{626}$ A comunidade cristã, tomada de forma abrangente, seria menos perfeita que a comunidade da Igreja, mas ainda assim mais perfeita que outros povos encontrados dispersos pelo globo. Esses povos entre si teriam graus de perfeição, conforme sua organização política. Assim, comparando com os "brasis", por exemplo, os tibetanos seriam civilizados, ainda que possam ser chamados de bárbaros quando em referência à comunidade eclesiástica católica.

Mais uma vez percebemos a complexidade da tarefa de Desideri. Ele precisa descrever como se dá uma eleição para o que ele identifica como o cargo mais alto da comunidade eclesiástica tibetana. $\mathrm{O}$ processo lhe parece um tanto obscuro, pois é regido fundamentalmente por uma lei que ele rechaça: a lei da reencarnação. No entanto, ele reconhece o povo tibetano como civilizado, isto é, como uma comunidade política perfeita: uma multidão composta por um corpo eclesiástico, uma cabeça civil (o rei) e o povo. É, portanto, capaz de governar autonomamente a si mesma. Além disso, ele reconhece que entre esta comunidade encontram-se "governantes habilidosos e temidos, juízes vigilantes e um rei

\footnotetext{
${ }^{625}$ Esta aparente contradição é indicada por Sweet, mas o autor infelizmente não a problematiza em seu artigo: "Tibetans are too civilized and rational to be deceived by a fraud, but too barbarous to peacefully agree on a choice of a pontiff without demonic intervention". SWEET, M.J. The Devil's Stratagem or Human Fraud: Ippolito Desideri on the Reincarnate Succession of the Dalai Lama. Buddhist-Christian Studies 29, n. 1, p. $135,2009$.

626 "Pode conceber-se uma [comunidade] que havia sido adicionada à [comunidade] da natureza [isto é, a comunidade do gênero humano, que abarca todos os homens, regida universalmente pela lei natural], mas não por direito humano senão por [direito] divino, por ter sido fundada pelo mesmo Deus abaixo de uma cabeça indicada por Ele e com alguma união em ordem a fim sobrenatural. Tal foi antigamente a Sinagoga, e agora é muito mais perfeita - a Igreja Católica.” SUÁREZ, F. Tractatus de legibus ac Deo legislatore. Madri, 1967, p. 36-7. Primeira edição: Coimbra, 1612, p. 36. Tradução nossa.
} 
soberano absoluto." ${ }^{927}$ Como explicar que pessoas que, em geral, agem tão conforme à lei natural, ${ }^{628}$ escolham um líder de forma tão "supersticiosa" ${ }^{229}$ ?

O jesuíta recorre, portanto, a uma hipótese fundada na ação de uma força transcendente, isto é, o Demônio. Como vimos, para validar tal hipótese, ele inicia sua argumentação indicando a existência de um consentimento universal, que seria estranho à natureza da disputa política. Em seguida, ele afirma ser muito difícil que um grupo de homens conseguisse sustentar um segredo por tanto tempo, o que refutaria a hipótese de que se trataria de uma fraude humana. O terceiro argumento de Desideri é a constância da criança.

Ele permanece sempre constante em sua asserção original, e não há perigo dele ser surpreendido pelo interrogatório, (...) mesmo que o questionem sobre coisas muito diferentes (...) ele não comete erros em suas respostas. (...) Para harmonizar tantas asserções com respostas, para fazer com que tantas conversas concordem uma com a outra, para combinar tantas provas aparentes que seriam necessárias para encobrir a mentira seria além da capacidade humana, que dirá a de um menino. ${ }^{630}$

Este terceiro argumento do missionário baseia-se no que ele entende por constância, coragem e firmeza do menino lama. Segundo as impressões do missionário, o garoto inquirido não comete qualquer erro em suas respostas. Além disso, o menino permanece firme em suas assertivas, não cede nem volta atrás, mesmo sob pressão ou ameaça dos lamas. "Tal coragem e perseverança é mais apropriado para quem foi possuído por um espírito diabólico, que é a minha opinião sobre o que acontece." ${ }^{631}$

$\mathrm{O}$ quarto argumento do religioso é que nenhum dos meninos lamas morre durante a investigação, nem logo depois. Pelo raciocínio do italiano, seria natural que houvesse pelo

627 “Governatori esperti e temuti, magistrati che vegliano, un Re sovrano assoluto.” DESIDERI, I. La relazione di Ippolito Desideri, apud: PETECH, L. I missionari italiani nel Tibet e nel Nepal. Libr. dello Stato, vol. VI, DR. 3, p. 122.

${ }^{628}$ Para maiores informações sobre o nosso entendimento de lei natural, consultar o capítulo V do segundo livro do Tractatus de legibus ac Deo legislatore. SUÁREZ, F. Tractatus de legibus ac Deo legislatore. Madri, 1967, p. 36-7. Primeira edição: Coimbra, 1612, p. 115-7.

${ }^{629}$ A expressão do missionário é "superstiziosa maniera di successione". DESIDERI, I. La relazione di Ippolito Desideri, apud: PETECH, L. I missionari italiani nel Tibet e nel Nepal. Libr. dello Stato, op. cit., p. 122.

630 "La terza ragione me la suggerisce la costanza di quel piccolo figliuolo com altre circonstanze ad esso appartenenti. Questo si tien sempre saldo su la prima assertiva, ne v'è pericolo che resti sorpreso dalle interrogazioni, che all'improviso li fanno que' tanti deputati per esaminarlo, benchè siano di cose disparate, e sia tante volte rimesso al tormento del interrogatório; nè meno accade che sai colto in fallo nelle risposte, o convinto d'incoerenza ne' suoi detti, o preso in bugia negli'indizi e nelle prove che dà d'essere egli stato un'altra volta nel mondo. (...) Supera di troppo la capacità umana, non che d'un ragazzo, il concertate tante proposte e risposte, accordare tanti dialogi, combinare tante prove apparenti, quante farebbero di mestieri per coprire la bugia, se il Demonio non fusse la principale, o anche l'única macchina di tutta questa menzogna." Ibidem, p. 123-4. Tradução nossa.

631 "Intrepidezza e constanza simile è propria più tosto d'un invasato da spirito diabolico, come io son di parere che allora accadesse." Ibidem, p. 124. Tradução nossa. 
menos um caso de morte, pois a criança viaja quilômetros de sua região até Lhasa, podendo sofrer muito com este traslado:

Se uma fraude fosse instigada por homens, diria-se que o fato de nenhum desses meninos morrerem jovens ocorre totalmente por sorte e pela felicidade dos eleitores, que, sem saber e felizmente, sempre escolhem meninos sadios. ${ }^{632}$

Desideri nos diz ainda que a experiência mostra que quase metade das crianças, em geral, não chega à fase adulta. No entanto, os meninos lamas prosseguem saudáveis, tornam-se jovens e envelhecem, alcançando idades avançadas. Para explicar esse fato - tão improvável quanto uma pessoa atirar uma flecha 50 ou 100 vezes sem olhar e ainda assim acertar o mesmo lugar ${ }^{633}$-, a hipótese do missionário é que o Diabo, conhecendo a composição física e orgânica dos indivíduos, escolhe um menino específico em detrimento de todos os outros. Além disso, continua Desideri, o demônio pode contribuir de várias formas para a saúde desse indivíduo, auxiliando na cura de possíveis doenças e protegendo-o de perigos diversos.

O quinto argumento de Desideri diz respeito ao que ele chama de um "espírito quase sobre-humano", ou seja, um comportamento grave e digno, próprio de pessoas santas. $\mathrm{Na}$ opinião do religioso, o jovem lama não é avarento nem ambicioso, vícios que facilmente seriam encontrados em alguém venerado desde tão pouca idade.

Nesse caso, também poderíamos pensar que os homens, ao escolher os meninos que são mais aptos que outros para a farsa, poderiam prever seu futuro sucesso em serem sábios, moderados e sempre consistentes. Como isso é impossível (...) existe apenas a possibilidade de que o Diabo seja o diretor chefe e perpetuador desta fraude. ${ }^{634}$

O último argumento de Desideri relaciona-se com a opinião que o padre tem acerca dos lamas responsáveis pela investigação e seu discernimento: "Devemos dizer que eles são desajeitados, maçantes e ordinários, ou que eles são espertos e maliciosos?" ${ }^{635}$

\footnotetext{
632 “Onde se l'ingano venisse dagl'uomini, dovrebbe dirsi che se non morisse mai in età acerba veruno di detti fanciulli fusse un'accidente totalmente casuale e fortuito rispetto agl'elettori, che si fussero sempre imbattuti senza saperlo e per fortuna a fare scelta di ragazzi di lunga vita." DESIDERI, I. La relazione di Ippolito Desideri, apud: PETECH, L. I missionari italiani nel Tibet e nel Nepal. Libr. dello Stato, vol. VI, DR. 3, p. 125. Tradução nossa.

${ }^{633}$ Metáfora do próprio missionário, Ibidem, loc. cit.

634 "Qui ancora bisognerebbe dire, che gl'huomini, scegliendo que' fanciulli più tosto che altri a fare quell'impostura, prevedessero la futura riuscita di quelli, savia, moderata e uniforme un tutti, che è impossibile (...). Resta però che il Demonio sia il principal capo e attore della frode. Ibidem, p. 126. Tradução nossa.

635 "O vogliam dire che questi siano goffi, stolidi, e semplici; o vogliam dire che siano essi astuti e maliziosi?" Ibidem, loc. cit. Tradução nossa.
} 
A primeira hipótese, segundo o missionário, é pouco provável. Afinal, se fossem os lamas estúpidos, eles não teriam como fabricar um discurso com tantas mentiras e conseguir que tantas pessoas acreditassem neles. "Isso não é trabalho de pessoas desajeitadas, comuns e de pouca inteligência." ${ }^{\prime 36}$

Porém, para o caso dos lamas serem astutos e maliciosos:

como poderia uma pessoa prudente e inteligente, mesmo uma que bastante juizo, se quisesse enganar povos e reinos inteiros, decidir, independentemente do quanto ela for estimulada, usar como ferramentas pessoas tão duvidosas e não confiáveis, como um menino inexperiente e uma mulher, ou seja, a mãe do menino ou ama, em quem ele necessariamente precise confiar, para essas intrincadas falsidades? $?^{637}$

Afinal, de contas, segundo o raciocínio do próprio missionário, não seria prudente, mas descuidado ou precipitado, esperar que o segredo da fraude prosseguisse indefinidamente em sigilo quando é necessário ter tantos cúmplices?

Haveria o risco óbvio de um traidor romper com o sigilo para vingar uma ofensa ou por inveja da boa sorte de alguém. (...) Essas não são, certamente, indicações de prudência ou bom senso. ${ }^{638}$

Para concluir sua argumentação, o religioso lança mão da questão cui bono? Isto é, quem se beneficiaria com essa suposta fraude, os homens ou o Diabo? Supor que seriam os primeiros não parece crível, pois, segundo o missionário, não é possível identificar o que os lamas tibetanos lucrariam com o embuste. A possibilidade de interesse financeiro é descartada pelo religioso italiano, pois os lamas "já são bem providos de rendas". ${ }^{639}$

Ambição também parece não ser um motivo, pois

em virtude de serem lamas, eles pertencem ao primeiro posto de nobreza no Tibete, são considerados na mais alta estima pela sua aprendizagem e são considerados no maior respeito como pessoas santas e professores religiosos. Assim, não há nenhuma posição mais elevada para que alcancem e também não há nada mais para eles almejarem. ${ }^{640}$

\footnotetext{
636 "Non è questo lavoro da gente goffa, semplice, e di corto entendimmento." DESIDERI, I. La relazione di Ippolito Desideri, apud: PETECH, L. I missionari italiani nel Tibet e nel Nepal. Libr. dello Stato, vol. VI, DR. 3, p. 126. Tradução nossa.

637 "Poi chi è prudente e accorto, anzi se ha fior di giudizio, quando vogli ingannare tanta gente et intieri regni come potrà mai indursi per quanto ne sia stimolato, a prevalersi s'intromenti sì dubbij e da non potersene punto fidare, como sono un rozzo inesperto fanciullo e una donna, cioè la di lui madre o balia, che per necessità converrebbe farla consapevole di sì intrigate finzioni?" Ibidem, loc. cit. Tradução nossa.

638 "Con manifesto rischio d'un traditore che rompa il sigillio per vendetta d'un offesa o per astio dell'atrui fortuna, come tanto facilmente succede. (...) Non sono questi certamente dettami di prudenza nè di giudizio." Ibidem, p. 127-8. Tradução nossa.

639 “Già sonoben provvisti di rendite”. Ibidem, p. 129. "Tradução nossa.

640 "Sia essi per essere Lama sono nel Tibet nel primo onore in linea di nobilità, nella prima stima in riputazione di dottrina, nem primo rispetto in ordine di persone sagre e di maestri della religione. Onde non hanno più dove salire, nè dove aspirare con le lor brame.” Ibidem, loc. cit.. Tradução nossa.
} 
Interesses políticos, da mesma forma, parecem não ser atrativo suficiente, porque caso o rei se oponha à escolha, eles podem sofrer perseguições do soberano, como perder propriedades e outras punições. Além disso, não poderiam esperar créditos ou se gabarem pelo feito, pois isso colocaria em xeque o suposto segredo que viabilizaria a própria fraude.

Depois de expostas todas essas considerações, a conclusão do italiano é a de que "o diabo é o verdadeiro e único agente causal direto de toda a mentira." ${ }^{641}$

Nosso objetivo com a exposição da argumentação feita por Desideri é analisar não só como ele percebe a sucessão dos Dalai Lamas, mas também identificar a descrição feita sobre a estrutura política e social atrelada à "seita dos lamas" no Tibete. Nesse sentido, é necessário desde já reconhecer a sensibilidade e perspicácia do italiano na elaboração de um sofisticado quadro da estrutura político-religiosa.

Ao procurar defender sua posição, o missionário retrata a complexidade do equilíbrio político entre poder espiritual e temporal. Além disso, podemos perceber, a partir da leitura dessa obra do século XVIII, como tal equilíbrio era (e ainda é) fundamental para a configuração social do Tibete, em especial no que diz respeito à figura do Dalai Lama como personagem central da organização sociopolítica.

Não obstante, em seu texto, Desideri reconhece e nomeia os principais atores políticos: o povo, os lamas e o rei. O italiano também indica sua hierarquia, afirmando que os lamas gozam de grande respeito e estão no mais importante patamar social. Fora isso, ele acrescenta ainda que os religiosos budistas são pessoas instruídas, intelectualmente preparadas, que ensinam a religião e são consideradas sagradas.

No que poderíamos chamar de periferia do texto - isto é, subjacente ao conteúdo principal da argumentação do autor - identificamos atributos que qualificam e descrevem a sociedade tibetana e suas partes, dentre lamas e reis. Esses atributos - civilizados, bárbaros, cultos, inteligentes, prudentes etc. - são predicativos que constroem categorias, as quais subsidiam e justificam a prática missionária, além de determinarem as mais prudentes estratégias de conversão para cada sociedade a ser evangelizada.

A relação direta entre o conteúdo - central e periférico - da cuidadosa descrição feita por Desideri do processo sucessório do Dalai Lama e a prática missionária fica evidente no

641 "Il demonio sai il ver e solo agente immediato di tuttoquell'inganno". DESIDERI, I. La relazione di Ippolito Desideri, apud: PETECH, L. I missionari italiani nel Tibet e nel Nepal. Libr. dello Stato, vol. VI, DR. 3, p. 129. Tradução nossa. Grifo nosso. 
início do capítulo seguinte. ${ }^{642}$ Logo em seu primeiro parágrafo, o religioso evidencia a quem principalmente ele dirige suas considerações:

O missionário evangélico pode ainda não estar plenamente convencido de que o Grande Lama, e outros lamas da mesma forma eleitos, são as bocas do diabo desde o início. (...) Portanto, os missionários não serão capazes de se armarem com a resolução necessária para combater aqueles que tão grandiosamente são assistidos pelo Inferno, a menos que eles entendam claramente o que realmente é esse tipo de lama. ${ }^{643}$

É necessário, portanto, que não fiquem dúvidas acerca da posição do religioso neste assunto, para que "aqueles que sejam atribuídos a este campo de missão vão para lá bem instruídos e prevenidos sobre esse ponto." ${ }^{644}$

A utilidade prática do texto é explicitada pelo próprio Ippolito Desideri, estabelecendo, portanto, uma relação direta entre a produção escrita e a atuação missionária, entre texto e prática, entre retórica e política. Sabemos, pois, que essa constatação por si só não traz coisa alguma de essencialmente novo para o campo dos estudos das relações interculturais, em especial aos trabalhos relativos à atuação da Companhia de Jesus na Idade Moderna. No entanto, a premissa é fundamental para o desenvolvimento da hipótese central desta tese, isto é, a relação entre retórica e política missionária, a qual procuramos aprofundar e esmiuçar para o caso das missões aqui recortadas.

Retomando a análise do texto: Desideri levanta então três possíveis críticas que sua posição poderia sofrer, e as refuta. Segundo o missionário, a imensa atuação do Diabo no Tibete poderia pôr em questão a redenção, ou seja, a própria vinda de Cristo ao mundo. Porém, o italiano defende que o triunfo de Cristo não estaria no fato de Ele, com sua vinda, ter aprisionado o Diabo. Ao contrário, o triunfo seria a libertação dos homens, que, a partir do sacrifício do Deus Homem, passaram a serem capazes de subjugar um adversário em essência mais poderoso que eles. ${ }^{645}$

\footnotetext{
642 "Risposta a gl'argumenti di chi stima che l'inganno riferito sai artifizio degl'huomini e non del demonio." Ibidem, p. $130-138$.

643 "Il Missionario evangélico non può ancora restar bem persuaso che il Gran Lama e gli altri Lama simili a lui nel modo d'esser eletti siano stati da principio bocche parlanti del demonio. (...) Onde nè meno ouò armarsi di quello spirito, che è necessario a combattere gente si fatta e tanto assistita dall'inferno, finchè non si chiarisca che di fatto son tali questi Lama." DESIDERI, I. La relazione di Ippolito Desideri, apud: PETECH, L. I missionari italiani nel Tibet e nel Nepal. Libr. dello Stato, vol. VI, DR. 3, p. 130. Tradução nossa.

644 "Chi è destinato a questo campo vi vada ben struito e premunito su questo ponto." Ibidem, loc. cit. Tradução nossa.

${ }^{645}$ Percebe-se que Desideri preocupa-se em resolver a questão da especificidade da idolatria tibetana sem entrar em conflito com a doutrina da Igreja. Frisamos que São Tomás de Aquino dedica-se exclusivamente à Idolatria na questão 94 da II Seção da II parte da Suma Teológica. Cf: AQUINO, T. Suma Teológica. Tradução Alexandre Correa. São Paulo: Faculdade de Filosofia Sede Sapiens, 1956, p. 385-410.
} 
A segunda possível objeção a ser feita à posição do italiano, seguindo o raciocínio, seria que a frequência com que o Diabo interfere no Tibete poderia ser entendida como uma diminuição do poder e da atuação de Deus. A resposta para essa questão é que "desde que a mesma causa continue e não seja impedida de ocorrer, o mesmo efeito aparecerá." ${ }^{946}$ Assim, o suposto poder do Diabo no Tibete não é indício de fraqueza de Deus, mas consequência da teimosia e cegueira dos tibetanos. Para reiterar sua posição, o missionário finaliza este argumento recorrendo a Paulo: "Não deis lugar ao demônio". ${ }^{647}$

A última crítica hipotética que o religioso indica ser necessária refutar pode ser resumida na seguinte pergunta: “Como é possível (...) que a Providência permita uma situação tão desordenada e inédita regularmente?" ${ }^{448}$ Como é possível que a Divina Providência, que tudo regula e dispõe com infinita sabedoria, permita tamanha desordem e abandone os tibetanos na escuridão e no erro?

Infelizmente, no entanto, o religioso italiano não terminou o capítulo. ${ }^{649}$ Não temos, pois, acesso ao que ele pretendia responder a essa crítica, a qual ele identifica como o "tendão de Aquiles" de sua argumentação.

De qualquer forma, gostaríamos de encerrar esta parte de nossa análise destacando a sofisticação da observação e argumentação do missionário associada ao visível cuidado de não deixar qualquer brecha em seu texto que o torne vulnerável a críticas que partam do corpo doutrinário da Igreja. Isto é, Desideri teve não só que observar e descrever esses aspectos da sociedade tibetana, como também se dispôs a explicá-los segundo os princípios cristãos. Em um dado momento de seu texto, o jesuíta explica que todas essas informações sobre o Dalai Lama e o seu processo sucessório foram adquiridas de quatro maneiras: pela opinião pública ou senso comum, pelos livros da "seita tibetana"; pelo relato de pessoas críveis; por sua própria experiência. ${ }^{650}$ Disto, a imagem que nos ocorre - fictícia, evidentemente - é que Desideri tinha, em sua mão esquerda, os cânones tibetanos e, em sua mão direita, a Suma

\footnotetext{
646 "Fin tanto que persevera l'istessa causa non impedita ad operare, forza è che segua sempre l'istesso effetto a farsi vedere.” DESIDERI, I. La relazione di Ippolito Desideri, apud: PETECH, L. I missionari italiani nel Tibet e nel Nepal. Libr. dello Stato, vol. VI, DR. 3, p. 136. Tradução nossa.

${ }^{647}$ Efesos, 4: 27.

${ }^{648}$ Como dunque è possible (...) che ella [Providência] permeta nel Tibet constantemente uno sconcerto si inaudito?" Ibidem, vol. VI, DR. 3, p. 137. Tradução nossa.

${ }^{649}$ Para maiores informações sobre as possíveis causas dessa interrupção, sugerimos a leitura da introdução à Notícia Histórica do Tibete, especialmente a sessão III, ponto 9, p. 98-101, na seguinte publicação: DESIDERI, I. Mission to Tibet: the extraordinary eighteenth-century account of father Ippolito Desideri, S.J. Tradução Michael J. Sweet, Edição Leonard Zwilling. Boston: Wisdom Publications, 2010.

650 "Dalla publica fama, e da' libri di quelli genti, e dalle relazione d'uomini degnissimi di fede, che l'hanno scritto prima di me, e dalla mia stessa esperienza." DESIDERI, I. La relazione di Ippolito Desideri, apud: PETECH, L. I missionari italiani nel Tibet e nel Nepal. Libr. dello Stato, vol. VI, DR. 3, p. 138.
} 
Teologica. Assim, o texto produzido pelo italiano é composto como em camadas, adequando o conteúdo dos canones à verdade da Suma. Qualquer fato que chega ao missionário - via observação, leitura, diálogos - vai se acomodando nas folhas de seus manuscritos. História, política, religião: tudo isso vai ganhando lugar no texto. 


\subsubsection{PONTO 2: A DESCRIÇÃO DO DALAI LAMA: DOMINIUM E PRUDÊNCIA}

Como eu disse acima, o Grande Lama do Tibete não é apenas reconhecido e reverenciado por todos os tibetanos em todos os lugares no Tibete, mas também reconhecido pelos tártaros, pelos pagãos do Indostão e pelos chineses como seu chefe, mestre, protetor e pontífice, e é adorado e honrado com oferendas, não como um homem comum, mas como o próprio Cheresik. ${ }^{651}$

A pena do missionário dedica-se agora a considerações sobre a figura do Dalai Lama, extrapolando as questões acerca da sua sucessão. É necessário explicar para o público europeu e missionário quem é o líder religioso da seita tibetana. É necessário expor os limites de sua autoridade. No entanto, epistemologicamente, percebemos uma primeira dificuldade. Como o conceito de budismo é inexistente, é necessário que o jesuíta ressalte que a reverência ao líder religioso expande-se tanto quanto sua seita correspondente, mas sem pressupor que a religião budista (que não existe como categoria para Desideri) esteja dispersa por toda a Ásia. ${ }^{652}$

Além disso, se a autoridade do Dalai Lama não se limita aos espaços de influência tibetana, ela também não se limita estritamente ao campo temporal:

A autoridade e o domínio do Grande Lama sobre essas pessoas não se limita apenas a questões de religião, mas também se estende até a esfera temporal, já que ele é, estritamente falando, o governante absoluto de todo o Tibete principal. É verdade que, em parte para aliviar suas funções e em parte para não interferir diretamente em questões civis, militares e penais, há muito tempo nomeou um rei, que, em seu lugar e dependente dele, governa este reino inteiro em assuntos temporais. Assim sendo, o rei do Tibete não é realmente rei, mas é, estritamente falando, um administrador comum. Além disso, o Grande Lama não é tão inteiramente removido do governo temporal do Tibete que ele não possa exercer diretamente seu governo e dominio e governar a seu critério, como de fato que ele faz muitas vezes por meio de suas ordens diretas por escrito. O rei nunca se atreveria a opor-se ou invalidar essas ordens, ou impedir sua execução. ${ }^{653}$

651 "Come sopra avevo detto, il Gran Lama del Tibet è riconosciuto e venerato non solamente da tutti i Thibettani di qualunque Thibet (SIC), ma ancora da' Tartari, da' Gentili dell'Hendustan e da' Cinesi per loro capo, maestro, protetore e pontefice, et è adorato e onorato di sacrifizij come uomo non ordinário, ma come l'istesso Cen-rêesij." Apesar das inconststências nas grafia (ex: Tibet e Thibet), optamos por repeti-las como aparecem na publicação citada. DESIDERI, I. La relazione di Ippolito Desideri, apud: PETECH, L. I missionari italiani nel Tibet e nel Nepal. Libr. dello Stato, vol. VI, DR. 3, p. 138. Tradução nossa.

${ }^{652} \mathrm{O}$ missionário João Cabral, no entanto, parece ter dado esse passo em sua carta publicada por Didier. Relação da Missão do reino de Uçangue, cabeça dos do Potente, escrita pelo Padre João Cabral da Companhia de Jesus. DIDIER, H. Os portugueses no Tibete. Os primeiros relatos dos jesuítas (1624-1635). Lisboa: Comissão Nacional pra Comemoração dos Descobrimentos Portugueses, 2000.

653 "L'autorità e dominio del Gran Lama appresso quelle genti non solamente è in materia di religione, ma ancora nel temporale, essendo egli propriamente il padron assoluto di tutto il primário Thibet. Vero è che, parte per alleggerersi del carico e parte per non ingerirsi immediatemente nelle cose civili, militari e criminali, ha egli $\mathrm{ab}$ antiquo constituito un Re, che in suo luogo e com dependenza da lui governi tutto quel Regno nel temporale. Con che il Re di quel Thibet propriamente non è Re, ma in rigore è un semplice amministratore. Oltre di cio non 
Esse período é de extrema importância para a nossa análise, pois ele demonstra que Desideri identifica o Dalai Lama não apenas como líder da seita tibetana, mas também como soberano - que tem autoridade e domínio - do que ele chama de "Tibete principal". Além disso, Desideri explica a figura que ele, ao longo do texto, denomina “rei”, e nós, nesta tese, repetimos a nomenclatura. No entanto, não se trata de um rei no sentido próprio do termo. A figura política mais importante do Tibete é o Dalai Lama, no temporal e no espiritual, e o "rei" com quem ele travou contato é, na verdade, um "administrador" ou "regente".

Desideri prossegue:

As riquezas do Grande Lama são imensas; na verdade, elas são realmente enormes. Os tributos, impostos e receitas regulares do reino pertencem a ele e ao rei em comum. Além disso, o Grande Lama tem suas próprias receitas, como as grandes esmolas, oferendas e presentes diários que são reservados apenas para ele. ... Há um grande número de comerciantes que trabalham para ele, que ganha uma quantia incrível do comércio com a China e outros lugares. ${ }^{654}$

A autoridade e domínio do Grande Lama estão, evidentemente, associados à fiscalidade. Porém, em decorrência de sua dupla autoridade (espiritual e temporal), o Dalai Lama não tem apenas direito a recolher impostos, como também recebe uma significativa quantidade de esmolas. Além disso, afirma Desideri, o líder tibetano parece ganhar dinheiro indiretamente com o comércio, pois teria mercadores a seu serviço trabalhando nas trocas comerciais com a China. O jesuíta prossegue, descrevendo as responsabilidades atribuídas ao Grande Lama:

Sua ocupação e suas responsabilidades são fazer oferendas e rezar para todos os seres vivos, nomear oficiais e administradores para vários mosteiros e conventos, certificar outros lamas de seus compromissos, receber visitas, enviar expedições e reconhecer agradecimentos por escrito, com seu grande selo impresso em vermelho, atribuir vários deveres e receber os relatórios de como suas propriedades são administradas. ${ }^{655}$

si è il Gran Lama talmente spogliato del governo temporale del Thibet, che non si sai riservato a suo placito l'esercizio immediato di tal governo e domínio, come in fatti l'esercita sovente in molte cose con suoi dispacci immediati, a' quali non oserebbe giammai il re d'opporsi o d'invalidarli e d'impedirne l'esecuzione." DESIDERI, I. La relazione di Ippolito Desideri, apud: PETECH, L. I missionari italiani nel Tibet e nel Nepal. Libr. dello Stato, vol. VI, DR. 3, p. 138-9. Tradução nossa.

654 "Le richezze del Gran Lama son assai grandi, e per così dir immense. I tribute ordinari, le gabelle e le rendite ordinarie del Regno son communi a lui e al Re. Ha oltre di ciò le proprie rendite a lui riservate. Le limosine, offerte e presenti de' popoli son copiosissime e quotidiane. (...) E avendo infinità di gente al suo servizio e una gran quantità di mercanti al suo soldo, è incridibile il guadagno che ritira dal commercio della Cina e d'altri parti." Ibidem, loc. cit. Tradução nossa.

655 'Le sue occupazzioni e impieghi sono far sacrifizj e preghiere per tutt'i viventi, provveder a' varj offizj e governi de' conventi, approvar gl'atri Lama, ricever visite, dar dispacci e compartir grazie in iscritto col suo gran sigillo, che deve imprimersi col color rosso, dar varj carichi e ricever conti dell'amministrazione de' suoi beni." Ibidem, p. 142. Tradução nossa. 
Julgamos importante reiterar que, novamente, o jesuíta confirma em seu relato o duplo papel de chefe de Estado e chefe religioso do Dalai Lama. Insistimos nesse ponto, pois, em ambos os casos, trata-se de um entendimento político, isto é, de governo das comunidades políticas - civil e eclesiástica- organizadas abaixo da mesma "cabeça". Supomos que Desideri, ao observar e descrever a figura do Dalai Lama - reconhecendo suas atribuições temporais e religiosas, e, portanto, reconhecendo o Tibete como uma comunidade politicamente organizada -, deve ter se deparado com um aparente paradoxo. Como já dissemos, de um lado, ele percebia um povo "civilizado" e "político". Do outro, ele via um povo iludido pelo demônio, mesmo reconhecendo que seus religiosos eram sábios e prudentes e seu governo justo. Era necessário juntar as duas características, a princípio antagônicas, criando uma categoria que desse conta deste aparente contrassenso. O que fazia com que os tibetanos parecessem, em alguns momentos, alheios à luz da razão natural, se em tantos momentos eles agiam conforme o entendimento?

Essa gente cega e iludida adora o Grande Lama de tal forma que solicitam seu excremento, feito em pequenas pílulas, como uma grande relíquia. (...) Quando estão doentes ou em circunstâncias semelhantes, elas tomam esses comprimidos com grande fé, considerando-as um poderoso remédio para seus males e um preventivo certo contra todos os infortúnios. ${ }^{656}$

No trecho acima, podemos perceber essa suposta incongruência. Gostaríamos de frisar, desde já, que o período inicia-se com a expressão "pessoas cegas”. Já havíamos identificado essa mesma categoria há algumas páginas. Retornaremos a esse tema em um momento mais oportuno, sendo por ora suficiente reiterarmos o uso dessa sentença, associada ao que identificamos como um paradoxo na descrição feita por Desideri.

Retomemos, pois, as considerações do jesuíta sobre os lamas em geral, decorrentes da descrição inicial das funções atribuídas ao Grande Lama:

Agora, detalhes à parte, há, de um modo geral, três tipos de lamas no Tibete. $\mathrm{Na}$ primeira e mais respeitada classe estão aqueles que, de acordo com as crenças dessa gente, são sempre a mesma pessoa, que sucessivamente retornam e renascem na mesma condição de lama. A segunda classe é mais distinta em sua autoridade temporal e riqueza; estes lamas casam e têm filhos que viram lamas, e que lhes sucederão. A terceira classe é composta por aqueles que são selecionados e nomeados lamas pelo rei e pelo Grande Lama devido a seus conhecimentos, prudência e confiabilidade. ${ }^{657}$

\footnotetext{
656 "Finalmente a tale eccesso arriva l'adorazione di quelle cieche e illuse genti verso il Gran Lama del Thibet, che $\mathrm{i}$ medesime suoi escrementi, ridotti in piccolo pillole, li dimandano come una molto gran reliquia. (...) $\mathrm{E}$ nelle mallattie o simili occorrenze prendono con molta fede di tali pillole, come potente rimedio a' loro mali e come sicuro preservative da ogn'infortunio.” DESIDERI, I. La relazione di Ippolito Desideri, apud: PETECH, L. I missionari italiani nel Tibet e nel Nepal. Libr. dello Stato, vol. VI, DR. 3, p. 143. Tradução nossa.

${ }^{657}$ Lasciati dunque i particulari, dirò qui in generale che ter scorti di Lama vi sono nel Thibet. La prima classe e più stimata è di quelli che in opinione de quelle genti son sempre i medesimi soggetti e che successivamente
} 
Mais uma vez, percebemos que, nos relatos de Desideri, aparecem imiscuídos os poderes temporais e espirituais seja para a figura do Dalai Lama, seja para a caracterização do “clero" tibetano no geral. O primeiro tipo de lama indicado pelo italiano são aqueles que já mencionamos acima, chamados de tulkuls. ${ }^{658}$ É importante perceber que, para o segundo tipo de religiosos, o jesuíta está atento ao fato de que uma classe de lamas não observa o voto de castidade. Por último, Desideri parece identificar um grupo mais "comum" de lamas, a quem ele associa características como conhecimento, prudência e confiabilidade. Evidentemente que o missionário não afirma que ele mesmo julga estes lamas nesses termos, dizendo apenas que eles são assim reconhecidos pelo rei e pelo Grande Lama. No entanto, julgamos ser importante que essas características estejam associadas (lama e prudência), mesmo que indiretamente, na escrita de Desideri. Qualquer que seja sua classe, no entanto, todos eles são reconhecidos como preceptores espirituais e mestres em leis religiosas:

Os lamas, em geral, de qualquer classe que sejam, são reconhecidos como mestres da lei religiosa e diretores espirituais para os outros. (...) Em uma palavra, os lamas do Tibete têm a mesma autoridade, respeito e status neste reino que temos por bispos e arcebispos, e o Grande Lama é respeitado como o pontífice. ${ }^{659}$

O missionário associa, portanto, a autoridade de um lama à autoridade de um bispo ou arcebispo, da mesma forma que estabelece uma analogia entre o Grande Lama e o Papa. Fica aberta, porém, a seguinte questão: por que Desideri resolveu, ainda que pontualmente, traçar analogias entre o clero secular e os lamas, em detrimento de traçar comparações com Ordens religiosas? Acreditamos que uma hipótese para esta pergunta seria que a intenção, neste trecho, é justamente ressaltar aspectos de autoridade, governo e administração (da Igreja), e por isso ele lançou mão de cargos como bispo ao invés de ressaltar, por exemplo, semelhanças com ordens conventuais.

tornano a risascere nella medesima qualità di Lama. La senconda classe e più cospicua per il domínio temporale e per la richezza è di quelli che son maritati e generano altri Lama, che devono a loro succedere. La terza classe è di quelli, che in riguardo della loro scienza, prudenza e probità, sono eletti e constituiti Lama per elezion del Re e del Gran Lama. DESIDERI, I. La relazione di Ippolito Desideri, apud: PETECH, L. I missionari italiani nel Tibet e nel Nepal. Libr. dello Stato, vol. VI, DR. 3, p. 143-4. Tradução nossa.

${ }^{658}$ Cf: tópico "A questão da autoridade religiosa" desta tese.

659 "I Lama, in genere, e di qualunque classe siano, son riconosciuti come maestri della Legge e direttori degl'altri, e ciascun d'essi è superiore d'alcun convento di religiosi, e ha la sua diocesi assegnata e i suoi sudditi in materia di religione. Qualsivoglia Lama ha le sue rendite, la sua corte, il suo stato e si tratta com magnificenza. (...) In uma parola, i Lama del Thibet sono in quel regno nella medesima autorità, considerazione e stato, in cui apresso di noi sono i vescovi e arcivescovi, e il Gran Lama è in considerazione di pontefice." DESIDERI, I. La relazione di Ippolito Desideri, apud: PETECH, L. I missionari italiani nel Tibet e nel Nepal. Libr. dello Stato, vol. VI, DR. 3, p. 145. Tradução nossa. 
Achamos pertinentes tais pontuações porque, se formos comparar este trecho com outras descrições do clero tibetano feitas por Antônio de Andrade, por exemplo, perceberemos que por vezes são enfatizadas as semelhanças com o clero regular europeu (vida em comunidade, observação dos votos de castidade e pobreza) e, em outros momentos, ressalta-se as semelhanças com o clero secular, isto é, com a estrutura administrativa da Igreja. É interessante notar, portanto, o cuidado e certa sofisticação na condução de Desideri da tarefa descritiva a que ele se dedicou. Percebe-se que as comparações e analogias servem ao objetivo de explicar para um europeu como se organiza a seita tibetana, a partir de conceitos reconhecíveis por seus leitores, isto é, católicos e, principalmente, futuros missionários. Essa ponte fica ainda mais evidente em trechos como o seguinte:

Não devo esquecer de mencionar que nós missionários europeus somos conhecidos e reconhecidos como lamas no Tibete e somos chamados de gokargyi lama (Gogar-kyi-Lama), ou seja, lamas europeus. Isso é porque nós somos reconhecidos como diretores espirituais e mestres da nossa santa Lei e somos religiosos celibatários. Devido a todas essas qualidades, que são facilmente reconhecidas em nós, eles nos respeitam como lamas. ${ }^{660}$

Fica claro, portanto, que quando ele descreve os lamas como preceptores espirituais, mestres em leis religiosas, cultos e prudentes, Desideri, de certa forma, antecipa a analogia entre lamas e missionários. Mais do que isso, ele indica que tipo de missionário deve ir ao Tibete e como o religioso deve apresentar-se. Não obstante, este trecho confirma, de forma literal, nossa hipótese de que Desideri acomodou-se no papel de lama, isto é, de preceptor espiritual. Esta adaptação desenvolveu-se a partir da noção de autoridade espiritual e da função de preceptor espiritual, a partir do ponto de vista da organização político-religiosa tibetana.

Em paralelo, na escrita de Desideri, tal acomodação se dá através da atribuição de qualidades. Na medida em que o jesuíta se utiliza de determinadas características, isto é, lança mão de determinados adjetivos, ele estabelece uma ponte entre as funções de lama e missionário. Esse exercício retórico é feito de forma a reiterar a função comum aos sacerdotes de ambas as religiões: o papel de diretor espiritual e mestre de leis espirituais. No texto do italiano, a função é identificada, mas a acomodação retórica ganha efeito a partir da

\footnotetext{
${ }^{660}$ ‘ Non devo qui tralasciar d'avvertire che noi altri missionarj europei nel Thibet siamo chiamati e riconosciuti per Lama, e ci chiamo Gogar-ki-Lama [mgo-dkar-gyi-bla-ma], cioè Lama degl'Europei; e cio perchè siamo riconosciuti per direttori spirituali e per maestri della nostra $\mathrm{S}$. Legge e perchè siamo in stato celibe e religioso. Per tutte queste qualità, che ben riconoscono in noi, ci rispettano come Lama. DESIDERI, I. La relazione di Ippolito Desideri, apud: PETECH, L. I missionari italiani nel Tibet e nel Nepal. Libr. dello Stato,, vol. VI, DR. 3, p. 145. Tradução nossa.
} 
operação de atribuição de qualidades comuns: conhecimento, prudência e confiabilidade, por exemplo.

Assim, gostaríamos de ressaltar dois aspectos principalmente importantes da parte do texto em que Desideri descreve o Grande Lama e os lamas em geral. Em primeiro lugar, ele reconhece o Grande Lama como cabeça de duas comunidades políticas, imiscuídas na tessitura social tibetana: a civil e a religiosa. Em segundo lugar, ele descreve as funções de um lama no geral, bem como suas principais características. Estes dois pontos de partida servem para que o jesuíta possa desenvolver a noção de preceptor espiritual e assim indicar para os possíveis missionários da Companhia de Jesus que papel eles devem tomar quando designados para essa parte das "Índias". Mais uma vez, observamos a função descritiva associada à proposição de estratégias de conversão. No tópico a seguir, trataremos não mais das descrições político-sociais e seu impacto na missionação, mas sim das questões teológicas levantadas pelo italiano e suas repercussões na atividade missionária. 
4.5.3 Ponto 3: ERros DA SEITA TIBETANA: CONSTRUINDO E DESMONTANDO O ATEÍSMO TIBETANO

O erro principal e fundamental que causa todos os outros, ou melhor dizerendo, no qual todos os erros da falsa seita tibetana estão subordinados é o erro nefasto de metempsicose ou transmigração das almas. ${ }^{661}$

Até este ponto, podemos perceber como o missionário ocupou-se da descrição dos tibetanos, reconhecendo-os como uma comunidade política perfeita, identificando os principais componentes da multidão tibetana (povo, governantes, lamas), esmiuçando a importância da principal figura religiosa e política do Tibete: o Grande Lama. É justamente a partir da descrição da figura do Dalai Lama que Desideri inicia a descrição da religião tibetana no livro 4 de sua Notícia Histórica.

Como vimos, segue-se a hipótese de que o aparecimento de um novo Grande Lama é obra direta do demônio, e, na periferia do exercício retórico argumentativo do missionário, encontramos valiosos atributos dados à sociedade tibetana. Segue-se uma descrição mais genérica dos lamas menores. Por fim, chega-se ao que consideramos o centro do trabalho descritivo e de categorização feito pelo italiano: a explicação da falsa religião dos tibetanos. Essa explicação concentra-se na identificação de seus dois principais erros: o sistema de metempsicose (aquele que torna possível a sucessão do Grande Lama e alguns lamas menores) e a negação da existência de um deus criador não criado, causa primeira de todas as coisas. Para analisar tais erros, o jesuíta realiza primeiramente um esforço "historiográfico", isto é, ele procura estabelecer uma história da disseminação dessas “falsas noções” pela Ásia:

Apesar de serem idólatras e gentios, a seita dos tibetanos é muito diferente
dos costumes e doutrinas da dos outros gentios da Ásia. Embora seja verdade
que receberam sua religião dos gentios antigos do Indostão, ou seja, do
Mogol, os livros antigos e costumes não são mais usados no Indostão devido
à passagem do tempo e à introdução de novas crenças e fábulas recém-
inventadas. Ademais, os tibetanos, devido a sua inteligência sutil e
contínua atividade especulativa, rejeitaram muito do que se opunha à
lógica do discurso humano comum e abraçaram apenas os pontos que
podem mais facilmente, devido a uma certa aparência de bondade, enganar o
entendimento humano, que, por si só, é abandonado e completamente não
iluminado pela luz pura, invencível e sobrenatural da verdadeira fé
esclarecida. Portanto, os tibetanos desviaram dos seus próprios professores

661 "Il primario e fundamental errore da cui scaturiscono, o, per meglio dire, in cui si racchiudono tutti gli altri errori che compongono la falsa setta de' Thibettani, è il pessimo errore della metempsicosi, o sia della transmigrazion dell'anime." DESIDERI, I. La relazione di Ippolito Desideri, apud: PETECH, L. I missionari italiani nel Tibet e nel Nepal. Libr. dello Stato, vol. VI, DR. 3, p. 166. Tradução nossa. 
e, no presente, os indianos e os tibetanos têm escolas filosóficas que diferem entre si, e seguem as religiões muito diferentes. ${ }^{662}$

Reiteramos, portanto, a iniciativa "historiográfica" de Desideri, associando a seita tibetana ao "paganismo" indiano. No entanto, para explicar as atuais diferenças, o jesuíta recorre à ideia de "desvio", similar a ideia de "erros de mistura" de Antônio de Andrade. Contudo, o italiano insinua algo de positivo nessa passagem sobre o paganismo indiano para o Tibete. O jesuíta diz que, devido a sua sutil inteligência e contínua atividade especulativa, os tibetanos rejeitaram muito do que se opunha à lógica. Assim, por mais que Desideri reconheça semelhanças entre a seita tibetana e o "paganismo" da Índia, ele assegura que se tratam de duas religiões distintas. Mais do que isso, ele reconhece que escolas filosóficas diferentes se relacionam a cada uma das religiões. Acreditamos que esse é um grande (e, em certo sentido, generoso) passo na observação do jesuíta: associar as religiões a escolas filosóficas - o que está muito distante do uso de termos como "patranhas". ${ }^{663}$

Desideri mais uma vez reconhece fatores como "lógica" e "filosofia" nos tibetanos e indianos. A partir daí, é necessário pensar como é possível para uma comunidade conhecer "lógica" e "filosofia" e ser tão bárbara a ponto de negar em absoluto a existência de Deus. Desideri depara-se com a questão do ateísmo:

Os tibetanos, guiados por sua religião falsa, positiva e diretamente negam a existência do Deus verdadeiro. Sendo assim, alguém poderia desejar saber se eles aceitam pelo menos algum outro tipo de divindade, pois parece que não há nenhuma nação na Terra que seja tão inculta e bárbara que não reconheça sequer um ser supremo de alguma forma, ou algum tipo de divindade, mesmo uma que seja imaginária ou, ainda mais, monstruosa.

A isso, eu responderia que outras nações idólatras da Ásia comumente aceitam algumas divindades imaginárias e monstruosas (...) atribuindo-lhes um domínio e poder supremo sobre o mundo inteiro, que é específico deles e não compartilhado com outros objetos de sua veneração (...). Os tibetanos,

\footnotetext{
662 "Quantunque idolattri e gentili siano i Thibettani, contuttociò molto differente è la loro setta dai costume e massime degli altri gentili del l'Asia; e quantunque abbiano presa la loro religion dagli antichi gentili dell'Hindustàn, o sia del Mogol, nondimeno, parte per esseri col decorso del tempo aboliti nell'Hindustàn gli antichi libri e costumi per essersi introdotte e di nuovo inventate nuovo favole e nuovi assiomi, e parte ancora por aver I Thibettani, in vigor della loro sottigliezza d'ingegno e del continuo esercizio della speculazione, rigettate molte cose che maggiormente s'opponevano alla ragione del puro umano discorso e solamente abbracciato alcune $\operatorname{cosec}$ he possono più facilmente con una certa apparenza di bene ingannar l'intendimento dell'uomo a sè stesso derelitto e niente rischiarito dalla pura, indefettibile e soprannatural luce della vera Fede illuminato; da ciò proviene che dagl'istessi suoi maestria allontanastisi i Thibettani, abbiano gli uni e gli altri presentemente scuole fra di sè diverse e seguitino religion fra di sè molto dissomiglianti.” DESIDERI, I. La relazione di Ippolito Desideri, apud: PETECH, L. I missionari italiani nel Tibet e nel Nepal. Libr. dello Stato, vol. VI, DR. 3, p. 166. Tradução nossa.

${ }^{663}$ Referimos aqui, por exemplo, a opinião de Coresma exposta no capítulo anterior: "são lamases (sic), com que não há que tratar de mudança de lei, por viverem de cantar suas patranhas ao povo, inda que entre eles há bem poucos que em as contar sejam coerentes ainda que todos os mais não saibam nem podem dizer em que lei vivem." CARTA do Padre Nuno Coresma ao Provincial de Goa, Tsaparang, 30 de Agosto de 1635. ARSI, Goa $73, \mathrm{fl} .97 \mathrm{r}$.
} 
por outro lado, rejeitam não só completamente a verdadeira divindade que a verdadeira fé nos apresenta, mas também não aceitam ou recebem nenhuma das divindades monstruosas e falsas dos antigos pagãos do Indostão, isto é, do Mogol, de onde aprenderam sua religião falsa. Isso se dá porque seu intelecto naturalmente afiado os impede (...) de acreditar nas incoerências, absurdos e contradições dos seus mestres. Eles preferiram não reconhecer qualquer criador supremo do mundo com poder absoluto e independente sobre ele e os seres humanos, ao invés de aceitar um da forma que enganosamente foi proposto a eles. Assim, digo que segundo a sua religião ou seita, os tibetanos não só ignoram completamente a existência de uma verdadeira divindade, mas também não reconhecem qualquer divindade falsa e monstruosa, como muitas outras nações idólatras na Ásia.

Alguém pode retrucar: "Você está querendo dizer que os tibetanos são ateus? $?^{664}$

Ao perceber que os tibetanos não reconhecem nenhuma divindade criadora não criada, Desideri depara-se com um grave problema epistemológico e teológico. Como vimos, a atribuição de um lugar no sistema de entendimento do mundo cristão é atividade fundamental da prática missionária. A atribuição de lugar se dá a partir da associação de atributos com as sociedades descritas. Essa operação retórica de predicação ou categorização é justamente o objeto da nossa tese.

No entanto, como descrever uma comunidade que não é idólatra como os outros pagãos da Ásia, mas que, ao mesmo tempo, já deu indícios de não ser tão bárbara a ponto de não crer em Deus? Como significar essa "falta", isto é, a ausência de um deus criador, de um deus pai, de um deus juiz na religião tibetana? Pois se não é possível atribuir aos tibetanos a categoria "idólatra" à semelhança do que foi feito aos vizinhos indianos, seriam os tibetanos

${ }^{664}$ Reproduzimos do italiano sem supressões: "Supposto l'aver io detto di sopra e spiegato che in vigor della loro falsa religione positivamente e direttamente negano i Thibetani l'existenza del vero Dio, potrebbe alcuno desiderar di sapere se almeno ammettino alcun'altra specie de divinità; poichè pare che non vi sai alcuna nazione nel mondo sì inculta e sì barbara che non riconosca in qualche modo alcun essere supremo e alguna specie almeno di favolosa e per lo più anche monstruosa divinità. A ciò rispondo che ammettendo comunemente l'atre nazioni idolatre dell'Asia qualche favolosa e monstruosa divinità, non solamente riconoscono in tali oggetti capacità e merito d'esser dagl'uomini invocati e venerati, ma attribuiscono loro di più un domínio e poter supremo sopra tutto il mondo, che è loro specifico e non già comune agli oggetti ai quali prestano venerazione e che parimente con sommo culto invocano e con adorazion riveriscono. Dico dunque che i Thibetani non solamente escludono affato la vera divinità che la vera fede ci propone, ma ancora non ostante che abbiano preso la loro falsa religione dagli antichi gentili dell'Hindustàn, o sia del Mogol, contuttociò, non avendo com la loro natural sottigliezza d'ingegno potuto in questo genere, siccome in varie altre cose, seguir l'incoerenze, assurdi e contraddizioni de loro maestri, non ano ammesa nè ricevuta alcuna di sì false e si monstruose divinità; e più tosto non hanno voluto riconoscere alcun supremo autor del mondo e alcun potere assoluto e independente sopra di esso e sopra degli uomini, che ammetterlo nel modo che loro veniva ingannevolmente proposto. Posto cio, dico i Thibetani secondo la loro setta o religone, non solamente escludono affatto l'existenza della vera divinità, ma nè pur riconoscono alcuna falsa e mostruosa divinità, come comunemente l'ammettono altre molte idolatrenazioni dell'Asia. Che se taluno cosi me replicasse: dunque voi venite a dir che i Thibetani son atei?" DESIDERI, I. La relazione di Ippolito Desideri, apud: PETECH, L. I missionari italiani nel Tibet e nel Nepal. Libr. dello Stato, vol. VI, DR. 3, p. 206-7. Tradução nossa. 
ateus? Em sendo essa comunidade ateia e não apenas composta por alguns indivíduos ateus, que tipo de estratégia de conversão seria mais prudente nesse caso?

Retomemos, pois, a ordem dos argumentos apresentados pelo missionário. Em seu décimo primeiro capítulo do quarto livro, Desideri apresenta a possibilidade de os tibetanos serem considerados ateus por negarem verbalmente a existência de um deus criador. No entanto, o próprio missionário indica ter como objetivo nesta etapa de sua obra informar que "essas pessoas cegas, sem estarem cientes, aceitam de fato e reconhecem confusamente a divindade que eles com palavras negam e com falácia descartam. ${ }^{9655}$

Este extrato é central para nossa análise por condensar três elementos basilares da argumentação de Desideri. O primeiro elemento é a categoria já identificada em momentos anteriores: pessoas cegas. Aqui, ela surge associada ao segundo elemento grifado, aquilo que o jesuíta chama de reconhecimento confuso de uma divindade. Por último, o missionário lança mão da expressão "com palavras negam", a qual, na medida em que desqualifica o debate filosófico budista acerca da inexistência de um deus criador, esvazia teologicamente o suposto ateísmo tibetano.

Mas esse esvaziamento ou desqualificação das crenças da seita dos lamas não é o único argumento de Desideri para desmontar a negação da existência de Deus. O missionário também lança mão de outras premissas genéricas ou universais. A primeira delas é a inexistência de uma sociedade absolutamente ateia. Como consequência disso, o jesuíta italiano indica que outras sociedades asiáticas (idólatras) aceitam divindades imaginárias monstruosas, reconhecendo objetos veneráveis ${ }^{666}$ e atribuindo-lhes um poder supremo.

Em seguida, Desideri aponta, dialeticamente, que os tibetanos negam a verdadeira divindade e não aceitam as divindades pagãs do Indostão, de onde teriam recebido sua lei. O que, supostamente, parece um desqualificador da sociedade tibetana, surge na elaboração do jesuíta como uma vantagem. Acreditamos, pois, que existe uma gradação implícita às categorias utilizadas por Desideri. Os povos mais rudes e bárbaros desconheceriam a existência de Deus. Mas, na prática, isso seria uma impossibilidade, pois Deus tocou a todos os homens, universalmente, e, por serem homens, a luz da razão permite que tenham entendimento para conceberem a existência de um ser supremo, ainda que apenas a razão não

\footnotetext{
665 "Solamente mi basta qui il far conoscere che quelle cieche genti senza punto accorgersene ammettono infatti e confusamente riconoscono quella divinità, che con parole negano e com fallacie escludono." 'DESIDERI, I. La relazione di Ippolito Desideri, apud: PETECH, L. I missionari italiani nel Tibet e nel Nepal. Libr. dello Stato, vol. VI, DR. 3, p. 209. Tradução nossa.

666 O termo "objetos" aqui não tem necessariamente uma conotação material, podendo ser qualquer ente (material ou não) que seja receptáculo deste tipo de investimento religioso, isto é, que seja passível de atribuição de capacidades sobrenaturais relacionadas a um poder supremo.
} 
possa, necessariamente, dar conta de todos os mistérios que cercam Deus segundo a Doutrina. ${ }^{667}$ Assim, a idolatria, mesmo sendo um pecado por incentivar a crença em um falso Deus, seria um avanço frente à etapa (hipotética) de um ateísmo absoluto. ${ }^{668}$

No entanto, o missionário sugere sutilmente uma inversão dessa ordem para o caso da seita dos lamas. Desideri aponta um aspecto positivo no suposto ateísmo tibetano, ao afirmar que ele foi resultado do rechaço às crenças pagãs, que iam contra a razão, sendo, portanto, consequência da natureza sutil do intelecto deste povo.

Percebemos, até este momento, a seguinte ordenação no texto do jesuíta: os tibetanos são ateus $\rightarrow$ premissa universal que nega a existência de sociedades absolutamente ateias $\rightarrow$ identificação de uma origem pagã/idólatra para a seita dos lamas $\rightarrow$ reafirmação do ateísmo tibetano como indício de uma natureza perspicaz e razoável.

Nesse ponto, o missionário recorre a outro artifício para desmontar o suposto ateísmo dos tibetanos. Desideri recorre a um debate moral:

[Para a suposição de que os tibetanos são ateus,] eu responderia primeiramente que se por ateu quiser-se dizer (...) uma pessoa ou povo que não reconhecem qualquer divindade, não adimitam qualquer recompensa ou punição por virtude ou vício, absolutamente negam a imortalidade da alma e seguem o epicurismo cego de edamus et bibamos, cras num moriemur et post mortem nulla voluptas, nesse sentido, eu declaro que você não pode (...) dar os tibetanos o título desmerecido de ateus. ${ }^{669}$

No extrato acima percebemos, tal como já exposto por Trent Pomplun, que Desdideri recorre à distinção escolástica entre ateu prático e ateu teórico:

\footnotetext{
667 "Deve-se dizer que está impresso naturalmente em nós algum conhecimento geral e confuso da existência de Deus, isto é, Deus como a felicidade do homem, pois o homem deseja naturalmente a felicidade, e o que por sua própria natureza ele deseja, naturalmente também conhece." (Ergo dicendo quod cognoscere Deus esse in aliquot communi, sub quadam confusion, est nobis naturalier insertum, inquantum scilicet Deus est hominis beatitudo: homo enin naturaliter desiderat beatitudinem, et quod naturaliter desideratur ab homine, naturaliter cognoscitur ab eodem.”) AQUINO, T. Suma Teológica. São Paulo: Ed. Loyola, 2001. Primeira parte, Questão 2, Vol. I, p. 163. É interessante notar que Desideri usa a mesma expressão que aparece na Suma: "confusão".

${ }^{668}$ Ela seria ainda preferível se comparada à heresia, pois: "A gravidade do pecado poder ser considerada relativamente ao pecador; assim dizemos ser mais grave o pecado cometido com conhecimento do que o por ignorância. E então nada impede pequem mais gravemente os heréticos, que cientemente corrompem a fé que receberam, do que os idólatras, que pecam por ignorância." ("Alio modo potest attendi gravitas peccati ex parte ipsius peccantis; sicut dicitur gravius esse peccatum ejus qui peccat scienter quam ejus qui peccat ignoranter. Et secundum hoc nihil prohibet gravius peccare haereticos, qui scienter corrumpunt fidem quam acceperunt, quam idololatras ignoranter peccantes.”) AQUINO, T. Suma Teológica. Tradução Alexandre Correa. São Paulo: Faculdade de Filosofia Sede Sapiens, 1956, vol. 19, p.402-3.

669 "A ciò rispondo primeramente, che se per ateo voglia intendersi quel tanto che assolutamente seco porta um tal nome in tutta la sua estensione, cioè, persona o gente che nè riconosce alccuna ricompensa o castigo del bene e del vizio, nè consente in alcun modo all'imortalità dell'anima e siegue il cieco epicureismo dell' edamus et bibamos, crase num moriemur et post mortem nulla voluptas, in tal senso dico non potersi senza gravissima calunnia e ingiustizia chiamarsi i Thibetani col meritato titolo do atei.” DESIDERI, I. La relazione di Ippolito Desideri, apud: PETECH, L. I missionari italiani nel Tibet e nel Nepal. Libr. dello Stato, vol. VI, DR. 3, p. 207. Tradução nossa. Grifo do autor.
} 
Um ateu prático vive como se Deus não existe (...), mesmo se ele intelectualmente admite que Deus existe. Um ateu teórico, por outro lado, nega intelectualmente que Deus exista, mesmo que ele ou ela leve muito bem uma vida moral exemplar. Em discussões escolásticas de ateísmo, o ateu hipotético nunca considerou seriamente o problema da existência de Deus. ${ }^{670}$

Evidentemente, como também foi dito por Pomplun, os tibetanos consideraram seriamente a existência de Deus e rejeitaram a crença em um deus nos moldes cristãos. Essa associação entre teísmo e virtude é fundamental para a elaboração de um discurso que negasse o ateísmo da seita dos lamas, ainda que os próprios tibetanos afirmassem abertamente que rejeitavam um deus criador como o cristão. O jesuíta dá continuidade aos seus argumentos contra o suposto ateísmo dos tibetanos:

Assim, eu diria que, não obstante o fato de que os tibetanos, em teoria, especulativa e reflexivamente, não só não aceitam, mas como também descartam qualquer divindade, aceitam e reconhecem uma divindade de forma confusa, na prática e implicitamente. Isso parece ser um paradoxo, mas não é o caso. (...) Eles acreditam, confessam e aceitam que deve haver algum objeto de refúgio e de oração, e que de fato há. Além disso, ao falar em geral sobre as perfeições que devem existir em qualquer objeto de adoração e invocação, eles afirmam que estas devem ser, principalmente: (1) perfeitamente abençoar e livrar de todo o mal; (2) onisciente, ou seja, ver e entender todas as coisas; (3) onipotente, capaz de ajudar a todos em todas as coisas; e, finalmente, (4) ter compaixão infinita, sem excluir ninguém sempre que é invocado. E onde essas perfeições são encontradas se não em Deus? ${ }^{671}$

Percebe-se nesta passagem que Desideri não admite que os tibetanos sejam ateus, pois reconhece neles a crença em um objeto de refúgio que possui atributos divinos: bondade, paz, onisciência, onipotência e compaixão infinita. $\mathrm{O}$ missionário também ressalta que os tibetanos

\footnotetext{
670 "A practical atheist lives as though God does not exist (...) even if he intellectually concedes that God exist. A theoretical atheist, on the other hand, denies that God exist intellectually, even though he or she may very well lead a morally exemplary life. In scholastic discussions of atheism, this hypothetical atheist has never seriously considered the problem of God existence." POMPLUN, T. Jesuit on the Roof of the World: Ippolito Desideri's Mission to Eighteenth-Century Tibet. Nova Iorque: Oxford University Press, 2002, p. 95-96. Tradução nossa. Pomplun desenvolve detalhadamente essa questão no tópico "O paradoxo do ateísmo tibetano" ("The paradox buddhist atheism").

671 "Dico, dunque non ostante che i Thibetani in teorica, speculativamente et riflexe, non solo non ammetindo, ma di più ancora escludando ogni divinità, contuttociò confusamente, in pratica et simplicite l'ammetono e la riconoscono. Par questo un paradosso, ma non è tale. Nello spiegar l'opinioni di quelle genti, ho già chiaramente ditto, e più distintamente spieghero qui a basso, che esse credono, confessano e ammettono dovervi essere alcun oggetto di refugio e d'invocazione, e in fatto esservi. De più parlando in genere delle perfezioni che devono ritrovarsi nell'oggetto d'adorazione e d'invocazione, asseriscono essere queste principalmente, cioè: 1 . che sia perfettamente beato e esente da ogni male. 2. Omnisciente, che il tutto veda e il tutto intenda. 3. Omnipotente che tutti e in tutto iudar possa. 4. Finalmente infinitamente misericordioso e senza accetazion di persone, che a tutti indiferentemente voglia far bene, qualora l'invocano. E di chi altro son o posson elleno esser proprie sì fatteperfezioni, e in chi altro possono mai ritrovarsi se non in Dio.” DESIDERI, I. La relazione di Ippolito Desideri, apud: PETECH, L. I missionari italiani nel Tibet e nel Nepal. Libr. dello Stato, vol. VI, DR. 3, p. 208. Grifo do autor. Tradução nossa.
} 
assumem não ser possível fazer o bem e evitar o mal sem a assistência de tal objeto de refúgio.

Os tibetanos dizem ainda que ninguém, por conta própria, pode evitar os males do erro e suas penas, ou atingir a virtude, muito menos a perfeição, mas que todos exigem a ajuda de algum objeto de refúgio e de oração. O que mais pode ser isso se não uma aceitação da divindade que de outra forma negam (...)? $?^{672}$

Partindo dos atributos dados pelos próprios tibetanos ao seu objeto de refúgio e oração, ${ }^{673}$ Desideri identifica neles perfeições divinas, atribuindo ao objeto, por consequência, a própria Divindade. A relação identitária entre tal objeto de refúgio e Deus, portanto, é feita pelo missionário, sem ser explícita na doutrina da "seita dos lamas".

Depois de ponderar sobre as questões levantadas acima, Desideri encerra seu capítulo com a seguinte conclusão: "Os tibetanos rejeitam tanto a existência da verdadeira divindade quanto a existência de qualquer divindade falsa na forma que são comumente aceitas e reconhecidas pelos outros asiáticos pagãos." 674

Ao terminar assim suas considerações, o missionário não só dá um lugar teológico e histórico aos tibetanos, mas insere-os no contexto asiático. Dessa forma, o jesuíta atribui-lhes um lugar em seu projeto missionário, a partir de uma dupla negação: não são ateus, nem pagãos. Evidentemente, não são cristãos, mas ao negar a idolatria e, principalmente, o ateísmo dos tibetanos, Desideri garante para eles uma possibilidade de salvação. Como formulado por Pomplun:

Reconhecendo que os tibetanos podem ter uma fé implícita na existência de Deus e da providência - mesmo que explicitamente neguem ambos Desideri concede aos tibetanos a possibilidade de uma graça que muitos teólogos negaram. ${ }^{675}$

\footnotetext{
${ }^{672}$ Più ancora dicono ii Thibetani che nessuno è valevole a sbarazzarsi da se stesso, sì dai mali di colpa come da quelli di pena, nè ad arrivar alle virtù e molto meno alla perfezione, ma che ognuno ha in ciò bisogno dell'aiuto di qualche oggetto di refugio e d'invocazione. Che altro è ciò, se non ammettere infatti quella divinità che per altro negano e positivamente escludono? DESIDERI, I. La relazione di Ippolito Desideri, apud: PETECH, L. I missionari italiani nel Tibet e nel Nepal. Libr. dello Stato, vol. VI, DR. 3, p. 208. Tradução nossa.

${ }^{673}$ Cf: DESIDERI, I. Mission to Tibet: the extraordinary eighteenth-century account of father Ippolito Desideri, S.J. Tradução Michael J. Sweet, Edição Leonard Zwilling. Boston: Wisdom Publications, 2010, nota 979, p. 720.

674 "I Thibetani non solamente escludono l'existenza della vera divinità, ma nè pur ammettono alcuna falsa divinità, nel modo che dagli altri gentili dell"Asia vien comunemente ammesa e riconosciuta." Ibidem, p. 210. Tradução nossa.

675 "By recognizing that Tibetans might have an implicit faith in God existence and providence - even as they explicitly denied both - Desideri granted Tibetans the possibility of a grace that many theologians have denied." POMPLUN, T. Jesuit on the Roof of the World: Ippolito Desideri's Mission to Eighteenth-Century Tibet. Nova Iorque: Oxford University Press, 2002, p. 95-96. Tradução nossa.
} 
Os tibetanos, portanto, são muito razoáveis para repetirem as crenças contra a razão que lhes foram transmitidas pelos idólatras da Índia. A elas, preferiram a total e absoluta negação de uma divindade. Mas, evidentemente, mantiveram um pequeno feixe da luz da graça, de que são indício o seu comportamento virtuoso e a sua capacidade intelectual e dialética. A negação da divindade, portanto, é apenas uma expressão verbal e sofista de sua recusa do paganismo indiano. A seita dos lamas, ainda que eles próprios não a reconheçam dessa forma, é um teísmo confuso de argumentação falaciosa. Nas palavras do missionário, os seguidores da seita são, por consequência, uma gente cega. Mas não se trata de uma cegueira absoluta, mas uma espécie de visão turva, pois, fica evidente por meio da existência de seu objeto de refúgio, que os tibetanos possuem alguma noção da existência do Deus verdadeiro.

É com este exercício teológico e retórico que Desideri constrói uma possibilidade de salvação - isto é, de missão - na mesma medida em que desconstrói o ateísmo da gente cega tibetana. 
4.6 A ESCRITA DE DESIDERI, A ELABORAÇÃO DA CATEGORIA GENTE CEGA E SEU PROJETO DE MISSÃO

Neste último capítulo da tese, procuramos, a exemplo já havíamos feito anteriormente, identificar as categorias retóricas elaboradas ou utilizadas para a descrição das sociedades nas quais a Companhia de Jesus estabeleceu missões evangelizadoras. Nosso objetivo é realizar uma análise política, isto é, levar em conta as disputas de poder e os atores políticos envolvidos nas estratégias de conversão. Isso significa que as categorias ou os predicativos aqui destacados e analisados possuem função prática e não apenas teórica ou retórica, na atividade missionária.

Ao longo de seu trabalho de observação e descrição da sociedade tibetana, Desideri afirma que o Tibete possui governo civil e governo eclesiástico. O Tibete, portanto, possui uma cabeça, que é entendida como uma espécie de pontífice, que abre mão parcialmente do governo civil, instituindo um "rei”. Este deve dedicar-se às questões temporais em nome do grande chefe religioso.

Estabelecendo um diálogo entre os relatos do italiano e dos jesuítas que antecederam a missão no Tibete, identificamos principalmente quatro categorias utilizadas de forma contínua e retoricamente estruturada. A primeira delas, encontrada nos textos de Antônio de Andrade, como vimos anteriormente, é a categoria gente pia. Em seguida, um jesuíta contrário às posições de Andrade descreveu os tibetanos como gente rude, ou cristãos de barriga ${ }^{676}$ Por último, destacamos aqui as categorias cunhadas por Desideri. A primeira delas foi uma suposta atribuição de ateísmo, baseada principalmente no entendimento que o jesuíta italiano construiu das seguintes crenças da seita tibetana: metempsicose e reencarnação; a negação de um deus criador não criado; o princípio do Karma (não necessariamente assim denominado pelo religioso), que prescinde de um deus juiz supremo; e a ideia de vacuidade.

No entanto, Desideri abre mão desse predicativo, pois reconhece um objeto de adoração e invocação na seita tibetana. Esse objeto "perfeitamente abençoado e livre de todo

\footnotetext{
676 “[Só na feitiçaria] reconhecem santidade, e tudo o mais em que não entra trejeito ou feitiçaria, não é possível perceberem, pois sua capacidade e natural rudeza os não ajuda a mais, salvo se for proveito de barriga." CARTA do Padre Nuno Coresma ao Provincial de Goa, Tsaparang, 30 de Agosto de 1635. ARSI, Goa 73, fl.97v.
} 
mal, onisciente, onipotente e infinitamente apaixonado", não poderia ser outro se não Deus, pois "em quem essas perfeições são encontradas se não em Deus?"'677

Para entendermos como foi possível que Desideri desenvolvesse essa negação do ateísmo, é necessário, como aponta Pomplun, notarmos a diferença feita entre ateu prático e ateu teórico.

Abandonada a categorização dos tibetanos como ateus, circunscritas todas as suas semelhanças com as gentilidades dos vizinhos e finalmente negada a pregação direta de apóstolos no Tibete durante a antiguidade, Desideri insiste na seguinte categoria: pessoas cegas.

Podemos observar, portanto, que a construção dessa categoria e sua atribuição aos tibetanos foi baseada em três premissas:

A premissa política, ou seja, foi necessária a observação e a análise da organização social e da estrutura do Estado Tibetano para contrapor a ideia de que os tibetanos seriam uma nação "tão bárbara" a ponto de negarem resolutamente a existência de qualquer divindade.

Desideri partiu também, obviamente, de premissas teológicas, as quais se centraram no estudo dos livros da seita tibetana e na eventual participação em disputas com monges budistas. Tais iniciativas possibilitaram que o jesuíta identificasse e refutasse (para o público europeu, mas, principalmente, para o público tibetano, mediante a escrita de obras em idioma local) os "erros" da falsa religião dos lamas.

A terceira premissa que permitiu a elaboração da categoria gente cega é do âmbito da moral. Em um capítulo exclusivamente dedicado a este tema "Do que a religiãod dos tibetanos contém acerca da moral, ou seja, acerca da virtude e do vício, e sobre a regulação dos costumes" ${ }^{678}$ Desideri dedica-se a analisar a moralidade tibetana, isto é, "o que prescreve a lei religiosa para a regulação de sua conduta, que é reconhecida por todas as seitas como o caminho que deve ser seguido para alcançar a salvação." ${ }^{679}$ A normatização e o regramento da conduta socialmente aceitável é objeto de observação e análise de Desideri. Matar, roubar, mentir, desejar o mal dos outros, todos estes pecados são regulados pela seita tibetana. As virtudes prezadas pelo budismo, segundo o próprio entendimento do jesuíta, seriam: fé,

\footnotetext{
${ }^{677}$ DESIDERI, I. La relazione di Ippolito Desideri, apud: PETECH, L. I missionari italiani nel Tibet e nel Nepal. Libr. dello Stato, vol. VI, DR. 3, p. 207.

${ }^{678}$ Ibidem, p. 221.

679 "Dar un succinto regguaglio della morale o sia di ciò che loro prescrive in ordine al regolamento de' costume, che in tutte le sette è riconosciuto per camino da tendersi per giugner alla salute." Ibidem, DR. 3, p. 221. Tradução nossa.
} 
esperança e amor; apenas a humildade não teria sido identificada pelo missionário. A aproximação da moralidade tibetana da cristã é a conclusão das observações de Desideri:

Tendo explicado até aqui os erros principais das falsas crenças dos tibetanos e tendo discutido em um breve resumo a sua moralidade (...) isso pode ser considerado suficiente para satisfazer a tarefa que eu me dei quando propus como o propósito final desta relação contar sobre sua seita e religião. ${ }^{680}$

Este trecho deixa claro os processos identificados por nós acima, isto é, a observação e análise da política, dos princípios teológicos da seita tibetana e da moralidade dos tibetanos, ainda que o missionário subordine o último à teologia e nós optemos por apresentar os dois aspectos de forma independente, ainda que relacionadas.

Para finalizar, gostaríamos de ressaltar mais dois aspectos principais:

O primeiro: Desideri promoveu um diálogo interno e externo na elaboração de suas obras. Do ponto de vista externo, o missionário dedica-se ao estudo do idioma local para poder compreender e refutar os principais erros da seita tibetana, travando assim um debate "literário" entre o cristianismo e o budismo tibetano. Interno porque Desideri demonstra que coletou informações sobre o Tibete para além de sua própria experiência. Ele leu os relatos de Andrade e faz inúmeras menções a Kircher, indicando sua tentativa de por em questão o saber da própria Ordem sobre a terra e a seita dos lamas. Mas o italiano não se contenta com o que poderia ser um debate de opiniões. Ele baseia-se teoricamente, não só em sua própria experiência, para refutar a suposta experiência dos companheiros da Companhia de Jesus. Desideri ampara-se no Tomismo e, assim, estabelece um terceiro diálogo entre o corpo doutrinário cristão e a prática missionária.

O segundo aspecto é que o exercício do religioso não se encerra no caráter intelectual de sua atividade. Desideri não se satisfaz apenas produzindo um texto em italiano que sirva

\footnotetext{
680 'Avendo fin'ora parlato di ciò che la legge de' Thibetani insegna loro in ordine alla crenza e in ordine all'ultimo fine d'un'eterna beatitudine da sperarsi da' medesime non posso qui dispensarmi di dar un succinto regguaglio della morale o sia di ciò che loro prescrive in ordine al regolamento de' costume, che in tutte le sette è riconosciuto per camino da tendersi per giugner alla salute. DESIDERI, I. La relazione di Ippolito Desideri, apud: PETECH, L. I missionari italiani nel Tibet e nel Nepal. Libr. dello Stato, DR. 3, p. 221. "Having explained up to here principal errors of the false beliefs of the tibetans, and having discussed in a brief summary their morality (...) this might be considered sufficient to satisfy the task I set myself above when I proposed as the final point of this relation to render an account of their sect and religion." DESIDERI, I. Mission to Tibet: the extraordinary eighteenth-century account of father Ippolito Desideri, S.J. Tradução Michael J. Sweet, Edição Leonard Zwilling. Boston: Wisdom Publications, 2010., p. 722, nota 1014. Tradução nossa. O extrato em inglês acima foi retirado do manuscrito "F", não pertencendo ao corpo central da publicação da fonte na edição de Sweet e Zwilling, nem na coletânea de Petech. Neste caso, traduzimos e mantivemos a citação a partir da edição em inglês. Para maiores informações sobre os manuscritos utilizados na publicação, verificar a introdução da publicação, especialmente as páginas do intervalo 62-80. Outra referência importante sobre os manuscritos é Bargiacchi: BARGIACCHI, E.G. Ippolito Desideri S.J - Opere e Bibliografia. Roma: Institutum Historicum, 2007.
} 
para o público europeu aprender sobre o Tibete. A finalidade desse trabalho intelectual é a missão. A elaboração do texto e o refinamento da palavra escrita servem à prática missionária: iniciam e terminam no campo missionário. 


\section{CONSIDERAÇÕES FINAIS}

Sem examinar o Orientalismo como um discurso, não se pode compreender a disciplina extremamente sistemática por meio da qual a cultura européia foi capaz de manejar - e até produzir - o Oriente política, sociológica, militar, ideológica, científica e imaginativamente durante o período do pósiluminismo. ${ }^{681}$

Edward Said, já na introdução de sua obra "Orientalismo", indica as necessárias implicações entre "discurso" e "prática". Mesmo atentando para as diferenças entre o caso aqui estudado e o objeto de estudo de Said, e cientes das críticas que a historiografia contemporânea já teceu ao autor, ${ }^{682}$ é válida a reflexão sobre as idéias deste estudioso no contexto aqui analisado: analogamente ao que pretendemos apresentar, dadas as diferentes conjunturas, Said traça uma relação entre os discursos acerca do Oriente e o projeto colonial europeu da época contemporânea, tal como supomos uma relação entre o projeto evangelizador e proselitista da Companhia de Jesus e a produção, circulação e publicação de relatos de missionários no "Oriente":

As idéias, as culturas e as histórias não podem ser seriamente compreendidas ou estudadas sem que sua força ou, mais precisamente, suas configurações de poder, também sejam estudadas. Seria incorreto acreditar que o Oriente foi criado - ou como digo "orientalizado" - e acreditar que tais coisas acontecem simplesmente como uma necessidade da imaginação. A relação entre o Ocidente e o Oriente é uma relação de poder, de dominação, de graus variáveis de uma hegemonia complexa. ${ }^{683}$

Para além da dicotomia "Oriente" versus "Ocidente" ao longo dessa tese, pudemos perceber, nas missões aqui estudadas, que a atuação de forte caráter político dos missionários, associada a sua nada ingênua disciplina retórica, caminharam lado a lado. As cartas e demais escritos aqui analisados - enquanto "espaço de tensão, negociação [...] e principalmente de ação" ${ }^{684}$, de papel central no planejamento e atualização da atividade da Companhia de Jesus - ressignificaram e reengendraram discrursivamente novas configurações de poder, Assim, é pertinente afirmar que as categorias elaboradas pelos jesuítas tiveram papel semelhante aos

${ }^{681}$ SAID, E. Orientalismo: o como invenção do Ocidente. São Paulo: Companhia das Letras, 2007, p. 29-30.

${ }^{682}$ If Edward Said's Orientalism has unmmasked the complicity of scientific representation with the workings of Power and politics of location, it has also, by omission, reinforced that Jesuit and Catholic Orientalist texts from early modern period were simply insignificant." ZUPANOV, I. Jesuit Orientalism; Correspondence between Tomas Pereira and Fernão de Queiros. In: BARRETO, L. (Ed.) Tomás Pereira, S. J. (1646-1708), Life, Work and World. Lisboa: Centro Cultural e Cientifico de Macau: 2010, p. 44.

${ }^{683}$ SAID, E. op. cit., p. 32.

${ }^{684}$ LONDOÑO, F.T. Escrevendo Cartas. Jesuítas, escrita e missão no século XVI. Revista Brasileira de História. São Paulo, vol.22, n. 43, 2002. 
conceitos antitéticos assimétricos definidos por Koselleck: ${ }^{685}$ eram politicamente eficazes, tinham pretensões universais, buscavam redefinir as fronteiras entre os evangelizadores e seus possíveis catecúmenos, pretendiam antecipar a estratégia de conversão mais prudente e funcionaram como articulação linguística de estruturas mentais que reorganizariam de forma incessante a arquitetura geopolítica jesuíta.

Evidentemente, este caráter intelectual e pragmático remonta ao próprio surgimento da Ordem. Desde sua fundação, em Paris, em meados do século XVI, a Companhia de Jesus foi se configurando com um duplo papel: o missionário, como fica claramente esmiuçado nos capítulos anteriores, e o pedagógico. Fundada por Loyola com objetivo de evangelizar a Terra Santa - isto é, pregar entre infiéis - a Sociedade consolida-se também como uma importante força transformadora do ambiente educacional e intelectual da Europa reformada. Tal associação entre o saber e o pragmatismo evangelizador, como amplamente reiterado pela historiografia, seria marca da Companhia de Jesus. ${ }^{666}$ Isso nos remete às ideias expostas por O’Malley em seu livro “Os primeiros Jesuítas”, no qual ele afirma que

Quando Nadal descreveu em termos gerais 'nossa forma de proceder', ele a reduziu à tríade de atuação 'em Espírito, do coração', na prática - 'spiritu, corde, practice.' Esse foi uma de suas sínteses mais informativas sobre o ideal da vida jesuíta. Agir 'em Espírito' significava encaminhar todos a Deus e a graça divina. Agir 'do coração' significava ter os sentimentos para suportar tudo que era feito, e nunca agir apenas de forma especulativa - 'Ut speculative tantum ne agamus.' Agir 'praticamente' significava que uma afetividade jesuíta não era contemplativa', mas direcionada ao auxílio de outros. Em resumo, agir 'praticamente' significava agir pastoralmente. ${ }^{687}$

Agir de forma prática ou pragmática significaria agir de forma evangelizadora. Assim, a ação especulativa era de suma importância, mas não tinha fim em si mesma: estava, necessariamente, a serviço da missão. Da mesma forma, a atividade retórica - de descrição narrativa, disciplina epistolar, elaboração discursiva, participação em fóruns de dabates e disputas, e produção de textos apologéticos e catecismos - encontra-se necessariamente

685 KOSELLECK, R. Futuro passado: contribuição à semântica dos tempos históricos. Rio de Janeiro, Contraponto / PUC-RJ, 2006, p. 208.

686 "The original members were all university trained, which not only Ient the group considerable prestigie, but set a pattern of cultural and intelectual excelence." O'MALLEY, J.W. The first jesuits. Harvard University Press, 1993, p. 225.

687، When Nadal described in general terms 'our way of proceeding,' he reduced it to the triad of acting 'in the Spirit, from the heart, practically' - 'spiritu, corde, practice.' This was one of his most telling summaries of the ideal of the Jesuit life. To act 'in the Spirit' meant to refer all to God and divine grace. To act 'from the heart' meant to bring the feelings to bear on whatever was being done, and never to act only speculatively- 'Ut speculative tantum ne agamus.' To act 'practically' meant that a Jesuit's affectivity was not like that of a 'contemplative,' but was directed to helping others. In a word, to act 'practically' meant to act pastorally." Ibidem, p. 251. Tradução nossa. 
associada a uma prudente observação e atuação política, guardadas as devidas particuridades literárias dos "gêneros" enumerados acima.

Destarte, as categorias elaboradas pelos jesuítas foram produto de relação dialógica, típica da identidade de Ordem de Loyola, estabelecida entre a formação intelectual e a experiência missionária. Complementares às chamadas estratégias de conversão, estes conceitos-chave elaborados no contexto do ministério da palavra, podem ser também denominados de estratégias epistemológicas ou representacionais. ${ }^{68}$

De maneira semelhante, procuramos demonstrar, ao longo desta tese, como as (supostas) falas atribuídas aos soberanos, a mulás e lamas, ganham valores análogos a expressões usadas para descrever sociedades e comunidades com as quais os missionários travaram contato. Tais expressões ou categorias - elaboradas a partir das observações e descrições que os missionários realizaram sobre os povos encontrados, sua cultura, sua organização social e política, e, evidentemente, suas "seitas" - foram fundamentais para a escolha e o emprego da estratégia de conversão mais prudente e eficaz para cada caso e para cada momento.

Ao mesmo tempo, em função da disciplina epistolar e relevante produção escrita dos integrantes da Ordem em missão, a experiência nos "confins" do mundo retornavam aos centros de saber europeu, realimentando esta reordenação epistemológica, simbólica e histórica do período moderno. Isso significa dizer que as ideias teológicas e políticas em debate na Europa, bem como valores herdados do aristotelismo atualizados nos colégios jesuítas, passavam ao campo missionário, submetidos à lógica evangelizadora e contingenciados pela realidade política e social encontrada. Uma vez lá, passaram muitas vezes a instrumentos para se fazer ouvir, serindo ao propósito da conversão mediante persuasão e convencimento:

A descoberta do Novo Mundo, o fracionamento da cristandade, as clivagens sociais que acompanham o nascimento de uma política e de uma razão novas engendram um outro funcionamento da escrita e da palavra. Presa na órbita da sociedade moderna, sua diferenciação adquire uma pertinência epistemológica e social que não tinha antes; em particular torna-se o instrumento de um duplo trabalho que se refere, por um lado à relação com o homem "selvagem", por outro à relação com a tradição religiosa. Serve para classificar problemas que o sol nascente do "Novo Mundo" e o crepúsculo da cristandade "medieval" abrem à intelligentsia. ${ }^{689}$

${ }^{688}$ Cf: ZUPANOV, I. Jesuit Orientalism; Correspondence between Tomas Pereira and Fernão de Queiros”, In: BARreto, L. (Ed.) Tomás Pereira, S. J. (1646-1708), Life, Work and World, Lisboa: Centro Cultural e Cientifico de Macau, 2010, p. 43-74.

${ }^{689}$ CERTAU, M. A escrita da História. Rio de Janeiro: Forense Universitária, 2002. p. 213. Itálico: rifos do 
Para o estudo desse "duplo trabalho" e compreensão da função da escrita e da palavra nas fontes aqui analisadas, alguns conceitos foram indispensáveis, tais como aggiornamento e noster modus procedenti. ${ }^{690}$ Com o auxílio conceitual de Eisenberg, essa atualização do tomismo foi por nós abordada também a partir de ideias políticas em desenvolvimento dentro da própria Ordem, durante esse momento de gêneses do pensamento político moderno. Os escritos políticos de Francisco Suárez, suas proposições sobre lei e definições políticas elementares presentes em sua obra foram basilares na condução de nossas análises.

Ao lado de Suárez, outro jesuíta do século XVI difundiu ideias fundamentais para o nosso trabalho. O missionário atuante no Novo Mundo José de Acosta além de categorizar os povos seguindo critérios como hábitos, costumes, leis e uso da escrita, associou tais categorias a estratégias de conversão. Este exercício dialético de observação (dos costumes) e adequação (das estratégias) exposto por Acosta e implícito muitas vezes nas fontes aqui abordadas tornou-se indispensável em nossa argumentação.

Não obstante, a gradação do uso da reta razão em comunidades humanas e suas manifestações no campo político - sistema estável de governo, leis públicas, cidades fortificadas etc - foram atestados mediante atenta observação dos padres. Em seguida, transformam-se em uma espécie de índices que, trabalhado pela retórica jesuíta, fazem surgir na escrita missionária significantes aos quais são atribuídos significados simultaneamente religiosos e políticos.

A reta razão, a lei natural e especialmente o conceito de entendimento, são, pois, fundamentais tanto para a argumentação política quanto para a argumentação teológicofilosófica dos missionários. O entendimento - comunicado por Deus à criatura, e que permite a um ser espiritual conhecer o universal ou imaterial - possibilita que, em certa medida, conheçamos Deus, sendo, portanto, de sobremaneira considerado e exercitado nas disputas aqui analisadas. Não obstante, o entendimento também é concebido como aquilo que permite que o homem exerça domínio e governo sobre os animais e sobre outros homens: o homem é senhor de outros homens na medida em que os excede em entendimento.

Em conjunto, conceitos gerados dentro das próprias sociedades com os quais os jesuítas "compartilharam" embates dialógicos também foram basilares para a elaboração e desenvolvimento de nossas hipóteses. O chamado wahdat al wujud e o problema da unidade

\footnotetext{
autor. Negrito: grifo nosso.

${ }^{690}$ Cf: EISENBERG, J. As missões jesuíticas e o pensamento político moderno. Belo Horizonte: UFMG, 2000.
} 
de Deus transcenderam os limites das discussões metafísicas e religiosas. Podendo exprimir tanto ideias místicas sufis quanto um projeto político de integração e construção discursiva da soberania política, (associado ao chamado sulk-i-kul ou paz com todos) esse conceito revelouse uma espécie de ponte simbólica, e viabilizou a permanência e atuação dos padres no Indostão. Tais questões, à época em voga na corte de Akbar, uma vez apropriadas pelos jesuítas, também se transformaram em instrumentos para se fazer ouvir, na medida em que os religiosos europeus se mostraram capazes de manipular e expor conteúdos de teologia e filosofia em busca do convencimento de seus interlocutores. A metafísica, como a política e a teologia, serviram como instrumento retórico para que o missionário se qualificasse, do ponto de vista do "outro", como interlocutor, ou mesmo como um preceptor espiritual. Foram, portanto, meios para a implementação do projeto catequético. Ao trazerem para o debate sua "atualização" tomista, garantiram espaço para o cristianismo nos fóruns multilinguísticos e de debate inter-religioso promovidos por Akbar.

Neste contexto, a acomodação típica da atuação jesuíta na Ásia residiu, para o caso da missão no norte da Índia, naquilo que chamamos de transposição de finalidade ou usus iustus. Como exposto por Maijastina Khalos: "uma das soluções que os pais da Igreja ofereceram foi o "uso correto". (...) No uso correto, o que era crucial não seria quais textos seriam lidos (...), mas sim como a literatura seria lida." Por isso, propomos em nosso primeiro capítulo, que os religiosos se apropriaram de duas instituições centrais do projeto político de Akbar ('Ibādatkhānah e Maktabkhana) e modificaram-nas, isto é, transpuseram suas finalidades.

Foi a partir dessas premissas que dirigimos nosso olhar à corresponência dos religiosos e seus demais escritos, na corte mogol e na terra dos lamas. No final do século XVI, Antônio Montserrat termina seu Mongolicae Legationis Commentarius, uma narrativa sobre a presença dos padres jesuítas no Mogol. "Rei muito bem inclinado, e amigo das coisas de Deus"691, Akbar, a princípio, mostrava-se muito próximo dos padres e simpático ao cristianismo. Essa proximidade, defendemos, foi ilustrada a partir da suposta "transcrição" de falas do soberano em meio às disputas travadas com os mulás. Os dizeres do imperador serviram como predicatos, reiterando a ideia de que se tratava de um governante justo, prudente, um homem de razão.

À descrição de Akbar, linguisticamente apresentada pela adjetivação, foi associada a (supostas) opiniões manifestadas por ele oralmente, transformando-o em um poderoso soberano na eminência de converter-se, onde os jesuítas consideravam o coração da Ásia.

${ }^{691}$ CÓPIA de uma [carta] da Índia para a província de Portugal do ano de [15]79. Arquivo Nacional da Torre do Tombo, (ANTT, Lisboa, Portugal), Armário Jesuítico, n. 28, f. 91-2 
Para tanto, foi necessário observar, descrever, estudar e retrar o imperador de forma adequada, atribuindo e imputando-lhe falas prudentes e razoaveis. Os diálogos, pois, revelam-se simultaneamente como uma estratégia de conversão e como uma forma de ratificar, exemplificar e confirmar a descrição de Akbar como um soberano amigo da razão, prudente, amável com os padres: uma espécie de Constantino, um verdadeiro aliado da cristandade na Índia. No entanto, tal promessa se revelou mais um desejo dos missionários do que uma vontade real do imperador.

O passo seguinte ao Commentarius, em termos de estratégias de conversão que se baseavam no uso da palavra escrita, foi a elaboração de obras em persa com o objetivo de explicar o cristianismo e refutar os erros do islamismo. Passou-se dos diálogos não ficcionais narrados aos diálogos ficcionais, ou seja, o diálogo passa a surgir como recurso da operação de escrita. Isso é observado no tratado apologético dirigido a Akbar, chamado Fonte de Vida. Jerônimo Xavier adaptou-se ao processo de tradução para o persa de obras sagradas tomando parte em uma instituição atrelada ao projeto político de Akbar, chamada de Maktabkhana. Fonte de Vida foi, desta forma, um refinamento das estratégias anteriores, pois os debates não aparecem descritos em referência direta às audiências promovidas por Akbar, mas apresentam-se estritamente como um gênero literário a serviço dos objetivos principais dos missionários: a evangelização e a conversão.

Um terceiro movimento estratégico de grande importância, mas que, infelizmente não pode ser contemplado nesta tese, foi a elaboração, também por Xavier, de Mir'at Al-quds (Espelho da Santidada). Trata-se de uma obra dedicada à apresentação da vida de Cristo, encomendada pelo próprio Akbar. Pedro Moura Carvalho, em sua recentemente publição de Mir'at Al-quds, ${ }^{692}$ indica o uso de fórmulas muçulmanas na introdução do texto, de forma semelhante ao que procuramos demonstrar em nosso trabalho. $\mathrm{O}$ autor também debate a possibilidade do missionário ter recorrido à Suma Teológica durante a elaboração de seu texto. No entanto, nesta fontes especificamente, observamos que o missionário recorre à imagens para captar a atenção e cativar seu leitor, mormente o próprio soberano. Um desenvolvimento natural de nossa pesquisa seria, num momento futuro, darmos continuidade à nossa investigação a partir dessa fonte.

692 CARVALHO, P.M. Mir'at al-quds (Mirror of Holiness): A Life of Christ for Emperor Akbar: A Commentary on Father Jerome Xavier's Text and the Miniatures of Cleveland Museum of Art, Acc. No. 2005, Tradução e transcrição Wheeler M. Thakson. Brill: Lieden, Boston, 2012, p.145. 
Finalmente, quanto à missão jesuíta no Indostão, defendemos que se associaram - em meio à negociação social, política e estética da consolidação da soberania de Akbar - a retórica jesuíta e a atuação política de ambas as partes: do soberano muçulmano e dos padres cristãos. Foi relevante a importância dada ao uso eficaz da linguagem falada e escrita, com o objetivo de influenciar e persuadir, ressaltando que essa eficiência é consequência de uma prática, de uma habilidade adquirida por meio de formação intelectual prévia, exercício e treinamento.

No entanto, apesar dos esforços dos missionários, nem Akbar nem seu filho Jahagir se converteram. Então, com o passar do tempo, percebemos que Fatehpur se revelou um laboratório, no qual o modelo de conversão essencialmente dialógico foi aplicado e testado, no que, propomos, pode ser entendido como uma tentativa simétrica ao que a Companhia estava exercitando no extremo-oriente, especialmente na China e no Japão.

Além disso, observamos que a missão no Mogol ganhou, progressivamente, outras funções na geopolítica da Companhia de Jesus, tornando-se uma espécie de porta para todo o continente. Ela passa a não ter apenas um fim em si mesma, sendo entendida como uma etapa de um caminho que se abre para a Ásia Central. Não é mais tão restritivo o apoio nas "bordas" do continente: a Ordem pode (e deve) interiorizar sua presença missionária na Ásia.

Suscedeu-se, então, a partida de religiosos da Companhia de Jesus em busca da suposta comunidade cristã das montanhas, da qual fundou-se a missão de Tsaparang. Travava-se assim a primeiro contato entre a Europa moderna e o Tibete, entre o cristianismo e a "seita dos lamas". Neste contexto, procuramos sustentar que as missões da Ordem no Tibete se constituíram enquanto uma experimentação da proposta geopolítica de Rodolfo Acquaviva, revelando-se também como um local de teorização e aplicação do método dialógico como estratégia de conversão.

Em nosso modelo de análise, no qual dividimos a missão em Gugê em três fases, ressaltamos que, inicialmente, é estabelecida uma relação identitária o Tibete e o Cataio. Além disso, indicamos que a descrição da potência dos tibetanos quanto à sua capacidade de reconhecer, receber e conservar a santa fé, e a justificativa de investimento na missão, é sustentada especialmente por Antônio de Andrade.

Com a sua instalação propriamente dita da missão (1626 - segunda fase), observamos a negociação e busca pela garantia de sustento temporal para a empreitada missionária, além da reiteração da justificativa de investimento na missão mediante descrições positivas. 
Observa-se também o início da implementação das estratégias de conversão. Silencia-se, no entanto, a identificação Tibete/Cataio.

A terceira e última fase aqui proposta caracteriza-se pela decadência da missão, seguida de um de debate epistolar, no qual dois jesuítas - Nuno Coresma e Antônio Mendes tomam posições opostas. Não obstante, como observamos, fatos externos à missão contribuem para o seu declínio: o rei de Gugê é feito cativo em Leh, e seu principal "protetor" junto à Companhia de Jesus é envenenado dentro do refeitório do Colégio de São Paulo, em Goa.

Enquanto ativo na missão, Antônio de Andrade observou o cenário político e as tensões entre os poderes espirituais e temporais no reino de Gugê. O missionário, então, reverteu essa observação em uma espécie de propaganda, retratando o Tibete como um local propício para a missionação. Em seguida, o jesuíta se engaja em debates com os lamas na presença do soberano, com o claro objetivo de desqualificar os sacerdotes budistas. Como já antecipado por Tomás de Aquino, não seria necessário que Andrade provasse a sua fé, apenas que, de forma eficaz, fosse capaz de apontar na doutrina da seita dos lamas tudo aquilo que ia contra a razão.

Proposmos, desta forma, que a estratégia dialógica de conversão, associada ao seu projeto de expandir da missão mogol rumo ao Tibete Ocidental, encontrou sua materialidade retórica na expressão "gente pia", categoria elaborada pelo missionário para descrever os tibetanos. Essa categoria é fundamental para levar ao seu leitor uma ideia descritiva da sociedade tibetana, mas também é pedra basilar para a escolha da estratégia dialógica como método prudente de catequese. Ao lançarem mão de categorias como "gente branca", "gente pia" e outras expressões semelhantes, os jesuítas já apontam para uma estratégia de conversão baseada no convencimento em detrimento da força física ou da coerção. As disputas serviriam simultaneamente a dois propósitos: convencer o rei e enfraquecer os lamas, não apenas no aspecto teológico, mas também na esfera política.

No entanto, para que Andrade pudesse participar ou conduzir debates, foi necessário que ele adaptasse ou acomodasse um costume tradicional associado a disceminação do budismo: o apoio que era esperado de um rei, ou nobre, em relação a um mosteiro, ordem religiosa budista ou lama. Andrade passou-se por lama - no sentido de preceptor espiritual ganhando assim autoridade para pregar. Fazendo parte de uma comunidade religiosa que 
possui um superior (padre grande), observando o celibato e mantendo distância de questões temporais, o missionário se assemelha a um religioso budista. ${ }^{693}$

No entanto, toda a ponte retórica erigida por Andrade rui frente as descrições presentes nas missivas de seu companheiro de Ordem, Nuno Coresma, Em suas cartas, a missão é condenada com o surgimento de uma "nova" descrição dos tibetanos. Porém, a importância do relato de Coresma não é apenas a de dar conta da história da missão após Andrade, nem apenas de indicar quão deslocada da realidade poderiam estar as notícias dadas por ele. O que nos salta aos olhos, principalmente, é a relação entre a descrição geopolítica e da natureza dos tibetanos associada à estratégia que deveria ser adotada.

Percebemos, então, um descompasso com o projeto de Rodolfo Acquaviva e com as expectativas de Andrade. Como o régulo local não é favorável ao cristianismo, segundo Coresma, faz-se necessária a força do Estado Português. O convencimento ou a persuasão, enquanto estratégia, dão lugar a força. Sem o apoio local, sem o braço secular cristão no Tibete, não há esperança de converter os tibetanos, nem manter na fé os "cristãos de barriga". Afinal, desde desde os tempos de Francisco Xavier, como bem pontuado por Ricardo Ventura, a missão já se sustentava a partir de três pontos: o esforço em estudar os idiomas de seus possíveis catecúmenos, suas formas de religiosidade e costume; o estabelecimento de uma "rede de contatos entre padres jesuítas"; e o estabelecimento das missões "sobre uma base política e diplomática o mais sólida possível, que garantisse a autonomia das missões e, em simultâneo, uma representação política e econômica do Estado da Índia.",694

A elaboração de Coresma - sintetizada na categoria "cristão de barriga" - enterra a missão do Tibete. Mas, longe de ser consensual, ela é rebatida por Antônio Mendes, que intenta defender a missão e criticar a decisão de retorno dos padres do Tibete. Sobre as ruinas da missão entre os "cristãso de barriga", Mendes edifica uma missão entre gente branca e benevolente. ${ }^{65}$ Sua argumentação parte das razões gerais pra se interromper qualquer missão para demonstrar que a missão tibetana não apresentava nenhuma dessas razões ou motivos que justificasse sua descontinuidade. Por isso, propomos que a importância de sua carta não

\footnotetext{
${ }^{693}$ Erik Zürcher, ao debater o budismo e o cristianismo na China, define os monges como um "grupo puramente parasitário do ponto de vista econômico". Assim, ele aborda a questão que aqui nomeamos como patronagem do ponto de vista do contexto chinês, e explica em que medida este processo foi determinante para a disseminação do Budismo na China. No entanto, ao contrário desse autor, em nossa tese procuramos demonstrar justamente como os jesuítas se utilizaram desta relação, enquanto Zucker está preocupado em apontar porque o cristianismo, apresentado pelos missionários da Ordem de Loyola, não tiveram muito sucesso em espalhar a Santa Lei no Império do Meio. ZÜRCHER, E. Bouddhisme, Christianisme et société chinoise. Paris: Gallimard, 1990.

${ }^{694}$ VENTURA, R. O Budismo nas fontes do Padroado Português do Oriente (séculos XVI e XVII) - um roteiro documental. In: BORGES, P.; BRAGA, D. (Comp.) In: O Buda e o Budismo no Ocidente e na Cultura Portuguesa. Lisboa: Ésquilo Edições e Multimédia, 2007, p. 137.

${ }^{695}$ CARTA de Antônio Mendes, ARSI, Goa 73, fl: 102r.
} 
se encerra apenas em sua potencialidade informativa referente às questões particulares de Gugê: Mendes também expõe a construção de um ideal de missão da Companhia de Jesus no século XVII. No entanto, os argumentos de Mendes não parecem ter sido suficientes para sustentarem a missão que se extingue entre os anos de 1635 e 1640.

Porém, a Ordem foi insistente e, no século seguinte, enviou para o teto do mundo um missionario italiano chamado Ippolito Desideri, para quem os maiores obstáculos não seriam as instabilidades políticas, a dificuldade da língua ou o frio das "serras". Esse jesuíta foi, na verdade, uma espécie de vítima das disputas que ocorriam dentro da própria Igreja Católica: os capuchinhos receberam permissão da Propaganda Fide e aprovação do Papa Clemente XI, em 1703, para atuarem na região tibetana, em detrimento da participação jesuíta. ${ }^{69}$ Nesse mesmo ano, a Companhia de Jesus foi condenada por permitir que os chineses e indianos convertidos em suas missões mantivessem alguns de seus ritos e costumes. O episódio ficou conhecido como "Querela dos Ritos" e é um dos fatos centrais desse período considerado de declínio para a Ordem fundada por Loyola.

No entanto, em 1712, o Geral da Companhia de Jesus, Michelangelo Tamburini (1648-1730) envia o italiano Ippolito Desideri ao Tibete. Tamburini havia sido investido como Geral 12 anos antes e foi um personagem fundamental no cenário de disputas entre ordens religiosas ao longo de sua vida. Curiosamente, o próprio Papa Clemente XI - o mesmo que garantira o "monopólio" capuchinho sobre o Tibete - abençoa a viagem de Desideri em uma audiência pouco antes de sua partida.

Apesar de ser uma espécie de herdeiro de Andrade, podemos indicar pelo menos duas distinções entre eles: um era português, o outro, italiano. Isso poderia indicar uma inclinação maior do primeiro, evidentemete, em associar a missão aos interesses portugueses na Ásia. Além disso, ao contrário de seu predescessor, Desideri estava imerso em um contexto de antipatia em relação à Ordem fundada por Loyola. Para ele, defender uma missão e defender um modelo de missão era o mesmo que tomar partido em uma disputa global, filiando-se a um projeto específico e rejeitando outro.

Foi isso que procuramos defender ao indicarmos o propósito triplo do italiano: descrever e atribuir um lugar -histórico, político e religioso - aos tibetanos; propor um modelo de atuação para missionários que vão para as Índias; e, por último, defender a

\footnotetext{
${ }^{696}$ A expulsão dos jesuítas do Tibete, além de ser um problema para a missão e para a Ordem em si mesmo, representa ainda uma admoestação, uma reprovação institucional do método de adaptação conduzido pelos missionários da Companhia.
} 
Companhia de Jesus e sua forma de atuar. Assim, ressaltamos que o exercício do religioso não se encerra no caráter intelectual de sua atividade. Desideri não se satisfaz apenas produzindo um texto em italiano que sirva para o público europeu aprender sobre o Tibete. A finalidade desse trabalho intelectual é a missão. A elaboração do texto e o refinamento da palavra escrita servem à prática missionária: iniciam e terminam no campo missionário. Tanto que, mesmo expulso da missão, Desideri não desiste de seu projeto de um modelo missionário a ser aplicado à "gente cega" das Índias Orientais. Em alguns dos capítulos finais de sua Notícia Histórica do Tibete, e em uma espécie de manual destinado aos padres que fossem enviados para as Índias, o italiano faz um esboço do que nós entendemos como uma tentativa de normatização do projeto da Companhia de Jesus para a Ásia. Supomos que esse texto seja fruto de uma experiência de quase um século e meio (1580-1720) de atuação na região, período no qual os religiosos documentaram e compartilharam sua experiência através da disciplina epistolar e, de certa forma, da atividade literária.

Podemos notar, no capítulo XVII do último livro da Notícia, chamado "Sentimento do autor sobre a doutrina que se requer do missionário das Índias e primeiramente quão grande ela deve ser" ${ }^{\prime 697}$, que Desideri se dedica a abordar dois importantes temas: indicar qual o conhecimento da doutrina que um missionário precisa ter para atuar de forma eficaz nas Índias Orientais; e mostrar ao leitor que promover as missões entre infiéis é obrigação de todo cristão $^{698}$. Dediquemo-nos à primeira questão.

O conhecimento da doutrina que um missionário deve ter, segundo o italiano, não deve ser comum ou medíocre, mas amplo e sublime. Para demonstrar esse ponto, o jesuíta inicia sua argumentação retomando o exemplo do próprio Cristo: nos apóstolos, Jesus teria incutido prudência, zelo, coragem e vigor. ${ }^{699}$ Aquele que fosse instruir os infiéis e converter o mundo deveria seguir o modelo de Cristo:

Queria o Divino Maestro fazer entender que, quem quer que fosse instruir e converter o mundo deveria ser dotado de uma não ordinária nem medíocre,

\footnotetext{
697 'Sentimente dell'autore intorno alla dottrina che si richiede ne' missionarij dell'Indie e primeramente quanto grande Ella debba essere.” DESIDERI, I. La relazione di Ippolito Desideri, In: PETECH, L. I Missionari italiani nel Tibet e nel Nepal. Roma: Libreria dello Stato, 1952-1956, vol. VII, p. VI. Tradução nossa.

698 'Il primo [punto] è il far conoscere quanto gran dottrina si richieda ne' missionarjdell'Indie, qual in particolare debba questa essere, e in qual modo possa promoversi ne' missionarj che per l'Indie si destinato. Il $2^{\text {a }}$ (sic) sarà il mostrar la grave e strettissima obbligazione che a ogni cristiano indispensabilmente corre d'aiutar e promover le missioni da farsi tra gl'infedeli e in qual modo possa da ciascuno nel próprio suo stato adempirsi uma tal'obbligazione." Ibidem, vol VII, DR. 4, p. 107.

699 "E per cominciar dalla dottrina, non ordinária ma ampia e sublime, che negli operaij evangelici destinati alle missioni tra gl'infedeli si richiede avendo N. S. Giesú Cristo scelti i dodici apostoli per addestrarli ala conversion del mondo, andò loro instilando tutte quelle virtù e prerogative che per si grand'opera si richiendo. Ora recomando loro la prudenza, (...) tal ora insinuò loro uno zelo che a tutte le creature e a tutto il mondo si stendesse.” Ibidem, vol VII ,DR 4, p. 107-8.
} 
mas muito profunda, doutrina e muito sublime sabedoria. Na verdade, se consideramos, na prática, um ministério tão apostólico e divino, o vemos sempre exercitado ora por meio de uma maravilhosa instrução da mais recôndita verdade e ora por meio de sutilíssima disputa, de aguda dissertação, de vivíssima persuasão e de vigorosa e eficacíssima refutação, no combate dos erros e derrota dos enganos. Olhemos para a maneira [de viver] observada pelo Salvador do mundo, norma e espelho de todos os pregadores apostólicos e dos operários evangélicos. ${ }^{700}$

Este talvez seja um dos extratos do texto que, de forma mais sucinta, apresenta as ideias de Desideri sobre a atividade missionária. Para nós, essa é a síntese de um projeto de missão para o contexto asiático, fruto da experiência compartilhada pelos jesuítas no século e meio de presença no subcontinente indiano e no Tibete. Possivelmente, também poderíamos incluir a experiência da Ordem nas missões na China e no Japão, que acreditamos terem contribuído para o modelo dialógico e "disputativo" proposto por Desideri. Porém, não temos, no âmbito desta tese, análise documental que nos permita, de forma legítima, sustentar a hipótese que englobaria as missões do norte da Índia ao Japão.

Retornando ao extrato, julgamos que os seguintes elementos compõem a síntese do modelo de missão delineado pelo italiano: primeiro, o perfil do missionário deve ser, necessariamente, o de alguém que possui pleno domínio da doutrina católica, além de possuir sabedoria; segundo, o missionário deve estar constantemente engajado em disputas, debates, argumentações e refutações, que devem ser os meios através dos quais se deve buscar a demonstração da verdade, a refutação dos erros da seita do outro, a persuasão e a conversão. Enfatizamos ainda o período "per mezzo di sottilissime dispute", pois acreditamos que ele condensa duas ideias fundamentais que procuramos desenvolver ao longo desta tese: a importância da disputa, evidentemente; e o entendimento de "meio" ou de instrumento. Isto é, a disputa como instrumento. Ela não é um fim em si. Os debates, como vimos, têm uma dupla finalidade: apontar os erros do interlocutor e, mediante persuasão e convencimento, converter o outro.

Isso significa dizer que o assunto do debate pode ser um ponto teológico, sem precisar ser necessariamente um artigo de fé. A disputa, como meio ou instrumento, serve para

700 "Volesse il Divin Maestro darci a intendere che chiunque ha da instruir e convertir il mondo fa di mestiere che sia adornato d'una non ordinária, non mediocri, ma molto profonda dottrina e molto sublime sapienza. Infatti, se in pratica ben si consideri un sì apostólico e divin ministerio, lo vedremo sempre esercitato ora per mezzo di maravigliosissime instruzioni de le più recondite verità e ora per vigomezzo di sottilissime dispute, d'acute dissertazioni, di vivissime persuasioni e di nervose efficacissime confutazioni de' combattuti errori e de' conquisi inganni. Diasi un'occhiata alla maniera osservata dal Salvator del mondo, norma e specchio di tutti gli apostolici predicatori e de gli evangelici operari." PETECH, L. I Missionari italiani nel Tibet e nel Nepal. Roma: Libreria dello Stato, 1952-1956, vol. VII, DR 4, p. 109. Tradução nossa. 
demonstrar a racionalidade - e, por tanto, a superioridade - da argumentação do jesuíta, consequentemente refletindo a superioridade de sua lei. Ganhar um debate, em qualquer campo do conhecimento, é um meio para se fazer ouvir, um passo para que, em seguida, se possa convencer o outro da superioridade da Lei de Cristo sobre todas as demais. Nesse sentido, aproximamo-nos das ideias de Majeistina Khalos: "Na missão cristã, o diálogo era

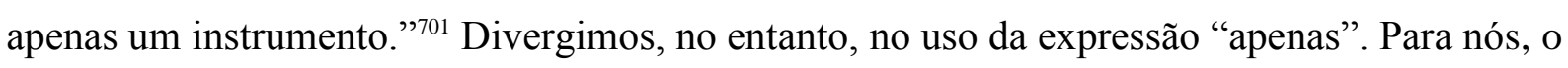
diálogo era um importante instrumento, ou ainda, uma fundamental estratégia.

Tal fato se torna ainda mais importante quando vemos manifesto nos escritos dos missionários que tais povos têm "dialética própria". Reconhecer no outro um modo de disputar, argumentar e debater obriga o jesuíta a adaptar-se a esse modo, tornando impensável um método catequético que preveja simplesmente a adoção e prática de exercícios e disciplinas típicas da formação jesuíta:

Aos missionários que vierem a esta missão, é necessário que (além de espírito e virtude) sejam de ótima natureza, de constituição robusta, de grande engenho e doutrina e de boa disposição para aprender a língua. Eu disse (...) que o missionário deveria ser dotado de grande engenho e doutrina (...) porque, além de ser costumeiro o exercício cotidiano da dialética, da argumentação formal e do doutoramento na sua universidade, seus livros (...) são muito sutis, metafísicos e sofísticos, e [além disso] o sistema da sua falsa religião muito amplo, enigmático, metafísico, para bem compreendê-lo é necessário uma capacidade incomum. Soma-se a isso o fato de que os tibetanos, apesar de serem muito dóceis e terem boa vontade em ouvir, não são superficiais ou condescendentes, mas querem ver, pesar e discutir tudo muito minuciosamente, com [o uso da] razão, e não querem ser instruídos, mas convencidos. ${ }^{702}$

O missionário deve, portanto, conhecer a lei do outro, identificar seus erros e refutálos. Tudo isso deve ser feito a partir do modo de disputar do outro, segundo o que podemos inferir da proposta de Desideri. No caso específico dos tibetanos, frisamos aqui a ênfase que o missionário dá ao convencimento, em detrimento da mera pregação ou instrução. Mais uma

\footnotetext{
701 "In Christian mission, dialogue was only na instrument." KAHLOS, M. Debate and Dialogue: Christian and Pagan Cultures. Aldershot: Ashgate, 2007, p. 79. Tradução nossa.

702 "I missionari che s'invieranno a quella missioni è necessário che (oltre lo espiritu e virtu) siano d'ottimo naturale, di robusta complessione, di grande ingegno e dottrina e di buona disposizioni per imparate le lingue. (...) Dissi in terzo luogo dover que' missionari esser dotati di grand'ingegno e dottrina. La ragione è perchè, oltrel'essere in uso apresso quellegentil'esercizio quotidiano dela dialettica, dell'argumentazione in forma e degl'addottoramenti nelle università loro, i di loro libri (...) sono molto sottili, metafisici e sofistici, e il sistema dela loro falsa religione è molto ampio, astruso, metafisico e che a ben comproenderlo richiede uma non ordinária capacità. A questo s'agginge che, quantunque i Thibettani siano molto docili quanto al sentir volentieri, non sono però leggieri e corrivi, ma vogliono vedere, pesare e discutire tutto molto minutamente, con ragioni, e vogliono essere non intruiti ma convinti." PETECH, L. I Missionari italiani nel Tibet e nel Nepal. Roma: Libreria dello Stato, 1952-1956, vol VII, App. II, p. 189-190. Tradução nossa.
} 
vez, fica nítida a opção por uma estratégia de conversão dialógica, centrada no debate e na disputa.

Tal fato se torna ainda mais importante quando vemos manifesto nos escritos dos missionários que tais povos têm "dialética própria". Reconhecer no outro um modo de disputar, argumentar e debater obriga o jesuíta a adaptar-se a esse modo, tornando impensável um método catequético que preveja simplesmente a adoção e prática de exercícios e disciplinas típicas da formação jesuíta.

Nesse sentido, gostaríamos de indicar que, as estratégias de conversão, desde seu esboço no Mogol, já apresentavam características que foram consolidadas, elaboradas e defendidas de forma mais estruturada por Desideri, por exemplo, nos séculos seguintes. Percebemos que o aprendizado da língua e a produção de textos em idioma local já era uma prática na missão, iniciada algumas décadas após a fundação da Ordem. Além disso, mesmo antes da finalização da Ratio Studiorum, já podemos deduzir, pela forma de atuar dos missionários na corte mogol, que o peso da retórica e da erudição - isto é, a importância da formação intelectual a serviço da missão - já aparecia como determinante. Era necessário persuadir. Era necessário convencer. Era necessário dar as razões de sua fé. Portanto, fica muito patente, já na virada do século XVII, a atualização do tomismo não apenas como forma de debate e formação intelectual na Europa, mas como instrumento catequético. Agir de forma prática ou pragmática significaria agir de forma pastoral, evangelizadora. Assim, a ação especulativa era de suma importância, mas não tinha fim em si mesma: estava, necessariamente, a serviço da missão.

Não obstante, Desideri filia-se a um modelo de missão paulino, reiterando a posição adaptacionista da Companhia de Jesus:

E o Apóstolo dos gentios, qual coisa ou qual exercício teve ele mais frequentemente que o de responder a intrincadas questões, dissolver dúvidas, desfazer argumentos, convencê-los de seus erros? Os gentios se mostravam incrédulos? Com a doutrina, os persuadia. ${ }^{703}$

No entanto, a opção pela persuasão, pelo convencimento e pelas formas dialógicas de atuação não foi apenas uma dinâmica de tentativa e erro. Foi, simultaneamente, uma escolha necessária em decorrência de uma situação específica, subscrita e contingente. Os jesuítas não se lançaram nos debates apenas em função da sua prática pedagógica e formação intelectual.

703 “E l'Apostolo delle genti qual cosa o qual'esercizio ebb'egli più frequente che il responder a intrigate questioni, Che scioglier dubbij, Che disfar argomenti, Che convincer errori? Increduli se mostravano i gentilli? Com la dottrina li persuadva." PETECH, L. I Missionari italiani nel Tibet e nel Nepal. Roma: Libreria dello Stato, 1952-1956, vol VII, DR 4, p. 109. 
Eles não recorreram ao tomismo e à metafísica apenas porque assim teriam sido formados e treinados nos Colégios da Ordem na Europa. A atuação dialógica, mediante a participação em disputas, foi, em parte, uma espécie de imposição externa. Nesse cenário, as disputas apareciam como método mais prudente e eficaz, aproximando-se de uma imitação do modelo paulino entre os pagãos. Mas não se tratava apenas disso. Participar das disputas e escrever obras, em persa, abordando temas teológicos e metafísicos - como a geração de Cristo, a Santíssima Trindade e a unidade de Deus etc. - significava, ao mesmo tempo, pôr em prática a formação recebida nos Colégios e adaptar-se a um processo político local.

Essa espécie de embrião de estratégia dialógica missionária foi, de certa forma, herdada, testada, implementada e aperfeiçoada nas missões tibetanas, desde a iniciativa de Antônio de Andrade até a elaboração missionológica de Desideri. Não podemos esquecer que o italiano fez referência ao tratado apologético escrito por Jerônimo Xavier, um século antes, no Indostão.

Por fim, frisamos que nesta tese procuramos relacionar a retórica e a atuação política dos jesuítas nas missões aqui recortadas. Desideri recomenda aos missionários que fossem enviados ao Tibete:

Procure obter a benevolência de todos, nobres ou plebeus, monarca ou secular. Ganhe a proteção dos grandes porque esta lhe garantirá respeito e lhe renderá a boa vontade dos outros. ${ }^{704}$

Fica evidente nesta passagem o conselho político dado pelo italiano aos jesuítas que fossem ao Tibete. Conforme mencionamos ao longo de nossa análise, a leitura do contexto político, a aproximação da "cabeça" e a chamada relação de patronagem eram fundamentais para a implementação das estratégias de conversão na terra dos lamas. Ainda que o missionário esteja fazendo referência ao Tibete, supomos ser possível entender essas orientações de forma mais abrangente. Isto é, imaginamos que tal método seria também aplicável para comunidades cuja forma sociopolítica fosse análoga àquela encontrada no Tibete. Ressaltamos ainda que, com o apoio do governante local, tornaria-se menor a dependência da missão em relação a uma instituição europeia de evangelização: quer fosse a própria Ordem, quer fosse a Propaganda Fide.

Para finalizar, propomos que podemos desdobrar essa maneira de agir jesuíta, segundo as fontes analisadas, em uma espécie de tríade retórico-política, composta pelos seguintes

704 "Procurino di procacciarsi la benevolenza di tutti, così nobili come plebei, si monaci come secolari. Si guadagnino la protezione de' grandi, perchè questa li concilierà il respecto e li renderà bem voluti da gli altri." PETECH, L. I missionari italiani nel Tibet e nel Nepal. Libr. dello Stato, 1952, App. II, p. 190. Tradução nossa. 
elementos: a epístola, a narrativa e o diálogo. A epístola teria como função a difusão da informação, a edificação, a propaganda e a prestação de contas, ou seja, deveria manter o superior a par do que se passava no terreno missionário. A narrativa, por sua vez, possuiria também a função informar, associada ao papel de descrever e categorizar. Elaborar ou atribuir uma categoria é uma ação também política, não sendo nem apenas contemplativa, nem superficialmente retórica. ${ }^{705} \mathrm{O}$ diálogo, a seu turno, teria como função hierarquizar, convencer e converter. No entanto, retomando a citação de Desideri acima, nada disso teria efeito se a observação, a perspicácia e a busca por alianças políticas locais não fossem prioridades para os missionários.

Podemos perceber, então, um ciclo incessante de (re) formulação e esgotamento de categorias, que se renovam no ritmo ditado pela iminente limitação de vocábulos como idólatra, pagão, infiel etc. Na medida em essas categorias tornavam-se ineficazes para resolver os problemas epistemológicos e missiológicos enfrentados pelos padres, fazia-se necessário (re) elaborar um novo complemento, um outro predicado, que fosse capaz de descrever o possível futuro converso e antecipar a forma mais prudente de catequese.

705 "Reduzir a humanidade a dois tipos mutuamente excludentes com base na natureza realiza uma função semântica politicamente eficaz" como indica-nos Kosseleck referindo-se ao mundo antigo. KOSELLECK, R. Futuro passado: contribuição à semântica dos tempos históricos. Rio de Janeiro, Contraponto / PUC-RJ, 2006, p. 207. 


\section{APÊNDICES}


APÊNDICE A: DESCRIÇÃO DO DOCUMENTO MONGOLICAE LAGATIONIS COMMENTARIUS

MONTSERRAT, A. Mongolicae Lagationis Commentarius. Texto integral, em latim: HOSTEN, H. (Ed.) Mongolicae Lagationis Commentarius. Memoirs of the Asiatic Society of Bengal, Calcutá, vol. III, n. 9, p. 518-704, 1914. Serviu de base para as duas traduções que utilizaremos nesta pesquisa:

HOYLAND, J.S.; BANERJEE, S.N. The commentary of father Montserrat on his journey to court of Akbar. Mahindra College, Patiala. Londres: Humphrey Milford, Oxford University Press, 1922.

ALAY, J.L. Ambaixador a la cort del Gran Mogol: Viatges d'um Jesuïta Català Del segle XVI a l'India, Pakistan, Afganistan, Himalaia. Edição e tradução (do latim para o catalão): Josep Lluis Alay. Lleida: Pagès, 2002. Esta é uma edição contemporânea, em catalão, que se apresenta como uma tradução integral do Comentário; Utilizaremos principalmente a sua tradução em espanhol, Embajador en la corte del Gran Mogol, feita por Ramon Sala, e publicada em 2006 pela Editorial Milênio.

O Commentarius possui uma história curiosa: tudo indica que Montserrat tenha começado a escrever suas primeiras linhas entre o fim de 1579 e o início de 1580, isto é, durante sua viagem de Damão a Fatehpur Sikri, àquela altura corte do imperador Akbar. Em 1582, Montserrat deixou Fatehpur Sikri e retornou à Goa. No entanto, em 1588, ele foi enviado à Abissínia, levando consigo as anotações, ainda não finalizadas, do período em que permanecera no norte da Índia. Em sua viagem para a nova missão, o padre foi preso em Dhafar e depois transferido para a cidade de Sanaa (no atual Iêmen), em dezembro de 1590. Libertado em 1596, ele retornou a Goa, portando ainda o manuscrito que o acompanhou por todo esse tempo. O jesuíta, contudo, morreu em Salsete, em 1600, sem publicar sua obra. De fato, não temos indícios de que seu manuscrito sequer fora enviado a Roma ou a Lisboa. Ao que tudo indica, permaneceria esquecido na Índia até ser encontrado, séculos depois.

Em 1906, o manuscrito foi descoberto pelo Reverendo W.K. Firminger, um estudioso da História de Bengala, na biblioteca do Colégio de São Paulo, em Calcutá. Este seria o primeiro passo para a sua publicação contemporânea, em latim, nos Memoirs of the Asiatic 
Society of Bengal, em 1914. ${ }^{706}$ A publicação ficou a cargo de H. Hosten, responsável pela divulgação, em diversos periódicos indianos, de inúmeros documentos relativos às missões jesuítas que lá se estabeleceram.

Com exceção da primeira página, e talvez de um mapa que teria sido feito pelo próprio padre, ambos perdidos, o manuscrito foi integralmente publicado, e depois traduzido para inglês, catalão e espanhol. Serão estas as versões da obra que utilizaremos em nossa pesquisa, apesar de termos sérias ressalvas à edição feita por Josep Lluis Alay. ${ }^{707}$ A publicação catalã parece não ter respeitado o formato original do texto, inserindo em seu corpo subtítulos e até mesmo comentários do editor, os quais deveriam ter sido acrescentados em notas de rodapé. Além disso, se Alay se permite "enriquecer" com seus comentários o texto de Montserrat, ele nos priva de maiores detalhes sobre as fontes originais e informações por ele utilizadas e citadas. Supomos que à época de sua primeira publicação, o manuscrito continuava sob a guarda da Biblioteca da Catedral de São Paulo, em Calcutá. No entanto, segundo Alay, atualmente não há informações sobre a sua localização.

Em sua obra, o jesuíta descreve rios, cidades, países, e também os hábitos, templos e costumes religiosos dos habitantes das terras que visitou. Uma vez na corte de Akbar, Montserrat passa a descrever também o próprio governante, além de compor uma narrativa detalhada do que nós identificamos como estratégias de conversão, e que, para o padre, seria a relação construída entre o soberano e os religiosos da Companhia de Jesus. ${ }^{708}$

A obra é apresentada pelo próprio autor da seguinte forma:

He dividido mi obra en dos libros, de los cuales este primero es un relato de la primera misión a la corte del ré de los mongoles, mientras que el segundo es un apéndice y comentario do primero, donde he recogido hechos relacionados con la geografía y la historia natural de la índia del interior del Ganges, de las costumbres de sus antepasados y de sus habitantes actuales.

En otros dos libros que he añadido a los dos mencionados anteriormente, he descrito de una manera similar mi viaje a Etiopia, así como un relato sobre la geografía y la historia natural de Arabia. ${ }^{709}$

\footnotetext{
706 MONTSERRAT, A. Mongolicae Lagationis Comentarius. Texto original em latim, publicado por $\mathrm{H}$. Hosten in: Memoirs of the Asiatic Society of Bengal, Vol. III, n. 9, p. 518-704. Calcutá, 1914.

${ }^{707}$ MONTSERRAT, A. Ambaixador a la cort del Gran Mogol: Viatges d'um Jesuïta Català Del segle XVI a l'India, Pakistan, Afganistan, Himalaia. Edição e Tradução Josep Lluis Alay. Lleida: Pagès, 2002. Esta é uma edição contemporânea, em catalão, que se apresenta como uma tradução integral da "Mongolicae"; Utilizaremos principalmente a sua tradução em espanhol, Embajador en la corte del Gran Mogol, feita por Ramon Sala, e publicada em 2006 pela Editorial Milênio; HOYLAND, J.S.; BANERJEE, S.N. The commentary of father Montserrat on his journey to court of Akbar. Mahindra College, Patiala. Londres: Humphrey Milford, Oxford University Press, 1922.

${ }^{708}$ Assim sendo, a maior parte das informações e extratos textuais presentes nesta tese foi retirada da obra em espanhol, da qual traduzimos livremente para o português, acrescida de outras passagens encontradas em fontes subsidiárias, como cartas dos próprios jesuítas da missão e crônicas da Companhia de Jesus.

${ }^{709}$ MONTSERRAT, A. Ambaixador a la cort del Gran Mogol: Viatges d'um Jesuïta Català Del segle XVI a
} 
Para a nossa pesquisa, no entanto, nos concentramos nas partes em que Akbar é descrito, assim como aquelas que narram os encontros entre os religiosos e o governante, em especial quando ocorrem "disputas". Esta perece ter sido a principal, mas não a única, estratégia utilizada pelos padres em seus esforços de converter Akbar. Através do seu convencimento e da "desautorização" dos demais representantes de outras religiões que também viviam na corte, principalmente os muçulmanos, os missionários buscavam o batismo do soberano. ${ }^{710}$

No que diz respeito às disputas, podemos identificar os seguintes temas abordados:

○ Exatidão, autoridade de valor das "sagradas escrituras" e do Corão;

- O mistério da Santíssima Trindade;

○ "Glória Celestial", conceito de céu ou paraíso;

○ Filho de Deus, modo e propósito da sua geração Divina;

○ Paixão e morte de Cristo;

○ Nascimento de cristo;

- Natureza divina de Cristo;

○ Contradições do Corão sobre a morte de Cristo.

Ainda que Akbar parecesse demonstrar alguma dificuldade em aceitar alguns dos pontos defendidos pelos jesuítas, não nos parece ter sido esse o principal obstáculo ao batismo do governante: Montserrat menciona que a simpatia de Akbar por outras religiões e o pouco zelo que demonstrava ter pela ortodoxia da fé islâmica causaram o levante de seu irmão apoiado por outros "nobres" descontentes com o imperador indiano. ${ }^{711}$

Para finalizar, gostaríamos de enfatizar a importância do relato: em um período frequentemente descrito pela historiografia como tendo sido marcado pela rivalidade extrema entre cristãos e infiéis - isto é, muçulmanos - encontramos uma obra em que toda uma relação estabelecida entre religiosos cristãos e um soberano muçulmano - em sua faceta

l'India, Pakistan, Afganistan, Himalaia. Edição e Tradução Josep Lluis Alay. Lleida: Pagès, 2002. p. 58.

${ }^{710}$ Alem disso, identificamos neste relato outras estratégias, como o aprendizado da língua persa - para melhor "disputar" com os "mulas" e traduzir textos bíblicos-; as reiteradas negativas às ofertas de dinheiro feitas por Akbar - para ganhar sua simpatia e confiança -; e o aceite do cargo de instrutor do filho do meio de Akbar que, ao lado de outros poucos jovens nobres, recebia aulas de português e catequese do próprio padre Montserrat.

${ }^{711}$ Essa visão é extremamente parcial, mas como por hora apenas apresentamos nossa fonte, deixemos sua análise e crítica para um momento mais oportuno. 
religiosa, mas também política - é descrita em pormenores. Isso indica que, para além das simplificações que em geral tendem a ser feitas no que diz respeito à história da presença portuguesa, ou cristã, no Oriente durante a Idade Moderna, faz-se ainda necessária uma leitura mais atenta e minuciosa das fontes do período para que consigamos trazer à luz a complexidade das relações Ocidente/Oriente, cristãos/infiéis, missionários/catequizandos no subcontinente indiano, em especial quando estas relações se estabeleceram fora dos limites do Estado da Índia.

Nesse sentido, a missão do Mogol, conforme apresentada nesta fonte, parece-nos ser mais uma peça no quebra-cabeça da atuação da Companhia de Jesus na Ásia, tendo um papel de modelo e exemplo para a missão do Tibete (séc. XVII). 
APÊNDICE B: TABELA DE MISSIONÁRIOS JESUÍTAS QUE ATUARAM EM BENGAL712

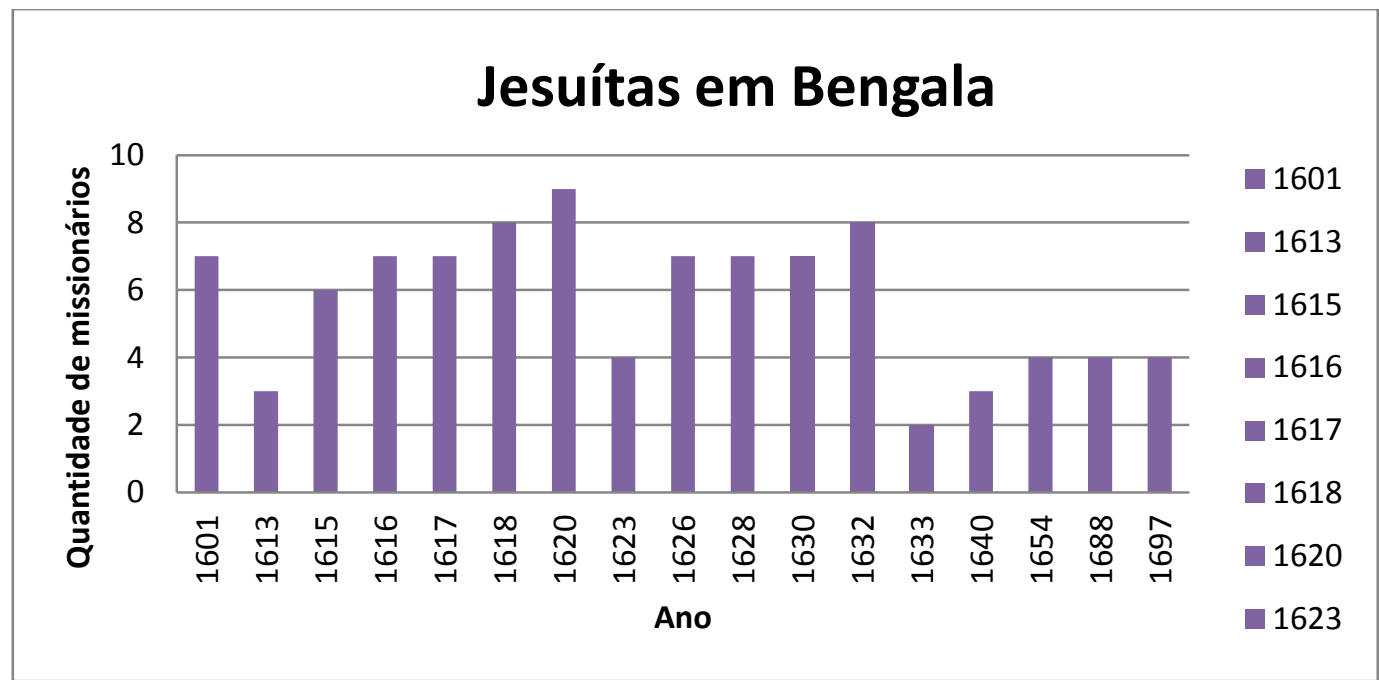

712 Tabela produzida a partir de informações contidas em: HOSTEN, H.; BESSE, P. A List of Portuguese Jesuit missionaries in Bengal and Burma, 1576-1742 . Journal of Asiatic Society of Bengal. Calcutá, vol. VII, 1911. 
APÊNDICE C: LISTA DE MISSIONÁRIOS QUE ATUARAM EM BENGALA713

\begin{tabular}{|c|c|c|c|c|}
\hline Candekan & Sundiva & Pegu & Hugli & Cathay \\
\hline $\begin{array}{l}\text { André Boves } \\
\text { Dominic de } \\
\text { Souza }\end{array}$ & $\begin{array}{l}\text { Blasius Nunes } \\
\text { Natalius Salerno } \\
\text { Jonh Mary } \\
\text { Grecus } \\
\text { Blasius Nunes } \\
\text { Balthasar de } \\
\text { Sequeira }\end{array}$ & $\begin{array}{l}\text { Emanuel Pires } \\
\text { Emanuel da } \\
\text { Fonseca } \\
\text { Bartolomeu } \\
\text { Fonteboa }\end{array}$ & $\begin{array}{l}\text { Peter Gomes } \\
\text { Anthony } \\
\text { Rodrigues } \\
\text { Simão de } \\
\text { Figueiredo } \\
\text { Benedito } \\
\text { Rodrigues } \\
\text { Gondisalus Paes } \\
\text { Aluisio } \\
\text { Orlandini }\end{array}$ & $\begin{array}{l}\text { Jerônimo Xavier } \\
\text { Emmanuel } \\
\text { Pinheiro } \\
\text { Bento de Goes }\end{array}$ \\
\hline
\end{tabular}

${ }^{713}$ Esta tabela não pretende ser uma listagem definitiva. Apontamos aqui alguns nomes identificados por $\mathrm{H}$. Hosten, os quais, uma vez sistematizados, podem auxiliar futuras buscas por fontes jesuítas relativas à atuação da Ordem na Ásia. Cf: JOURNAL of the Asiatic Society, New Series, Calcutá, vol. VII, 1911. p. 15-35. 
APÊNDICE D: DESCRIÇÃO DO DOCUMENTO RELAÇÃO DE AKBAR

MONTSERRAT, A. Relação de Equebar. Texto original em português. Publicação de referência in: Documenta Indica, v. XII (1580-1583), doc. 114, p.645-662. ${ }^{714}$

Este documento, escrito por Montserrat em 26 de novembro de 1582, tem como tema principal a descrição do soberano do Mogol chamado de Equebar, ou Akbar. No entanto, o jesuíta extrapola a descrição do indivíduo e faz uma espécie de descrição do Estado Mogol, ou Indostão. Iniciando por sua "cabeça", o missionário descreve também a corte, a burocracia do Indostão, o funcionamento do Estado, a justiça etc.

Se o Commentarius possui apenas um “original”, que permaneceu perdido por anos e que nunca teria sido enviado à Europa, esta fonte, por outro lado, parece possuir várias versões, dentre manuscritos e impressos. As versões manuscritas encontram-se principalmente em dois arquivos - no Arquivo Romano Societatis Iesu (ARSI) e no Arquivo Nacional da Torre do Tombo (ANTT) -, nos dossiês Goa 13 I e 38 e no Armário Jesuítico no 28, respectivamente.

É curioso notar ainda que, ao final da publicação de Alay do Commentarius, encontramos uma espécie de apêndice ${ }^{715}$ e também uma última parte com o título História de Equebar, Rey de los Mongoles ${ }^{716}$. Esses dois textos descrevem Akbar, sendo que o último parece mais uma publicação da Relação, ainda que o autor - Alay - nos prive de qualquer informação ou referência. Por outro, o chamado "apêndice I" não é equivalente à Relação: ainda que o conteúdo seja semelhante, o formato e a ordem dos temas abordados são radicalmente distintos.

\footnotetext{
714 Outras versões:

Relacao de akbar rei dos mogóis. Versão manuscrita encontrada no livro 28 do Armário Jesuítico (fl. 81-85), no Arquivo Nacional da Torre do Tombo (Lisboa, Portugal).

Relação de Equebar. Relação publicada por Hosten in: JASB vol. VIII, 1912, p. 185-221.

História de Equebar, Rey de los Mongoles, texto publicado por Alay in: Embajador em la corte Del Gran Mogol, p. 306-320.

${ }^{715} \mathrm{Na}$ publicação aparece como "parte VII: Zeladin, Rey de los Mongoles", ALAY, J.L. Embajador en la corte del Gran Mogol. Tradução Ramon Sala. Lleida: Milenio, 2006. p. 239.

${ }^{716}$ ALAY, op. cit. p. 306-320.
} 
Antônio Montserrat inicia sua Relação identificando Akbar por nome e título: rei dos mogores, e, em seguida, aponta sua genealogia - neto de Tamorlam, de nação e pátria Chaquata, localizada entre a Pérsia e a Tartária, a Índia a leste.

Os chamados mogores são identificados pelo jesuíta como turcos, não tártaros, nem parthos. A sua língua é turquesa, mas diferente das dos turcos, devido à pronúncia.

Feita a genealogia do soberano, passa-se para a sua descrição física, seguida da descrição de suas roupas e costumes e de sua personalidade. Parece ganhar destaque o seu senso de justiça. Sobre sua "educação", Montserrat indica que o soberano mogol era analfabeto, mas vivia rodeado de "homens letrados". 717

O jesuíta descreve então os divertimentos de Akbar, distrações ou, em termos contemporâneos o seu "lazer". Em seguida, identifica a função de vazir: conselheiro. E continua com o tema do divertimento, descrevendo o gosto de Akbar por atividades de caça.

O tema da justiça, do ponto de vista do "sistema judiciário", é retomado. São oficiais de justiça: juiz ordinário, juiz de apelações, meirinho. Tudo se julga verbalmente. Segue a descrição do modo de negociar e da "etiqueta".

Montserrat passa então passa à descendência de Akbar: três filhos homens e duas filhas. E, em seguida, para a descrição do reino: três capitais: Delhi, Agra e Fatehpur. O missionário fala das demais cidades principais do Indostão e as compara com cidades portuguesas. As moradias e casas também são descritas.

Passa-se para uma descrição "geográfica" do Mogol. Os rios Indus e Ganges são citados, marcando a diferença entre a Índia interior e Índia exterior, segundo a divisão da antiguidade. A cadeia de montanhas do Himalaia (Imao) é mencionada.

Segue uma brevíssima "História" do Indostão, com a menção a antigos reis cristãos. Passa-se ao "estado de coisas": levantes e instabilidade política. Sobre este tema, Montserrat apresenta o poder bélico e descreve guerras, fala dos cavalos do exército mogol e de suas técnicas de combate.

Outro ponto mencionado é a divisão de terras ganhas em guerra, uma espécie de "vassalagem" que depende do numero de pessoas de que um "nobre" dispõe ao seu serviço.

Montserrat aponta então as "nações" que habitam o Indostão. E, em seguida, faz menção as suas riquezas. Passa-se então a uma breve história da missão e aproximação de Akbar ao cristianismo. Uma menção ao Tibete, chamado de Botthan, ${ }^{718}$ encerra a relação.

\footnotetext{
${ }^{717}$ Documenta Indica, v. XII (1580-1583), doc. 114, p.649.

${ }^{718}$ Em hindi, Bothanta é o mesmo que Tibet.
} 
Essa primeira leitura da fonte nos permitiu, em primeiro lugar, confirmar sua fundamental importância para o nosso estudo. Foi possível identificar os temas principais de nossa investigação nessa descrição fundamentalmente política de Akbar e do Estado Mogol. Se o autor não aprofunda as descrições sobre as disputas ou outras estratégias de conversão, ele fornece uma rica visão da estrutura do Estado, da composição social do Indostão, as relações entre gentios e mouros etc. Além disso, esse "silêncio" sobre as disputas neste documento reforça nossa hipótese de que a missão possuiu, para além de objetivos religiosos óbvios, uma agenda política de coleta e divulgação de informações acerca do interior do subcontinente indiano.

Por outro lado, gostaríamos de destacar um trecho do documento: "Os homens em que [Akbar] acha partes naturais para se servir deles (...) ainda que sejam baixos ou estrangeiros fá-los grandes". ${ }^{719}$ Acreditamos que essa ideia, atribuída ao soberano pelo jesuíta, diz muito sobre a maneira que Akbar se relaciona com membros de sua corte - incluindo os missionários - e seu projeto de composição de uma nobreza mista.

${ }^{719}$ Documenta Indica, v. XII (1580-1583), doc. 114, p. 651, n.25. 


\begin{tabular}{|c|c|c|}
\hline Poder e aspectos políticos & Economia e sociedade & Cultura e mentalidade \\
\hline $\begin{array}{l}\text { Identificação e descrição de } \\
\text { limites de reinos e fronteiras. }\end{array}$ & $\begin{array}{c}\text { Trocas mercantis e rotas de } \\
\text { comércio. }\end{array}$ & $\begin{array}{c}\text { Religião: aspectos teológicos e } \\
\text { doutrinários. }\end{array}$ \\
\hline $\begin{array}{l}\text { Identificação e descrição de } \\
\text { figuras e atores políticos: reis, } \\
\text { rainhas, membros da } \\
\text { "corte }{ }^{720 "} \text { etc. }\end{array}$ & $\begin{array}{l}\text { Produção: agricultura, } \\
\text { manufatura, artesanato etc. }\end{array}$ & $\begin{array}{c}\text { Religião: aspectos “exteriores" } \\
\text { (etiqueta, indumentária e } \\
\text { materialidade). }\end{array}$ \\
\hline $\begin{array}{l}\text { Relações de poder dentro da } \\
\text { "corte", tensões, agremiações, } \\
\text { complôs etc. }\end{array}$ & Organização do trabalho. & $\begin{array}{l}\text { Mitos fundadores, lendas, } \\
\text { histórias etc. }\end{array}$ \\
\hline $\begin{array}{c}\text { Aspectos administrativos e de } \\
\text { governo. }\end{array}$ & $\begin{array}{c}\text { Organização social: grupos, } \\
\text { castas etc. }\end{array}$ & $\begin{array}{l}\text { Calendário religioso, costumes, } \\
\text { festas e datas sagradas, } \\
\text { romarias e rotas de } \\
\text { peregrinação etc. }\end{array}$ \\
\hline $\begin{array}{l}\text { História ou memória política: } \\
\text { guerras, revoltas e problemas } \\
\text { de sucessão. }\end{array}$ & & \\
\hline
\end{tabular}

720 "Corte" entendida aqui no seu sentido mais amplo, ou seja, pessoas ou grupos de pessoas que cercam o soberano que, nos casos aqui analisados, pode ser laica ou religiosa. Encontramos majoritariamente o segundo tipo. 
APÊNDICE F: TABELA DE ASSUNTOS PRINCIPAIS DE NotícIA HistóRICA DO TiBETE

\begin{tabular}{|c|c|c|}
\hline $\begin{array}{l}\text { Definição e descrição } \\
\text { "Tibete" e sua "seita" }\end{array}$ & $\begin{array}{l}\begin{array}{l}\text { Estratégias e métodos de } \\
\text { convencimento e conversão }\end{array} \\
\end{array}$ & "Erros" da "seita" tibetana \\
\hline $\begin{array}{l}\text { É feita uma definição - talvez } \\
\text { historicamente a primeira } \\
\text { definição mais precisa -do que é } \\
\text { Tibete, isto é, do que a palavra } \\
\text { significa, a que ela se refere, } \\
\text { quais as divisões do "Tibet." } \\
\text { (primeiro Tibet., grande Tibet. } \\
\text { etc.), como ele se apresenta } \\
\text { estruturado politicamente, suas } \\
\text { fronteiras e divisões internas } \\
\text { etc. }{ }^{2} 1\end{array}$ & $\begin{array}{l}\text { O missionário destaca a } \\
\text { importância de aprender a } \\
\text { língua, o que não chega a ser } \\
\text { uma especificidade de Desideri. } \\
\text { No entanto, esta iniciativa } \\
\text { apresenta uma defesa } \\
\text { considerável em seus escritos, o } \\
\text { que também não encontramos } \\
\text { nos relatos anteriores dos } \\
\text { missionários no Tibet. do século } \\
\text { XVII. }\end{array}$ & $\begin{array}{l}\text { A ausência de um deus criador } \\
\text { (ateísmo). }\end{array}$ \\
\hline $\begin{array}{l}\text { A descrição "sociológica" ou } \\
\text { "antropológica" do Tibete, } \\
\text { esboçada pelos missionários } \\
\text { anteriores }- \text { Andrade, Cacela, } \\
\text { Cabral etc. - ganha } \\
\text { complexidade no relato de } \\
\text { Desideri. }\end{array}$ & $\begin{array}{l}\text { O italiano busca produzir obras } \\
\text { escritas e não só disputas } \\
\text { verbais como forma de } \\
\text { convencer os lamas tibetanos. }\end{array}$ & $\begin{array}{l}\text { A ideia de transmigração das } \\
\text { almas (reencarnação) }\end{array}$ \\
\hline $\begin{array}{l}\text { A primeira descrição mais } \\
\text { detalhada do budismo tibetano, } \\
\text { também esboçada por outros } \\
\text { missionários, mas de forma } \\
\text { superficial se comparada à obra } \\
\text { do italiano. }\end{array}$ & $\begin{array}{l}\text { Desideri procura convencer os } \\
\text { lamas mediante a refutação de } \\
\text { seus erros, que devem ser } \\
\text { previamente identificados e } \\
\text { analisados a partir da leitura - } \\
\text { no idioma original - dos textos } \\
\text { sagrados da seita tibetana e, } \\
\text { além disso, devem ser refutados } \\
\text { conforme as "regras" da } \\
\text { formação dos próprios lamas, } \\
\text { isto é, de acordo com a } \\
\text { "dialética" dos lamas tibetanos, } \\
\text { e não só a partir da maneira } \\
\text { "jesuíta europeia". }\end{array}$ & $\begin{array}{l}\text { Ainda que, de forma genérica, } \\
\text { as "leis e costumes" tibetanos } \\
\text { estejam, muitas vezes, conforme } \\
\text { a razão, os fundamentos por trás } \\
\text { destas leis são obras de } \\
\text { inspiração do Diabo. }\end{array}$ \\
\hline
\end{tabular}

721 Até aspectos mais genéricos - e menos importantes para a nossa pesquisa - como, por exemplo, a descrição de aspectos naturais, rios, vegetação etc. 
APÊNDICE G: TABELA DE FONTES IDENTIFICADAS NO ARQUIVO ROMANO SOCIETATIS

IESU722

\begin{tabular}{|c|c|c|c|c|}
\hline $\begin{array}{l}\text { Título ou } \\
\text { Remetente }\end{array}$ & Local & Data & Localização & Observações \\
\hline $\begin{array}{c}\text { "Alcuni farto } \\
\text { notabili", Î́ndia, } \\
\text { 1599, "excerpta } \\
\text { ex annuis } \\
\text { indiarum." . }\end{array}$ & & & Goa 14, fl: 374-78 & \\
\hline $\begin{array}{l}\text { "Arrezoado sobre } \\
\text { as missões ..." }\end{array}$ & & & Lus.74, fl.133-136v. & \\
\hline Akbar, Imperator & Fatehpur & 24.02 .1583 & & $\begin{array}{l}\text { Documenta Indica, v. } \\
\text { XII (1580-1583) doc. } \\
\text { 127, p.731-33. }\end{array}$ \\
\hline $\begin{array}{l}\text { André (?) } \\
\text { Buccerio }\end{array}$ & Travancor & 05.12 .1599$. & Goa 14, fl:409-11. & \\
\hline Andre Boves & Sthomae & 22.08 .1599 & Goa 14, fl:381-2. & Assunto: Bengala \\
\hline Andre Boves & Chatigan/Bengala & 18.01.1602 & Goa 15 , fl:74-5 & \\
\hline Andre Boves & Orixa & 28.01 .1604 & Goa 15, fl: 224-5. & $\begin{array}{c}\text { Assunto: Bengala } \\
\text { destruída. }\end{array}$ \\
\hline Andre Boves & Chatigan & & Goa 14, fl: 404 & Assunto: Bengala \\
\hline $\begin{array}{l}\text { André de } \\
\text { Rabais(?). }\end{array}$ & Bengala & 25.01 .1602$. & Goa $15, \mathrm{fl}: 77-8$. & $\begin{array}{l}\text { Relatio de missione } \\
\text { bengalensi Pegu. }\end{array}$ \\
\hline André Palmeiro & & 08.01 .1626 & & $\begin{array}{l}\text { Assunto: Andrade e } \\
\text { a missão do Mogol }\end{array}$ \\
\hline
\end{tabular}

${ }^{722}$ Esta listagem não se pretende um levantamento definitivo, mas apenas uma sistematização de fontes identificadas ao longo de nossa pesquisa. 


\begin{tabular}{|c|c|c|c|c|}
\hline André Palmeiro & & 25.01 .1624 & Goa 9-1, fl.72-3 & \\
\hline André Pereira & Golim & 03.10 .1615 . & Goa 17, fl:138-9. & \\
\hline $\begin{array}{l}\text { Antônio de } \\
\text { Andrade }\end{array}$ & & $1624: 8 / 11$ & $\begin{array}{c}\text { Goa 46. (fl:104- } \\
111 \mathrm{v})\end{array}$ & \\
\hline $\begin{array}{l}\text { Antônio de } \\
\text { Andrade }\end{array}$ & & $1626: 20 / 2$ & Goa 73 & \\
\hline $\begin{array}{l}\text { Antônio de } \\
\text { Andrade }\end{array}$ & & $1627: 29 / 8.2 / 9$ & Goa 73 & \\
\hline $\begin{array}{l}\text { Antônio de } \\
\text { Andrade }\end{array}$ & & $1633: 4 / 2(?)$ & Goa 73 & \\
\hline Antônio Freire & & 15.05 .1632 & Lus. 74 fl.210-211. & \\
\hline Antônio Freire & & 29.09 .1635 & Lus.74, fl.263-264v & $\begin{array}{l}\text { Assunto: morte de } \\
\text { Andrade }\end{array}$ \\
\hline $\begin{array}{l}\text { Antônio } \\
\text { Montserrat }\end{array}$ & Fatehpur & 09.09 .1580 & Goa 13, fl: $24-27$ & $\begin{array}{l}\text { Documenta Indica, v. } \\
\text { XII (1580-1583), } \\
\text { doc. 08, p.64-77. }\end{array}$ \\
\hline $\begin{array}{c}\text { Antônio } \\
\text { Montserrat }\end{array}$ & Cochim & 12.01 .1579 & Goa 12, fl: 521-8. & \\
\hline $\begin{array}{c}\text { Antônio } \\
\text { Montserrat }\end{array}$ & Cochim & 6.01 .1577 & Goa 12, fl:382-83 & \\
\hline $\begin{array}{l}\text { Antônio } \\
\text { Montserrat }\end{array}$ & Cochim & 08.01 .1578 & Goa 12 , fl:444-5 & \\
\hline $\begin{array}{l}\text { Antônio } \\
\text { Montserrat }\end{array}$ & Baçaim & 15.02 .1589 & Goa 13 II, fl: 442-3 & \\
\hline
\end{tabular}




\begin{tabular}{|c|c|c|c|c|}
\hline $\begin{array}{l}\text { Antônio } \\
\text { Montserrat }\end{array}$ & & 12.12 .1596 & Goa 14, fl: $327-8$ & $\begin{array}{l}\text { Documenta Indica, v. } \\
\text { XVIII (1595-1597), } \\
\text { doc. 79, p. 632-634 }\end{array}$ \\
\hline $\begin{array}{l}\text { Antônio } \\
\text { Montserrat }\end{array}$ & Goa & 26.10 .1579 & Goa 31, fl: 411-22 & $\begin{array}{l}\text { Documenta Indica, v. } \\
\text { XI (1577-80), doc. } \\
\text { 89, p. 641-671. }\end{array}$ \\
\hline $\begin{array}{l}\text { Antônio } \\
\text { Montserrat }\end{array}$ & Goa & 05.12 .1583 & & $\begin{array}{c}\text { Documenta Indica, v. } \\
\text { XIII (1583-1585) } \\
\text { doc. 7, p.382-84 }\end{array}$ \\
\hline $\begin{array}{l}\text { Antônio } \\
\text { Rodrigues }\end{array}$ & Cochim & 04.01 .1627 & Goa 18, fl: 93-94 & Cataio \\
\hline $\begin{array}{l}\text { Claudio } \\
\text { Acquaviva }\end{array}$ & Roma & 22.12 .1582 & $\begin{array}{c}\text { Roma, biblioteca } \\
\text { Nazionale Vittorio } \\
\text { Emanuele II, Mss. } \\
\text { 1386, fasc. } 11 .\end{array}$ & $\begin{array}{l}\text { Documenta Indica, v. } \\
\text { XII (1580-1583) doc. } \\
\text { 120, p.685-701 }\end{array}$ \\
\hline $\begin{array}{l}\text { Cópia de um } \\
\text { capítulo de uma } \\
\text { carta de pero } \\
\text { Tavares... } \\
\end{array}$ & Goa & 1579 (sic) & $\begin{array}{l}\text { Armário jesuítico, } \\
\text { n²8 (Cartas do } \\
\text { Japão), ff. } 88 \mathrm{v}-89 \mathrm{r}\end{array}$ & $\begin{array}{l}\text { Documenta Indica, v. } \\
\text { XI (1577-80), doc. } \\
\text { 49, p. 427-430 }\end{array}$ \\
\hline Diogo de Mathos & & 23.01 .1639 & $\begin{array}{c}\text { Goa 9-1, fl: } 157- \\
158 \mathrm{v} .\end{array}$ & $\begin{array}{l}\text { Sobre o fim da } \\
\text { missão do Tibete }\end{array}$ \\
\hline $\begin{array}{l}\text { Eduardus de } \\
\text { Sande }\end{array}$ & Goa & 07.11 .1579 & $\begin{array}{l}\text { Armário Jesuítico, } \\
\mathrm{n}^{\circ} 28 \text { (Cartas do } \\
\text { Japão) ff. } 118 \mathrm{v}-20 \mathrm{r}\end{array}$ & $\begin{array}{l}\text { Documenta Indica, v. } \\
\text { XI (1577-80), doc. } \\
\text { 90, p. 672-679. }\end{array}$ \\
\hline $\begin{array}{l}\text { Eduardus de } \\
\text { Sande }\end{array}$ & & & & $\begin{array}{l}\text { Documenta Indica, v. } \\
\text { XII (1580-1583) doc. } \\
\text { 142, p.891-910 }\end{array}$ \\
\hline Estevão Cacella & & $1619: 1 / 12$ & Goa 17. & \\
\hline Estevão Cacella & & $1620: 21 / 12$ & Goa 18. & \\
\hline Estevão Cacella & & $1626: 10 / 7$ & Goa 18, fl: 84 & \\
\hline Estevão Cacella & & $1627.4 / 10$ & Goa 48. & \\
\hline
\end{tabular}




\begin{tabular}{|c|c|c|c|}
\hline Francisco Cabral & 5.11 .1593 & Goa 14, fl:70-88 & Anua de Goa \\
\hline Francisco Corsi & 1599:9/3(?) & Japsin 13. & \\
\hline Francisco Corsi & $1627: 8 / 9$ & Goa 9. & \\
\hline Francisco Corsi & $1629: 6 / 1 ; 15 / 11$ & $\begin{array}{l}\text { Goa 9. fl: } 149-149 \mathrm{v} ; \\
\text { fl: } 142-43 \mathrm{v} .\end{array}$ & \\
\hline Francisco Corsi & $1633: 5 / 10$ & Goa 9. fl:152-153v. & \\
\hline Francisco Corsi & $1604: 10 / 8$ & Goa 46 & \\
\hline Francisco Corsi & $1607: 18 / 10$ & Goa 46 & \\
\hline Francisco Corsi & $1616: 18 / 10$ & Goa 46 & \\
\hline Francisco Corsi & $1619: 3 / 4$ & Goa 46 & \\
\hline Francisco Corsi & $1620: 28 / 9$ & Goa 46 & \\
\hline Francisco Corsi & $1624: 17 / 9$ & Goa 46 & \\
\hline Francisco Corsi & $1626: 15 / 10$ & Goa 46 & \\
\hline Francisco Corsi & $1622: / 12(?)$ & Goa 73 & \\
\hline
\end{tabular}




\begin{tabular}{|c|c|c|c|c|}
\hline $\begin{array}{l}\text { Francisco de } \\
\text { Monclaro }\end{array}$ & & $\begin{array}{c}11 \text { de Janeiro de } \\
1592\end{array}$ & & \\
\hline $\begin{array}{l}\text { Francisco } \\
\text { Fernandes }\end{array}$ & Chatigan & 14.11 .1599 & Goa 14, fl: 393 & Sobre Bengala \\
\hline $\begin{array}{l}\text { Francisco } \\
\text { Fernandes }\end{array}$ & Goa & 07.11 .1594 & Goa 14, fl:209-210 & \\
\hline $\begin{array}{l}\text { Francisco } \\
\text { Henriques }\end{array}$ & Fatehpur & 06.04 .1580 & $\begin{array}{l}\text { ARSI GOA } 38 \text { I, fl: } \\
121 \mathrm{r}-24 \mathrm{v}\end{array}$ & $\begin{array}{l}\text { Documenta Indica, v. } \\
\text { XII (1580-1583), } \\
\text { doc. } 01, \text { p. 03-08 }\end{array}$ \\
\hline Francisco Pasio & Goa & 13.10 .1580 & Goa 47, ff. 141r-42v & $\begin{array}{l}\text { Documenta Indica, v. } \\
\text { XII (1580-1583), } \\
\text { doc. 12, p.89-93. }\end{array}$ \\
\hline Francisco Cabral & Goa & 16.12 .1596 & $\begin{array}{l}\text { ARSI GOA 32, fl: } \\
\text { 600r-13v }\end{array}$ & $\begin{array}{l}\text { Documenta Indica, v. } \\
\text { XVIII (1595-1597), } \\
\text { doc. 82, p. 646-686 }\end{array}$ \\
\hline $\begin{array}{l}\text { Georgio de } \\
\text { Abraham }\end{array}$ & Cochim & 13.10 .93 & Goa 14 fl:34-35. & $\begin{array}{c}\text { Menciona a } \\
\text { conversão de Akbar } \\
\text { (?). }\end{array}$ \\
\hline $\begin{array}{l}\text { Georgius de } \\
\text { Castro }\end{array}$ & Cocini & 05.01 .1581 & $\begin{array}{l}\text { GOA } 13 \text { I, fl: } 56 \mathrm{r}- \\
57 \mathrm{v}\end{array}$ & $\begin{array}{l}\text { Documenta Indica, v. } \\
\text { XII (1580-1583), } \\
\text { doc. } 35, \text { p. } 245-7\end{array}$ \\
\hline Gil Pereira & Fatehpur & 05.06 .1579 & $\begin{array}{c}\text { Goa 12, fl:530-1; } \\
\text { Armário Jesuítico, } \\
\text { no } 28 \text { (Cartas do } \\
\text { Japão) ff. 85v-87 (?) }\end{array}$ & $\begin{array}{l}\text { Documenta Indica, v. } \\
\text { XI (1577-80), doc. } \\
\text { 80, p. } 593-598\end{array}$ \\
\hline Gregorii XIII & Roma & 18.02 .1582 & $\begin{array}{l}\text { Archivo secreto } \\
\text { vaticano; Inst. } 194 \text {, } \\
\text { fl: } 236 \text { r-v. }\end{array}$ & $\begin{array}{l}\text { Documenta Indica, v. } \\
\text { XII (1580-1583) }\end{array}$ \\
\hline $\begin{array}{c}\text { Informatio } \\
\text { anônima } 26.11 .82 \\
\text { e } 1582,91,96 \\
\text { (SIC). Goa 13, fl: } \\
139-61 .\end{array}$ & & & & \\
\hline Jerônimo Xavier & Goa & 28.10 .1594 & Goa 14, fl: 200 & \\
\hline Jerônimo Xavier & & 11.01 .1581 & Lus.68 fl.280-280v. & \\
\hline
\end{tabular}




\begin{tabular}{|c|c|c|c|c|}
\hline Jerônimo Xavier & Lahore/Caxemira & 18.08 .1597 & Goa 14, fl:344-45 & \\
\hline Jerônimo Xavier & & $\begin{array}{l}\text { de } 20 \text { de abril } \\
\text { de } 1580\end{array}$ & $\begin{array}{c}\text { Lus. } 68, \text { fl.279- } \\
\text { 279v. }\end{array}$ & $\begin{array}{l}\text { Documenta Indica, v. } \\
\text { XII (1580-1583), } \\
\text { doc. 02, p. 08-10 }\end{array}$ \\
\hline Jerônimo Xavier & Ulyssipone & $\begin{array}{c}11 \text { de Janeiro de } \\
1581 .\end{array}$ & $\begin{array}{c}\text { Lus } 68, \text { fl: } 280- \\
280 \mathrm{v} .\end{array}$ & $\begin{array}{l}\text { Documenta Indica, v. } \\
\text { XII (1580-1583), } \\
\text { doc. } 36, \text { p. } 247-8\end{array}$ \\
\hline Jerônimo Xavier & Cochim & 02.01 .1587 & Goa 13 II, fl:335-7 & \\
\hline Jerônimo Xavier & Cochim & 01.01 .1589 & Goa 13 II, fl:338-9 & \\
\hline Jerônimo Xavier & Cochinla & 28.12 .1587 & Goa 13 II, fl: $378-80$ & \\
\hline Jerônimo Xavier & Goa & 12.11 .1593 & Goa 14, fl: 59-64 & \\
\hline Jerônimo Xavier & Goa & 25.10 .1582 & $\begin{array}{c}\text { GOA 47, fl: } 185- \\
\text { 86v }\end{array}$ & $\begin{array}{c}\text { Documenta Indica, v. } \\
\text { XII (1580-1583), } \\
\text { doc. } 111, \text { p.627-35 }\end{array}$ \\
\hline Jerônimo Xavier & Lahore & 08.09 .1596 & $\begin{array}{l}\text { ARSI GOA } 46 \text { I ff. } \\
23 r-34 v .\end{array}$ & \begin{tabular}{|c} 
Documenta Indica, v. \\
XVIII (1595-1597), \\
doc. 72, p. 539-584. \\
ARSI GOA 46 I ff. \\
23r-34v. \\
\end{tabular} \\
\hline Jerônimo Xavier & $\begin{array}{l}\text { Srinagar, } \\
\text { Caxemira }\end{array}$ & 18.08 .1597 & $\begin{array}{l}\text { ARSI GOA 14, } \\
\text { fl:344r-45v. }\end{array}$ & $\begin{array}{l}\text { Documenta Indica, v. } \\
\text { XVIII (1595-1597), } \\
\text { doc. } 102 \text {, p. 826-836 }\end{array}$ \\
\hline Jerônimo Xavier & $\begin{array}{l}\text { Srinagar, } \\
\text { Caxemira }\end{array}$ & 01.09 .1597 & & \begin{tabular}{|c} 
Documenta Indica, v. \\
XVIII(1595-1597), \\
doc. 103, p. 837-840 \\
ou ALCAZAR. \\
Chrono-Historia de \\
la Compañia de \\
Jesus. Madrid, 1710, \\
p. $207-209$ \\
\end{tabular} \\
\hline João Cabral & & $1566: 15 / 11$ & $\begin{array}{c}\text { Japsin 6. fl: } 175- \\
181 \mathrm{v} .\end{array}$ & \\
\hline
\end{tabular}




\begin{tabular}{|c|c|c|c|c|}
\hline João Cabral & & 1654:1.d(?) & Japsin 19. & \\
\hline João Cabral & & $\begin{array}{c}1661: 18 / 9 ; 10.17 \\
.31 / 10 \text { (SIC) }\end{array}$ & Lus 75. & \\
\hline João Cabral & & $1663: 26 / 12$ & Goa 9. & \\
\hline João Cabral & & $1628: 17 / 6$ & Goa 18. & \\
\hline João Cabral & & 1635 & Japsin 22.334(SIC) & $\begin{array}{c}\text { Por indicações } \\
\text { posteriores anexadas } \\
\text { na carta, ela deve ter } \\
\text { sido escrita em } 1655 .\end{array}$ \\
\hline Jorge Gomes & Goa & 16.11.1594 & Goa 14, fl:228-9. & $\begin{array}{l}\text { Sobre o Mogol, mas } \\
\text { praticamente } \\
\text { ilegível. }\end{array}$ \\
\hline José de Castro & Agra & 08.10 .1633 & Goa 18, fl:141-2. & $\begin{array}{l}\text { Narrat historiam suar } \\
\text { vitae et missionis } \\
\text { mogolensis }\end{array}$ \\
\hline Laertio & Cochim & 15.01.1604. & $\begin{array}{c}\text { Goa 15, fl:207- } \\
9 ; 211-12 .\end{array}$ & Parte sobre Bengala \\
\hline Laertio & & 25.11.1611, & Goa 17, fl:54-5. & $\begin{array}{l}\text { Pequeno parágrafo } \\
\text { sobre os passa em } \\
\text { Bengala. }\end{array}$ \\
\hline Laertio & & 16.12 .1582 & Goa 13, fl: 129-30 & Sobre o Mogol \\
\hline $\begin{array}{l}\text { Ludovico (?) da } \\
\text { Silva }\end{array}$ & Ugolim & 26.11.1685. & Goa 19, fl:137. & $\begin{array}{l}\text { De fundatione } \\
\text { colégii bengalensis }\end{array}$ \\
\hline $\begin{array}{l}\text { Manuel (?) } \\
\text { Pinheiro }\end{array}$ & Lahore & 25.08 .1599 & Goa 14, fl:383-4 & \\
\hline Manuel Pinheiro & Lahore & 12.08 .1605 & & $\begin{array}{c}\text { Documentação } \\
\text { ultramarina } \\
\text { portuguesa III, p.30- } \\
46\end{array}$ \\
\hline
\end{tabular}




\begin{tabular}{|c|c|c|c|c|}
\hline Manuel Dias & Goa & 07.12 .1596 & Goa 14, fl: $325-6$ & $\begin{array}{l}\text { Sobre a eleição de } \\
\text { N. Pimenta para } \\
\text { visitador }\end{array}$ \\
\hline Mateus Ricci & Goa & 25.11 .1581 & Goa 47, fl: 195r-96v & $\begin{array}{l}\text { Documenta Indica, v. } \\
\text { XII (1580-1583), } \\
\text { doc. } 72, \text { p.448-52 }\end{array}$ \\
\hline Mateus Ricci & Goa & 01.12 .1581 & $\begin{array}{l}\text { ARSI GOA } 38 \text { I, fl: } \\
129 \mathrm{r}-20 \mathrm{v}\end{array}$ & $\begin{array}{l}\text { Documenta Indica, v. } \\
\text { XII (1580-1583), } \\
\text { doc. } 75, \text { p.471-477 }\end{array}$ \\
\hline Matthaeus Ricci & Cocino & 30.01 .1580 & & $\begin{array}{l}\text { Documenta Indica, v. } \\
\text { XI (1577-80), doc. } \\
118, \text { p. } 845-847\end{array}$ \\
\hline Nicolau Pimenta & Margan & $\begin{array}{l}1 \text { de dezembro } \\
\text { de } 1601\end{array}$ & Goa 09, fl.08-14. & \begin{tabular}{|c|} 
Journal ... of the \\
asiatic society, new \\
series, vol. XXIII, \\
1927. Calcuta, 1929 \\
\end{tabular} \\
\hline Nicolau Pimenta & & 1592: $15 / 1.28 / 2$ & Lus 71 & \\
\hline Nicolau Pimenta & & $1594: 22 / 6$ & Lus 72 & \\
\hline Nicolau Pimenta & & $1596: 15 / 2.9 / 4$ & Lus 73 & \\
\hline Nicolau Pimenta & Goa & 09.12 .1599 & Goa 14, fl:412-13 & $\begin{array}{l}\text { Em latim. Parece ser } \\
\text { sobre Damão }\end{array}$ \\
\hline Nicolau Pimenta & & 1599:13/1 & Japsin 13 fl:236-7v & \\
\hline Nicolau Pimenta & & 1606:6/12 & Goa 9 & \\
\hline Nicolau Pimenta & & 1596:1/12 (?). & Goa 14 & \\
\hline Nicolau Pimenta & & 1599:9/12 & Goa 14 & \\
\hline
\end{tabular}




\begin{tabular}{|c|c|c|c|c|}
\hline Nicolau Pimenta & & $\begin{array}{l}\text { 1613:1.2/1 } \\
\quad \text { (SIC) }\end{array}$ & Goa 17 & \\
\hline Nicolau Pimenta & & 1.11 .1601 & Goa 48 & $\begin{array}{c}\text { Carta anua de } \\
\text { Nicolau Pimenta. }\end{array}$ \\
\hline Nicolau Pimenta & Évora & $\begin{array}{c}31 \text { de janeiro de } \\
1587\end{array}$ & Lus.70, fl.44-44v & \\
\hline Nicolau Pimenta & Goa & 21.12.1599 & $\begin{array}{c}\text { ARSI GOA } 32 \mathrm{ff} . \\
691-699\end{array}$ & \begin{tabular}{|c|} 
Journal ... of the \\
asiatic society, new \\
series, vol. XXIII, \\
1927. Calcuta, 1929 \\
\end{tabular} \\
\hline Nicolau Pimenta & Goa & 13.01.1599 (?) & $\begin{array}{c}\text { ARSI GOA } 32 \mathrm{ff} . \\
691-710\end{array}$ & \\
\hline $\begin{array}{c}\text { Novas que } \\
\text { vieram da Índia } \\
\text { Oriental anno } \\
1582\end{array}$ & & & $\begin{array}{l}\text { Armário Jesuítico, } \\
\text { cod. } 28 \text { ff. } 162 \mathrm{r}-64 \mathrm{v} \text {. }\end{array}$ & \begin{tabular}{|c} 
[Pater S.I. Sociis \\
Lusitanis]. [Goa, \\
dezembro] de 1582. \\
Documenta Indica, v. \\
XII (1580-1583), \\
doc. 118A, p.675- \\
683 \\
\end{tabular} \\
\hline Nuno Rodrigues & & & Lus.69, fl.120-120v & $\begin{array}{l}\text { " de suis desideriis } \\
\text { urutus in Índia ". }\end{array}$ \\
\hline Nuno Rodrigues & Goa & 11.11 .1582 & $\begin{array}{c}\text { GOA 47, fl: } 227 r- \\
29 v\end{array}$ & $\begin{array}{l}\text { Documenta Indica, v. } \\
\text { XII }(1580-1583), \\
\text { doc. } 113, \text { p.637-644 }\end{array}$ \\
\hline P. Francisco & Nagapatão & 30.08 .1614 . & Goa 17, fl:130-1. & Sobre Bengala \\
\hline $\begin{array}{c}\text { Praelatorum } \\
\text { orientis Lusitani } \\
\text { votum de } \\
\text { suscipienda a } \\
\text { iesuitis missione } \\
\text { ab imperatore } \\
\text { akbar petita } \\
\end{array}$ & Goa & 07.11 .1579 & $\begin{array}{l}\text { Armário Jesuítico, } \\
\text { no }^{\circ} 28 \text { (Cartas do } \\
\text { Japão) ff. 89r-90r }\end{array}$ & $\begin{array}{l}\text { Documenta Indica, v. } \\
\text { XI (1577-80), doc. } \\
\text { 91, p. 679-682. }\end{array}$ \\
\hline $\begin{array}{l}\text { Relação de } \\
\text { Equebar }\end{array}$ & & & $\begin{array}{l}\text { Armário Jesuítico, } \\
\text { no } 28 \text { (Cartas do } \\
\text { Japão) ff. } 815\end{array}$ & $\begin{array}{l}\text { Documenta Indica, v. } \\
\text { XII (1580-1583), } \\
\text { doc. } 114, \text { p.645-662 }\end{array}$ \\
\hline $\begin{array}{l}\text { Rodolfo } \\
\text { Acquaviva }\end{array}$ & Ulyssipone & $\begin{array}{l}25 \text { fevereiro } \\
1578\end{array}$ & Jap-sin 37 fl:92-3. & \\
\hline
\end{tabular}




\begin{tabular}{|c|c|c|c|c|}
\hline $\begin{array}{l}\text { Rodolfo } \\
\text { Acquaviva }\end{array}$ & Goa & $\begin{array}{l}31 \text { de outubro } \\
\text { de } 1578\end{array}$ & Jap-sin 37 fl: 94-6. & \\
\hline $\begin{array}{l}\text { Rodolfo } \\
\text { Acquaviva }\end{array}$ & $\begin{array}{l}\text { Fatibur in Mogol } \\
\text { (SIC) }\end{array}$ & $\begin{array}{c}18 \text { de julho de } \\
1580,\end{array}$ & $\begin{array}{l}\text { Jap-sin } 37 \text { fl: } 98-99- \\
102 \text { ou Jap-sin. } 37 \\
\text { fl: } 100 \mathrm{r}-02 \mathrm{v}\end{array}$ & $\begin{array}{c}\text { Documenta Indica, v. } \\
\text { XII (1580-1583), } \\
\text { doc. 06, p.44-52 }\end{array}$ \\
\hline $\begin{array}{l}\text { Rodolfo } \\
\text { Acquaviva }\end{array}$ & $\begin{array}{l}\text { Fatibur in Mogol } \\
\text { (SIC) }\end{array}$ & $\begin{array}{c}29 \text { de julho de } \\
1581\end{array}$ & Jap-sin 37 fl: 103-4. & $\begin{array}{l}\text { Documenta Indica, v. } \\
\text { XII (1580-1583), } \\
\text { doc. } 50, \text { p. } 289-91\end{array}$ \\
\hline $\begin{array}{l}\text { Rodolfo } \\
\text { Acquaviva }\end{array}$ & $\begin{array}{l}\text { Fatibur in Mogol } \\
\text { (SIC) }\end{array}$ & $\begin{array}{c}25 \text { de abril de } \\
1582\end{array}$ & $\begin{array}{c}\text { Jap-sin 37, fl: 109r- } \\
111 \mathrm{v}\end{array}$ & $\begin{array}{l}\text { Documenta Indica, v. } \\
\text { XII (1580-1583), } \\
\text { doc. } 106, \text { p.582-586 }\end{array}$ \\
\hline $\begin{array}{l}\text { Rodolfo } \\
\text { Acquaviva }\end{array}$ & $\begin{array}{l}\text { Fatibur in Mogol } \\
\text { (SIC) }\end{array}$ & $\begin{array}{c}24 \text { de julho de } \\
1582\end{array}$ & $\begin{array}{c}\text { Jap-sin } 37 \text { fl: } 112- \\
115 .\end{array}$ & $\begin{array}{l}\text { Documenta Indica, v. } \\
\text { XII (1580-1583), } \\
\text { doc. } 108, \text { p.588-593 }\end{array}$ \\
\hline $\begin{array}{l}\text { Rodolfo } \\
\text { Acquaviva }\end{array}$ & $\begin{array}{l}\text { Fatibur in Mogol } \\
\text { (SIC) }\end{array}$ & $\begin{array}{c}30 \text { de julho de } \\
1581\end{array}$ & Jap-sin 37 fl: 105-8. & $\begin{array}{l}\text { Documenta Indica, v. } \\
\text { XII (1580-1583), } \\
\text { doc. } 51, \text { p. 291-295 }\end{array}$ \\
\hline $\begin{array}{l}\text { Rodolfo } \\
\text { Acquaviva }\end{array}$ & Agra & 13.07 .1580 & $\begin{array}{l}\text { Armário Jesuítico } \\
\mathrm{n}^{\circ} 28, \text { ff.109r-12v. }\end{array}$ & $\begin{array}{c}\text { Documenta Indica, v. } \\
\text { XII (1580-1583), } \\
\text { doc. } 05, \mathrm{p} .34-44\end{array}$ \\
\hline $\begin{array}{l}\text { Rodolfo } \\
\text { Acquaviva }\end{array}$ & Fatehpur & 20.07 .1580 & $\begin{array}{c}\text { Jap-sin. } 37, \text { fl: } 100 \mathrm{r}- \\
02 \mathrm{v} \text { ou Armário } \\
\text { Jesuítico, } \mathrm{n}^{\circ} 28, \mathrm{ff} \text {. } \\
112 \mathrm{v}-14 \mathrm{r} \text { ou ARSI } \\
\text { GOA } 46 \mathrm{I} \text { fl: } 17 \mathrm{r}- \\
18 \mathrm{v} \\
\end{array}$ & $\begin{array}{l}\text { Documenta Indica, v. } \\
\text { XII (1580-1583), } \\
\text { doc. 07, p.52-59 }\end{array}$ \\
\hline $\begin{array}{l}\text { Rodolfo } \\
\text { Acquaviva }\end{array}$ & Fatehpur & 10.09 .1580 & $\begin{array}{l}\text { Rom. 192, ff. 76r- } \\
77 \mathrm{r}\end{array}$ & $\begin{array}{l}\text { Documenta Indica, v. } \\
\text { XII (1580-1583), } \\
\text { doc. 09, p.77-81. }\end{array}$ \\
\hline $\begin{array}{l}\text { Rodolfo } \\
\text { Acquaviva }\end{array}$ & $\begin{array}{l}\text { Fatibur in Mogol } \\
\text { (SIC) }\end{array}$ & $\begin{array}{c}24 \text { de julho de } \\
1582 \text { ou } \\
27.09 .1582 ?\end{array}$ & $\begin{array}{l}\text { Jap-sin } 37 \text { fl: 112- } \\
\text { 115; ou London, } \\
\text { British Museum, } \\
\text { add. Mss, 9854, fl: } \\
\text { 1-4. Publicação: } \\
\text { Documentação } \\
\text { ultramarina } \\
\text { portuguesa III, p.3-5 }\end{array}$ & $\begin{array}{l}\text { Documenta Indica, v. } \\
\text { XII (1580-1583), } \\
\text { doc. } 109, \text { p.595-600 }\end{array}$ \\
\hline Ruy Vicente & Goa & 27.03 .1580 & $\begin{array}{l}\text { GOA } 13, \text { I, fl: } 11 \mathrm{r}-\mathrm{v} \\
\quad+14 \mathrm{r}-\mathrm{v}-(\mathrm{sic})\end{array}$ & $\begin{array}{l}\text { Documenta Indica, v. } \\
\text { XI (1577-80), doc. } \\
119, \text { p. } 848-852\end{array}$ \\
\hline Simão de Sá & Goa & 01.01 .1598 & $\begin{array}{l}\text { ARSI GOA } 32 \text { I, fl: } \\
622-41 \mathrm{v} \text {. }\end{array}$ & $\begin{array}{l}\text { Documenta Indica, v. } \\
\text { XVIII (1595-1597), } \\
\text { doc. } 102 \text {, p. } 826-836\end{array}$ \\
\hline
\end{tabular}




\begin{tabular}{|c|c|c|c|c|}
\hline Vaz Gomes & Cochim & 21.12 .1600$. & Goa 15, fl:18-9. & Akbar. \\
\hline Vicente (?) & Goa & 20.10 .1580 & $\begin{array}{c}\text { ARSI GOA 31 ff } \\
431-40 \mathrm{v}+441-42 \mathrm{v}\end{array}$ & $\begin{array}{c}\text { Documenta Indica, v. } \\
\text { XII (1580-1583), } \\
\text { doc. 13, p.93-114 }\end{array}$ \\
\hline Vicente (?) & Goa & $6-7.11 .1581$ & $\begin{array}{c}\text { Goa 74, fl: 333r-34v } \\
\text { Documenta Indica, v. } \\
\text { XII (1580-1583), } \\
\text { doc. 64, p. 375-384 }\end{array}$ \\
\hline Vicente (?) & Goa & 08.11 .1581 & $\begin{array}{c}\text { Várias indicações } \\
\text { em ARSI GOA 32 e } \\
47\end{array}$ & $\begin{array}{c}\text { Xocumenta Indica, v. } \\
\text { XI580-1583), } \\
\text { doc. 68, p.403-31. }\end{array}$ \\
\hline Vicente (?) & Goa & 21.10 .1582 & $\begin{array}{c}\text { Várias indicações } \\
\text { em ARSI GOA 32 e } \\
47\end{array}$ & $\begin{array}{c}\text { XII (1580-1583), } \\
\text { Documenta Indica, v. } \\
\text { doc. 110, p.600-627. }\end{array}$ \\
\hline
\end{tabular}


APÊNDICE H: SUMÁRIO PARCIAL DOS DOCUMENTOS ENCONTRADOS NO ARMÁRIO

JESuítico, LIVRO 28, ARQUiVo NACIONAL DA TORRE DO TOMBO (ANTT), LISBOA,

PORTUGAL. 723

\begin{tabular}{|c|c|c|c|c|}
\hline Remetente ou Título & Local & Data & Localização & Publicação \\
\hline $\begin{array}{l}\text { Praelatorum orientis } \\
\text { Lusitani votum de } \\
\text { suscipienda a iesuitis } \\
\text { missione ab imperatore } \\
\text { akbar petita }\end{array}$ & Goa & 07.11 .1579 & $\begin{array}{c}\text { Armário Jesuítico, no } 28 \\
\text { (Cartas do Japão) ff. } \\
\text { 89r-90r }\end{array}$ & $\begin{array}{l}\text { Documenta Indica, v. XI } \\
(1577-80), \text { doc. } 91, \text { p. 679- } \\
682 .\end{array}$ \\
\hline Rodolfo Acquaviva & Agra & 13.07 .1580 & $\begin{array}{l}\text { Armário Jesuítico n²8, } \\
\text { ff.109r-12v. }\end{array}$ & $\begin{array}{c}\text { Documenta Indica, v. XII } \\
\text { (1580-1583), doc. 05, } \\
\text { p.34-44 }\end{array}$ \\
\hline Rodolfo Acquaviva & Fatehpur & 20.07 .1580 & $\begin{array}{c}\text { Jap-sin. 37, fl: 100r-02v } \\
\text { ou Armário Jesuítico, } \\
\text { n²8, ff. 112v-14r ou } \\
\text { ARSI GOA 46 I fl: } 17 \mathrm{r}- \\
18 \mathrm{v}\end{array}$ & $\begin{array}{c}\text { Documenta Indica, v. XII } \\
\text { (1580-1583), doc. 07, } \\
\text { p.52-59 }\end{array}$ \\
\hline Eduardus de Sande & Goa & 07.11 .1579 & $\begin{array}{c}\text { Armário Jesuítico, no } 28 \\
\text { (Cartas do Japão) ff. } \\
\text { 118v-20r }\end{array}$ & $\begin{array}{c}\text { Documenta Indica, v. XI } \\
(1577-80), \text { doc. } 90, \text { p. 672- } \\
679 .\end{array}$ \\
\hline $\begin{array}{c}\text { Novas que vieram da } \\
\text { Índia Oriental anno } \\
1582\end{array}$ & & & $\begin{array}{l}\text { Armário Jesuítico, cod. } \\
28 \text { ff. 162r-64v. }\end{array}$ & $\begin{array}{c}\text { [Pater S.I. Sociis } \\
\text { Lusitanis]. [Goa, } \\
\text { dezembro] de 1582. } \\
\text { Documenta Indica, v. XII } \\
(1580-1583), \text { doc. } 118 \mathrm{~A}, \\
\text { p.675-683 } \\
\end{array}$ \\
\hline $\begin{array}{c}\text { Anua da Província da } \\
\text { Índia }\end{array}$ & & 16.10 .1578 & $\begin{array}{c}\text { Armário Jesuítico, cod. } \\
28 \text { ff. 66-79 }\end{array}$ & \\
\hline $\begin{array}{c}\text { Sumário das novas que } \\
\text { vieram das ilhas } \\
\text { molucas do ano de } \\
1578\end{array}$ & & & $\begin{array}{l}\text { Armário Jesuítico, cod. } \\
28 \text { ff. 79-80v }\end{array}$ & \\
\hline Relação de Equebar & & & $\begin{array}{l}\text { Armário Jesuítico, no } 28 \\
\text { ff. } 81-5\end{array}$ & $\begin{array}{c}\text { Documenta Indica, v. XII } \\
\text { (1580-1583), doc. } 114, \\
\text { p.645-662 }\end{array}$ \\
\hline $\begin{array}{c}\text { Cópia de uma do padre } \\
\text { Gileanes (?) Pereira } \\
\text { para o arcebispo de } \\
\text { Goa }\end{array}$ & Fatehpur & 05.06 .79 & $\begin{array}{l}\text { Armário Jesuítico, no } 28 \\
\text { ff. } 85 \mathrm{v}-87\end{array}$ & \\
\hline
\end{tabular}

${ }^{723}$ Deu-se prioridade a identificação e indicação das cartas relativas ao mogor e as anuas da Índia. Outras fontes não foram identificadas. 


\begin{tabular}{|c|c|c|c|c|}
\hline $\begin{array}{c}\text { Cópia de um capítulo de outra carta do mesmo } \\
\text { padre... }\end{array}$ & & & $\begin{array}{c}\text { Armário } \\
\text { Jesuítico, } \mathrm{n}^{\circ} \\
28 \mathrm{ff} .87-88 \mathrm{v}\end{array}$ & \\
\hline $\begin{array}{c}\text { Cópia de um capítulo de uma carta de pero } \\
\text { Tavares... }\end{array}$ & Goa & 1579 (sic) & $\begin{array}{c}\text { Armário } \\
\text { jesuítico, } \\
\mathrm{n}^{\mathrm{o}} 28 \mathrm{ff} .88 \mathrm{v}- \\
89 \mathrm{r}\end{array}$ & $\begin{array}{c}\text { Documenta } \\
\text { Indica, v. XI } \\
(1577-80) \text {, doc. } \\
49, \text { p. } 427-430 \\
\end{array}$ \\
\hline $\begin{array}{c}\text { Conselho do Arcebispo de Goa e demais } \\
\text { arcebispos da Índia sobre o que faria acerca da } \\
\text { embaixada do Grão Mogol }\end{array}$ & & & $\begin{array}{l}\text { Armário } \\
\text { jesuítico, } \\
\text { no28 ff. } 89- \\
\quad 90\end{array}$ & \\
\hline $\begin{array}{c}\text { Cópia de uma [carta] da Índia para a província } \\
\text { de portugal no ano de } 1579\end{array}$ & & & $\begin{array}{l}\text { Armário } \\
\text { jesuítico, } \\
\mathrm{n}^{\circ} 28 \text { ff. } 90- \\
93 \mathrm{v}\end{array}$ & \\
\hline Pero Gomes & Goa & 17.11 .1579 & \begin{tabular}{|c|} 
Armário \\
jesuítico, \\
$\mathrm{n}^{\circ} 28 \mathrm{ff} .93 \mathrm{v}-$ \\
$97 \mathrm{v}$ \\
\end{tabular} & \\
\hline $\begin{array}{c}\text { Traslado de uma carta que o visitador A. } \\
\text { Vellignano escreveu da China }\end{array}$ & Macau & 09.02 .1579 & $\begin{array}{c}\text { Armário } \\
\text { jesuítico, } \\
\mathrm{n}^{\circ} 28 \text { ff. } 98- \\
99 \mathrm{v}\end{array}$ & \\
\hline $\begin{array}{c}\text { Carta do padre Luis Froes que escreveu de } \\
\text { Bungo }\end{array}$ & & [18.10.15?] & \begin{tabular}{|c} 
Armário \\
jesuítico, \\
$\mathrm{n}^{\circ} 28 \mathrm{ff} .99 \mathrm{v}-$ \\
$102 \mathrm{r}$ \\
\end{tabular} & \\
\hline $\begin{array}{c}\text { Carta que escreveu o padre [Organtiro?] do } \\
\text { reino de Macau }\end{array}$ & & & $\begin{array}{l}\text { Armário } \\
\text { jesuítico, } \\
\text { nº } 28 \mathrm{ff} . \\
102 \mathrm{r}-104 \mathrm{v}\end{array}$ & \\
\hline $\begin{array}{c}\text { Carta que o padre Francisco Anriques escreveu } \\
\text { de Fatehpur no reino dos Mogores a } 6 \text { de abril } \\
\text { de } 1580 \text { anos }\end{array}$ & & & $\begin{array}{l}\text { Armário } \\
\text { jesuítico, } \\
\text { nº } 28 \mathrm{ff.} \\
104 \mathrm{v}-106 \mathrm{r}\end{array}$ & \\
\hline
\end{tabular}




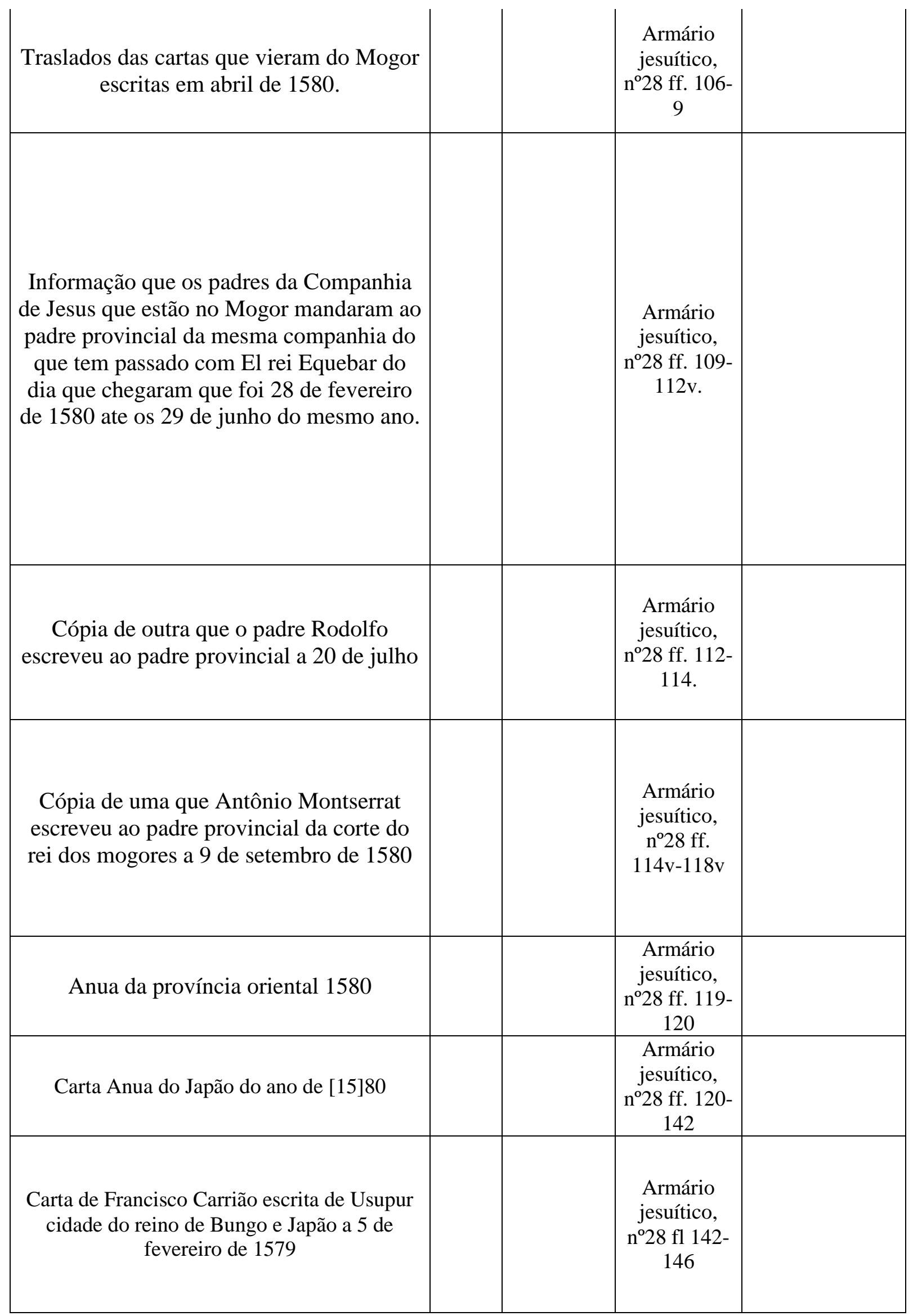




\begin{tabular}{|c|c|c|}
\hline Cópia da anua da Índia oriental & & $\begin{array}{l}\text { Armário } \\
\text { jesuítico, } \\
\mathrm{n}^{\circ} 28 \mathrm{ff} . \\
146 \mathrm{v}-148 .\end{array}$ \\
\hline Da anua de Cochim [de Duarte Leitão] & & $\begin{array}{c}\text { Armário } \\
\text { jesuítico, } \\
\text { n²8 ff. } \\
148 \mathrm{v}-149\end{array}$ \\
\hline Carta geral do Japão [de Luis Froes] & 19.05 .1581 & $\begin{array}{c}\text { Armário } \\
\text { jesuítico, } \\
\text { no } 28 \text { ff. } 149- \\
153 \\
\end{array}$ \\
\hline $\begin{array}{l}\text { De outra do Padre Luis Froes para um padre } \\
\text { da Companhia }\end{array}$ & & $\begin{array}{c}\text { Armário } \\
\text { jesuítico, } \\
\mathrm{n}^{\circ} 28 \mathrm{ff} .153- \\
155\end{array}$ \\
\hline Carta do padre Luis Froes do Japão & 14.04 .1581 & $\begin{array}{c}\text { Armário } \\
\text { jesuítico, } \\
\text { no } 28 \text { ff.156- }^{61} \\
\end{array}$ \\
\hline $\begin{array}{l}\text { Novas que vieram da Índia oriental do ano } \\
\text { de } 1582\end{array}$ & & $\begin{array}{c}\text { Armário } \\
\text { jesuítico, } \\
\text { no } 28 \text { ff. 162- } \\
170 . \\
\end{array}$ \\
\hline $\begin{array}{c}\text { Carta que o padre Rodolfo Acquaviva } \\
\text { escreveu do reino de mogores ao padre Rui } \\
\text { Vicente provincial da Índia } 1582\end{array}$ & & $\begin{array}{l}\text { Armário } \\
\text { jesuítico, } \\
\mathrm{n}^{\circ} 28 \mathrm{ff} .170- \\
171 \mathrm{v} .\end{array}$ \\
\hline $\begin{array}{c}\text { Carta que o padre Pero Gomes escreveu de } \\
\text { Amacao (?) acerca do seu naufrágio que fez } \\
\text { indo da China para o Japão }\end{array}$ & 13.12 .1582 & $\begin{array}{c}\text { Armário } \\
\text { jesuítico, } \\
\text { no2 } 28 \mathrm{ff.} 171- \\
175\end{array}$ \\
\hline
\end{tabular}


APÊNDICE I: RESUMO DA TESE, EM FRANCÊS, PARA DEPÓSITO NA EHESS 
ÉCOLE DES HAUTES ÉTUDES EN SCIENCES SOCIALES

Centre d'Études de l'Inde et de l'Asie du Sud (CEIAS)

\section{POLITIQUE ET RHÉTORIQUE: DES LETTRES ET DES STRATÉGIES DE CONVERSION AU MOGOL, AU TIBET, ET AU BENGALE (XVI-XVIII)}


Directeur de thèse: Carlos Alberto de Moura Ribeiro Zeron (FFLCH-USP) Codirectrice de thèse: Ines Zupanov (EHESS-CEIAS)

São Paulo - Paris

2014

\section{Prologue}

En 1510, les Portugais occupèrent l'île de Goa. Seize ans plus tard, une armée venant de l'Afghanistan et de l'Asie Centrale et commandée par un turc appelé Babur - futur fondateur de la dynastie mogole - envahit le Nord de l'Inde. C'est son petit-fils Akbar (15561605) qui consolidera l'Empire Mogol en étendant son territoire. Akbar, de surcrô̂t, engagea d'importantes réformes structurelles d'ordre social, politique et culturel.

Par l'intermédiaire de commerçants portugais qui "mordillaient" la côte du souscontinent indien, Akbar prend connaissance de l'existence du christianisme. Le premier contact de l'empereur avec les Portugais se fera en 1573 lors du siège qu'il mène contre le 
sultanat de Gujarat, à l'occasion des pourparlers engagés avec une députation commandée par un certain Antônio Cabral.

En 1576, Akbar apprend que deux jésuites du Bengale s'étaient récusés à absoudre les négociants chrétiens qui refusaient de payer leurs impôts. Il décide alors d'inviter un prêtre appelé Julião, (également connu sous les noms de Julianes ou Gileanes) Pereira, à venir à sa cour à Fatehpur Sikri. Julião arrive en mars 1579.

Ce prêtre, qui n'était pas jésuite participe à divers débats en présence du souverain, avec lequel il s'entretenait fréquemment. Il semble, toutefois, que Pereira, un homme plus vertueux que cultivé, n'avait pas été capable de répondre de façon convaincante aux questions posées par l'empereur. A la suggestion du religieux, Akbar envoie alors un ambassadeur à Goa porteur de lettres adressées au Vice-Roi, à l'Archevêque et aux Jésuites, et demande que deux prêtres soient envoyés à sa cour.

A l'opposé des gentils, les suiveurs de Mahomet étaient vus par les chrétiens comme des renégats du christianisme, car ils étaient par définition une communauté moins réceptive à la Loi du Christ. Les difficultés de la réalisation de missions en milieu infidèle étaient bien connues, et jusqu'alors on croyait que l'empereur était un musulman fervent. L'analyse de la documentation - tout particulièrement celle qui a trait aux délibérations du Conseil - montre de façon très claire l'insécurité éprouvée par la communauté chrétienne en Inde concernant la possibilité d'envoyer un contingent de missionnaires à une partie du continent aussi éloignée de l'appui séculaire de la couronne portugaise. Toutefois, même devant ces obstacles apparents, l'installation de la mission - prometteuse du fait de partir de l'invitation d'un puissant souverain - fut décidée par les jésuites. Le 10 novembre 1579, une commission d'évêques se manifeste favorablement à l'envoi de religieux. Les prêtres choisis étaient Rodolfo Acquaviva, Antonio Montserrat et Francisco Henriques. Ce dernier, d'origine persane, né à Ormuz et converti de l'islamisme, remplirait les fonctions d'interprète attitré de la mission.

Nous débuterons donc notre analyse par l'observation de l'expérience de ces premiers jésuites qui, à la fin du XVI ${ }^{\mathrm{e}}$ siècle s'étaient installés dans le nord de l'Inde. Puis nous pousserons notre investigation jusqu'au XVIII ${ }^{\mathrm{e}}$ siècle en abordant la mission conduite par l'italien Ippolito Desideri au Tibet. Notre thèse est donc partagée en deux volets. Dans le premier nous nous consacrons aux missions établies en Inde mogole. Le deuxième volet aborde les initiatives de l'Ordre au Tibet, à Tsaparang et à Lhassa. 
Notre premier chapitre traite de l'œuvre produite à la fin du $\mathrm{XVI}^{\mathrm{e}}$ siècle par un jésuite catalan envoyé à la Cour mogole à l'occasion de la première tentative de la part de la Compagnie de Jésus d'y établir une mission. Antonio Monserrat avait à l'époque 34 ans. Il arriva à la ville de Fathepur Sikri en février 1580. L'œuvre en question a pour titre Mongolicae Legationis Commentarius. ${ }^{724}$ Nous nous sommes concentrés particulièrement sur les dialogues décrits par le jésuite dans son récit, car notre objectif est de situer les religieux chrétiens dans les débats promus par Akbar dans l'Ibādatkhānah, de contextualiser leur action et analyser leurs stratégies,

Dans le deuxième chapitre nous poursuivons l'analyse de l'action des missionnaires de la Compagnie de Jésus dans le nord de l'Inde. Nous continuons notre investigation sur les aspects dialogiques des stratégies de conversion en analysant l'oeuvre Fonte da Vida écrite par le missionnaire Jerônimo Xavier, né à Navarra, en l'an $1549 .{ }^{725}$ Notre hypothèse est que cet ouvrage peut être tenu comme une adaptation jésuitique d'un processus qui s'amorçait à la Cour d'Akbar, caractérisé par la traduction en langue persane d'œuvres sacrés d'autres religions que l'islamisme.

Nous chercherons à défendre l'idée que l'ouvrage Fonte da Vida, écrit sous forme de dialogue, est une espèce de raffinement des stratégies antérieures. Dans cet ouvrage, les débats ne semblent pas décrits en référence directe aux audiences promues par Akbar, et apparaissent strictement comme un genre littéraire au service des objectifs principaux des missionnaires : l'évangélisation et la conversion.

Dans la seconde partie de notre thèse, comme nous l'avons dit, nous abordons les missions jésuites au Tibet. Le troisième chapitre aura pour objet l'examen de la première mission établie à Tsaparang par le jésuite portugais Antonio de Andrade (1624-35). La question principale est encore une fois le rapport entre les disputes en tant que stratégies de conversion, et le contexte politique délicat dans lequel se trouvaient les rois du Tibet et les moines bouddhistes. Les premiers voyaient le clergé grandir à un rythme accéléré et suivaient les pas de l'Ecole Gelupa en direction d'une hégémonie politico-religieuse. Les derniers, étaient l'objet de représailles et souffraient des persécutions qui ont souvent débouché sur leur laïcisation forcée. Il convient de rappeler que le Tibet, pendant cette période, n'était pas un

${ }^{724}$ MONTSERRAT, A. Mongolicae Lagationis Comentarius. Apud: ALAY, J.L. Embajador en la corte del Gran Mogol. Traduction: Ramon Sala. Lleida : Milenio, 2006.

${ }^{725}$ XAVIER, J. Fuente de Vida: Traité apologétique adressé au Roi Mogol de l'Inde en 1600. San Sebástian: Universidad de Deusto, 2007. 
État théocratique et que par conséquence la figure centralisatrice du Dalaï Lama n'existait pas encore en tant que représentant des pouvoirs temporels et spirituels.

Nous avons utilisé comme sources pour ce chapitre les lettres jésuites qui se rapportaient à cette première initiative de l'Ordre au "sommet du monde". Ces rapports jouent dans le présent travail une double fonction : celle de nous procurer des descriptions de bouddhistes tibétains associées à des indications des stratégies utilisées, et celle de rendre témoignage des dernières années d'un Tibet laïque durant la période qui va de 1620 jusqu'à l'année de l'investiture du V ${ }^{\text {ème }}$ Dalaï Lama (1642).

Finalement, nous prendrons comme objet d'étude, dans notre quatrième chapitre, la mission conduite par le jésuite italien Ippolito Desideri, déjà au cours des premières décennies du XVIII ${ }^{\mathrm{e}}$ Siècle. Bien entendu, nous avons été attentifs aux grandes différences que cet intervalle de temps peut renfermer, tout particulièrement en ce qui concerne l'espace que la Compagnie de Jésus a perdu dans les plans missionnaires de l'Église, outre les conséquences des dites "Querelles des Rites" et des implications apportées par le déclin des couronnes ibériques dans le contexte mondial. D'autre part, nous croyons que notre dernière analyse peut être construite justement à partir de l'observation de ces conjonctures associées au parcours suivi par la Compagnie de Jésus aux "Indes".

Desideri s'est établi à Lhassa entre 1717 et 1721. Ce missionnaire a écrit un ouvrage intitulé Nouvelle Historique du Tibet (Notizie Istoriche del Thibet) composé de quatre tomes, dans lesquels nous avons décidé prioritairement d'analyser certains chapitres abordant de façon plus spécifique les thèmes traités dans notre thèse. Nous focaliserons notre attention sur les descriptions de la "secte des lamas" par Desideri et ses implications politiques, tout particulièrement en ce qui a trait au protocole de succession des Dalaï Lamas. Nous développerons notre analyse dans le but de montrer comment l'élaboration de la catégorie "gens aveugles" et son application au cas des tibétains s'est faite au moyen de l'observation de l'organisation socio-politique de cette société, et a constitué ainsi une étape fondamentale permettant d'établir la persuasion et le dialogue comme étant les stratégies les plus prudentes de conversion et de catéchèse dans le cas de la mission au Tibet.

A l'issue de ce parcours, nous aurons donc déjà abordé le thème de la relation entre la politique et la rhétorique jésuite - c'est-à-dire le bon usage de la parole dite et écrite, dont l'efficacité est nécessairement attelée à l'objectif final de l'Ordre : la conversion. Nous aurons ainsi proposé que l'action des religieux de la Compagnie de Jésus a été forcément associée à des pratiques discursives et à des élaborations linguistiques qui étayaient la prudente sélection 
des stratégies de conversion les plus appropriées. Ensuite, nous traiterons de façon résumée la façon dont s'est effectué le parcours de cette analyse dans la thèse, en explicitant principalement le cadre théorique qui a soutenu notre investigation, et les concepts fondamentaux qui ont permis l'avancée de notre recherche. 


\section{Politique, rhétorique et stratégies de conversion employées dans les missions jésuites au Mogol, au Tibet, et au Bengale (XVI-XVIII : un résumé.}

Si l'on n'étudie pas l'orientalisme en tant que discours, on est incapable de comprendre la discipline extrêmement systématique qui a permis à la culture européenne de gérer - et même de produire - l'Orient du point de vue politique, sociologique, militaire, idéologique, scientifique et imaginaire. ${ }^{726}$

Edward Said, dans l'introduction de son ouvrage "Orientalisme " faisait déjà ressortir les implications nécessaires entre le "discours" et la "pratique". Même en tenant compte des différences entre le cas ici étudié et l'objet de l'étude de Said, et en étant conscients des critiques que l'historiographie a adressé à cet auteur ${ }^{727}$, la réflexion sur les idées de celui-ci dans le contexte ici analysé continue valable. De façon analogue à ce que nous nous proposons de présenter, en raison des conjonctures différentes existantes, Said trace un rapport entre les discours sur l'Orient et le projet colonial européen de l'époque contemporaine de la même façon que nous supposons l'existence d'un rapport entre le projet évangélisateur et prosélytique de la Compagnie de Jésus, et la production, la circulation et la publication de récits de missionnaire en "Orient":

Les idées, les cultures et les histoires ne pourront être sérieusement comprises ou étudiées sans que leur force, ou plus précisément leurs configurations de pouvoir soient également étudiées. Il serait incorrect de croire que l'Occident a été créé - ou comme je le dis "orientalisé" - et croire que ces choses arrivent simplement comme un besoin de l'imagination. La relation entre l'Occident et l'Orient est une relation de pouvoir, de domination, à degrés divers, d'une hégémonie complexe. ${ }^{728}$

\footnotetext{
${ }^{726}$ SAID, E. Orientalismo: o Oriente como invenção do Ocidente. São Paulo: Companhia das Letras, 2007, p. 29-30. C'est nous qui traduisons.

${ }^{727}$ If Edward Said's Orientalism has unmasked the complicity of scientific representation with the workings of power and politics of location, it has also, by omission, reinforced that Jesuit and Catholic Orientalist texts from early modern period were simply insignificant." ZUPANOV, I. «Jesuit Orientalism; Correspondence between Tomas Pereira and Fernão de Queiros"IN: Tomás Pereira, S. J. (1646-1708), Life, Work and World, ed. Luis Barreto, Centro Cultural e Científico de Macau: Lisbon, 2010, p. 44.

${ }^{728}$ SAID, E. Orientalismo: o Oriente como invenção do Ocidente. São Paulo: Companhia das Letras, 2007, p. 32. C'est nous qui traduisons.
} 
Une fois établi le rapport entre politique et rhétorique que nous avons cherché à élaborer tout au long de cette thèse, nous avons pu apercevoir, dans les missions ici étudiées que les actions à fort caractère politique des missionnaires, associées à leur discipline rhétorique - qui n'avait rien d'ingénu - ont cheminé côte à côte. Les lettres et autres écrits ici analysés sont conçus et considérés en tant qu'un "espace de tension, de négociation [...] et principalement d'action" ${ }^{729}$ dont le rôle a été central dans la planification et l'actualisation de l'activité de la Compagnie de Jésus. Il est donc pertinent d'affirmer que les catégories élaborées par les jésuites ont joué un rôle semblable aux concepts antiétiques asymétriques définis par Koselleck ${ }^{730}$ : ils étaient politiquement efficaces, se voulaient universels, cherchaient à redéfinir les frontières entre les évangélisateurs et leurs possibles catéchumènes, prétendaient prévoir la stratégie de conversion la plus prudente, et fonctionnaient comme une articulation linguistique de structures mentales qui allaient réorganiser de façon incessante l'architecture géopolitique des Jésuites.

Les catégorisations ici référenciées peuvent être synthétisées dans des expressions telles que "gens discrets", " gens pieux"et "gens aveugles", expressions qui peuvent être trouvées, respectivement dans les écrits de Francisco Xavier, ${ }^{731}$ Antonio de Andrade ${ }^{732}$ et Ippolito Desideri. ${ }^{733}$ Nous soutenons, en outre, que les dialogues, en plus de leur propre fonction de stratégie, ont une valeur sémantique équivalente aux expressions ou catégories susmentionnées, et partagent la même fonction prédicative que ces compléments offrent aux sujets décrits.

Cette activité rhétorique - de description narrative, de discipline épistolaire, d'élaboration discursive, de participation à des forums de débats et de disputes, et de production de textes apologétiques et catéchismes - se trouve nécessairement associée à une observation prudente et à une action politique, compte tenu des particularités littéraires des "genres" ci-dessus énumérés. De cette sorte, du fait d'être complémentaires aux dites stratégies de conversion, ces concepts-clés élaborés dans le contexte du ministère de la

\footnotetext{
${ }^{729}$ LONDOÑO, Fernando Torres. Escrevendo Cartas. Jesuítas, escrita e missão no século XVI. In: Revista Brasileira de História. Vol. 22. № 43. São Paulo: 2002.

730 KOSELLECK, R. Futuro passado: contribuição à semântica dos tempos históricos. Rio de Janeiro, Contraponto / PUC-RJ, 2006, p. 208.

${ }^{731}$ XAVIER, F. Cartas y escritos de San Francisco Javier. Noté par Felix Zubillaga, S.J. Madrid: Editorial Católica, 1968, p. 395.

${ }^{732}$ Lettre écrite par Antônio de Andrade, le 15 août 1626. In: DIDIER, H. Os portugueses no Tibete. Os primeiros relatos dos jesuítas (1624-1635). Lisboa: Comissão Nacional para Comemoração dos Descobrimentos Portugueses, 2000, p. 107.

${ }^{733}$ DESIDERI, I. Notizie Istoriche del Tibet.Apud: PETECH, L. I Missionari italiani nel Tibet e nel Nepal. Libreria dello Stato: Roma, 1952-1956.
} 
parole, peuvent être également dénommés stratégies épistémologiques ou représentationnelles ${ }^{734}$.

Dans cette thèse, donc, nous nous consacrons à l'étude des missions ci-dessus répertoriées, en nous concentrant sur la question des disputes en tant que stratégies de conversion, associées à la (re)élaboration de catégories qui indiqueraient et appuieraient le dialogue et la conviction comme méthode catéchétique. Par le terme stratégie, nous voulons indiquer une série d'actions visant à un but donné : l'évangélisation et la conversion. Par conversion, nous entendons un processus de transition d'un système religieux à un autre, ou d'une absence de confession religieuse à l'adoption d'une religion. Dans les cas ici traités, la conversion signifierait plus spécifiquement la reconnaissance et l'acceptation de la doctrine catholique et de l'autorité papale. ${ }^{735}$ A ce propos, nous avons également jugé pertinent de prendre en compte l'idée de Koselleck exposée dans son livre Futur passé:

Tous sont potentiellement chrétiens - en tant que destinataires de la mission - mais converti, il ne peut plus retourner au paganisme: il deviendrait un hérétique. Pour cette raison, selon Saint Thomas d'Aquin, il était nécessaire de procéder contre les hérétiques avec une vigueur encore plus accrue qu'avec les juifs et les païens, qui se trouvaient à l'antichambre de la voie en direction de Dieu ${ }^{736}$

Notre analyse donc, se focalise sur les débats et dialogues - que nous appelons les disputes fictionnelles ou disputes non-fictionnelles narrées - réalisés entre les missionnaires et les religieux musulmans ou bouddhistes tibétains. Nous nous proposons d'identifier et d'analyser ces stratégies défendues et mises en pratique dans les missions jésuites à partir de la correspondance de ces missions et des ouvrages écrits par des missionnaires qui y ont travaillé. ${ }^{737}$ Dans le but de convertir ces religieux, mais principalement le souverain ou le

${ }^{734}$ Cf: ZUPANOV, I. Jesuit Orientalism; Correspondence between Tomas Pereira and Fernão de Queiros ”, In: BARRETO, L. Tomás Pereira, S. J. (1646-1708), Life, Work and World, ed., Lisboa: Centro Cultural e Cientifico de Macau, 2010, pp. 43-74.

${ }^{735}$ Nous sommes partis d'un entendement de la conversion proche de celui qui a été proposé par Maijastina Kahlos. L'auteur a mis un point d'honneur à souligner la distinction identitaire entre un premier moment et un deuxième. Après la conversion, selon Kahlos, je ne suis plus ce que j'étais auparavant. "Conversion may be delineated as a process of transition from one religious or non-religious allegiance to another. [...] Conversion is depicted either as a gradual personal growth or a radical personal change. In any case, it entails changes in structures and contents of beliefs.[...]What I was before I am no more." Kahlos, Maijastina. Debate and Dialogue: Christian and pagan cultures. Aldershot: Ashgate, 2007, p. 83.

${ }^{736}$ KOSELLECK, Reinhart. Futuro passado: contribuição à semântica dos tempos históricos. Rio de Janeiro, Contraponto / PUC-RJ, 2006, p. 215. C'est nous qui traduisons.

${ }^{737}$ Ces oeuvres composaient ce qui est génériquement appelé "le ministère de la parole" : "Jesuits histories and information concerning mission territories, often entitled as Sumário, Relação, Informatio, Apologia etc, were an integral part of what is called Jesuit "ministries of the word", defined broadly as preaching, teaching, sacred conversation, confession, and writing and publishing edifying as pastoral literature". : ZUPANOV, I. Jesuit Orientalism; Correspondence between Tomas Pereira and Fernão de Queiros”, In: BARRETO, L. Tomás Pereira, S. J. (1646-1708), Life, Work and World, ed., Lisboa: Centro Cultural e Cientifico de Macau , 2010, 
représentant du pouvoir temporel local, ces assauts discursifs étaient un expédient adopté de façon récurrente à la cour de l'Empereur Akbar, au Mogol (du XVI ${ }^{\mathrm{e}}$ au XII ${ }^{\mathrm{e}}$ siècle), et aux missions tibétaines établies à Tsaparang (XVII ${ }^{\mathrm{e}}$ siècle). Les missionnaires se sont consacré, sur la base de ces rencontres dialogiques, à composer des narratives des catéchismes et des traités apologétiques qui décrivaient ou faisaient référence à ces disputes, en les apportant à la connaissance d'un public qui n'était pas présent aux missions. Les débats captés par les écrits jésuites, allaient atteindre d'autres lecteurs-auditeurs, peut-être "tout près" à Goa, ou bien qui sait à Lisbonne ou à Rome.

D'une façon synthétique, nos objectifs peuvent être résumés en deux problèmes qui se déploient à leur tour dans les questions suivantes: (a) pourquoi et comment les jésuites ont-ils accommodé $^{738}$ les débats qui se déroulaient déjà à la cour mogol et dans les espaces de culture tibétaine comme Gugé et Lhassa, en transformant ces débats en un expédient pour convaincre musulmans et bouddhistes ? De quelle façon ces disputes ont acquis le rôle de stratégies de conversion ? : b) une fois transformées en narratives ces dialogues auraient-ils fonctionné comme une façon décrire, d'interpréter et de classer les mogols et les tibétains ? Autrement dit : pouvons-nous entendre le récit de ces débats comme une espèce de prédicat dont la fonction serait de catégoriser, de classer et de réitérer des expressions comme hommes de raison, gens de couleur blanche, gens pieux ou gens aveugles?

Em ce qui touche la première question, notre hypothèse est que les jésuites ont tiré parti du contexte de restructuration politico-idéologique en cours à la cour mogol, en modifiant la finalité des deux processus religieux-culturels, icônes de cette restructuration. Le premier processus que les missionnaires ont cherché à accommoder était le cycle de débats qui se déroulait à l'Ibādatkhānah ("Maison d'adoration" ou "Maison du culte"). Le deuxième processus auquel les jésuites ont pris part, est celui de la traduction d'ouvrages dans la langue persane, et la production de commentaires sur ces ouvrages. ${ }^{739}$ Du point de vue jésuitique, l'idée dans les deux cas serait de participer aux débats et au travail de production d'œuvres écrites sans, toutefois, partager le même objectif final. Si pour Akbar ce qui était en jeu était l'élaboration d'un discours justifiant sa souveraineté, l'objectif des missionnaires était autre chose: ce qui était en question était la conversion des âmes, et tout particulièrement celle de l'empereur lui-même.

pp. $43-74$

${ }^{738}$ ZUPANOV, I. Accommodation. In: AZRIA, R.; HERVIEU-LEGER, D. Dictionnaire des faits religieux, ed., Paris: PUF, p. 1-4.

${ }^{739}$ Cf: GANERI, J. The Lost Age of Reason: Philosophy in Early Modern India 1450-1700. EUA: Oxford University Press, 2011. 
Nous travaillons sur une hypothèse analogue dans le cas des missions tibétaines. Nous proposons qu'au VVII ${ }^{\mathrm{e}}$ siècle, les premier jésuites établis à Tsaparang ont cherché à tirer quelque bénéfice des tensions entre les moines et le roi de Gugé. Les missionnaires par le biais de stratégies visant à discréditer les lamas et à favoriser le souverain, se sont engagés dans des disputes verbales qui allaient être ultérieurement narrées dans les lettres adressées à leurs supérieurs de l'Ordre.

Quant à la seconde question, notre hypothèse est qu'une fois transformés en narrative ces dialogues ont acquis une valeur prédicative. L'appropriation écrite des paroles des autres assume, dorénavant, les fonctions de décrire, d'interpréter et de classer mogols et tibétains. Nous avons cherché à démontrer tout au long de cette thèse comment ces paroles (présumées) acquièrent des valeurs analogues à des expressions employées pour décrire des sociétés et des communautés avec lesquelles les missionnaires ont pris contact. Ces expressions ou catégories - élaborées à partir des observations et descriptions réalisées par les missionnaires sur les peuples découverts, sur leur culture, leur organisation sociale et politique, et, évidemment leurs "sectes" - ont été fondamentales pour le choix et l'emploi de la stratégie de conversion la plus prudente et efficace pour chaque cas et pour chaque moment.

Nous formulons donc l'hypothèse que les catégories élaborées par les jésuites ont été le produit d'une relation dialogique typique de l'identité de l'Ordre de Loyola, établie entre la formation intellectuelle et l'expérience missionnaire. De cette sorte, des idées théologiques et politiques en cours de débat en Europe, de même que des valeurs héritées de l'Aristotélisme et actualisées dans les collèges jésuites, passaient au domaine missionnaire, soumises à la logique évangélisatrice et contingentés par la réalité politique et sociale trouvée. Une fois établies dans ce domaine, elles se sont souvent transformées en instruments pour se faire entendre, servant ainsi au propos de la conversion moyennant persuasion et conviction.

Em même temps, en fonction de la discipline épistolaire et l'importance de la production d'écrits par les intégrants de l'Ordre en mission, l'expérience obtenue dans les "confins" du monde retournaient aux centres du savoir européens, en réalimentant ainsi ce nouvel ordre épistémologique, symbolique et historique de la période moderne:

"La découverte du Noveau Monde, le morcellement de la chrétienté, les clivages sociaux qui accompagnent la naissance d'une politique et d'une raison nouvelle engendrent un autre fonctionnement de l'écriture et de la parole. Pris dans l'orbite de la société moderne, leur différenciation acquiert une pertinence épistémologique et sociale qu'elle n'avait pas encore; en particulier, elle devient l'instrument d'un double travail qui concerne d'une part le rapport à l'homme «sauvage», d'autre part le rapport à la tradition religieuse. Elle sert à classer les problèmes qu'ouvrent à une intelligentsia le 
soleil levant du «Nouveau Monde» et le crépuscule du christianisme «médiéval» ${ }^{70}$

Pour étudier ce "double travail" et pour comprendre la fonction de l'écriture et de la parole dans les sources ici analysées, quelques concepts ont été indispensables. Nous avons commencé par ceux qui ont été présentés par José Eisenberg et qui ont accompagné nos analyses tout au long de cette thèse: l'aggiornamento, c'est-à-dire, l'actualisation et la réinterprétation de la théologie de Saint Thomas d'Aquin de la part des religieux de cet Ordre; et celui de noster modus procedenti, identifié par l'auteur comme une spécificité de l'entreprise du jésuite, et qui consistait en une dialectique entre l'obéissance et la prudence, étayée institutionnellement par l'activité épistolaire. ${ }^{741}$

Favorisée par l'aide conceptuelle de l'auteur susmentionné, cette actualisation du Thomisme est abordée par nous également à partir d'idées politiques en cours de développement dans l'Ordre lui-même, pendant ce moment de genèses de la pensée politique moderne. Les écrits politiques de Francisco Suarez, ses propositions sur la loi et les définitions politiques élémentaires présentes dans son œuvre ont été basilaires pour la conduction de nos analyses.

Aux côtés de Suarez, un autre jésuite du XVIe siècle a diffusé des idées qui ont été fondamentales pour notre travail. Le missionnaire José de Acosta en action dans le Nouveau Monde, en plus d'avoir procédé à la catégorisation des peuples selon les critères habituels habitudes, coutumes, lois, et usage de l'écriture, a associé ces catégories à des stratégies de conversion. Cet exercice dialectique d'observation (des coutumes) et d'adéquations (aux stratégies) exposé par Acosta et souvent implicite dans les sources ici abordées est devenu indispensable pour notre argumentation.

Cependant, la gradation de l'usage de la droite raison dans les communautés humaines et leurs manifestation dans le champ politique - système stable de gouvernement, lois publiques, villes fortifiées, etc. - ont été attestés grâce à l'observation attentive des prêtres. Puis ils se sont transformés en une espèce d'indices, qui travaillés par la rhétorique jésuite dans les écrits missionnaires significatifs, font surgir dans l'écriture missionnaire des signifiants auxquels sont attribuées des significations simultanément religieuses et politiques.

La droite raison, la loi naturelle et tout particulièrement le concept d'entendement sont donc fondamentaux autant pour l'argumentation politique que pour l'argumentation

${ }^{740}$ CERTAU, M. A escrita da História. Rio de Janeiro: Forense Universitária, 2002. p. 213. Itálico: grifos do autor. Negrito: c'est nous qui soulignons. C'est nous qui traduisons.

${ }^{741}$ Cf: EISENBERG, J. As missões jesuíticas e o pensamento político moderno. Belo Horizonte: UFMG, 2000. 
théologico-philosophique des missionnaires. L'entendement - communiqué par Dieu à la créature, et qui permet à un être spirituel de connaître l'universel ou l'immatériel - permet, dans une certaine mesure, que nous connaissions Dieu, et est donc, pris en compte et exercé dans les disputes ici analysées. Cependant, l'entendement est également conçu comme quelque chose qui permet que l'homme exerce domination et gouvernement sur les animaux et sur d'autres hommes: l'homme est le seigneur d'autres hommes dans la mesure où il les dépasse en entendement.

Collectivement, les concepts engendrés à l'intérieur des propres sociétés avec lesquelles les jésuites ont "partagé" des discussions dialogiques ont été également basilaires pour l'élaboration et le développement de nos hypothèses. Ce qui est appelé le wahdat al wujud et le problème de l'unité de Dieu ont transcendé les limites des discussions métaphysiques et religieuses. Ce concept, capable d'exprimer aussi bien des idées mystiques subtiles, qu'un projet politique d'intégration et de construction discursif de la souveraineté politique (associé au dit sulk-i-kul ou paix avec tous) s'est révélé une espèce de pont symbolique, et a rendu possible la permanence et l'action des prêtres dans l'Hindoustan. Ces questions - à l'époque en vogue à la cour d'Akbar, une fois appropriées par les jésuites, se sont transformées en instruments pour se faire comprendre. Dans la mesure où les religieux européens se sont montrés capables de manipuler et d'exposer des contenus de théologie et de philosophie pour chercher à convaincre leurs interlocuteurs. La métaphysique, de même que la politique et la théologie, ont servi d'instruments rhétorique pour que le missionnaire se qualifie, du point de vue de "l'autre" comme interlocuteur où même comme un précepteur spirituel. Ces instruments ont constitué les moyens nécessaires pour la mise en œuvre du projet catéchétique. Em apportant à ce débat leur "actualisation" thomiste, ils ont assuré un espace au christianisme dans les forums linguistiques et de débat interreligieux promus par Akbar.

Dans ce contexte, l'accommodation typique de l'action jésuite en Asie, résidait, dans le cas de la mission du nord de l'Inde, dans ce que nous avons appelé "la transposition de finalité ou usus iustus. Comme Maijastina Khalos l'a exposé, l'une des solutions que les pères de l'Église ont proposé a été "l'usage correct". (...) Dans l'usage correct, ce qui était crucial n'était pas quels seraient les textes lus, mais plutôt comment la littérature serait lue." ${ }^{742}$ Pour ce faire, nous soulevons dans notre premier chapitre, l'hypothèse que les religieux

\footnotetext{
742 "One of the solutions that church fathers offered was the 'right use' (usus iustus). (...) In the right use, what was crucial was not which texts were read (...) but rather how literature (...) was read". KAHLOS, Maijastina. Debate and Dialogue: christianandpagancultures. Aldershot: Ashgate, 2007, p. 87. C'est l'auteur qui souligne.
} 
s'approprièrent de deux institutions centrales du projet politique d'Akbar ('Ibādatkhānah et Maktabkhana) et les modifièrent, c'est-à-dire, transposèrent les finalités de ces institutions.

Dans le cas du Tibet, la métempsycose - également un problème religieux qui devint essentiellement politique dans le contexte tibétain - est l'objet d'une analyse soigneuse et d'une sévère critique de la part des jésuites. A ses côtés, la dénégation de l'existence d'un Dieu créateur, non crée, cause première de toutes les choses, s'est également montrée comme un autre problème religieux, épistémologique et politique pour les missionnaires. Il a été nécessaire de déconstruire l'idée de l'athéisme comme caractéristique principale de la secte des lamas. Et à sa place, ériger ou élaborer un autre qualitatif, c'est-à-dire un autre prédicat susceptible de rendre compte de ce «manque » ou «lacune» dans le système religieux des tibétains. Nous percevons, simultanément que l'institution de la réincarnation, essentiellement religieuse à son origine, prend désormais une signification politique une fois qu'elle est adoptée comme règle de succession et de gouvernement spirituel et temporel. C'est-à-dire qu'un rite originairement du domaine religieux se transforme en un critère de "choix" d'un chef d'État, Cette relation complexe entre le pouvoir temporel et séculaire au Tibet sera l'objet d'une recherche, d'une description et de l'action des prêtres de la Compagnie de Jésus, toujours de conserve avec "l'actualisation" thomiste et le souci d'efficacité missionnaire.

C'est en tenant compte de ces prémisses que nous avons tourné notre regard sur la correspondance des religieux et leurs autres écrits à la cour mogol, et dans le pays des lamas. Dans leurs lettres les prêtres narraient ce qui se passait dans la cour d'Akbar, comme c'était la règle entre les membres de la Compagnie de Jésus. Après quelques années la mission gagne un récit non épistolaire lorsqu'à la fin du $\mathrm{XVI}^{\mathrm{e}}$ siècle, Antônio Monserrat achève son Mongolicae Legationis Commentarius, une narrative sur la présence des prêtres jésuites au Mogol. "Le roi est bien incliné, et ami des choses de Dieu"743. Akbar, en principe se montrait très proche des prêtres et sympathique au christianisme. Cette promesse d'un souverain dans l'imminence de se convertir dans ce que les jésuites considéraient le cœur de l'Asie, s'est tout de suite avéré plutôt comme un souhait des missionnaires qu'une volonté réelle de l'empereur.

Bien que certaines difficultés auxquelles la mission était confrontée soient mentionnées - comme l'apprentissage de la langue persane, la complexité des relations politico-religieuses qui à ce moment s'établissait dans le nord du sous-continent indien, et la dissimulation présumée d'Akbar - les lignes de Monserrat présentent au lecteur un gouvernant opposé à l'islamisme et, en conséquence, réceptif au projet jésuite. Dans les dialogues ici

\footnotetext{
${ }^{743}$ Copie d'une [lettre] de l'Inde à la province de Portugal de l'année [15]79. Archives nationales de la Tour de Tombo, (ANTT, Lisbonne, Portugal), Armoire jésuite, $n^{\circ} 28$, pages. 91-2
} 
analysés, l'empereur mogol apparaît comme un musulman prudent et hétérodoxe, un puissant souverain dans le cœur de la véritable Inde, ami de la raison et des prêtres de la Compagnie.

Les jésuites soutenaient dans leurs écrits - lettres, relations et autres œuvres ici indiquées - la viabilité et le potentiel de la mission au Mogol. Même lors de moments de doute, les prêtres ne préconisaient d'aucune façon d'abandonner la mission, mais suggéraient un changement de stratégie, ou plutôt, une diversification des stratégies. Mais, pour ce faire il fallait observer de très près le souverain mogol, le décrire, l'étudier, le dépeindre à l'aide des "couleurs" appropriées, et le catégoriser en termes précautionneux. Les dialogues à notre sens, ont surgi en même temps qu'une stratégie de conversion et comme une façon de ratifier, d'exemplifier et de confirmer la description d'Akbar comme un souverain ami de la raison, prudent, aimable à l'endroit des prêtres et donc allié de la chrétienté en Inde.

De cette sorte, du fait de toutes les raisons débattues jusqu'ici, nous soutenons que dans la mission du Mogol, se sont unies et la rhétorique jésuite, et l'action politique des deux parties : de la part du souverain musulman et de la part des prêtres chrétiens. Nous insistons sur l'idée de rhétorique car nous soutenons qu'une grande importance a été donnée à la parole, au langage, au discours et à l'écriture au cours de la mission au Mogol. On sait que l'étude de la rhétorique ${ }^{744}$ était une étape importante de la formation missionnaire des membres de la Compagnie de Jésus. Il convient cependant de souligner que nous entendons le vocable "rhétorique" d'une façon plus large, autant en ce qui a trait à la forme de ce qui est dit, qu'en ce qui concerne le contenu, c'est-à-dire l'érudition.

Du point de vue des jésuites, le débat sur les points doctrinaires était une chose commune à leur formation: le trivium médiéval (rhétorique, logique et grammaire), la pratique de défendre une position au moyen d'un "discours" était exercée formellement par ceux-ci. Cependant, en fonction de la période durant laquelle la mission s'est réalisée, Il ne nous a pas été possible d'utiliser la Ratio Studiorum - règlement d'études jésuitique - comme source pour pouvoir identifier la formation rhétorique jésuite. La Ratio n'a trouvé sa forme finale qu'en 1599, époque où les jésuites avaient déjà exercé la "disputatio" à la cour mogol il y avait au moins 19 ans.

\footnotetext{
744 "Classical rhetoric is superficially very easy to describe: it is that theory of discourse developed by Greeks and Romans of the classical period, applied both in oratory and in literary genres, and taught in schools in antiquity, in Greece and western Middle Ages, and throughout the Renaissance and early modern period." KENNEDY, G. A. Classical Rhetoric and Its Christian and Secular Tradition from Ancient to Modern Times. 2 Rev Upd. The University of North Carolina Press, 1999, p. 3.
} 
Il convient de préciser, donc, que nous employons ce terme (rhétorique) dans le sens d'usage efficace de la langue parlée et écrite dans le but d'influencer et de persuader,en faisant ressortir que cette efficience est la conséquence d'une pratique, d'une habilité acquise au moyen d'une formation intellectuelle préalable, d'exercice et d'entraînement.

Nous avons donc élargi notre entendement du terme "rhétorique", et en conséquence nous signalons la présence de trois niveaux d'entendement spécifiques dans le cas ici analysé:

(a) Le niveau discursif: les jésuites ont pensé et "actualisé” un discours qui - avant de présenter le christianisme - attaque l'islamisme.

(b) Le niveau érudit: les jésuites, dans leurs attaques à la foi islamique, ont fourni des informations, c'est-à-dire des arguments ou des contenus allant au-delà de la forme.

(c) Le niveau idéologique : les jésuites, aux côtés des autres religieux ont fait parti du projet politique d'Akbar de réélaboration théorique et discursive de sa souveraineté politique.

En fait, notre objectif n'a pas été de démontrer que l'importance de la rhétorique réside dans le fait que les débats ont été la seule forme de stratégie adoptée par les prêtres. Ce que nous soutenons est que son importance est légitimée, d'un côté par le fait qu'elle a permis aux prêtres de prendre part à un processus politique en cours dans l'Hindoustan durant le $\mathrm{XVI}^{\mathrm{e}}$ siècle, en se secourant de la formation jésuitique et du modèle d'adaptation (comme nous l'avons vu, le prêtre que les avait précédé n'avait pas été capable de jouer ce rôle). D'autre part, la discipline de l'écriture de la part des jésuites s'est anticipée au dialogue comme stratégie principale en décrivant Akbar comme "un homme de raison".

Nous croyons donc que l'adéquation, l'ajustement de la réalité à la narrative, l'élaboration de l'écriture et le geste de narration des discours par les jésuites avaient pour but principal non seulement la description d'Akbar et des musulmans de sa cour, mais principalement la catégorisation de celui-ci. La catégorie dépasse la simple description: elle encadre un peuple ou une société dans une place à partir de laquelle il est possible de planifier l'action missionnaire. Nous considérons, donc, que les disputes non fonctionnelles narrées et les expressions prédicatives comme "homme de raison" ou "gens blancs" ont acquis cette même fonction dans l'écriture missionnaire

Ainsi, nous considérons que les disputes, en tant que stratégies, signifièrent, en vérité, une adaptation des jésuites aux processus politico-culturels en cours sous le règne d'Akbar. La 
participation à ces discussions, outre le fait d'être un expédient familier à la formation jésuitique, a été également rapportée, de façon dialogique dans les écrits des jésuites. Dans ces dialogues non fictionnels narrés, Akbar apparaît comme un musulman hétérodoxe et prudent, un puissant souverain en plein cœur de la véritable Inde, ami de la raison et des prêtres de la Compagnie. Pour l'audience virtuelle ${ }^{745}$ de ces discussions, il s'agirait d'un nouveau Constantin, protecteur de la fois catholique en Orient, et, fort de son appui, l'Hindoustan se convertirait en un havre sûr pour la chrétienté en Asie.

En dépit de l'optimisme initial et le zèle missionnaire des jésuites, Akbar ne renonça pas formellement à l'islamisme. Après la frustration des premières tentatives, l'Ordre envoie, encore une fois, des missionnaires au Mogol, et les stratégies de conversion, associées à la production écrite réalisée par les prêtres - se diversifient. Nous constatons tout d'abord qu'outre leurs épîtres, les jésuites ont produit une narrative qui rendait compte de ce que nous avons appelé dans cette thèse les dialogues non fictionnels narrés. L'étape suivante, en termes catéchétiques, a été l'élaboration, par Jerônimo Xavier, d'un traité apologétique adressé à Akbar, Empereur des Mogols. Dans son ouvrage Fontes de Vida il ne traitait plus de la description ni faisait la narration de dialogues qui, présumablement s'étaient déroulés au sein de la cour. Il s'agissait maintenant de l'usage d'un genre spécifique - apologétique - revêtant une forme spécifique : le dialogue. Xavier a écrit son œuvre en persan, avec une dédicace au souverain mogol et une espèce d'introduction lyrique et poétique qui n'anticipait pas, en termes stylistiques, les débats métaphysiques qu'un prêtre, un philosophe et un mullah allaient entretenir au cours de l'ouvrage.

Notre hypothèse est que cette œuvre peut être entendue comme une adaptation jésuitique d'un processus qui s'entamait dans la cour d'Akbar, caractérisé par la traduction vers le persan d'œuvre sacrées d'autres religions que l'islamisme. C'est-à-dire que nous soutenons que les religieux ont pris part à une institution se rapportant au projet politique d'Akbar, sous le nom de Maktabkhana.

De plus, nous défendons l'idée que "Fonte de Vida", écrite sous la forme de dialogue, est une espèce de raffinement des stratégies antérieures. Dans cet ouvrage, les débats n'apparaissent pas décrits en référence directe avec les audiences organisées par Akbar et

\footnotetext{
${ }^{745}$ Comme l'image d'une lentille ou d'un miroir, l'audience, peut être réelle ou virtuelle : la première est celle qui était présente au moment où le débat a eu lieu ; la seconde n'a eu accès qu'au débat médiat, à partir de la lecture de l'ouvrage qui en fait le rapport.
} 
donc se présentent strictement comme un genre littéraire au service des objectifs primordiaux des missionnaires : l'évangélisation et la conversion.

Finalement, nous suggérons que les missionnaires au Mogol ont en fait testé un modèle de mission à la cour d'Akbar. Nous pourrions dire que Fatehpur a été une espèce de laboratoire - s'il était possible de commettre l'anachronisme d'imputer aux prêtres un profil "scientifique". Ce modèle essentiellement dialogique, peut être vu comme une tentative symétrique du procédé en cours d'application de la Compagnie en Extrême-Orient, tout particulièrement en Chine et au Japon.

Selon donc ce qui a été proposé au cours de nos premiers chapitres, nous avons fait la constatation que la mission au Mogol a acquis progressivement d'autres rôles dans la géopolitique de la Compagnie de Jésus et que cette mission représentait une espèce d'escale, de port d'entrée au continent entier. Dans les écrits de Rodolpho Acquaviva nous pouvons discerner la proposition d'un nouveau projet géopolitique pour la Compagnie de Jésus en Orient. La mission mogole devient maintenant un lieu privilégié dans le sous-continent indien, et une porte d'entrée pour l'Asie centrale En effet, Acquaviva dans ses écrits présente un plan d'intériorisation de la présence missionnaire en Asie, radicalement distinct de la pratique de l'Ordre à ce moment. Forts de la présence du bras séculier coercitif de l'Empire portugais, les jésuites entamaient maintenant l'occupation des bords du sous-continent indien. Pour le missionnaire italien, cependant, c'était ne pas se rendre compte que l'Hindoustan était en fait l'Inde "elle-même".

Em fonction du libre espace de débat religieux, et en ligne avec ce nouveau projet, les jésuites acquirent la sécurité nécessaire pour s'établir en Asie à partir de l'Hindoustan, et décidèrent d'investiguer les rumeurs sur la présence de chrétientés au nord des frontières de l'Empire mogol. En suivant la route des marchands et des pèlerins, quelques religieux de la Compagnie de Jésus se mirent à la recherche de la prétendue communauté chrétienne des montagnes, ébauchant l'intériorisation de la présence de l'Ordre dans ce continent. Parmi les prêtres qui quittèrent la mission mongole vers le centre du continent, nous pouvons citer Bento de Góis et Antônio de Andrade. Góis voyagea dans l'Inde entre 1602 et 1607. Le deuxième fonda la mission du Tibet en 1626, qui sera l'objet de notre analyse dans cette thèse.

Vers le milieu des années 1620, quinze ans après la mort d'Akbar, les missionnaires de la Compagnie de Jésus n'avaient pas encore renoncé à la mission du nord de l'Inde. Là-bas, les prêtres, pouvaient, en plus de répondre aux besoins de la communauté chrétienne locale, et de chercher de nouveaux fidèles, recueillir des informations sur les régions voisines en 
contribuant ainsi à la formulation des stratégies géopolitiques de l'Ordre. Ainsi, lorsque le supérieur de la mission mogole d'alors part (sans recommandation ou permission du provincial) à la recherche de chrétiens dans le centre du continent asiatique, on attend qu'il emporte avec lui un peu de l'expérience missionnaire obtenue à la cours d'Akbar et de son fils Jahangir.

Il s'agissait là donc du premier contact entre l'Europe moderne et le Tibet, entre le christianisme et la "secte des lamas". Dans ce contexte nous cherchons à soutenir que les missions de l'Ordre au Tibet, s'avéraient être, en fait, une expérimentation de la proposition géopolitique de Rodolfo Acquaviva, mais également un lieu de théorisation et d'application de la méthode dialogique en tant que stratégie de conversion.

Nous proposons dans notre thèse une division de l'histoire de la mission, en trois phases. La première à trait à l'arrivée d'Andrade au royaume de Gugé en 1624. A ce moment, une relation d'identité s'établit entre le Tibet et le mythe du Cataio. Cette confusion ne semble pas avoir été le fait d'Andrade lui-même, mais la conséquence de la publication et de la divulgation de ses nouvelles au sein de la Compagnie et hors de celle-ci en Inde et en Europe. Cette première phase est particularisée, donc, par la relation identitaire établie entre le Tibet et le royaume mythique chrétien de Cataio, et également par deux autres facteurs principaux: la description positive à l'endroit des tibétains portant sur la capacité de ceux-ci de reconnaître, de percevoir et de conserver la Sainte Foi, et la justification de l'installation de la mission, défendue tout particulièrement par Antônio de Andrade.

La deuxième phase de la mission commence en 1626, par son installation proprement dite. Andrade, suivi par d'autres religieux, retourne à Gugé et est reçu par le roi. Il fonde la mission, assure le soutien temporel de celle-ci et commence à écrire à ses supérieurs pour leur donner des nouvelles. Cette phase est caractérisée, donc, par l'établissement de missions à Tsaparang et dans la région d'Utsang, par la négociation et l'assurance de son soutien temporel, et, finalement, par le début de la mise en œuvre des stratégies de conversion. A ce moment, cependant, l'identification Tibet/Cataio n'est plus mentionnée.

La troisième et dernière phase que nous proposons correspond à la décadence de la mission. La Province est consultée sur le maintien ou la suspension de la mission. A cette consultation se suit un débat épistolaire où deux jésuites - Nuno Coresma et Antonio Mendes - prennent des positions opposées et argumentent respectivement, contre et en faveur de la mission. 
La dernière phase de la mission est marquée par trois faits extérieurs au développement de celle-ci. Le premier est lié au contexte politique du royaume de Gugé : en vertu du non-accomplissement d'un accord de mariage par le roi de Gugé, le roi de Ladakh envahi Tsaparang et emmène la famille royale en captivité à Leh. La mission perd ainsi son plus important "protecteur local". A cette même période, l'initiative de l'Ordre dans le Sommet du Monde perd également son principal protecteur" à la Compagnie de Jésus : Andrade est empoisonné dans le réfectoire du Collège de Saint Paul à Goa. L'enquête qui a suivi son assassinat, nous permet d'ímaginer que sa mort n'était pas liée à la mission au Tibet, quoique cette mission était loin de constituer une unanimité entre les pères de la Compagnie au Mogol et à Goa

Le troisième facteur a trait à la relation de "filiation" entre la mission du Tibet et la mission au Mogol. En 1628, l'empereur Aha Jahan accède au trône Mogol. A l'opposé de son père et de son grand père, il ne s'intéresse pas au maintien de bonnes relations avec les chrétiens, qu'ils soient marchands portugais ou religieux jésuites. Les prêtres à Agra ne peuvent plus compter sur la bonne volonté de la "tête" de l'Empire Mogol" et l'éventualité prometteuse d'un nouveau Constantin au cœur de l'Asie cède la place à la certitude d'un souverain infidèle, ennemi du Christ et des Portugais. Comme si cela ne suffisait pas, après la suspension de l'appui temporel à la mission jésuite en 1632, Shah Jahan encercle les Portugais établis au Bengale, et entame une confrontation armée.

Nous constatons, donc, que dans le contexte de ce que nous avons appelé la première et la deuxième phase, Antônio de Andrade procéde à une observation de la scène politique et des tensions entre les pouvoirs spirituels et temporels du royaume de Gugé. Le missionnaire transforme cette observation en une espèce de propagande dépeignant le Tibet comme un lieu propice au travail missionnaire. Au surplus, le jésuite s'engage également dans des débats avec les lamas, en présence du souverain dans le but précis de déqualifier les prêtres bouddhistes. Comme Saint Thomas d'Aquin l'avait déjà prévu, il n'était point nécessaire qu'Andrade prouve sa foi, mais seulement qu'il soit capable de signaler, dans la doctrine de la secte des Lamas tout ce qui allait à l'encontre de la raison. La stratégie dialogique de la conversion, associée à son projet d'étendre la mission mogol au Tibet Occidental, trouve sa matérialité rhétorique dans l'expression "gens pieux", une catégorie crée par le missionnaire pour décrire les Tibétains. Cette catégorie a été fondamentale pour transmettre au lecteur une idée descriptive de la société tibétaine, mais a été également basilaire dans le choix de la stratégie dialogique comme méthode avisée de catéchèse. En recourant à des catégories telles 
que "gens blancs", "gents pieux", et à d'autres expressions similaires, les jésuites avancent déjà l'idée d'une stratégie de conversion basée sur la persuasion au détriment de la force physique ou de la coercition. De cette sorte, dans le cas des "gens pieux" tibétains, la persuasion serait le moyen le plus approprié pour leur conversion. Andrade nous raconte avec ses propres mots que "pour ces personnes, les sujets palpables et communs sont meilleurs pour les persuader et les convaincre, que pour celles dont la posture est théologique et interrogatrice, car ils ignorent ces concepts." ${ }^{746}$ Ce qui veut dire que pour ceux qui sont dévoués et qui possèdent une bonne nature, l'attitude pacifique et l'argumentation rationnelle sont les façons les plus appropriés de conversion, ce qui transformerait les disputes en une méthode prudente. Cette méthode satisferait en même temps le besoin de convertir le roi et celui d'affaiblir les lamas non seulement en ce qui concerne l'aspect théologique, mais également l'aspect politique.

Toutefois, pour que Andrade soit à même de participer ou de conduire les débats et les disputes, il a été nécessaire qu'il adapte ou accommode une coutume traditionnelle dans les sociétés de culture tibétaine: la relation de "patronage" - c'est-à-dire l'appui qui était attendu d'un roi ou d'un noble à l'endroit d'un monastère, d'un ordre religieux bouddhiste ou lama et la relation - "Maître-Disciple". Andrade s'est probablement fait passer pour un Lama dans le sens de précepteur spirituel, ou "gourou" - ou tout au moins à été reçu comme tel par Thi Taghsi Dagpa. Le religieux a été "pris pour un Grand-Maître", et une fois cette relation établie, il s'est vu nanti de l'autorité nécessaire pour prêcher. Voilà mimétisée l'image d'un Lama : un précepteur spirituel venu enseigner la Sainte Loi, et qui fait partie d'une communauté religieuse qui possède un supérieur («padre grande »), et qui, pour ce faire, reçoit les autorisations nécessaires et l'appui du roi - son protecteur. Cette mimétisation passe par des indices pratiques, tout particulièrement ceux qui ont été renforcés lors du surgissement de l'Ecole Gelupa, c'est-à-dire le monasticisme, le célibat, et, dans un certain sens, le distancement des questions temporelles. A l'exception du premier, tous les autres sont, idéalement attribuées à un jésuite. Même dans le cas du monasticisme, et bien que la Compagnie de Jésus ne soit pas un Ordre conventual, le fait, de la part d'un jésuite, de se présenter comme appartenant à une communauté religieuse donnée - justement un ordre - a été vu par les tibétains comme quelque chose d'attendu de la part d'un précepteur religieux. Si l'on excepte l'accent sur la doctrine et en si l'on se focalise sur la présentation d'une nouvelle

\footnotetext{
${ }^{746}$ Carta ânua de Antônio de Andrade, Tibete, 1626. In: DIDIER, H. Os portugueses no Tibete. Os primeiros relatos dos jesuítas (1624-1635). Lisboa: Comissão Nacional para Comemoração dos Descobrimentos Portugueses, 2000, p.126.
} 
méthode, un jésuite qui mimétise ou qui est reconnu comme un Lama sera apte à devenir le précepteur spirituel d'un noble ou d'un roi et donc susceptible d'obtenir que ce roi ou ce noble devienne son "protecteur".

Em outre, dans sa "géographie" - ou autrement dit, dans sa tentative de créer un espace pour le Tibet dans la conception européenne de l'Orient ou de l'Asie - Andrade a défendu l'importance stratégique du pays des lamas, et, en conséquence, l'importance de la propre mission au Tibet. Dans cet endroit, ao nord de l'Empire Mogol, et proche de la Chine, Andrade avait trouvé de grands royaumes que suivaient la même secte et qui parlaient presque la même langue. En dépit du fait de n'avoir pas encore trouvé des chrétiens, il semblait proche $\mathrm{du}$ "christianisme perdu" duquel on entendait parler depuis quelque temps.

Nous faisons cette affirmation non pas parce que les Tibétains avaient été en fait anciennement une société chrétienne, mais à cause de l'instrument rhétorique que cette description peut représenter. Du fait que Andrade fait ressortir que le Tibet n'est pas un royaume musulman et que, de surcroît, il pourrait avoir été chrétien dans le passé, le jésuite était en train, d'une certaine façon, de construire un pont - rhétorique et politique - rendant la mission possible et souhaitable. Cette description permettait de concevoir dans l'horizon des possibilités, la conversion des bouddhistes tibétains. La narrative cependant peut être entendue comme un pont reliant deux points dans le temps : le chrétien du passé et le futur chrétien, de la même façon que Koselleck nous présente le dualisme de Paul dans Futur passé. ${ }^{747}$ Cet état de choses ${ }^{748}$ présenté par Andrade est une façon d'anticiper la stratégie de conversion qu'il défend pour le futur comme étant la plus cohérente et la plus prudente pour le peuple tibétain.

Durant la période que nous avons convenu d'appeler la troisième phase de la mission tibétaine, la représentation positive, presque mythique qu'Andrade avait élaboré de Gugé prend fin. Le regard généreux du fondateur de la mission ne survit pas aux critiques de son frère de l'Ordre, Nuno Coresma, selon lequel, dans ses lettres, la mission est condamnée. Nous voyons surgir alors une "nouvelle" description des Tibétains. Mais l'importance du récit de Coresma n'est pas seulement de rendre compte de l'histoire de la mission après Andrade, ni non plus de démontrer combien distantes les nouvelles qu'il rapportait se trouvaient par rapport à la réalité. Ce qui nous saute surtout aux yeux, est la relation entre la description géopolitique et celle de la nature des Tibétain associée à la stratégie qui devrait être adoptée.

\footnotetext{
747 Cf: KOSELLECK, R. Futuro passado: contribuição à semântica dos tempos históricos. Rio de Janeiro, Contraponto / PUC-RJ, 2006, p. 208.

${ }^{748}$ Cf: PÉCORA, A. Máquina de gêneros. São Paulo: Editora Universidade de São Paulo, 2001.
} 
Si le roi local n'est pas favorable au christianisme, affirme Coresma, alors la force de l'Etat portugais se fait nécessaire. Si la persuasion n'est pas capable, la force devient de nouveau indiquée, et non plus la conviction ou la persuasion. Sans appui local, sans l'action du bras séculaire chrétien au Tibet, il n'y aura aucun espoir de convertir les tibétains, ni de maintenir, les "chrétiens du ventre" (« Cristãos de barriga ») au sein de la foi.

L'opinion du père Nuno est réfutée par Antonio Mendes, qui cherche à défendre la mission et critiquer la décision - soutenue par le premier - de faire revenir les pères établis au Tibet. L'argumentation de Mendes est organisée de la façon suivante : en premier lieu il expose les raisons générales pouvant motiver l'interruption de toute mission. En deuxième lieu, il démontre que le contexte de la mission tibétaine ne faisait pas apparâtre des raisons susceptibles de provoquer sa cessation. Ensuite, le jésuite mentionne les raisons exposées par Nuno Coresma dans ses lettres où il mettait en question l'avenir de la mission: devait-elle être abandonnée ou maintenue, raisons qui ont plus tard débouché sur la décision d'interrompre les activités de la Compagnie de Jésus dans le royaume de Gugé. Tous les arguments de ce jésuite sont de grande importance pour la compréhension de la mission tibétaine, car ils synthétisent des aspects factuels et des informations contenues dans d'autres rapports, en construisant ainsi un tableau complexe de la mission. Nous proposons, cependant, que l'importance de la lettre ne se trouve pas seulement dans le potentiel d'informations sur les aspects particuliers de Gugé. En vérité, dans la mesure où il se dispose à défendre la mission fondée par Andrade, Mendes nous expose des idées extrêmement pertinentes sur ce qu'est une mission, quels sont ses objectifs, comment doit-elle être pensée, comment les missionnaires doivent-ils ou ne doivent-ils pas agir, etc. L'analyse de cette lettre nous permet de nous rapprocher de la construction de l'idée de mission de la Compagnie de Jésus, un concept croyons-nous, qui sera perfectionné dans le travail de Desideri. Pour cela, nous maintiendrons les deux niveaux d'interprétation de la source dans nos analyses: le premier concernant le contexte de la mission mise en place par Antônio de Andrade; et le deuxième concernant un contexte plus élargi de l'activité missionnaire en Asie, que nous proposons comme étant le modèle d'action de la Compagnie de Jésus lorsqu'en contact avec des "gens blancs".

Em défense de la mission tibétaine, Mendes présente trois arguments soutenant que les tibétains étaient susceptibles de recevoir la Sainte Foi. Premièrement il affirme qu'Antônio de Andrade avait déjà fait cette démonstration dans ses écrits. Deuxièmement, le jésuite affirme que les autres religieux de la mission au Tibet, avaient également défendu la capacité naturelle des tibétains. Puis le jésuite nous fournit une information quelque peu curieuse: il affirme 
qu'en revenant du Tibet, Andrade s'était fait accompagner de Tibétains pour que d'autres religieux - à Goa ou à Agra - puissent se certifier personnellement de la capacité de ce peuple. De plus, "il suffit de savoir qu'il s'agit de "gens blancs" ${ }^{749}$, qui ont reçu facilement et de façon bénévole les pères et la nouvelle du véritable Dieu avec notre Sainte Foi, et en y (retrouvant?) des vestiges de ancienne chrétienté". ${ }^{750}$

La troisième phase, donc, concentre les arguments contre et en faveur de la mission, liés à certains points principaux: la subsistance temporelle de la mission, la nature du peuple tibétain et sa capacité de recevoir et de garder la Sainte Foi. Aussi bien Coresma que Mendes prennent position en ce qui concerne ces questions centrales. Le rapport entre la description de la nature du peuple à être évangélisé, l'élaboration d'une catégorie rendant compte de cette nature (qui prend des aspects de puissance "chrétienne") et ensuite la stratégie à être adoptée - dans le cas précis le dialogue pour ceux qui défendent la "nature pieuse" et les "gens blancs » et la coercition pour les "gens bruts" et pour les "chrétiens du ventre" - devient évident ".

Néanmoins, les arguments de Mendes semblent ne pas avoir été suffisants pour soutenir la mission. De plus, à la mort d'Andrade et du fait de l'instabilité politique grandissante du Royaume de Gugé, la mission entame une période de décadence, et s'éteint entre 1635 et 1640 .

Mais l'Ordre insiste, et au cours du siècle suivant un italien est envoyé au Sommet du monde, un homme qui avait le temps, la volonté et la capacité de réaliser tout cela. A l'encontre des contemporains d'Andrade, Ippolito Desideri n'a pas considéré l'instabilité politique ni les difficultés de la langue, ni la hauteur des "serras" (les montagnes), ni le froid comme des obstacles sérieux. Le missionnaire italien a été, en fait, une espèce de victime des différends qui avaient cours au sein de la propre Église Catholique: la Propaganda Fide, au cours d'une période de difficultés traversée par les jésuites, décide que le Tibet serait le terrain d'évangélisation des capucins.

Le siècle suivant serait marqué par d'intenses disputes entre les jésuites et les capucins, qui reçurent la permission de Propaganda Fide et l'approbation du Pape Clément XI, en 1703,

\footnotetext{
${ }^{749}$ Un autre missionnaire qui a choisi la formule "gens blanc" est Estêvão Cacella. En faisant référence au Tibétains du Tibet Central, le missionnaire affirme que " Les gens de ces royaumes sont blancs, quoique que le manque de propreté qui leur est coutumier ne le laisse pas tellement paraître" "Rapport que le Père Estevão de Cacella de la Compagnie de Jésus a envoyé au père Alberto Laércio, provincial de la province de Malabar des Indes Orientales, sur son voyage au Cataio, jusqu'à atteindre le Royaume de Potente". DIDIER, H. Os portugueses no Tibete. Os primeiros relatos dos jesuítas (1624-1635). Lisboa: Comissão Nacional para Comemoração dos Descobrimentos Portugueses, 2000, p. 241.

${ }^{750}$ Lettre de Antônio Mendes, ARSI, Goa 73, fl: 102r. C'est nous qui soulignons.
} 
pour s'installer dans la région tibétaine, au détriment de la participation jésuite. Cette même année, la Compagnie de Jésus fut condamnée du fait d'avoir permis que les chinois et les hindous convertis gardent quelques-uns de leurs rites et coutumes. Cet épisode a été connu comme "la querelle des rites" et constitue un fait central de cette période, considérée comme un cycle de déclin pour l'ordre fondé par Loyola.

C'est dans ce contexte, en 1712, que le Général de la Compagnie de Jésus, Michelangelo Tamburini (1648-1730) envoie l'italien Ippolito Desideria au Tibet. Tamburini avait été investi des pouvoirs de Général douze ans auparavant, et fut un personnage fondamental dans la scène des disputes entre les ordres religieux au cours de sa vie. Curieusement, c'est le Pape Clément XI - le même qui avait garanti le "monopole" capucin sur le Tibet - qui bénit le voyage de Desideri pendant une audience concédée un peu avant son départ.

Desideri part alors comme une espèce d'héritier d'Andrade, sans toutefois démontrer qu'il disposait d'informations de voyage du Portugais. L'itinéraire de l'Italien, par exemple, passe par Srinagar, dans le Cachemire - où il consacre quelque temps à étudier le persan lorsqu'en vérité, la ville de Srinagar décrite par Andrade et située dans la région de Garhwal, État actuel de Uttaranchal, est une autre ville.

Dans sa Notice Historique sur le Tibet, document analysé dans le dernier chapitre de notre thèse, Desideri, fait non seulement part de ses propres expériences, mais dresse un bilan bibliographique de ce qui avait été divulgué jusqu'alors en Europe sur le Tibet, ce qui inclut, parmi d'autres ouvrages, la publication de la lettre de Antônio de Andrade. En outre, Desidéri propose une lecture critique des autres auteurs qui avaient écrit sur le pays des Lamas, ce qui démontre qu'il avait fait des recherches et avait beaucoup lu avant d'achever son œuvre, mais également qu'il était capable de "corriger" les erreurs des descriptions antérieures.

Nous proposons de partager en quatre aspects différents les thèmes abordés par Desideri, qui nous sont pertinents : La définition et la description du "Tibet" et de sa "secte"; la présentation et la défense des stratégies et des méthodes de conviction et de conversion défendus et appliqués par celui-ci : l'identification des "erreurs "de la "secte" tibétaine; et les relations entre la politique, le pouvoir ou l'État tibétain et les stratégies de Desideri.

Nous pouvons donc faire l'observation que le débat réalisé par Desideri dans sa présentation de la secte tibétaine, et en particulier des "erreur" de cette secte, est intéressant car il ajoute une catégorie supplémentaire qui, jusqu'alors n'avait pas encore été mentionnée 
dans d'autres rapports, aussi bien sur l'Inde que sur le Tibet : l'athéisme ${ }^{751}$. Même si le jésuite lui-même à l'issue de sont argumentation nie le prétendu athéisme des Tibétains, il nous semble évident qu'il y a là un épuisement des catégories antérieures de description et l'anticipation d'une forme prudente de catéchèse. Idolâtres, payens, infidèles, aucunes de ces catégories ne semble avoir été suffisantes pour résoudre les problèmes épistémologiques et missiologiques présentés par le bouddhisme tibétain.

Comme nous l'avons dit au long de notre thèse, nous nous sommes également employés à associer les descriptions faites par Desideri aux stratégies de conversion que celuici a adopté lorsqu'il était au Tibet, et au modèle futur d'action missionnaire qu'il proposera à la fin de son œuvre. Nous réitérons que notre prémisse est le fait que ces descriptions sont intrinsèquement liées à la méthode proposée de conduire la mission et sont l'objet d'une analyse poussée et d'un soin rhétorique appliqué. Cet aspect est particulièrement mis en relief dans l'oeuvre de Desideri qui a été probablement l'objet de bon nombre de révision. En outre, le missionnaire propose une triple espèce de programme: décrire le Tibet et les Tibétains selon la pratique jésuitique de réorganisation du monde et d'attribution d'une place (historique, politique et religieuse) ux peuples trouvés ; proposer et justifier une méthode d'action pour les missionnaires que iront en Inde ; et finalement défendre la Compagnie de Jésus et sa façon d'opérer. Dans le cas spécifique de la mission de Lhassa, Desideri a cherché à argumenter et à soutenir la primauté de l'Ordre dans le territoire de culture tibétaine, d'où il a été expulsé en faveur des missionnaires capucins.

D'une façon générale, nous pouvons dire que Desideri suit la description positive faite par Antonio de Andrade du peuple tibétain, même si le souffle et la profondeur de son œuvre écrite peut être difficilement comparée à celle des missionnaires antérieurs, y compris les lettres d'Andrade lui-même. Malgré tout, il est évident que l'Italien présente le Tibet comme un lieu approprié à l'exercice des missions. Dans notre analyse, la démonstration de cette hypothèse (c'est-à-dire que le Tibet est un lieu de choix pour un investissement en termes de missions) se fait à partir des descriptions politiques et anthropo-sociologiques positives. Politiques parce que le Tibet - soit sous le régime monarchique, soit sous le régime mandchou - exhibe une organisation politique favorable à l'exercice de missions. Pour reprendre une

\footnotetext{
${ }^{751}$ Sur la question de l'athéisme dans d'autres contextes de relations entre missionnaires et représentants de la religion bouddhiste, voir : VENTURA, R. O Budismo nas fontes do Padroado Português do Oriente (séculos XVI e XVII) - um roteiro documental. In: O Buda e o Budismo no Ocidente e na Cultura Portuguesa, org. Paulo Borges e Duarte Braga. Ésquilo Edições e Multimédia: Lisboa, 2007, pp. 167.
} 
expression que d'autres jésuites avaient déjà utilisé, la présence d'une "tête" rendrait plus facile le travail d'évangélisation. ${ }^{752}$

Em termes de ce que nous dénommons "descriptions anthropo-sociologiques" nous nous consacrons à l'analyse des impressions de Desideri sur le comportement général des Tibétains. De façon assez élogieuse le missionnaire affirme que ce sont des gens ayant bon caractère, et très enclins à la piété. La piété comme nous le savons, est une vertu, et toute vertu indique un penchant à la réalisation de bonnes œuvres ou de bonnes actions. De ce fait, un homme vertueux, est essentiellement incliné à pratiquer le bien, c'est-à-dire à agir conformément à la droite raison. Dans le cas spécifique de la miséricorde, ce penchant est un mouvement de sensibilité à l'endroit de la souffrance du prochain, et une mobilisation naturelle pour lui venir en aide ${ }^{753}$. Mais le missionnaire ne se satisfait pas du seul fait de reconnaître cette qualité au peuple tibétain : il compare ceux-ci aux mauvais chrétiens, en disant que les premiers serviraient de réprobation aux derniers.

Ce jugement, cependant, incorpore un paradoxe : comment peut-on comparer des chrétiens à des gentils ? C'est justement sur ce point que Desideri élabore le sens dont nous avons parlé précédemment. Il a été nécessaire d'élaborer un signifiant pour rendre compte de ce peuple vertueux, mais ne suivant pas la véritable loi en dépit de son penchant naturelle aux œuvres de miséricorde. Pour Desideri ils ne sont pas des gentils parce que ce terme ne rendrait pas compte de ce que le missionnaire veut décrire e anticiper au lecteur et à ses compagnons de l'Ordre. Pour rendre compte de ce "manque" dans l'altérité tibétaine. L'italien s'utilise de l'expression "gens aveugles". Mais pourquoi recourir à cette catégorie plutôt qu'à l'autre?

Notre hypothèse est que Desideri faisait allusion à l'aveuglement dont parle Saint Thomas d'Aquin à la question 79 de la Prima Secundia de sa Somme Théologique sous le titre La cause du péché du côté de Dieu:

L'aveuglement est un préambule du péché. Or le péché mène à deux choses : par lui-même à la damnation, mais par miséricorde et providence de Dieu, à la guérison (....) Par conséquent,_l'aveuglement de sa propre nature mène à la damnation; mais par la divine miséricorde il est temporairement ordonné comme un traitement médicinal pour le salut de ceux qui s'en trouvent atteints. Néanmoins cette miséricorde n'est pas accordée à tous mais

${ }^{752}$ ACOSTA, J. De procuranda Indorum salute. Madri: Consejo superior de investigaciones cientificas, 1984. SUÁREZ, Franciso. Tractatus de legibus ac Deo legislatore. Madrid, 1967. Primeira edição: Coimbra, 1612.

${ }^{753}$ Cf: TOMAS, de Aquino. Suma Teológica. Traduction: Alexandre Correa. Faculdade de Filosofia Sede Sapiens: São Paulo, 1956, vol. 17, p. 289; 300-1. 
uniquement aux prédestinés, chez qui tout concourt au bien, comme dit l'Apôtre. De sorte que pour les uns l'aveuglement aboutit à la guérison. ${ }^{754}$

Ceci signifie qu'il ne s'agit pas d'une qualité essentielle au peuple tibétain, telles que la piété ou la miséricorde. Il s'agit d'un aveuglement temporaire, d'une difficulté passagère, d'un obstacle qui pour le moment ne permet pas que la lumière de la grâce atteigne ce peuple. Et en partie, elle est également une punition du fait de l'adoration d'une fausse loi. ${ }^{755}$

Cet aveuglement, donc, est la puissance chrétienne nommée par le missionnaire. C'est justement cette catégorie qui orientera les stratégies de conversion de Desideri, et qui constituera la pierre fondamentale de l'édification du jésuite.

Voilà donc l'accommodation proposée par Desideri: remplacer l'objet. C'est un projet fondé sur la description politique et morale (relative au comportement et aux vertus) du peuple tibétain. Nul besoin de lui inculquer les préceptes chrétiens de base, tels que l'amour du prochain, car les Tibétains sont déjà sensibles à la souffrance d'autrui. Nul besoin non plus de les organiser politiquement, car ils savent ce qu'est un gouvernement et s'avèrent être une communauté parfaite. Ainsi donc la conversion, dans le cas du peuple du pays des lamas, signifiait changer l'objet de la dévotion, en substituant à la fausse secte la véritable loi. Pour cela, il se faisait nécessaire, moyennant l'usage de la raison, de convaincre les Tibétains de leurs erreurs et du fourvoiement de leur loi.

Dans une autre partie de son œuvre, le missionnaire procède à la description $\mathrm{du}$ système religieux observé au Tibet. L'exposé sur la "secte des lamas" débute par l'introduction de la figure du Grand Lama, chef de la religion, et comparé au Pape catholique. Subséquemment, le jésuite italien aborde le processus complexe de la succession des grands lamas $^{756}$. Pour le missionnaire, ce processus instigateur basé sur la possibilité de transmigration des âmes, ne peut pas être le fait des hommes, mais est plutôt l'oeuvre directe du Diable.

Après une description assez précise des processus de reconnaissance du nouveau Grand Lama, le jésuite offre ses propres impressions. Son interrogation principale tourne autour de deux hypothèses : Ce processus de succession du leader religieux du Tibet serait-il

\footnotetext{
${ }^{754}$ Voir : AQUINO, T. Suma Teológica. São Paulo: Ed. Loyola, 2001. Première partie de la seconde partie, question 79, article 3, Vol. IV, pages. 410-11. C'est nous qui traduisons.

${ }_{755}$ Pour d'autres exemples de l'utilisation du terme "aveuglement"en référence au bouddhisme dans d'autres parties de l'Asie, nous suggérons la lecture de VENTURA, R O Budismo nas fontes do Padroado Português do Oriente (séculos XVI e XVII) - um roteiro documental», in O Buda e o Budismo no Ocidente e na Cultura Portuguesa, org. Paulo Borges e Duarte Braga, Lisboa, Ésquilo Edições e Multimédia, 2007, pp. 127-172.

756 Cf: SWEET, M.J. The Devil's Stratagem or Human Fraud: Ippolito Desideri on the Reincarnate Succession of the Dalaï Lama. In: Buddhist-Christian Studies 29, nº 1, 2009. p.131-140.
} 
une œuvre du Diable, ou bien une astuce des parents de l'enfant en collusion avec les lamas? Ces deux seules options découlent évidemment de l'impossibilité de la part du missionnaire d'accepter comme "véritable" le processus de succession, car ce serait la même chose qu'accepter la possibilité de transmigration des âmes. Quoique cette conception ait déjà été bannie de la doctrine de l'Église à l'époque de Desideri, sa découverte parmi les croyances des sociétés au sein desquelles les jésuites établissaient des missions était un facteur de grande importance. En plus d'être présente dans les doctrines religieuses dites "orientales" (appelées, de nos jours, par exemple, l'hindouisme et le bouddhisme), la possibilité d'une renaissance de l'âme dans un nouveau corps avait déjà été défendue par des philosophes de l'antiquité comme Pythagore et Platon. Ce serait donc un pas crucial pour l'adoption du dialogue comme stratégie de conversion, possiblement calqué sur la stratégie dialogique et épistolaire de Paul.

Desideri penche en faveur de la première hypothèse, c'est-à-dire qu'il attribue au Diable la responsabilité du processus de succession des Grands Lamas. Pour étayer sa position, l'italien s'appuie sur sept arguments principaux qui peuvent être synthétisés par les idées suivantes : consensus universel, fréquence, persévérance et constance (de l'enfant lama) survivance, esprit surhumain, discernement ou artifice des lamas, et cui bono, c'est-à-dire dans quel intérêt?

Nous discernons une fois de plus la complexité de la tache à laquelle s'attelait Desideri. Il lui fallait décrire comment se réalisait une "élection" au poste qu'il reconnaissait comme le plus élevé de la communauté ecclésiastique tibétaine. Le processus lui semblait quelque peu obscur car il était régi fondamentalement par une loi qu'il refusait : la loi de la réincarnation. Il reconnaît cependant, que le peuple tibétain est civilisé, c'est-à-dire qu'il forme une communauté politique parfaite : un ensemble composé d'un corps ecclésiastique, d'une tête civile (le Roi) et du peuple. Ce peuple est donc capable de se gouverner de façon autonome. En plus, il reconnaît qu'au sein de cette communauté vivent "des gouvernants habiles et redoutés, des juges vigilants et un roi absolument souverain"757. Comment alors expliquer que des personnes qui, d'une façon générale agissent de façon tellement conforme à

\footnotetext{
757 "Governatori esperti e temuti, magistrati che vegliano, un Re sovrano assoluto." DESIDERI, I. La relazione di Ippolito Desideri, apud: PETECH, L. I missionari italiani nel Tibet e nel Nepal. Libr. dello Stato, vol. VI, DR. 3, p. 122. C'est nous qui traduisons.
} 
la loi naturelle, choisissent un leader d'une manière aussi superstitieuse"758. La conclusion de l'Italien est que "le diable est le seul véritable agent causal direct de toute la supercherie." 759

Pour défendre sa position, le missionnaire dépeint la complexité de l'équilibre politique entre le pouvoir spirituel et le pouvoir temporel. En plus, nous pouvons percevoir en lisant cette œuvre du XVIII ${ }^{\mathrm{e}}$ siècle, comme ledit équilibre était (et est toujours) fondamental pour la configuration sociale du Tibet, notamment en ce qui concerne la figure du Dalaï Lama en tant que personnage central de l'organisation sociopolitique.

Dans son texte cependant, Desideri reconnaît et nomme les principaux acteurs politiques : le peuple, les lamas, le roi. L'Italien indique également la structure de la hiérarchie en affirmant que les lamas jouissent d'un grand respect et occupent le sommet de la pyramide sociale. En plus, il ajoute que les religieux bouddhistes sont des personnes instruites, intellectuellement préparés, qui enseignent la religion et sont considérés sacrés.

$\mathrm{Au}$ surcroît, dans ce que nous pourrions appeler la périphérie du texte - c'est-à-dire qui est sous-jacent au contenu principal de l'argumentation de l'auteur - nous identifions des attributs qui qualifient et décrivent la société tibétaine et ses parties. Ces attributs - civilisés, barbares, cultes, intelligents, prudents etc. sont des prédicatifs qui construisent des catégories, qui soutiennent et justifient la pratique missionnaire en plus de déterminer les stratégies les plus prudentes de conversion pour chaque société à être évangélisée.

D'ailleurs, l'utilité pratique du texte est explicitée par Ippolito Desideri lui-même, en établissant une relation directe entre la production écrite et l'action missionnaire, entre le texte et la pratique, entre la rhétorique et la politique.

Lorsque Desideri constate que les tibétains ne reconnaissent aucune divinité créatrice non créée, il se voit devant un grave problème épistémologique et théologique. Comme nous l'avons vu, l'attribution d'une place dans le système d'entendement du monde chrétien est une activité fondamentale de la pratique missionnaire. L'attribution de cette place se fait à partir de l'association d'attributs aux sociétés décrites. Cette opération rhétorique de prédication ou de catégorisation est justement l'objet de notre thèse.

Néanmoins, comment décrire une communauté qui n'est pas idolâtre comme les autres païens de l'Asie, mais qui, en même temps, fournit des indications qu'elle n'est pas

\footnotetext{
${ }^{758}$ L'expression employée par le missionnaire est superstiziosa maniera di successione”. DESIDERI, I. La relazione di Ippolito Desideri, apud: PETECH, L. I missionari italiani nel Tibet e nel Nepal. Libr. dello Stato, MINT, vol. VI, DR. 3, p. 122.

759 "Il demonio sai il ver e solo agente immediato di tuttoquell'inganno". Ibidem, vol. VI, DR. 3, p. 129.C'est nous qui traduisons et qui soulignons.
} 
suffisamment barbare au point de ne pas croire en Dieu ? Comment signifier ce "manque", c'est-à-dire l'absence d'un Dieu créateur, d'un Dieu père, d'un Dieu juge dans la religion tibétaine ? Car s'il n'est pas possible d'attribuer aux tibétains la catégorie d'idolâtres, à l'instar de ce qui a déjà été fait pour leurs voisins indiens, pourrait-on dire que les tibétains sont athées ? Et si cette communauté est athée et non pas simplement composée d'individus athées, dans ce cas quelle type de stratégie de conversion serait la plus prudente?

Ce qui supposément semble être un élément de déqualification de la société tibétaine apparaît comme un avantage dans l'élaboration faite par le jésuite. Nous croyons donc qu'il existe une gradation implicite dans les catégories utilisées par Desideri. Les peuples les plus rudes et les plus barbares ignoreraient l'existence de Dieu. Mais, en pratique, cela serait une impossibilité, car Dieu a touché tous les hommes universellement, et du fait d'être des hommes, la lumière de la raison permet qu'ils possèdent l'entendement nécessaire pour concevoir l'existence d'un être suprême, encore que la raison toute seule ne puisse pas, nécessairement, rendre compte de tous les mystères qui d'après la doctrine entourent Dieu,. ${ }^{760}$

De cette sorte, le missionnaire suggère subtilement une inversion de cet ordre dans le cas de la secte des lamas. Il indique un aspect positif dans l'athéisme présumé des Tibétains, lorsqu'il affirme que cet athéisme est le résultat du refus des croyances païennes allant contre la raison, et est donc la conséquence de la nature subtile de l'intellect de ce peuple.

Um autre pas important franchi par le missionnaire est la distinction scolastique entre athée pratique et athée théorique. Les Tibétains seraient plus raisonnables du fait de répéter les croyances contre la raison qui leur avaient été transmise par les idolâtres de l'Inde. A celles-ci, ils ont préféré le refus absolu d'une divinité. Mais évidement ils ont gardé un mince faisceau de lumière de la grâce, ce qui est un indice de leur comportement vertueux et de leur capacité intellectuelle et dialectique. La négation de la divinité n'est alors qu'une expression verbale et sophiste de leur refus du paganisme indien. La secte des lamas, même si euxmêmes ne le reconnaissent pas, est un théisme confus dont l'argumentation est fallacieuse.

Une fois abandonnée la catégorisation des tibétains comme athées, une fois circonscrites toutes leurs similarités avec la gentilité des voisins, et, finalement, une fois contesté l'enseignement direct au Tibet par des apôtres pendant l'antiquité, Desideri passe à une autre catégorie: celle des personnes aveugles. Mais il ne s'agit pas d'un aveuglement absolu, mais plutôt d'un trouble de vision, car il est évident du fait de l'existence d'un objet de

${ }^{760}$ Cf: AQUINO, Tomas de. Suma Teológica,. Edições Loyola: São Paulo, 2001. volume 1, parte I, questões 143. 
refuge que les tibétains possèdent une certaine notion de l'existence du véritable Dieu. C'est à l'aide de cet exercice théologique et rhétorique que Desideri construit une possibilité de salut - c'est-à-dire de mission - dans la même mesure où il déconstruit l'athéisme des gens aveugles du Tibet.

Nous pouvons donc constater que la construction de cette catégorie et son attribution aux Tibétains a été édifiée sur trois prémisses:

La prémisse politique, c'est-à-dire que l'observation et l'analyse de l'organisation sociale et de la structure de l'État Tibétain ont été nécessaires pour réfuter l'idée que les tibétains seraient une nation " barbare" à un degré tel qu'ils nieraient résolument l'existence de toute divinité.

Desideri, manifestement, part aussi de prémisses théologiques, qui se sont concentrées sur l'étude de livres de la secte tibétaine et sur l'éventuelle participation dans des discussions avec des moines bouddhistes. Ces initiatives ont permis que le jésuite identifie et réfute (pour le public européen, mais principalement pour le public tibétain moyennant de la publication en langue locale) les "erreurs" de la fausse religion des lamas.

La troisième prémisse qui a permis l'élaboration de la catégorie "gens aveugles" appartient au domaine de la morale, car l'Italien se consacre à analyser la morale tibétaine, c'est-à-dire ce que la loi religieuse prescrit pour la régulation de la conduite de ce peuple, et qui est connue par toutes les sectes comme la voie qui doit être suivie pour arriver au salut ${ }^{761}$. La normatisation et le règlement de la conduite socialement acceptable est l'objet de l'observation et de l'analyse du jésuite. Tuer, voler, mentir, désirer le mal des autres, tous ces péchés sont régulés par la secte tibétaine. Les vertus honorées par le bouddhisme, d'après le propre entendement du religieux seraient : la foi, l'espérance, l'amour; seule l'humilité n'aurait pas été décelée par le missionnaire.

A l'issue de ses considérations, nous constatons que le missionnaire non seulement attribue une place théologique et historique aux tibétains, mais il les insère dans le contexte asiatique. Ainsi, le jésuite leur attribue une place dans son projet missionnaire à partir d'une double négation: ils ne sont ni athées ni payens. Et de toute évidence ils ne sont pas chrétiens non plus, mais en leur niant le statut d'idolâtres et principalement d'athées, Desideri leur assure une possibilité de salut.

\footnotetext{
761 "Dar un succinto regguaglio della morale o sia di ciò che loro prescrive in ordine al regolamento de' costume, che in tutte le sette è riconosciuto per camino da tendersi per giugner alla salute.” Ibidem, DR. 3, p. 221. C'est nous qui traduisons.
} 
Cependant, nous souhaiterions souligner encore que Desideri a encouragé un double dialogue - interne et externe - dans l'élaboration de son ouvrage. Du point de vue externe, le missionnaire se consacre à l'étude de la langue locale pour pouvoir comprendre et réfuter les principales erreurs de la secte tibétaine, en engageant un débat "littéraire" entre le christianisme et le bouddhisme tibétain. Interne parce que Desideri démontre qu'il a réuni des informations sur le Tibet qui vont au-delà de sa propre expérience. Il a lu les rapports d'Andrade et fait de nombreuses mentions à Kircher, en parlant de sa tentative de mettre en question le savoir du propre Ordre sur le pays et sur la secte des lamas. Mais l'Italien ne se satisfait pas de ce qui pourrait être un débat d'opinions. Il se base théoriquement non seulement sur sa propre expérience, pour réfuter la soi-disant expérience de ses compagnons de la Compagnie de Jésus, mais s'appuie sur le Thomisme et, de cette sorte, établit un troisième dialogue entre le corps doctrinaire chrétien et la pratique missionnaire.

En plus, nous soulignons que l'exercice du religieux ne s'achève pas sur le caractère intellectuel de son activité. Desideri ne se contente pas de produire un texte en italien pouvant servir au public européen. Le but de ce travail intellectuel est la mission. L'élaboration du texte et le raffinement de la parole écrite servent la pratique missionnaire: ils commencent et finissent dans le domaine missionnaire. Tant et si bien qu'après avoir été expulsé de la mission, Desideri ne renonce aucunement à son projet d'un modèle missionnaire à être appliqué aux "gens aveugles" des Indes Orientales. Dans quelques-uns des derniers chapitres de sa note Historique du Tibet, et dans une espèce de manuel destiné aux pères qui allaient être envoyés aux Indes, l'Italien fait une ébauche de ce que nous entendons comme une tentative de normatisation du projet de la Compagnie de Jésus pour l'Asie. Nous supposons que ce texte est le fruit d'une expérience de près d'un siècle et demi (1580-1720) d'action dans la région, période au cours de laquelle les religieux ont documenté et ont partagé leur expérience au moyen de la discipline épistolaire et, d'une certaine façon, de l'activité littéraire.

A partir de ses écrits, nous estimons que les éléments suivants composent la synthèse du modèle de mission ébauché par l'Italien : premièrement, le profil du missionnaire doit être, nécessairement, celui de quelqu'un possédant une parfaite connaissance de la doctrine catholique, en plus de dominer le savoir ("sapienza"); deuxièmement, le missionnaire doit être constamment engagé dans des disputes, des débats, des argumentations et des réfutations, moyens à l'aide desquels on doit chercher la démonstration de la erreurs de la vérité, la réfutation des secte de l'autre, la persuasion et la conversion. Nous mettons en exergue la 
période "per mezzo di sottilissime dispute", ${ }^{762}$ car nous estimons qu'elle condense deux idées fondamentales que nous cherchons à développer tout au long de cette thèse : l'importance de la dispute, évidemment, et la compréhension du "moyen" ou de l'instrument. C'est-à-dire " la dispute comme instrument". Elle n'est pas une fin en soit. Les débats, comme nous l'avons vu, ont une double finalité : montrer les erreurs de l'interlocuteur, et moyennant la persuasion et la conviction, convertir l'autre.

Cela signifie dire que le sujet du débat peut être un point théologique sans être nécessairement un article de foi. La dispute, en tant que moyen ou instrument, sert à démontrer la rationalité - et donc, la supériorité de sa loi. Vaincre un débat dans n'importe quel domaine de la connaissance, est un moyen pour se faire entendre, un pas supplémentaire pour qu'ensuite on puisse convaincre l'autre de la supériorité de la loi du Christ sur toutes les autres. Dans ce sens, nous nous approchons des idées de Majeistina Khalos : Dans la mission chrétienne le dialogue n'est qu'un instrument. "763 Nous divergeons cependant de l'usage de l'expression "n'est qu'un". A notre sens, le dialogue était un instrument puissant, ou encore, une stratégie fondamentale.

Ce fait devient encore plus significatif lorsque nous voyons dans les écrits des missionnaires que ces peuples ont "une dialectique propre". Reconnaître chez l'autre l'existence d'un modèle pour disputer, pour argumenter et pour débattre, oblige le jésuite à s'adapter à ce mode, ce qui rend impensable une méthode catéchétique prévoyant simplement l'adoption et la pratique d'exercices et de disciplines typiques de la formation jésuite.

Pour passer aux considérations finales de notre thèse, nous aimerions examiner la période initiale de surgissement et de formation de la Compagnie de Jésus, pour que nous puissions mettre en perspective le processus ici ébauché, qui est parti de l'action des prêtres à la cour mogole à la fin du XVIe siècle et a débouché sur une proposition d'Ippolito Desideri d'un modèle missionnaire, à l'orée du XVIII' siècle.

Lorsque la Compagnie de Jésus a été constituée à Paris, vers la moitié du XVIe siècle, le premier objectif d'Ignace de Loyola et de ses compagnons était d'évangéliser la Terre

\footnotetext{
762 "Volesse il Divin Maestro darci a intendere che chiunque ha da instruir e convertir il mondo fa di mestiere che sia adornato d'una non ordinária, non mediocri, ma molto profonda dottrina e molto sublime sapienza. Infatti, se in pratica ben si consideri un sì apostólico e divin ministerio, lo vedremo sempre esercitato ora per mezzo di maravigliosissime instruzioni de le più recondite verità e ora per vigomezzo di sottilissime dispute, d'acute dissertazioni, di vivissime persuasioni e di nervose efficacissime confutazioni de' combattuti errori e de' conquisi inganni. Diasi un'occhiata alla maniera osservata dal Salvator del mondo, norma e specchio di tutti gli apostolici predicatori e de gli evangelici operari.” PETECH, L. I Missionari italiani nel Tibet e nel Nepal. Roma: Libreria dello Stato, 1952-1956, vol. VII, DR 4, p. 109.

763 "In Christian mission, dialogue was only na instrument." KAHLOS, M. Debate and Dialogue: Christian and pagan cultures. Aldershot: Ashgate, 2007, p. 79. C'est nous qui traduisons.
} 
Sainte, c'est-à-dire de prêcher aux infidèles. Ce but ne s'est pas concrétisé à cette époque, mais comme nous pouvons le voir, les héritiers de Loyola et de François Xavier ont prêché entre les musulmans encore pendant le $\mathrm{XVI}^{\mathrm{e}}$ siècle.

On sait également que depuis sa création, la Compagnie de Jésus s'est structurée autour d'un double rôle: le rôle missionnaire, comme les chapitres antérieurs l'ont clairement détaillé, et le rôle pédagogique. L'Ordre fondée par Loyola surgit également comme une source importante de transformation de l'environnement éducationnel et intellectuel de l'Europe réformée. Cette association entre le savoir et le pragmatisme évangélisateur, comme l'historiographie l'a démontré de façon répétitive, allait être la marque de la Compagnie de Jésus. ${ }^{764}$

En outre, comme l'observe Ricardo Ventura, le modèle missionnaire depuis le temps de François Xavier, s'appuyait sur trois points : l'effort d'étudier les langues des possibles catéchumènes, leurs formes de religiosité et de coutumes ; l'établissement d'un "réseau de contacts entre pères jésuites"; et l'embasement des missions "sur un socle politique et diplomatique le plus solide possible assurant l'autonomie des missions et simultanément une représentation de la politique et de l'économie de l'État de l'Inde."765

Bien entendu, l'analyse des sources relatives aux missions jésuites ici étudiées ne contredit pas les deux principes fondamentaux du mode d'action et de l'identité de l'Ordre d'Ignace. Mais il est nécessaire en outre que nous soyons capables d'ajouter quelque chose à ce qui a été déjà pleinement établi par l'historiographie.

Nous souhaiterions ajouter que les stratégies de conversion, depuis leur ébauche au Mogol, étaient dotées de particularités qui ont été consolidées, élaborées et défendues d'une façon plus structurée par Desideri, par exemple, au cours des siècles subséquents. Nous avons décelé que l'apprentissage de la langue et la production de textes en langue locale était déjà une pratique courante à la mission, initiée quelques années seulement après la fondation de l'Ordre. En outre, avant même l'achèvement de la Ratio Studiorum, nous pouvons déduire, par la façon d'agir des missionnaires à la cour mogole que le poids de la rhétorique et de l'érudition - c'est-à-dire l'importance de la formation pour la mission - semblait déterminant. Il était nécessaire de persuader. Il était nécessaire de convaincre. Il était nécessaire de

\footnotetext{
764 "The original members were all university trained, which not only Ient the group considerable prestigie, but set a pattern of cultural and intellectual excellence." O’MALLEY, J.W. The first jesuits. Harvard University Press, 1993, p. 225.

${ }^{765}$ VENTURA, R. O Budismo nas fontes do Padroado Português do Oriente (séculos XVI e XVII) - um roteiro documental», in O Buda e o Budismo no Ocidente e na Cultura Portuguesa, org. Paulo Borges e Duarte Braga, Lisboa, Ésquilo Edições e Multimédia, 2007, p. 137.
} 
démontrer les raisons de sa foi. Le tournant du XXIII ${ }^{\mathrm{e}}$ siècle met en évidence de façon très claire l'actualisation du thomisme non seulement comme forme de débat et de formation intellectuelle en Europe mais comme instrument catéchétique. Agir de façon pratique ou pragmatique signifierait agir de façon pastorale, évangélisatrice. Ainsi, l'action spéculative était d'une importance primordiale, mais sans signifier une fin en soi-même : elle devait être nécessairement au service de la mission.

Cependant, le choix de la persuasion, de la conviction et des formes dialogiques d'action n'a pas été le seul fait d'une dynamique d'essais et d'erreurs. Cette option a été simultanément un choix nécessaire découlant d'une situation spécifique, souscrite et contingente. Les jésuites ne se sont pas lancés au débat en fonction uniquement de leur pratique pédagogique et de leur formation intellectuelle. Ils ne firent pas appel au Thomisme ni à la métaphysique en raison de leur formation et de leur entraînement dans les Collèges de l'Ordre en Europe. L'action dialogique, par le biais de la participation à des disputes, a été, en partie, une espèce d'imposition extérieure. Dans ce scénario les disputes semblaient la méthode la plus prudente et efficace s'approchant d'une imitation du modèle de Saint Paul. Mais il ne s'agissait pas seulement de cela. Participer aux disputes et écrire des ouvrages en persan abordant des thèmes théologiques et métaphysiques - comme la conception du Christ, la Sainte Trinité et l'Unité de Dieu, etc. - signifiait en même temps la mise en pratique de la formation reçue dans les Collèges, et l'adaptation à une procédure politique locale.

Cet espèce d'embryon de stratégie dialogique missionnaire a été, d'une certaine façon, héritée, testée, mise en œuvre et perfectionnée dans les missions tibétaines depuis l'initiative de Antônio de Andrade jusqu'à l'élaboration missionologique de Desideri. Il convient de ne pas oublier que l'Italien a fait référence au traité apologétique écrit par Jerônimo Xavier, un siècle auparavant, en Hindoustan.

Nous soulignons, finalement que dans cette thèse nous avons cherché à mettre en rapport la rhétorique et l'action politique des jésuites dans les missions ici recoupées. Desideri recommande aux missionnaires qui allaient être envoyés au Tibet :

Cherchez à obtenir la bénévolence de tous, nobles ou plébéiens, monarques ou séculiers, Gagnez la protection des puissants car elle vous assurera le respect et la bonne volonté des autres. ${ }^{766}$

\footnotetext{
766 "Procurino di procacciarsi la benevolenza di tutti, così nobili come plebei, si monaci come secolari. Si guadagnino la protezione de' grandi, perchè questa li concilierà il respecto e li renderà bem voluti da gli altri." PETECH, L. I missionari italiani nel Tibet e nel Nepal. Libr. dello Stato, 1952, App. II, p. 190. Tradução nossa.
} 
Le conseil politique offert par l'Italien aux jésuites à destination du Tibet est évident, dans ce passage. Comme nous l'avons mentionné au long de notre analyse, la lecture du contexte politique, la proximité avec la "tête" et ce qu'on appelait la relation de patronage étaient des facteurs fondamentaux pour la mise en œuvre des stratégies de conversion dans le pays des lamas. Le missionnaire faisait en vérité référence au Tibet, mais nous pensons que ces conseils peuvent être entendus d'une façon plus globale, à savoir que nous imaginons que cette méthode était également applicable à des communautés dont la forme sociopolitique soit analogue à celle retrouvée au Tibet.

Pour conclure, nous nous proposons de scinder cette façon d'agir des jésuites en une espèce de triade rhétorico-politique composée des éléments suivants : l'épître, la narrative et le dialogue. La fonction de l'épître est de diffuser l'information, l'édification, la propagande et la reddition de comptes, c'est-à-dire maintenir le supérieur informé de ce qui se passait dans le territoire missionnaire. La narrative, pour sa part, posséderait également la fonction d'informer, associée au rôle de décrire et de catégoriser. Élaborer ou attribuer une catégorie est également une action politique et non pas seulement une action contemplative ni superficiellement rhétorique ${ }^{767}$. Au dialogue, de son côté serait attribué la fonction de hiérarchiser, de convaincre et de convertir. Mais si nous reprenons la citation susmentionnée de Desideri rien de tout cela ne produirait l'effet escompté si l'observation, la perspicacité et la recherche d'alliances politiques locales n'était pas une priorité pour les missionnaires.

La connaissance qu'un missionnaire doit avoir de la doctrine, d'après l'Italien, ne doit pas être ordinaire ou médiocre, mais ample et sublime. Pour démontrer ce point, le jésuite débute son argumentation en reprenant l'exemple du Christ lui-même : il aurait inculqué chez les apôtres la prudence, le zèle, le courage et la vigueur. ${ }^{768}$

Le contexte politique trouvé par Desideri est sensiblement différent de celui de l'époque d'Antônio de Andrade. Au début du XVII ${ }^{\mathrm{e}}$ siècle, le Tibet - et particulièrement sa région occidentale - était morcelé en petits royaumes. Cette organisation politique, comme nous avons déjà eu l'occasion de le dire, s'est modifiée au cours du processus qui a débouché

\footnotetext{
767 "Réduire l'humanité à deux types mutuellement exclusifs sur la base de la nature, effectue une fonction sémantique politiquement efficace", nous dit Kosseleck en faisant référence au monde ancien.

KOSELLECK, R. Futuro passado: contribuição à semântica dos tempos históricos. Rio de Janeiro, Contraponto / PUC-RJ, 2006, p. 207.

768 "E per cominciar dalla dottrina, non ordinária ma ampia e sublime, che negli operaij evangelici destinati alle missioni tra gl'infedeli si richiede avendo N. S. Giesú Cristo scelti i dodici apostoli per addestrarli ala conversion del mondo, andò loro instilando tutte quelle virtù e prerogative che per si grand'opera si richiendo. Ora recomando loro la prudenza, (...) tal ora insinuò loro uno zelo che a tutte le creature e a tutto il mondo si stendesse.” PETECH, L. I missionari italiani nel Tibet e nel Nepal. Libr. dello Stato, 1952, DR 4, p. 107-8.
} 
sur l'investiture du V Dalaï Lama. D'autre part, pendant le XVII ${ }^{\mathrm{e}}$ siècle, à l'occasion de l'arrivée du missionnaire italien à Lhassa, la figure centralisatrice du V Dalaï Lama n'existait plus car il était mort en 1682. Desideri s'est installé donc dans un Tibet plus centralisé du point de vue politique, mais orphelin de son chef politico-spirituel plus important.

Cet aspect est important pour notre analyse car il nous fournit également des indices sur la méthode d'adaptation anticipée par le missionnaire. Desideri se présente comme un "lama" mais pas seulement sous cette forme : il est reconnu comme une espèce de "sage", un homme cultivé et érudit. Ce trait peut rapprocher la méthode de l'Italien des méthodes que d'autres missionnaires de l'Ordre auraient adopté, tout particulièrement en Chine et au Japon.

Nous pouvons distinguer, alors un cycle intéressant de (re)formulation et d'épuisement des catégories, qui se renouvelle à un rythme dicté par la limitation imminente de vocables tels qu'"idolâtre", "payen", infidèle, etc. A mesure que ces catégories devenaient inefficaces pour résoudre les problèmes de nature épistémologique et missionologique affrontés par les pères, de nouveaux compléments et prédicats devaient être élaborés susceptibles de décrire le futur nouveau converti et d'anticiper la forme la plus prudente de catéchèse. 
AnEXos 
ANEXo A: MAPA DA ÁSIA, SÉCULO XVI.769

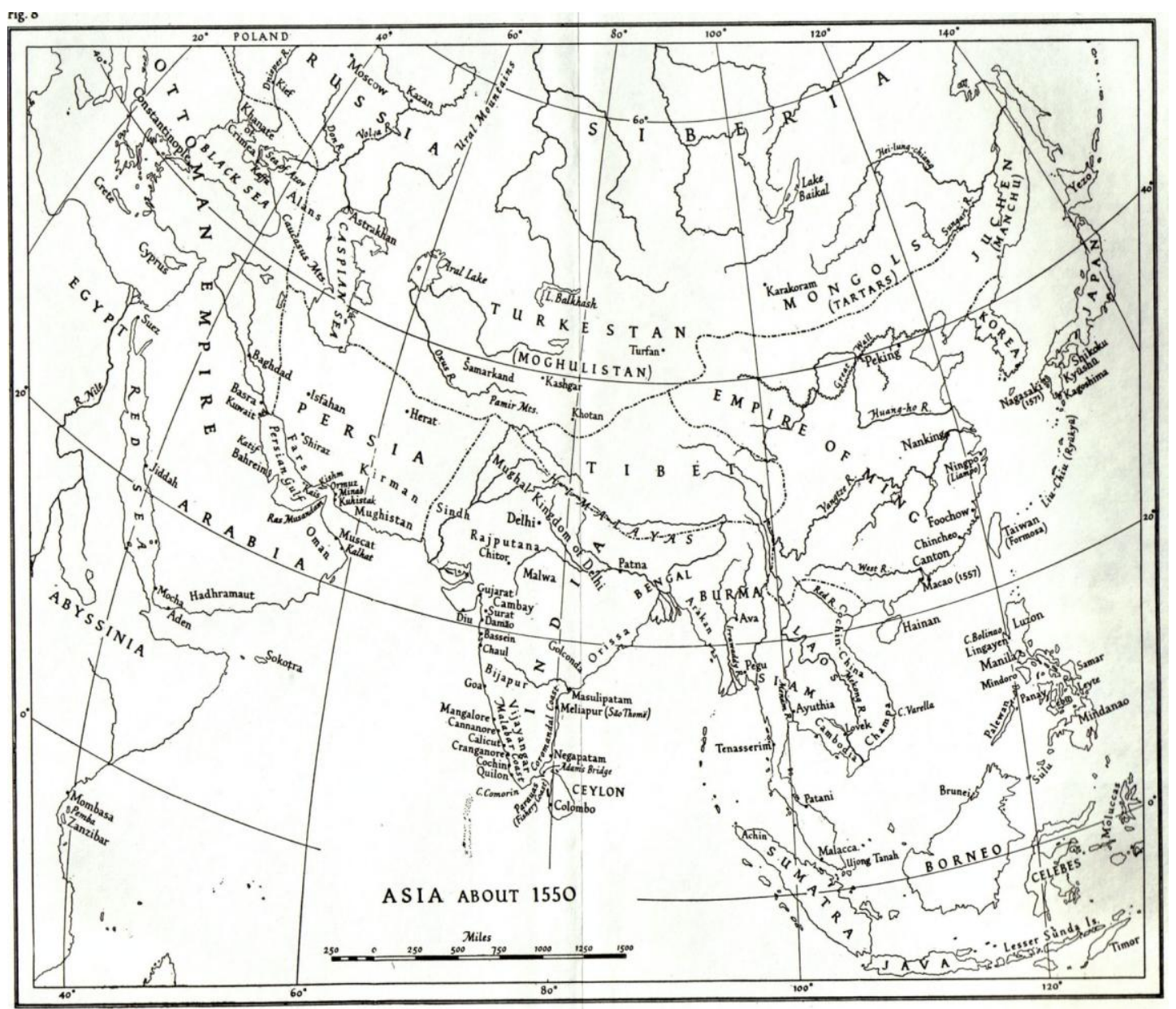

${ }^{769}$ BOXER, C. South China in the Sixteenth Century. Bangkok: Orchid Press, 2004, p. 399. 
ANEXo B: MAPA DO IMPÉRIO MOGOL E SUAS CONQUISTAS770

HISTORICAL ATLAS OFTHE ISLAMIC WORLD

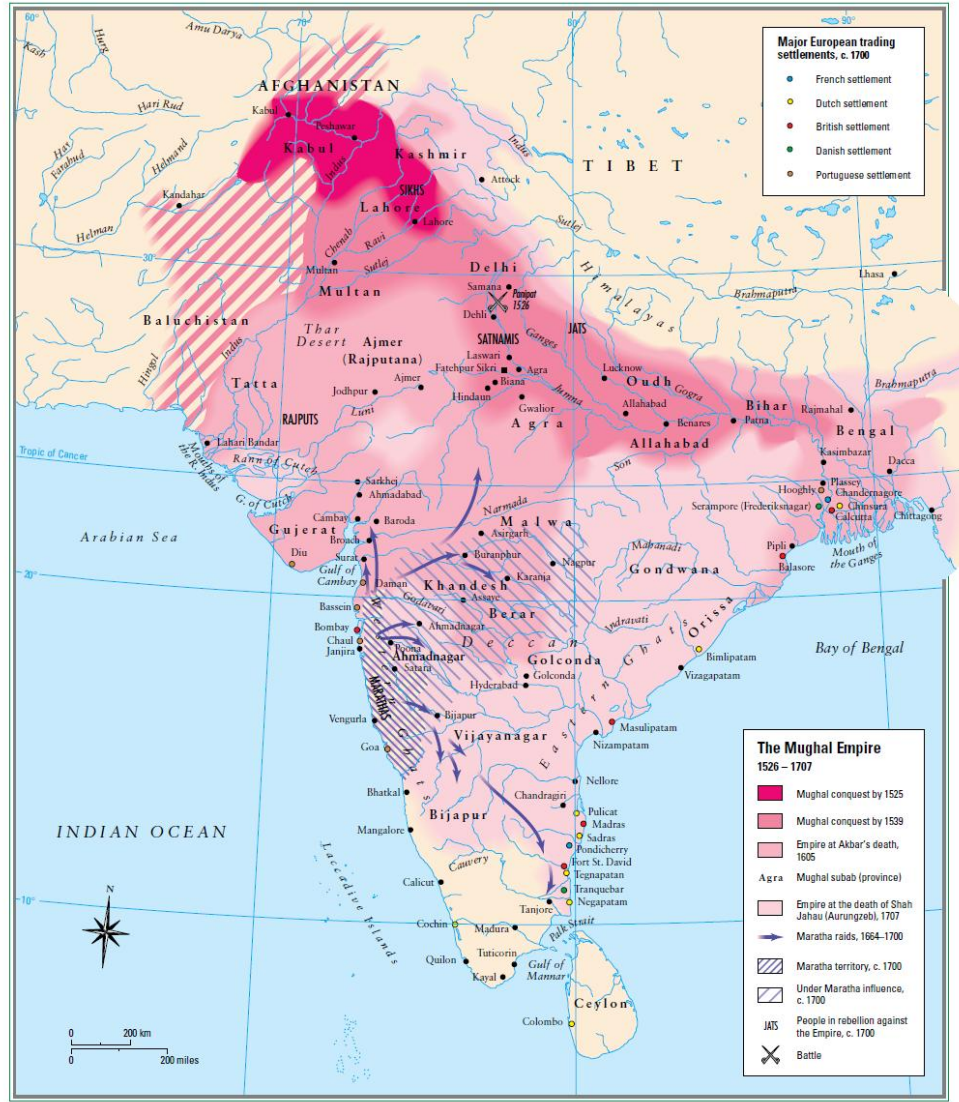

$\left(\frac{10}{20}\right.$

${ }^{770}$ RUTHVEN, M.; AZIM A.. Historical Atlas of Islam. Harvard University Press, 2004, p. 98. 
ANEXo C: VERSO DA CARTA DE ANTÔNIO DE ANDRDADE DE 1627

(ARSI GOA, FF: 51V)

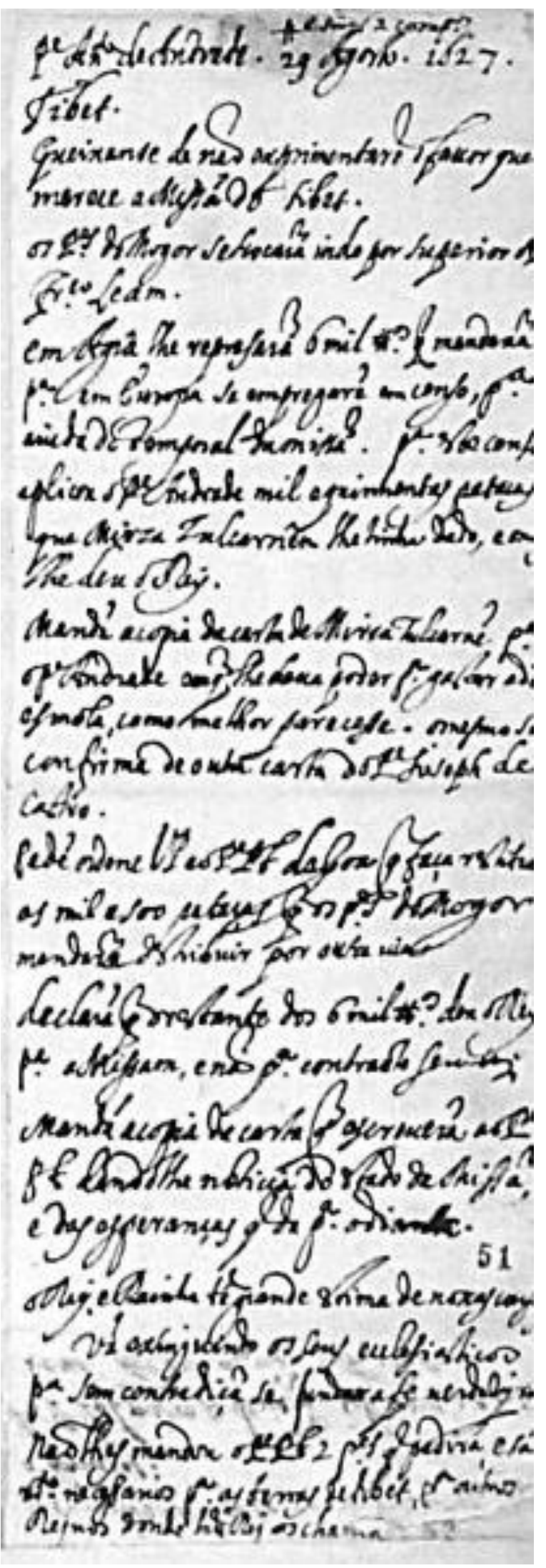


ANEXO D: ITINERÁRIO DO MISSIONÁRIO ANTÔNIO DE ANDRADE771

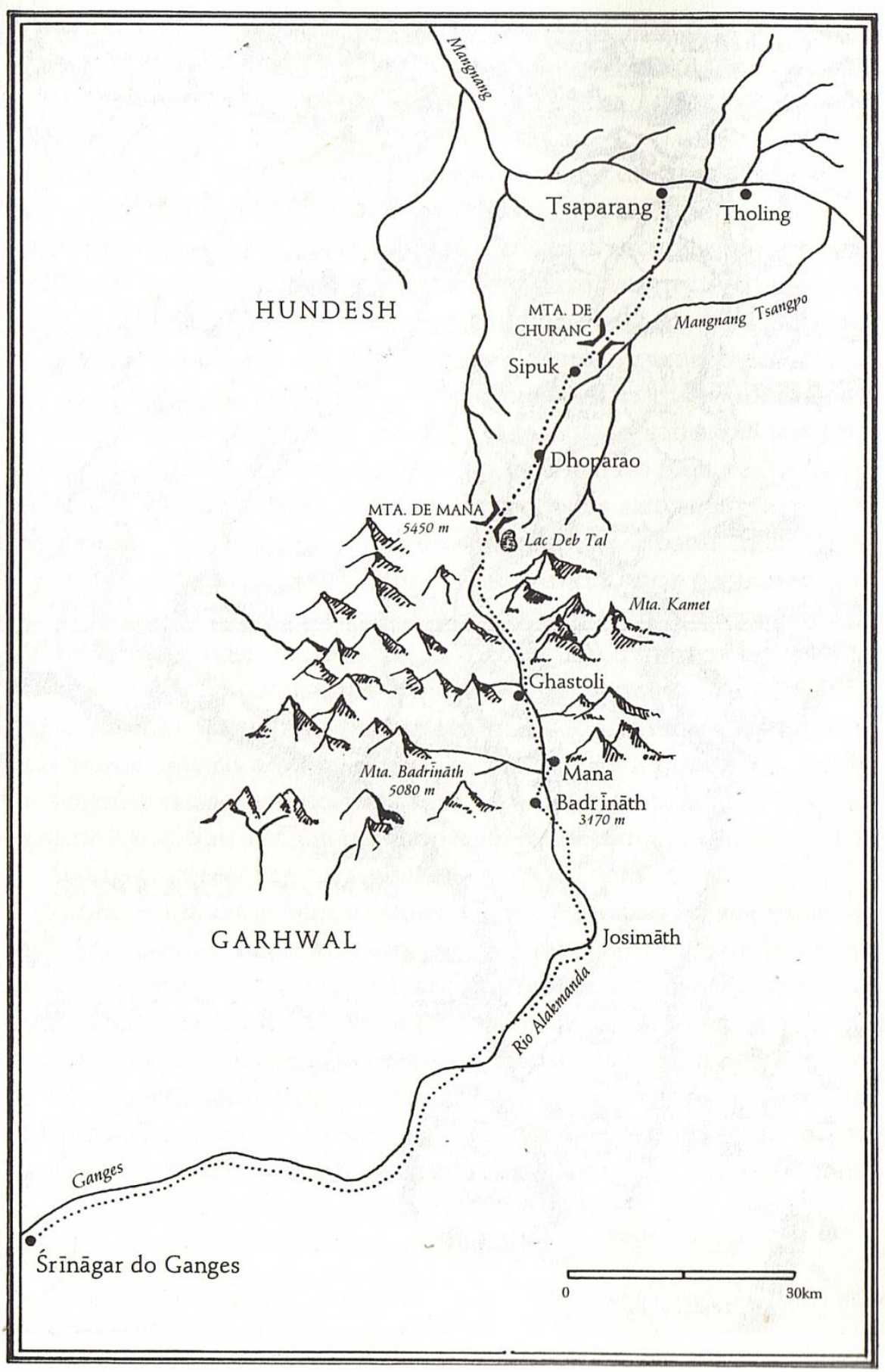

O itinerário tibetano do Pe. António de Andrade.

${ }^{771}$ DIDIER, H. Os portugueses no Tibete. Os primeiros relatos dos jesuítas (1624-1635). Lisboa: Comissão Nacional pra Comemoração dos Descobrimentos Portugueses, 2000, p.78. 
ANEXO E: ITINERÁRIO DO MISSIONÁRIO FRANCISCO AZEVEDO. ${ }^{772}$

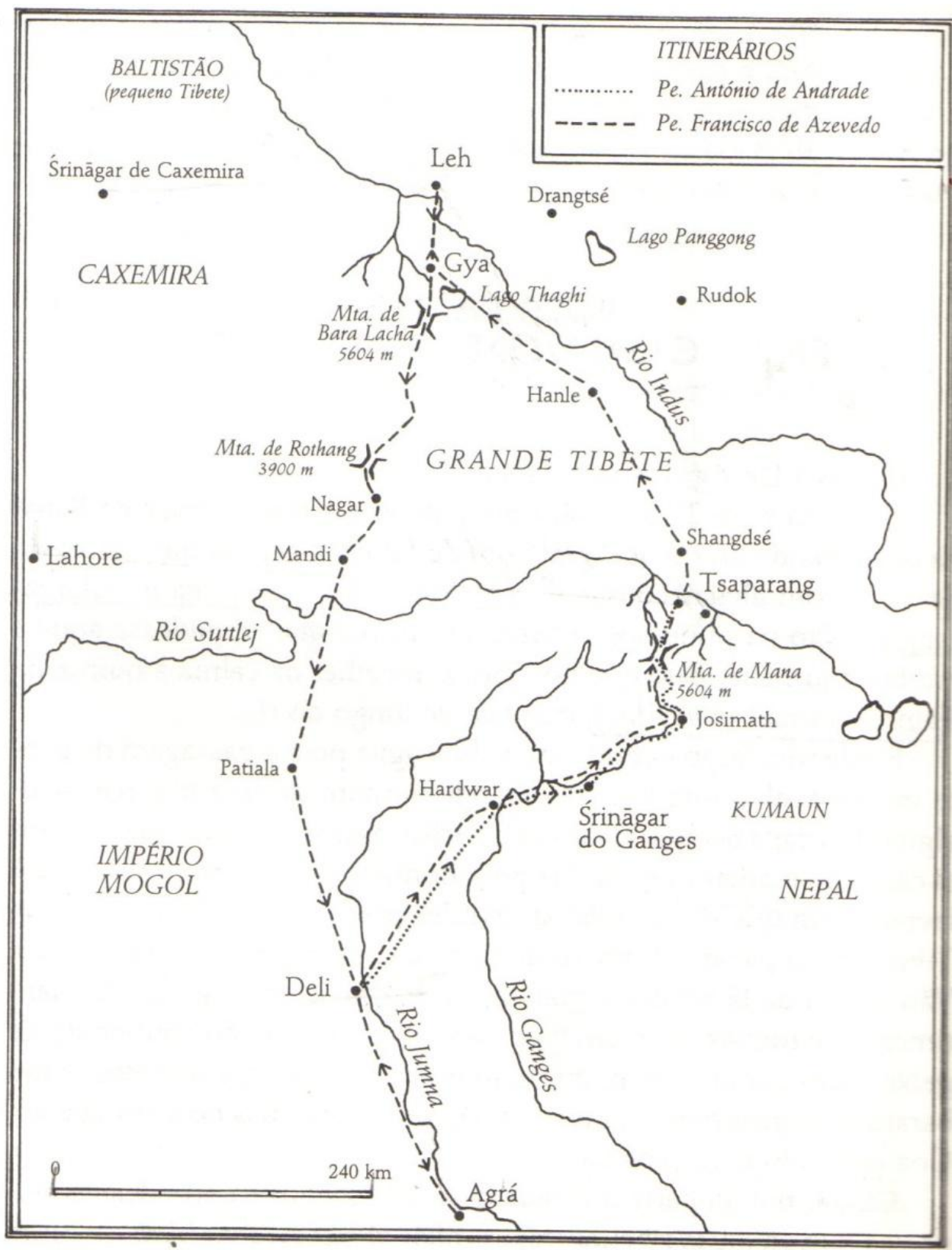

O percurso do padre Francisco de Azevedo.

${ }^{772}$ DIDIER, H. Os portugueses no Tibete. Os primeiros relatos dos jesuítas (1624-1635). Lisboa: Comissão Nacional pra Comemoração dos Descobrimentos Portugueses, 2000, p.162. 
ANEXo F: ITINERÁRIOS DOS MISSIONÁRIOS ESTÊVÃo CACELA E JOÃO CABRAL ${ }^{773}$

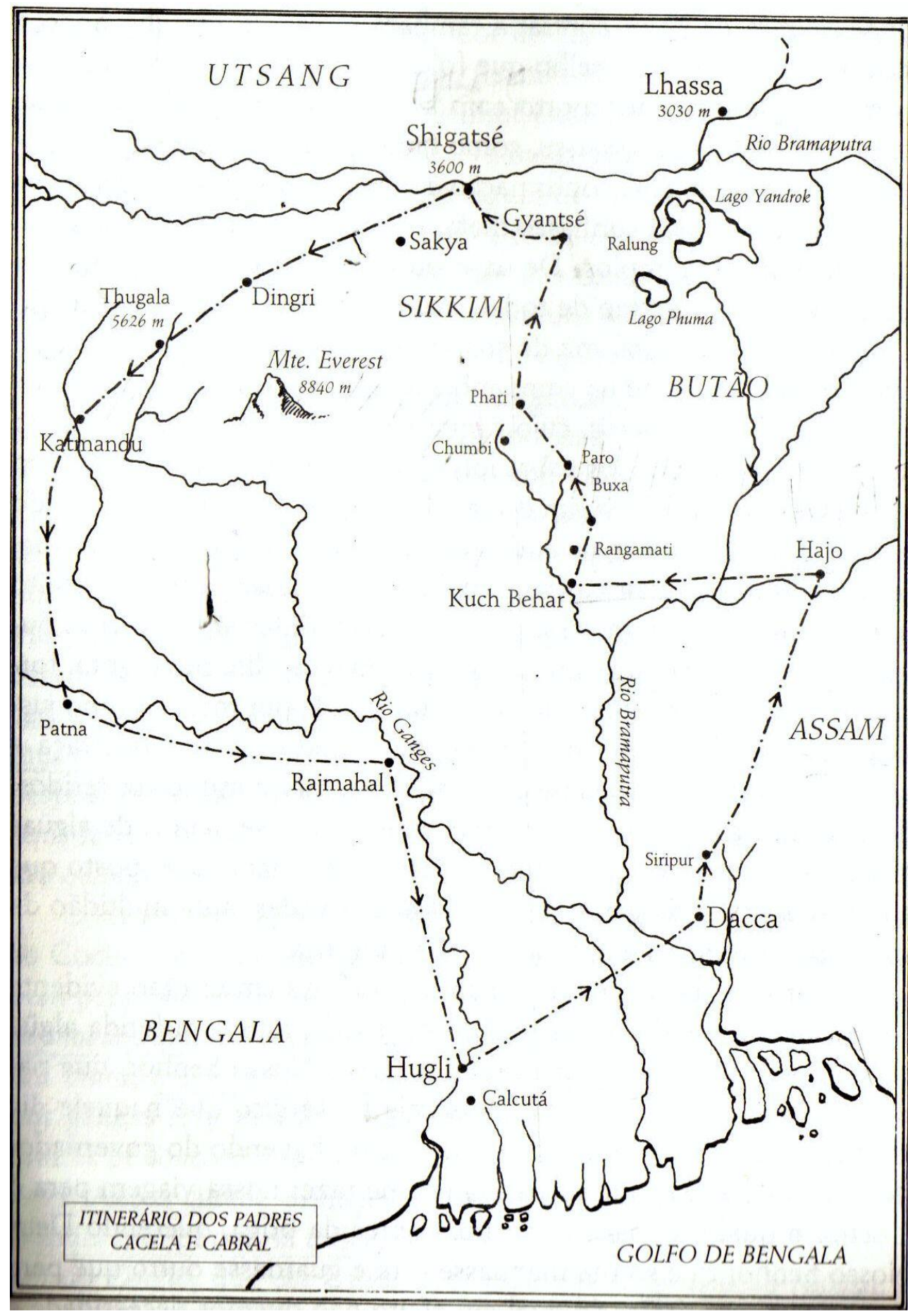

773 DIDIER, H. Os portugueses no Tibete. Os primeiros relatos dos jesuítas (1624-1635). Lisboa: Comissão Nacional pra Comemoração dos Descobrimentos Portugueses, 2000, p.217. 
ANEXO G: MAPA DAS MISSÕES E SUAS RESPECTIVAS PROVÍNCIAS NO SUBCONTINENTE INDIANO, SÉCULOS XVI-XVIII. ${ }^{774}$

'TERTITORIAL RANGE

JESUITS IN INDIA

1542-1773

PRINGIPAL ADMINISTRATIVE DIVISIONS AND STATIONS

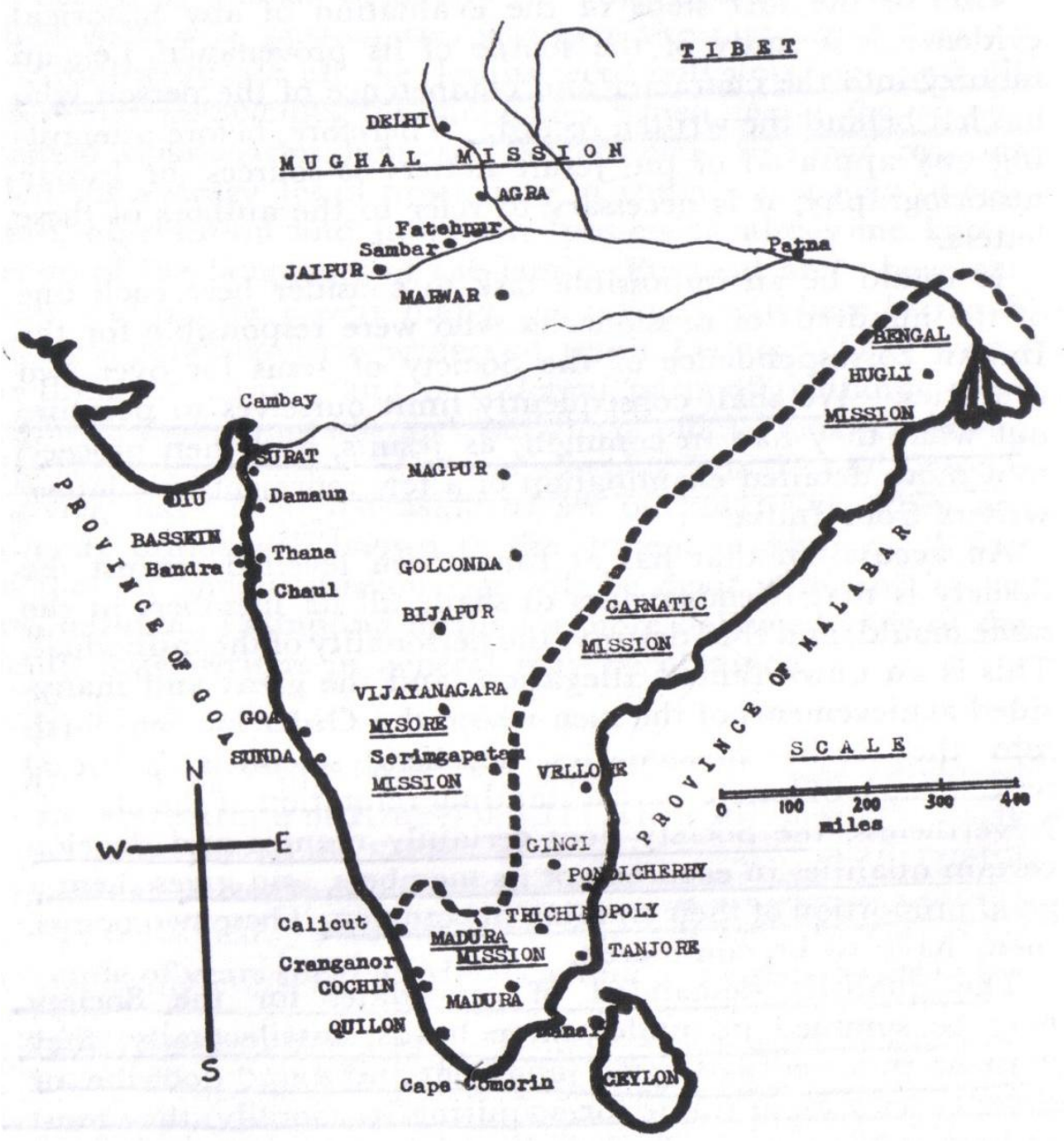

${ }^{774}$ CORREIA, A.J. Jesuit Letters and Indian History. Oxford University Press, 1969, p. 55. 
ANEXO “H”: ROTEIRO DE IPPOLITO DESIDERI775

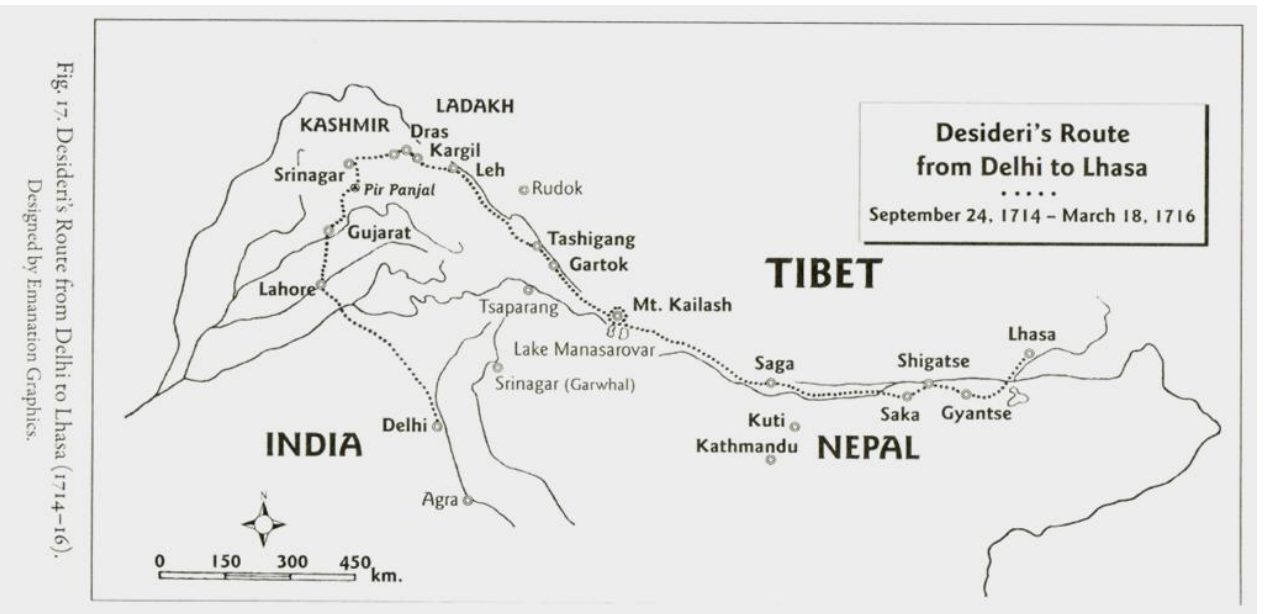

${ }^{775}$ Ilustração retirada de DESIDERI, I. Mission to Tibet: the extraordinary eighteenth-century account of father Ippolito Desideri, S.J. Tradução Michael J. Sweet, Edição Leonard Zwilling. Boston: Wisdom Publications, 2010, p. 159. 
ANEXo I: TRADUÇÃO, PUBLICADA POR VINCENT SMITH, DO DECRETO DE 1579.

\section{Petition.}

Whereas Hindostan is now become the centre of security and peace, and the land of justice and beneficence, a large number of people, especially learned men and lawyers, have immigrated and chosen this country for their home. 'Now we, the principal Ulama, who are not only wellversed in the several departments of the Law and in the principles of jurisprudence, and well acquainted with the edicts which rest on reason or testimony, but are also known for our piety and honest intentions, have duly considered the deep meaning, first, of the verse of the Koran :

"Obey God, and obey the Prophet, and those who have authority among you " ; and secondly, of the genuine tradition :

"Surely the man who is dearest to God on the day of judgment is the Imam-i-adil; whosoever $\mathrm{ob}^{\wedge} \mathrm{ys}$ the Amir, obeys Thee ; and whosoever rebels against him, rebels against Thee ";

And thirdly, of several other proofs based on reasoning or testimony : and we have agreed that the rank of Sultan-iadil is higher in the eyes of God than the rank of a Mujtahid.

Further, we declare that the King of the Islam, Amir of the Faithful, Shadow of God in the world, AbQl-fath Jalalud- din Muhammad Akbar, Padshah Ghazi (whose kingdom God perpetuate !), is a most just, a most wise, and a most God-fearing king.

Should, therefore, in future a religious question come up, Regarding which the opinions of the Mujtahids are at variance, and His Majesty, in his penetrating understanding and clear wisdom be inclined to adopt, for the benefit of the nation and as a political expedient, any of the conflicting opinions which exist on that point, and should issue a decree to that effect; 
We do hereby agree that such a decree shall be binding on us and on the whole nation. Further, we declare that should His Majesty think fit to issue a new order, we and the nation shall hkewise be bound by it; Provided always, that such order be not only in accordance with some verse of the Koran, but also of real benefit to the nation; and further, that any opposition on the part of his subjects to such an order passed by His Majesty shall involve damnation in the world to come and loss of property and reUgious privileges in this.

This document has been written with honest intentions, for the glory of God and the propagation of the Islam, and is signed by us, the principal Ulama and lawyers, in the month of Rajab in the year nine hundred and eighty-seven (987). ${ }^{776}$

\footnotetext{
776،“Esta transcrição do Decreto tal qual foi preservado pelos cronistas do Império Mogol Nizamu-d e Badaoni. Apud: SMITH, V.A. Akbar the Great Mogul, 1542-1605. Clarendon Press, 1919, p: 179-80. Para uma interpretação distinta, que leve com conta as relações entre o Hindustão e outros Estados muçulmanos, cf: BUCKLER F. W. A New Interpretation of Akbar's 'Infallibility' Decree of 1579. Journal of the Royal Asiatic Society of Great Britain and Ireland n. 4, p. 591-608, 1 out. 1924.
} 


\section{REFERÊNCIAS}


FONTES

ACOSTA, J, S.J. De procuranda Indorum salute. Madri: Consejo superior de investigaciones cientificas, 1984.

S.J., História natural y moral de las Indias, en que se tratan las cosas notables del cielo, y elementos, plantas, y animales dellas ; y los ritos, cerimónias, leyes y govierno y guerras de los Indios (Sevilla, J. de León, 1590) Madrid: Historia 16, 1986.

ALAY, J.L. Ambaixador a la cort del Gran Mogol: Viatges d'um Jesuïta Català Del segle XVI a l'India, Paquistão, Afeganistão, Himalaia. Edição e tradução (do latim para o catalão): Josep Lluis Alay. Lleida: Pagès, 2002.

AGOSTINHO, SANTO. A Cidade de Deus, trad., pref., nota biográfica e transcrições deJ. Dias Pereira. Lisboa: Fundação Calouste Gulbenkian, 1993-2000.

AQUINO, T. Suma Teológica. São Paulo: Ed. Loyola, 2001.

Suma Teológica. Tradução Alexandre Correa. São Paulo: Faculdade de Filosofia Sede Sapiens: São Paulo, 1956.

De Rationibus Fidei. Tradução Joseph Kenny, O.P. Edição bilíngue latiminglês. Disponível em: <www.dhspriory.org/thomas/Rationes.htm>.

Suma contra os gentios. Tradução D. Odilão Moura e D. Ludgero Jaspers.

Porto Alegre: Escola Superior de Teologia São Lourenço de Brindes, 1990.

Cartas de Jerônimo Xavier:

Carta do Padre Jerônimo Xavier ao padre Mercuriano Preposito geral. Évora, 20 de Abril de 1580. In: Documenta Indica, v. XII (1580-1583), doc. 02, p. 08-10. Lus, 68, f.279r-v.

Carta do padre Jerônimo Xavier para o provincial da Companhia de Jesus na Índia, 6 de setembro de 1604. DOCUMENTAÇÃO Ultramarina Portuguesa. Lisboa: Centro de Estudos Históricos Ultramarinos, 1963, p. 7-29.

CARTA de Jerônimo Xavier, Laore, 25 de setembro de 1606. In: Documentação Ultramarina Portuguesa. Lisboa: Centro de estudos históricos ultramarinos, 1963, p. 62-91. 
Cartas de Rodolfo Acquaviva:

CARTA do Padre Rodolfo Aquaviva ao Padre Mercuriano, de Fatehepur [Sikri], 18 de julho de 1580. Jap-sin. 37, ff: 100r-02v. Documenta Indica, v. XII (1580-1583), doc. 06, p.44-52.

CARTA dos padres Rodolfo Aquaviva, Antônio de Montserrat e Francisco Henriques ao padre Provincial Roderico Vicente. Agra, 13 de julho de 1580. Documenta Indica, v. XII (1580-1583), doc. 05, p. 35-6. ANTT, Armário Jesuítica n. 28, ff.109r-12v.

CARTA de Rodolfo Acquaviva para Claudio Acquaviva, Praep. Gen. S.I., Fatepur, 25 de abril de 1582. Documenta Indica, vol. XII (1580-1583), doc 106, p. 584. ARSI Jap-sin 37, ff: $109 \mathrm{r}-111 \mathrm{v}$.

CARTA dos padres Rodolfo Aquaviva, Antônio de Montserrat e Francisco Henriques ao padre Provincial Roderico Vicente. Agra, 13 de julho de 1580. In: Documenta Indica, v. XII (1580-1583), doc. 05, p. 34-44. Arquivo Nacional da Torre do Tombo, (ANTT, Lisboa, Portugal). Armário Jesuítico n²8, ff.109r-12v.

CARTA de Rodolfo Acquaviva, Fatepur, 25 de abril de 1582. Documenta Indica, vol. XII, doc 106, p.62-91.

Cartas de Francisco Henriques:

Carta do Padre Francisco Henriques ao padre Laurentio Peres. Fathepur, 6 de abril de 1580. Documenta Indica, v. XII (1580-1583), doc. 01, p. 03-08. ARSI GOA 38 I, ff: 121r-24v.

Cartas de Antônio de Andrade:

CARTA de Alano dos Anjos e Antônio de Andrade, Tibete, 29 de agosto de 1627. ARSI, Goa 73, fl: 50r-50v.

CARTA do Padre Antônio de Andrade para o Provincial da Companhia de Jesus na Índia (Agra, 14 de agosto de 1623) In: Documentação Ultramarina Portuguesa. Lisboa: Centro de estudos históricos ultramarinos, 1963, p. 159-179.

CARTA de Antônio de Andrade, Agra, 8 de novembro de 1624. In: DIDIER, H. Os portugueses no Tibete. Os primeiros relatos dos jesuítas (1624-1635). Lisboa: Comissão Nacional pra Comemoração dos Descobrimentos Portugueses, 2000, p. p. 75-102. 
CARTA escrita por Antônio de Andrade, em 15 de agosto de 1626. In: DIDIER, H. Os portugueses no Tibete. Os primeiros relatos dos jesuítas (1624-1635). Lisboa: Comissão Nacional pra Comemoração dos Descobrimentos Portugueses, 2000, p. 103-146.

CARTA de Antônio de Andrade, Tibete, 1627. In: DIDIER, Hugues. Os portugueses no Tibete. Os primeiros relatos dos jesuítas (1624-1635). Lisboa: Comissão Nacional pra Comemoração dos Descobrimentos Portugueses, 2000, p. p.147-160.

CARTA de Antônio de Andrade, Tsaparang (Tibete Ocidental), 1628. ARSI, Goa 73, ff: 47$48 \mathrm{v}$.

CARTA de Antônio de Andrade de 4 de fevereiro de 1633. ARSI, Goa 73, fl: 93-95.

\section{Cartas de Nuno Coresma:}

CARTA do Padre Nuno Coresma ao Provincial de Goa, Tsaparang, 30 de Agosto de 1635. ARSI Goa 73, fl.97r-99r.

Carta do Padre Nuno Coresma ao Provincial de Goa, Agra, 14 de Dezembro de 1635. ARSI Goa 73, fl.100r-100v. (Cópia digital.)

\section{Carta de Antônio Mendes:}

CARTA de Antônio Mendes, ARSI, Goa 73, 101r-106v.

Outras cartas:

CÓPIA de uma [carta] da India para a província de Porugal do ano de [15]79. Arquivo Nacional da Torre do Tombo, (ANTT, Lisboa, Portugal), Armário Jesuítico, no 28, ff. 91.

CARTA ânua, escrita pelo padre Rui Vicente ao Geral, Goa, 20 de outubro de 1580. Documenta Indica, vol. XII, doc. 13, p. 99.

CARTA de André Pereira, Golim, outubro de 1615. ARSI, Goa, 17, fl: 138v, fl: 139.

CARTA de Francisco Azevedo, Agra, 1631. In: DIDIER, H. Os portugueses no Tibete. Os primeiros relatos dos jesuítas (1624-1635). Lisboa: Comissão Nacional pra Comemoração dos Descobrimentos Portugueses, 2000. 
CARTA do Padre Francisco Corsi para o Provincial da Companhia de Jesus na Índia (Agra, 28 de outubro de 1619); In: Documentação Ultramarina Portuguesa. Lisboa: Centro de Estudos Históricos Ultramarinos, 1963.

CARTA do Padre Francisco Corsi para o Provincial da Companhia de Jesus na Índia (Agmir, 3 de abril de 1627); In: Documentação Ultramarina Portuguesa. Lisboa: Centro de Estudos Históricos Ultramarinos, 1963.

CARTA de Gileanes Pereira (sic), de Fatepur, 5 de junho de 1579. ANTT, Armario Jesuitico, n. 28 , ffl: $86-87$.

CARTA do padre Francisco Leão para o provincial da Companhia de Jesus na Índia (Agra, 6 de outubro de 1628); In: Documentação Ultramarina Portuguesa. Lisboa: Centro de Estudos Históricos Ultramarinos, 1963.

CARVALHO, P.M. Mir'at al-quds (Mirror of Holiness): A Life of Christ for Emperor Akbar: A Commentary on Father Jerome Xavier's Text and the Miniatures of Cleveland Museum of Art, Acc. No. 2005, Tradução e transcrição Wheeler M. Thakson. Brill: Lieden, Boston, 2012.

CONSELHO do Arcebispo de Goa e mais bispos da Índia sobre o que se faria acerca da embaixada do Grão Mogor. Arquivo Nacional da Torre do Tombo, (ANTT, Lisboa, Portugal), Armário Jesuítico, fl: 89v-90.

CÓPIA de um capítulo de uma carta de Pero Tavares, Capitão-mor de Satagão nos reinos de Bengala, que escreveu da corte do Grão Mogor ao padre provincial da Companhia de Jesus da Índia” ANTT, Armário Jesuítico, n. 28, fl: 86v.

CÓPIA de uma [carta] da Índia para a província de Portugal do ano de [15]79. ANTT, Armário Jesuítico, n. 28, ff. 91-2.

CORÃO. ROMAN Traslitaration of The Holy Qur-'ann, with full arabic text. Tradução Allama Abdullah Yusuf Ali. Lahore: Qudrat Ullah co., s/d.

CORÃO. Tradução de Mansur Chalita. Rio de Janeiro: Best bolso, 2011.

DESIDERI, I. La relazione di Ippolito Desideri, apud: PETECH, L. I missionari italiani nel Tibet e nel Nepal. Libr. dello Stato, 1952-1956, 6v.

DESIDERI, I. Mission to Tibet: the extraordinary eighteenth-century account of father Ippolito Desideri, S.J. Tradução Michael J. Sweet, Edição Leonard Zwilling. Boston: Wisdom Publications, 2010. 
EREDIA, M. G. "Discurso sobre a província do Indostão chamada Mogul e corruptamente Mogôr com declaração do reino de Guzarate e mais reinos de seu destricto: ordenado por Manuel Godinho de Erédia, cosmographo mor do Estado de Índias Orientaes, anno 1611". In: Documentação Ultramarina Portuguesa. Lisboa: Centro de Estudos Históricos Ultramarinos, 1963.

FAZL, A. The Akbarnāma of Abu-1-Faẓl, a history of the reign of Akbar including an account of his predecessors. Tradução H. Beveridge. Calcutá: Asiatic Society, 1910-1939. Tradução nossa. Grifos nossos. Disponível em: <http://persian.packhum.org/persian/main?url=pf\%3Ffile\%3D00701023\%26ct\%3D0>.

Acesso em 1 maio 2013.

FORMÃO de Zeladin Machamede Achebar, rei posto por Deus, [aos] principais padres da Ordem de São Paulo. Arquivo Nacional da Torre do Tombo, (ANTT, Lisboa, Portugal), Armário Jesuítico, n²8, fl: 88v-89.

GREGORII XIII Litterae "Misericors Deus" imperatori Akbar Missae Roma, 18 de fevereiro de 1582. Documenta Indica, v. XII (1580-1583), doc. 102, p.372-374. Archivo secreto vaticano; Inst. 194, ff: 236r-v.

HOYLAND, J.S.; BANERJEE, S.N. The commentary of father Montserrat on his journey to court of Akbar. Mahindra College, Patiala. Londres: Humphrey Milford, Oxford University Press, 1922.

MANRIQUE, S. Itinerario de las missiones que hizo el Padre F. Sebastian Manrique. Roma: F. Caballo, 1649.

MONTSERRAT, A. Mongolicae Lagationis Commentarius. Apud: ALAY, J.L. Embajador en la corte del Gran Mogol.Tradução: Ramon Sala. Lleida: Milenio, 2006.

Mongolicae Lagationis Commentarius. Texto integral, em latim: HOSTEN, H. (Ed.) Mongolicae Lagationis Commentarius. Memoirs of the Asiatic Society of Bengal, Calcutá, vol. III, n. 9, p. 518-704, 1914.

Relação de Akbar, rei dos mogóis. Texto original em português. Versão manuscrita encontrada no livro 28 do Armário Jesuítico (fl. 84v-85) no Arquivo Nacional da Torre do Tombo, em Lisboa, Portugal. In: Documenta Indica, v. XII (1580-1583), doc. 114, p. 645662.

MONTSERRAT. Antonio. Relação de Akbar, rei dos mogois. Versão manuscrita encontrada no livro 28 do Armário Jesuítico (fl. 81-85), no Arquivo Nacional da Torre do Tombo (ANTT, Lisboa, Portugal). Versão publicada: Documenta Indica, v. XII (1580-1583), doc. 114, p.645-662. 
PAYNE, C. H. (Ed.) Akbar and the Jesuits. An account of the Jesuit Missions to the court of Akbar by Father Pierre du Jarric, S.J., Nova Deli: LPP, 1999 (1926).

RELAÇÃO da Missão do reino de Uçangue, cabeça dos do Potente, escrita pelo Padre João Cabral da Companhia de Jesus. In: DIDIER, H. Os portugueses no Tibete. Os primeiros relatos dos jesuítas (1624-1635). Lisboa: Comissão Nacional pra Comemoração dos Descobrimentos Portugueses, 2000.

RELAÇÃO da missão do Tibete, fevereiro de 1626. ARSI, Goa 73, fl.47r.

RELAÇÃO da missão Mogor do ano de 1666 até 1671, inclusive In: Documentação Ultramarina Portuguesa. Lisboa: Centro de Estudos Históricos Ultramarinos, 1963.

RELAÇÃO que mandou o Padre Estevão de Cacela Da Companhia de Jesus ao Padre Alberto Laércio, provincial da Província do Malabar da Índia Oriental, de sua viagem para o Cataio, até chegar ao reino de Potente. In: DIDIER, H. Os portugueses no Tibete. Os primeiros relatos dos jesuítas (1624-1635). Lisboa: Comissão Nacional pra Comemoração dos Descobrimentos Portugueses, 2000.

SOUZA, F. O Oriente conquistado a Jesu Christo pelos padres da companhia de Jesus da provincia de Goa... Lisboa: na officina de V. Da Costa Deslandes, 1710. vol. 2.

SUÁREZ, F. Suárez on individuation: Metaphysical disputation V, individual unity and its principle. Tradução Jorge J. E. Gracia. Milwaukee: Marquette University Press, 1982.

Tractatus de legibus ac Deo legislatore. Madri: Consejo Superior de Investigaciones Cientificas, vol. I, livroI, 1971-81.

WESSELS, C. Early Jesuit travellers in Central Asia, 1603-1721 Delhi: Low Price Publications, 2008.

XAVIER, J. Fuente de Vida: Tratado apologético dirigido al Rey Mogol de la India en 1600. San Sebastián: Universidad de Deusto, 2007. 


\section{BIBLIOGRAFIA}

AHMAD, Z. Sino-Tibetean relations in the seventeenth century. Roma: Istituto Italiano per il medio ed estremo Oriente, 1970.

ALAM, M. Languages of Political Islam in India. Orient Blackswan, 2004.

The Pursuit of Persian: Language in Mughal Politics. Modern Asian Studies, vol. 32, n' 2, p. 324, maio 1998.

ALAM, M.; SUBRAHMANYAM, S. Writing the Mughal World: Studies on Culture and Politics. Nova Iorque: Columbia University Press, 2012.

ALDEN, D. The making of an enterprise: the society of Jesus in Portugal, Its Impire and Beyond, 1540-1750. Stanford: Stanford University Press, 1996.

ALI, M. A. Towards an Interpretation of the Mughal Empire. The Journal of the Royal Asiatic Society of Great Britain and Ireland, Cambridge University Press, n. 1, p. 40, 1978. Disponível em: <http://www.jstor.org/stable/25210917>.

ALVARES, F. A verdadeira informação das terras de Preste João das Índias. Publicações Europa-américa, 1989.

AUBIN, F. Missionnaires en Chine... missionnaires sur la Chine. In : Archives des sciences sociales des religions. n.63/2, 1987, p. 177-188.

BACOT, J. Introduction à l’Histoire du Tibete. Societé Asiatique. Paris, 1962.

BAIÃO, A. História da expansão portuguesa no mundo. Lisboa: Ática, 1937. Volume 3.

BAILLIE, L.M. Father Estevão Cacella's report on Bhutan in 1627. Notas de Michael Aris.

BAILEY, G.A. The Truth-Showing Mirror: Jesuit Catechism and the Arts in Mughal India. In: O'MALLEY, J.W. (Ed.) The Jesuits: cultures, sciences, and the arts, 1540-1773. University of Toronto Press, vol. 1, 1999, p. 484-5. 
BAREJA, A. The history of ancient Tibete according to the XVIIth Mongolian chronicle Erdeni-yin Tobci by Sayang Secen.Tibetean studies. Naritasan Shinshoji, vol. 2. p. 341-351, 1992.

BARGIACCHI, E.G. Ippolito Desideri S.J - alla scoperta del Tibete e del budhismo, Pistoia: Edizioni Brigata Del Leoncino, 2006.

Opere e Bibliografia [Subsidia ad Historiam Societatis Iesu 15]. Roma: Institutum Historicum Societatis Iesu, 2007.

BETHENCOURT, F.; CHAUDURI, K. (Dirs.) História da expansão portuguesa. Lisboa: Círculo de Leitores e Autores, v. 2, 1998-9.

BOUCHON, G. Bengal and Pegu at the beginning of the sixteenth century according to an anonymous Portuguese narrative. In: II seminário internacional de História IndoPotuguesa (actas). Instituto de Investiçacão Científica e Tropical. Centro de Estudos de História e Cartografia antiga. Lisboa, 1985.

BOXER, C. O Império Marítimo Português. São Paulo: Cia. das Letras, 2002.

BRAY, J. Christian missionaries on the Tibetean border: the Moravian church in Poo (Kinnaur) 1865-1924. Tibetean studies. Proceedings of the $5^{\text {th }}$ Seminar of the International Association for Tibetean Studies. Naritasan Shinshoji, vol. 2, p. 369-375, 1992.

BRAZÃO, E. Em demanda ao Catai. Lisboa: Agência do Ultramar, 1954.

BROGGIO, P. et. at. I Gesuiti ai Tempi di Cláudio Acquaviva. Brescia: Morcelliana, 2007.

BUCKLER F. W. A New Interpretation of Akbar's 'Infallibility' Decree of 1579. Journal of the Royal Asiatic Society of Great Britain and Ireland n. 4, p. 591-608, 1 out. 1924.

CAMPS, A. Studies in Asian Mission History. Leiden, Boston, Köln: Brill, 2000, p. 45.

CASTELO-BRANCO, F. Aspectos da vida e da obra do explorador do Tibete padre António de Andrade. In: II seminário internacional de História Indo-Potuguesa (actas). Instituto de Investiçacão Científica e Tropical. Centro de Estudos de História e Cartografia antiga. Lisboa, 1985.

CERTAU, M. A escrita da História. Rio de Janeiro: Forense Universitária, 2002. p. 213. 
CHATTOPADHYAYA, Debiprasad. Lokayata: A study in ancient Indian materialism. Deli: People's Publishing House, 1959.

CHAUDURI, N. K. Some reflections on the town and the country in Mughal India. Modern Asian Studies, 12, I, p.77-96, 1978.

COLLIS, M. Na terra da grande imagem. Porto: Livraria Civilização, 1944.

COLOMBO, E. Jesuítas y musulmanes en la Euorpa del siglo xvii. In: WILDE (Ed.). Saberes de la conversion: Jesuítas, indígenas e impérios coloniales em las fronteras de la cristandad. Buenos Aires: Grupo Editorial Sb, 2011.

COMNEMO, M.A.L. Nestorianism in Central Asia during the First Millennium: archeological evidence. Journal of Assyrian Academic Studie. vol. XI, n. 1., p. 20-53.

CORREIA-AFONSO, J. Documents of the first jesuit mission from Goa to the Great Moghal. In: II seminário internacional de História Indo-Potuguesa (actas). Instituto de Investiçacão Científica e Tropical. Centro de Estudos de História e Cartografia antiga. Lisboa, 1985.

Jesuit Letters and Indian History. Oxford University Press, 1969.

DAUVILliER, J. Byzantins d'Asie Centrale et d'Extrême Orient. In : Revue des études byzantines, tomo 11,1953 , p.62-87.

DEI, N. Notes on the History of the district of Hugli or the ancient Ráda. Journal and proceedings of the Asian Society of Bengal. New series. Calcutá, vol. VI., 1910.

DESHAYES, L. Histoire du Tibet. Paris: Fayard, 1997.

DIDIER, H. As fontes e o Tibete. In: A Companhia de Jesus e a missionação no Oriente: actas do colóquio internacional. Lisboa: 2000.

Muslim heterodoxy, Persian murtaddun and jesuit missionaries at the court of king Akbar (1580-1605). The Heythrop Journal, nov. 2008.

Os portugueses no Tibete. Os primeiros relatos dos jesuítas (1624-1635). Lisboa: Comissão Nacional pra Comemoração dos Descobrimentos Portugueses, 2000. 
DIETZ, S. Cosmogony as presented in thibetan historical literature and its sources. Tibetean studies. Proceedings of the $5^{\text {th }}$ Seminar of the International Association for Tibetean Studies Naritasan Shinshoji, vol. 2, p: 435-438, 1992.

DORE, A. Império Sitiado: as fortalezas portuguesas na Índia (1498-1622) Tese de doutorado. Universidade Federal Fluminense. Ano de Obtenção: 2002.

EISENBERG, J. As missões jesuíticas e o pensamento político moderno. Belo Horizonte: UFMG, 2000.

FAITANIN, Paulo. A Querela da Individuação na Ecolástica. Aquinate, n 1, p. 74-91, 2005.

FLORES, J. Firangistan' e 'Hindustan'. O Estado da Índia e os confins meridionais do Império Mogol (1572-1636). Tese de doutorado inédita. Lisboa: Universidade Nova de Lisboa.

crises. "I'll do as my father did": on and other Europeans views of Mughal succession <http://www.brown.edu/Departments/Portuguese_Brazilian_Studies/ejph/html/issue6/pdf/jflo res.pdf $>$ Acesso em: 21 jan. 2008.

Relic or Springboard? A note on the 'rebirth' of Portuguese Hughli, ca.1632-1820. Indian Economic Social History Review, v. 39, 2002.

GANDOLFO, R. Bhutan and Tibete in European Cartography (1597-1800). In: The spider and the pliget: Proceedings of the first International Semminar on Bhutan Studies. Thimpu: Centre fir Buddhist Studies, 2004. p. 96-107.

GANERI, J. The Hindu Syllogism: Nineteenth-Century Perceptions of Indian Logical Thought. Philosophy East and West, v. 46, n 1, 1996, p. 1-16.

The Lost Age of Reason: Philosophy in Early Modern India 1450-1700. EUA: Oxford University Press, 2011.

GASTÃO, M. Os missionários jesuítas portugueses no Tibete: evocação históricoreligiosa, Lisboa: Ed. Rei dos Livros, 1905.

GRAÇA, L. O mundo indiano de deiscentos e a literatura portuguesa de viagens. . In: II seminário internacional de História Indo-Potuguesa (actas). Instituto de Investiçacão Científica e Tropical. Centro de Estudos de História e Cartografia antiga. Lisboa, 1985. 
GRUPPER, S.M. Manchu patronage and Tibetean Buddhism during the first half of the Ch'ing dynasty. The Journal of Tibetean Society. Bloomington, vol. 4, p. 47-75, 1984.

GUINOTE, P. Ascensão e declínio da carreira da Índia. Disponível em <http://nautarch.tamu.edu/SHIPLAB/01 guifrulopes/Pguinote-nauparis.htm>.

HANSEN, E.R. Het Boeddha-boek. Havelte: Binkey Kok Publications, 2004. . (Org.). Cartas do Brasil. São Paulo: Hedra, 2003.

HARTOG. O espelho de Heródoto. Belo Horizonte: UFMG, 1999.

HEDIN, S.A. Central Asia and Tibet. Londres: Hurst and Blackett, vol. 1, 1903.

Southern Tibet: discoveries in former times compared with my own researches in 1906-1908. B.R. Deli: Publishing Corporation, 1991.

HERMANN, P. A conquista da Ásia. São Paulo: Boa leitura, s/d.

HOSTEN, H. List of the missionaries in "Mogor". Journal and proceedings of the Asian Society of Bengal. New series. Calcutá, vol. VI, 1910.

. The Marsden MSS. and the Indian Mission Bibliography. Bulletin of the School of Oriental Studies. University of London, vol. 3, n. 1, p. 129-150, 1923.

The Marsden Mss. In the British Museum, by PHILIPS, W.R; BEVERIDGE, H. Journal and proceedings of the Asian Society of Bengal. Journal and proceedings of the Asian Society of Bengal. New series. Calcutá, vol. VI, 1910.

HOSTEN, H.; BESSE, P. A List of Portuguese Jesuit missionaries in Bengal and Burma, 1576-1742. Journal of Asiatic Society of Bengal. Calcutá, vol. VII. p. 16, 1911.

HYER, P. Les Dalai Lamas et l'Asie Centrale. Nouvelles Tibeteaines, n. 3, Quarto trimestre 1982.

ISHIHAMA, Y. A study of the Seals and Titles conferred by the Dalai Lamas. Tibetean studies. Proceedings of the $5^{\text {th }}$ Seminar of the International Association for Tibetean Studies Naritasan Shinshoji, vol. 2, p: 501-514, 1992. 
ISHTIAQ Husain Qureshi. Administration of the Mughal Empire. Deli: Low Price Publications, 2002. Primeira publicação: 1973.

JAMSPAL, L. The three provinces of Mna' - ris: traditional accounts of ancient western Tibete. In: Proceedings of the $\mathbf{1 9 8 2}$ Seminar of the International Association for Tibetean Studies. Manohar. 1985. p. 152-156.67

JOUSSELANDIÈRE, Victor Santos Vigneron de la. A dupla marginalidade de José de Acosta: religião e soberania no Vice-Reino do Peru (séc. XVI). Revista de História. n. 164, p. 101-125, 2011.

KAHLOS, M. Debate and Dialogue: Christian and Pagan Cultures. Aldershot: Ashgate, 2007.

KENNEDY, G. A. Classical Rhetoric and Its Christian and Secular Tradition from Ancient to Modern Times. The University of North Carolina Press, 1999.

$\mathrm{KOCH}$, E. Jahangir as Francis Bacon's Ideal of the King as an Observer and Investigator of Nature. Journal of the Royal Asiatic Society, v. 19, n. 3, p. 297, 2009. Disponível em <http://journals.cambridge.org/abstract_S1356186309009699>.

- The Symbolic Possession of the World: European Cartography in Mughal Allegory and History Painting.Journal of the Economic and Social History of the Orient, 2012.

KOSELLECK, R. Futuro passado: contribuição à semântica dos tempos históricos. Rio de Janeiro, Contraponto / PUC-RJ, 2006.

LANDRY-DERON, I. La preuve par la Chine.Paris: Ed. EHESS, 2002.

LAIRD, T. Une Histoire du Tibet. Conversations avec le Dalai Lama. Tradução do inglês Christophe Mercier. Paris: Plon, 2007, p. 169.

LEFEVRE, C. The Majālis-i Jahāngīī (1608-11): Dialogue and Asiatic Otherness at the Mughal Court. Journal of the Economic and Social History of the Orient 55, n. 2-3, p. 255-286, 1 jan. 2012.

LONDOÑO, F.T. Escrevendo Cartas. Jesuítas, escrita e missão no século XVI. Revista Brasileira de História. São Paulo, vol.22, n. 43, 2002. 
LORENZEN, D. Who invented Hinduism? Essays on Religion in History. Nova Deli: Yoda Press, 2006.

LORENZEN, D.N. Gentile religion in South Índia, China, and Tibete. Studies by three Jesuit missionaries. Comparative Studies of South Asia, Africa and the Middle East, 27/1, p. 203-213, 2007.

MACLAGAN, Sir. E. Os Jesuítas e o Grão Mogol. Porto: Editora Livraria Civilização, 1946.

MAHIDASSAN, S. Bezoar presented to emperor Jehangir (sic). Annals of the Bhandarkar Oriental Research Institute. vol. 56. n. 1/4, p. 232-233, 1975.

MCKAY, A. The History of Tibet. Londres: Routledge, 2003.

McCLEARY, R.; KUJIP, L.W.J.V.D. The formation of the Tibetan state religion the geluk school 1419-1642. Disponível em: <http://buddhism.lib.ntu.edu.tw/BDLM/toModule.do?prefix=/search\&page=/search_detail.jsp ?seq=209832 >. Acesso em: 1 de abril de 2013.

MILLS, M. Identity, ritual and State in Tibetan Buddhism.Nova Iorque: Routledge, 2003

MONTEIRO, J.M. Negros da Terra: Índios e Bandeirantes Nas Origens de São Paulo. São Paulo: Companhia das Letras, ed. 2, 1994.

NEWITT, M. Formal and Informal Empire in History of Portuguese Expansion In: King's College London Portuguese Studies. Londres, vol 17, 2001.

NORBU, D. An analisys of Sino-Tibeteana relationshis, 1245-1911. In: Proceedings of the 1982 Seminar of the International Association for Tibetean Studies. Manohar. 1985. p. 177-195.

NORWICK, B. Why Tibete disappeared from "scientific" $16^{\text {th }}-17^{\text {th }}$ century European maps. Tibetean studies. Proceedings of the $5^{\text {th }}$ Seminar of the International Association for Tibetean Studies Naritasan Shinshoji, vol. 2, p: 633-644, 1992.

PÉCORA, A. Máquina de gêneros São Paulo: Editora Universidade de São Paulo, 2001.

PETECH, L. Selected papers on Asian history. Roma: Ismeo, 1988. 
PETECH, L. A Study on the Chronicles of Ladakh. The Calcutta Oriental Press, 1937

PETECH, L. The Dalai Lamas and the regents of Tibet: a cronological study. In: MCKAY, Alex. The History of Tibet. Routledge, 2003, vol 2

PIRES. Portugal no tecto do mundo. Macau: Instituto Cultural, 1988.

POMMARET, F. Lhasa: lieu du divin. Geneve: Edition Olizane, 1997.

POMPLUN, T. Jesuit on the Roof of the World: Ippolito Desideri's Mission to EighteenthCentury Tibete. Nova Iorque: Oxford University Press, 2002.

Natural Reason and Buddhist Philosophy: The Tibetan Studies of Ippolito Desideri, SJ (1684-1733). History of Religions, vol. 50, n. 4, p. 390, maio 2011.

. The Holy Trinity in Ippolito Desideri's Ke ri se ste an kyi chos lugs kyi snying po.

Buddhist-Christian Studies. Vol. 29, nº 1, p. 117-130, 2009

POWELL, A.A. Muslims and missionaries in pre-mutinyIndia. Londres: Rpoutledge Curzon, 2003,

POWERS, J. Introduction to Tibetean Budhism. Ithaca: Snow Lion Publications, 1995.

PREVATTO, A. Conversão à comunicação: a trajetória do missionário que foi São Francisco Xavier. 1542-1552. 2010. 192 f. Dissertação de Mestrado apresentada ao programa de pós-graduação em História Social. Universidade de São Paulo, 2010.

RECHUNG, J.K. Notes and Topics. Bulletin of Tibeteology, n. 1, 1992. Disponível em: <www.Tibeteology.net/publications.htm>. Acesso em 13.05.2008.

REZAVI, S.A.N. Religious Disputation and Imperial Ideology: The Purpose and Location of Akbar's Ibadatkhana. Studies in History. Sage, vol. XXIV, n.2, p.195-210, julho-dez. 2008.

. Religious disputations and Imperial Ideology: The purpose and Location of Akbar's Ibadatkhana. Studies in History. Los Angeles, Londres, Nova Deli, Cingapura, v. 24, n. 2, 2008 .

RICHARDSON, H .The fifth Dalai Lama's decree appointing Sangs-Rgyas Rgya-Mtsho as regent. Bulletin of the School of Oriental and African Studies. Vol. XLIII, parte 2, p. 329343, 1980. 
63-67, 1981.

Armenians in India and Tibete. Journal of the Tibete Society. Bloomington, n. 1, p.

ROMANO, A. Entre Nature et écriture. Artigo apresentado no Colóquio Anciens, Modernes, Sauvages, na USP, São Paulo, 2009.

ROMMEN, H. Francis Suarez. The Review of Politics. vol. 10, n. 4, 1948.

ROQUE DE OLIVEIRA, F.M. A construção do conhecimento europeu sobre a China, c. 1500 - c. 1630. Impressos e manuscritos que revelaram o mundo chinês à Europa culta. Disponível em: <http://www.tdx.cat/TDX-1222103-160816>. Acesso em: 18 abril 2008.

RUEGG, S. Mchod yon, yon mchod and mchod gnas/yon gnas: on the historiography and semantics of a tibetan religio-social and religio-political concept". In: Tibetan history and language: studies dedicated to Uray Géza on his seventieth birthday, n. 26, 1991, p. 441-453.

RUTHVEN, M.; AZIM A.. Historical Atlas of Islam. Harvard University Press, 2004.

SAID, E. Orientalismo: o como invenção do Ocidente. São Paulo: Companhia das Letras, 2007.

SAMUEL, G. Tibet as a Stateless Society and Some Islamic Parallels. The Journal of Asian Studies, 41, n. 2, p. 215-229, 1 fev. 1982.

SANDBERG, G. The Exploration of Tibete, its history and particulars, from 1623 to 1904. Calcutá: Thacker, Spink and Co., 1904.

SEN, A. The argumentative Indian. Londres: Penguin, 2005.

SHAKABPA, W. D. Tibet: A Political History. Nova Iorque: Potala Publications, 1984, p. 123.

SIMÕES, V. O infante D. Henrique: seu tempo e sua ação. In: História da expansão portuguesa no mundo. volume 3. p. 311-356. 
SLOANE, H. Of the Use of the Root IPecacuanha, for Loosenesses. Traduzido de um artigo em francês, com notas do autor. Philosophical Transactions, n. 20, p. 69-79.

SMITH, V.A. Akbar, the great Mogul, 1542-1605. Oxford: Clarendon Press, 1917.

SNEllgROVE, D.; RICHARDSON, H. A Cultural History of Tibet. Bangkok: Orchid Press, 2003.

SPENCE, J.D. The search for modern China. Nova Iorque: Norton, 1991.

STEIN, R.A. La civilization Tibétaine. Paris: Ed. L'Asiatèque, 2011 (1962).

SUBRAHMANYAM, S. Explorations in connected history: Mughals and Franks. Nova Deli: Oxford University Press, 2005.

O Império político português 1500-1700 - Uma História Política e Econômica. Lisboa: Difel, 1993.

Comércio e conflito: a presença portuguesa no Golfo de Bengala, 1500-1700. Lisboa: Ediçoes 70, 1994.

SWEET, M. Desperately Seeking Capuchins: Manoel Freyre's Report on the Tibets and their Routes (Tibetorum ac Eorum Relatio Viarum)' and the Desideri Mission to Tibet. Journal of the International Association of Tibetan Studies 2, 2005.

TAVARES, C.. Jesuítas e inquisidores em Goa. Lisboa: Roma editora, 2004.

TELTSCHER, K. The High Road to China: George Bogle, the Panchen Lama and the first British expedition to Tibete. Londres: Bloomsbury Press, 2006.

THOMAS, D. Christian Doctrines in Islamic Theology. Lieden, Boston: Brill, 2008. Early Muslim Relations with Christianity. Anvil, vol. 6, n. 1, 1989.

THOMAZ. L.F. A lenda de S.Tomé Apóstolo e a expansão portuguesa. Lusitania Sacra, Revista do Centro de Estudos de História Religiosa. Lisboa: Universidade Católica Portuguesa, $2^{\mathrm{a}}$ série, vol.III. 
TOSCANO, G. Contributto dei missionari gesuiti del ' 600 alla conescenza della geografia del Tibete, dell'antica regione Tibeteana detta bon e del buddhismo Tibeteano. Estrato da Annali dell'Instituto niversitario Orientali. Volume 44. 1984.

TOSCANO, J. Jesuit contribution to the geographical knowledge of Tibete. The Tibet journal, vol. V, n. 3. s/d.

TRUSCHKE, A. Cosmopolitan encounters: Sanskrit and Persian at the Mughal court. Tese de doutorado inédita. Columbia University, 2012.

TSERING, N. A survey of the spread of buddharma in Ladakh. In: Proceedings of the 1982 Seminar of the International Association for Tibetean Studies. Manohar, 1985. p.157-164.

TUCCI, G. The religions of Tibet. Berkley: University of California, 1988.

USARSKI, F. O Budismo e as outras. Encontros e desencontros entre as grandes religiões mundiais. Aparecida: Ideias \& Letras, 2009

VAN SCHAIK, S. Tibet: a history. Londres: Yale University Press, 2011.

VENTURA, R. O Budismo nas fontes do Padroado Português do Oriente (séculos XVI e XVII) - um roteiro documental. In: BORGES, P.; BRAGA, D. (Comp.) O Buda e o Budismo no Ocidente e na Cultura Portuguesa. Lisboa: Ésquilo Edições e Multimédia, 2007.

WARIKOO, K. Ladakh's trade relations. with Tibete under Dogras. In: Tibetean studies. Proceedings of the $5^{\text {th }}$ Seminar of the International Association for Tibetean Studies. Naritasan Shinshoji, vol.2, p. 853-61, 1992.

WESSELS, C. Antônio de Andrade. SJ. Viajante no Himalaia e no Tibete. (1624-1630). Lisboa, 1912.

WYLIE, T. Mar-Pā's Tower: Notes on Local Hegemons in Tibet. History of Religions, vol. 3, n. 2, p. 278-291, inverno 1964

ZÜRCHER, Erik. Bouddhisme, Christianisme et société chinoise. Paris: Julliard, 1990.

ZUPANOV, I. Compromise: India. In: Hsia, R. P.-C. (ed) In: A Companion to the Reformation World. Oxford: Blackwell Publishing Ltd., 2007. 
Currents and Counter-Currents: Jesuit geopolitics in Asia (16th century) In: CANTÙ, F. et. al. (Ed.) Strategie politiche e religiose nel mondo moderno: la Compagnia di Gesù ai tempi di Claudio Acquaviva (1581-1615). Brescia: Morcelliana, 2007.

Disputed Mission: Jesuit Experiments and Brahmanical Knowledge in 17th-century South India. Oxford University Press, 1999.

Jesuit Orientalism; Correspondence between Tomas Pereira and Fernão de Queiros, In: BARRETO, L. Tomás Pereira, S. J. (1646-1708), Life, Work and World, ed., Lisboa: Centro Cultural e Cientifico de Macau, 2010.

Le repli du religieux: Les missionnaires jésuites du XVIIe siècle entre la théologie chrétienne et une éthique païenne. In: Annales HSS, 6, 1996, p. 1201-1223. Disponível em: <http://www.ineszupanov.com/publications/zupanov\%20Annales\%201996.pdf.>

Les reliques de St. Thomas; la politique, le sacré et la fondation d'une ville coloniale portugaise au XVIe siècle, at the research seminar coordinated by Ph. Boutry, D. Julia and P.A. Fabre, La relique; XVIe-XIXe siècle, CARE/EHESS, Paris, 3 junho 1997. Disponível em: $<$ http://www.ineszupanov.com/publications/zupanov\%20Mylapore\%20Une\%20ville\%20reliq uaire\%202002.pdf > 